\title{
O combate à corrupção: a contribuição do direito econômico
}

\author{
Tese de Doutorado
}

Orientador: Prof. Dr. José Tadeu de Chiara

FACULDADE DE DIREITO DA UNIVERSIDADE DE SÃO PAULO

São Paulo

2010 


\section{RESUMO}

PAGOTTO, Leopoldo U. C. O combate à corrupção: a contribuição do direito econômico. 2010. 409 f. Tese (Doutorado) - Faculdade de Direito, Universidade de São Paulo, São Paulo, 2010.

A tese analisa o problema da corrupção sob a perspectiva do direito econômico, buscando compreendê-la a partir da dicotomia público-privado e direito posto-pressuposto. Ambas as dicotomias são expostas e contextualizadas, voltando-se gradativamente ao contexto brasileiro. Por isso, em vez de conceber o objeto de estudo como universal e atemporal, a corrupção é localizada historicamente na formação do Estado brasileiro e nas relações patrimoniais deste com a sociedade: embora, com a importação de regras jurídicas do Estado moderno, tenha havido um verniz modernizante nos direitos penal, administrativo e políticoconstitucional, o substrato cultural atua de modo a condicionar sua aplicação e eficácia. No patrimonialismo brasileiro, o poder estatal é visto como um direito daquele investido da função pública, passível de ser exercido com pessoalidade, enquanto, de acordo com os princípios gerais de direito no Estado moderno, ao poder estatal corresponde um dever a ser exercido no cumprimento de uma função. Esse descompasso se encontra presente tanto nas formas mais explícitas de corrupção, claramente reprimidas pela regulamentação microjurídica, quanto em comportamentos mais sutis, muitos dos quais aceitos socialmente por parcelas significativas da população. Essas premissas informam a análise de variados aspectos do direito brasileiro, tais como os vários aspectos da discricionariedade, o corporativismo, o assimétrico federalismo fiscal e o orçamento público da União. Apesar de úteis e necessários, os mecanismos de combate à corrupção típicos da regulamentação microjurídica, expressos no direito posto, adotam uma lógica mercantilista no combate à corrupção, reduzindo-a ao mero jogo de alteração de incentivos e desincentivos. Logo, as propostas de reforma devem focar também os aspectos macrojurídicos do problema.

Palavras-chave: corrupção, poder, orçamento público da União, federalismo fiscal, direito econômico. 


\begin{abstract}
PAGOTTO, Leopoldo U. C. O combate à corrupção: a contribuição do direito econômico. [The fight against corruption: the contribution of the economic law]. 2010. 409 p. Thesis $(\mathrm{PhD})$ - Law School, University of São Paulo, São Paulo, 2010.

The thesis analysis the problem of corruption from the perspective of the economic law and tries to understand it with the support of the dichotomies between public-private spheres and positive-overpositive law. Both dichotomies are described and set within a context in order to gradually approach the Brazilian situation. For this reason, instead of conceiving of the subject matter as universal and timeless, the corruption has historically been found in the formation of the Brazilian state as well as in its patrimonial relationships with society; although a modernizing colour has been added following the importation of legal rules of the modern state in the criminal, administrative and political-constitutional laws, the underlying culture operates as a restraint on its application and efficiency. In the Brazilian patrimonialism, state power is deemed as a right of one individual vested with the public function, which can be used according to his or her private interests, whereas, according to the general principles of law in the modern state, state power consists of a duty to be fulfilled in order to perform a function. Such a mismatch is present both in gross corrupt behaviour, which is clearly banned by the microjuridical regulation, and in the more subtle practices, many of which are socially accepted by a significant number of people. These premises are used as guidelines for the analysis of several aspects of Brazilian law, such as the various facets of discretionary power, the corporativism, the asymmetric fiscal federalism and the federal budget. Even though the mechanisms for the fight against corruption used by the microjuridical regulation (positive law) are useful and necessary, they approach the problem using a mercantilistic logic which narrows down the debate on the dissuasion as to how to change the incentives and desincentives to corruption. In view of that, proposals for reform should also focus on the macrojuridical aspects of corruption.
\end{abstract}

Key words: corruption, power, federal budget, fiscal federalism, economic law. 


\section{RÉSUMÉ}

PAGOTTO, Leopoldo U. C. O combate à corrupção: a contribuição do direito econômico

[Le combat à la corruption: la contribution du droit économique]. 2010. 409 f. Thèse (Doctorat) - Faculté de Droit, Université de São Paulo, São Paulo, 2010.

La thèse analyse le problème de la corruption sous la perspective du droit économique, tout en cherchant à la comprendre à partir de la dichotomie public-privé et droit posé-présupposé. Les deux dichotomies sont exposées et contextualisées, en revenant progressivement au contexte brésilien. Pour ce faire, au lieu de concevoir l'objet d'étude en tant qu'universel et atemporel, la corruption est située historiquement dans la formation de l'État brésilien et dans les relations patrimoniales de ce dernier vis-à-vis de la société : même s'il ait eu un vernis modernisateur suite à l'importation de règles juridiques de l'État Moderne dans les droits pénal, administratif et politique-constitutionnel, le substrat culturel intervient de manière à conditionner son application et efficacité. Dans le patrimonialisme brésilien, le pouvoir de l'État est vu en tant qu'un droit de celui-ci investi de la fonction publique, passible d'être exercé avec personnalisation, alors que, conformément aux principes généraux de droit public dans l'État Moderne, le pouvoir de l'État consiste dans un devoir à être exercé dans l'accomplissement d'une fonction. Cette dissemblance est présente aussi bien dans les formes les plus explicites de corruption, nettement réprimées par la réglementation micro-juridique, que dans les comportements les plus subtils, beaucoup d'entre eux acceptés socialement par des parcelles significatives de la population. Ces prémisses annoncent l'analyse de différents aspects du droit brésilien, tels que les différents aspects de la discrétionnarité, le corporatisme, l'asymétrique fédéralisme fiscal et le budget public de l'Union. Même s'ils sont utiles et nécessaires, les mécanismes de combat à la corruption, typiques de la réglementation microjuridique, exprimés dans le droit posé, adoptent une logique mercantiliste dans le combat à la corruption, en la réduisant au simple jeu d'altération de subsides et manque de subsides. Ceci étant, les propositions de réforme doivent se baser également dans les aspects macrojuridiques du problème.

Mots-clefs: corruption, pouvoir, budget public de l'Union, fédéralisme fiscal, droit économique. 


\section{ZUSAMMENFASSUNG}

PAGOTTO, Leopoldo U. C. Die Bekämpfung der Korruption: der Beitrag des Wirtschaftsrechts. 2009. 409 S. These (Doktorat) - Rechtsfakultät, Universidade de São Paulo, São Paulo, 2010.

Die These analysiert das Problem der Korruption aus der Perspektive des Wirtschaftsrechts und versucht das Phänomen ausgehend von den Dikotomien öffentliches-privates Recht und gesetztes-vorausgesetztes Recht zu begreifen. Beide Gegensatzpaare werden dargelegt, in Zusammenhang gesetzt und graduell zum brasilianischen Kontext überführt. Das heisst, dass das Untersuchungsobjekt nicht als universell und zeitlos betrachtet wird, sondern, dass die Korruption geschichtlich in der Formation des brasilianischen Staates und seiner patrimonialistischen Beziehungen mit der Gesellschaft lokalisiert wird: eine dünne Schicht der Modernisierung, mit der Einführung der juristischen Regeln des Modernen Staates im Straf-, Verwaltungs- und Politischen- und Verfassungsrecht, wurde auf eine kulturelle Basis aufgetragen, die deren Anwendung und Rechtskraft konditioniert. Im brasilianischen Patrimonialismus wird die Staatsmacht als ein Recht derjenigen angesehen, die in der öffentlichen Funktion investiert sind und welches im jeweiligen persönlichem Interesse ausgeführt werden kann, während gemäss den allgemeinen Prinzipien des Öffentlichen Rechts des Modernen Staates, die Staatsmacht in einer Pflicht besteht, die bei der Ausführung öffentlicher Funktionen eingehalten werden muss. Dieser Unterschied ist sowohl in den eindeutigen Formen der Korruption, welche konsequent durch die mikrojuristische Regelung bekämpft werden, als auch in subtileren und oft von wichtigen Teilen der Bevölkerung akzeptierten Verhaltensformen erkennbar. Diese Premissen durchdringen die Analyse der verschiedenen Gesichtspunkte des brasilianischen Rechtswesen, wie die verschiedenen Aspekte des Ermessens, des Korporativismus, desasymetrischen Steuerföderalismus und des öffentlichen Haushaltes der Union. Obwohl die typischen Instrumente der im gesetzten Recht ausgedrückten microjuristischen Regelung zur Bekämpfung der Korruption nützlich und notwendig sind, wenden sie eine merkantilistische Logik gegen die Korruption an und reduzieren das Phänomen auf das einfache Spiel der Veränderung von Anreizen und Abschreckungen. Aus diesem Grund, müssen die Reformvorschläge auch die makrojuristischen Aspekte der Korruption behandeln um erfolgreich zu sein.

Schlüsselwörter: Korruption, Macht, Haushalt, Steuerföderalismus, Wirtschaftsrecht. 


\section{SUMÁRIO}

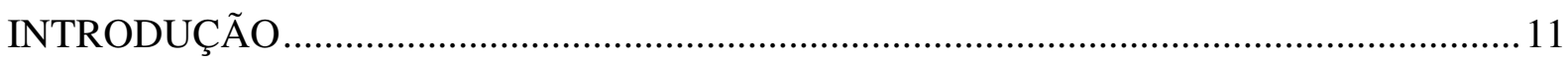

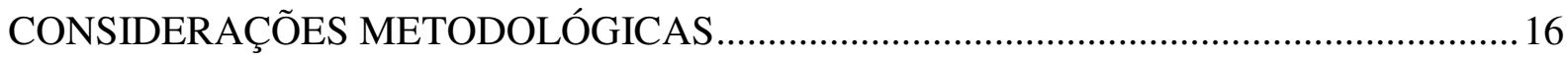

\section{PARTE I}

FUNDAMENTOS PARA A COMPREENSÃO DA CORRUPÇÃO NO BRASIL ............23

CAPÍTULO 1 - LIMITES ENTRE OS ESPAÇOS PÚBLICO E PRIVADO .......................23

1.1 Corrupção: da etimologia e da semântica à perversão da dicotomia público-privado ...24

1.2 Origem e evolução da noção de espaços público e privado ...........................................32

1.2.1 Labor, trabalho e ação nas origens da distinção entre os espaços público e privado

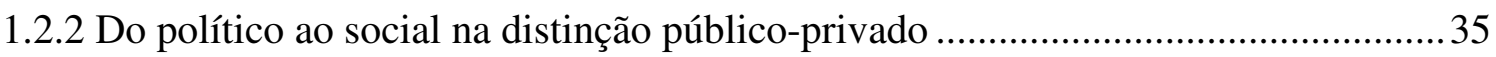

1.2.3 A dicotomia Estado-sociedade civil e interesses públicos-privados ........................37

$1.3 \mathrm{O}$ reconhecimento do bem comum como finalidade do Estado ...................................... 40

1.3.1 O caráter patrimonial da distinção público-privado .................................................45

1.3.2 O caráter impessoal da distinção público-privado..................................................47

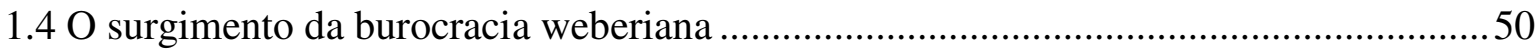

CAPÍTULO 2 - CORRUPÇÃO: CONCEITO E EFEITOS …................................................56

2.1 A corrupção enquanto subversão do valor confiança ...................................................56

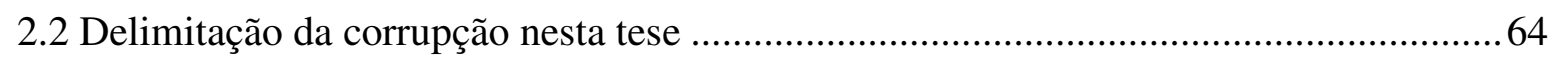

$2.3 \mathrm{O}$ bem comum no combate à corrupção ……................................................................ 70

2.3.1 Efeitos políticos negativos da corrupção ................................................................ 71

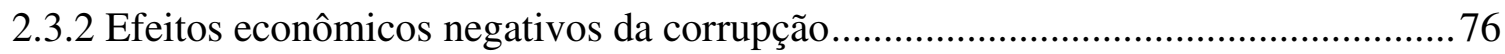

2.4 A legitimidade da ordem constitucional como pressuposto do combate à corrupção....78 
CAPÍTULO 3 - A CORRUPÇÃO NO CONTEXTO DA DICOTOMIA PÚBLICO-

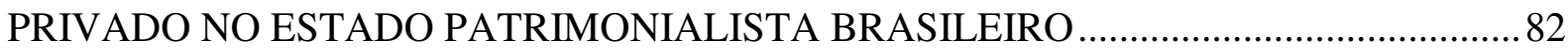

3.1 Direito posto e direito pressuposto enquanto parâmetro para a compreensão da evolução

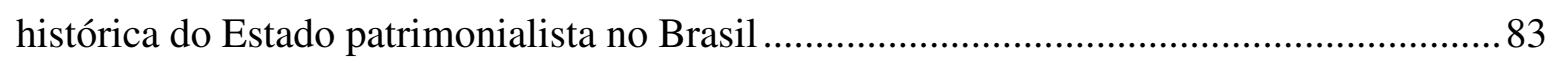

3.2 Antecedentes da colonização portuguesa no Brasil.................................................. 88

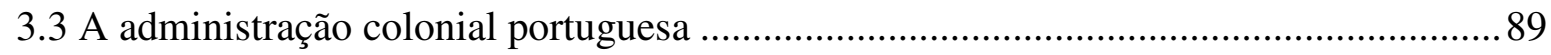

3.4 A progressiva importação de modelos de separação entre os espaços público e privado a

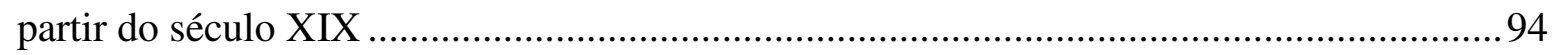

3.4.1 A manutenção do Estado patrimonialista após 1822 ….......................................95

3.4.2 Descentralização política no contexto da modernização formalista...................... 100

3.4.3 O acobertamento dos interesses privados no Estado patrimonialista no pós-1930104

3.4.4 Aperfeiçoamento normativo e incentivo estatal à formação do poder econômico no

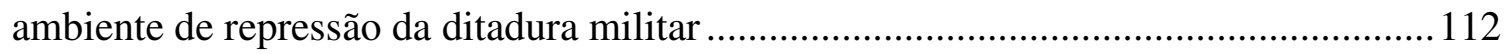

\section{PARTE II}

\section{A PERSPECTIVA MICROJURÍdICA NO COMBATE À CORRUPÇÃO .................. 118}

CAPÍTULO 4 - A CORRUPÇÃO NO DIREITO POSTO ..................................................... 118

4.1 Delimitação jurídica do conceito “corrupção" ............................................................. 120

4.1.1 Identificação e localização do fato corrupção no direito penal ..............................120

4.1.1.1 A globalização no combate à corrupção microjurídica ..................................126

4.1.2 Identificação e localização do fato corrupção no direito administrativo.................129

4.1.3 Identificação e localização do fato corrupção no direito político-constitucional.. 134

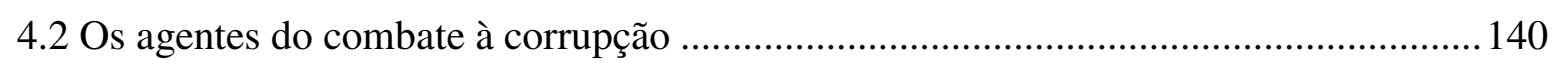

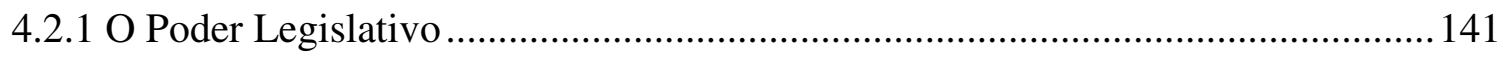

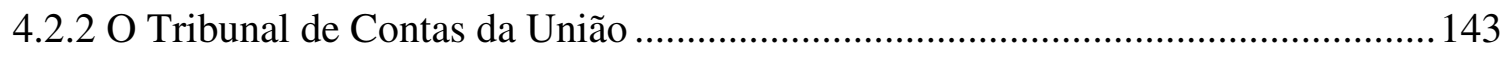

4.2.3 A ação policial de combate à corrupção ............................................................... 151

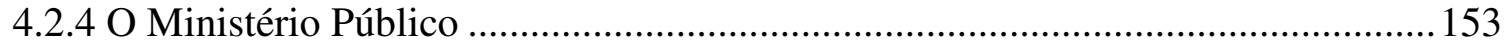

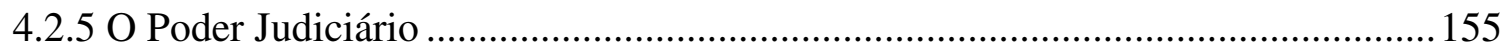

4.2.6 O papel da Controladoria-Geral da União.......................................................... 156

4.2.7 Combate à lavagem de dinheiro e recuperação de ativos ..................................... 159

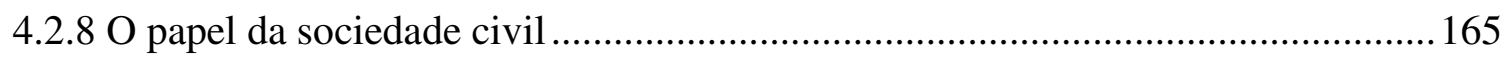

4.3 Existe um sistema nacional de combate à corrupção?................................................. 168 
4.4 Existe uma política nacional de combate à corrupção?

CAPÍTULO 5 - O FATO CORRUPÇÃO TOMADO COMO FUNDAMENTO DA REGULAMENTAÇÃO MICROJURÍDICA DOS DIREITOS PENAL, ADMINISTRATIVO

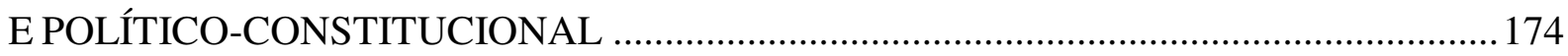

5.1 Abordagem tipológica da corrupção .................................................................. 174

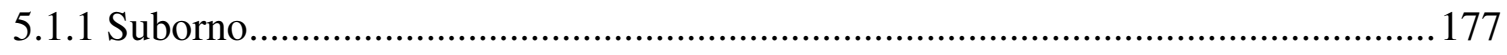

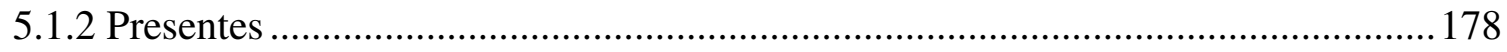

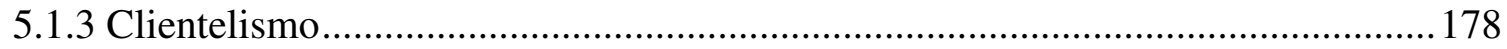

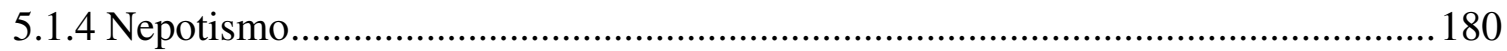

5.1.5 Favorecimento de amigos em cargos públicos .................................................. 181

5.1.6 Apropriação de bens e recursos públicos ........................................................... 181

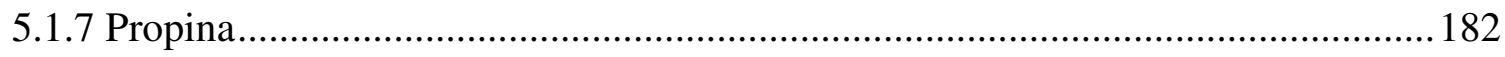

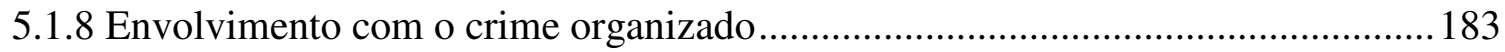

5.2 Características criminológicas dos ilícitos de colarinho branco................................... 184

5.3 Algumas variáveis normalmente associadas à corrupção........................................... 188

5.4 Arranjos político-administrativos e sua relação com a corrupção.................................. 193

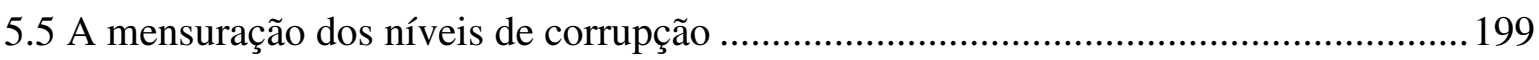

5.5.1 Alguns desdobramentos do Índice de Percepção da Corrupção.............................203

5.5.2 O Índice de Percepção da Corrupção e o Brasil ......................................................204

5.6 A indignada visão popular sobre a corrupção ............................................................206

5.6.1 Visão dos políticos sobre a corrupção ……….......................................................2210

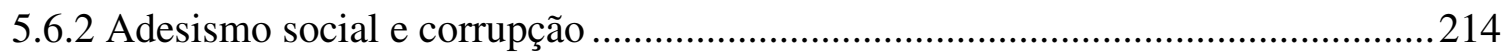

\section{CAPÍtUlO 6 - RESPOSTAS ALTERNATIVAS DA REGULAMENTAÇÃO}

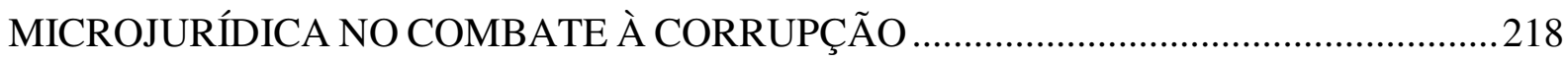

6.1 A teoria da regulação responsiva enquanto modelo para formulação e implementação de políticas públicas

6.2 Alguns aspectos da aplicação da teoria da regulação responsiva no combate à corrupção no Brasil.

6.2.1 A benign big gun e a possibilidade de cooperação com as autoridades de combate à corrupção ...

6.2.2 A compreensão das possíveis motivações dos agentes corruptos

6.2.2.1 Calculador amoral 
6.2.2.2 Cidadão político

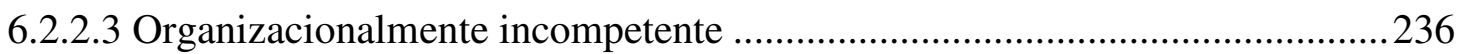

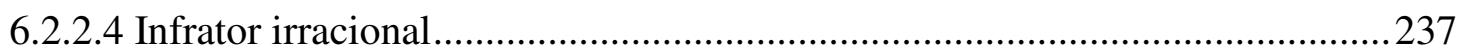

6.2.3 Diferentes estratégias para diferentes motivações.............................................238

6.2.4 Manipulação institucional de incentivos e desincentivos à corrupção ...................241

6.3 A necessária imagem de invencibilidade na repressão à corrupção vis-à-vis a

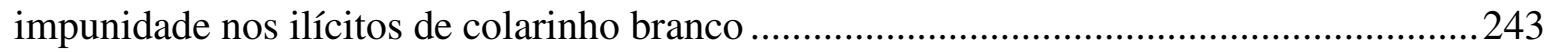

6.4. Teoria da regulação econômica: a tênue diferença entre captura e corrupção .............246

\section{PARTE III}

PREMISSAS PARA O COMBATE À CORRUPÇÃO NO PLANO MACROJURÍDICO

\section{CAPÍtUlO 7 - O FATO CORRUPÇÃO VISTO SOB A ÓTICA DO DIREITO

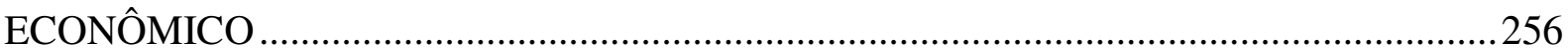

7.1 Poder, dever e autoridade na teoria geral do direito e na realidade do Estado

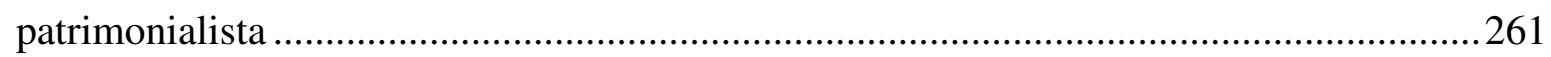

7.2 Funcionalismo público entre o profissionalismo e o corporativismo...........................268

7.3 A transparência e os interesses privados nas decisões estatais......................................244

7.4 Discricionariedade, separação entre os poderes e interesses privados .........................282

7.4.1 Revisão judicial do ato administrativo enquanto limitação aos interesses privados, exame da finalidade do ato e teoria do desvio de poder.................................................286

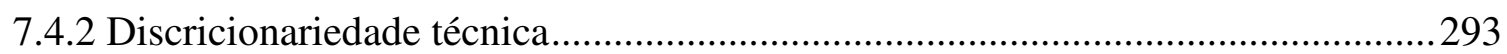

7.5 Corrupção e descentralização na federação brasileira ................................................298

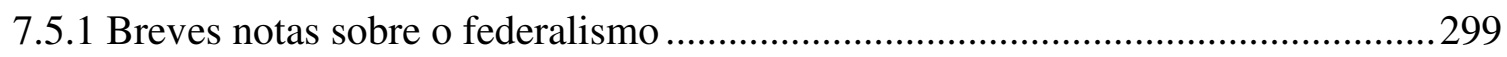

7.5.2 Qual o grau de descentralização ou centralização da federação brasileira? ...........302

7.5.3 O tridimensionalismo na federação e sua relação com a fragilidade econômica ..306

7.5.4 A problemática divisão das receitas sob a ótica do federalismo fiscal...................310

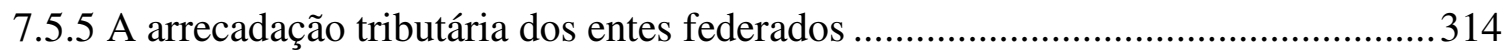

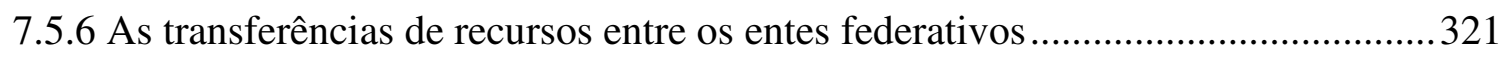

7.5.6.1 Do Fundo Social de Emergência às Desvinculações de Receita da União:

impacto sobre as transferências obrigatórias para os entes federativos. 
7.5.6.2 A insuficiência das transferências obrigatórias e o papel das transferências voluntárias

7.5.6.3 Transferências voluntárias na Lei de Responsabilidade Fiscal

7.5.7 Os recursos para as autarquias de fomento de desenvolvimento regional

7.5.8 Efeitos do desequilíbrio entre receitas e despesas dos entes federativos mais

fragilizados

7.6 O processo orçamentário como incentivo à subversão da dicotomia entre os espaços público e privado

7.6.1 Visão geral do processo de elaboração orçamentária

7.6.1.1 O processo orçamentário perante o Poder Executivo

7.6.1.2 O processo orçamentário perante a Comissão Mista de Planos, Orçamentos

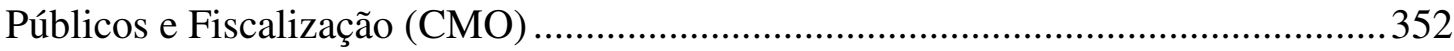

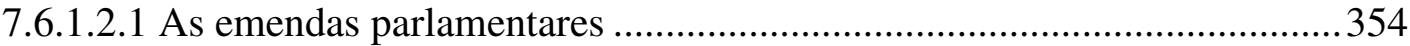

7.6.3 O orçamento novamente perante o Poder Executivo...............................................358

7.6.4 A realização das despesas pelo Executivo e a não impositividade do orçamento. 361 


\section{INTRODUÇÃO}

"Ou o Brasil acaba com a saúva, ou a saúva acaba com o Brasil."

É controversa a autoria dessa frase, que tem sido utilizada pelo menos desde o século XIX para chamar a atenção para uma das principais pragas que assolam a agricultura brasileira. Talvez tenha sido Auguste de Saint-Hilaire, em sua obra Viagem pelas províncias de São Paulo e Santa Catarina, datada de 1851, quem registrou a célebre frase, mas com preocupação voltada para o problema meramente ecológico. ${ }^{1}$ Em 1915, Lima Barreto publica Triste fim de Policarpo Quaresma, no qual a saúva, ao lado das mesquinharias da política interiorana, aparece como empecilho para a concretização do pleno desenvolvimento agrícola do país, tal como propugnado pelo protagonista do romance. ${ }^{2}$

Contudo, em 1928, coube a Mário de Andrade utilizar a palavra "saúva" na sua obra Macunaíma: o herói sem nenhum caráter num sentido metafórico. "Pouca saúde e muita saúva, os males do Brasil são", ${ }^{3}$ proclama o herói sem nenhum caráter para se referir indiretamente à politicagem eleitoreira e assistencialista que àquela época já vilipendiava o princípio republicano. Em poucos anos, o uso se popularizou, especialmente por volta de meados do século XX, quando o regime democrático, juntamente com a conformação das forças político-sociais, permitiu o desnudamento de práticas ilegítimas e ilegais para grande parcela da população.

Desde então, a saúva continua a assolar a agricultura nacional sem ter sido encontrada uma solução adequada para a praga. Para adicionar seriedade e complexidade ao cenário, novas pragas foram introduzidas, tais como o amarelinho, a ferrugem asiática e o capim anoni. A comparação com a vida política brasileira é inevitável. Da mesma forma, o coronelismo, o clientelismo explícito e a mera apropriação da máquina pública pelo vencedor das eleições não foram expurgados, mas a eles foram adicionadas formas mais dissimuladas

\footnotetext{
${ }^{1}$ SAINT-HILAIRE, Auguste de. Voyage dans les provinces de Saint-Paul et de Sainte-Catherine. Paris: A. Bertrand, 1851.

${ }^{2}$ BARRETO, Lima. Triste fim de Policarpo Quaresma. São Paulo: Moderna, 1984. p. 38 e ss.
} 
de corrupção, muitas das quais de tipificação jurídica difícil. $\mathrm{O}$ abuso do poder econômico nas eleições, o sucesso de políticos locais que prometem obter verbas federais para obras, o fiscalismo associado a um sistema arrecadador pródigo em criar dificuldades e as negociatas de grandes contratações públicas são algumas das formas que a corrupção assume em princípios do século XXI.

A nota comum entre a saúva e a corrupção é a sua persistência ao longo do tempo. Apesar de esforços reiterados, tanto a saúva quanto a corrupção continuam a assolar o país dados da ONG Transparência Internacional afirmam que, entre 1998 e 2008, a percepção de corrupção no Brasil permaneceu praticamente estável. Historicamente, inúmeros controles foram instituídos para frear a corrupção, mas, ainda assim, ela continua a existir sob a égide de tais controles. $\mathrm{O}$ mesmo acontece com as ações para ressarcimento para os danos causados à Fazenda Pública - o pagamento das indenizações, especialmente quando há repatriação de ativos envolvida, revela-se tarefa hercúlea em que apenas fração dos recursos usurpados é recuperada, quando isso ocorre. O paradoxo é que, apesar desse fracasso, há instrumentos legais que permitem a repressão, ao menos em sua faceta mais evidente. Como se explica, então, a persistência da corrupção em níveis tão elevados, quer seja na esfera da administração pública, quer seja no âmbito das práticas políticas?

Apesar do aparente fracasso no combate à corrupção, é notável que ainda persista a indignação na sociedade brasileira, quer seja nos esforços daqueles que se dedicam à sua repressão, quer seja nas manifestações populares, quer seja na vocalização da mídia. $O$ inconformismo popular é o justifica e até mesmo torna necessário estudar a corrupção sob os mais variados aspectos. A existência de várias regras jurídicas sobre o tema revela que, pelo menos, os políticos ecoam algo por que a população clama, e a comunidade jurídica sempre esteve à frente do combate à corrupção, especialmente em virtude do caráter repressivo criminal e indenizatório.

Desde a separação ocorrida entre o patrimônio do soberano e do Estado e a impessoalização das relações entre o cidadão e o Estado, o direito tem se preocupado em garantir que a confusão não volte a ser a regra. O processo histórico de formação do Estado no Brasil torna a confusão uma tendência que dissipa a eficácia das formais regras das divisoras do público e do privado: se atualmente a apropriação pura e simples do patrimônio é pouco factível, essa tendência se metamorfoseou e assumiu formas diversas. O suborno em dinheiro, escondido em peças do vestuário, continua a oferecer à mídia espetáculo constante

\footnotetext{
${ }^{3}$ ANDRADE, Mário. Macunaíma, o herói sem nenhum caráter. São Paulo: Livraria Martins, 1944. p. 87.
} 
que indigna os cidadãos, pagadores de impostos. A corrupção, porém, toma outras formas mais sutis que igualmente revelam uma subversão do público pelo privado.

Para compreender o modus operandi dessa metamorfose da corrupção, o auxílio à teoria geral do direito é instrumental. A divisão entre o público e o privado não decorre somente nas regras formais, explicitamente aprovadas pelo Legislativo. Juntamente com tais regras, foi estruturada uma nova forma de relação entre o poder estatal e o seu detentor: aquele investido de cargo público somente pode utilizar o poder para o cumprimento de um dever (poder-dever). Sob essa perspectiva, a corrupção, caracterizada por práticas nascentes no direito pressuposto, aflora sob outras formas, subvertendo a finalidade que instituiu a divisão entre os espaços público e privado.

Por conta dessa premissa, um dos principais pontos desta tese se assenta justamente na identificação de que, ao lado das necessárias medidas da regulamentação microjurídica no combate à corrupção, a corrupção se desdobra em implicações macrojurídicas e decorre, em parte substancial, do direito pressuposto, impregnado por condicionantes histórico-culturais. Em outras palavras, há um conflito latente entre o direito posto, manifestado pelas medidas legais positivadas de combate à corrupção, e o direito pressuposto, que trabalha a favor da manutenção do status quo nessa seara. A existência do conflito em si demonstra que a corrupção não constitui um problema atávico do brasileiro, mas sim parte de uma realidade histórica específica.

$\mathrm{Na}$ condição de estudo na área de direito econômico, esta tese parte de uma visão holística sobre as várias divisões didáticas do direito e pretende se afastar de uma concepção restritiva do direito que lhe retira grande parte da utilidade. Se o "direito não se interpreta em tiras", devem-se estudar as várias regulamentações microjurídicas que se voltam para o combate à corrupção. Por isso, propõe-se a adotar a multidisciplinaridade, inclusive no que tange aos próprios métodos do direito, para investigar a corrupção. Nesse contexto, compreender pelo menos o básico regulado pelo direito penal, administrativo e políticoconstitucional e a forma como se dá o seu relacionamento recíproco é passo inerente para uma efetiva multidisciplinaridade. Esse é o motivo por que se julgou necessário tecer algumas considerações metodológicas sobre a forma de desenvolver o trabalho antes de se analisar o tema da corrupção propriamente.

Feitas as considerações metodológicas pertinentes para atingir o objetivo a que se propõe, esta tese será dividida em três partes principais. Na primeira parte ("Fundamentos para a compreensão da corrupção no Brasil’”), a tese analisará a corrupção de uma perspectiva 
multidisciplinar, propondo compreender como historicamente se verificou a incorporação cultural de certas práticas corruptas até o cenário pós-Constituição de 1988. O capítulo 1 ("Limites entre os espaços público e privado") fornece o instrumental teórico necessário para compreender o problema, distinguindo o que se deve entender por espaço público e privado a corrupção surge quando se estabelece uma zona de penumbra nessa dicotomia, permitindo a vulgarização da máxima do Barão de Itararé de que, "no Brasil, a vida pública é, muitas vezes, uma continuação da privada". O capítulo 2 ("Corrupção: conceito e efeitos") apresenta a aproximação adotada para o termo "corrupção", apresentando definições delimitadoras de seu conteúdo com base na dicotomia público-privado. O capítulo 3 (“A corrupção no contexto da dicotomia público-privado no Estado patrimonialista brasileiro") analisa como a importação dessa dicotomia para o Brasil, ocorrida algumas décadas após o seu amadurecimento na teoria política europeia e norte-americana, foi recepcionada e transformada pelas condições culturais nacionais. À análise das condições formais da separação entre o público e o privado é adicionada a transformação operada pela importação formal, que teve por consequência redefinir alguns comportamentos das autoridades.

$\mathrm{Na}$ segunda parte (“A perspectiva microjurídica no combate à corrupção”), a tese descreverá e analisará as estratégias da regulamentação microjurídica de combate à corrupção, inclusive as novas técnicas de modelagem institucional sugeridas. Assim, o capítulo 4 ("A corrupção no direito posto") concluirá a descrição do processo histórico, expondo um quadro que resume o estágio atual da dicotomia público-privado na legislação, bem como a atuação dos principais agentes envolvidos no combate à corrupção. Os mecanismos jurídicos de combate à corrupção são objeto de reflexão tanto no seu aspecto formal, quanto no aspecto relacionado ao impacto efetivo sobre as condutas reprimidas.

O capítulo 5 (“O fato corrupção tomado como fundamento da regulamentação microjurídica dos direitos penal, administrativo e político-constitucional”) investigará os principais caracteres da corrupção numa perspectiva microjurídica, explicitando o que é regulamentado pelos direitos penal, administrativo e político-constitucional - ao término, serão traçadas algumas considerações sobre o comportamento de parte da sociedade e dos políticos em relação ao tema e sobre as suas implicações. Sem considerar a corrupção como um fenômeno universal e atemporal, o texto fornecerá subsídios informativos sobre como se pode verificar a formatação do direito pressuposto. Por seu turno, o capítulo 6 ("Respostas alternativas da regulamentação microjurídica no combate à corrupção”) sintetizará a discussão sobre alguns novos modelos de combate à corrupção, voltados para a tentativa de 
compreender e alterar o racional mercantil da corrupção, e apontará em que proporção algumas sugestões para aperfeiçoar as medidas microjurídicas podem ser aplicadas no Brasil. Como se observará, embora tais técnicas tenham alguma eficácia, elas tendem a ignorar o direito pressuposto brasileiro. A teoria da regulação econômica, associada à "compra" de legislação pelos interessados, também será abordada, uma vez que muitas de suas ponderações se encontram numa área limítrofe entre o lícito e o ilícito.

Por fim, na terceira parte ("Premissas para o combate à corrupção no plano macrojurídico"), com base no diagnóstico feito, o capítulo 7 ("O fato corrupção visto sob a ótica do direito econômico") analisará uma parcela do fenômeno corrupção que não é regulada pelo ordenamento jurídico, embora possa ser considerada uma subversão do espaço público pelos interesses privados - algumas delas têm origem em desenhos institucionais constitucionalizados, ou se disfarçam sob os seus mantos. A relevância dessa abordagem deriva do fato de essas condutas também impactarem o desempenho dos mecanismos repressivos no plano microjurídico, na medida em que práticas e condutas, por exemplo, relacionadas ao orçamento da União alimentam uma cultura política em que os recursos públicos são utilizados para fins privados dos ocupantes de funções públicas. Quando há ilícito, as repercussões ficam restritas ao âmbito dos direitos criminal e administrativo, não obstante ser possível vislumbrar repercussões que se espraiam por toda a economia, determinando práticas políticas e empresariais e condicionando o grau de eficiência da economia.

Ao fim do trabalho, mais especificamente, haverá duas contribuições originais à ciência jurídica brasileira. A primeira consistirá na sistematização da literatura jurídica e não jurídica sobre a corrupção, indicando-se as suas linhas gerais. Já a segunda contribuição é exatamente o desnudamento da omissão do aspecto macrojurídico importante no combate à corrupção, o que, voluntária ou involuntariamente, compromete a eficiência das medidas microjurídicas adotadas. Com a incorporação da teoria geral do direito à análise, a tese demonstrará a existência de um problema na forma como a autoridade enxerga o seu relacionamento com o poder: visto como um direito, o poder exercido pela autoridade é desvinculado de qualquer função a ser exercida e, dessa forma, fica sujeita aos meros interesses pessoais do seu titular. Tal concepção, obviamente, é incompatível com a moderna visão do direito público, que atribui ao titular de um poder o dever de agir de acordo com uma finalidade. 


\section{CONSIDERAÇÕES METODOLÓGICAS}

Antes de adentrar propriamente no estudo da corrupção, é necessário posicionar o trabalho metodologicamente.

Os objetivos visados nesta tese só poderão ser atingidos se houver um método do direito que seja consistente com a realidade e com a multidisciplinaridade das premissas adotadas. À primeira vista, esta essa asserção pode parecer simplória e, sob dada perspectiva, até mesmo redundante - a comprobabilidade de uma tese depende umbilicalmente do método adotado. Entretanto, o tradicional pensamento jurídico no Brasil faz essa tarefa não ser tão fácil quanto possa parecer. A causa dessa dificuldade metodológica reside justamente na forma particular como o positivismo impregnou o pensamento jurídico brasileiro. Conforme resume Reale, o objeto do direito nessa visão seria "compreender e aplicar a norma jurídica na plenitude lógica inerente ao ordenamento, e não em função de fatores metajurídicos". ${ }^{4}$ A exacerbação da busca pela "plenitude lógica" produz uma miopia na análise do direito vis-àvis a realidade que o circunda. Nada poderia ser mais nefasto para a compreensão da corrupção do que se centrar nas formas e ignorar a realidade, pois, muitas vezes, as práticas corruptas se camuflam e se confundem sob o véu da legalidade.

Veja-se o caso do nepotismo nos cargos comissionados: a ausência de vedação explícita conduziria à assunção de que é permitido. Silogisticamente, nada pode ser repreendido nesse raciocínio, repetido a esmo pelos defensores da prática. Contudo, confrontado com os princípios da impessoalidade e da moralidade na administração pública, o nepotismo se torna vedado. Ainda que inexistentes tais princípios, a própria noção de poderdever, inerente ao direito público, o vedaria, na medida em que o poder de nomear cargos comissionados precisaria se pautar por critérios aplicáveis a toda a máquina administrativa. $\mathrm{O}$ excesso de formalismo conspira a favor da corrupção, pois quem detém o poder decisório, inclusive os corruptos e os corruptores, é capaz de influenciar na moldagem dela.

\footnotetext{
${ }^{4}$ REALE, Miguel. $O$ direito como experiência: introdução à epistemologia jurídica. São Paulo: Saraiva, 1968. p. 98. O autor analisa as repercussões de certa corrente positivista no direito penal, área em que a "problemática axiológica" é tão presente. Penalistas reconheceriam a necessidade de "estudo das causas das relações jurídicas ou do crime", bem como a "observação da realidade social e dos fins da convivência quando da feitura da norma". Todavia, esses tópicos não seriam "objeto da Ciência Jurídica como tal, mas de ciências perfeitamente distintas, como seriam a Sociologia, a Criminologia ou a Política stricto sensu. Os juristas devem ficar adstritos à sua tarefa própria, representada pelo estudo sistemático e objetivo do direito vigente".
} 
O uso de métodos formalistas tão criticados para tratar de um tema atual pode levar à conclusão de algo em desacordo com a realidade e de utilidade limitada ao debate no âmbito do formalismo jurídico. Critica-se o positivismo de viés formalista, ignorando-se que a mera substituição da temática é incapaz de produzir uma ruptura que aproxime as conclusões da realidade. Um método novo (ou, ao menos, diferente) é necessário. Ignora-se que as normas jurídicas, especialmente aquelas de caráter programático, devem ser interpretadas de acordo com a realidade, ${ }^{5}$ minorando a importância da adequação meramente silogística a um conceito preestabelecido. $^{6}$

Não é objetivo desta tese repisar as críticas comuns ao formalismo jurídico - estas já são bem conhecidas na literatura jurídica. ${ }^{7}$ Embora a limitação funcional seja inerente ao positivismo jurídico em $\mathrm{si}^{8}{ }^{8}$ o verdadeiro problema reside na leitura formalista que dele se faz no Brasil. Nesse contexto, quid iuris é saber como superar as dificuldades impostas diante de um vácuo metodológico.

O ponto inicial é substituir o objeto do direito, o qual deixaria de ser "um sistema de regras já postas e transmitidas" e passaria a ser "um conjunto de regras em movimento, a serem propostas e repropostas continuamente". Em outras palavras, seriam deixadas de lado as "valorações sociais nas quais as regras consistem" e seriam adotados os "próprios fatos sociais dos quais as regras jurídicas são valorações". ${ }^{9}$

Seguindo a leitura brasileira sobre a orientação positivista de apartar o direito da realidade, os interesses envolvidos foram marginalizados do debate jurídico. Ainda que a noção de interesse ensaie um retorno à cena principal, especialmente na terminologia sobre interesses coletivos e difusos, ela ainda é limitada, em sua maior parte, à legislação processual. Tal estreitamento pode ser apontado como a causa da progressiva marginalização do direito do processo de elaboração das normas - enquanto sistema baseado somente em si mesmo, incapaz de visualizar o contexto de pressões sociais em que as normas jurídicas nascem, seria natural que a contribuição do direito fosse excluída do de lege ferenda. Até mesmo a teoria da regulação econômica, inspirada por economistas de orientação liberal,

\footnotetext{
${ }^{5}$ CARVALHOSA, Modesto Souza Barros. Poder econômico: a fenomenologia - seu disciplinamento jurídico. São Paulo: Revista dos Tribunais. 1967. 145 f. Tese (Doutorado em Direito Comercial)-Faculdade de Direito, Universidade de São Paulo, São Paulo. p. 142.

${ }^{6}$ AZEVEDO, Antonio Junqueira. O direito ontem e hoje. Crítica ao neopositivismo constitucional e à insuficiência dos direitos humanos. Revista do Advogado, São Paulo, AASP, ano 28, n. 99, p. 12, set. 2008.

${ }^{7}$ Para uma síntese das críticas mais comuns ao positivismo, ver KELSEN, Hans. Teoria pura do direito. 4. ed. São Paulo: Martins Fontes, 1994. p. XI-XV.

${ }^{8}$ ALVES, Alaôr Caffé. Lógica, pensamento formal e argumentação: elementos para o discurso jurídico. Bauru: Edipro, 2000. p. 25.

${ }^{9}$ BOBBIO, Norberto. Da estrutura à função: novos estudos de teoria do direito. Barueri: Manole, 2007. p. 40.
} 
identifica os interesses por trás da produção normativa. É difícil situar a dicotomia públicoprivado sem considerar o móvel da ação dos atores envolvidos no processo de formação do interesse público.

Mais do que em qualquer tema de direito processual, os interesses, ligados do ponto de vista psicológico às necessidades, ${ }^{10}$ ajudam a compreender o comportamento humano em relação à res publica, especialmente quando esta se encontra sob assédio constante. As normas jurídicas constituem produtos dos interesses que impregnam o processo decisório, cabendo ao juiz identificar a sua finalidade e persegui-la ${ }^{11,}$ o que guarda certa semelhança à doutrina utilitarista inglesa de Bentham, fundada nos fins e interesses. ${ }^{12}$ A compreensão dos interesses encapsulados nas normas jurídicas facilita o desnudamento de como estas contribuem para a perpetuação das práticas corruptas. O modus operandi das instituições jurídicas relacionadas ao surgimento e à manutenção de práticas corruptas requer a identificação dos interesses por trás dessas instituições - podem estas ser estruturadas para perpetuar a corrupção?

Nem sempre os interesses refletidos nas normas jurídicas serão homogêneos. Pelo contrário, o advento do Estado intervencionista positivou uma pletora de interesses dos diversos grupos protagonistas do processo político. ${ }^{13}$ No Brasil do pós-1930, o ápice desse processo foi a Constituição de 1988, a qual aloja interesses travestidos de "normas-objetivo" aparentemente contraditórias - um exemplo dessa contradição é a mera enunciação da forma republicana federativa sem que a isso corresponda uma divisão de tributos condizente. $\mathrm{O}$ processo político nas sociedades democráticas permitiria esse embate de interesses. Como sugere Nusdeo, “esta mesma dimensão procedimental aplica-se igualmente ao próprio processo de elaboração de normas legais ou regulamentares, as quais não podem ser fruto exclusivo de decisões por órgãos puramente políticos (parlamento, câmaras de vereadores,

\footnotetext{
${ }^{10}$ ROSS, Alf. Direito e justiça. Bauru: Edipro, 2000. p. 409.

${ }^{11}$ HECK, Phillip. Gesetzeauslegung und Interessenjurisprudenz. In: Archiv für die civilistische Praxis, n. 112, p. 17 Apud LARENZ, Karl. Metodologia da ciência do direito. 3. ed. Tradução de José Lamego. Lisboa: Fundação Calouste Gulbenkian. 1997. p. 65-66.

${ }^{12}$ HORN, Norbert. Introdução à ciência do direito e à filosofia jurídica. Tradução da $2^{\mathrm{a}}$ edição alemã de Elisete Anoniuk. Porto Alegre: Sérgio Fabris Editor, 2005. p. 167.

${ }^{13}$ MEYNAUD, Jean. L'executif dans l'État moderne. Bulletin international des sciences sociales, Paris: Unesco, v. 10, n. 2, p. 199, 1958. "Cette proposition semble d'autant plus valuable que la fragmentation politique du parlement est plus accentuée: comment envisager, par exemple, la reconnaissance, même tacite, de normes d'intérêt général par une assemblée composée de multiples fractions qui ne cessent de s'entredéchirer et qui sont conduites, par une logique insurmontable, à apprécier toute mesure en termes d'influence électorale?"
} 
assembléias) permeáveis a grupos de pressão, mas devem envolver, de forma aberta, a presença dos interesses relevantes por ela afetados". ${ }^{14}$

Apesar do aparente caos relacionado à procedimentalização dos interesses, as ciências sociais já identificaram algumas práticas, vinculadas a interesses que possuem excepcional capacidade de permanência no Brasil - no exemplo dado, contrapõem-se interesses político-burocráticos centralizadores aos de autonomia local. Como explica Bobbio, trata-se de "utilizar os conhecimentos cada vez mais adequados que as ciências sociais estão à altura de nos fornecer sobre as motivações do comportamento desviante e sobre as condições que o tornam possível com o objetivo não de recorrer às reparações quando ele já houver sido praticado, mas de impedir que ocorra". ${ }^{15}$

Quando interesses se positivam em regras jurídicas e, simultaneamente, os titulares de tais interesses agem sem o elemento limitador da dicotomia público-privado, inclusive as legais, o discurso jurídico legislado pode-se transformar num instrumento legitimador de práticas corruptas. Nesse momento, o positivismo jurídico, na sua vertente formalista, contribui para a manutenção sistêmica das práticas corruptas, uma vez que revela sua faceta redutora e simplificadora da realidade - a corrupção deve ser tratada com a aplicação dos tipos penais ou sanções administrativas. Colocada na frente de batalha da corrupção no plano jurisdicional e normativo, a particular visão positivista do direito brasileiro utiliza seus instrumentais sem atentar para as possíveis contribuições das demais ciências sociais e perde consciência da finalidade de seu trabalho. Ainda que não se interprete o "direito em tiras", como recomenda Grau, existe esse risco - tratar da corrupção é particularmente arriscado, uma vez que o penalista tende a focar o direito penal, o administrativista, no direito administrativo, e o constitucionalista, no direito político-constitucional. Enquanto método, o direito econômico tem o potencial de lançar um olhar diferenciado sobre o problema tratado isoladamente e pode auxiliar no estabelecimento das relações entre a regulamentação micro e macrojurídica. Por esse motivo, o passo seguinte deste trabalho é revelar como e em que medida o caráter valorativo do direito pode propiciar a tomada de decisões que visem a expulsar interesses contrários ao sistema democrático do seio do Estado.

Entra em cena o caráter axiológico do direito. Os valores ajudarão a guiar a identificação dos objetivos da ordem jurídica que devem ser usados como parâmetros válidos de interpretação. Entretanto, não se pretende apelar para valores metafísicos, distantes da

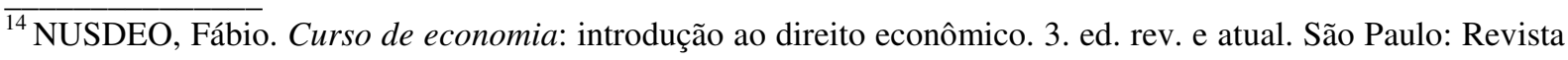
dos Tribunais, 2001. p. 222.

${ }^{15}$ BOBBIO, Norberto. Op. cit. p. 36.
} 
realidade. O que é a democracia moderna e quais são os limites da res publica são duas perguntas cujas respostas fornecidas hic et nunc por certos grupos de interesse não correspondem efetivamente na prática ao discurso exteriorizado nas normas vigentes, especialmente aquelas de natureza constitucional. Mais do que isso, o cenário brasileiro adiciona complexidade, uma vez que a distinção entre o espaço público e o privado nunca foi bem definida - vide o famoso "jeitinho brasileiro".

Nesse cenário, a obediência às regras jurídicas não pode ser só gramatical: a finalidade das normas deve assumir um papel nodal na aplicação do direito, levando-se em consideração a situação social dos interesses envolvidos. Mesmo assim, para uma certa posição cética, poderia permanecer alguma dúvida sobre como se estabelecer a finalidade a ser seguida, uma vez que a indicação de uma finalidade pela ordem jurídica poderia prescindir do detalhamento dos meios adotados. Por exemplo, alguns economistas argumentaram que, do ponto de vista essencialmente microeconômico, certas práticas corruptas não teriam consequências sobre o bem-estar social - logo, o combate à corrupção seria um falso moralismo que desperdiçaria recursos da sociedade. A sedução dos números normalmente associada à filosofia utilitarista pode conduzir a equívocos. Se observadas isoladamente, tais práticas corruptas podem até não ser nefastas economicamente sob certas circunstâncias, embora possam, sim, ter efeitos negativos, quer seja na corrosão do tecido social, quer seja na corrosão do ambiente de negócios com efeitos permanentes no longo prazo. Numa perspectiva mais ampla, esses efeitos se encontram ligados a fatores culturais que se relacionam ao funcionamento do sistema político. Por isso, a presente tese sempre atentará para o risco de sofismas nas conclusões.

Toda essa multiplicidade dos métodos contribuirá para a obtenção de resultados cientificamente inovadores e aceitáveis para o direito econômico. Enquanto método, o direito econômico contribuirá para amalgamar os fatos e produzir resultados. ${ }^{16} \mathrm{Na}$ síntese de Grau,

Pensar Direito Econômico é optar pela adoção de um modelo de interpretação essencialmente teleológica, funcional, que instrumentará toda a interpretação jurídica, no sentido que conforma a interpretação de todo o Direito. É compreender que a realidade jurídica não se resume ao Direito formal. É concebê-lo - o Direito

\footnotetext{
${ }^{16}$ A diversidade dos métodos não conduzirá à perda da consciência da unidade da tese. De outra perspectiva, a junção se fará também pela relativa similitude dos métodos aplicável às humanidades, que podem ser enquadrados em três elementos: a) pesquisa e observação; b) comparação; c) sistematização. Não se pode esquecer de que esses três elementos não se situam em tempos sucessivos ou diferentes da pesquisa: não se pesquisam primeiro os fatos para analisá-los em seguida pelo método comparativo e tirar ao fim uma sistematização. Comparação e sistematização estão presentes desde a fase de pesquisa; estão intrinsecamente ligadas à pesquisa e não têm condições de avançar sem ela. A distinção entre os três elementos só traz clareza e lógica à exposição.
} 
Econômico - como um novo método de análise, substancial e crítica, que o transforma não em direito de síntese, mas sim em sincretismo metodológico. ${ }^{17}$

Inspirado nesse sincretismo metodológico, o capítulo 6 se dedicará a identificar de que maneira a regulamentação microjurídica pode ser analisada através de um olhar distinto com base em algumas estratégias regulatórias, tais como a teoria da regulação responsiva, crescentemente utilizada a partir dos anos 1990 na persecução de objetivos de políticas públicas. De fato, as sugestões analisadas são flexíveis e permitem readequação constante às finalidades da política pública traçada. Mesmo assim, sua aplicabilidade permanece com um foco restrito, o que a torna propensa à utilização em microssistemas jurídicos, nos quais as motivações mercantis dos agentes possam ser identificadas com relativa facilidade.

Embora algumas das soluções propostas pela regulação responsiva tenham utilidade e eficácia em sistemas isolados, ignora-se o contexto macrojurídico, do qual podem provir estímulos contrários. Em algumas partes, esta tese analisará como as estratégias microjurídicas podem sofrer e sofrem reveses ao ignorar o(s) direito(s) pressuposto(s) brasileiro(s). Uma norma concebida com determinado objetivo pode ter efeito limitado ou oposto ao pretendido. De fato, condicionantes culturais podem fazer com que haja um descompasso, em determinada sociedade em determinado momento histórico, entre o direito pressuposto e o seu direito posto. ${ }^{18}$

Tal raciocínio é particularmente aplicável para a regulamentação microjurídica, que tem "como objeto a unidade de atividade e de sujeito". ${ }^{19} \mathrm{O}$ paralelismo com a microeconomia é evidente, o que se traduz, no caso específico do tema corrupção, na profusão de estudos sobre sistemas específicos regulados juridicamente, tais como o de compras públicas, financiamento de campanhas políticas e grau de transparência de contas públicas. Todavia, há questões mais abrangentes que realimentam as práticas corruptas no plano microjurídico. Os efeitos das políticas públicas no plano microjurídico podem perder a eficácia se desprovidas de medidas e rearranjos mais profundos - afinal, a penumbra existente na divisão das esferas

\footnotetext{
${ }^{17}$ GRAU, Eros Roberto. A ordem econômica na Constituição de 1988. 3. ed. rev. e atual. São Paulo: Malheiros, 1997. p. 168.

${ }^{18}$ GRAU, Eros Roberto. O direito posto e o direito pressuposto. 3. ed. São Paulo: Malheiros, 2000. p. 44. A afirmação encontra-se implícita na seguinte passagem: "Isso significa [...] que o termo direito pressuposto condiciona a elaboração do direito posto (direito positivo), mas este modifica o direito positivo".

${ }^{19}$ GRAU, Eros Roberto. Ibidem, p. 29. Embora Grau reconheça que haja paralelo entre a microeconomia e o microjurídico, os exemplos utilizados para descrever não parecem ser adequados. $\mathrm{Na}$ realidade, o microeconômico e, por via indireta, o microjurídico podem se referir a agregados, mas o nível de agregação não atinge a economia como o todo. A microeconomia trata de mercados, entendidos como sistemas, relativamente isolados do resto da economia: ainda que a ação individual seja relevante, o que conta é o todo do mercado. Por seu turno, nos exemplos de Grau, o macrojurídico se referiria a um agregado ainda menos amplo do aquele tratado pela macroeconomia, que engloba todos os mercados, vistos separadamente pela microeconomia.
} 
pública e privada produz efeitos palpáveis no plano microjurídico. Para tratar de dilemas como o da mal resolvida implantação do interesse público no Brasil, é imprescindível expandir o horizonte de análise para o macrojurídico, cujo objeto são os "agregados de atividades e de sujeitos" ou "agregados de ações econômicas, de um conjunto de agentes econômicos". ${ }^{20}$

Não é fácil alterar instituições consolidadas ao longo do processo histórico. A evolução institucional recente comprova que a permanência de certas estruturas e arranjos políticos resulta diretamente de interesses na manutenção do status quo, independentemente do fato de haver consenso de que certos padrões deveriam ser afastados. Aqui cabe o alerta de Rui Barbosa: "Ainda que a Constituição fosse tão perfeita, como se tivesse sido baixada dos céus, o País haveria de ser julgado não pelo seu texto, mas sim, segundo o modo pelo qual a pusesse em prática". ${ }^{21}$ Definitivamente este é o grande desafio de como se deve analisar o combate à corrupção: enxergar além do texto normativo para compreender o porquê da sua eficácia limitada.

\footnotetext{
${ }^{20}$ GRAU, Eros Roberto. Elementos de direito econômico. São Paulo: Revista dos Tribunais, 1981. p. 29.

${ }^{21}$ ATALIBA, Geraldo. Instituições de direito público e república. 1984. 215 f. Tese (Professor Titular)Faculdade de Direito, Universidade de São Paulo, São Paulo. p. 2.
} 


\section{PARTE I \\ FUNDAMENTOS PARA A COMPREENSÃO DA CORRUPÇÃO NO BRASIL}

\section{CAPÍTULO 1}

\section{LIMITES ENTRE OS ESPAÇOS PÚBLICO E PRIVADO}

O tratamento sistemático da corrupção somente pode ser feito se houver distinção clara entre os espaços público e privado ${ }^{22}$ o que só acontece com o advento do Estado Democrático de Direito. É nesse momento da evolução histórica que os papéis da sociedade e do Estado se delineiam mais claramente e a dicotomia sociedade civil-Estado adquire sentido mais palpável.

A ênfase é na corrupção no espaço público, o que traz uma dificuldade na medida em que este é multifacetado e apresenta diversas nuanças. Mais do que isso, embora abstratamente o Estado Democrático de Direito delineie onde estão as fronteiras entre o público e o privado, tal distinção deve ser compreendida concretamente, ou seja, num contexto histórico específico em determinado lugar.

Um exemplo da dificuldade e complexidade para se determinar o referencial é dado por La Palombara. A ciência política identifica três faces principais em que se desdobra o espaço público: a legislativa, a eleitoral e a administrativa. La Palombara as denomina arenas legislativa, eleitoral e administrativa, expressão que reflete o campo de embate de interesses opostos. ${ }^{23} \mathrm{~A}$ arena legislativa englobaria não somente a atividade dos corpos legislativos, mas também os detentores de cargos altos do Executivo. A arena eleitoral estaria relacionada ao processo de rodízio de cargos sujeitos ao escrutínio democrático, ao passo que a arena administrativa, à atividade da máquina estatal em sentido amplo, incluindo até mesmo os poderes Legislativo e Judiciário.

\footnotetext{
$\overline{22}$ Não se devem confundir as expressões "espaço público" e "espaço privado", tal como utilizadas neste trabalho, com as utilizadas em urbanismo, para contrapor a segregação imposta pelo direito de propriedade no uso do espaço urbano. Para o urbanismo, o espaço público se refere àquele que tem acesso franqueado a todos, ao passo que o espaço privado tem acesso condicionado ao que estabelecer o seu proprietário.

${ }^{23}$ LA PALOMBARA, Joseph G. A política no interior das nações. Tradução do $1^{\circ}$ ao $5^{\circ}$ capítulo de Marilu Seixas Correa e do $6^{\circ}$ em diante de Oswaldo Biato. Brasília: UnB, 1982. p. 373.
} 
É intuitivo perceber que tal distinção entre as três arenas, oriunda da ciência política, não é precisa. Onde enquadrar um juiz corrupto? Qual a distinção exata entre a arena legislativa e a eleitoral? Ou entre a arena eleitoral e a administrativa? Entretanto, a espécie de precisão requerida pelo direito pode ser amenizada por outras ciências sociais, uma vez que as três arenas fornecem uma visão geral de espaços e processos em que ocorre a corrupção. Deixando de lado os conceitos tradicionais de separações de funções estatais, um juiz corrupto poderia ser colocado na arena administrativa. Da mesma forma, a arena legislativa engloba o processo político a partir de dada conformação e distribuição de poder, enquanto a arena eleitoral trata da substituição dessa conformação.

Para a perfeita compreensão desse tema fundante para qualquer estudo sobre a corrupção, este capítulo tratará da origem e da evolução histórica da noção de espaço público e privado, enfatizando como a finalidade do Estado atuou na modernização da máquina burocrática e na definição da corrupção. Essa é uma usurpação do público pelo privado que subverte a confiança (trust) necessária às relações em cada esfera. Com base no conceito de confiança, será possível relacionar o substrato cultural à própria delimitação de espaço público e privado, o que ficará mais evidente ao se analisarem os antecedentes históricos dessa dicotomia. Nesse contexto, elemento cultural fomentador da corrupção pode surgir como descompasso entre o chamado direito posto e o direito pressuposto.

\subsection{Corrupção: da etimologia e da semântica à perversão da dicotomia público-privado}

Todos os trabalhos jurídicos deveriam conter algum estudo semântico, pois a precisão requerida pelo direito torna a semântica ferramenta importante para delimitar o alcance e sentido do objeto de estudo. ${ }^{24}$ Termos jurídicos podem sofrer mutação semântica sem que haja alteração extrínseca, quer pela "superveniência de certas normas", quer "pela alteração da tábua de valores da comunidade", quer "pelo advento de imprevistas condições técnicas, no plano fático". ${ }^{25}$

Essas assertivas não poderiam ser mais verdadeiras ao se tratar da palavra “corrupção", pois a percepção popular pode adicionar uma pletora de sentidos, uma vez que

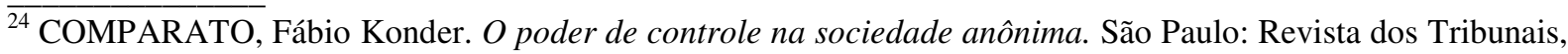
1976. p. 9. Ao analisar o vocábulo "controle", o autor tece as seguintes considerações introdutórias, plenamente aplicáveis ao que se propõe neste item: "Não se cuida, assim, em saber, de início, o que é controle, qual sua natureza jurídica ou a sua essência - indagações clássicas da teoria jurídica - porém, mais prudentemente, em que sentido empregamos o vocábulo, na linguagem vulgar e nos textos normativos".

${ }^{25}$ REALE, Miguel. $O$ direito como experiência: introdução à epistemologia jurídica. São Paulo: Saraiva, 1968. p. 210 .
} 
não coincide exatamente com os dicionarizados, fato que adiciona complexidade à delimitação do que se deve entender por corrupção. Mais ainda, esta pletora de sentidos impregna como a população compreende a dicotomia público-privado e lhe atribui consequiências. Talvez a poucos termos se aplique tão bem a assertiva de Hobbes: “[da] ignorância do significado das palavras [...] deriva que os homens dêem nomes diferentes a uma única e mesma coisa, em função das diferenças entre suas próprias paixões. Quando aprovam uma determinada opinião, chamam-lhe opinião, e quando não gostam dela, chamamlhe heresia". ${ }^{26}$

Essa inflação normativa decorre, entre outros fatores, de ser a corrupção um dos temas da agenda política brasileira da atualidade. Não houvesse a possibilidade de definir precisamente "corrupção", o debate entre os partidos políticos que se acusam mutuamente dessa prática seria inócuo. Uma mostra dos problemas decorrentes dessa abordagem fluida é que o debate sobre corrupção, ao atingir o plano político via mídia, enfrenta tentativas de defesa mediante a desqualificação das acusações, apresentadas como se fossem permitidas juridicamente, ainda que pudessem ser reprováveis moralmente - em outras palavras, nem tudo que é imoral é ilícito. Para um lado, determinada prática não seria corrupta, ao passo que para outro seria. No momento seguinte, quando os papéis se invertem, o que acontece na política brasileira com frequência impressionante, a polêmica seria revitalizada sem nenhuma perspectiva de solução. Para evitar essas idiossincrasias da política, deve-se tecer esclarecimentos sobre o significado da palavra "corrupção". A recomendação se torna mais percuciente quando a tese adota a interdisciplinaridade como nota orientadora. Como alerta Hobbes, os estudiosos de diferentes ciências sociais, cada qual dotado das suas "paixões", possuem opiniões sobre o objeto de estudo e acusam os demais de hereges.

As variadas perspectivas da população, dos políticos, dos estudiosos, entre outros, fornecem múltiplas concepções sobre a corrupção, as quais podem ser distintas entre si, mas não por causa disso menos afeitas à realidade. Pitorescamente, ao lado das divergências em estudos científicos, abundam palavras em diversas línguas e culturas para denominar a vantagem entregue ao detentor do poder na esfera pública. Conforme relata La Palombara,

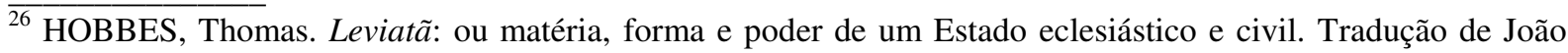
Paulo Monteiro e Maria Beatriz Nizza da Silva. Prefácio e revisão de João Paulo Monteiro. 2. ed. Lisboa: Imprensa Nacional, 1999. p. 94.
} 


\begin{abstract}
Algumas culturas têm palavras, algumas delas bastante coloridas para descrever tais práticas. Na Ásia, paga-se a baksheesh, enquanto na Itália paga-se la bustarella, isto é, o pequeno envelope, por cima ou por baixo da mesa. Nos países de língua espanhola ouve-se mencionar la mordida, literalmente, "a bola", que os servidores públicos recebem em troca de favores. Na Índia, tais pagamentos são chamados "dinheiro veloz"; na África, "pitada". A língua inglesa é rica em tais expressões, como: cinco-por-cento, payola, vendedor de influência, enxerto, graxa, comissão, suborno e restituição, para denotar as várias formas de corrupção política. ${ }^{27}$
\end{abstract}

O Brasil também possui seu espectro próprio de palavras coloridas para denominar as práticas corruptas: jabá, dinheirinho do café, lembrancinha e dez por cento podem ser adicionadas ao repertório mundial.

A riqueza vocabular não pode levar à perda do foco. Ao examinar a etimologia da palavra "corrupção", além da conotação ética, emerge um sentido físico-químico, uma vez que o latim corruptio indicaria a noção de "putrefação" e "decomposição". A palavra "corrupção" tem origem no latim corruptio, e seu sentido pode ser esmiuçado com mais detalhe. Para tanto, é necessário dividi-la em três partes: cor + rup + tio.

De plano, cabe apontar que o sufixo -tio corresponde ao sufixo -ção da língua portuguesa e que é utilizado de modo similar na formação de substantivos derivados de verbos com a ideia de ação. Portanto, corruptio deriva do verbo corrumpere. ${ }^{28} \mathrm{O}$ núcleo da palavra encontra-se na combinação do prefixo cor- com o verbo rumpere, ${ }^{29}$ que significa "romper", "quebrar", “despedaçar", "violar", "infringir". ${ }^{30}$ Assim, no verbo "corromper” está o sentido de "romper" e "quebrar", proveniente do radical rup, que, por sua vez, tem sua raiz no sânscrito lup. Essa raiz, oriunda de uma das mais famosas famílias linguísticas indoeuropeias, revela um forte significado de destruição e estrago. ${ }^{31}$ Já o prefixo cor- deriva da

\footnotetext{
${ }^{27}$ LA PALOMBARA, Joseph G. Op. cit. p. 369.

${ }^{28}$ LEITE, J. F. Marques; JORDÃO, A. J. Novaes. Dicionário latino vernáculo: etimologia, literatura, história, mitologia e geografia. Rio de Janeiro: Lanston do Brasil e Henrique Velho, 1944. p. 116. "Cōrrūptǐo, cōrrūptīōniss, s. f. Corrupção, depravação, deterioração. Cf.: corrumpere. [...] Cōrrūmp-ĕrĕ (o, ǐs, i, cōrrūpī, cōrrūptŭm), v. trans. Estragar, corromper, prejudicar, deteriorar; perder; danificar, viciar; perverter; subornar, peitar. Cf.: rumpĕre.

${ }^{29}$ JURET, A. Dictionnaire étymologique grec et latin. Macon: Protar Frères, Imprimeurs, Publications de la Faculté des Lettres de L’Université de Strasbourg, 1942. p. 154. "Rumpere, rūpī, ruptim: rompre, briser brutalement, casser; di+rumpere: mettre em pièces; inter+rumpere: séparer em brisant; cor+rumpere: briser l'énergie, la bonne qualité, d'où gâter, corrompre."

${ }^{30}$ LEITE, J. F. Marques; JORDÃO, A. J. Novaes. Op. cit. p. 421. "Rump-ĕrě (o, ı̌s, rūpī, rūptŭm), v. trans. Romper, quebrar, despedaçar, rasgar, fender, varar, penetrar, violar, infringir, arrebentar, importunar, interromper, estorvar, perturbar, atirar, lançar, arremessar, despenhar. A raiz aparece no sânscr. lumpāmi destruo."

31 MACDONELL, Arthur Anthony. A practical Sanskrit dictionary with transliteration, accentuation and etymological analysis throughout. Londres: Oxford University Press, Humphrey Milford, 1924. p. 263-264. "LUP, VI.P. (Â. metr.) lumpá [later form of rup; rare in V.] break, injure, spoil; seize, fall, or pounce upon; rob, plunder; waste; suppress, cause to disappear, elide (letter, word, etc.); ps. lupyate, be broken or torn, be waster,
} 
aproximação do prefixo co- com a letra " $r$ ". Como na língua portuguesa, o prefixo exprime união, simultaneidade ou intensificação. ${ }^{32}$ No caso do verbo corrumpere, o prefixo coraparece originalmente intensificando o verbo rumpere. Dessa maneira, de acordo com a sua etimologia, o verbo "corromper" apresenta dois principais significados: (i) de deterioração (originalmente relacionado à ideia de morte); e (ii) de intensa ruptura, tendo em vista que o verbo "corromper" é derivado do verbo "romper". ${ }^{33}$

Essas considerações se encontram presentes nos sentidos atuais. Do ponto de vista semântico, de acordo com o Dicionário Houaiss da língua portuguesa, a palavra corrupção possui seis acepções distintas:

\begin{abstract}
Corrupção. [...] Acepções — substantivo feminino: ato, processo ou efeito de corromper 1 deterioração, decomposição física, orgânica de algo; putrefação Ex.: c. dos alimentos 2 modificação, adulteração das características originais de algo Ex.: c. de um texto 3 Derivação: sentido figurado. depravação de hábitos, costumes etc.; devassidão 4 ato ou efeito de subornar uma ou mais pessoas em causa própria ou alheia, ger. com oferecimento de dinheiro; suborno Ex.: usou a c. para aprovar seu projeto entre os membros do partido 5 emprego, por parte de grupo de pessoas de serviço público e/ou particular, de meios ilegais para, em benefício próprio, apropriar-se de informações privilegiadas, ger. acarretando crime de lesa-pátria Ex.: é grande a c. no país 6 Rubrica: termo jurídico. disposição apresentada por funcionário público de agir em interesse próprio ou de outrem, não cumprindo com suas funções, prejudicando o andamento do trabalho etc.; prevaricação. ${ }^{34}$
\end{abstract}

Estes seis sentidos podem ser agrupados em dois grupos principais: os de número 1, 2 e 3 remetem à noção de deformação ou desvio, ao passo que os de número 4, 5 e 6 apresentam

be broken or violated (vow, etc.); be lost (share), disappear, be destroyed, be elided: pp. lupta, injured; plundered, deprived of $\left(\left(^{\circ}\right)\right.$; suppressed, lost, disappeared, destroyed, dropped, elided; elliptical (simile: opp. Pûrna); cs. lopaya, P. neglect; violate, infringe; divert or cause to swerve from (ab.); $\hat{A}$. cause to disappear, efface; intv. lolupya Â, lolup, P. confuse (any one). apa, pull out: sever; ps. Be troubled or clouded (gaze). viâ, remove, dispel (languor); ps. Disappear. pari, take away, remove, dispel; ps. be dropped. pra, pull out; rob, steal: $p p$. robbed, taken away, destroyed. vi-pra, snatch away, afflict; disturb, interrupt. vi, pull to pieces, break off; lacerate; pluck out; carry off, take away, rob, plunder; destroy, ruin; $\hat{A}$. \& ps. be impaired or destroyed, perish, disappear, be lacking:: pp. vilupta, pulled to pieces; snatched away; destroyed, lost; cs. withhold; extinguish; disregard, neglect. pra-vi, $p p$. removed, disappeared; cs. give up, abandon."

${ }^{32}$ LEITE, J. F. Marques; JORDÃO, A. J. Op. cit. p. 91. "co--- = con---. Prefixo inseparável que exprime união, simultaneidade ou intensificação. A forma co é principalmente usada antes de vogal inicial."

33 ERNOUT, A.; MEILlET, A. Dictionnaire etymologique de la langue latine, histoire des mots. Paris: Klincksieck, 2001. v. 2. "Rumpō, -is, rūpī (sur un future archaïque rupsit, V. Fest. Cite s.u. tāliō, et $d \overline{\mathrm{e}} r u m p \overline{0}$ ), ruptum, rumpere: briser avec force, rompre [...] corrumpō: a dû signifier d'abord 'faire crever'. S'est étendu ensuite à tout ce qui est susceptible de se gâter ou de se corrompre, sans que l'idée de 'briser, rompre' ait été envisagée, cf. Cés., BG. 7,55 relicum frumentum flumine atque incendio corruperunt, et s'est employé aussi au sens moral (cf. corruptiō, corruptor, corruptēla; incorruptus (class.), et les formes tardives incorruptiō, -tēla, tibilis, - tiuss, -torius de la 1 . de l'Église - a̋ $\varphi \theta$ o $\rho \varsigma_{\varsigma}$ á $\left.\varphi \theta o \rho i \alpha\right)$; le sens de 'mettre en pièces' étant reservé à confringō. Les formes romaines supposent un derive *corruptiāre, M.L. 2261, cf. 2262 *corruptum, d'où irl. corpte."

${ }^{34}$ HOUAISS, Antônio; VILLAR, Mauro de Salles. Dicionário Houaiss da língua portuguesa. Elaborado por Instituto Antônio Houaiss de Lexicografia e Banco de Dados da Língua Portuguesa S/C Ltda. Rio de Janeiro: Objetiva, 2001. p. 848. 
conotação mais técnico-jurídica, ainda que dotada de alguma imprecisão. Embora os sentidos do primeiro grupo lancem certa luz sobre a semântica da palavra "corrupção", para se obter um significado mais preciso da raiz é necessário estudar o verbo “corromper”, cujas acepções são transcritas abaixo:

Corromper [...] Acepções: a verbo transitivo direto e pronominal 1 tornar(-se) apodrecido ou estragado (falando de algo concreto); deteriorar(-se) Ex.: <a ferrugem corrompe o ferro $><$ os alimentos expostos corrompem-se facilmente $><$ o ambiente corrompia-se com a falta de ventilação $>$ transitivo direto e pronominal 2 perverter(-se) moral ou fisicamente Ex.: <os hábitos desregrados corrompem os jovens $><$ corrompeu-se na bebida $>$ transitivo direto 3 tornar diferente do que era originalmente; adulterar, alterar Ex.: a publicação descuidada corrompeu o texto produzido pelo cientista transitivo direto 4 subornar (pessoa) em função de interesse próprio ou de outrem Ex.: inescrupuloso, tentou c. o juiz. ${ }^{35}$

A análise do verbo "corromper" revela que a sua raiz guarda relação com uma noção estrita de deturpação, apodrecimento, deformação, degeneração, afastamento do ideal. Este sentido pode ser utilizado em diversos contextos. Na biologia, pode-se considerar corrupção como sinônimo do processo de decomposição. Na química, uma barra de ferro corrompida pode ser entendida como uma barra de ferro enferrujada.

Esse sentido de corrupção pode ser empregado também em contextos associados às humanidades em sentido figurado, mas sem se afastar da noção de ruptura com o ideal. Agora, o ideal é o modelo que é considerado como desejável. Duas perspectivas surgem: (i) corrupção enquanto afastamento de um modelo teórico e (ii) corrupção enquanto afastamento de uma determinada visão da sociedade sobre si mesma.

$\mathrm{Na}$ primeira acepção, Aristóteles ${ }^{36} \mathrm{em}$ A política fornece o paradigma em sua análise dos tipos de governo, traçando uma distinção entre os que são bons (monarquia, aristocracia e democracia ordeira), quando o governo age de acordo com o interesse comum, e os que são corruptos (tirania, oligarquia e democracia anárquica), quando o governo age de acordo com os interesses daqueles que detêm o poder. Tal distinção determinará o modo como a ciência política delimitou o estudo das formas de governo, replicando uma concepção valorativa sobre o que seria um governo bom ou corrupto. ${ }^{37}$

\footnotetext{
${ }^{35}$ Idem, Ibidem.

${ }^{36}$ ARISTÓTELES. A política. Tradução de Nestor Silveira Chaves. Introdução de Ivan Lins. Rio de Janeiro: Ediouro, [s.d.]. p. 61-67.

${ }^{37}$ CHAUI, Marilena. Introdução à história da filosofia: dos pré-socráticos a Aristóteles. São Paulo: Companhia das Letras, 2002. p. 469. “A diferença entre os regimes é estabelecida por dois critérios: pelo número de cidadãos, isto é, pelo número dos que exercem a autoridade e o poder político, e pela excelência específica (areté) que é valorizada nos governantes. Um só e a honra como areté nos dão a realeza; um só e o vício contrário à honra (vilania) nos dão a tirania. Alguns e as virtudes éticas nos dão a aristocracia; alguns e o
} 
Já na segunda noção, a corrupção seria um desvio em relação a um modelo ideal de sociedade e envolveria uma avaliação valorativa, envolta num forte componente subjetivo e moral. Na visão bíblica de Isaías, haveria corrupção numa cidade assim descrita:

\begin{abstract}
Como se prostituiu a cidade fiel, Sião, cheia de retidão? A justiça habitava nela, e agora são os homicidas. Tua prata converteu-se em escória, teu vinho misturou-se com água. Teus príncipes são rebeldes, cúmplices de ladrões. Todos eles amam as dádivas e andam atrás do proveito próprio, não fazem justiça ao órfão e a causa da viúva não é evocada diante deles. ${ }^{38}$
\end{abstract}

Por isso, um conservador enxergaria corrupção da sociedade em que prevalecesse a liberdade sexual. Numa sociedade fortemente patriarcal, a participação feminina no mercado de trabalho e no processo político poderia ser considerada uma forma de corrupção do tecido social.

Semelhante variação se daria também ao longo do tempo: talvez o conservador de hoje já não encare a liberdade sexual como tabu, ou uma sociedade patriarcal admita a participação feminina no processo político, sem, no entanto, eleger mulheres para cargos de liderança. Os variados níveis de adesão a valores permitem, por exemplo, que alguém que se considera antiamericano, posicionando-se contra a invasão do Iraque em 2003, não se incomode em fazê-lo vestindo calça jeans e bebendo Coca-Cola. A concepção do que seria corrupção é impregnada pela Weltanschauung de cada sociedade, sofrendo variações no tempo e no espaço.

Por sua vez, a segunda concepção admite ainda outros possíveis sentidos para a palavra “corrupção". Esta pode se manifestar em outras áreas em que seja exercido o poder, inclusive no setor privado. Assim, o poder econômico impõe ao seu titular o dever de se comportar de acordo com certos critérios estabelecidos constitucionalmente, de modo que a violação a esses critérios caracteriza o seu abuso ou, sob outra perspectiva, a sua corrupção. ${ }^{39}$

privilégio conferido à riqueza com seus vícios (prodigalidade e avareza) nos dão a oligarquia. Todos e a igualdade nos dão o regime constitucional ou popular; todos e o privilégio conferido à pobreza com seus vícios (grosseria, inveja, malevolência) nos dão a democracia. A tirania é o governo do interesse de um só e não é política senão no nome; a oligarquia é o governo dos ricos; a democracia, o governo dos pobres. Um regime é normal, correto ou bom e justo quando o governo é exercido para o bem de todos; é anormal, incorreto, mau e injusto quando é exercido em proveito próprio. Com isso temos o princípio da constituição política, isto é, aquilo que determina por que há regimes em que um só governa e outros em que alguns ou todos governam. Esse princípio é a virtude política, isto é, a capacidade e disposição para comandar para o bem de todos, ou seja, para assegurar o cumprimento da finalidade da Cidade, a autarquia coletiva ou felicidade do bem-viver comum."

${ }^{38}$ ISAÍAS. Português. In: Bíblia sagrada. 168. ed. Tradução portuguesa da versão francesa dos originais grego, hebraico e aramaico pelos monges beneditinos de Maredsous. Revisada por Frei José Pedreira de Castro. São Paulo: Ave Maria, 2005. p. 940 (Capítulo I, Versículos 21-23).

${ }^{39}$ LA PALOMBARA, Joseph G. Op. cit. p. 369. O autor exemplifica como nem mesmo a percepção do que seja corrupção no setor privado é uniforme. "A política de duas medidas chega a extremos nos Estados Unidos, onde 
De igual maneira, o diretor de uma sociedade anônima que, em benefício próprio, descumpre os deveres de lealdade estabelecidos na legislação societária age como um corrupto.

No entanto, para essa concepção, há condutas que configuram corrupção quando praticadas em espaços públicos, mas o mesmo não se verifica no espaço privado, uma vez que a corrupção só ocorreria na quebra de confiança. Imagine-se que um atacadista ofereça presentes a um pequeno comerciante para que este exponha com destaque um novo produto em detrimento de outros. ${ }^{40}$ Alguns logo poderiam denunciar a "corrupção" existente, mas, dados os padrões vigentes nas atividades mercantis, esse procedimento é lícito - se advir algum prejuízo ao pequeno comerciante, este deverá suportá-lo na íntegra, porque a aceitação "corrupta" do presente só se reflete na sua própria esfera patrimonial. Em certas circunstâncias, esse comportamento pode ser considerado legítimo no contexto do capitalismo concorrencial, que pressupõe uma acirrada disputa pela clientela - a quebra de confiança só ocorreria por atos de concorrência desleal ou práticas anticompetitivas. Por outro lado, essa mesma prática seria provavelmente considerada corrupta se ocorresse numa corporação de ofício medieval, na qual existia uma relação de confiança entre seus membros - até mesmo hoje, a vedação à mercantilização nos códigos de ética profissional de algumas profissões, tais como a medicina e a advocacia, reflete uma relação de confiança entre os seus pares.

O raciocínio utilizado por essa segunda visão poderia explicar, por exemplo, por que a grande maioria das pessoas não se sente "corrupta" quando incorre em atos de evasão fiscal, mesmo sabendo que isso causa a perda de arrecadação, o que pode prejudicar o atendimento das necessidades públicas pelo Estado e transferir do ônus da evasão aos contribuintes adimplentes regulares, entre diversos outros problemas sociais graves. Geralmente, esse tipo de comportamento tenta se justificar por um raciocínio similar à regra dos contratos bilaterais segundo a qual nenhum dos contratantes pode exigir o implemento da obrigação do outro antes de cumprir a própria obrigação. No entanto, problemas relacionados à moralidade no Poder Público não eximem as pessoas de cumprir a lei.

um dos mais fortes imperativos morais sempre foi o 'Seja Grande! Seja Rico!' As pessoas que conseguem ser ambas essas coisas no setor privado merecem elogios e todas as honras. Mas, se esse sucesso ocorre na esfera pública, ouvimos imediatamente protestos de que se trata de dominação e a velha suspeita de que tornar-se rico significa envolver-se em práticas corruptas. No setor privado, é perfeitamente aceitável que os executivos, jogadores de bola, atores de cinema e até mesmo banais trabalhadores também queiram 'entrar na bolada', mas não quando o patrimônio ou empresa em questão pertencem ao setor público. Podemos erigir um monumento ao empresário que açambarca o mercado de algodão, mas poremos na prisão a autoridade que açambarca o mercado de favores políticos."

${ }^{40}$ BRASZ, H. A. The sociology of corruption. In: HEIDENHEIMER, Arnold J. Political corruption: readings in comparative analysis. 2. ed. New Brunswick: Transaction Books, 1978. p. 42-43. O exemplo foi extraído deste texto. 
A dicotomia público-privado remete a regras de conduta distintas para cada um.

Apesar da existência da corrupção e de seus impactos na esfera privada, a população não percebe seus efeitos nitidamente. Esse sentido encontra-se implícito na maioria das denúncias de corrupção veiculadas pela mídia que, por essa razão, se referem à esfera pública. Devido à sua amplitude, a corrupção na esfera pública pode abarcar uma série de práticas distintas que não se encontram necessariamente abrangidas pelos tipos criminais, mas que têm em comum essa nota da confusão do que seria interesse público e privado. Dessa perspectiva, por exemplo, são consideradas práticas corruptas (i) o pagamento de propina para obtenção de vantagens em procedimentos licitatórios públicos; (ii) o pagamento de suborno para autoridade de trânsito visando à não imposição de multa pelo guarda de trânsito; (iii) doações, ainda que registradas perante a Justiça Eleitoral, para campanhas políticas com o objetivo de obter favores do candidato eleito; (iv) a contratação de parentes para exercer cargos públicos comissionados; (v) o uso de veículo oficial para levar o cachorro de ministro ao veterinário; (vi) o voto favorável ao governo federal em troca de cargos públicos para correligionários ou liberação de recursos para a base eleitoral; (vii) a manipulação arbitrária do orçamento da União; e (viii) o corporativismo de parcela do funcionalismo público. Dessa perspectiva, a corrupção se revela multifacetada.

Essa segunda noção delimita o espectro das práticas consideradas corruptas. Em grande parte, o processo legislativo, baseado na troca de "favores", é caracterizado pelo que a população considera corrupção. Certamente, há distorções e não se pode descartar que o Parlamento legisle em causa própria em várias ocasiões. Porém, havendo uma visão social predominante sobre o conceito de corrupção, surge o sentimento de que o legislar em causa própria é uma forma de corrupção. Esse é o ponto de partida para questionar a limitação jurídica do conceito de corrupção: ${ }^{41}$ em que medida certas práticas corruptas não estão abarcadas e proibidas pelo sistema jurídico? Para responder a esse questionamento, propõe-se o estudo sobre os limites entre os espaços público e privado, inserto numa dada evolução histórica.

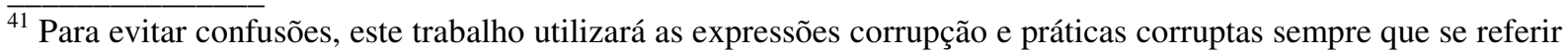
aos fatos que envolvem algumas das dimensões deste segundo sentido, quer sejam fatos tipificados criminalmente ou não. Logo, tais expressões não tratarão a priori das hipóteses tipificadas como corrupção nos diplomas penais. Quando for o caso de se referir especificamente a um dado tipo criminal, haverá uma referência explícita ao tipo no texto.
} 


\subsection{Origem e evolução da noção de espaços público e privado}

Talvez os primeiros relatos implícitos de uma separação entre o público e o privado remontem aos tempos bíblicos. Recomendava-se à testemunha que não recebesse presentes, "porque o presente cega os que têm vista, e perverte as palavras dos justos", ${ }^{42}$ e ao juiz que: "não torcerás o juízo, não farás acepção de pessoas, nem tomarás peitas; porquanto a peita cega os olhos dos sábios, e perverte as palavras dos justos". ${ }^{3}$

Apesar desses relatos bíblicos, que posteriormente seriam incorporados à concepção moral presente nas civilizações judaica, cristã e islâmica, a origem mais próxima da distinção entre as esferas pública e privada pode ser localizada já na Antiguidade clássica.

Na Roma do século I, a distinção ganha terreno no debate político que precedia a instituição do império. Influenciado pela filosofia grega, Cícero cunha a expressão res publica para designar os assuntos de interesse coletivo, expressão que originaria a palavra "república". Mais tarde, esta se afastaria das denominações negativas e se firmaria positivamente, ainda que de modo impreciso, como a forma de governo "em que o governo é exercitado em nome do povo, por representantes seus, para tanto designados por ele próprio". ${ }^{44}$ É em Roma que se origina a noção de peculato, embora apresentasse significado ligeiramente distinto do atual. ${ }^{45}$

Apesar de os antecedentes históricos indicarem que a dicotomia espaço públicoespaço privado estivesse em gestação desde a Antiguidade, somente após o Iluminismo político, no século XVIII, ela se estabelece, quer no plano das ideias, com as obras de pensadores iluministas, quer no plano político, com as Revoluções Americana e Francesa. Mesmo assim, uma evolução histórico-filosófica revela que o assentamento da res publica, voltada para o atendimento do bem comum, decidido legitimamente pelo processo político,

\footnotetext{
$\overline{42}$ EXXODO. Português. In: Bíblia sagrada. 168. ed. Tradução portuguesa da versão francesa dos originais grego, hebraico e aramaico pelos monges beneditinos de Maredsous. Revisada por Frei José Pedreira de Castro. São Paulo: Ave Maria, 2005. p. 124 (Capítulo XXIII, Versículo 8).

${ }^{43}$ DEUTERONÔMIO. Português. In: Bíblia sagrada. 168. ed. Tradução portuguesa da versão francesa dos originais grego, hebraico e aramaico pelos monges beneditinos de Maredsous. Revisada por Frei José Pedreira de Castro. São Paulo: Ave Maria, 2005. p. 233 (Capítulo XVI, Versículo 18).

44 ATALIBA, Geraldo. Instituições de direito público e república. 1984. 215 f. Tese (Professor Titular)Faculdade de Direito, Universidade de São Paulo, São Paulo. p. 27.

${ }^{45}$ ALMEIDA, Fernando H. M. Dos crimes contra a administração pública. São Paulo: Saraiva, 1955. p. 11. "A palavra peculato aplicou-se, de início, a furto de coisa do Estado. Era, então, crime equiparado ao sacrilégio. [...] O étimo da palavra está em pecus, tal como em suas convizinhas pela raiz (pecus = gado) [...] e se reporta à época em que o gado foi havido como moeda."
} 
seguiu um processo lento e contraditório de mudança ideológica no qual, somente após a incorporação gradativa do povo ao jogo democrático, se consolidou efetivamente.

Do mesmo modo que a noção de liberdade dos gregos e romanos, ligada à possibilidade de participação no funcionamento do ente político, se diferencia da moderna, relacionada à ideia de ausência de coerção, ${ }^{46}$ o mesmo ocorreu com a dicotomia públicoprivado. Noções dessa natureza não são universais e atemporais e se desenvolvem influenciadas pelas circunstâncias sociais, econômicas, culturais e políticas específicas de determinado lugar, num determinado tempo. ${ }^{47}$ Para entender como os limites entre os espaços público e privado se estabeleceram, será empreendida uma análise de como a Weltanschauung se alterou ao longo da história até atingir uma concepção moderna que permite delinear quando há corrupção.

\subsubsection{Labor, trabalho e ação nas origens da distinção entre os espaços público e privado}

Por se tratar de uma distinção que remonta à Antiguidade clássica, o primeiro passo é tentar compreender como as esferas pública e privada foram originariamente concebidas desde já, reafirme-se que o significado greco-romano da dicotomia não se assemelha ao hodierno, embora guarde traços significativos de sobreposição.

$\mathrm{Na}$ Grécia antiga, simultaneamente à dicotomia público-privado, figurava a do profano e do sagrado. Essa dicotomia também apresenta sua importância, na medida em que o sagrado praticamente se colocava ao lado do público e privado. Saldanha explica que "nas cidades se torna mais definida e funcional a distinção, fundamental, entre espaços: espaço sagrado e espaço profano, espaço público e espaço privado". ${ }^{48}$ Nessa direção, Aristóteles relata que, de acordo com o pensador Hipodamos de Mileto, as terras da pólis deveriam ser repartidas em sagradas, públicas e particulares. ${ }^{49}$

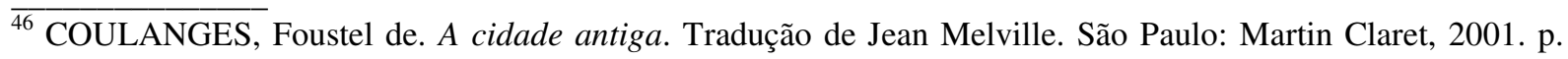
252.

47 Um bom exemplo é fornecido pelos significados adquiridos pela raiz da palavra "público" em algumas línguas. Enquanto na língua portuguesa ela remete prontamente ao que pertence ao público e ao Estado, no idioma inglês public remete ao que é aberto ao público. No idioma português, "escola pública" significa aquela que pertence ao público, ao passo que num país de língua inglesa significa uma escola aberta ao público, ou seja, que aceita todo e qualquer tipo de aluno, podendo pertencer ao Estado ou não. Do mesmo modo, empresa pública, na língua portuguesa, significa aquela que pertence ao Estado, ao passo que nos países de língua inglesa significa empresa que pode pertencer ao público, ou seja, uma sociedade anônima com ações negociadas em bolsa de valores.

${ }^{48}$ SALDANHA, Nelson. Ética e história. 2. ed. rev. e ampl. Rio de Janeiro: Renovar, 2007. p. 43-44.

49 ARISTÓTELES. Op. cit. p. 39. "Repartia igualmente o território em três partes, as terras sagradas, as terras públicas e as terras particulares. As primeiras deveriam socorrer às despesas do culto, as segundas à alimentação dos guerreiros, as últimas pertenciam aos lavradores."
} 
Embora (i) a dicotomia profano-sagrado tenha sua significação histórica para a separação da Igreja e do Estado e (ii) o Estado esteja imerso nas relações sociais, o foco deste trabalho é voltado para como o espaço público se constituiu autonomamente em relação ao privado. Parte-se da distinção entre labor, trabalho e ação feita por Arendt em $A$ condição humana. ${ }^{50}$

Nessa obra, a atividade humana ativa (vita activa) é classificada em três espécies distintas: o labor, o trabalho e a ação. ${ }^{51}$ Ao labor corresponderia o suprimento das necessidades biológicas do corpo humano, o qual teria como resultado a própria vida - "a condição humana do labor é a vida em si mesma" - tudo direta e indiretamente relacionado à subsistência humana, tal como o cultivo de alimentos e a fabricação de ferramentas para a agricultura. O caráter introspectivo do labor, voltado para a subsistência da família, relacionava-o à esfera privada. Já o trabalho é o que transforma o meio ambiente e possibilita o surgimento de um mundo artificial circundante: há a transformação de algo que pode ser voltado para terceiros, ou seja, não para a própria subsistência, ao menos imediatamente. No trabalho, o resultado pode-se voltar para o mercado, distanciando-se da família, da esfera essencialmente privada - daí a afirmação de Arendt de que "o trabalho é interessado pelos assuntos mundanos". A manufatura de objetos e o comércio seriam bons exemplos de trabalho na acepção arendtiana. Por fim, a ação diz respeito ao relacionamento direto entre os homens sem a interferência da natureza, caracterizando-se pela pluralidade - tudo que dizia respeito à pólis (a política) se caracterizaria como uma forma de ação.

Tanto Platão quanto Aristóteles são algumas das bases de partida para as conclusões de Arendt, que também se inspira na forma como os gregos concebiam a organização da pólis. $^{52}$ Platão ataca a liberalidade do homem democrático, que, excessivamente individualista, tem "repulsa a toda autoridade" e apresenta um "desejo perverso de independência, de querer viver cada um a seu bel-prazer" ${ }^{53}$ - a opinião demonstra o desprezo pela esfera privada, pois a organização ideal da pólis pressupunha a inexistência de interesses contraditórios em relação à comunidade. Todavia, mesmo no organicista Aristóteles, a

\footnotetext{
$\overline{50}$ ARENDT, Hannah. A condição humana. Tradução de Roberto Raposo. Posfácio de Celso Lafer. 9. ed. São Paulo: Forense Universitária, 1999.

51 ARENDT, Hannah. The human condition. In: Philosophy and the problems of work: a reader. Maryland: Rowman \& Littlefield, 2001. p. 23-24. "In addition to the conditions under which life is given to a man on Earth, and partly out of them, men constantly create their own, self-made conditions, which, their human origin and variability notwithstanding, possess the same conditioning power as natural things."

${ }^{52}$ Idem, 1999, p. 137.

53 CARDOSO, Sérgio. Platão e Aristóteles. In: AVRITZER, Leonardo et al. (Org.). Corrupção: ensaios e críticas. Belo Horizonte: UFMG, 2008. p. 30.
} 
caracterização do homem como um animal político (zoon politikon), destinado a viver em sociedade, revela implicitamente a existência de uma esfera reservada à ação na crítica ao indivíduo que decide se isolar dos demais e viver sozinho, "merecedor da censura cruel de ser um sem família, sem leis, sem lar". ${ }^{4}$

A diferenciação fornece subsídios para a compreensão de como distinguiam as esferas pública e privada na Antiguidade. $\mathrm{O}$ espaço privado se relacionaria à atividade de labor, ao passo que o espaço público, ao trabalho e à ação. Tal dicotomia se sentiria também no agir típico a cada uma dessas esferas: enquanto o uso da força seria aceitável na esfera privada, o mesmo não se verificaria na esfera pública, na qual a tônica seria a persuasão. ${ }^{55} \mathrm{O}$ direito romano adotou a diferenciação entre direito público e privado, que se diferenciariam conforme o interesse tutelado. ${ }^{56}$ Apesar dessa percepção distinta entre o público e o privado, os romanos tratavam a corrupção como se fosse um delito privado, ${ }^{57}$ provavelmente porque não tinham a noção de supremacia do interesse público. Ferraz Júnior considera que essa distinção impregnou o pensamento de Ulpiano ao tratar da clássica distinção entre o direito público e o privado. ${ }^{58}$

\subsubsection{Do político ao social na distinção público-privado}

A partir da Idade Média, o labor se confundiu conceitualmente com o trabalho. Este, pensado na origem como uma "atividade solitária", se aproxima cada vez mais do labor, na medida em que se aperfeiçoa a divisão social do trabalho, mormente nas atividades agrícolas. Com a Idade Moderna, o ritmo e a velocidade do labor se intensificam, fazendo o resultado do

\footnotetext{
$\overline{{ }^{54} \text { ARISTÓTELES. Op. cit. p. } 13 .}$

55 ARENDT, Hannah. Op. cit., 1999, p. 35-36. "O ser político, o viver numa pólis, significa que tudo era decidido mediante palavras e persuasão, e não através de fora ou violência. Para os gregos, forçar alguém mediante violência, ordenar ao invés de persuadir, eram modos pré-políticos, típicos da vida fora da pólis, característicos do lar e da vida em família, na qual o chefe da casa imperava com poderes incontestes e despóticos, ou na vida nos impérios bárbaros da Ásia, cujo despotismo era frequientemente comparado à organização doméstica”. Neste último aspecto, é possível traçar um paralelo entre a comparação da esfera privada enquanto modo de governar os impérios asiáticos e práticas políticas que confundem a esfera pública com a privada, utilizando o Estado para seus fins pessoais.

${ }^{56}$ Digesto, 1.1.1.2. "Huius studii duae sunt positiones, publicum et privatum. publicum ius est quod ad statum rei Romanae spectat, privatum quod ad singulorum utilitatem pertinet. dicendum est igitur de iure privato, quod tripertitum est; collectum est enim ex naturalibus praeceptis aut gentium aut civilibus."

${ }^{57}$ LIVIANU, Roberto. Corrupção e direito penal: um diagnóstico da corrupção no Brasil. Coimbra: Coimbra Editora, 2007. p. 34.

${ }^{58}$ FERRAZ JÚNIOR, Tercio Sampaio. Introdução ao estudo do direito: técnica, decisão, dominação. 2. ed. São Paulo: Atlas, 1995. p. 135. "Quando Ulpiano, pois, distinguia entre jus publicum e jus privatum certamente tinha em mente a distinção entre a esfera do público, enquanto lugar da ação, do encontro dos homens livres que se governam, e a esfera do privado, enquanto lugar do labor, da casa, das atividades voltadas à sobrevivência."
} 
labor confundir-se com seu próprio autor - é, na nomenclatura marxista, o surgimento da chamada "força de trabalho".

Nesse pano de fundo, trabalho e labor, antes pertencentes respectivamente às esferas pública e privada, são amalgamados pela noção de social. Arendt observa que, na Baixa Idade Média, Tomás de Aquino traduz "político" como "social", expressões que possuem sentidos convergentes, mas distintos. ${ }^{59} \mathrm{O}$ social, para os antigos, era localizado na esfera do privado, referindo-se mais a preocupações sobre a subsistência da unidade familiar. A partir da distinção entre o social e o individual, construiu-se a diferenciação entre o público e o privado. Esse processo seria facilitado pela progressiva confusão entre ação e trabalho assim, "como o trabalho do artesão é solitário (o mestre não era senhor do artífice, mas amo das técnicas) e o lugar da sua socialização é o mercado, transporta-se para a esfera pública a noção de mercado". ${ }^{60}$

Ao longo da Idade Média, o cristianismo, com a sua noção modificada de bem comum, adiciona um caráter teleológico ao fenômeno estatal - um governante deve atuar para o bem comum de todos os cidadãos. Faz-se a assimilação de que o bem comum está relacionado às condições de subsistência, tal como implicitamente sugerido pela moral cristã. A finalidade da unidade familiar, a subsistência humana, é assimilada pelo conjunto humano maior, fazendo com que a finalidade da sociedade também passe a ser a subsistência, mas numa escala maior do que a da unidade familiar ${ }^{61}$ - essa mudança de concepção se insere no contexto do surgimento da economia política no século XVIII. A política se transforma numa “função da sociedade", posto que o lar, esfera do privado, invade a política, esfera do público. $^{62}$

\footnotetext{
${ }_{59}$ ARENDT, Hannah. Op. cit., 1999, p. 32. "Melhor do que qualquer teoria complicada, esta substituição inconsciente do social pelo político revela até que ponto a concepção original grega havia sido esquecida. Para tanto, é significativo, mas não conclusivo, que a palavra 'social' seja de origem romana, sem qualquer equivalente na língua ou pensamento gregos. Não obstante, o uso latino da palavra societas tinha também originalmente uma acepção claramente política, embora limitada: indicava certa aliança entre pessoas para um fim específico, como quando os homens se organizavam para dominar outros ou para cometer um crime".

${ }^{60}$ FERRAZ JÚNIOR, Tercio Sampaio. Op. cit. p. 136.

${ }^{61}$ ARENDT, Hannah. Op. cit., 1999, p. 37-38. Arendt explica que o predomínio do social e da sociedade corresponde, no pensamento científico, à assunção da economia nacional, social ou política ("administração doméstica coletiva") em detrimento da ciência política, tal como vista pelos gregos antigos.

${ }^{62}$ AVRITZER, Leonardo. Esfera pública. In: AVRITZER, Leonardo et al. (Org.). Op. cit. p. 134. Habermas apresenta uma visão semelhante à de Arendt sobre o declínio da esfera pública. Conforme sintetiza Avritzer, "o conceito de esfera pública em Habermas tem como modelo a formação de dois tipos de públicos, os públicos políticos formados na Inglaterra junto com o surgimento da imprensa e os públicos culturais formados nos salões franceses do século 18. A idéia central que está por trás dos dois tais tipos de públicos é a formação de um grupo de indivíduos que questionam o poder e o dinheiro enquanto geradores de propostas políticas ou do melhor argumento".
} 


\title{
1.2.3 A dicotomia Estado-sociedade civil e interesses públicos-privados
}

No contexto da ascensão do social, afirmou-se igualmente a distinção entre Estado e sociedade civil. Para os pensadores jusnaturalistas na esteira de Hobbes e Kant, o Estado é uma construção artificial, oposta à sociedade civil, uma organização natural dos homens. ${ }^{63}$ Nessa linha, a noção de sociedade civil surge como "contraposição (ignorada pela tradição) entre uma esfera política e uma esfera não política", de modo que se apresenta a "sociedade civil como um conjunto de relações não reguladas pelo Estado, e portanto como tudo aquilo que sobra uma vez bem delimitado o âmbito no qual se exercer o poder estatal". ${ }^{64}$ Nesse modelo de Estado moderno em que há uma dicotomia entre os espaços público e privado, cabem tanto o chamado Estado liberal quanto o do bem-estar social. ${ }^{65}$ Conforme elucida Alves,

\begin{abstract}
Aqui já se observa a origem da separação entre a sociedade civil, palco dos conflitos de interesses econômicos, sociais e ideológico-culturais, e o Estado ou sociedade política, responsável pela coesão social e monopolizador da violência legítima. Como essa dissociação entre o civil e o político, entre o privado e o público ocorre dentro de uma perspectiva de "exterioridade" e de forma relativamente não-difusa (distinção e separação entre as instituições estatais e privadas), não se percebe bem por que se torna necessário o poder político, não ficando evidente a relação estatal como condição ou como resultado do processo produtivo, exigindo-se, portanto, uma justificação para a existência do Estado. ${ }^{66}$
\end{abstract}

Essa diferenciação, cuja clareza ainda hoje é objeto de questionamento, se difundiria a partir do fim do Iluminismo. Os teóricos políticos dos séculos XVIII e XIX construíram essa dicotomia, agora baseada na distinção entre os interesses do Estado e da sociedade civil: ao primeiro, caberia a tutela da esfera pública, enquanto ao segundo a da esfera privada - aliás, o interesse foi elevado ao fator de legitimação da defesa do privado no público. Como explica Filgueiras, a democracia e o capitalismo podem coexistir na medida em que a primeira

[...] é o regime de liberdades individuais que se dão no plano dos interesses. Não se trata, portanto, de qualquer democracia, mas de uma democracia que permite ao

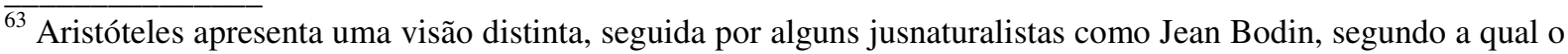
Estado seria uma organização natural para o zoon politikon. Ver BOBBIO, Norberto. Estado, governo, sociedade: por uma teoria geral da política. Tradução de Marco Aurélio Nogueira. Rio de Janeiro: Paz e Terra, 1987. p. 45.

${ }^{64}$ Ibidem, p. 34.

${ }^{65}$ ROTH, André-Noël. O direito em crise: fim do Estado moderno?. In: FARIA, José Eduardo (Org.). Direito e globalização econômica: implicações e perspectivas. São Paulo: Malheiros, 1996. p. 18.

${ }^{66}$ ALVES, Alaôr Caffé. Estado e ideologia: aparência e realidade. Apresentação de Dalmo de Abreu Dallari. São Paulo: Brasiliense, 1987. p. 228.
} 
indivíduo racional egoísta da modernidade representar seus interesses na esfera pública. ${ }^{67}$

Nessa ruptura com a visão grega da dicotomia público-privado, o interesse privado, na modernidade, seria representado pela miríade de entes que formam a sociedade civil, cada qual com sua própria visão do que seria melhor para si, sem que em si mesmo isso seja considerado uma corrupção.

Uma das características marcantes desse processo foi a personalização crescente dos defensores dos interesses da sociedade civil, representada por essa miríade de entes. Atualmente, a dicotomia Estado-sociedade civil se assenta em tal personalização. BresserPereira sintetiza a diferença sobre a concepção atual da dicotomia:

A sociedade civil é constituída pelas classes sociais e grupos, que têm acesso diferenciado ao poder político efetivo, enquanto o Estado é a estrutura organizacional e política, fruto de um contrato social ou de um pacto político, que garante a legitimidade ao governo. Em outras palavras, a sociedade civil é o povo, ou seja, o conjunto dos cidadãos, organizado e ponderado de acordo com o poder de cada indivíduo e de cada grupo social, enquanto o Estado é o aparato organizacional e legal que garante a propriedade e os contratos. ${ }^{68}$

Funcionalmente, para a teoria política, a sociedade civil, esfera do privado, zela para que o Estado, esfera do público, permaneça na busca do bem comum. ${ }^{69}$ Essa posição especial ocupada pelo Estado, a de guardião do interesse público, lhe conferiu certas prerrogativas, entre as quais se pode citar o princípio da supremacia do interesse público.

Muitas vezes, essa simplificação ignora o fato de que nem sempre o interesse público coincide com o interesse estatal. ${ }^{70}$ Com frequência variável, se reconhece que a sociedade civil personalizada pode assumir o papel de defensora do bem comum, ao passo que o Estado patologicamente tutela interesses privados, não relacionados com o interesse

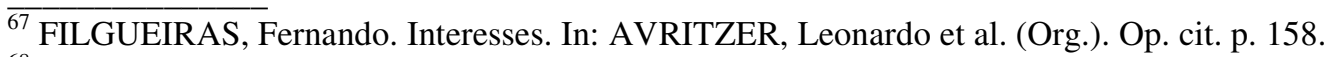

${ }^{68}$ BRESSER-PEREIRA, Luiz Carlos. Estado, sociedade civil e legitimidade democrática. Lua Nova - Revista de Cultura e Política, São Paulo: Cedec, n. 36, p. 87,1995.

${ }^{69}$ BOBBIO, Norberto. Op. cit. p. 34. "[...] a idéia geral tão eficazmente expressa por Thomas Paine (não por acaso autor de um célebre escrito exaltante dos direitos do homem) de que a sociedade é criada por nossas necessidades e o Estado por nossa maldade, pois o homem é naturalmente bom e toda sociedade, para conservarse e prosperar, precisa limitar o emprego das leis civis impostas com a coação a fim de consentir a máxima explicitação das leis naturais que não carecem de coação para serem aplicadas [...]."

${ }^{70}$ A propósito, Mello afirma que o princípio da supremacia do interesse público sobre o privado "[...] trata-se de verdadeiro axioma reconhecível no moderno direito público. Proclama a superioridade da coletividade, firmando a prevalência dele sobre o do particular, como condição, até mesmo, da sobrevivência e asseguramento deste último. É pressuposto de uma ordem social estável, em que todos e cada um possam sentir-se segurados e garantidos". MELLO, Celso Antônio Bandeira de. Curso de direito administrativo. 19. ed. São Paulo: Malheiros, 2005. p. 19.
} 
comum ou mesmo com o interesse estatal. ${ }^{71}$ Apesar desse reconhecimento, a moderna noção de supremacia do interesse público, corolário do direito administrativo de tradição continental, se afirma como balizadora da ação estatal. O direito desenvolve o papel de integração social entre os interesses individuais ou privados, pessoalizados por natureza, e os interesses sociais ou comuns, impessoalizados. ${ }^{72}$

Outro processo identificável paralelo à assunção da dicotomia Estado- sociedade civil se refere à afirmação do individualismo. Historicamente, à medida que as condições culturais foram propiciando a corrosão dos preconceitos medievais com relação ao lucro e à reprovação moral ao interesse pessoal, o individualismo se impôs lenta e gradativamente na sociedade. ${ }^{73} \mathrm{O}$ espaço privado, porém, entendido como excludente de participação ou presença externa, se reduziu consideravelmente, de forma que se transformou apenas num reduto da intimidade, algo bem mais restrito do que o âmbito da economia doméstica dos antigos. Já na Idade Média, a máxima cristã “dai, pois, a César o que é de César e a Deus o que é de Deus" ${ }^{\text {74 }}$ servirá para realçar a separação entre Estado e consciência humana. ${ }^{75}$ No bojo do processo de redução do espaço privado, a consciência será o reduto do privado, posição defendida por Rousseau. ${ }^{76}$

Reflexamente, essa transformação significou o deslocamento do mercado da esfera do público para o privado, bem como uma subversão da lógica, implícita para os antigos, segundo a qual o interesse privado era necessariamente incompatível com o público. Afinal, a

\footnotetext{
$\overline{71}$ MARQUES NETO, Floriano Peixoto de Azevedo. Regulação estatal e interesses públicos. São Paulo: Malheiros, 2002. p. 94-95. FAUPIN, Hervé. Le contrôle du financement de la vie politique, partis et campagnes. Prefácio de Claude Goyard. Paris: L.G.D.J/ Montchrestien, 1998. p. 43.

${ }^{72}$ GRAU, Eros Roberto. Elementos de direito econômico. São Paulo: Revista dos Tribunais, 1981. p. 59.

${ }^{73}$ HAYEK, Friedrich A. von. Individualism and economic order. Chicago: University of Chicago Press, 1948. p. 6. A Reforma Protestante do século XVI pode ser vista como a verdadeira legitimadora do individualismo, porque deixara à consciência de cada um estabelecer o que seria moralmente correto. Assim, o individualismo desenvolveu-se como uma nova atitude nas esferas política e social, fortemente ligada ao protestantismo - seria "uma tentativa de entender as forças que determinam a vida social do homem e, somente em segunda instância, um aparato de idéias políticas derivadas dessa visão da sociedade". Tradução livre do seguinte original: "The first thing that should be said is that [individualism] is primarily a theory of society, an attempt to understand the forces which determine the social life of man, and only in the second instance a set of political maxims derived from this view of society".

${ }^{74}$ MARCOS. Português. In: Bíblia sagrada. 168. ed. Tradução portuguesa da versão francesa dos originais grego, hebraico e aramaico pelos monges beneditinos de Maredsous. Revisada por Frei José Pedreira de Castro. São Paulo: Ave Maria, 2005. p. 1338 (Capítulo XIII, Versículo 17).

${ }^{75}$ BONAVIDES, Paulo. Teoria do Estado. 4. ed. rev. e ampl. São Paulo: Malheiros, 2005. p. 70 . "O reino de Deus estava bem separado do reino de César. O Estado predominava sobre o indivíduo, mas não o absorvia. Essa a conseqüência vigorosa e extraordinária da doutrina cristã, que debaixo desse ângulo, deu à consciência humana um de seus primeiros e mais seguros impulsos de libertação."

${ }^{76}$ ARENDT, Hannah. Op. cit., 1999, p. 48. "A intimidade do coração, ao contrário da intimidade da moradia privada, não tem lugar objetivo e tangível no mundo, nem pode a sociedade contra qual ela protesta e se afirma ser localizada com a mesma certeza que o espaço público.”
} 
plenitude da vida na pólis, desinteressada dos interesses privados, somente era alcançada quando o cidadão podia se despreocupar da subsistência de sua família.

A busca dos interesses privados, típica do individualismo e rechaçada pela medieval aversão ao lucro, não é mais incompatível com o interesse comum. Smith resume bem essa nascente concepção: “[...] cuidando do seu interesse próprio, o indivíduo, quase sempre, promove o interesse da sociedade mais eficientemente do que quando realmente deseja promovê-lo". ${ }^{77}$ Essa transferência faz a distinção originária entre labor, trabalho e ação tornarse ainda mais desprovida de sentido no mundo massificado, em que o resultado final do processo deve atender às necessidades de consumo. Em especial a partir da Revolução Industrial, a explosão populacional implica novas condições que não se replicavam antes, sugerindo que o bem comum assumisse uma função historicamente inovadora na prática política. $^{78}$

Com a ascensão do social, uma nova leitura da dicotomia público-privado se estabeleceu sobre premissas diferentes daquelas dos antigos. Ideologicamente, o Estado se torna cada vez mais responsável pela ordem social, ocupando funções antes desempenhadas pela igreja, pela comunidade e pela família - "qualquer governo é melhor do que a ausência de governo". ${ }^{79}$ A esfera pública se torna a defensora do social e do comum, ambos direcionados cada vez mais ao bem estar material.

\subsection{O reconhecimento do bem comum como finalidade do Estado}

Em princípio, a organização estatal era voltada apenas para o atendimento das necessidades dos detentores do poder e a sua finalidade correspondia aos interesses dos seus líderes. A ideia de que a organização estatal deveria se pautar pelo bem comum era estranha à prática política - a população simplesmente nada espera do Estado. Mesmo assim, um idealizado e romantizado bem comum foi alçado à condição de finalidade do Estado. Pode-se

\footnotetext{
$\overline{77}$ SMITH, Adam. A riqueza das nações: investigação sobre sua natureza e suas causas. Tradução de Luiz João Baraúna. São Paulo: Abril Cultural, 1983. p. 30. "O esforço natural de cada indivíduo no sentido de melhorar sua própria condição, quando sofrido para exercer-se com liberdade e segurança, é um princípio tão poderoso, que ele é capaz, sozinho e sem qualquer ajuda, não somente de levar a sociedade à riqueza e à prosperidade, mas de superar centenas de obstáculos impertinentes com os quais a insensatez das leis humanas muitas vezes obstacula seus atos."

${ }^{78}$ SALDANHA, Nelson. Op. cit. p. 75.

${ }^{79}$ FONSECA, Eduardo Giannetti da. Vícios privados, benefícios públicos?: a ética na riqueza das nações. São Paulo: Companhia das Letras, 2007. p. 81. "O despotismo, por pior que seja, é preferível ao mal maior da anarquia, da violência civil generalizada e do medo permanente de morte violenta. A filosofia hobbesiana atende a uma demanda universal e profunda dos homens gerada pela ameaça de desintegração e colapso das normas que garantem a ordem social - a demanda por autoridade e segurança."
} 
compreender melhor tal noção, vaga e indeterminada por natureza, com base em um relato histórico sobre como o termo foi incorporado ao discurso político da modernidade.

É na Grécia antiga que se podem encontrar as primeiras manifestações coerentes sobre a finalidade das sociedades políticas. Com a sua visão organicista, Aristóteles considera o Estado como "comunidade perfeita, formada pela pluralidade de grupos comuns, comunidade que, de certo modo, logrou o fim de inteira suficiência e surgiu mercê da vida, e, mercê da vida, em seu conjunto se mantém". ${ }^{80}$ Àquela época, o indivíduo vivia em função do Estado e não o inverso ${ }^{81}$ fato que se reflete no pensamento platônico idealista. Em Platão, o indivíduo e suas aspirações sucumbem à pólis, de modo que o Estado seria uma ampliação do homem - inexiste uma finalidade estatal, tal como ocorre em Aristóteles. ${ }^{82}$ Apesar dessas divergências, ambos atribuíam à politeia o papel de "articulação entre o fim visado pela política e os meios que tinham que ser empregados para realizá-la". ${ }^{83}$

O senso prático romano trouxe mais concretude ao debate. Possivelmente influenciado pelo organicismo aristotélico, Cícero trata do bem comum como atrelado à res publica e associa o público ao consenso do direito e à utilidade comum. ${ }^{84}$ Pelo consenso do direito, devia-se entender o primado deste sobre a violência e o arbítrio. ${ }^{85}$ Já para a busca da utilidade comum, Cícero considerava necessária a existência de um povo valoroso, comprometido com uma finalidade maior. Como ensina Lafer,

[...] a busca da communis utilitatis na res publica, o outro componente de que falava Cícero, requer um populus frugal e incorruptível. Essas características foram, na história das idéias políticas, vistas como o apanágio da Roma Republicana, na qual vicejavam as virtudes de uma cidadania cuja ambição maior era servir à pátria. ${ }^{86}$

Com a expansão do cristianismo, a doutrina católica modificou o debate, adicionando mais um elemento à dicotomia Estado-indivíduo: a espiritualidade. Sobretudo os

\footnotetext{
$\overline{{ }^{80} \text { ARISTÓTELES. Op. cit. Livro 1, cap. } 2 .}$

${ }^{81}$ BONAVIDES, Paulo. Op. cit. p. 69.

${ }^{82}$ Ibidem, p. 120.

${ }^{83}$ GOYARD-FABRE, Simone. Os princípios filosóficos do direito político moderno. Tradução de Irene A. Paternot. São Paulo: Martins Fontes, 2002. p. 102.

${ }^{84}$ LAFER, Celso. O significado de república. Estudos históricos, Rio de Janeiro, v. 2, n. 4, p. 222, 1989. "Para Cícero, o público diz respeito ao bem do povo que, para ele, não é uma multidão qualquer de homens mas sim um grupo numeroso de pessoas associadas pela adesão a um mesmo direito e voltadas para o bem comum. São, portanto, na concepção ciceroniana, dois os vínculos que configuram o populus, como o destinário da respublica: consensus juris (o consenso do direito) e communis utilitatis (a comum utilidade), e são as conotações a eles inerentes o que vou tentar explorar, para delinear o significado de república."

${ }^{85}$ Idem, ibidem. "O consensus juris ciceroniano na história das idéias políticas indica o papel do direito para que a res publica não se veja comprometida pela violência e pelo arbítrio. Daí, modernamente, o ter este conceito em Kant se precisado na constituição, enquanto idéia reguladora da razão prática, necessária para estabelecer-se um estado de direito, entre uma multiplicidade de homens em relação recíproca na res publica."

${ }^{86}$ Ibidem, p. 226.
} 
estudos de Tomás de Aquino atribuem ao Estado uma finalidade de concretização dos fins espirituais da Igreja. Essa postura fica evidente com a Igreja Católica, cujas pretensões de poder a aproximavam da organização estatal, desejosa da realização de seus fins espirituais. ${ }^{87}$ Ademais, conforme Arendt explica,

[...] o conceito medieval de "bem comum", longe de indicar a existência de uma esfera política, reconhecia apenas que os indivíduos privados têm interesses materiais e espirituais em comum, e só podem conservar sua privatividade e cuidar dos próprios negócios quando um deles se encarrega de zelar por esses interesses comuns. $^{88}$

Com a decadência da hegemonia da Igreja, essa visão foi abandonada. Entretanto, seu mérito principal foi ter provido uma alternativa à visão orgânica sobre o bem comum, a qual anulava o indivíduo. Dessa forma, preparava-se a mudança ideológica que traria o individualismo ao centro das atenções e moldaria o que se entende por bem comum no moderno contexto da dicotomia público-privado. A nascente noção de sociedade civil, em que o primado do indivíduo seria estabelecido, precisou ser canalizada, o que se deu com a atribuição de uma finalidade à organização política.

No século XIX, no ápice do desenvolvimento das ideias individualistas, Jellinek retoma o tema da finalidade do Estado, apresentando-a como mutável conforme a evolução histórica, sem que haja uma finalidade específica em si mesma ${ }^{89}$ - está-se diante do que Dallari denomina fins relativos do Estado. ${ }^{90}$ Novamente, a visão de Jellinek encontra-se impregnada do organicista, que faz conceber o Estado num fim em si mesmo. ${ }^{91}$

Apesar do debate, a maioria desses pensadores jogou suas ideias em solos pouco férteis à sua época. Qualquer tentativa de direcionamento da ação estatal para o bem comum estava em descompasso com a realidade, uma vez que o comando residia no soberano que considerava os bens estatais como sua propriedade privada, sujeita exclusivamente aos seus interesses e pudores. Demorou muito para que o bem comum como uma finalidade da política começasse a ser aceito na sociedade e pela organização estatal. No Estado moderno, a própria

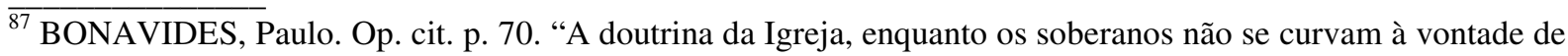
Deus, tem o efeito de arrancar-lhes ou contestar-lhes a jurisdição que mantinham sobre áreas privilegiadas de sua tirania: as que rodeiam a consciência humana que vai se tornar inviolável em matéria de fé cristã. Importou o cristianismo, por esse aspecto, uma antecipação capital dos sistemas individualistas de direito natural."

${ }^{88}$ ARENDT, Hannah. Op. cit.,1999, p. 44.

${ }^{89}$ JELLINEK, Georg. Teoría general del Estado. Tradução da 2. ed. alemã. Prólogo de Fernando de Los Ríos. México: Nacional, 2000. p. 339.

${ }^{90}$ DALLARI, Dalmo de Abreu. Elementos de teoria geral do Estado. 19. ed. atual. São Paulo: Saraiva, 1995. p. 90.

${ }^{91}$ BONAVIDES, Paulo. Op. cit. p. 113.
} 
atribuição de uma finalidade estatal é controversa: sua compreensão deveria se voltar apenas para as suas estruturas e, se houver uma finalidade, esta lhe seria interna, consistindo “exclusivamente na expansão contínua do seu próprio poder". ${ }^{92}$

Mais recentemente, Dallari argumenta no sentido de que a finalidade do Estado é o bem comum. ${ }^{93}$ Essa forma de encarar as doutrinas teleológicas do Estado apresentaria um caráter conciliador entre as vistas acima. Trata-se de uma finalidade evidente, mas de amplíssimo alcance, de modo a determinar-se conforme as peculiaridades de cada povo em cada época. Conforme a política preenche o conteúdo dessa finalidade, ${ }^{94}$ as diversas configurações estatais surgem - por exemplo, nesse quadro se encaixa a distinção entre um Estado liberal ou um Estado de bem-estar social. Isso explica por que a fórmula "bem comum" estar presente, de uma forma ou de outra, em boa parte das constituições escritas do século XX, inclusive na atual Constituição de $1988 .{ }^{95}$

A exposição revela que a finalidade das organizações políticas sempre foi um tópico a preocupar e a dividir os pensadores - alguns nem sequer consideram existir uma finalidade estatal. ${ }^{96}$ Visto de outro ângulo, pode-se opor aqueles pensadores que visualizam o Estado como algo positivo àqueles que o visualizam como algo negativo. No primeiro grupo, alguns o consideram um mal não necessário e postulam o seu desaparecimento - ao questionarem a necessidade do Estado, os marxistas, anarquistas e ramos do cristianismo colocam em xeque, também, a sua legitimidade. ${ }^{97}$ Nesse mesmo grupo dos negativistas, ainda há os que consideram o Estado um mal necessário, pois refreia as paixões humanas e evita a guerra civil

\footnotetext{
$\overline{92}$ POGGI, Gianfranco. A evolução do Estado moderno. Tradução de Álvaro Cabral. Rio de Janeiro: Zahar. p. 105.

${ }^{93}$ DALLARI, Dalmo de Abreu. Op. cit. p. 91.

${ }^{94}$ SALDANHA JUNIOR, Cezar. A supremacia do direito no Estado Democrático e seus modelos básicos. Porto Alegre: Novembro, 2002. p. 29: "Na efetivação do bem comum, cumpre à política o estabelecimento de um clima de convívio, um modus operandi, no qual cada membro da sociedade possa desenvolver, com liberdade, os potenciais próprios da personalidade. A política é a dimensão de atividades que se define pela criação de uma ordem segura, onde as diferenças humanas, naturais e adquiridas, sejam tratadas com o respeito proporcional devido às pessoas, à luz do bem comum, ou seja, do bem de todos, naquilo que todos temos em comum".

${ }^{95}$ BRASIL. Constituição (1988). Art. 3․ "Constituem objetivos fundamentais da República Federativa do Brasil: I - construir uma sociedade livre, justa e solidária; II - garantir o desenvolvimento nacional; III - erradicar a pobreza e a marginalização e reduzir as desigualdades sociais e regionais; IV - promover o bem de todos, sem preconceitos de origem, raça, sexo, cor, idade e quaisquer outras formas de discriminação."

${ }^{96}$ KELSEN, Hans. Teoría general del Estado. Tradução da 2. ed. alemã. Prólogo de Fernando de Los Ríos. México: Nacional, 2000. p. 52. No que diz respeito ao estudo das finalidades do Estado, Kelsen argumenta a favor da irrelevância dessa discussão para o direito por se tratar de uma questão eminentemente política: expressões amplas e genéricas como "bem comum" e "bem-estar" não teriam conteúdo típico da natureza estatal. Tal raciocínio se coaduna com o seu pensamento normativista, pois é indiferente à análise de finalidade estatal ou da justificação estatal, porque o Estado já teria sido dado a priori pelo direito.

${ }^{97}$ BOBBIO, Norberto. Op.cit. p. 131-134. “[...] fim do Estado quer dizer nascimento de uma sociedade que pode sobreviver e prosperar sem a necessidade de um aparato de coerção."
} 
entre os homens: Hobbes é certamente o maior expoente dessa linha de pensamento. ${ }^{98}$ Essa segunda concepção, a do Estado como um mal necessário, está na gênese de parte considerável do pensamento liberal que prega o absenteísmo estatal, o qual atribui tarefas limitadas ao Estado.

É patente como a evolução da dicotomia público-privado influenciou uma série de conceitos da teoria geral do Estado, tais como bem comum, liberdades públicas e sistemas políticos. Mais do que isso, tal evolução pode ser associada propriamente ao estabelecimento do moderno Estado Democrático de Direito, na medida em que, subjacente a tais conceitos, está a questão do limite entre o interesse público e o privado. Quando se trata de definir o Estado Democrático de Direito no século XX, ou se enfatiza o seu caráter absenteísta como garantidor dos direitos individuais, ou se enfatiza o seu caráter intervencionista como garantidor das necessidades básicas dos cidadãos.

Entretanto, no pós-1930 o absenteísmo estatal é inconsistente com a legitimidade do Estado Democrático de Direito, o que exigiu uma nova adaptação do conceito. Em parcela considerável, a legitimação do Estado ao longo da incorporação gradativa das massas ao processo político é dependente do surgimento, expansão e efetivação dos direitos econômicos, sociais e culturais. ${ }^{99}$ A legitimidade vincula-se ao êxito de tais objetivos programáticos, e não apenas com a garantia formal dos direitos fundamentais.

A distinção entre público e privado e suas implicações figuram como instrumentais necessários do regime republicano para a realização do bem comum $^{100}$ apesar de expressos de modo distinto. Além do seu caráter meramente instrumental, o regime republicano impõe a responsabilidade dos agentes envolvidos na execução dessa tarefa. Por essa razão, a República se caracteriza como um "regime de responsabilidade", em que "os agentes públicos respondem por seus atos". ${ }^{101}$ Essa responsabilidade resulta do dever de agir na busca da finalidade estatal, legitimamente estabelecida, e, dessa forma, pressupõe que os agentes

\footnotetext{
$\overline{98}$ Ibidem, p. 128-131.

${ }^{99}$ LIMA, M. Madeleine H. de P. Corrupção: obstáculos à implementação dos direitos econômicos, sociais e culturais. Revista de Direito Constitucional e Internacional, São Paulo: Revista dos Tribunais, n. 33, p. 204, out./dez. 2000.

${ }^{100}$ LAFER, Celso. O significado de república. Estudos históricos, Rio de Janeiro, v. 2, n. 4, p. 222, 1989. "Em síntese, estão presentes no conceito de República, que busquei delinear, fazendo também referência aos desdobramentos da idéia republicana em nosso país: (i) a ênfase no bem público, que não se confunde com o interesse dos particulares; (ii) a importância do papel do direito para impedir a violência e o arbítrio; (iii) as virtudes cívicas de cidadania, necessárias para aperfeiçoar a convivência coletiva, voltada para a utilidade comum que tem como um de seus ingredientes o tema da educação pública ao alcance de todos; e (iv), o princípio federalista como fórmula capaz de conciliar o tamanho com a proximidade, tanto no plano interno quanto no plano internacional."

${ }^{101}$ ATALIBA, Geraldo. Op. cit. p. 70.
} 
públicos se abstenham de agir ou se omitir de modo confuso quanto aos limites entre os espaços público e privado. Alerta Afonso da Silva que a noção de República extrapola a mera oposição à monarquia e se refere a uma "coletividade política com características da res publica, no seu sentido originário, ou seja, coisa do povo e para o povo". ${ }^{102}$

Junto com o processo que consolidou o bem comum como o objetivo da organização estatal, desenvolvem-se premissas políticas que visam evitar o seu desvirtuamento. Verificase a gradual profissionalização da administração pública, a qual passa a gerir mais eficientemente o patrimônio estatal, agora separado do patrimônio do soberano. Abrem-se as portas para o surgimento da dicotomia público-privado como conhecida atualmente. De fato, a emergência da sociedade civil, quer na teoria política, quer na organização de sociedades menos dependentes da religião e do aparato estatal, impôs gradativamente ao Estado uma agenda programática. A extensão dessa agenda é objeto de controvérsia. O que deve ser considerado como bem comum? Se, por um lado, não se tolera mais que o governante use o Estado a seu talante, por outro, tampouco, em sua essência, a miríade de interesses sociais privados parece auxiliar para estabelecer um rumo para as ações de políticas públicas.

O caráter idealista da noção de bem comum não sobrevive por si só: ele precisa ser instrumentalizado para permitir que o Estado possa efetivamente desempenhar tarefas que visem ao seu atingimento. ${ }^{103}$ Enquanto defensor do interesse público, o Estado legitima sua atuação por meio da boa gestão dos recursos arrecadados aos particulares, o que se desenvolve com (i) a separação patrimonial entre o soberano e o Estado e (ii) a impessoalização da atuação da administração pública.

\subsubsection{O caráter patrimonial da distinção público-privado}

A confusão reinante entre o patrimônio pessoal e o do soberano poderia prejudicar a busca do bem comum. Isso explica por que a questão patrimonial ter sido percebida como o Calcanhar de Aquiles da organização estatal que estivesse voltada para uma finalidade. Ações concretas para atingir essa finalidade exigem recursos, os quais, se bem geridos, podem

\footnotetext{
${ }^{102}$ SILVA, José Afonso da. Curso de direito constitucional positivo. 11. ed. São Paulo: Malheiros, 1996. p. 104. Dessa maneira, é lícito afirmar que as democracias parlamentares monarquistas são republicanas em certo sentido, na medida em que haja responsabilidade do agente público e a persecução do bem comum democraticamente decidido.

${ }^{103}$ MARQUES NETO, Floriano Peixoto de Azevedo. Op. cit. p. 32. "Para se afirmar como eixo do poder político, centro do poder decisório, o Estado Moderno dependia da demonstração de que a razão de sua existência era a ação voltada ao atingimento de metas universais. A única forma de fazê-lo seria recorrendo a cláusulas abertas, a categorias totalizantes: o bem comum, a satisfação coletiva, o interesse público.”
} 
apresentar resultados acima dos esperados. Todavia, o soberano poderia ter interesse em usar recursos arrecadados à sociedade para fazer guerras ou desejar construir um grandioso palácio para si, mesmo quando a população vivesse em condições indignas. Obviamente, em nenhum dos dois exemplos, há um avanço na busca do bem comum tal como visto hodiernamente.

Em certa medida, essa preocupação tem sido uma constante desde a Antiguidade, quando existia embrionariamente a noção de que o patrimônio do Estado se diferenciava do dos particulares. Em Roma, há a clássica distinção de Ulpiano que indiretamente refletia a preocupação com os bens do Estado romano ${ }^{104}$ - a própria palavra "república" reflete essa noção. ${ }^{105}$ Também o caráter prático dos romanos se revelou por meio da pioneira diferenciação entre a coisa pública e as demais, feita por Cícero. ${ }^{106}$ Endossando essas assertivas teóricas, ainda que de modo reticente, o direito penal romano comprova que havia certo comprometimento com a proteção da coisa pública, de modo que o furto de coisa pública, o peculatus, já era punido. ${ }^{107}$

Quando a democracia representativa assume o bem comum como finalidade estatal, essas divagações e desvios na utilização do patrimônio público se tornam cada vez mais inaceitáveis pela sociedade civil. Na fase do Estado liberal, em que o bem comum era associado simplesmente ao provimento da justiça e segurança, os regimes políticorepresentativos consolidaram gradualmente a separação patrimonial entre os soberanos e o Estado. ${ }^{108} \mathrm{O}$ desenvolvimento da teoria do físco na Alemanha do século XIX desempenhou papel nodal nesse processo, ${ }^{109}$ identificando movimento iniciado em que as rendas do fisco, personalidade jurídica distinta da do soberano, seriam formadas por aquelas provenientes de

\footnotetext{
$\overline{104}$ Digesto 50, 16, 15 . "Bona civitatis abusive publica dicta sunt; sola enin ea publica sunt, quae populi Romani sunt." Tradução livre do original: "Os bens pertencentes ao Estado são chamados públicos de modo abusivo, uma vez que assim devem ser chamados unicamente os bens que pertencerem ao povo romano".

${ }^{105}$ LAFER, Celso. O significado de república. Estudos históricos, Rio de Janeiro, v. 2, n. 4, p. $216,1989$. "República vem do latim res publica, literalmente o bem público, chamando, portanto, a etimologia da palavra a atenção para a coisa pública, a coisa comum."

${ }^{106}$ LAFER, Celso. O significado de república. Estudos históricos, Rio de Janeiro, v. 2, n. 4, p. 216, 1989. "Foi Cícero quem classicamente examinou a especificidade do conceito de república, ao diferenciar res publica de outras, como a privata, a domestica, a familiaris, estabelecendo, dessa maneira, uma distinção entre o público, isto é, o comum - que corresponde, no grego antigo, às formas substanciadas do adjetivo koinós (comum, público) e, modernamente, à expressão italiana il comune, ao alemão die Gemeinde - e o privado, que não é comum a todos, mas é particular a alguns."

${ }_{107}^{10}$ MOMMSEN, Teodoro. Derecho penal romano. Reimpresión. Santa Fe de Bogotá: Temis, 1999. p. 457.

108 FERRAZ JÚNIOR, Tercio Sampaio. Ética administrativa num país em desenvolvimento. Cadernos de Direito Constitucional e Ciência Política, São Paulo: Revista dos Tribunais, p. 40, jan./mar. 1998.

${ }^{109}$ NOHARA, Irene Patrícia. O motivo no ato administrativo. 2002. 185 f. Dissertação (Mestrado em Direito do Estado)-Faculdade de Direito, Universidade de São Paulo, São Paulo. p. 87.
} 
impostos. ${ }^{110}$ Nos regimes monárquicos parlamentares, o soberano passa a sobreviver com seu próprio patrimônio ou com dotações orçamentárias estatais, votadas pelo Poder Legislativo. Inicia-se o processo de aperfeiçoamento da disciplina orçamentária, bem como da sistemática dos crimes contra a Administração Pública.

Reflexos dessa separação afloram em vários ramos do direito público. No direito administrativo, a afetação do patrimônio público a uma finalidade específica e a inalienabilidade do bem público são aspectos dessa tendência - o primeiro porque decisivamente circunscreve o bem público a uma finalidade a ser cumprida pelo Estado, e o segundo porque caracteriza uma barreira ao arbítrio do soberano para se afastar dessa finalidade. No direito tributário, embora a limitação ao poder de taxar do soberano existisse em muitas normas medievais, a partir do século XVII ela se transforma em limitação ao poder de tributar e é transferida do soberano para o Estado por meio dos mecanismos de representação política. ${ }^{111}$ Posteriormente, no direito financeiro, após as Revoluções Americana e Francesa, acentua-se movimento que começa a exigir autorização do Poder Legislativo para a realização de gastos pelo Estado. Com isso, firma-se no direito público a noção de indisponibilidade do patrimônio público.

O caráter patrimonial da distinção se acentuou em especial após a assunção de grandes responsabilidades no período do Estado de bem-estar social. A crescente incorporação de novos atores sociais ao cenário político tornou maiores as pressões sobre o Estado para o atendimento das necessidades da sociedade e ainda mais inaceitáveis desvios da finalidade estatal. Não é sem razão que a repressão criminal dos delitos contra a Administração Pública ganha maior importância no século XX por meio do endurecimento gradual das penas e da criação de tipos penais para condutas anteriormente atípicas - vide a inclusão do crime de "emprego irregular de verbas ou rendas públicas" no Código Penal de $1940^{112}$ e a Lei $n^{0}$ 10.028/2000, ${ }^{113}$ inserida no contexto de proliferação de "leis de responsabilidade fiscal" em vários países.

\subsubsection{O caráter impessoal da distinção público-privado}

\footnotetext{
$\overline{110}$ BALEEIRO, Aliomar. Uma introdução à ciência das finanças. 15 ed. rev. e atual. por Dejalma de Campos. Rio de Janeiro: Renovar, 1997. p. 142.

${ }^{111}$ TOLDO, Nino Oliveira. O orçamento como instrumento de efetivação das políticas públicas no Brasil. 2006. 205 f. Tese (Doutorado em Direito Econômico-Financeiro)-Faculdade de Direito, Universidade de São Paulo, São Paulo. p. 138.

112 BRASIL. Código Penal. Art. 315. "Dar às verbas ou rendas públicas aplicação diversa da estabelecida em lei: Pena - detenção, de um a três meses, ou multa."

${ }^{113}$ BRASIL. Lei no 10.028 , de 19 out. de 2000.
} 
A separação do patrimônio do soberano e do Estado constitui passo fundamental na estruturação da moderna Administração Pública. Contudo, isoladamente, a mera distinção patrimonial é insuficiente para caracterizar uma separação clara entre o público e o privado. $\mathrm{O}$ patrimônio pessoal e o estatal podem ser bem separados do ponto de vista da forma, mas o detentor do poder político pode utilizar a máquina pública para outros fins que não o bem comum - o soberano pode possuir patrimônio separado, mas lançar mão de recursos públicos para construir um suntuoso palácio e mantê-lo, usufruindo o mesmo. Por esse motivo, ao lado do caráter patrimonial, há outro aspecto mais sutil, relacionado aos fundamentos do próprio regime político: como o governante, em especial aquele democraticamente eleito, faz uso da máquina burocrática que lhe é colocada à disposição pelos eleitores?

Originariamente, o passo inicial para a compreensão desse questionamento é um tanto ingênuo. Conforme explica Ferraz Júnior,

[...] no espírito dessa coordenação, o princípio ético diretor é a imagem do bom rei, do bom senhor, ao que corresponde a imitação como principal virtude cortesã. Administrar exige honra ou disposição para manter a palavra e os próprios princípios, magnanimidade ou disposição à clemência, magnificência ou liberalidade, disposição de estar acima das mesquinharias do cotidiano. ${ }^{114}$

A visão romântica não se sustenta. Com o advento da democracia representativa, a prática política do Estado Democrático de Direito opera a despersonalização desse tratamento, afastando a figura do soberano enquanto "bom pai". Embora se admita a existência dessas figuras nobres, a organização do Estado Democrático de Direito não se assenta na confiança subjetiva dos cidadãos em seus governantes: nem sempre estes estão dotados das melhores intenções, nem sempre estes pretendem perseguir o bem comum para o qual foram eleitos. A autoridade, incumbida de uma função pública, tem o poder para perseguir o bem comum não porque o quer - a autoridade, engessada pela finalidade orientadora do interesse público, tem o poder de agir justamente porque deve fazê-lo de acordo com o interesse público. Inexiste espaço para qualquer voluntarismo ou personalismo por parte da autoridade. Nas palavras de Poggi,

[...] o ideal moral que fundamentalmente legitima o Estado moderno é a domesticação do poder através da despersonalização de seu exercício. Quando o poder é gerado e regulamentado através das leis gerais, a probabilidade de seu exercício arbitrário é minimizada; correspondentemente minimizado é o elemento de submissão pessoal nas relações dos indivíduos em geral com aqueles que exercem as prerrogativas de governo, uma vez estes últimos só exercem autoridade como

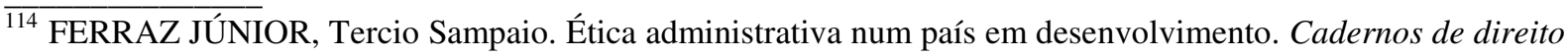
constitucional e ciência política. São Paulo: Revista dos Tribunais, jan./mar. 1998. p. 40.
} 
ocupantes de posições especificadas e legalmente controladas. No fundo, em suas relações políticas, os indivíduos não obedecem uns aos outros mas à lei. ${ }^{115}$

Consequentemente, o Estado se despersonalizou, expurgando as simpatias e antipatias porventura existentes no relacionamento com os cidadãos, dotados de seus próprios interesses privados. Esse processo de profissionalização estatal forjou a dimensão e o alcance atuais do princípio jurídico da igualdade, segundo o qual todos são iguais perante a lei ${ }^{116}$ - não se admite o favorecimento ou desfavorecimento de um em detrimento de outro com base em motivos essencialmente subjetivos. Como explica Mello, "sendo encarregada de gerir interesses de toda a coletividade, a Administração não tem sobre estes bens disponibilidade que lhe confira o direito de tratar desigualmente àqueles cujos interesses representa". ${ }^{117}$ Para que se permita uma distinção, faz-se necessário algo que objetivamente coloque determinada pessoa em situação especial. Por isso, é legítima a imunidade a parlamentares por opiniões emitidas, pois estes possuem função especial no sistema político; entretanto, outorgar-lhes imunidades ou privilégios na totalidade dos tipos penais ou nas relações de direito privado atenta contra a responsabilidade, noção basilar do princípio republicano. ${ }^{118}$

Onde não houve a monarquia e a confusão entre o patrimônio do soberano e do Estado, o processo de despersonalização da máquina burocrática se verificou. Por exemplo, nos Estados Unidos, país que jamais experimentou in loco uma monarquia e no qual esta, na fase colonial, exercera controle tênue, a apropriação e o uso da máquina administrativa pelos vencedores das eleições, denominada spoils system (sistema de espólio), foi regra na prática

\footnotetext{
$\overline{115}$ POGGI, Gianfranco. Op.cit. p. 111. No mesmo sentido, ver LAFER, Celso. O sistema político brasileiro. São Paulo: Perspectiva, 1975. p. 44. "[...] a administração se preocupa com a execução de decisões já tomadas. O que se requer, portanto, em princípio, em matéria de administração é precisão, estabilidade e controle na execução da decisão já tomada. O tipo e o escopo da decisão determinam o rigor do seu possível controle."

${ }^{116}$ BRASIL. Constituição (1988). Art. 5. "Todos são iguais perante a lei, sem distinção de qualquer natureza, garantindo-se aos brasileiros e aos estrangeiros residentes no País a inviolabilidade do direito à vida, à liberdade, à igualdade, à segurança e à propriedade, nos seguintes termos: I - homens e mulheres são iguais em direitos e obrigações, nos termos desta Constituição."

${ }^{117}$ MELLO, Celso Antônio Bandeira de. Op. cit. p. 31.

118 TEMER, Michel. Elementos de direito constitucional. 15. ed. São Paulo: Malheiros, 2000. p. 129-130. “A inviolabilidade diz respeito à emissão de opiniões, palavras e votos. Opiniões e palavras que, ditas por qualquer pessoa, podem caracterizar atitude delituosa, mas que assim não se configuram quando pronunciados por parlamentar. Sempre, porém, quando tal pronunciamento se der no exercício do mandato. Quer dizer: o parlamentar, diante do Direito, pode agir como cidadão comum ou como titular de mandato. Agindo na primeira qualidade não é coberto pela inviolabilidade. A inviolabilidade está ligada à idéia de exercício de mandato. Opiniões, palavras e votos proferidos sem nenhuma relação com o desempenho do mandato representativo não são alcançados pela inviolabilidade."
} 
política por várias décadas - a escolha dos funcionários era feita sem nenhum requisito quanto à sua capacidade. ${ }^{119}$

Tocqueville observava a prática como desdobramento do princípio da soberania popular, embora afirmasse também que o exercício pela população de várias tarefas fosse intenso. ${ }^{120}$ As críticas ao spoils system, associado ao populismo político, sempre foram intensas, mas igualmente foram intensas as resistências à forma alternativa de acesso baseada no mérito, visto como um sistema aristocrático de acesso ao emprego público de acordo com a argumentação de políticos populistas.

Somente em 1883, no âmbito da administração pública federal, o Pendleton Act criou uma comissão que deveria avaliar os candidatos a um emprego público com base no mérito. Devido à alternância de grupos políticos nas eleições subsequentes, o escopo da lei foi expandido e, por volta de 1900, a maioria dos cargos públicos já era ocupada por funcionários públicos escolhidos com base no mérito e dotados de relativa estabilidade. ${ }^{121}$ Tal sistema foi aprofundado em 1939 com a promulgação do Hatch Act, que proibiu funcionários públicos federais de participar de atividades político-partidárias. ${ }^{122}$

\section{$1.4 \mathrm{O}$ surgimento da burocracia weberiana}

Especialmente no que tange à separação patrimonial entre o soberano e o Estado e à impessoalização das relações com o Estado, encontra-se explícita a noção de profissionalização da máquina burocrática, tema caro a Weber em Economia e sociedade: fundamentos da sociologia compreensiva. ${ }^{123}$ De fato, Weber analisa o Estado sob o prisma da

\footnotetext{
119 GOODNOW, Frank J. The principles of administrative law of the United States. Clark: The Lawbook Exchange, 2003. p. 265. O espírito do spoils system é sintetizado na mensagem ao Congresso, datada de 8 de dezembro de 1829, enviada pelo presidente Jackson: "There are, perhaps, few men who can for any great length of time enjoy office and power without being more or less under the influence of feelings unfavorable to the public discharge of their public duties. [...] The duties of all public officers are, or at least admit of being made, so plain and simple that men of intelligence may readily qualify themselves for their performance; and I cannot but believe that more is lost by the long continuance of men in office than is generally to be gained by their experience. I submit, therefore, to your consideration, whether the efficiency of the government would not be promoted and official honesty and integrity better secured by the general extension of the law which limits appointments to four years".

${ }^{120}$ TOCQUEVILLE, Alexis de. Democracy in America. Adelaide: University of Adelaide Library, 2008, Livro I, Cap. 4. Disponível em: <http://ebooks.adelaide.edu.au/t/tocqueville/alexis/democracy/>. Acesso em: 27 set. 2009 às $15 \mathrm{~h} 11$.

${ }^{121}$ GOODNOW, Frank J. Op. cit. p. 266.

${ }^{122}$ BALEEIRO, Aliomar. Op. cit. p. 114.

${ }^{123}$ WEBER, Max. Economia e sociedade: fundamentos da sociologia compreensiva. Tradução de Regis Barbosa e Karen Elsabe Barbosa. Revisão técnica de Gabriel Cohn. Brasília: UnB, 1999. 2 v.
} 
dominação, ${ }^{124}$ a qual não necessariamente "se serve de meios econômicos", tampouco "possui fins econômicos". ${ }^{125} \mathrm{O}$ que embasa a dominação é a natureza dos motivos, que podem ser basicamente de três tipos: (i) costumeiros ou afetivos, (ii) interesses materiais e (iii) ideais quanto aos valores.

Tais motivos encontram-se presentes em graus variáveis e são amalgamados pela crença na legitimidade da dominação. A identificação destas é tarefa complexa: "as formas pelas quais a legitimidade se insere ou se descola de um sistema jurídico e político, garantindo ou ameaçando um regime, isto é, o modo de organização do poder, não comporta uma resposta fácil ou unívoca”. ${ }^{126}$

Embora se reconheça a existência de outras explicações para a questão da legitimidade na formação do Estado brasileiro, inclusive as de caráter marxista, ${ }^{127}$ adotou-se Weber como paradigma devido ao fato de este ter exercido influência preponderante sobre os estudos da formação do Estado patrimonialista no Brasil. ${ }^{128}$ Contudo, nenhuma dessas explicações é mutuamente excludente e até mesmo se complementam.

Conforme explica Weber, "dependendo da natureza da legitimidade pretendida diferem o tipo da obediência e do quadro administrativo destinado a garanti-la, bem como o

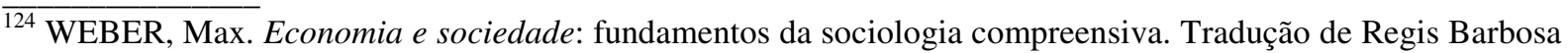
e Karen Elsabe Barbosa. Revisão técnica de Gabriel Cohn. Brasília: UnB, 1999. v. 1. p. 139. "[...] chamamos 'dominação' a probabilidade de encontrar obediência para ordens específicas para ordens específicas (ou todas) dentro de determinado grupo de pessoas. Não significa, portanto, toda espécie de possibilidade de exercer "poder' ou 'influência' sobre outras pessoas."

${ }^{125}$ Ibidem.

${ }^{126}$ LAFER, Celso. Op. cit., 1975. p. 40.

${ }^{127}$ A formação do Estado no Brasil resulta da relação entre três elementos fundamentais, a saber, a sociedade, as elites e a máquina burocrática. Seguindo a tradição historiográfica marxista, na qual o Estado se constitui como instrumento daqueles que detêm o poder econômico, Prado Jr. apresenta o Estado como instrumento absoluto da relação com a classe economicamente preponderante - a dominação política seria apenas um reflexo da dominação econômica, inexistindo uma elite política com interesses diversos da elite econômica. PRADO JR., Caio. História econômica do Brasil. São Paulo: Brasiliense, 2006. Numa abordagem menos direta, outros consideram o Estado como instrumento das relações clientelistas, em que as elites rurais controlam as eleições e, mediatamente, o Estado. Uma terceira linha nessa tradição marxista é apresentada por MATOS, Ilmar Rohloff de. O tempo saquarema: a formação do Estado imperial. Rio de Janeiro: Hucitec, 1987. p. 171. Este desenvolve o conceito de Estado instrumento, atenuando a presença da elite econômica no Estado, com o aperfeiçoamento da noção de elite política enquanto uma parte da classe econômica dominante. Para Matos, haveria fatores de afastamento entre o membro da elite econômica, que dirige suas atividades mercantis, e o da elite política, que governa o Estado, embora sejam todos membros da mesma elite - por esse motivo, ambos os membros da elite econômica e política defendem a manutenção do status quo. Mais distanciada da tradição marxista, identifica-se atualmente uma elite política que se distancia da classe econômica dominante, usando o referencial da burocracia. Os representantes mais significativos dessa corrente são Sérgio Buarque de Holanda, Raymundo Faoro, José Murilo de Carvalho, entre outros. Para a explicação da dicotomia entre as esferas pública e privada, Faoro e Carvalho desempenham um papel fundamental entre os historiadores brasileiros. FAORO, Raymundo. Os donos do poder. 3. ed. Porto Alegre: Globo, 2001. CARVALHO, J. Murilo de. A construção da ordem e teatro de sombras. 3. ed. São Paulo: Civilização Brasileira, 2003.

${ }^{128}$ Para críticas à abordagem que relaciona corrupção e patrimonialismo no Brasil, ver SOUZA, Jessé. Weber. In: AVRITZER, Leonardo et al. (Org.). Op. cit. p. 81-90.
} 
caráter do exercício da dominação". Com base nessa assertiva, podem-se identificar "três tipos puros de dominação" com pretensões de legitimidade: 
1. de caráter racional: baseada na crença na legitimidade das ordens estatuídas e do direito de mando daqueles que, em virtude dessas ordens, estão nomeados para exercer a dominação (dominação legal), ou

2. de caráter tradicional: baseada na crença cotidiana na santidade das tradições vigentes desde sempre e na legitimidade daqueles que, em virtude dessas tradições, representam a autoridade (dominação tradicional), ou, por fim,

3. de caráter carismático: baseada na veneração extracotidiana da santidade, do poder heróico ou caráter exemplar de uma pessoa e das ordens por esta reveladas ou criadas (dominação carismática). ${ }^{129}$

A autoridade tem uma legitimidade oriunda do direito, fator que faz o indivíduo obedecer ao comando superior. Em termos da teoria geral do direito, a autoridade possui o poder na medida em que possui uma função, consistente num dever, estabelecido pelo ordenamento jurídico.

Essa explanação permite associar o modelo em que prevalece a distinção entre os espaço público e privado à dominação racional. Nesta, inspirado no profissionalismo da burocracia austríaca e alemã da passagem do século XIX ao século XX, Weber enxergava o ápice da evolução estatal, bem como os rudimentos do Estado Democrático de Direito. ${ }^{130}$ Nas palavras de Bucci,

[...] no paradigma burocrático de Weber encontram-se, explícitos ou implícitos, os princípios da igualdade perante a lei, da legalidade (autoridade delimitada por normas, governante como primeiro servidor do Estado) e até mesmo um embrião dos princípios da motivação e da procedimentalização, na obrigatoriedade tanto de registro dos atos da Administração Pública em documentos escritos, quanto do devido processo legal e na recorribilidade das decisões administrativas. ${ }^{131}$

Ainda na síntese de Weber, a dominação racional se baseia nas seguintes ideias:

1. todo direto, mediante pacto ou imposição, pode ser estatuído de modo racional $[\ldots]$;

2. todo direito é, segundo sua essência, um cosmos de regras abstratas, normalmente estatuídas com determinadas intenções; que a judicatura é a aplicação dessas regras ao caso particular e que a administração é o cuidado racional dos interesses previstos pelas ordens da associação, dentro dos limites das normas jurídicas e segundo princípios indicáveis de forma geral [...]";

3. o senhor legal típico, o "superior", enquanto ordena e, com isso, manda, obedece por sua parte à ordem impessoal pela qual orienta suas disposições;

4. quem obedece só o faz como membro da associação e só obedece ao "direito";

5. a idéia de que os membros da associação, ao obedecerem ao senhor, não o fazem

à pessoa destes, mas sim àquelas ordens impessoais e que, por isso, só são

\footnotetext{
${ }^{129}$ WEBER, Max. Economia e sociedade: fundamentos da sociologia compreensiva. Op. cit. p. 141.

${ }^{130}$ HEIDENHEIMER, Arnold J. The content of analysis. In: HEIDENHEIMER, Arnold J. Political corruption: readings in comparative analysis. 2. ed. New Brunswick: Transaction Books, 1978. p. 15-16.

${ }^{131}$ BUCCI, Maria Paula D. Direito administrativo e políticas públicas. São Paulo: Saraiva, 2002. p. 103.
} 
obrigados à obediência dentro da competência objetiva, racionalmente limitada, que lhe foi atribuída por essas ordens. ${ }^{132}$

A análise weberiana revela um perceptível apego à lei, típico dos pensadores dos séculos XVIII e XIX, e o positivismo jurídico deita raízes exatamente sobre esse apego. ${ }^{133}$ Certamente, a legitimidade não se reduz à legalidade. Entretanto, para fins de confronto com a realidade, este arquétipo burocrático pode ser tomado como um modelo ideal do Estado Moderno, pois este tem sido usado para descrever a superação de organizações políticas baseadas em outras legitimidades que não a racional, típicas em muitos dos países hoje considerados desenvolvidos hoje. ${ }^{134}$

A essa categoria idealizada por Weber se somaria a dominação sob a forma carismática e tradicional. Para a análise da formação do Estado brasileiro, a dominação tradicional na sua vertente patrimonialista apresenta maior relevância. Em realidade, uma breve análise das características da dominação tradicional explica o porquê de tal recurso.

$\mathrm{Na}$ dominação tradicional, inexiste um fim objetivo e impessoal, do mesmo modo que inexiste o dever de obedecer a normas abstratas. A obediência é devida "em relações de piedade rigorosamente pessoais". ${ }^{135}$ A autoridade possui um poder que pode ser usado ao seu talante, pois inexiste um fim impessoal ou função a ser desempenhada.

Nada poderia ser mais antitético em relação à moderna concepção delimitadora dos espaços público e privado do que a pessoalidade das relações estatais: o parente ou afilhado obtém o emprego por ser parente, o detentor do poder utiliza avião do Estado para levar a sogra ao exterior em férias, e o indivíduo alheio às teias relacionais detentoras do poder fica à mercê da arbitrariedade. As leis têm sentidos diferentes sob a dominação racional vis-à-vis a dominação tradicional:

\footnotetext{
Na dominação burocrática é a norma estatuída que cria a legitimação do detentor concreto do poder para dar ordens concretas.

$\mathrm{Na}$ dominação patriarcal é a submissão pessoal ao senhor que garante a legitimidade das regras por este estatuídas, e somente o fato e os limites de seu poder de mando têm, por sua vez, sua origem em "normas", mas em normas não estatuídas, sagradas pela tradição. ${ }^{136}$
}

\footnotetext{
$\overline{132}$ WEBER, Max. Op. cit. p. 142.

${ }^{133}$ GOYARD-FABRE, Simone. Op. cit. p. 281.

${ }^{134}$ HEIDENHEIMER, Arnold J. The content of analysis. In: HEIDENHEIMER, Arnold J. Political corruption: readings in comparative analysis. 2. ed. New Brunswick: Transaction Books, 1978. p. 16-17. O autor mostra como, até o século XIX, a dominação tradicional e patrimonialista era a regra nos Estados Unidos, na Inglaterra e na França.

${ }^{135}$ WEBER, Max. Op. cit. p. 234.

${ }^{136}$ Ibidem.
} 
A vertente patrimonialista da dominação tradicional possui alguns traços adicionais. Há descentralização "mediante cessão de terras e eventualmente utensílios para filhos e outros dependentes da comunidade doméstica", e o dependente se torna submisso aos desígnios do senhor, retribuindo-lhe com presentes, prestação de serviços, pagamento de tributos e auxílio como massa de manobra, inclusive para intimidação de oponentes, quando necessário.

Mais ainda, o senhor se considera no direito de retomar a propriedade e os privilégios concedidos. ${ }^{137} \mathrm{O}$ senhor não se submete à lei alguma, pois a tradição lhe garante o direito de agir a seu próprio talante. ${ }^{138}$

O Estado patrimonialista não significa necessariamente uma organização estatal voltada para o saque do público pelo privado. O modo como o patrimonialismo se desenvolveu historicamente no Brasil demonstra que há um comportamento parasítico do político em relação à coisa pública. Em virtude da importação formal da separação entre público e privado, a maioria dos políticos possui algum "espírito público", ${ }^{139}$ embora, por vezes até mesmo sem perceber, tomem o Estado como se fosse sua propriedade particular.

\footnotetext{
${ }^{137}$ Idem, p. 238.

${ }^{138}$ NOHARA, Irene Patrícia. Op. cit. p. 87. "Era o direito público, no Estado de Polícia, estruturado sobre princípios como os da regis voluntas suprema lex (a vontade do rei é a lei suprema), do quid principi placuit legis habet vigorem (aquilo que agrada ao príncipe tem força de lei) e the king can do no wrong (o rei não pode errar)."

${ }^{139}$ LEAL, Victor Nunes. Coronelismo, enxada e voto: o município e o regime representativo no Brasil. São Paulo: Alfa-Ômega, 1976. p. 37. "A falta de espírito público, tantas vezes irrogada ao chefe político local, é desmentida, com frequência, por seu desvelo pelo progresso do distrito ou município. É ao seu interesse e à sua insistência que se devem os principais melhoramentos do lugar. A escola, a estrada, o correio, o telégrafo, a ferrovia, a igreja, o posto de saúde, o hospital, o clube, o campo de foot-ball, a linha de tiro, a luz elétrica, a rede de esgotos, a água encanada -, tudo exige o seu esforço, às vezes um penoso esforço que chega ao heroísmo. É com essas realizações de utilidade pública, algumas das quais dependem só do seu empenho e prestígio político, enquanto outras podem requerer contribuições pessoais suas e dos amigos, é com elas que, em grande parte, o chefe municipal constrói ou conversa sua posição de liderança."
} 


\section{CAPÍTULO 2 \\ CORRUPÇÃO: CONCEITO E EFEITOS}

Uma vez explicitado o resultado histórico do processo de modernização do Estado, a corrupção pode ser considerada como subversão da premissa na qual se baseia a dicotomia público-privado. Erigida como uma técnica para atingir o bem comum, a dicotomia públicoprivado pode ser corrompida de maneiras e intensidades diversas. Em realidade, essa subversão não é fenômeno exclusivo da esfera pública, pois, da perspectiva da teoria geral do direito, a corrupção constitui uma quebra de confiança, o que pode ocorrer também na esfera privada. No caso do interesse público, o corrupto trai a confiança que nele foi depositada pela sociedade para perseguir o bem comum, o que significa que o agente público corrupto usa seu poder para fins outros que não os deveres decorrentes da dicotomia público-privado.

Muito mais do que mera quebra de formalidade ínsita ao Estado moderno, a corrupção possui efeitos deletérios sobre o tecido social, contaminando a política e a economia. Em razão desses efeitos, justifica-se a preocupação estatal na tomada de ações para combater a corrupção. Para evitar que as conclusões sejam por demais niilistas e resvalem num moralismo até mesmo midiático ou apontem para uma suposta equivocada deformação atávica da formação social do povo brasileiro, é necessário reafirmar a legitimidade do combate à corrupção enquanto parte da ação estatal. Por isso, na conclusão deste capítulo, será debatida a legitimidade da ordem político-democrática como pressuposto do combate à corrupção, enfatizando-se a sua premência em vista dos nefastos efeitos que minam os objetivos constitucionalmente estabelecidos.

\subsection{A corrupção enquanto subversão do valor confiança}

Delimitados os contornos do que se deve entender por uma moderna configuração da burocracia estatal no seio da dicotomia público-privado, o passo subsequente é localizar a corrupção nesse contexto. Duas alternativas se apresentam. 
Primeiro, pode-se considerar a corrupção como a situação normal de promiscuidade entre o público e o privado, inerente à organização do Estado patrimonialista. Afinal, alguns afirmam ironicamente que a corrupção seria a segunda mais velha profissão do mundo. No Estado em que a legitimidade repousa na dominação tradicional, a corrupção faz parte do próprio sistema, o qual desconhece a integralidade da finalidade inerente à dicotomia públicoprivado.

Todavia, essa análise sociológica, desprovida de qualquer valoração, causa repulsa àqueles que compreendem as implicações para o Estado moderno daquelas características da dominação racional no sentido weberiano. Dessa perspectiva, a corrupção pode ser vista muito mais como patologia social do que como propriamente algo inerente à organização estatal. Enquanto patologia social, a corrupção se volta contra a legitimidade racionalmente estabelecida, subvertendo o seu elemento de dominação. Em outras palavras, o "alvo" da corrupção repousa na subversão daquela finalidade estabelecida pelo direito.

Tal subversão pode se verificar em três planos: o das regras, o dos princípios e o dos valores.

Um grande número de regras é ofendido pelas diversas formas que as práticas corruptas tomam, seja na esfera pública, seja na esfera privada - aceitar suborno viola deveres funcionais e constitui crime. O mesmo se verifica em relação aos princípios: o nepotismo ofende aos princípios da impessoalidade e da moralidade administrativa. Entre as possibilidades abertas, porém, a corrupção mina mais seriamente os valores, na medida em que vilipendia a confiança, presente na organização social, esteja ela localizada na esfera pública ou na privada. Como explica Saldanha,

[...] a relação entre valores éticos e valores políticos se reflete, como não poderia deixar de ser, na fundamentação dos sistemas políticos e, com os termos "sistemas" estamos abrangendo as formas de governo e os chamados regimes, sobretudo se tivermos em conta o conceito amplo de política e politicidade [...]..$^{140}$

Ao impactar a política, efeitos também são sentidos na economia. Numa abordagem mais ampla, deve-se reconhecer que a visão sistêmica insula problemas como a corrupção e tende a ignorar o emaranhado de relações sociais existentes.

A confiança pode ser considerada como um dos principais pilares da vida social, refletindo-se sobre a política e a economia. Numa sociedade complexa, em que haja divisão social do trabalho, cada indivíduo precisa confiar sua subsistência a outrem - a subsistência

\footnotetext{
${ }^{140}$ SALDANHA, Nelson. Ética e história. 2. ed. rev. e ampl. Rio de Janeiro: Renovar, 2007. p. 45.
} 
do ermitão é inviável na escala das sociedades complexas. O consumidor de pão precisa confiar que o padeiro faça seu trabalho, bem como este precisa confiar no triticultor. Por seu turno, este necessita dos recursos que lhe são indiretamente destinados pelos consumidores de pão. Esse exemplo poderia ser expandido sucessivamente, de modo a explicitar as múltiplas e interligadas relações sociais. Até mesmo economistas, normalmente avessos às considerações sobre valores, reconhecem esse aspecto. ${ }^{141}$

Não é sem razão que alguns estudos relacionam o nível de confiança (trust) existente numa sociedade à corrupção - onde a confiança é maior a corrupção tenderia a ser menor, enquanto onde a confiança é menor a corrupção tenderia a ser maior. ${ }^{142}$ Essas premissas decorrem de observações da teoria dos jogos - quer seja em jogos repetidos em que os jogadores se veem diante do dilema dos prisioneiros, quer seja em jogos com uma única rodada do tipo ultimato, em que os jogadores tendem a se comportar razoavelmente ou, até mesmo, com lealdade. ${ }^{143} \mathrm{O}$ combate a algumas formas de corrupção seria facilitado pela maior cooperação entre agentes públicos e cidadãos devido à confiança recíproca entre ambos.

$\mathrm{O}$ direito privado captou esse fenômeno e o instrumentalizou, tornando-o operacionalmente vinculado às relações contratuais. Confiança se torna sinônimo de crédito. Como explica o verbete confiança na Enciclopédia Saraiva de Direito, “[...] o fato de se ter confiança em alguém revela que a pessoa, pelo seu caráter, comportamento e princípios morais, é merecedora de crédito, de modo que se deposita em sua ação e em seu comportamento". ${ }^{144}$ Os negócios jurídicos fiduciários ${ }^{145}$ e a boa-fé contratual, ${ }^{146}$ ambos positivadas no Código Civil, deixam transparecer mais fortemente o valor confiança, embora este impregne parte substancial das relações sociais e jurídicas. Em algumas jurisdições, a

\footnotetext{
$\overline{{ }^{141} \text { WILLIAMSON }}$, Oliver E. The economic institutions of capitalism. Nova York: The Free Press, 1985. p. 405.

${ }^{142}$ LAMBSDORFF, Johann Graf. The institutional economics of corruption and reform: theory, evidence, and policy. Cambridge: Cambridge University Press, 2008. p. 29.

${ }^{143}$ LA PORTA, R. et al. Trust in large organizations. National Bureau of Economic Research. NBER Working Paper n. 5864, Cambridge, 1996. p. 4. Disponível em <http://www.nber.org/papers/w5864.pdf>. Acesso em: 1 dez. 2008 às $18 \mathrm{~h} 36$.

${ }^{144}$ DINAMARCO, C. R. Confiança. In: FRANÇA, R. M. Enciclopédia Saraiva do direito. São Paulo: Saraiva, 1977. v. 17. p. 512.

145 BRASIL. Código Civil. Art. 1.361. "Considera-se fiduciária a propriedade resolúvel de coisa móvel infungível que o devedor, com escopo de garantia, transfere ao credor."

${ }^{146}$ Há muitas referências à boa-fé no Código Civil. Os arts. 113 e 422 são mais categóricos ao explicitar a relação com o valor confiança. BRASIL. Código Civil. Art. 113. "Os negócios jurídicos devem ser interpretados conforme a boa-fé e os usos do lugar de sua celebração." Art. 422. "Os contratantes são obrigados a guardar, assim na conclusão do contrato, como em sua execução, os princípios de probidade e boa-fé."
} 
"corrupção dos prepostos comerciais ou industriais" recebe tratamento similar ao dispensado à corrupção na esfera pública. ${ }^{147}$

Logo, a confiança é elemento integrante e fundamental de qualquer contrato, especialmente no contrato de trabalho, cuja qualidade essencial é a colaboração. Considerando-se que o elemento fiducial é inerente às relações de emprego, a legislação trabalhista prevê que o abalo da confiança depositada no empregado pelo empregador é capaz de ensejar o fim do vínculo empregatício, com a resolução do contrato de trabalho por justa causa.

O rol de faltas graves previstas no artigo 482 da CLT $^{148}$ enumera algumas situações típicas relacionadas à quebra da confiança, dentre as quais se destacam: (i) mau procedimento; (ii) ato de improbidade; (iii) violação de segredo de empresa; e (iv) negociação habitual que constitui ato de concorrência à empresa para a qual trabalha o empregado. Delgado considera o mau procedimento uma espécie de cláusula geral que abrange de uma maneira elástica todas as condutas do empregado que ofendam a moralidade na relação de trabalho, devendo ser levada em conta a gravidade da ofensa. Veja-se a definição proposta pelo autor:

\begin{abstract}
Mau procedimento (alínea "b", in fine). Trata-se de conduta culposa do empregado que atinja a moral, sob o ponto de vista geral, excluído o sexual, prejudicando o ambiente laborativo ou as obrigações contratuais do obreiro.

A amplitude desse tipo jurídico é manifesta, mostrando a plasticidade da tipificação de infrações seguida pela CLT. Tal amplitude autoriza enquadrar-se como mau procedimento condutas extremamente diferenciadas, tais como dirigir o veículo da empresa sem habilitação ou sem autorização, utilizar-se de tóxico na empresa ou ali traficá-lo; pichar paredes do estabelecimento; danificar equipamentos empresariais, etc. No quadro dessa perigosa amplitude, é essencial ao operador jurídico valer-se, com segurança, técnica e sensibilidade, dos critérios subjetivo, objetivos e circunstanciais de aferição de infrações e de aplicação de penalidades no Direito do Trabalho. Em especial, deve avaliar a efetiva gravidade da conduta, para que o conceito de moral, naturalmente largo, não estenda desmesuradamente o tipo jurídico em exame. ${ }^{149}$
\end{abstract}

\footnotetext{
$\overline{147}$ HUNGRIA, Nélson. Comentários ao Código Penal (Dec.-Lei no 2.848, de 7 de dezembro de 1940). v. 9, Art. 250 a 361. 2. ed. Rio de Janeiro: Forense, 1959. p. 267.

${ }^{148}$ BRASIL. Consolidação das Leis do Trabalho. Art. 482. "Constituem justa causa para rescisão do contrato de trabalho pelo empregador: a) ato de improbidade; b) incontinência de conduta ou mau procedimento; c) negociação habitual por conta própria ou alheia sem permissão do empregador, e quando constituir ato de concorrência à empresa para a qual trabalha o empregado, ou for prejudicial ao serviço; d) condenação criminal do empregado, passada em julgado, caso não tenha havido suspensão da execução da pena; e) desídia no desempenho das respectivas funções; f) embriaguez habitual ou em serviço; g) violação de segredo da empresa; h) ato de indisciplina ou de insubordinação; i) abandono de emprego; j) ato lesivo da honra ou da boa fama praticado no serviço contra qualquer pessoa, ou ofensas físicas, nas mesmas condições, salvo em caso de legítima defesa, própria ou de outrem; k) ato lesivo da honra ou da boa fama ou ofensas físicas praticadas contra o empregador e superiores hierárquicos, salvo em caso de legítima defesa, própria ou de outrem; l) prática constante de jogos de azar."

${ }^{149}$ DELGADO, Maurício Godinho. Curso de direito do trabalho. 8. ed. São Paulo: LTr, 2009. p. 1098.
} 
Por sua vez, o ato de improbidade, embora também configure mau procedimento, é caracterizado pela ofensa ao patrimônio tangível de alguém, especialmente do seu empregador. ${ }^{150}$ A violação de segredo de empresa é a divulgação não autorizada de patentes de invenção, métodos de execução, fórmulas, escrita comercial e demais informações de uso ou conhecimento exclusivo da empresa que não devam ser tornadas públicas, especialmente aos seus concorrentes. ${ }^{151}$ A negociação habitual que constitui ato de concorrência à empresa se configura quando o empregado exerce, extracontratualmente, atividade que faz concorrência ao seu empregador, ofendendo a lealdade implícita ao contrato. As duas últimas situações não só constituem falta grave, mas também podem configurar crimes de concorrência desleal nos termos da Lei $\mathrm{n}^{\mathrm{o}}$ 9.279/96. ${ }^{152}$ Apesar de existir um quadro de sanções para o que se pode considerar corrupção nas relações de trabalho, ao se deparar com condutas de tal natureza, habitualmente o empregador brasileiro considera mais conveniente demitir os empregados sem justa causa. Em linhas gerais, podem-se apontar duas justificativas para isso. A primeira é a aversão ao risco de pagar vultosas indenizações trabalhistas e civis. Os juízes do trabalho apreciam rigidamente as provas de demissões por justa causa, pois esta é uma medida extrema que imputa ao trabalhador restrições financeiras significativas. A prova produzida pelo empregador deve ser cabal e forte o suficiente para demonstrar a falta grave. O trecho de decisão transcrito abaixo ilustra o entendimento da Justiça do Trabalho:

Justa causa - Quebra de fidúcia - Comprovação - A resolução do vínculo laboral, a
par de representar a maior penalidade que pode ser imposta ao trabalhador, na
medida em que gera reflexos pecuniários imediatos e profissionais futuros, contraria
os princípios da boa-fé, dos quais deflui o dever de execução leal das obrigações
assumidas, e o da continuidade da relação de emprego, em que se presume o
interesse do empregado na manutenção do vínculo empregatício, eis que fonte de \begin{tabular}{l}
\hline 150 Idem, ibidem. Ato de improbidade é “[...] conduta faltosa obreira que provoque dano ao patrimônio \\
empresarial ou de terceiro, em função de comportamento vinculado ao contrato de trabalho, com o objetivo de \\
alcançar vantagem para si ou para outrem. O ato de improbidade, embora seja também mau procedimento, \\
afrontando a moral genérica imperante na vida social, tem a particularidade, segundo a ótica justrabalhista, de \\
afetar o patrimônio de alguém, em especial o empregador, visando, irregularmente, a obtenção de vantagens para \\
o obreiro ou a quem este favorecer. Aponta, desse modo, Wagner Giglio que a jurisprudência, inicialmente, e a \\
doutrina, em seguida, reservaram o conceito trabalhista de improbidade, por exclusão, somente para as \\
manifestações desonestas do empregado que constituam atentado ao patrimônio ou, mais exatamente, a bens \\
materiais". \\
151 NASCIMENTO, Amauri M. Iniciação ao direito do trabalho. 17. ed. São Paulo: LTr, 1991. p. 198. \\
152 BRASIL. Lei no 9.279 , de 14 maio 1996 . Art. 195. "Comete crime de concorrência desleal quem: [...] III - \\
emprega meio fraudulento, para desviar, em proveito próprio ou alheio, clientela de outrem; [...] X - recebe \\
dinheiro ou outra utilidade, ou aceita promessa de paga ou recompensa, para, faltando ao dever de empregado, \\
proporcionar vantagem a concorrente do empregador; XI - divulga, explora ou utiliza-se, sem autorização, de \\
conhecimentos, informações ou dados confidenciais, utilizáveis na indústria, comércio ou prestação de serviços, \\
excluídos aqueles que sejam de conhecimento público ou que sejam evidentes para um técnico no assunto, a que \\
teve acesso mediante relação contratual ou empregatícia, mesmo após o término do contrato; [...]."
\end{tabular} 
sua subsistência. Nesse diapasão, erigiram as Cortes Trabalhistas, de modo uníssono, entendimento segundo o qual a razão determinante da ruptura justificada do contrato de trabalho deve ser comprovada de modo cabal e inconteste pelo empregador, sob pena de se presumir injusta a dispensa, e devidas as verbas pecuniárias decorrentes. ${ }^{153}$

A segunda justificativa está em certa tolerância, seja por parte dos empregadores, seja por parte dos juízes do trabalho, em relação a atos imorais que tenham pequena repercussão patrimonial para o empregador. Da perspectiva da Justiça do Trabalho, essa tolerância funda-se no argumento de que há três medidas punitivas disponíveis pelo empregador para restaurar a confiança (advertência, suspensão e dispensa) e de que as sanções deveriam ser escalonadas conforme a gravidade da conduta do empregado. A subtração de bens de valor insignificante não poderia ensejar a penalidade mais pesada ao trabalhador ${ }^{154}$ - tal entendimento é corroborado inclusive pelo Tribunal Superior do Trabalho. ${ }^{155}$

Mesmo os empregadores toleram tal comportamento: veja-se o caso de empregados que utilizam o benefício do vale-transporte, mas usam condução própria para o deslocamento ao trabalho. Embora a Justiça do Trabalho tenha sido favorável às demissões por justa causa nessas hipóteses, tendo em vista que o ato de improbidade praticado abala a confiança na

$\overline{153}$ BRASIL. Tribunal Regional do Trabalho da $10^{\mathrm{a}}$ Região. Recurso Ordinário no 3469/2001. $3^{\mathrm{a}}$ Turma. Relatora: Juíza Márcia Mazoni Cúrcio Ribeiro. DJU 18/01/2002.

${ }^{154}$ BRASIL. Tribunal Regional do Trabalho da 23ª Região. Recurso Ordinário no 00935.2007.051.23.00-8. $1^{\text {a }}$ Turma. Rel.: Desembargador Edson Bueno. DJU 29 maio 2008. “dispensa por justa causa. Requisitos. Medidas punitivas. Gravidade. Não-cabimento. A dispensa com justa causa operária é medida extrema tomada pelo empregador para a extinção do contrato de trabalho, imputando ao trabalhador restrições financeiras e qualitativas. A terminação ocorre com a quebra da qualidade essencial desse tipo contratual, qual seja, a colaboração. Como contrato de colaboração onde o elemento fiducial é sua característica inerente, necessário que efetivamente o ato perpetrado torne insubsistente o vínculo de emprego. Inconteste a perpetração do ato punitivo ensejador da dispensa imposta pelo empregador. Todavia, as medidas punitivas disponíveis pelo empregador são a advertência, a suspensão e a dispensa. Ainda que doutrina e jurisprudência acenem pela possibilidade de dispensa sem que haja anteriormente advertido ou suspenso o empregado, imprescindível que, de fato, a comprovação seja plena e incisiva sobre o ato perpetrado e que tal ato torne insubsistente o contrato de trabalho, mormente após anos de trabalho de conduta irretocável. Para que haja a dispensa do trabalhador baseada em improbidade e mau procedimento, tendo em vista que lhe fora imputado cometimento de abuso de direito, em face de comercialização de passagens de cortesia entregues gratuitamente para fruição pessoal e intransferível, necessário que as provas sejam contundentes acerca do conhecimento da proibição e ainda que a gravidade retire toda a qualidade de colaboração do contrato de trabalho. Inexistindo qualquer uma dessas provas, tem-se como indevida a dispensa com justa causa, em face de uma análise atual da aplicabilidade imediata dos princípios da dignidade da pessoa humana e do valor social do trabalho."

${ }^{155}$ BRASIL. Tribunal Superior do Trabalho. Agravo de Instrumento em Recurso de Revista 153/2002-029-1540. $1^{\text {a }}$ Turma. DJ 02 set. 2005. "Agravo de instrumento. Demissão por justa causa. 1. Não se pode cogitar de ato de improbidade se a conduta imputada ao empregado sequer em tese configura ato ilícito, qualquer que seja o prisma sob o qual enfocado o do Direito Penal, ou o do Direito do Trabalho. A subtração de quatro pilhas usadas, sem qualquer valor econômico, não pode servir ao empregador de pretexto para por termo a contrato de trabalho havido por mais de dez anos, sem registro de qualquer deslize por parte do empregado. 2. O dolo caracterizado pela intenção maliciosa de causar prejuízo a outrem constitui elemento ínsito à conduta ímproba. A ausência de malícia por parte do empregado, aliada à inexistência de qualquer repercussão patrimonial negativa para o empregador decorrente do ato praticado, revelam-se suficientes a afastar a figura do ato de improbidade. 3. Agravo a que se nega provimento." 
relação do emprego e afeta o patrimônio do empregador, ${ }^{156}$ esse tipo de demissão não é frequente. Em geral, as empresas não consideram o assunto como falta grave.

Outro indício dessa valoração diferenciada quanto à corrupção nas esferas pública e privada pode ser encontrado na listagem de práticas anticompetitivas do artigo 21 da Lei no 8.884/94, listagem que menciona o conluio para licitações públicas, mas é omisso quanto a licitações privadas. ${ }^{157}$

Não é somente na esfera do direito do trabalho e concorrencial que ocorrem situações de ruptura da confiança que caracterizam corrupção. No direito societário, os administradores das sociedades anônimas devem agir com lealdade para com a empresa, ${ }^{158}$ mas não raro violam a confiança neles depositada. ${ }^{159}$

Esses casos remetem uma vez mais às considerações sobre os estudos que apontam relação entre a confiança existente na sociedade e o nível de corrupção. A confiança nas relações, quer sejam as meramente privadas, quer sejam as meramente públicas, quer sejam as inter-relacionadas, é parte do tecido social, sem o qual o funcionamento das instituições do livre mercado perde a eficiência. A corrupção objeto desta tese se verifica principalmente no espaço público, mas inegavelmente certas práticas do setor privado contaminam toda a sociedade, na qual o Estado se encontra imerso. Quando atinge proporções elevadas, a contaminação moral de uma sociedade raramente é fenômeno exclusivo do espaço público pressupõe práticas privadas igualmente corruptas. Esse aspecto precisa ser retido, uma vez

\footnotetext{
${ }^{156}$ BRASIL. Tribunal Regional do Trabalho da $2^{\mathrm{a}}$ Região. Recurso Ordinário 02458200247102002. Relator: Sérgio Pinto Martins. DJU 16/11/2004. "Justa causa. Improbidade. Constitui ato de improbidade o empregado requerer e receber vale-transporte quando ia trabalhar de motocicleta. $\mathrm{O}$ ato desonesto do reclamante abala a confiança existente na relação de emprego, além de fazer com que o empregador tenha de pagar parte do valetransporte."

${ }^{157}$ BRASIL. Lei no 8.884/94, de 11 jun. 1994. Art. 21. "As seguintes condutas, além de outras, na medida em que configurem hipótese prevista no art. 20 e seus incisos, caracterizam infração da ordem econômica: [...] VIII - combinar previamente preços ou ajustar vantagens na concorrência pública ou administrativa." O referido artigo arrola exemplificativamente as condutas anticompetitivas, ou seja, a lista é não exaustiva - logo, o conluio para licitações privadas também pode ser considerado anticompetitivo. Mesmo assim, essa omissão legislativa revela a falta de preocupação com a falta de confiança nas relações no espaço privado.

${ }^{158}$ BRASIL. Lei no 6.404, de 15 dez. 1976. Art. 155. "O administrador deve servir com lealdade à companhia e manter reserva sobre os seus negócios, sendo-lhe vedado: I - usar, em benefício próprio ou de outrem, com ou sem prejuízo para a companhia, as oportunidades comerciais de que tenha conhecimento em razão do exercício de seu cargo; II - omitir-se no exercício ou proteção de direitos da companhia ou, visando à obtenção de vantagens, para si ou para outrem, deixar de aproveitar oportunidades de negócio de interesse da companhia; III - adquirir, para revender com lucro, bem ou direito que sabe necessário à companhia, ou que esta tencione adquirir."

${ }^{159}$ CARVALHOSA, Modesto. A nova lei de sociedades anônimas. São Paulo: Paz e Terra, 1976. p. 85. O autor relata a experiência societária alemã pré-1965, em que os bancos custodiantes de ações eram automaticamente considerados como procuradores dos custodiados, exercendo "mandato não no interesse do acionista, mas no seu próprio" - uma série de conflitos de interesse surgiram em razão desta situação estabelecida pela legislação societária. Regra similar constava no então anteprojeto da atual Lei no 6.406 nos anos 1970, mas foi excluída posteriormente.
} 
que o relacionamento histórico entre as esferas pública e privada no Brasil tem sido marcado por forte simbiose.

Nos regimes capitalistas, uma interpretação extremada do individualismo poderia levar à conclusão de que a busca pura e simples do interesse público prescindiria da confiança nas relações privadas - os indivíduos desrespeitariam as regras contratuais sempre que fosse seu interesse ou agiriam de modo oportunista como regra. Contudo, essa "vontade dirigida exclusivamente para o eu"160 desestruturaria a sociedade. ${ }^{161}$ Já sugeria Von Jering que o interesse egoístico de cada um precisa ser canalizado para o bem comum, a fim de que todos atuem coordenadamente. ${ }^{162}$

$\mathrm{Na}$ esfera pública, a confiança permeia a organização estatal em suas mais diversas manifestações - o Estado brota e faz parte da sociedade: tratá-lo como algo isolado ou a par da sociedade seria um equívoco. Por trás da estruturação do Estado, os teóricos contratualistas transportaram o elemento voluntarista do direito privado para entender o funcionamento da organização política que começava a limitar os poderes monárquicos e garantir de forma mais efetiva certos direitos à população. Efeito visível dessa concepção pode ser observado no Reino Unido, onde já em 1783, período em que a modernização do Estado se iniciava, uma decisão judicial afirmava que "um homem que aceitar uma posição de confiança relativa ao público, especialmente se a exerceu com lucro, é responsável criminalmente perante o rei por mau comportamento em seu cargo". De acordo com Heidenheimer, "as cortes americanas e

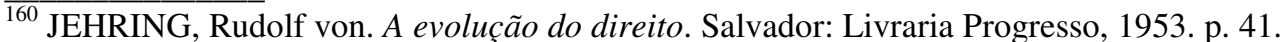

${ }^{161}$ FONSECA, Eduardo Giannetti da. Vícios privados, benefícios públicos?: a ética na riqueza das nações. São Paulo: Companhia das Letras, 2007. p. 154. "Há boas razões para acreditar que, sejam quais forem as regras do jogo econômico, o auto-interesse crasso é muito mais um obstáculo do que um insumo na busca da eficiência e do crescimento econômicos. O fato [...] é que a simples maximização do auto-interesse, sem inibições ou preocupações morais, é um princípio de conduta inadequado - e com frequiência letal - tanto para o bom desempenho da economia como para a própria existência do mercado enquanto mecanismo de coordenação política. Afirmar que a virtude pura não funciona na economia, o que é verdadeiro, de forma alguma significa dizer que o vício puro funcione, o que é falso."

162 JEHRING, Rudolf von. Op. cit. p. 47-48. "O egoísmo ao serviço do comércio jurídico - É a mesma natureza que ensina ao homem o meio de conquistar os outros para os seus fins, meio que consiste em ligar o seu próprio fim ao interesse de outrem. O Estado, a sociedade, as relações, os negócios, toda a vida humana repousa sobre esta fórmula. Só acontece que muitos homens caminham juntos para o mesmo fim, quando o interesse de todos vai dar ao mesmo resultado final. Nenhum deles, talvez, pensa no fim como tal; todos têm o espírito ocupado com o seu próprio interesse; mas esses interesses concordam com o fim comum, e, trabalhando por si só, cada um na realidade trabalha ao mesmo tempo pelos outros. Este juízo pode ter sido errôneo; a apreciação feita pelas partes, ou mesmo o seu interesse, podem ter variado ulteriormente; mas apesar de tudo isso sempre fica apurado que no momento decisivo as duas partes estiveram convencidas da concordância dos seus interesses, sem o que nunca elas se teriam posto de acordo. A unidade da vontade no contacto (consensus) é simplesmente o acordo das partes sobre a completa concordância dos seus interesses respectivos."
} 
inglesas seguiram regras semelhantes, ao afirmar que um gestor público, ocupando uma posição de confiança, é vinculado pelos deveres de um fiduciário". ${ }^{163}$

Os elementos de direito privado, tipicamente contratuais, foram gradativamente abandonados à medida que alguns princípios de direito administrativo, tais como o da autoexecutoriedade dos atos administrativos e o da prevalência do interesse público, se consolidaram nos países de tradição continental. ${ }^{164}$ Cada vez menos, o direito privado foi utilizado como referencial teórico para descrever o funcionamento do Estado. ${ }^{165}$ Apesar deste afastamento em relação ao direito privado, a "violação da confiança" ainda é característica dos crimes de colarinho branco, ${ }^{166}$ dos quais a corrupção é um exemplo.

Esse abandono não significa que certas relações, mais afeitas à teoria geral do direito do que exclusivamente ao direito privado, tenham perdido sua utilidade para a compreensão do funcionamento do Estado. Nesse contexto, a noção de confiança das relações intraestatais e extraestatais permanece presente: aquele a quem se confia algum poder deve agir de acordo com uma finalidade. A despeito das críticas que possam ser feitas, ideologicamente a própria ideia de que o Estado é o guardião do interesse público e/ou comum pressupõe a confiança transferida pela sociedade civil para a proteção de interesses que, em última instância, pertencem a esta. Conceber a democracia num sistema político representativo sem a presença do valor confiança é muito difícil.

\subsection{Delimitação da corrupção nesta tese}

Excluída a corrupção no espaço privado como objeto principal desta tese, resta analisar a corrupção no setor público. A evolução histórica da dicotomia público-privado explicita o fator cultural latente na organização estatal, variável geográfica e temporalmente. ${ }^{167}$ De maneira reflexa, semelhante variação ocorre para estabelecer o que se

\footnotetext{
$\overline{163}$ HEIDENHEIMER, Arnold J. The content of analysis. In: HEIDENHEIMER, Arnold J. Political corruption: readings in comparative analysis. 2. ed. New Brunswick: Transaction Books, 1978. p. 17. "[...] a man accepting an office of trust concerning the public, especially if attended with profit, is answerable criminally to the king for misbehavior in his office. American and English courts have followed the same rule that the public officer, occupying a position of trust, is bound by the duties of a fiduciary."

164 JEHRING, Rudolf von. Op. cit. p. 85.

${ }^{165}$ DI PIETRO, Maria Sylvia Zanella. Direito administrativo. 20. ed. São Paulo: Atlas, 2007. p. 19-22.

166 SHECAIRA, Sérgio Salomão. Criminologia e direito penal: um estudo das escolas sociológicas do crime. 2003. 406 f. Tese (Livre-Docência em Direito Penal)-Faculdade de Direito, Universidade de São Paulo, São Paulo. p. 191.

167 JOHNSTON, Michael. Agentes públicos, interesses particulares e democracia sustentável: quando política e corrupção se unem. In: ELLIOT, Kimberly Ann (Org.). A corrupção e a economia global. Tradução de Marsel Nascimento Gonçalves de Souza. Brasília: UnB, 2002. p. 112. "A corrupção não é algo que acontece numa
} 
deve entender por corrupção. O Estado brasileiro, patrimonialista em sua gênese, ainda hoje possui elementos que remontam à sua formação. A corrupção enquanto subversão do público pelo privado tem suas causas na forma como se deu a modernização do Estado brasileiro.

Para lidar com essa ideia de corrupção associada também a um contexto mais amplo, pode-se adotar uma classificação para uma primeira aproximação, especialmente considerando-se a distinção entre público e privado. Num sentido amplíssimo, voltado para a teoria política, corrupção é empregada "para denunciar uma mudança (negativa) no tipo de homem ou na comunidade, sempre em função de um dado padrão moral". Num sentido mais restrito, aplicável mais propriamente às sociedades modernas em que "existe a distinção entre o público e o privado", refere-se "ao comportamento de autoridades públicas que se desviam das normas aceitas, a fim de servir a interesses particulares”. Mais estritamente ainda, corrupção diz respeito "à conduta de autoridade que exerce o poder de modo indevido, em benefício de interesse privado, em troca de uma retribuição de ordem material". ${ }^{168}$

Aliás, esse último é o sentido mais recorrente no uso cotidiano, relacionado-se a um comportamento esperado do agente público no que tange à gestão da esfera pública ${ }^{169}$ - as regras de direito penal e administrativo atribuem sanções a esse tipo de corrupção, mas não dispõem as outras duas. Corrupção poderia ser entendida como uso indevido das prerrogativas do Poder Público, por aquele que o detém, para obtenção de vantagens privadas. Como conceitua Pasquino, corrupção é “o fenômeno pelo qual um funcionário público é levado a agir de modo diverso dos padrões normativos do sistema, favorecendo interesses particulares em troco de recompensa. Corrupto é, portanto, o comportamento ilegal de quem desempenha um papel na estrutura estadual". ${ }^{170}$ Alternativamente, como sugere Livianu, “a corrupção, numa diferenciação entre a esfera pública e a privada, consiste em tornar privado o que é público, uma vez que existe uma apropriação do que deve ser de todos, resultante de abuso de prerrogativas. Privatiza-se o que não pode ser privatizado". ${ }^{171}$ Logo, as referências anteriores à

sociedade como um desastre natural. Trata-se da atividade de pessoas e de grupos reais à medida que traficam influência em um dado ambiente de oportunidades, de recursos e de limitações."

${ }^{168}$ FERREIRA FILHO, Manoel Gonçalves. A corrupção como fenômeno social e político. Revista de Direito Administrativo, Rio de Janeiro, n. 185, p. 3, jul./set. 1991.

${ }^{169}$ BAYLEY, D. H. The effects of corruption in a developing nation. The Western Political Science Quarterly, Salt Lake City: University of Utah, v. 19, n. 4, p. 720. Por exemplo, o autor define corrupção como "the misuse of authority as a result of considerations of personal gain, which need not be monetary".

170 PASQUINO, Gianfranco. Corrupção. In: BOBBIO, Norberto; MATEUCCI, Nicola; PASQUINO, Gianfranco. Dicionário de política. 11. ed. Brasília: UNB, 1998. p. 291.

${ }^{171}$ LIVIANU, Roberto. Corrupção e direito penal: um diagnóstico da corrupção no Brasil. Coimbra: Coimbra Editora, 2007. p. 82. 
dicotomia público-privado surgem como parâmetro para aferição da existência ou não da corrupção.

Embora o objeto de estudo parta do sentido mais restrito em virtude da ênfase na dicotomia público-privado para a regulamentação microjurídica, essa classificação é insuficiente, uma vez que não capta a totalidade da patologia social corrupção. Não se trata de definir, aqui, cerradamente as diversas práticas que podem caracterizar corrupção: isso é tarefa dos direitos penal e administrativo, os quais, por força do princípio da legalidade, são pouco afeitos a reflexões político-sociológicas. De igual maneira, tampouco se trata de adotar uma definição apenas para delimitar o objeto de estudo, tal como muitos economistas o fazem. ${ }^{172}$

Por isso, os três vieses da corrupção precisam ser vistos conjuntamente pelo direito econômico. A subversão do público pelo privado se dá tanto por práticas corruptas atomizadas quanto pelas práticas políticas consideradas legais, mas que, se submetidas à comparação com a dominação racional e à estrutura burocrática decorrente da dicotomia público privado, causam repulsa. A simbiose dos vários níveis de corrupção constitui uma hipótese de trabalho, especialmente no que tange "à relação entre a corrupção por meio de retribuição material (a corrupção-suborno, diga-se assim para distingui-la das outras), a corrupção-favorecimento (a que importa no favorecimento do privado em detrimento do público) e a corrupção-solapamento (a que atinge o fundamento último de legitimidade)". ${ }^{173}$ Os desequilíbrios da federação brasileira, precipuamente em seu aspecto fiscal, inserida num contexto de modernização formal do Estado, criam oportunidades de ocorrência dos três tipos de corrupção. ${ }^{174}$ As várias facetas da corrupção se entrelaçam, estabelecendo uma cadeia de

\footnotetext{
$\overline{172}$ ROSE-ACKERMAN, Susan. A economia política da corrupção. In: ELLIOT, Kimberly Ann (Org.). Op. cit. p. 51-52. Tentar definir a corrupção é difícil - veja-se a exposição de Rose-Ackerman sobre as várias formulações feitas. "A maioria dos estudiosos cria categorias para definir comportamento corrupto. Muitos se apóiam em leis e em outros dispositivos formais, dada a relativa precisão e estabilidade desses expedientes para a identificação de atos corruptos (ver, por exemplo, Nye, 1967: 417; Scott, 1972, capítulo 1). Os críticos respondem afirmando que em muitas sociedades a lei carece de legitimidade e de aplicação consistente, que os legalismos pouco esclarecem a relevância social do comportamento e que a opinião pública ou os padrões culturais são os melhores para a formulação de definições realistas (Gibbons, 1988; Peters e Welch, 1978). Ainda assim há quem defenda o método da classificação de comportamento em si, encarando a saúde moral da sociedade, de um modo geral, como a principal questão para a definição de corrupção (Dobel, 1978; Euben, 1978; Modie, 1980; Philp, 1987; Thompson, 1993). Em face do exposto, definirei 'corrupção', de forma ampla, como o abuso de funções ou de recursos públicos, ou como o uso de meios ilegítimos de influência política por membros das esferas pública e privada. Mais adiante, porém, darei atenção diferenciada aos significados contestados politicamente, como 'público', 'privado', 'abuso' e 'ilegítimo', visto ser comum a verificação de que a controvérsia de se saber a quem cabe a decisão do significado desses termos constitui a mais importante dimensão política do problema."

${ }^{173}$ FERREIRA FILHO, Manoel Gonçalves. A corrupção como fenômeno social e político. Revista de Direito Administrativo, Rio de Janeiro, n. 185, p. 4, jul./set. 1991.

${ }^{174}$ Ver capítulo 7, infra.
} 
causalidade em que a corrupção-suborno, impregnada no cotidiano das relações com o Estado, fomenta "outra mais profunda", a corrupção-favorecimento. ${ }^{175}$ Esta já se encontra fora do reprimido pelo microjurídico e subverte a ideia de supremacia do interesse público. $\mathrm{O}$ efeito da disseminação da corrupção-suborno e corrupção-favorecimento é sentido na corrupção-solapamento, a qual desacredita a legitimidade estatal, quer por causa da falência do sistema político, quer por causa da incapacidade de provir o conforto material.

Cada um desses três tipos de corrupção deve receber um tratamento diferenciado por parte do direito. A corrupção-suborno deve ser sancionada nitidamente pelo sistema repressivo do direito. A corrupção-favorecimento depende do burilamento da democracia, com a exclusão daqueles descompromissados primordialmente com o interesse público. Por fim, os maiores desafios se encontram para a corrupção-solapamento, a qual afeta mais a legitimidade do próprio jogo político-social. Onde a tênue linha entre o interesse público e o privado deve ser colocada num Estado em que nunca foi bem traçada por aqueles que tradicionalmente ocupam o poder? Em que medida a transação política deve ser considerada legítima ou ilegítima? De que forma alterar instituições como o sistema federativo e o orçamento da União, fontes constantes de questionamentos sobre a legitimidade das práticas ali cometidas, se os interesses envolvidos estão contentes com as regras do jogo? Nem todos concordam com a necessidade de mudança por julgarem os eventos como parte legítima do jogo. ${ }^{176}$

O referencial para a resposta reside no interesse público. A corrupção-solapamento é fruto de uma ação política que transmite à sociedade valores que não primam pela confiança depositada. No contrato de representação, o representante deve atuar no "fiel cumprimento do mandato". Embora a teoria constitucional há muito reconheça que o "fiel cumprimento do mandato" de um político não significa necessariamente a obediência pura e simples a tudo quanto os seus eleitores desejam, isso igualmente não significa que possa agir de acordo com seu próprio talante. $\mathrm{O}$ interesse público norteia a finalidade do bem comum e, por consequência, limita o espectro da ação do político. Mormente na atualidade, não se pode imaginar o político como um indivíduo asceta, desprovido de paixões e motivações pessoais.

\footnotetext{
$\overline{175}$ FERREIRA FILHO, Manoel Gonçalves. A corrupção como fenômeno social e político. Revista de Direito Administrativo, Rio de Janeiro, n. 185, p. 4, jul./set. 1991.

${ }^{176}$ FERREIRA FILHO, Manoel Gonçalves. A corrupção como fenômeno social e político. Revista de Direito Administrativo, Rio de Janeiro, n. 185, p. 11, jul./set. 1991. "É o que confunde toda negociação com barganha, todo compromisso com imoralidade. Ora, a política envolve negociação e compromisso, conseqüentemente esse puritanismo leva a uma recusa da política e do político que hostiliza a institucionalização democrática. Tende ela a apresentar como corrupto todo político, abrindo caminho para os homens providenciais, os "não-políticos incorruptos e incorruptíveis'.,
} 
Obviamente, o político possui interesses privados, em especial o seu próprio sucesso na carreira política. Se o sucesso é medido pela conquista de votos que o alçam a cargos mais elevados, haveria em princípio uma confluência entre os interesses privados do político e os interesses de seu eleitorado. Ainda que o eleitorado possua uma visão míope e distorcida do que seria o melhor para si, sua opinião a aproxima do interesse público de acordo com uma visão tradicional da teoria política. Assim, em tese, funciona o sistema político representativo.

Todavia, essa teoria não funciona exatamente desta forma. $\mathrm{O}$ político pode adotar um discurso sedutor para angariar votos, fenômeno já identificado pelos gregos antigos na figura do demagogo, e se tornar mero ventríloquo da opinião pública, mesmo que o interesse público clame por ações que a contrariem. O elevado custo financeiro das campanhas eleitorais induz os políticos a estabelecer relações especiais com os detentores do poder econômico, os quais, por seu turno, possuem interesses perante o Estado que nem sempre são congruentes com o interesse público. Os políticos frequentemente podem não adotar o interesse público como norte da ação após vencer as eleições e se preocupar apenas com o seu próprio enriquecimento. Sob circunstâncias específicas, esses exemplos redundam na corrupção política. Conforme explica Filgueiras,

\begin{abstract}
Sendo a corrupção a elevação dos interesses privados ao interesse público, percebese que é fundamental a uma teoria política da corrupção uma discussão mais abrangente da moralidade pública. Só é possível definir a corrupção na política se buscarmos uma visão dos aspectos consensuais que organizam a prática política como um todo. A perspectiva, hoje, hegemônica, no entanto, cria uma miopia teórica a respeito da corrupção, visto que compreende apenas a lógica dos interesses mercantis. ${ }^{177}$
\end{abstract}

Visualizar a corrupção de uma perspectiva que contrapõe a dicotomia públicoprivado exige o uso de instrumental teórico diverso daquele associado às definiç̧ões de corrupção fornecidas somente pelos direitos penal e administrativo, os quais lidam com essa lógica dos interesses mercantis. De igual modo, os estudos de economistas se focam nessa lógica dos interesses mercantis dos agentes corruptos, buscando alterá-las. Com isso, por exemplo, abandona-se a visão aristotélica que associava a corrupção ao mau governo ou ao maus sistema.

O enfoque proposto pelo direito econômico difere das abordagens anteriores e busca oferecer uma nova visão sobre o problema da corrupção. O aspecto mercantil continua a ser nota importante do estudo, uma vez que os interesses privados orientam as ações dos agentes. Entretanto, não se pode perder de vista a ideia de que a corrupção se relaciona também a algo

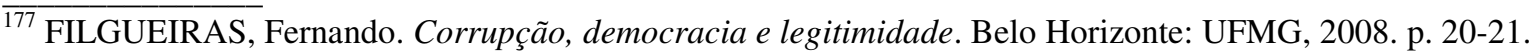


mais amplo do que a mera comparação financeira: esta afeta e deturpa o funcionamento do sistema político como um tudo. Por esse motivo, há uma gama de práticas que podem ser consideradas corruptas, embora passem ao largo das definições relacionadas à corrupçãosuborno, típicas da regulamentação microjurídica. O presidente do Senado que atende ao pedido de emprego feito pela neta para um amigo, o parlamentar que aceita votar a favor do governo em troca da indicação de apadrinhado político para cargo de confiança, o prefeito que muda de partido para receber recursos estaduais ou federais e o lobista que pressiona pela liberação de verbas para obra pública caracterizam comportamentos admitidos pela lei, embora resvalem na corrupção-solapamento e alguns possam insistir que princípios do direito público os proíbam. Ainda que inexista necessariamente prejuízo ao patrimônio público, estas práticas raramente estão desacompanhadas do comportamento esperado de um agente público. $^{178}$

Tais exemplos denotam a subversão do valor confiança depositada na dicotomia público-privado e decerto caracterizam corrupção, a despeito do fato de poderem não estar tipificadas e reprimidas pelos direitos penal e administrativo. O impacto da corrupçãosolapamento apenas pode ser integralmente compreendido numa perspectiva macrojurídica. Isoladamente, tais práticas seriam apenas imorais, mas, tomadas no conjunto, ditam comportamentos limítrofes que forjam o direito pressuposto brasileiro. À diferença da perspectiva microjurídica, que afirma a atipicidade dessas condutas ou busca a reparação civil, o ângulo macrojurídico é capaz de apontá-las como elementos de subversão da finalidade estatal.

Em todos os quatro exemplos citados, há em comum o desrespeito pela dicotomia público-privado, tal como estabelecido nos modernos regimes democráticos de responsabilidade dos governantes. O poder detido pelo agente público não é usado para atender a uma finalidade pública. As práticas descritas não são consideradas automaticamente ilegais, mas certamente estão impregnadas de ilegitimidade. Sob esse prisma, nada as diferencia da mera aceitação de propina pelo agente público - em realidade, essas condutas também são ilegítimas aos olhos da dicotomia público-privado, mas, à diferença das três anteriores, se submetem a sanções jurídicas pelos direitos penal e administrativo.

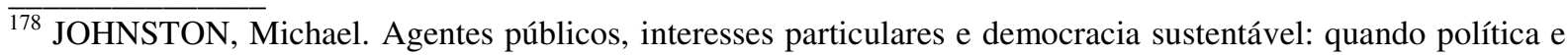
corrupção se unem. In: ELLIOT, Kimberly Ann (Org.). Op. cit. p. 106. “A maior parte das discussões sobre esses efeitos levanta a clássica questão de Harold Lasswell: ‘quem fica com o quê? quando? e como?’ A maioria das formas de corrupção que não chega a ser roubo incontestável por parte das autoridades pode ser encarada como tipos de influência política (Scott, 1972), o que distorce os processos de tomada de decisões e desvia os custos e benefícios do sistema."
} 
Tal viés de aproximação explora o elemento de ilegitimidade na subversão da dicotomia público-privado. A ilegitimidade das práticas citadas as torna assemelhadas. Por isso, o tratamento da corrupção sob a ótica microjurídica, típica dos direitos penal e administrativo, conduz a um diagnóstico parcial sobre a corrupção, o que, por seu turno, dita uma agenda composta por estudos, propostas e debates que apresentam prognósticos voltados apenas para esse lado do problema. Em outras palavras, as condutas políticas, geneticamente moldadas num Estado patrimonialista, não são enfrentadas sob o argumento de que se trata de um problema político, enquanto, em realidade, muitas dessas práticas representam um desvirtuamento dos princípios gerais de direito no Estado moderno.

\subsection{0 bem comum no combate à corrupção}

A teoria geral do Estado lida com o conceito de "bem comum" de modo um tanto contraditório e abstrato. É contraditório o tratamento, pois parte da doutrina se nega a estudála sob diversas justificativas. ${ }^{179} \mathrm{E}$ abstrato, porque retrospectivamente o conceito de "bem comum" se prestou aos mais diversos propósitos, inclusive à sua própria negação, como o fizeram os nazistas e fascistas. Por esses motivos, é necessário identificar em que medida o combate à corrupção se relaciona à busca do bem comum.

Como estudado no item 1.3, supra, falta concretude ao se tratar do bem comum. São apresentadas definições, ideias, diretrizes e conceitos que, vez por outra, sugerem preocupações éticas com os rumos da sociedade politicamente organizadas ou, ainda, com o bem-estar material do povo. Ora, se o bem comum no moderno Estado de bem-estar social está comprometido com a democracia e a prosperidade econômica, revela-se seu liame finalístico. Ferraz Júnior esclarece que "a legalidade deixa de ser o núcleo da administração, tornando-se apenas um freio que direciona os procedimentos guiados pela exigência de bons resultados". ${ }^{180}$ Como, então, se ligam a corrupção e o bem comum?

A corrupção é objeto de estudo científico da sociedade na medida em que tem consequências reconhecidamente negativas - o consenso em torno da prejudicialidade é tão grande que a corrupção é comparada, com frequência, a "um câncer que corrói o tecido

\footnotetext{
$\overline{179}$ DALLARI, Dalmo de Abreu. Elementos de teoria geral do estado. 19. ed. atual. São Paulo: Saraiva, 1995. p. 87-88.

180 FERRAZ JÚNIOR, Tercio Sampaio. Ética administrativa num país em desenvolvimento. Cadernos de Direito Constitucional e Ciência Política, São Paulo: Revista dos Tribunais, p. 42, jan./mar. 1998.
} 
cultural, político e econômico da sociedade e destrói o funcionamento dos órgãos vitais". ${ }^{181}$ Além destas considerações de ordem moral, a corrupção pode afetar o funcionamento do sistema político, especialmente o democrático, bem como comprometer a eficiência da atividade econômica.

Sutherland argumenta que, se comparada à perda financeira decorrente dos crimes de colarinho branco, entre os quais se encontra a corrupção, o dano às relações sociais se revela mais grave, uma vez que ela viola a confiança e gera desconfiança, "a qual baixa o moral social e produz desorganização social em grande escala", o que contrasta com outros crimes que "produzem relativamente pouco efeitos nas instituições sociais ou na organização social". ${ }^{182}$ No mesmo sentido, Rose-Ackerman ressalta que

[...] a corrupção pode produzir ineficiência e injustiça. Este mal tem o poder de minar a legitimidade política do Estado. A corrupção evidencia também a existência de problemas mais profundos nas relações do Estado com o setor privado. Os custos mais graves não são os subornos em si, e sim as distorções inerentes que revelam. ${ }^{183}$

A mesma autora ainda aponta seis consequências principais da corrupção: (i) a ineficiência das licitações e privatizações, (ii) atrasos e burocracia, (iii) uso de pagamentos corruptos por políticos e burocratas, (iv) desigualdades acirradas, (v) danos à legitimidade política e (vi) crescimento desacelerado. ${ }^{184}$

É possível citar e descrever uma série de outras listas sobre os malefícios da corrupção. Entretanto, ao se sintetizarem os efeitos negativos associados às práticas corruptas que prejudicam a busca do bem comum, tais listagens permitem identificar dois grupos principais: (i) os efeitos políticos e (ii) os efeitos econômicos.

\subsubsection{Efeitos políticos negativos da corrupção}

Na esfera política, há duas vertentes negativas decorrentes das práticas corruptas: a primeira se refere aos impactos sobre a legitimidade do próprio Estado e do regime democrático, ao passo que a segunda, à qualidade do resultado esperado do sistema político.

\footnotetext{
181 AMUNDSEN, Inge. Political corruption: an introduction to the issues. Development Studies and Human Rights. Working paper n. 1999:7. Bergen: Chr. Michelsen Institute, 1999, p. 1. Disponível em <http://www.cmi.no/publications/1999/wp/wp1999-7.pdf>. Acesso em: 24 nov. 2008 às 10h30.

182 SUTHERLAND, Edwin H. White collar criminality. American Sociological Review, v. 5, n. 1, p. 5, Feb. 1940.

${ }^{183}$ ROSE-ACKERMAN, Susan. A economia política da corrupção. In: ELLIOT, Kimberly Ann (Org.). Op. cit. p. 74 .

${ }^{184}$ Idem, p. 75 e ss.
} 
Quer seja a corrupção pura e simples, na perspectiva microjurídica, quer seja a corrupção política mais ampla e sofisticada, mitigada sob a forma de corrupção-solapamento, na qual a propina é camuflada pelo jogo de interesses envolvidos, o fenômeno mina a legitimidade do Estado, independentemente de este ser regido autoritária ou democraticamente. $\mathrm{O}$ resultado pode ser a instabilidade política, tanto sob a égide do autoritarismo quanto da democracia.

Os regimes autoritários perdem a legitimidade se a corrupção comprometer a crença de sua superioridade. A maioria deles busca algum fundamento de legitimidade que não a decorrente da representação política: crescimento econômico, comprometimento ideológico e manutenção da ordem são algumas das justificativas mais comuns utilizadas por regimes não democráticos. No Brasil, o regime militar iniciado em 1964 incluía o combate à corrupção entre seus objetivos. Mesmo quando há acusações recíprocas sobre práticas corruptas, muitas vezes elas podem não revelar a real extensão do problema. ${ }^{185}$ Também, não raro, líderes pródemocracia usam o argumento de que a estrutura de uma ditadura seria inerentemente corrupta devido à falta de transparência nas decisões.

Essas ponderações sobre a relação entre liberdade política e corrupção podem ser desenvolvidas. Johnston analisa corrupção amplamente, contrapondo o equilíbrio entre oportunidades políticas e econômicas, entendidas como as recompensas proporcionadas pela dedicação a uma vida política e/ou econômica, ao equilíbrio entre a acessibilidade das elites ao aparelho estatal, auferida pela rotatividade efetiva à máquina estatal, e não pela meramente a possibilidade teórica ${ }^{186}$ - em outras palavras, em que medida os pobres podem melhorar suas condições de vida e a oposição pode conquistar o poder? A lógica por trás desse raciocínio pode ser sintetizada da seguinte forma: se a maioria das oportunidades reside na atividade econômica, os incentivos para que as elites se "apeguem" ao Estado são menores do que se as oportunidades políticas representassem a maioria das oportunidades. A incidência de corrupção tende a ser superior quando a maioria dos incentivos reside na política, uma vez que inexistiriam atrativos comparáveis na iniciativa privada. No que tange à acessibilidade ao aparelho estatal, se as elites estão mais ligadas ao poder, sem o risco iminente de perdê-lo a cada eleição, há mais incentivos para que práticas corruptas floresçam do que em regimes sujeitos à alternância de poder. A tabela 1 sintetiza esse cenário descrito.

\footnotetext{
$\overline{185}$ JOHNSTON, Michael. Agentes públicos, interesses particulares e democracia sustentável: quando política e corrupção se unem. In: ELLIOT, Kimberly Ann (Org.). Op. cit. p. 107. "Em especial nos sistemas antidemocráticos, escândalos orquestrados oficialmente podem relevar mais sobre interesse políticos de elites, ou de conflitos entre elas, do que acerca da verdadeira extensão da desonestidade pública."

${ }^{186}$ Ibidem, p. 117.
} 
Do ponto de vista axiológico, para aqueles comprometidos com a causa democrática, é praticamente irrelevante saber que a corrupção pode desestabilizar ditaduras - deseja-se a desestabilização do regime para que a democracia possa ter uma oportunidade para florescer. Todavia, por mais estranho que isso possa parecer, a mesma corrupção que mina ditaduras também ameaça democracias e justifica golpes de Estado. ${ }^{187}$ Em realidade, a corrupção temse revelado mais resistente à mera queda de regimes autoritários pouco transparentes ou de regimes democráticos muito transparentes.

Tabela 1 - Variedades de corrupção como função do desequilíbrio político

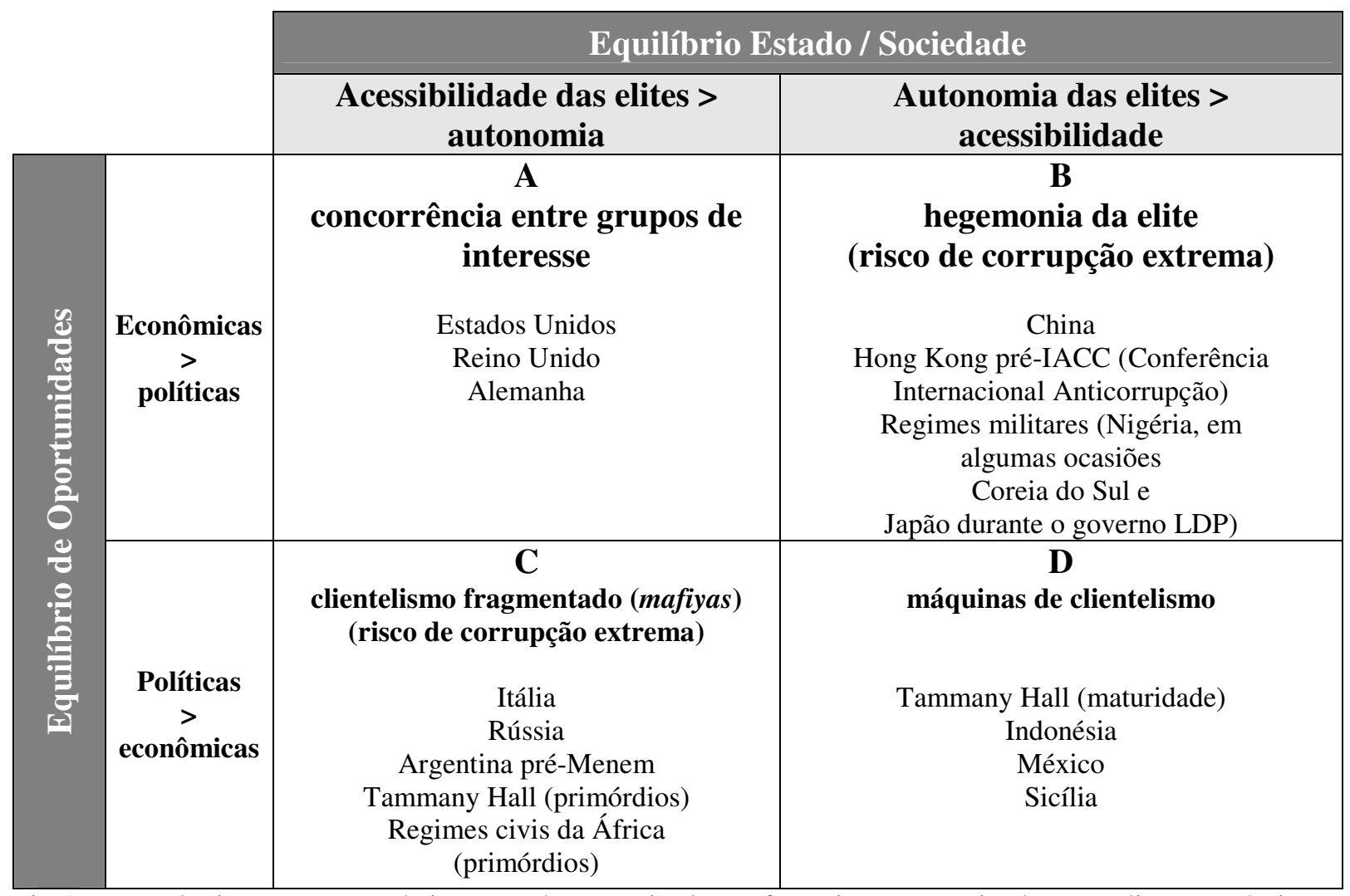

A: A concorrência entre grupos de interesse é caracterizada por fortes interesses privados, por elites acessíveis e por competição política e econômica. A riqueza é usada para a obtenção de influência política, o que resulta em corrupção da elite; porém é altamente desordenada e individualizada.

B: A hegemonia da elite é caracterizada por elites arraigadas no poder, cuja competição política limitada vende acesso político e enriquece a si própria e a seus aliados políticos e comerciais.

C: O clientelismo fragmentado é caracterizado por elites fragmentadas, politicamente inseguras, que formam séquitos pessoais usando, para isso, recompensas materiais. Os adeptos são mal disciplinados e vulneráveis a interesses e a facções da sociedade; parte da corrupção é ligada à intimidação.

$\overline{187}$ ROSE-ACKERMAN, Susan. A economia política da corrupção. In: ELLIOT, Kimberly Ann (Org.). Op. cit. p. 79. "Os cidadãos podem acabar acreditando que o governo simplesmente se encontra à venda para aquele que der o lance maior. A corrupção destrói a idéia de que o governo está substituindo decisões baseadas na capacidade de pagamento por valores democráticos. Esse mal pode provocar golpes de líderes antidemocráticos. Golpes militares são justificados, com freqüência, como uma resposta à corrupção de governantes democráticos." 
D: As máquinas de clientelismos são caracterizadas por fortes elites, que controlam a participação da massa, limitam a competição por meio do clientelismo e, muitas vezes, aproveitam-se da pobreza da massa de adeptos. Os partidos são bem disciplinados, hierárquicos e estendem o poder da elite à sociedade. Com frequência tem-se como resultado a corrupção sistemática, talvez acompanhada de intimidação.

Fonte: JOHNSTON, Michael. "Agentes públicos, interesses particulares e democracia sustentável: quando política e corrupção se unem”. In: ELLIOT, Kimberly Ann (Org.). A corrupção e a economia global. Tradução de Marsel Nascimento Gonçalves de Souza. Brasília: UnB, 2002. p. 117.

A falha no combate à corrupção pelos mecanismos tradicionais de um regime democrático, tais como as eleições e o Poder Judiciário, conduz à crença equivocada de que só o autoritarismo é capaz de superar a ineficiência institucional, discurso recorrente em vários países desde a crise da representação política no pós Primeira Guerra Mundial. Na América Latina, 54,7\% da população apoiaria um regime não democrático que implementasse uma solução para os problemas econômicos. ${ }^{188}$ Muitos manifestam nostalgia dos tempos autoritários - talvez porque os jornais deixassem de estampar tantos escândalos de corrupção em suas capas. A frustração da população com a política é fenômeno observado em vários países democráticos, inclusive naqueles em que a tradição democrática data de muitas décadas, ${ }^{189} \mathrm{e}$ tem conduzido à rejeição da política.

Os sistemas políticos sentem os reflexos dessa deterioração da legitimidade numa perspectiva diversa. Prioridades não conducentes ao bem comum, impregnadas de interesses próprios da classe política, possuem variados efeitos políticos, realimentando a corrupção. Do

\footnotetext{
${ }^{188}$ PNUD. A democracia na América Latina rumo a uma democracia de cidadãs e cidadãos. Tradução de Mônica Hirts. Santana de Parnaíba: LM\&X, 2004. p. 139-140. "Uma primeira leitura das opiniões cidadãos, comparada com as pesquisas anteriores de Latinobarômetro, indica que por volta de 1996, 61\% dos entrevistados, no âmbito da região, preferiam a democracia a qualquer outro regime; por volta de 2002, esse percentual era de 57\%. Essa preferência pela democracia não implica necessariamente um sólido apoio. $\mathrm{Na}$ realidade, muitas pessoas que dizem preferir a democracia a outros regimes têm atitudes pouco democráticas em relação a diversas questões sociais. Em 2002, quase metade $(48,1 \%)$ dos entrevistados que diziam preferir a democracia a qualquer outro regime, preferia igualmente o desenvolvimento econômico à democracia, e um percentual semelhante $(44,9 \%)$, que dizia preferir a democracia, estava disposto a apoiar um governo autoritário, desde que resolvesse os problemas econômicos do seu país. Grande parte das pessoas que manifestam sua preferência pela democracia tem atitudes contrárias a algumas regras básicas desse regime. Aproximadamente, de três pessoas, uma opina que a democracia pode funcionar sem instituições como o Parlamento e os partidos políticos. Essas respostas são um chamado de atenção: uma proporção significativa de latino-americanos dá mais valor ao desenvolvimento econômico do que à democracia, e estaria disposta a deixar de lado a democracia por um governo não-democrático que pudesse solucionar seus problemas econômicos."

189 SARTORI, Giovanni. Engenharia constitucional: como mudam as constituições. Tradução de Sérgio Bath. Brasília: UnB, 1996. p. 159. "O desencanto e a desilusão com a política não constituem novidades. Contudo, quando Lipset e Schneider (1983) registraram o 'hiato de confiança' entre os cidadãos e seus representantes eleitos, eles registraram uma tendência sem precedentes. E em muitos países a desilusão e a desconfiança chegaram hoje a um crescendum de frustração, raiva e, por fim, à completa rejeição da política. Finalmente, estamos confrontados com um surto de antipolítica, o que poderíamos chamar de política da antipolítica. O que aconteceu? Há uma variedade de explicações para essa rejeição. Uma delas é o negativismo a que nos referimos. A televisão também concorre para isso. Um terceiro fator é provavelmente a dissolução do cimento ideológico. Mas a melhor explicação isolada é, no meu entender, a corrupção política. É verdade que a atividade política nunca foi, e provavelmente nunca será, imaculada; a corrupção nessa área não é nova, mas nos últimos tempos atingiu dimensões sem precedentes, chegando ao ponto de corromper a própria política."
} 
ponto de vista da própria qualidade do produto do sistema político, a corrupção causa perdas para toda sociedade, na medida em que, por exemplo,

[...] encoraja governos a persistir com políticas econômicas perversas e oferece oportunidades para burocratas e políticos se enriquecerem através da extorsão de propinas daqueles que buscam favores governamentais. Portanto, a corrupção distorce os incentivos econômicos, desencoraja o empreendedorismo e desacelera o crescimento econômico. ${ }^{190}$

À diferença das abordagens microjurídicas e microeconômicas, nem sempre se está diante de algo facilmente identificável ou mensurável. Em termos de perda de riqueza, quão ruim para a sociedade é um cargo relevante ter sido ocupado por alguém indicado pela neta do presidente do Senado após telefonema meloso da mesma ao avô? O indicado pode até mesmo ser competente do ponto de vista técnico. Exceção feita ao desvio observável de conduta esperado, fato perfeitamente reprimido pela regulamentação microjurídico, o impacto mais amplo sobre o bem-estar é de difícil mensuração ${ }^{191}$ - talvez inexista um prejuízo direto ao patrimônio público, uma vez que a vaga deveria ser preenchida de qualquer jeito, mas há afronta perceptível ao interesse público devido à prevalência do interesse privado quando o detentor do poder deveria exercê-lo tendo em vista seus deveres funcionais. Ademais, os efeitos negativos da deterioração da eficiência do sistema político em razão da corrupção realimentam a frustração com a democracia.

A formação do Estado brasileiro foi arraigadamente patrimonialista no sentido weberiano do termo, mas seu desenvolvimento ulterior corroeu o arquétipo, afastando-o do primitivismo pré-burocrático (mais uma vez, no sentido weberiano do termo). Entretanto, a evolução histórica ocorrida foi insuficiente para "modernizar" por completo o Estado brasileiro a ponto de criar uma distinção entre os espaços público e privado com uma burocracia weberiana, tal como se verifica nas democracias mais maduras. Por consequência, os efeitos da corrupção sobre o funcionamento e a legitimidade estatal decorrem parcialmente esse processo de modernização incompleto.

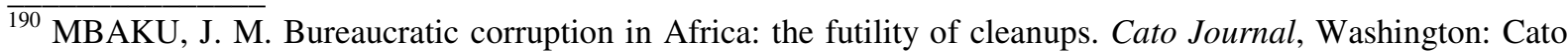
Institute, vol. 16, n. 1, p. 99, 1996. "[Corruption] encourages governments to pursue perverse economic policies, and provides opportunities to bureaucrats and politicians to enrich themselves through extorting bribes from those seeking government favors. Thus, corruption distorts economic incentives, discourages entrepreneurship, and slows economic growth."

${ }^{191}$ JOHNSTON, Michael. Agentes públicos, interesses particulares e democracia sustentável: quando política e corrupção se unem. In: ELLIOT, Kimberly Ann (Org.). Op. cit. p. 106. "Custos e benefícios são difíceis de ser comparados: a maioria dos benefícios, como um emprego ou um contrato, são tangíveis, divisíveis e imediatos, além de poder chegar ao agraciado de inúmeras formas. Em contraste, muitos custos, como a perda de confiança no sistema político ou os efeitos cumulativos da política de partido único na representação e nas escolhas políticas, são amplamente partilhados, intangíveis e se fazem sentir a longo prazo.”
} 


\subsubsection{Efeitos econômicos negativos da corrupção}

Hoje existe um consenso em torno dos efeitos negativos decorrentes de qualquer prática corrupta. Todavia, por muitos anos, acreditou-se que algumas práticas corruptas não seriam deletérias. Pelo contrário, essas práticas poderiam até mesmo produzir efeitos positivos para o bem-estar social. Esse raciocínio se assentava sobre a premissa de que a corrupção implicaria apenas e tão somente transferência de renda entre os agentes econômicos - o que seria parte do lucro do capitalista terminaria nas mãos do burocrata.

De fato, a economia foi a principal responsável por relegar o estudo da corrupção por muitas décadas a um plano secundário. Superadas concepções românticas e moralistas sobre os aspectos negativos da corrupção, a ciência econômica formulou proposições segundo as quais o pagamento de suborno não implicaria, na maioria das ocasiões, nenhuma perda de bem-estar social e, por isso, deveria até mesmo ser ignorada pelo sistema jurídico - da perspectiva microeconômica, não haveria perda do bem-estar social. Em outros cenários, a corrupção até mesmo poderia aumentar a eficiência alocativa, na medida em que "diminuiria" a burocracia administrativa e facilitaria o funcionamento dos mercados. Entre o custo de transação representado por uma barreira regulatória estatal e o custo de transação representado pelo suborno, a mera comparação de custos forneceria a resposta sobre a legitimidade ou não da corrupção. Na maioria das vezes, os economistas enxergam a corrupção como um fator que altera o funcionamento do livre mercado e, em consequência, pode causar distorções que geram ineficiências - tudo dentro do estereótipo de que a economia é associada à tentativa de redução da realidade a um número reduzido de variáveis, as quais são quantificadas em um modelo.

Mesmo atualmente, há céticos que argumentam contra a existência desses efeitos econômicos negativos. Uma das provas mais utilizadas é o fato de certos países, em que há crescimento econômico acelerado, conviverem com a corrupção em nível endêmico. ${ }^{192}$ Mais ainda, a corrupção existiria tanto em países pobres quanto em países ricos. Kang compara a Coreia do Sul e as Filipinas e, após encontrar várias semelhanças institucionais entre países,

\footnotetext{
$\overline{192}$ ROSE-ACKERMAN, Susan. A economia política da corrupção. In: ELLIOT, Kimberly Ann (Org.). Op. cit. p. 61. "[...] a corrupção é comum tanto nos países em desenvolvimento quanto nos industrializados. Mas será que ela deve ser motivo de preocupação? Alguns países com fama de muito corruptos tiveram altas taxas de crescimento econômico. Na Indonésia, na Tailândia e na Coréia, a corrupção e o crescimento caminharam lado a lado. Talvez os países pobres e em fase de transição não devessem se preocupar com a corrupção generalizada ao planejar políticas de reformas econômicas. Talvez os países vitimados pela corrupção e os altos índices de crescimento devessem simplesmente aceitar o desvio e verbas como algo normal."
} 
inclusive o caráter sistêmico da corrupção, conclui que o primeiro logrou superar o subdesenvolvimento, ao passo que o segundo enfrenta sérias dificuldades para melhorar as condições de vida da população. ${ }^{193}$

Tal postura foi sendo abandonada progressivamente a partir dos anos 1970, na medida em que novos trabalhos demonstraram os efeitos deletérios da corrupção sobre o bemestar social no médio e longo prazo. O trabalho de Susan Rose-Ackerman Corrupção: um estudo em economia política, publicado em $1978,{ }^{194}$ pode ser considerado como um dos divisores de água. Desde fins dos anos 1970, foi produzida uma grande quantidade de trabalhos que tratam de cada aspecto das distorções resultantes da corrupção. Após os anos 1990, os economistas têm enfatizado o papel da corrupção como um gargalo ao desenvolvimento. Como resultado, as instituições internacionais de crédito como o Banco Mundial têm condicionado a liberação de empréstimos e programas de assistência técnica ao compromisso de reformas institucionais para combater a corrupção. Para subsidiar tais estratégias, a ciência econômica voltou-se para responder ao questionamento de como se poderia combater melhor a corrupção somente com os recursos escassos disponíveis.

Essa nova tendência negava as premissas acerca da inocuidade das práticas corruptas. Reconhecendo de antemão que "o crescimento econômico não é a única meta digna de ser almejada", ${ }^{195}$ os economistas concluíram que, indiretamente, a distribuição de riquezas promovida pela corrupção é ineficiente, ${ }^{196} \mathrm{o}$ que por si só motivaria a irresignação quanto à confusão entre as esferas pública e privada. Assim, reconheceu-se o caráter socialmente maléfico da corrupção, justificando as tentativas de minimizá-la. Quanto ao argumento sobre a irrelevância da corrupção sobre o desempenho econômico global da economia, nada garante que, no longo prazo, a performance pretérita consiga se manter quando se exigirem novos padrões de confiança para o desenvolvimento econômico avançar. ${ }^{197}$ Ademais, a persistência

\footnotetext{
193 KANG, David C. Crony capitalism: corruption and development in South Korea and the Philippines. Cambridge: Cambridge University Press, 2002. p. 187-191.

194 ROSE-ACKERMAN, Susan. Corruption: a study in political economy. Nova York, Londres: Academic Press, 1978.

${ }^{195}$ ROSE-ACKERMAN, Susan. A economia política da corrupção. In: ELLIOT, Kimberly Ann (Org.). Op. cit. p. 62.

${ }^{196}$ Idem, ibidem. "A corrupção também tende a distorcer a alocação dos benefícios econômicos, favorecer aqueles que têm em detrimento daqueles que não têm, e levar a uma distribuição de renda menos igualitária. Mesmo quando a corrupção é uma forma de se contornar políticas governamentais excessivamente restritivas, ainda assim ela é uma opção inferior. Sobretudo para economias emergentes e em transição, um registro respeitável de crescimento não deveria ser utilizado para justificar a perpetuação de relações ineficientes e injustas nos setores público e privado."

${ }^{197}$ Ibidem. "[...] países com corrupção sistêmica que, apesar de tudo, obtiveram crescimento econômico satisfatório, correm o risco de cair em uma espiral decrescente. A corrupção pode virar uma bola de neve de modo que produza comissões ilegais mais elevadas até que o crescimento seja comprometido".
} 
da corrupção pode gerar estímulos equivocados aos agentes econômicos. ${ }^{198}$ De fato, "onde há corrupção os empreendedores estão cientes de que parte dos lucros de seus investimentos futuros pode ser reivindicada por funcionários públicos corruptos". ${ }^{199}$

Desde o advento do Estado de bem-estar social, o bem comum tem sido fortemente atrelado ao bem-estar material da população. Condições adequadas de saneamento básico, saúde, educação, moradia figuram na lista de prestações devidas pelo Estado à população. Há mesmo quem defenda que exista um dever de fornecer uma renda mínima. Neste contexto, a corrupção figura como verdadeiro "obstáculo para a implementação dos direitos econômicos, sociais e culturais". ${ }^{200}$ No limite, esse argumento conclui que a corrupção no Poder Público constitui uma violação aos direitos humanos. Paralelamente ao crescimento das prestações devidas, houve um correspondente aumento das receitas tributárias obtidas por meio da arrecadação tributária, para a qual toda a sociedade contribui. Sob certo prisma, a legitimidade dessa arrecadação adicional para o cumprimento das novas funções estatais decorre exatamente do bom emprego de tais recursos. A desobediência civil à Thomas Morus, que se recusou a pagar impostos para financiar uma guerra que julgava injusta, ecoa ainda hoje entre aqueles que desgostam de pagar seus tributos que seriam ilicitamente apropriados ou usados para alimentar a politicalha. Tal linha de argumentação tem sua razão de ser e lança um frontal ataque à legitimidade estatal. Por isso, como resposta institucional, um regime republicano existe somente quando houver responsabilização dos agentes políticos.

\subsection{A legitimidade da ordem constitucional como pressuposto do combate à corrupção}

As considerações precedentes mostram como os efeitos negativos da corrupção solapam a legitimidade da democracia. A conjugação da necessidade de atender ao bem comum e evitar desperdícios se justifica pelos nefastos efeitos econômicos e políticos. No contexto ideológico atual, em que boa parte da legitimidade estatal para a promoção de políticas públicas se justifica pela sua eficácia e resultados, desperdícios decorrentes da

\footnotetext{
$\overline{198}$ MAURO, Paolo. Os efeitos da corrupção sobre crescimento, investimentos e gastos do governo: uma análise de países representativos. In: ELLIOT, Kimberly Ann (Org.). Op. cit. p. 140. "Uma forma pela qual a taxa de crescimento pode ser afetada, mesmo para uma dada taxa de investimento, é por mudanças na alocação de recursos entre setores (Easterly, 1990), talvez incluindo-se aí a alocação entre o setor formal e o informal (Loayza, 1996).”

199 Idem, p. 139.

${ }^{200}$ LIMA, M. Madeleine H. de P. Corrupção: obstáculos à implementação dos direitos econômicos, sociais e culturais. Revista de Direito Constitucional e Internacional, São Paulo: Revista dos Tribunais, n. 33, p. 204, out./dez. 2000.
} 
corrupção não podem ser tolerados. Da perspectiva da autoridade, o poder a investe do dever de coibir e combater a corrupção.

Nesse momento, não se trata exatamente da legitimidade racional no sentido sugerido por Weber. Embora a crença na superioridade do comando legal faça parte da dicotomia público-privado, a legitimidade da ordem constitucional também se funda nos valores democráticos que inspiram o funcionamento do sistema político e a busca do bem comum. A ação política conjunta da sociedade é necessária:

\begin{abstract}
Esta idéia de "adesão a uma mesma lei por um grupo numeroso" permite chamar a atenção para o fato do poder fluir, como diz Hannah Arendt, da capacidade humana de agir em conjunto. $\mathrm{O}$ início da ação conjunta $-\mathrm{o}$ ato da fundação da comunidade política, cuja importância foi salientada pelos romanos - tem relevância na medida em que a ação política, no seu exercício conjunto e contínuo, confere a vida e legitimidade às normas e instituições que dela derivam. Legitimidade, portanto, como lembra Bobbio, diz respeito a título para o exercício do poder, título dado pela autoridade resultante do poder que provém da ação de muitos, na comunidade de uma adesão a uma mesma lei. $^{201}$
\end{abstract}

Setores da opinião pública por vezes se fartam da aparente falta de avanço no combate à corrupção, e esse título, mencionado por Bobbio, decorrente do voto popular, se enfraquece. Quando algo é feito, alguns percebem que existe sempre a tentativa de se deixar uma saída honrosa para que os acusados recebam sanção inferior à que seria devida. Especialmente no Brasil, onde impera a generalizada impressão de impunidade em relação aos ilícitos relacionados às práticas corruptas, esse tipo de opinião deve ser refutado, mesmo porque ele pode conduzir à corrupção-solapamento e, com isso, minar as bases do regime democrático.

Essa observação pode parecer despicienda, uma vez que uma tese jurídica teria dificuldades em argumentar a favor de uma ruptura no processo democrático. Considerandose, porém, que as características do Estado patrimonialista podem se desenvolver melhor na ausência da transparência, tão cara à democracia, movimentos autoritários frequentemente espreitam o regime.

À direita do espectro político, após os anos 1920, propagou-se a ideia da inadequação do regime democrático-representativo às condições brasileiras. A necessidade premente de uma modernização estatal que rompesse com o passado foi o mote de Oliveira Vianna, ideólogo do Estado Novo, e de Francisco Campos, ideólogo dos golpes de 1930 e $1964 .^{202}$ Sob

\footnotetext{
${ }^{201}$ LAFER, Celso. O sistema político brasileiro. São Paulo: Perspectiva, 1975. p. 38-39.

${ }^{202}$ FAUSTO, Boris. O pensamento autoritário nacional. Rio de Janeiro: Jorge Zahar, 2001. p. 28-29 e 46. "Apesar das diferenças de perspectivas, os nacionalistas autoritários concebiam uma modernização do país de cima para baixo, prescindindo das mobilizações populares, especialmente quando não controladas. A instituição
} 
o argumento da necessidade de modernização do Estado, o que não se verificava sob o regime representativo, os períodos autoritários no século XX escamotearam as condições patrimonialistas favoráveis à corrupção, as quais continuaram presentes sob formas diversas.

À esquerda do movimento político, é comum denunciar o Estado como mero comitê da burguesia e deslegitimar, dessa forma, todas as ações tomadas, inclusive as voltadas para o combate à corrupção. Enxergar essa realidade distorcida não exige muito esforço no Estado patrimonialista brasileiro, no qual a apropriação do público pelo privado muitas vezes nem sequer é camuflada. Consequentemente, todas as táticas para a ruptura revolucionária com a derrubada da ordem constitucional vigente se justificam dentro do espírito de que os fins justificam os meios. ${ }^{203}$ Ademais, a própria direita autoritária utilizou a ameaça comunista como pretexto para o golpe de 1937.

Nenhuma dessas duas posições extremas pode ser aceita. Igualmente, não se pode adotar ou considerar que este trabalho adota uma visão niilista sobre a corrupção no Brasil em virtude da aparente insolubilidade do cenário descrito. A análise realizada, que associa a corrupção ao processo de formação patrimonialista, apesar de poder remeter à crítica de "uma característica atávica e essencial das relações sociais no Brasil", ${ }^{204}$ não inspira a tese.

Pelo contrário, o bem comum da sociedade, democraticamente estabelecido de acordo com as regras político-constitucionais vigentes, é diretriz estatal aceita de modo amplo. Para sua persecução, além das técnicas de administração pública que escapam ao objeto desta tese, o combate à corrupção deve ser reconhecido como fundamental pela regulamentação microjurídica, pelas reformas macrojurídicas a ser implementadas e pela mudança de mentalidade informadora de parte do direito pressuposto. Isso não é bastante para desautorizar a substituição da democracia, mesmo porque a experiência histórica revela que essas abordagens autoritário-moralistas são igualmente incapazes de reduzir a corrupção. De fato, a corrupção, em todas as suas formas, compromete a busca do bem comum, na medida em que os seus efeitos políticos e econômicos deletérios comprometem o resultado das políticas públicas adotadas.

A manutenção da legitimidade da ordem constitucional atrela-se à superação dessas relações sociais patrimonialistas. Não se pretende especular sobre como esse desmonte possa

básica destinada a realizar a transformação, nas condições brasileiras, só poderia ser o Estado autoritário, centralizador, dotado de extensos poderes."

${ }^{203}$ BOBBIO, Norberto. Estado, governo, sociedade: por uma teoria geral da política. Tradução de Marco Aurélio Nogueira. Rio de Janeiro: Paz e Terra, 1987. p. 163 e ss.

204 SOUZA, Jessé. Weber. In: AVRITZER, Leonardo et al. (Org.). Corrupção: ensaios e críticas. Belo Horizonte: UFMG, 2008. p. 81. 
ser feito, embora algumas ideias sejam apresentadas. Nesse contexto, a identificação do modus operandi do Estado patrimonialista na atualidade contribui para demonstrar que o problema, verificado no passado, persiste ainda hoje. 


\title{
CAPÍTULO 3
}

\section{A CORRUPÇÃO NO CONTEXTO DA DICOTOMIA PÚBLICO-PRIVADO NO ESTADO PATRIMONIALISTA BRASILEIRO}

Quer do ponto de vista da legitimidade democrática, quer do ponto de vista da eficiência econômica para a sociedade, há razões suficientes que condenam as práticas corruptas, especialmente nas suas modalidades corrupção-suborno e corrupçãofavorecimento. As bases conceituais sobre as quais se assenta a distinção entre as esferas pública e privada, inclusive no que diz respeito à gestão patrimonial e impessoal do Estado, estão traçadas pela teoria política e instrumentalizadas pelo direito com base em preceitos democráticos. Aspecto muitas vezes negligenciado pela teoria geral do Estado, essa distinção fundamental foi incorporada de modo incompleto na construção do Estado brasileiro - por esse motivo, muitas vezes a corrupção-solapamento não aflora claramente. Sintetizam Belluzzo e Grau:

\begin{abstract}
A noção que temos da coisa pública relaciona-se não ao povo, porém ao Estado. O público é o estatal, não ao comum a todos. A sentença de Ulpiano, demarcando a distinção entre ambos [...] bona civitatis abusive publica dicta sunt; sola enin ea publica sunt, quae populi Romani sunt [os bens pertencentes ao Estado são abusivamente chamados de 'públicos', pois assim, devem ser considerados unicamente os bens pertencentes ao povo romano] [...] desconhecemos. Como desconhecemos também, inteiramente, a síntese de Cícero: res publica, res populi. Ainda que os nossos juristas exponham, e sempre com brilho, a distinção que a doutrina italiana põe entre interesse público primário [...] o interesse coletivo [...] e interesse público secundário, este último o interesse da Administração, a coisa pública, aqui, é do Estado, não a coisa do povo. O princípio da supremacia do interesse público resulta por privilegiar, assim, não o que se poderia supor ser o interesse do Estado, mas os interesses, privados, daqueles que detêm o controle do Estado, usado o vocábulo "controle", aqui sob o sentido de dominação. ${ }^{205}$
\end{abstract}

A importação da dicotomia público-privado não produziu as consequências sobre a organização da administração pública que se esperariam. Do ponto de vista formal, atualmente as instituições jurídicas e políticas brasileiras, consubstanciadas no direito posto,

\footnotetext{
$\overline{205}$ BELLUZZO, Luiz Gonzaga de Mello; GRAU, Eros Roberto. A corrupção no Brasil. Revista Brasileira de Estudos Políticos, Belo Horizonte: UFMG, n. 80, p. 12-13, jan. 1995.
} 
refletem o modelo ideal na letra da lei. Todavia, o direito pressuposto, imbricado no substrato cultural brasileiro, exerce pressão em sentido contrário e a operacionalização do modelo ideal do Estado moderno produz resultados muito aquém dos desejados - na prática, a teoria é outra. Ataliba expressa a frustração do jurista nesse cenário:

\footnotetext{
A república é a instituição publicística central do nosso direito. Entre suas postulações e exigências e a nossa prática efetiva há uma distância abissal. Nesse espaço grassam indiferença, acomodação, omissão, ignorância, complacência e conformismo. $^{206}$
}

O objetivo deste capítulo é compreender (i) como as bases para as práticas corruptas no bojo do Estado brasileiro se estabeleceram e (ii) como tais práticas são socialmente encaradas. Pretende-se formular um diagnóstico sobre as causas e o estágio atual da corrupção no Brasil, utilizando-se o arcabouço teórico sobre os espaços público e privado, ao qual será adicionada a dicotomia direito posto-direito pressuposto. Para tanto, uma narrativa histórica sobre a interação da cultura com a implantação do Estado brasileiro ilustrará em que proporção o patrimonialismo se fez presente até após a promulgação da Constituição de 1988. Como conclusão, será traçado um panorama sobre a visão atual da população brasileira sobre a corrupção, expondo as dificuldades para combatê-la em virtude do adesismo social.

\subsection{Direito posto e direito pressuposto enquanto parâmetro para a compreensão da evolução histórica do Estado patrimonialista no Brasil}

A exposição sobre a burocracia segundo Weber explicitou as linhas mestras que estruturam a dicotomia público-privado no Estado moderno. Trata-se de modelo teórico e, como tal, deve ser confrontado com a realidade. Nesse sentido, o próprio Weber considerava que os tipos de dominação podiam-se encontrar mesclados nas sociedades - a princípio, faz sentido que coexistam a busca pela legitimidade carismática, tradicional e racional, embora uma destas possa se tornar preponderante. A hipótese de trabalho adotada parte da assunção de que a formação do Estado brasileiro teve origem na dominação tradicional em sua vertente patrimonialista, mas o processo de modernização empreendido desde o século XIX introduziu elementos associados à dominação racional.

Antes de explicitar como se verificou esse processo aparentemente paradoxal, é necessário apresentar outra dicotomia, já referida en passant em algumas passagens ao longo

\footnotetext{
${ }^{206}$ ATALIBA, Geraldo. Instituições de direito público e república. 1984. 215 f. Tese (Professor Titular)Faculdade de Direito, Universidade de São Paulo, São Paulo. São Paulo. p. 8.
} 
do trabalho: a dicotomia entre o direito posto e o direito pressuposto, desenvolvida por Grau. ${ }^{207} \mathrm{O}$ autor, de início, nega a afirmação, normalmente atribuída a Marx, de que "o direito positivo (direito posto) seria a expressão de uma classe dominante", ${ }^{208}$ posição que, no Brasil, foi adotada por vários historiadores marxistas. ${ }^{209}$ Essa concepção, cercada de certo maniqueísmo por praticamente caracterizar o Estado como um comitê da burguesia, é repelida por Grau. Este retoma alguns fundamentos da análise marxista, ao explicar que

[...] a totalidade dessas relações de produção constitui a estrutura econômica da sociedade, a base real sobre a qual se ergue uma superestrutura jurídica e política e à qual correspondem formas de consciência social determinadas. $\mathrm{O}$ modo de produção da vida material determina o processo social, político, intelectual da vida em geral. $^{210}$

Por seu turno, o modo de produção da vida material é constituído por três "estruturas regionais", nomeadamente a econômica, a jurídico-política e a ideológica, uma das quais "domina as demais". ${ }^{211}$ Cada sociedade possui um modo de produção da vida material distinto no tempo e no espaço, de maneira que inexiste uniformidade - "o direito não existe, existem direitos". ${ }^{212}$ Além de ser "elemento constitutivo do modo de produção" da vida material, ${ }^{213} \mathrm{o}$ direito interage com as estruturas ideológica e econômica.

Essa interação é particularmente forte com a estrutura econômica no modo de produção capitalista, uma vez que o direito atua "como mediação específica e necessária das relações de produção - e isso de tal forma que as relações de produção capitalista não se podem reproduzir sem a 'forma' do direito". ${ }^{214}$ A simbiose do direito com a infra-estrutura econômica, "originariamente no nível da relação econômica", aflora via relação jurídica, expressa pelo contrato, na superestrutura jurídica. Como explica Grau,

\footnotetext{
A forma jurídica é imanente à infra-estrutura, como pressuposto interior à sociedade civil, mas a transcende enquanto posto pelo Estado, como direito positivo [...] A relação jurídica - que tem por forma de expressão o contrato - compõe o direito pressuposto e nela está refletida a relação econômica; o seu conteúdo é determinado pela própria relação econômica. A relação jurídica, pois já está na base econômica. Tanto é assim que é uma relação de vontade esteja ou não legalmente regulada - isto é, esteja ou não colhida, ordenada pelo direito posto (direito positivo). ${ }^{215}$
}

\footnotetext{
${ }_{207}$ GRAU, Eros Roberto. O direito posto e o direito pressuposto. 7. ed. São Paulo: Malheiros, 2008.

${ }^{208}$ Idem, p. 44.

${ }^{209}$ PRADO JR., Caio. História econômica do Brasil. São Paulo: Brasiliense, 2006. p. 124 e ss.

${ }^{210}$ GRAU, Eros Roberto. Op. cit. p. 45. "Não é a consciência do homem que determina o seu ser, mas sim, pelo contrário, seu ser social é que determina sua consciência."

${ }^{211}$ GRAU, Eros Roberto. Idem, p. 49.

${ }^{212}$ Idem, p. 43.

${ }^{213}$ Idem, p. 57.

214 Ibidem.

${ }^{215}$ Idem, p. 61.
} 
Na mesma direção, Alves argumenta que "o Estado não se explica por si mesmo, sua realidade deita raízes sobre a sociedade civil da qual promana e na qual tem sua razão de ser". ${ }^{216} \mathrm{O}$ chamado direito posto, parte da superestrutura jurídica, é colocado pelo Estado, ao passo que o direito pressuposto, que se origina da relação econômica num dado modo de produção da vida material, até mesmo preexistia ao direito posto - "assim, o direito pressuposto brota da (na) sociedade, à margem da vontade individual dos homens, mas a prática jurídica modifica as condições que o geram". ${ }^{217}$ Neste ponto, Grau defende que:

[...] o legislador não é livre para criar qualquer direito posto (direito positivo), mas este mesmo direito transforma sua (dele) própria base. O direito pressuposto condiciona a elaboração do direito posto, mas este modifica o direito pressuposto. $\mathrm{O}$ direito que o legislador não pode criar arbitrariamente - insisto - é o direito positivo. O direito pressuposto condiciona a produção do direito posto (positivo). Mas o direito pressuposto transforma sua (dele) própria base.

Isso significa - afirmo-o em outros termos - que o direito pressuposto condiciona a elaboração do direito posto (direito positivo), mas este modifica o direito pressuposto. ${ }^{218}$

Dessa forma, não procede a crítica de Souza de que "a noção de patrimonialismo 'simplifica' e 'distorce' a realidade social de diversas maneiras e sempre em um único sentido: aquele que 'simplifica' e 'idealiza' o mercado e subjetiviza e 'demoniza' o Estado". ${ }^{219}$ As relações recíprocas entre a infraestrutura econômica e a superestrutura-jurídica e entre o direito pressuposto e o direito posto resultam numa dada conformação social no Brasil, à qual se denomina patrimonialismo. É difícil detectar se a "origem" do problema reside na sociedade ou no Estado em razão da trama das relações sociais: da mesma maneira que o Estado patrimonialista atrapalha o desenvolvimento do mercado numa perspectiva do capitalismo europeu e norte-americano, os interesses privados adentram o Estado em busca das facilidades e privilégios. O patrimonialismo é exatamente esse caminho de mão dupla, e não apenas a mera exploração da sociedade pelo Estado, embora também o seja. ${ }^{220}$

A posição segundo a qual o legislador não pode criar arbitrariamente o direito posto merece atenção, ao se considerar o caso brasileiro. A importação da dicotomia público-

\footnotetext{
$\overline{216}$ ALVES, Alaôr Caffé. Estado e ideologia: aparência e realidade. Apresentação de Dalmo de Abreu Dallari. São Paulo: Brasiliense, 1987. p. 25.

${ }^{217}$ GRAU, Eros Roberto. Op. cit. p. 64.

${ }^{218}$ Idem, p. 61.

219 SOUZA, Jessé. Weber. In: AVRITZER, Leonardo et al. (Org.). Corrupção: ensaios e críticas. Belo Horizonte: UFMG, 2008. p. 84.

${ }^{220}$ DOMINGUES, José Maurício. Patrimonialismo e neopatrimonialismo. In: AVRITZER, Leonardo et al. (Org.). Corrupção: ensaios e críticas. Belo Horizonte: UFMG, 2008. p. 189. "É na vinculação entre interesses privados, do indivíduo isolado que suborna o guarda de trânsito à grande empresa que se articula a parlamentares e ministérios, passando pelo financiamento de campanhas eleitorais, que as próprias posições e cargos estatais são tomados como objeto de posse privada de seus ocupantes."
} 
privado para o direito posto ocorreu de modo inconsistente com a infraestrutura econômica era mais um projeto de uma elite política, preocupada em manter a unidade nacional e o poder central, do que um projeto de modernização político-econômica do país. ${ }^{221}$ Embora se reconheçam alterações significativas decorrentes da urbanização e da industrialização, ${ }^{222}$ estas foram mais recentes do que a importação das bases da dicotomia público-privado. Ademais, hoje persistem práticas típicas de um Estado patrimonialista, ainda que metamorfoseado. Vista desse ângulo, a justificativa de Grau, baseada em Poulantzas, faz sentido:

[...] em cada sociedade estatal, no entanto, coexistem vários modos de produção social, ainda que um deles seja característico dela. Ora, ainda que domine nela o direito pressuposto do modo de produção dominante, o direito posto de cada sociedade é resultante da coexistência histórica de todos esses modos de produção. $^{223}$

O paradoxo do caso brasileiro reside no fato de que o direito pressuposto, pelo menos na origem do processo de importação da dicotomia público-privado, encontrava-se em acentuado "descompasso" com esta última, contida no direito posto. Numa perspectiva autoritária, Oliveira Vianna já apontava a inadequação do sistema representativo à realidade brasileira - em certa medida, a identificação de um descompasso entre o direito legislado e as limitações enfrentadas na sua aplicação caracteriza um dos paradoxos do ordenamento jurídico brasileiro. Se a proporção desse paradoxo o tornava evidente no século XIX, atualmente a sua caracterização é mais complexa. Uma visão otimista do processo de modernização brasileiro argumentaria que, gradativamente, as alterações no modo de produção da vida material trouxeram a reboque as condições para o surgimento de uma burocracia weberiana. As práticas corruptas seriam meros resquícios da fase patrimonialista ou, então, parte aceitável do comportamento antissocial relacionado à corrupção, tal como existe e sempre existiu em todos os países. Conforme afirmava Durkheim, a criminalidade seria uma nota comum mesmo numa sociedade sã. ${ }^{224}$

\footnotetext{
${ }^{221}$ CARVALHO, José Murilo de. A construção da ordem. Rio de Janeiro: Civilização Brasileira, 2006. p. 229 e ss.

${ }^{222}$ LAFER, Celso. O sistema político brasileiro. São Paulo: Perspectiva, 1975. p. 62-64.

${ }^{223}$ GRAU, Eros Roberto. Op. cit. p. 65.

224 DURKHEIM, Émile. As regras do método sociológico. Tradução de Pietro Nassetti. São Paulo: Martin Claret, 2007. p. 82-83. "Se há um fato cujo caráter patológico parece incontestável é sem dúvida o crime. Todos os criminólogos estão de acordo sobre esse ponto. Apesar de explicarem esta morbidez de maneiras diferentes, são unânimes na sua constatação. [...] O crime não se produz só na maior parte das sociedades desta ou daquela espécie, mas em todas as sociedades, qualquer que seja o tipo destas. Não há nenhuma em que não haja criminalidade. Muda de forma, os atos assim classificados não são os mesmos em todo o lado; mas em todo o lado e em todos os tempos existiram homens que se conduziram de tal modo que a repressão penal se abateu sobre eles. [...] Não há, portanto, um fenômeno que apresente de maneira tão irrefutável como a criminalidade
} 
Por seu turno, uma visão mais pessimista sustentaria que tal depuração não se produziu. A despeito das novas regras esclarecedoras dos limites entre o público e o privado, enunciadas formalmente no direito posto, caracteres do Estado patrimonialista teriam sido apenas escamoteados sob o verniz modernizante.

Em que pese o modo de produção da vida material poder até pressionar por mudanças no direito pressuposto, haveria prevalência do elemento ideológico na conformação atual do Estado brasileiro que o impele para práticas corruptas - afinal, "o Estado, não obstante, está dentro da sociedade" 225 e esta pode ter mantido seu modo de pensar relativamente inalterado. A ideologia, contaminada pelo patrimonialismo, aflora em vários $\operatorname{aspectos}^{226}$ de como a sociedade encara a relação entre o público e o privado - o recorrente adesismo social é uma dessas formas.

Por esses motivos, o direito pressuposto está descomprometido com a justiça, ${ }^{227}$ a menos que por justiça se entenda algo não necessariamente positivo, mas sim dada concepção do que é justo para dada sociedade em dado tempo e dado espaço. Em outras palavras, a concepção de justiça que seria adotada poderia significar algo perverso na perspectiva da moderna separação entre o público e o privado, tal como o favorecimento dos detentores do poder em detrimento daqueles que não o detêm.

A dicotomia público-privado constitui uma técnica do Estado moderno para atingir uma finalidade que, nas democracias, deve beneficiar a todos, ou seja, visar ao bem comum. Eis que surge um novo paradoxo: parcelas da população consideram que essa técnica pode ser deixada de lado, desde que se sintam compensadas por algum tipo de favorecimento. Tal cooptação se faz não somente pela ideologia, mas também pelo poder econômico que deflui do próprio aparato estatal.

A persistência de práticas corruptas, desde as mesquinharias da corrupção-suborno e da corrupção-favorecimento até as formas aparentemente sutis de corrupção-solapamento, deita raízes na histórica dificuldade da sociedade brasileira em lidar com a dicotomia públicoprivado, o que, em boa parte, se deve a um amplo espectro de práticas não reprimidas juridicamente, mas que constituem uma patologia social.

todos os sintomas da normalidade, dado que surge como estreitamente ligada às condições da vida coletiva. Transformar o crime numa doença social seria o mesmo que admitir que a doença não é uma coisa acidental mas que, pelo contrário, deriva em certos casos da constituição fundamental do ser vivo; consistiria em eliminar qualquer distinção entre o fisiológico e o patológico."

${ }_{225}$ GRAU, Eros Roberto. Op. cit. p. 69.

${ }^{226}$ Idem, p. 70.

${ }^{227}$ Em sentido diverso, GRAU, Eros Roberto. O direito posto e o direito pressuposto. 7. ed. São Paulo: Malheiros, 2008. p. 81. "O povo - digo - produz o direito pressuposto; o Estado produz o direito posto, que conhecemos como direito moderno ou direito formal; apenas o direito produzido pelo povo é comprometido com a justiça." 


\title{
3.2 Antecedentes da colonização portuguesa no Brasil
}

Desde a época em que os romanos ocuparam a Península Ibérica, parece ter havido certa confusão quanto à correta compreensão do conceito de res publica - a expressão era usada indiscriminadamente, ${ }^{228}$ algo que, por si só, já denota quão problemática seria a importação da referida dicotomia para o Brasil colonial.

Na Europa feudal, como regra, os cargos públicos eram considerados mais uma propriedade pessoal de seu ocupante, desvinculado de quaisquer deveres. ${ }^{229}$ Esse aspecto da dominação tradicional, tipicamente patrimonialista na acepção weberiana, evoluiu diferentemente conforme a região da Europa. A peculiar formação territorial portuguesa na Idade Média pode ser identificada como a causa remota da confusão entre o público e o privado. A cruzada contra os mouros foi uma empresa real, e os espólios couberam ao monarca:

\begin{abstract}
A coroa conseguiu formar, desde os primeiros golpes da reconquista, imenso patrimônio rural (bens "requengos", "regalengos", "regoengos", "regeengos"), cuja propriedade se confundia com o domínio real, aplicado o produto nas necessidades coletivas ou pessoais, sob as circunstâncias que distinguiam mal o bem público do bem particular, privativo do príncipe. A conquista ao sarraceno ou ao inimigo se incorporava ao domínio do rei, ao reinado, se não apropriada a terra por legítimos títulos prévios. ${ }^{230}$
\end{abstract}

Diversamente de outros países europeus como Inglaterra e da Holanda, onde a distinção entre o público e o privado tomava corpo a partir do século XV, em Portugal o patrimônio real fazia toda a sociedade girar em torno do rei - "entre o rei e os súditos, não há intermediários: um comanda e todos obedecem". ${ }^{231}$

A simbiose entre o público, na figura do rei, e o privado, na figura da aristocracia, é dada por Faoro:

\footnotetext{
$\overline{228}$ ARCE, Javier; LE ROUX, Patrick (Org.). Cité et communauté civique en Hispania. Madrid: Consejo Superior de Investigaciones Científicas, Casa de Velázquez, 1993. p. 10. "La continuité perceptible d'un modèle de fonctionnement de la vie locale n'autorise pas la définition a priori d'un type d'évolution et la presénce dominante da la respublica comme structure constitutive des provinces à partir du $\mathrm{II}^{\mathrm{e}}$ siècle ne se confond aucun cas avec l'uniformisation des histoires particulières." Ver também DARDEINE, Sylvie. Une image des cités de Bétique aux $\mathrm{II}^{\mathrm{e}}$ et $\mathrm{III}^{\mathrm{e}}$ siècles après J.-C.: l'emploi du terme respublica dans les inscriptions de la province. In: ARCE, Javier; LE ROUX, Patrick. (Org.). Cité et communauté civique en Hispania. Madrid: Consejo Superior de Investigaciones Científicas, Casa de Velázquez, 1993. p. 47-58.

${ }^{229}$ HEIDENHEIMER, Arnold J. The content of analysis. In: HEIDENHEIMER, Arnold J. Political corruption: readings in comparative analysis. 2. ed. New Brunswick: Transaction Books, 1978. p. 11.

${ }^{230}$ FAORO, Raymundo. Os donos do poder: formação do patronato político brasileiro. 2. ed. rev. e aum. Porto Alegre: Globo; São Paulo: Edusp, 1975. v 1. p. 4.

${ }^{231}$ Idem, p. 5. "A independência da nobreza territorial e do clero, com lastro em seu domínio de terras, frustrouse, historicamente condicionada e tolhida, enferma de sua fragilidade congênita."
} 
Este o primeiro ato do drama. O súdito - o súdito qualificado, o nobre, já absorvido pelo clero nas malhas do poder supremo, e o súdito sem esporas - não paga serviços, tangíveis ou abstratos, como o contribuinte moderno. Um poderoso sócio, sócio e patrão, tosquia o melhor da lã, submetendo o proprietário nominal à obrigação de cuidar da ovelha. A nobreza, agarrada aos velhos privilégios, ainda se manterá no nível de companheira do soberano. Um pouco mais e ela, já cercada com as unhas embotadas, dividirá, domesticada depois de uma revolução, o segundo lugar com a burguesia. A ideologia completará a obra, vencendo as consciências e roubando à imaginação o estandarte da resistência. O Estado Patrimonial, implacável nos seus passos, não respeitará os pesos dos séculos, nem os privilégios de linhagem antiga. $^{232}$

Essas características serão exportadas para a administração colonial que será implantada no Brasil

\subsection{A administração colonial portuguesa}

É célebre a passagem constante da Carta de Pero Vaz de Caminha em que este escreve ao rei Dom João IV para informar sobre o descobrimento do Brasil e, ao mesmo tempo, pedir um favor para o genro:

E pois que, senhor, é certo que, assim neste cargo que levo, como em outra qualquer coisa que de vosso serviço for, Vossa Alteza há de ser de mim muito bem servida, a ela peço que, por me fazer graça especial, mande vir da ilha de São Tomé a Jorge de Osório, meu genro - o que dela receberei em muita mercê. ${ }^{233}$

Esse trecho é frequentemente apontado como presságio do que viria a ocorrer no Brasil Colônia. Autores denunciavam a corrupção aberta existente na administração colonial brasileira. Em um de seus sermões, o Padre Vieira era categórico ao se referir à corrupção na Justiça:

Come-o o meirinho, come-o o carcereiro, come-o o escrivão, come-o o solicitador, come-o o advogado, come-o o inquiridor, come-o a testemunha, come-o o julgador e ainda não está sentenciado, já está comido [...] o que anda em juízo, ainda não está sentenciado e já está comido. ${ }^{234}$

\footnotetext{
${ }^{232}$ Idem, p. 10.

${ }^{233}$ CAMINHA, Pero Vaz de. Carta a El Rey Dom Manuel. Transcrita por Maria Angela Vilella. Fotografia por Antônio Caetano Santos. Ilustrações por Jorge Valente. 2. ed. com. e ilustr. São Paulo: Ediouro, 1999. p. 95.

${ }^{234}$ VIEIRA, Pe. Antônio. Sermão de Santo António aos Peixes. Porto: Porto. p. 15 (Colecção Clássicos da Língua Portuguesa). Disponível em <http://web.portoeditora.pt/bdigital/pdf/NTSITE99_SerStoAntPeix.pdf>. Acesso em: 26 nov. 2009 às 14h49.
} 
Um século mais tarde,

[...] o Marquês do Lavradio afirmava o mesmo, justificando sua intervenção na administração da justiça e aconselhando seu sucessor a fazer o mesmo, pois, em caso contrário, "não só nascerão causas novas a todos os instantes, porém muitas das que já davam por feitas tornarão a nascer por este modo se conseguirá a ruína geral dos povos. ${ }^{235}$

Apesar da virulência da crítica de Padre Vieira e da advertência do Marquês de Lavradio, já havia algum esboço da dicotomia público-privado, embora esta se fundasse mais na ideia de se reprimir o ataque ao patrimônio do rei. Do ponto de vista jurídico, as Ordenações Manuelinas reprimiam o recebimento de "serviços ou peitas" por funcionários reais, bem como aqueles que "lhas dão ou prometem". As penas para o juiz podiam ser de degredo, perdimento de bens e a morte e para aquele que ofereceu "serviços ou peitas", a perda dos direitos pleiteados além das já mencionadas. ${ }^{236}$ Portanto, não se considerava ilícito dar pequenos presentes "que entre parentes e amigos se costumam dar e receber", tais como alimentos e bebidas. No mesmo sentido, a Coroa era condescendente para com pequenas desvirtuações do funcionalismo público, o que é prova cabal de quão intrínseca à sociedade está essencialmente atrelada à dificuldade de distinguir entre público e privado. ${ }^{237} \mathrm{Em}$ princípio, as eleições para as câmaras de vereadores também escapariam ao interesse da Coroa, "nem se declaram penas aos compreendidos no subornarem as tais eleições, se façam como convém ao meu serviço, atendendo-se sòmente o que fôr, mais benefício e bom govêrno da terra". ${ }^{238}$

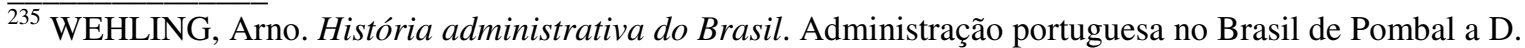
João. v. 6. Coordenação de Vicente Tapajós. Brasília: Fundação Centro de Formação do Servidor Público, 1986. p. 31.

${ }^{236}$ PORTUGAL. Ordenações manuelinas. Livro V. título LVI. "Dos Officiaes d'ElRey que recebem serviços, ou peitas, e das partes que lhas dam, ou prometem, e dos que deles defamam". Disponível em <http://www.ci.uc.pt/ihti/proj/manuelinas//ordemanu.htm>. Acesso em: 26 nov. 2009.

237 FLEIUSS, Max. Historia administrativa do Brasil. Rio de Janeiro: Imprensa Nacional, 1923. p. 59. O trecho seguinte ilustra que eram tratados no mesmo plano o recebimento de presentes e a colocação de retratos dos funcionários públicos em repartições. "Tanto aos governadores geraes ou vice-reis, como a quaesquer auctoridades publicas coloniaes, era defeso 'mandar presentes aos membros do Conselho Ultramarino, não podiam, outrossim, permitir representassem as Camaras em seu favor estando ainda em exercício do cargo, nem consentir que se lhes tirasse o retrato para ser posto na sala do Senado da Camara ou em outros quaesquer logares publicos, sem a representação prévia da Camara a el-rei, como se verificou com o caso do conde de Borbadella (provisão de 27 de Novembro de 1788)."

${ }^{238}$ FERREIRA, Waldemar Martins. O direito público colonial do estado do Brasil sob o signo pombalino. Rio de Janeiro, Editora Nacional de Direito, 1960. p. 59.
} 
Mais tarde, essa atitude de desinteresse mudou. No caso das câmaras de vereadores, a Coroa passou a reprimir fortemente fraudes eleitorais. ${ }^{239}$ A provisão de 27 de novembro de 1788, que vedava certas práticas corruptas, já apontava para uma primeira tentativa de importar para o Brasil o modelo de separação entre as esferas pública e privada, ainda em grau muito incipiente. Está-se diante da gênese do abismo entre a forma da organização administrativa do Brasil e a prática da mesma organização administrativa - umas leis pegam, enquanto outras não.

Outra possível causa dessa confusão entre o público e o privado reside no fato de que todo o processo de colonização portuguesa do Brasil foi marcado pela ausência de recursos da Coroa, o que se manifestava "o exagerado desnível entre os objetivos e recursos foi uma constante na estrutura administrativa colonial". ${ }^{240}$ Esse aspecto marcará de forma decisiva a organização administrativa. Os capitães hereditários possuíam as terras e ao mesmo tempo, exerciam tarefas tipicamente do Estado por delegação real. ${ }^{241}$ A própria conquista de cerca de dois terços do atual território nacional, assunto normalmente levado a cabo pelo Estado, foi majoritariamente uma empresa privada. À semelhança do que aconteceu com o rei de Portugal, os bandeirantes paulistas consideravam as terras conquistadas como sua propriedade, fato que motivou inclusive a Guerra dos Emboabas. ${ }^{242}$

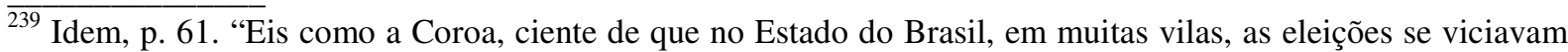
pela corrupção eleitoral pelo subôrno, cuidou de sanar o mal, punindo com degredo para África e multa quantos nas devassas se apurassem terem sido subornadores ou subornados. Tratou-se evidentemente de cortar o mal, que se prenunciava, no nascedouro. A vida política da colônia lusitana deveria processar-se em regime de dignidade e de honra, sem se conspurcar pelas práticas indecorosas que tanto contribuíram para o malefício das instituições democráticas, que então se instalavam."

${ }^{240}$ WEHLING, Arno. Op. cit. p. 25. “A opção pelo sistema de capitanias, as sucessivas divisões e centralizações administrativas em 1572, 1602-1608, 1623-1652 e 1654-1774, o sistema de companhias comerciais, de frotas e de contratos demonstram como, a par de problemas circunstanciais e locais, procurou-se criar mecanismos, nem sempre bem-sucedidos, que desonerassem o Estado de algumas das tarefas administrativas, ou as reduzissem a um mínimo compatível com os escassos recursos do Tesouro."

${ }^{241}$ FERREIRA, Waldemar Martins. Op. cit. p. 25. "[...] o govêrno da ilha do Pôrto Santo, lha houvesse concedido juro e herdade, de modo a que, por morte, o filho mais velho lhe recolhesse a sucessão por transmitirse de geração em geração. Era o regime da autoridade que se instituia, com outorga ao donatário de jurisdição civil e crime, exercida por delegação e em nome do infante, com restrição da pena de morte e de amputação de membros. Para que a autoridade se tornasse efetiva, pois era, em regra, de 'mero e misto império', não poucas vêzes derrogada a Lei Mental, os donatários se investiram de direitos de tributação e de privilégios, variáveis de capitania para capitania. [...] Distribuiria, de conformidade com seu foral, terras em sesmaria, condicionadas ao aproveitamento dentro de cinco anos, sem prejuízo todavia do infante dar a quem quisesse as ainda não sesmadas."

${ }^{242}$ SCANTIMBURGO, João de. Os paulistas. São Paulo: Imprensa Oficial, 2006. p. 198. (Paulística, v. 21). “Os paulistas não queriam concorrência, sobretudo considerando intrusos na terra que, com imensos sacrifícios, colonizavam, os reinóis, cada vez mais distantes dos sentimentos nacionais progressivamente acentuados nos moradores da terra, notadamente da terra paulista. Não se tratava, segundo as fontes históricas, de luta ideológica, que esta nem era cogitada na época, porquanto mesmo a palavra não se conhecia, mas que os paulistas entendiam exercer e dela disporem da terra, cuja conquista se averba predominantemente como obra de seus conterrâneos."
} 
A dinâmica patrimonialista da relação entre as esferas pública e privada fica muito evidenciada ao se analisar a organização burocrática no período colonial. Os cargos públicos eram tidos como de propriedade do soberano, ${ }^{243}$ que os doava àqueles que mais bem o remunerasse. Esse mecanismo de "compra" de cargos públicos era recompensado pela convicção de que o cargo em si traria a remuneração ao seu ocupante, mediante atos de corrupção. Aos olhos da atual concepção sobre a dicotomia público-privado, essa forma de enriquecimento ilícito era estimulada para desonerar o Tesouro. ${ }^{244}$ Pode ser que essa tática para lidar com as restrições de recursos tenha tido efeito contrário:

Criou-se, portanto, além da dicotomia Estado sociedade civil, ordem pública privada, um mecanismo supostamente auto-regulador no interior da engrenagem estatal, mas que se revelou, na verdade, oneroso (pela quantidade de intermediários que exigia) e corruptor (pelas possibilidade de cooptação que suscita). ${ }^{245}$

Essa "autorregulação" consistiria numa resposta da população que ajustou seus padrões de comportamento em relação ao Estado, a fim de sobreviver num ambiente em que a organização política persegue os interesses privados de seus ocupantes.

Embora o período pombalino e os anos subsequentes tenham trazido alguma eficiência para a máquina burocrática, ficou evidente que vários fatores ligados à infraestrutura econômica e jurídico-política conspiravam contra o surgimento de uma burocracia weberiana. ${ }^{246}$ Exemplo evidente é a situação dos magistrados, os quais, ainda que

\footnotetext{
${ }^{243}$ FAORO, Raymundo. Op. cit. p. 5. Diversamente do Brasil colonial, Faoro observa no Portugal medieval, o rei remunerava pelos serviços de que necessitava. "O corpo de funcionários recebia a remuneração das rendas dos casais, aldeias e freguesias, dos estabelecimentos não beneficiados com a imunidade fiscal. Os cargos eram, dentro de tal sistema, dependentes do príncipe, de sua riqueza e de seus poderes. Extremava-se tal estrutura existente na Europa, marcando um prematuro traço de modernidade. O rei, quando precisava do serviço militar da nobreza territorial, pagava-a, como se paga a um funcionário."

${ }^{244}$ WEHLING, Arno. História administrativa do Brasil. Administração portuguesa no Brasil de Pombal a D. João (1777-1808). Coordenação de Vicente Tapajós. Brasília: Fundação Centro de Formação do Servidor Público, 1986. p. 33. "Sabemos que geralmente tinha um caráter prebentário, 'antigo regime', pelo qual o cargo era encarado como uma doação do soberano, em troca de uma quantia em dinheiro, paga imediatamente ou amortizada pelo regime das 'terças partes'. A arrematação de cargos públicos no Brasil colonial não diferiu, portanto, da organização burocrática de outras sociedades ditas 'concentradas', de caráter pré-industrial. Esperava-se que o próprio cargo remunerasse seu ocupante, mediante as comissões, propinas e outros ingressos, de forma a desonerar o tesouro. O objetivo, em tese, era conseguir para os cofres reais a remuneração pelos ofícios cedidos e a sua manutenção pela própria sociedade, não pelo Estado. Estimulava-se, de fato, a corrupção e o enriquecimento ilícito e as repetidas acusações de 'opressão dos povos'. Não se pode, entretanto, concluir, como alguns historiadores, que a Coroa remunerava mal seus funcionários esperando que se locupletassem; era, simplesmente um sistema administrativo prebentário em funcionamento. Se o sistema funcionava mal, era muito mais pela ausência de sentido profissional nas funções públicas - características que encontramos nos modelos modernos, concentrados - do que pela corrupção que lhe seria inerente."

${ }^{245}$ Idem, p. 31.

${ }^{246}$ Idem, p. 28. "Esta afirmação não implica em desconhecer o abismo entre o 'Brasil formal' da organização administrativa e o 'Brasil real' de sua prática. O exercício do poder monárquico e a eficiência discutível das políticas administrativas postas em prática no período de 1777-1808 revela menos uma desarticulação formal na
} 
buscassem aplicar a lei imparcialmente, cediam às tensões e demandas locais devido à realidade local e à distância. ${ }^{247}$ Em outras palavras, os interesses dos poderes políticos locais tendiam a se sobrepor aos da Coroa portuguesa.

Exceção feita aos períodos de opulência minerária e de conflitos armados, a inserção da administração colonial portuguesa se torna ficta, gerando uma "desconfiança fundamental", isto é, a atuação do Estado lusitano junto aos elementos da elite econômica passa a ser cada vez mais mediata. Como desdobramento dessa falta de confiança generalizada, estrutura-se como resposta um "formalismo burocrático", ${ }^{248}$ gerando-se uma série de mecanismos que pudessem estimular a inserção do Estado nas relações interpessoais. Tal formalismo se torna traço inconfundível da formação do país. Como assevera Holanda, trata-se de "um amor pronunciado pelas formas fixas e pelas leis genéricas, que circunscrevem a realidade complexa e difícil dentro do âmbito dos nossos desejos, é dos aspectos mais constantes e significativos do caráter brasileiro". ${ }^{249}$

No contexto de ausência de profissionalização da burocracia, o Estado estimula o combate à corrupção em si por meio de delações, previstas no direito posto, bem como pela imposição do dever para aqueles que ocupassem os cargos públicos de devassar ${ }^{250}$ a gestão que o antecedera. ${ }^{251} \mathrm{Em}$ vista da inexistência de uma sociedade civil organizada no período colonial, essa se tornou a forma simplória de dissuasão da corrupção.

ação administrativa (que existia em níveis toleráveis) do que a existência de fatores básicos outros, como a lavoura de subsistência, o baixo consumo local, a dependência a preços externos dos produtos de exportação, a escravidão, o mandonismo local etc. É certo que a multiplicidade de atos legais e a falta de consolidação implicava em desordem; mas os fatores básicos impediam uma ação mais eficaz 'moderna' (no sentido da metade do século XVIII) da administração pública."

${ }^{247}$ Idem, p. 30. "Assim, os pólos em tensão mantêm o equilíbrio centro-periferia, sem que se alcance a eliminação radical de um ou outro. Repete-se, com as tentativas pós-pombalinas de centralização, o fenômeno constatado por Schwartz em ponto monográfico, na relação da Bahia: se mantido o esquema real da colonização portuguesa (linhas administrativas, reconhecimento do rei, recolhimento de impostos), havia aquiescência da Coroa à independência de fazendeiros e senhores de engenho - significando que os magistrados da relação, mesmo que desejassem aplicar imparcialmente as leis, acabavam curvando-se à realidade local, pela distância, no interior ou pela sua inserção nas relações primárias de grupo, família ou classe, na capital.”

248 "Burocrático" não no sentido weberiano, mas sim no sentido pejorativo, correspondendo aos custos e às ineficiências associadas à ação burocrática.

${ }^{249}$ HOLANDA, Sérgio Buarque de. Raízes do Brasil. 26. ed. São Paulo: Companhia das Letras, 1995. p. $157-$ 158.

${ }^{250}$ WEHLING, Arno. Op. cit. p. 30. "Os juízes, quando chegados a seu termo, tinham prazo de dez dias para fazer devassa da administração anterior; as inquirições faziam-se tendo por base a testemunha de pelo menos 30 depoentes, subordinando-se o questionário aos seguintes itens: [...] 2 - se os juízes não cumpriam sua função por temor, peita, ódio ou negligência; [...] 4 - se receberam serviços ou presentes de fidalgos ou outras pessoas; 5 se utilizavam seu ofício para receber bens gratuitamente, ou a baixo preço; [...] 12 - se funcionários seus fizeram pedidos para receber quaisquer bens; 13 - se funcionários seus permitiram o uso indevido de armas, sem corrupção."

${ }^{251}$ Ibidem. "Certamente a peculiaridade estatista da colonização portuguesa (em contraste, por exemplo, com a inglesa ou holandesa e semelhante à espanhola) pode explicar a questão: a direção da empresa colonizadora do Estado e a difícil relação com os elementos heterogêneos da nobreza, da burguesia (nacional e estrangeira) e do 
Tais mecanismos visavam compensar a desarticulação do Estado, inserido em relações sociais desfiguradas, desprovidas de qualquer noção sobre onde estavam os limites do público e do privado. Além de ser onerosa e fomentadora de práticas corruptas, a estruturação desse mecanismo "autorregulador" gerou um grave entrave para a engrenagem estatal. $^{252}$

Nesse momento, outra tendência particular ao patrimonialismo toma corpo: o fiscalismo. Este visava ao infindável crescimento da arrecadação estatal, por meio da implementação de políticas, criação de instituições e atividade normativa em detrimento de quaisquer outras preocupações. Tudo que importava era arrecadar mais para fazer frente às crescentes necessidades financeiras do Estado patrimonialista. ${ }^{253}$

Dessa forma, foi transposto o esquema geral do Estado patrimonialista de Portugal para o Brasil, mas temperando-se o mesmo com características peculiares da infraestrutura econômica de uma colônia de exploração. ${ }^{254}$ É sobre tais características que um projeto modernizante, pelo menos do ponto de vista do direito posto, se implantaria a partir do século XIX.

\subsection{A progressiva importação de modelos de separação entre os espaços público e privado a partir do século XIX}

No século XIX, começa o processo de formação propriamente dito do Estado brasileiro moderno. Evidentemente, há grande herança dos traços da administração da Coroa

clero podem justificar a 'desconfiança fundamental' que caracterizou a ação do governo e a sua legislação. Essa desconfiança traduziu-se num formalismo burocrático, que envolvia inúmeros registros, provas, testemunhas e devassas, cujo objetivo era fazer com que cada membro da burocracia fiscalizasse a faixa da sociedade a que lhe correspondia e seus próprios companheiros, antecessores ou contemporâneos. Foram comuns, previstas em diversos regimentos e nas próprias ordenações do reino, a denúncia, premiada em dinheiro ou bens, e a devassa do trabalho realizado pelo antecessor; a primeira obrigação dos juízes de fora - e, às vezes de governadores - era abrir devassa sobre a gestão a que sucedia."

${ }^{252}$ Idem, p. 31. "Criou-se, portanto, além da dicotomia Estado/sociedade, ordem pública privada, um mecanismo supostamente auto-regulador no interior da engrenagem estatal, mas que se revelou, na verdade, oneroso (pela quantidade de intermediários que exigia) e corruptor (pela possibilidade de cooptação que suscita)."

253 Idem, p. 111. "Fiscalismo ou necessidade de aumentar a arrecadação face aos sempre crescentes compromissos do Estado - e cartesianismo fazendário - ou necessidade de racionalizar a administração econômica, para atingir as potencialidades fiscais da sociedade e corrigir os abusos mais crônicos, como a supertaxação, o peculato e a corrupção são os dois vetores da administração econômica entre 1777 e 1808 . Criam-se instituições, muda-se a legislação e implementam-se políticas com vistas à sua consecução. A história da administração fazendária neste período é, fundamentalmente, a das ações e reações com que ambos os vetores marcaram a sociedade colonial e o Estado."

${ }^{254}$ FAUSTO, Boris. O pensamento autoritário nacional. Rio de Janeiro: Jorge Zahar, 2001. p. 32-33. RIBEIRO, R. J. B Possibilidades de combate à corrupção pelo Estado burocrático-patrimonialista na América Latina no contexto da sociedade informacional. Revista do Tribunal de Contas da União, Brasília: TCU, v. 32, n. 88, p. 76 abr./jun., 2001. 
lusitana, tanto na metrópole quanto na colônia - afinal, a independência do Brasil representa a opção pela continuidade sem rupturas. Nem o direito posto nem o direito pressuposto foram afetados.

\subsubsection{A manutenção do Estado patrimonialista após 1822}

Apesar do continuísmo, um dos mais marcantes fatores de modernização da relação entre o Estado e a população brasileira foi a importação da diferenciação entre as esferas pública e privada, iniciada no século XIX. A tropicalização inconsciente dessa forma de organização estatal dos modelos constitucionais europeu e norte-americano teve o condão de atuar como princípio da lenta e inconclusa história de ruptura com a situação de simbiose entre os espaços público e privado.

Embora há algum tempo a administração colonial portuguesa contivesse feições da separação de patrimônio do soberano e do tesouro, o começo do século XIX ainda se caracteriza por conceitos fluidos quanto ao uso de recursos e bens públicos pelos ocupantes do poder, especialmente no modo como a terceirização da ocupação territorial acontecia. Ademais, a ausência de eleições e a tendência à permanência nos cargos incentivavam a confusão do público com o privado.

Após a Revolução Liberal do Porto de 1820 e a promulgação da primeira Constituição portuguesa, em 1822, estabeleceu-se a separação formal entre as esferas pública e privada. Os políticos liberais tinham em mente a redução poder do monarca absoluto, e, indiretamente, uma das formas de obter isso e era reduzir o seu poder sobre os bens e recursos do Estado. ${ }^{255}$ Tal estratégia de limitação dos poderes da monarquia já era evidente havia muito tempo: em 1215, a imposição da Carta Magna ao soberano inglês João Sem Terra explicitava muito mais uma limitação ao poder de taxar dos soberanos. ${ }^{256}$

No Brasil, em que pese a dissolução da Assembleia Constituinte de 1823, menos conservadora do que agradava a Dom Pedro I, uma conjunção de fatores contribuiu para que a Constituição de 1824 incorporasse alguns desses avanços no direito posto. Antes disso, o descontentamento com a condução dos negócios públicos pelo então príncipe regente Pedro

\footnotetext{
${ }^{255}$ CARVALHO, José Murilo de. Op. cit. p. 199-228.

${ }_{256}$ REINO UNIDO. $\quad$ Carta Magna. <http://www.bl.uk/treasures/magnacarta/translation/mc_trans.html>. Acesso em: 26 nov. 2009 às 15h22. "12. No 'scutage' or 'aid' may be levied in our kingdom without its general consent, unless it is for the ransom of our person, to make our eldest son a knight, and (once) to marry our eldest daughter. For these purposes only a reasonable 'aid' may be levied. 'Aids' from the city of London are to be treated similarly."
} 
mostra como pode ser falso o mito sobre a superioridade moral do regime monárquico sobre o republicano. ${ }^{257} \mathrm{O}$ artigo 170 da Constituição de $1824^{258}$ assinalava a primeira regra de direito financeiro, separando as receitas e despesas da Fazenda Nacional, ao mesmo tempo em que os artigos $114^{259}$ e $115^{260}$ estabeleciam uma dotação para o sustento da família real e a separação entre os bens do imperador e os do Estado. Existia a possibilidade de fiscalização das contas do governo, mas esta ocorria de modo diverso se comparado com a atualidade. ${ }^{261}$ Não havia uma instituição própria para tal função - sua aprovação se dava pela apresentação à Câmara dos Deputados. ${ }^{262}$ Torres afirma que as inovações "lançaram o país, indubitavelmente, na modernidade do Estado Fiscal", muito embora caracteres patrimonialistas permanecessem,

${ }^{257}$ VINHOSA, Francisco Luiz Teixeira. História administrativa do Brasil. Brasil sede da monarquia, Brasil Reino. Coordenação de Vicente Tapajós. Brasília: Fundação Centro de Formação do Servidor Público, 1984. v. 8. p. 172-173. "O Príncipe regente, por outro lado, tinha a assessorá-lo elementos muito suspeitos nos meios pulares. A escolha de Paulo Fernandes Viana para a Intendência de Polícia, por exemplo, mais do que por seus méritos de magistrado, ocorrera em virtude de pertencer por afinidade à célebre família Carneiro Leão, grandes comerciantes do Rio de Janeiro já no início do século XIX. Esse parentesco permitia ao intendente adiantar certas quantias necessárias ao governo para cobrir despesas, quando o Erário, estando em apuros financeiros, não era capaz de cobri-las. Também muito se falava nos meios pulares do Rio de Janeiro daquela época na situação do chanceler do Erário Régio, Francisco Bento Maria Targini, que, de modesto arrecadador de rendas no Ceará, galgou subitamente o alto posto de tesoureiro-mor do reino. Essa ascensão rápida deu origem a muitos mexericos em torno de seu nome. A razão de sua grande influência, no entanto, vinha de tropeços infligidos ao governo por aperturas financeiras, tal qual sucedia - em menor escala naturalmente - com o intendente de Polícia. Atrás do tesoureiro também havia poderoso grupo de negocistas, em mor parte ingleses, como Guilherme Young, Gustavo Kickofer e outros, que adiantavam as quantias necessárias a negócios urgentes. [...] As maiores críticas à administração brasileira, durante a época joanina, foram feitas indubitavelmente pelo cônsul francês Maler, em sua correspondência oficial. Em ofício de 13 de julho de 1818, analisando a caótica situação do Tesouro e da ação dos ministros de D. João dizia: 'Os numerosos vícios da administração parecem-me constituir os primeiros motivos da penúria; por causa de uma infinidade de abusos os rendimentos públicos escoam-se em parte dos bolsos dos que os percebem; a fraude, outrossim provocada pela elevação dos direitos aduaneiros, mais prejudica a cobrança; as despesas na realidade módicas sobem a somas consideráveis graças à improbidade dos que se acham delas encarregados; a nobreza que acompanhou o príncipe é pobre e vive do Tesouro, que a chegada da arquiduquesa, o casamento do príncipe real e a coroação de S.M. acabaram de esgotar. A simplicidade do monarca e sua família, traduzindo-se em gostos e hábitos consentâneos, não impede que sejam muito consideráveis os gastos da sua casa porque a desordem e má fé são análogas nas suas despesas particulares às que lavram nas despesas gerais do Estado'."

${ }^{258}$ BRASIL. Constituição (1824). Art. 170. “A Receita, e despeza da Fazenda Nacional será encarregada a um Tribunal, debaixo de nome de 'Thesouro Nacional' aonde em diversas Estações, devidamente estabelecidas por Lei, se regulará a sua administração, arrecadação e contabilidade, em reciproca correspondencia com as Thesourarias, e Autoridades das Provincias do Imperio."

259 BRASIL. Constituição (1824). Art. 114. "A Dotação, Alimentos, e Dotes, de que fallam os Artigos antecedentes, serão pagos pelo Thesouro Publico, entregues a um Mordomo, nomeado pelo Imperador, com quem se poderão tratar as Acções activas e passivas, concernentes aos interesses da Casa Imperial."

${ }^{260}$ BRASIL. Constituição (1824). Art. 115. "Os Palacios, e Terrenos Nacionaes, possuidos actualmente pelo Senhor D. Pedro I, ficarão sempre pertencendo a Seus Successores; e a Nação cuidará nas acquisições, e construcções, que julgar convenientes para a decencia, e recreio do Imperador, e sua Familia."

${ }^{261}$ BRASIL. Constituição (1824). Art. 37. "Tambem principiarão na Camara dos Deputados: I. O Exame da administração passada, e reforma dos abusos nella introduzidos."

262 TEMER, Michel. Elementos de direito constitucional. São Paulo: Malheiros, 2000. p. 133. A Constituição de 1824 preceituava, em seu art. 172: "O Ministro de Estado da Fazenda, havendo recebido dos outros Ministros os orçamentos relativos às despesas das suas repartições, fará na Câmara dos Deputados, anualmente, logo que esta estiver reunida, um balanço geral de todas as despesas públicas do ano futuro e da importância de todas as contribuições e rendas públicas". 
inclusive no plano das ideias, no qual se manifestava uma aversão a se falar de recursos públicos. ${ }^{263}$

Somente aos poucos as demais regras jurídicas do período colonial foram sendo substituídas. Assim, as Ordenações Manuelinas estiveram em vigência até o advento do Código Penal de 1830. O Código Penal de 1830 não utilizava ainda a nomenclatura "crimes contra a administração pública”, mas sim "crimes contra a boa Ordem, e Administração Publica" no seu Título V. Mais especificamente, as seções II, III e IV desse título tratavam, respectivamente, da peita, ${ }^{264}$ do suborno ${ }^{265}$ e da concussão. ${ }^{266}$

O mais curioso dessa época formativa é verificar algumas omissões constantes das regras proibitivas, demonstração clara da tensão citada. Por exemplo, nos crimes de peita e

${ }^{263}$ TORRES, Ricardo Lobo. Tratado de direito constitucional, financeiro e tributário. v. 5. (O orçamento na Constituição). 3. ed. atual. Até 31.12.2007, incluindo a Emenda Constitucional $\mathrm{n}^{\mathrm{o}}$ 56, de 20.12.2007. Rio de Janeiro: Renovar, 2008. p. 31-32. "O orçamento nem sempre foi visto como plano de Governo, mas serviu muitas vezes à manutenção de privilégios injustificados do clero e da burguesia, muitos dos quais dissonantes das idéias liberais. A doutrina contemporânea à Constituição do Estado Orçamentário nem sempre soube cultivar e difundir as idéias básicas sobre as finanças públicas: Cairu dissertou longamente sobre as teorias de Adam Smith e Ricardo, autores que examinaram atentamente a matéria fiscal, ma não cuidou senão incidentalmente, dos grandes temas das finanças públicas, chegando mesmo a só atribuir importância ao dinheiro no tempo excepcional da guerra e da necessidade; o seu filho, Bento da Silva traduziu para português o livro de Adam Smith sobre a 'Riqueza das Nações', mas lhe extirpou todo o livro V dedicado aos impostos e à despesa pública. Essa dificuldade em discursar sobre o dinheiro e refletir a respeito das finanças públicas, aliás, está em intimo contacto com a mentalidade cavalheiresca presente na cultura luso-brasileira: não é de bom tom falar sobre vil metal."

${ }^{264}$ BRASIL. Código Penal (1830). Art. 130. "Receber dinheiro, ou outro algum donativo; ou aceitar promessa directa, e indirectamente para praticar, ou deixar de praticar algum acto de officio contra, ou segundo a lei. Penas - de perda do emprego com inhabilidade para outro qualquer; de multa igual ao tresdobro da peita; e de prisão por tres a nove mezes. A pena de prisão não terá lugar, quando o acto, em vista do qual se recebeu, ou aceitou a peita, se não tiver effectuado. [...] Art. 132. O que der, ou prometter peita, será punido com as mesmas penas impostas ao peitado na conformidade dos artigos antecedentes, menos a de perda do emprego, quando o tiver; e todo o acto, em que intervir a peita, será nullo."

${ }^{265}$ BRASIL. Código Penal (1830). "Art. 133. Deixar-se corromper por influencia, ou peditorio de alguem, para obrar o que não dever, ou deixar de obrar o que dever. Decidir-se por dadiva, ou promessa, a eleger, ou propôr alguem para algum emprego, ainda que para elle tenha as qualidades requeridas. Penas - as mesmas estabelecidas para os casos da peita. Art. 134." Todas as disposições dos artigos cento e trinta, cento trinta e um, e cento trinta e dous, relativas aos peitados, e peitantes, se observarão a respeito dos subornados e subornadores." ${ }^{266}$ BRASIL. Código Penal (1830). Art. 135. Julgar-se-ha commettido este crime: $1^{\circ}$ Pelo empregado publico, encarregado da arrecadação, cobrança, ou administração de quaesquer rendas, ou dinheiros publicos, ou da distribuição de algum imposto, que directa, ou indirectamente exigir, ou fizer pagar aos contribuintes, o que souber não deverem. Penas - de suspensão do emprego por seis mezes a dous annos. No caso, em que o empregado publico se aproprie o que assim tiver exigido, ou o exija para esse fim. Penas - de perda do emprego; prisão por dous mezes a quatro annos, e de multa de cinco a vinte por cento do que tiver exigido, ou feito pagar. [...] $3^{\circ}$ Pelo que, tendo de fazer algum pagamento em razão do seu officio, exigir por si, ou por outrem, ou consentir que outrem exija de quem o deve receber algum premio, gratificação, desconto, ou emolumento não determinado por lei. Penas - de perda do emprego; prisão por dous mezes a quatro annos, e de multa de cinco a vinte por cento do valor exigido, que restituirá se o tiver recebido. [...] $5^{\circ}$ Pelo que, para cumprir o seu dever, exigir directa, ou indirectamente gratificação, emolumento, ou premio não determinado por lei. Penas - perda do emprego; prisão por dous mezes a quatro annos, e de multa de cinco a vinte por cento do valor exigido, que restituirá, se o tiver recebido. Art. 136. As pessoas particulares, encarregadas por arrendamento, ou por outro qualquer titulo, de cobrar, e administrar rendas, ou direitos, que commetterem algum dos crimes referidos no artigo antecedente, incorrerão nas mesmas penas, como se fossem empregados públicos." 
suborno, a condenação à prisão não seria imposta aos fatos não consumados, ou seja, a tentativa de suborno não seria reprimida. Do mesmo modo, o peculato não se referia aos bens de particulares, mas somente aos bens públicos, o que significava que o uso de um bem privado, confiado por alguma causa ao Poder Público, não caracterizaria peculato. ${ }^{267}$

A dicotomia entre as esferas pública e privada persistia, mitigada pelas regras da Constituição de 1824 no alto escalão imperial, mas latente em toda a organização da máquina burocrática. O tema está presente no debate historiográfico sobre as relações entre a sociedade e o Estado, especialmente pelo modo como as elites locais se relacionavam com o poder estatal central e como a unidade nacional foi mantida. O ponto de partida é o movimento de emancipação do Brasil via afirmação da nacionalidade brasileira.

Faoro utiliza o conceito weberiano de dominação carismática, patrimonialista e racionalista, ao caracterizar o Estado patrimonialista, sem que haja a distinção patrimônio público e privado, inclusive quanto aos cargos do aparelho estatal. Defende ter havido o aparecimento de um estamento, uma classe fechada não no sentido marxista de classe, mas no de formação comum. Já Carvalho argumenta que existiu uma verdadeira elite política dirigente do Estado com características socioculturais próprias, tais como formação universitária comum e mesma origem social. ${ }^{268}$

Segundo Faoro, apesar do discurso oficial na Constituição de 1824, não teria havido representatividade no Estado brasileiro ao longo do século XIX, pois o que existe é um Estado caracterizado pela dominação tradicional-patrimonialista, o que se reflete num profundo divórcio entre Estado e sociedade civil. Por esse motivo, os donos do poder usam o Estado como se fosse seu. O Estado imperial se autodesignasse representativo, mas ocorreria um falseamento do governo representativo, especialmente devido ao uso do Poder Moderador e às fraudes nas eleições parlamentares. ${ }^{269}$

A simples existência do Poder Moderador não permite concluir por uma centralização completa do Estado nas mãos do imperador. O debate teórico sobre o Poder

\footnotetext{
${ }^{267}$ PAGLIARO, Antonio; COSTA JÚNIOR, Paulo José. Dos crimes contra a administração pública. 4. ed. São Paulo: Atlas, 2009. p. 30. "O Código do Império e o de 1890 omitiam do dispositivo [sobre peculato] os bens particulares. O Código atual [...] não distinguiu entre bens públicos ou particulares.”

268 CARVALHO, José Murilo de. Op. cit. p. 125. FAORO, Raymundo. Op. cit. p. 379. Além de usar indiscriminadamente as designações "burocracia" e "estamento", o que seria um equívoco na tipologia de Weber, para quem a burocracia é ao modelo de Estado racional, Faoro não demonstra qual seria a fonte de legitimidade desse estamento.

${ }^{269}$ FAORO, Raymundo. Os donos do poder: formação do patronato político brasileiro. 2. ed. rev. e aum., v. 1. Porto Alegre: Globo; São Paulo: Edusp, 1975. p. 379. Tal falseamento se verificava através do Poder Moderador e das fraudes eleitorais. Era um parlamentarismo às avessas, uma vez que o Ministério dá origem à maioria parlamentar e não esta ao Ministério. O imperador usa com frequência a prerrogativa do Poder Moderador para demitir arbitrariamente todo um Ministério de maioria na Câmara.
} 
Moderador nasce na França pós-napoleônica, onde havia a necessidade de justificar o forte poder do monarca num regime representativo. O Poder Moderador seria concebido como um poder neutro que intermediaria os conflitos entre os outros poderes; logo, em tese, seria apenas uma forma de reação para tratar de um conflito. Na primeira metade do século XIX, atribuía-se, também, uma boa parcela de poderes aos reis francês e inglês, bem maiores que na atualidade. Formalmente, o imperador brasileiro tinha atribuições semelhantes às dos monarcas francês e inglês, cujas nações são tidas como berços da representatividade moderna. Todavia, o contexto social é distinto e, na prática, o monarca brasileiro age com personalismo no exercício do Poder Moderador para manipular a representação política. Aqui reside a origem de outro ponto relacionado ao comportamento dos políticos: o trato do Estado como se fosse dos governantes resultava na perspectiva pessoal que a autoridade possui em relação ao interesse público. Não se aplica a ideia de que alguém detém um poder porque possui um dever, ínsita à burocracia weberiana.

Com base na terminologia weberiana do estamento como um todo coeso e homogêneo, Faoro sustenta que, no Brasil, esse corpo caminhava para um ponto comum. Tal visão não contradiz necessariamente a ideia do que a importação gradual da dicotomia público-privado tenha sido feita por inspiração desse estamento. Carvalho apresenta o conceito de elite política "como se constituindo das pessoas que ocupavam as posições formais de poder" ${ }^{270}$ e a identifica com o núcleo de decisão política no Brasil Império:

\footnotetext{
Nos países [...] de revolução burguesa abortada, como Portugal, predominou na elite o elemento burocrático. [...] a magistratura portuguesa, o principal setor da elite [...]. No caso do Brasil, foi principalmente a herança burocrática portuguesa que forneceu a base para a manutenção da unidade e estabilidade na ex-colônia. [...] A elite brasileira, sobretudo na primeira metade do século XIX, teve treinamento em Coimbra, concentrado na formação jurídica, e tornou-se, em sua grande maioria, parte do funcionalismo público, sobretudo da magistratura e do Exército. [...] O que acontecia com a burocracia brasileira acontecia também com a elite política, mesmo porque a última em boa medida se confundia com os escalões mais altos da primeira. [...] elite política como se constituindo das pessoas que ocupavam as posições formais de poder [...]. É razoável supor que as decisões da política nacional eram tomadas pelas pessoas que ocupavam os cargos do Executivo e do Legislativo, isto é, além do imperador, os conselheiros de Estado, os ministros, os senadores, e os deputados. ${ }^{271}$
}

O primeiro elemento fundamental, tratado por Carvalho, é a gênese social dos grupos da burocracia, membros da elite política. Ao contrário de países como os Estados Unidos ou a Inglaterra, o exercício da burocracia no Brasil não era considerado como um hobby. Em

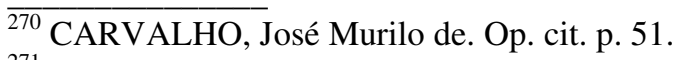

${ }^{271}$ Idem, p. 32-51.
} 
outras palavras, no Brasil, muito dos burocratas, mesmo de altos cargos, dependiam financeiramente de sua ocupação. Ao se tornar burocrata, aquele oriundo de determinado grupo social tendia, no desempenho de suas funções, devido à dependência financeira e ao processo de cooptação ideológica, a se guiar não pelos interesses de seu grupo de origem, mas pelos interesses da burocracia. Isso explicaria o distanciamento relativo entre a elite política e econômica e a forte persistência do fiscalismo na administração pública.

Ao se compararem informações como a origem social e a ocupação dos ministros em todo o período imperial, as ocupações majoritárias (magistratura e advocacia) provinham dos proprietários rurais, ${ }^{272}$ evidenciando que elites política e econômica misturavam-se. Ademais, prevalecia uma grande diversidade de interesses entre as diversas elites, mesmo entre proprietários rurais - vide o episódio da Guerra dos Farrapos.

A elite política formou-se como um grupo extremamente coeso e homogêneo por meio da educação superior, ocupação e treinamento, o que gera algumas implicações no confronto da existência dessa elite com a diversidade da elite econômica como um todo. Primeiro, a elite política congregava apenas uma pequena parcela dos grupos sociais dominantes, o que é comprovado com alguns conflitos das primeiras décadas do Império. Segundo, de acordo com Carvalho, como as decisões políticas eram efetivamente influenciadas pela elite política, esta logrou impor ao imperador e manter o modelo de Estado que convinha a burocratas e descendentes da política lusitana, a saber, um Estado centralizado, patrimonialista e fiscalista - um grupo determinado conseguiu consolidar no Brasil sua concepção de Estado devido à sua coesão e à sua homogeneidade.

É necessário compreender a consolidação da relação Estado-sociedade civil no Brasil para a análise do fenômeno do mandonismo local, conceito basilar para a formação das oligarquias que sustentariam o coronelismo que se estruturou com o fim do Império e a vitória do projeto descentralizador naquela ocasião. Em larga escala, este significava diluir a simbiose entre público e privado, cujos frutos eram antes colhidos, na sua maioria, pela elite política.

\subsubsection{Descentralização política no contexto da modernização formalista}

Com a Proclamação da República, seria de esperar uma nova onda modernizante no arcabouço jurídico-constitucional. Diversamente do Império, em que o soberano era agraciado

\footnotetext{
${ }^{272}$ Idem, p. 112.
} 
pela Constituição de 1824 com a irresponsabilidade, ${ }^{273}$ a República se caracteriza pela responsabilidade como princípio. Mesmo mitigada pelos interesses latentes que influenciam a formação do direito posto, haverá um movimento para impor alguma responsabilidade aos ocupantes dos cargos eletivos. A dificuldade das elites locais em compreender que o poder existe em decorrência de um dever legal acentuará a já dificultosa relação delas com o conceito de autoridade.

Uma das características marcantes da República Velha foi a outorga de ampla autonomia para os estados, o que permitiu às elites locais agrárias se apossar sistematicamente do Estado como não ocorrera antes. Semelhante descentralização ocorre nos estados em relação aos municípios. ${ }^{274}$ Entretanto, o apoderamento da máquina burocrática pode ser visto como uma Vitória de Pirro, pois os estados não dispunham de verbas para desenvolver suas atribuições. ${ }^{275}$ Para sua sobrevivência, acentua-se o adesismo dos entes federativos mais frágeis ao governo, ${ }^{276}$ tal como instruções do então governador de Minas Gerais João Pinheiro a um senador:

\begin{abstract}
Ah! Compreendo. Não há nenhuma dificuldade. Diga sempre que é solidário com o Governo. Tudo se reduz a obedecer. Obedeça e terá politicamente acertado. Do contrário, o Senhor sabe, estou aqui com o facão na mão, para chamar à ordem aqueles que insurgirem. A minha missão principal é essa: manobrar o facão, ou em cima, quando se trata de política federal, ou em baixo, quando da estadual. O nosso meio de orientação é esse. Portanto, olho no facão, não esqueça e faça boa viagem. ${ }^{277}$
\end{abstract}

Nesse sentido, a Constituição de 1891 regulava detalhadamente os crimes de responsabilidade cometidos por vários integrantes do Estado, incluindo o presidente da República, ${ }^{278}$ os ministros ${ }^{279}$ e os magistrados. ${ }^{280} \mathrm{O}$ art. 54 definia como crime de

\footnotetext{
$\overline{273}$ BRASIL. Constituição (1824). Art. 99. “A Pessoa do Imperador é inviolavel, e Sagrada: Elle não está sujeito a responsabilidade alguma."

274 CARONE, Edgar. A República Nova (1930-1937). São Paulo: Difusão Europeia do Livro, 1970. p. 253.

${ }^{275}$ Idem, p. 249-250. “[...] o desequilíbrio financeiro decorrente do fato de grande parte das rendas arrecadadas destinarem-se ao governo federal; o resultado é a contínua falta de verbas. As reclamações provinciais são constantes e gerais, porque elas vêem sair para a união um numerário cada vez maior, dele recebendo somente uma diminuta parcela."

${ }^{276}$ Idem, p. 253. "Porém, só se conseguem favores quando se é partidário do governo, daí o interesse em ser situacionista: numa época em que as oportunidades de emprego e rendas são limitadas, o Estado é uma das poucas fontes de privilégio. Por sua vez, a oposição sempre procura aproximar-se do governo, beneficiar-se da situação e tornar-se situacionista, só não o fazendo quando circunstâncias particulares não o permitem: esta é uma das razões da grande fraqueza da oposição no Brasil, já que não existe, em geral, motivação ideológica nas suas atitudes."

${ }^{277}$ FAORO, Raymundo. Os donos do poder: formação do patronato político brasileiro. Vol II. 2. ed. rev. e aum. Porto Alegre: Globo; São Paulo: Edusp, 1975. p. 629.

278 BRASIL. Constituição (1891). "Art 53. O Presidente dos Estados Unidos do Brasil será submetido a processo e a julgamento, depois que a Câmara declarar procedente a acusação, perante o Supremo Tribunal Federal, nos crimes comuns, e nos de responsabilidade perante o Senado."
} 
responsabilidade, entre outros, os cometidos contra a "probidade da administração", "a guarda e emprego constitucional dos dinheiros públicos" e "as leis orçamentárias votadas pelo Congresso". ${ }^{281}$ Logo após, foi aprovado Decreto $\mathrm{n}^{\mathrm{o}}$ 27/1892, que regulamentava esses crimes. $^{282}$

Ao mesmo tempo em que o direito posto atendia aos princípios básicos da dicotomia público-privado, a consolidação do modelo coronelista-oligárquico trouxe o ápice do mandonismo local nas primeiras duas décadas do século XX. A descentralização da federação resultou da maneira como os detentores do poder concebiam a autoridade pública - o direito até poderia atribuir funções à autoridade investida de poder, mas esta as ignora e age de acordo com seus objetivos privados.

A origem do termo "coronel" e da própria estrutura coronelista remontam ao Período Regencial, quando foram criadas as patentes da Guarda Nacional, ocupadas mediante cessão ou pagamento pelos membros das elites locais. ${ }^{283} \mathrm{Na}$ realidade, o conceito é a exorbitação do poder privado. ${ }^{284}$ Socialmente, o coronel cria em torno de si uma extensa rede de atuação e influência, dispensando-lhe favores e empregos públicos. ${ }^{285}$

Enquanto no regime anterior ao Código de 1890 a concussão se referia a toda e qualquer extorsão praticada por uma autoridade, a mudança efetuada restringiu a conduta apenas àquela praticada por funcionários encarregados da arrecadação das receitas do Estado, ao que se adicionava a ausência de repressão criminal para a advocacia administrativa ${ }^{286}$ - tal combinação favorecia o uso da máquina burocrática pelo coronel para atender aos seus fins privados.

\footnotetext{
${ }^{279}$ BRASIL. Constituição (1891). “Art 52. Os Ministros de Estado não serão responsáveis perante o Congresso, ou perante os Tribunais, pelos conselhos dados ao Presidente da República. $\S 1^{\mathrm{o}}$ - Respondem, porém, quanto aos seus atos, pelos crimes em lei. $\S 2^{\circ}-$ Nos crimes, comuns e de responsabilidade serão processados e julgados pelo Supremo Tribunal Federal, e, nos conexos com os do Presidente da República, pela autoridade competente para o julgamento deste."

${ }^{280}$ BRASIL. Constituição (1891). Art 57, § 2. "O Senado julgará os membros do Supremo Tribunal Federal nos crimes de responsabilidade, e este os Juízes federais inferiores."

${ }^{281}$ BRASIL. Constituição (1891). "Art 54 - São crimes de responsabilidade os atos do Presidente que atentarem contra: $1^{\circ}$ ) a existência política da União; $2^{\circ}$ ) a Constituição e a forma do Governo federal; $3^{\circ}$ ) o livre exercício dos Poderes políticos; $4^{\circ}$ ) o gozo, e exercício legal dos direitos políticos ou individuais; $5^{\circ}$ ) a segurança interna do Pais; $6^{\circ}$ ) a probidade da administração; $7^{\circ}$ ) a guarda e emprego constitucional dos dinheiros públicos; $8^{\circ}$ ) as leis orçamentárias votadas pelo Congresso. $\S 1^{\circ}$ - Esses delitos serão definidos em lei especial. $\S 2^{\circ}-$ Outra lei regulará a acusação, o processo e o julgamento. $\S 3^{\circ}$ - Ambas essas leis serão feitas na primeira sessão do Primeiro Congresso."

${ }^{282}$ BRASIL. Decreto no 27 , de 7 jan. 1892.

${ }^{283}$ CARONE, Edgar. Op. cit. p. 251.

${ }^{284}$ LEAL, Victor Nunes. Coronelismo, enxada e voto: o município e o regime representativo no Brasil. São Paulo: Alfa-Ômega, 1976. p. 8.

${ }^{285}$ Aqui, referência expressa à íntima relação entre coronelismo e patrimonialismo.

286 HUNGRIA, Nélson. Comentários ao Código Penal (Dec.-Lei nํ 2.848, de 7 de dezembro de 1940). v. 9, Art. 250 a 361. 2. ed. Rio de Janeiro: Forense, 1959. p. 359 e 182.
} 
O poder do coronel se origina não só da rede de influência que o circunda, tampouco exclusivamente de um carisma pessoal diferenciado. Os favores oferecidos a seus agregados são fundamentais para a manutenção dessa rede e caracterizam sua atuação corrompida perante o Poder Público, que por seu turno alimenta sua rede de influência.

O voto de cabresto funciona como instrumento para a manutenção do status quo do coronel, que manipula seu curral eleitoral para a eleição do candidato de sua preferência, capaz de garantir a rede de influência. ${ }^{287}$ Nas palavras de Leal,

\begin{abstract}
[...] concebemos o "coronelismo" como resultado da superposição de formas desenvolvidas do regime representativo a uma estrutura econômica e social inadequada. Não é, pois, mera sobrevivência do poder privado, ou seja, uma adaptação em virtude da qual os resíduos do nosso antigo e exorbitante poder privado têm conseguido coexistir com um regime político de extensa base representativa.

Por isso mesmo, o "coronelismo" é sobretudo um compromisso, uma troca de proveitos entre o poder público, progressivamente fortalecido, e a decadente influência social dos chefes locais, notadamente dos senhores de terras. Não é possível, pois, compreender o fenômeno sem referência à nossa estrutura agrária, que fornece a base de sustentação das manifestações de poder privado ainda tão visíveis no interior do Brasil.

Paradoxalmente, entretanto, esses remanescentes de privatismo são alimentados pelo poder público, e isto se explica justamente em função do regime representativo, com sufrágio amplo, pois o governo não pode prescindir do eleitorado rural, cuja situação de dependência ainda é incontestável. ${ }^{288}$
\end{abstract}

Uma das formas mais diretas pela qual o Poder Público se relaciona com o coronelismo é uso privado da força policial. Não se pense que o coronel dispunha apenas de seus capangas, pagos com recursos próprios. Pelo contrário, em algumas regiões, quando se sente contestado, o coronel utiliza a força armada que se forma em torno de si. Foram muito comuns momentos de embate entre grupos ligados a diferentes coronéis e o pouco estruturado governo central assistia resignado ao embate para, então, apoiar o grupo vencedor. ${ }^{289}$

Havia uma distinção nas estruturas patrimonialistas de estados mais desenvolvidos em relação aos menos desenvolvidos já no início do século XX. Nos estados mais avançados, os conflitos entre diferentes grupos se atenuavam devido atuação à mais presente partidária, cuja estrutura agregava mais grupos e suavizava as divergências. ${ }^{290}$

Os anos 1920 trouxeram os primeiros sinais de desgaste desse modelo descentralizado, e contestações como as feitas pelos tenentistas se proliferavam. Em São Paulo, já desde 1905 buscava-se a modernização da máquina estatal, com a criação da polícia

\footnotetext{
$\overline{287}$ CARONE, Edgar. Op. cit. p. 253.

${ }^{288}$ LEAL, Victor Nunes. Op. cit. p. 20.

${ }^{289}$ CARONE, Edgar. Op. cit. p. 255.

${ }^{290}$ Idem, p. 264.
} 
de carreira, para que o cargo fosse ocupado por bacharéis em direito, profissionalizando a administração - como era de esperar, a medida encontrou forte resistência dos chefes locais, mas logrou ser implementada. ${ }^{291}$

Após 1947, o mesmo movimento acontece em Minas Gerais, com o gradual afastamento da polícia das atividades político-partidárias. ${ }^{292}$ Carone explica a mudança argumentando que

[...] as únicas medidas executadas pelos Estados são fruto de interesses particulares de governantes, ou de pressão da coletividade. Na verdade, é a contradição entre tendência centralizadora (governativa) e expansão urbana de um lado, e a política regional de outro, que vai, a longo prazo, significar o declínio deste regime. ${ }^{293}$

\subsubsection{O acobertamento dos interesses privados no Estado patrimonialista no pós-1930}

Ao menos na superfície, coube à era Vargas atacar frontalmente o coronelismo. Boa parte da inspiração político-ideológica para a Revolução de 1930 provinha de uma particular leitura sobre a realidade nacional: as oligarquias locais eram o fator de atraso que tendia à desagregação do país. Em 1930, Oliveira Vianna publica sua obra Problemas de política objetiva, na qual é exposto esse pensamento em três presunções:

Primeira presunção: - Nossa Constituição presume, por exemplo, difundida de alto a baixo do povo, uma consciência nacional forte, viva, preponderante. Do contrário a descentralização federativa teria sido um crime de lesa-pátria...

Segunda Presunção: - Nossa Constituição presume em todos os brasileiros homens de campo, homens da cidade, homens do sul, homens do norte - e jacente no íntimo do caráter de cada um, com a força de um instinto, o sentimento profundo e enérgico dos interesses públicos do Município, do Estado e da Nação. Do contrário, as diversas autonomias estaduais e municipais não teriam justificação possível...

Terceira presunção: - Nossa Constituição presume grandes correntes de idéias, circulando e dominando, de uma maneira contínua, a consciência e a vida de toda nação. Do contrário, não se explicariam ainda o regime descentralizado, nem também a periodicidade limitadíssima dos mandatos presidenciais, à maneira americana. $^{294}$

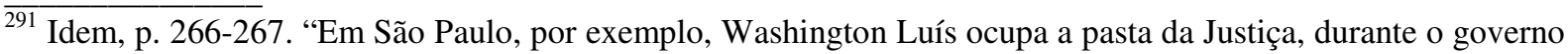
de Jorge Tibiriçá, e executa medida já preconizada por seu antecessor. Em 1905, põe em execução uma nova lei criando a polícia de carreira. Até o momento, os policiais remunerados e nomeados pelo Estado eram o chefe de Polícia, dois delegados auxiliares, cinco delegados da capital e dois de Santos e Campinas; todos outros tinham atribuições honoríficas, isto é, eram impostos pelos coronéis locais. A nova lei exige que o cargo seja ocupado por formados em Direito. Esta medida encontra oposição, mas o governo consegue aplicá-la, o que enfraquece as lideranças políticas locais, que não poderão usar este poder de coerção com tanta liberdade como até então. Em 1924, o governador Góes Calmon, da Bahia, tenta medida semelhante, mas com outra terapêutica: anula 100 promoções ilegais da polícia, feitas de última hora pelo governo anterior, e extingue delegacias regionais entregues a chefes políticos do interior."

${ }^{292}$ LEAL, Victor Nunes. Op. cit. p. 198.

${ }^{293}$ CARONE, Edgar. Op. cit. p. 266.

${ }^{294}$ VIANNA, Francisco José de Oliveira. Problemas de política objetiva. Rio de Janeiro: Nacional, 1930. p. 30.
} 
Embora não tenha sido o único a ter desenvolvido essas ideias, Oliveira Vianna certamente influenciou os tenentistas que desejavam reformar o Estado com base num projeto autoritário. ${ }^{295}$

No bojo do processo de centralização do pós-1930, uma de suas principais ações seria a promoção do desarmamento dos coronéis, além de ações contra o cangaço no Nordeste - muitos dos cangaceiros eram protegidos pelos coronéis para servir como soldados. ${ }^{296}$

Na década de 1930, houve o primeiro movimento concreto de profissionalização da burocracia, objetivando abandonar a lógica clientelista - até então, somente os juízes dispunham de uma carreira dotada de garantias formais mínimas para o exercício das funções dentro do espírito de dominação racional weberiano. No âmbito da proposta autoritária de fortalecimento do Estado, negando o caos descentralizador começado em 1889, era imprescindível a reestruturação da máquina administrativa.

O Estado Novo pretendeu se erigir numa iniciativa para destruir a lógica do mandonismo local, expurgando os princípios federativos, fonte do poder das elites regionais. Expande-se a máquina estatal, pautando-se em tese pelo modelo weberiano de burocracia. ${ }^{297} \mathrm{E}$ um momento de grande expansão e consolidação do direito administrativo.

Um dos pontos da ruptura foi o Decreto-lei $n^{0} 579 / 38$, que institui o Departamento Administrativo do Serviço Público (Dasp), responsável pela nova organização administrativa, 298 "cuja meta declarada era a superação do patrimonialismo herdado do Estado Colonial brasileiro e mantido no período imperial". ${ }^{299}$

A ênfase do Dasp na gestão eficiente do serviço público, que culminou com a regulamentação do recrutamento no serviço público e com o Estatuto dos Funcionários Públicos Civis em 1939, o qual exigia a aprovação em concurso para provimento em cargo público $^{300}$ e arrolava, quase que didaticamente, uma série de condutas privadas incompatíveis com o exercício de cargo destinado a zelar pelo interesse público. ${ }^{301}$

\footnotetext{
${ }^{295}$ WEFFORT, Francisco. Formação do pensamento político brasileiro: idéias e personagens. São Paulo: Ática, 2006. p. 249-253 e 269-271.

${ }^{296}$ CARONE, Edgar. Op. cit. p. 266-267.

${ }^{297}$ REZENDE, Flávio da Cunha. Por que falham as reformas administrativas?. São Paulo: FGV, 2004. p. 46.

${ }^{298}$ BRASIL. Decreto-lei no 579 , de 30 jul. 1938.

${ }^{299}$ BUCCI, Maria Paula D. Direito administrativo e políticas públicas. São Paulo: Saraiva, 2002. p. 109.

300 BRASIL. Decreto-lei no 1.713 , de 28 out. 1939. Art. 13. "Só poderá ser provido em cargo público quem satisfizer os seguintes requisitos: VIII. Ter-se habilitado previamente em concurso, salvo quando se tratar de cargos para os quais não haja essa exigência."

${ }^{301}$ BRASIL. Decreto-lei no 1.713 , de 28 out. 1939. Art. 226. "É ainda proibido ao funcionário: I. Fazer contratos de natureza comercial ou industrial com o governo, por si ou como representante de outrem; II. Exercer funções
} 
O desafio dessa modernização formal é descrito por Holanda:

Não era fácil aos detentores das posições públicas de responsabilidade, formados por
tal ambiente, compreenderem a distinção fundamental entre os domínios do privado
e do público. Assim, eles se caracterizam justamente pelo que separa o funcionário
"patrimonial" do puro burocrata conforme a definição de Max Weber. Para o
funcionário "patrimonial", a própria gestão política apresenta-se como assunto de
interesse particular: as funções, os empregos e os benefícios que deles aufere
relacionam-se a direitos pessoais dos funcionários e não a interesses objetivos, como
sucede no verdadeiro Estado burocrático, em que prevalecem a especialização das
funções e o esforço para se assegurarem garantias jurídicas aos cidadãos. A escolha
dos homens que irão exercer funções públicas faz-se de acordo com a confiança
pessoal que mereçam os candidatos, e muito menos de acordo com as suas
capacidades próprias. Falta a tudo a ordenação impessoal que caracteriza a vida no
Estado burocrático. O funcionalismo patrimonial pode, com a progressiva divisão
das funções e com a racionalização, adquirir traços burocráticos. Mas em sua
essência ele é tanto mais diferente do burocrático, quanto mais caracterizados
estejam os dois tipos.

Contudo, o sistema ainda apresentava pontos frágeis: os concursados adquiriam estabilidade após dois anos na função, ao passo que os não concursados, em dez anos. ${ }^{303} \mathrm{Em}$ consonância com a tendência centralizadora, baseada na busca da eficiência administrativa, o controle do Dasp sobre a burocracia enfrentou também grande resistência - de fato, os mecanismos de controle do Dasp foram desarticulados por ocasião da reabertura democrática em 1945. ${ }^{304}$ Retrocesso similar pode ser identificado com o retrocesso na polícia mineira, que na mesma época tinha passado por processo de modernização. ${ }^{305}$ Mesmo assim, o movimento de modernização afasta o Estado um pouco da dominação tradicional, e "a eficiência da burocracia não está em contradição com aqueles elementos patrimoniais" da origem da formação do Estado brasileiro. ${ }^{306}$

de direção ou gerência de empresas bancárias ou industriais, ou de sociedades comerciais, subvencionadas ou não pelo Governo; [...] IV. Exercer, mesmo fora das horas de trabalho, emprego ou função em empresas, estabelecimentos ou instituições que tenham, ou possam ter, relações com o Governo, em matéria que se relacione com a finalidade da repartição ou serviço em que esteja lotado; [...] VI. Comerciar, ou ter parte em sociedades comerciais, exceto como acionista, quotista ou comanditário, não podendo, em qualquer caso, ter funções de direção ou gerência: [...] IX. Constituir-se procurador de partes ou servir de intermediário perante qualquer repartição pública, exceto quando se tratar de interesses de parente até o segundo grau; X. Receber estipêndios de firmas fornecedoras ou de entidades fiscalizadas, no país ou no estrangeiro, mesmo quando estiver em missão referente à compra de material ou fiscalização de qualquer natureza; XI. Valer-se de sua qualidade de funcionário para melhor desempenhar atividade estranha às funções ou para lograr qualquer projeto, direta ou indiretamente, por si ou interposta pessoa."

302 HOLANDA, Sérgio Buarque de. Op. cit. p. 145-146.

${ }^{303}$ BRASIL. Decreto-lei no 1.713 , de 28 out. 1939. Art. 191.

${ }^{304}$ REZENDE, Flávio da Cunha. Op. cit. p. 49.

${ }^{305}$ LEAL, Victor Nunes. Op. cit. p. 198.

306 DOMINGUES, José Maurício. Patrimonialismo e neopatrimonialismo. In: AVRITZER, Leonardo et al. (Org.). Op. cit. p. 189. 
A reforma implementada pelo Dasp não se mostrou completamente eficaz quanto à importação de um modelo racional de burocracia, o que fez Holanda afirmar que somente em raros momentos houve profissionalismo na administração pública. ${ }^{307}$ Fez-se uma reforma dual, de modo que alguns setores se mantinham abertos ao clientelismo e negociação de cargos, enquanto outros funcionavam segundo critérios meritocráticos. ${ }^{308}$ Pereira aponta aspectos positivos e negativos da reforma empreendida pelo Dasp. ${ }^{309}$ Seus principais pontos positivos se referem às novas tendências de modernização da administração, bem como a renovação nos padrões de recrutamento do funcionalismo público, tentando deixar de lado as práticas patrimonialistas de clientelismo.

Data do Estado Novo o acirramento do fiscalismo, outra característica histórica do patrimonialismo no Brasil. Para fazer frente às crescentes despesas públicas decorrentes do intervencionismo, a ação arrecadadora se torna truculenta sobre o espaço privado. $\mathrm{O}$ patrimonialismo não se transforma em intervenção estatal como pretende Souza, ${ }^{310}$ mas sim se metamorfoseia, por exemplo, no corporativismo de parcelas do funcionalismo público ou, no pós-1945, no jogo político pelos recursos da União. Ao mesmo tempo em que o Estado começa a prestar serviços para a sociedade, as características de sua apropriação pelos interesses privados submergem sob a profissionalização incompleta da burocracia, os desequilíbrios do federalismo e as distorções do sistema representativo. O fiscalismo substitui gradativamente o uso da força física no controle da sociedade pelo Estado - os políticos e alguns setores da sociedade continuam a enxergar o Estado como algo seu, mas de modo distinto do passado analisado por Faoro: o que interessa no aparato estatal não são mais as grandes propriedades detidas no período colonial, mas sim os recursos necessários para, entre outras finalidades, a manutenção das relações sociais estabelecidas pelos novos donos do poder.

O período pós-1945 assistiu

\footnotetext{
${ }^{307}$ HOLANDA, Sérgio Buarque de. Op. cit. p. 145-156. "No Brasil, pode dizer-se que só excepcionalmente tivemos um sistema administrativo e um corpo de funcionários puramente dedicados aos interesses objetivos e fundados nesses interesses. E um dos efeitos decisivos da supremacia incontestável, absorvente, do núcleo familiar - a esfera, por excelência dos chamados contatos primários, dos laços de sangue e de coração - está em que as relações que se criam na vida doméstica sempre forneceram o modelo obrigatório de qualquer composição social entre nós. Isso ocorre mesmo onde as institucionais democráticas, fundadas em princípios neutros e abstratos, pretendem assentar a sociedade em normas antiparticularistas."

${ }^{308}$ REZENDE, Flávio da Cunha. Op. cit. p. 50.

309 BRESSER-PEREIRA, Luiz Carlos. Prefácio. In: NUNES, Edson de Oliveira. Gramática política do Brasil: clientelismo e insulamento. Rio de Janeiro: Zahar, 1997. p. 1.

${ }^{310}$ SOUZA, Jessé. Weber. In: AVRITZER, Leonardo et al. (Org.). Op. cit. p. 84. "[...] no âmbito de suas generalizações sociológicas, o patrimonialismo acaba se transformando, de forma implícita, em um equivalente funcional para a intervenção estatal."
} 
[...] a progressiva redução do significado da antiga estrutura agrária na estrutura global do país, que foi sendo transformada pelos processos de urbanização e industrialização. No entanto, coexistiram no sistema global duas culturas políticas: a do Brasil desenvolvido (Sudeste), que incluía os Estados do Rio de Janeiro, a antiga Guanabara, São Paulo, Paraná, Santa Catarina e Rio Grande do Sul; e a do Brasil subdesenvolvido, que abrangia o resto do país. Esta coexistência se reflete na origem e no crescimento do regime partidário. Os partidos mais conservadores - PSD, UDN, PR - obtiveram desde 1945 uma porcentagem claramente menor do total dos deputados federais, no Sudeste, onde aumentaram a sua força eleitoral de 1945 a $1962 .{ }^{311312}$

Tratou-se de importante período para a evolução da importação do modelo de separação entre as esferas pública e privada.

A urbanização e a industrialização começaram a tornar menos aceitáveis práticas de confusão explícita entre a esfera pública e a privada, inclusive nas regiões menos desenvolvidas. Por isso, durante a República populista, articula-se novo modus operandi que conciliava a tradição patrimonialista e a modernização decorrente da importação da dicotomia público privado - ao lado do Poder Moderador exercido episodicamente pelas Forças Armadas, o voto assumiria crescente relevância no novo contexto. ${ }^{313}$ A princípio, o voto de cabresto desempenhou papel central, mas, aos poucos, o processo de adesismo social o substituiu para parcela da população, desejosa de usufruir as benesses do Estado de modo mais igual que os outros.

$\mathrm{Na}$ evolução da importação do modelo de separação entre as esferas pública e privada, a República populista assistiu ao aperfeiçoamento do aparato repressivo aos desvios no direito político-constitucional, penal e civil-administrativo.

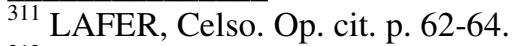

312 Idem, ibidem. Data venia, o automatismo dessa divisão do país não parece adequado, uma vez que há inúmeras peculiaridades a considerar. Além das recentes mudanças verificadas na região Centro-Oeste, uma das exceções notáveis a esse automatismo na divisão do país é o estado de Pernambuco. Vide SCHNEIDER, Aaron. Conflito político e instituições orçamentárias: aprofundando a democracia no Brasil. Revista de Sociologia Política, Curitiba, n. 24, p. 96, jun. 2005. "Em contraste, o rico Rio Grande do Sul era notavelmente semelhante a Pernambuco, seu primo distante no Nordeste. Em Pernambuco, o que começou com uma divisão histórica entre o interior e o litoral evoluiu para uma divisão entre esquerda e direita, produzindo um sistema de partidos fragmentado, polarizado e volátil. Essas dificuldades obrigaram os chefes do poder Executivo a agregar práticas democráticas às instituições orçamentárias e essas aberturas criaram espaço para que múltiplas demandas fossem apresentadas. Políticos de tendências variadas ocuparam o palácio do governo, mas o resultado geral foi uma política fiscal descontrolada que tornou impossível a dependência do mercado. Embora não chegando ao extremo verificado no Rio Grande do Sul, Pernambuco era decididamente democrático em seu processo orçamentário e governava o mercado em sua política fiscal."

${ }^{313}$ LAFER, Celso. Op. cit. p. 64. "A ampliação da participação política e a coexistência de duas culturas políticas - a do Brasil desenvolvido e a do Brasil subdesenvolvido - exigiram do sistema uma política que conciliasse diversos interesses num pacto de dominação que fosse viável. Este pacto teve duas moedas em circulação: (a) o voto, que no esquema da República Populista outorgava legitimidade ao sistema; (b) a coerção organizada (poder militar), que podia ser - e foi - utilizada em algumas intervenções militares num padrão que Stepan, entre outros, qualifica de moderador."
} 
A repressão penal remonta aos tempos do Império, ainda que de modo imperfeito e fragmentário. O Código Penal de 1940 suprira a maioria das omissões existentes, mas o aspecto civil-administrativo ainda era deficiente. Embora esse Código Penal já dispusesse sobre o dever de indenizar decorrente de sentença penal condenatória, ${ }^{314}$ o regramento de direito administrativo era insuficiente e carecedor de dissuasão: vigorava o princípio geral de direito segundo qual que o causador de um dano deveria indenizá-lo. Pela sistemática vigente, nem sequer ficava claro a quem incumbia buscar o ressarcimento. Embora houvesse alguns antecedentes da ação popular na Constituição de 1824 e na de $1934,{ }^{315}$ somente a partir da Constituição de 1946 esse mecanismo processual se firma como forma de proteção ao patrimônio público.

Um ponto constante da repressão à corrupção no Brasil, remontando ao período colonial, dizia respeito ao perdimento de bens em virtude de enriquecimento ilícito do ocupante de cargo público. O Decreto-lei nº 3240/41 segue essa tradição ao regulamentar o sequestro e a perda de bens resultantes de crimes contra a Fazenda Pública, medida que poderia inclusive atingir terceiros beneficiados. Além de repetir regras similares às constantes nas constituições anteriores sobre a perda de cargos por crime de responsabilidade, o art. 141 da Constituição de 1946 reforçava as regras do Decreto-lei n⿳ 3240/41, ao estabelecer que deveria ser editada lei que regulamentasse o sequestro e perdimento de bens na hipótese de enriquecimento ilícito, decorrente do exercício de função pública - trata-se de mais uma instituição de tutela extrapenal, reforçando determinações similares infraconstitucionais. Mais tarde, quando a Lei $\mathrm{n}^{\mathrm{o}} 3.164 / 57$ foi aprovada, regulamentando o referido art. 141, seu art. $2^{\circ}$ estabelecia a independência entre as esferas criminal e civil, de modo que a extinção da ação penal ou a absolvição no juízo criminal não impedia a perda dos bem adquiridos ilegitimamente. ${ }^{316}$ Ademais, o art. $3^{\circ}$ exigia o arrolamento dos bens pertencentes ao patrimônio daqueles que exercessem função pública, de modo que a falsa declaração poderia acarretar na demissão do agente.

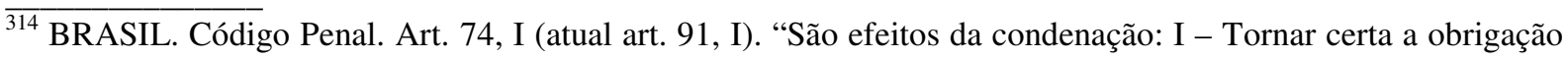
de indenizar o dano resultante do crime."

315 BRASIL. Constituição (1824). Art. 157. "Por suborno, peita, peculato, e concussão haverá contra elles acção popular, que poderá ser intentada dentro de anno, e dia pelo proprio queixoso, ou por qualquer do Povo, guardada a ordem do Processo estabelecida na Lei.” BRASIL. Constituição (1934). Art. 113, inc. XXXVIII: "Qualquer cidadão será parte legítima para pleitear a declaração de nulidade ou a anulação dos atos lesivos do patrimônio da União, dos Estados ou dos Municípios".

${ }^{316}$ BRASIL. Lei no 3.164 , de 1 jun. 1957. Art. $2^{\circ}$. "A extinção da ação penal ou a absolvição do réu incurso nos crimes capitulados no Título XI da Parte Especial do Código Penal ou em outros crimes funcionais, de que resulte locupletamento ilícito, não excluirá a incorporação à Fazenda Pública dos bens de aquisição ilegítima, ressalvado o direito de terceiros de boa- fé."
} 
A política econômica protecionista e fomentadora do desenvolvimento industrial também propiciou fértil terreno para práticas corruptas. Esse tipo de política gera incentivos para que funcionários oportunistas negociem licenças de importação, beneficiando-se financeiramente - conforme explica Mauro, "em termos mais gerais, a proteção da indústria doméstica contra a concorrência internacional gera rendas improdutivas que podem ser bem recebidas por empreendedores locais, pagas na forma de subornos". ${ }^{317}$ No Brasil, as críticas sobre corrupção na política industrial se voltavam principalmente contra o sistema de múltiplas taxas de câmbio e esquemas de alocação cambial, ${ }^{318}$ estratégia adotada nos anos 1950 para fomentar o desenvolvimento industrial e desestimular a importação de bens de consumo. ${ }^{319}$ De modo pioneiro, na mídia, Lacerda chamava a atenção da opinião pública para vários escândalos, tais as negociatas do sistema de múltiplas taxas de câmbio - atribui-se até mesmo o suicídio de Vargas às críticas recebidas. ${ }^{320}$

Aliás, esse é o momento em que a mídia começa a desempenhar um papel significativo na condução das medidas de combate à corrupção, inclusive na própria política. ${ }^{321} \mathrm{Se}$, por um lado, a ampla divulgação de atitudes que confundem o público e o privado e subvertem a confiança depositada nas autoridades ajuda na depuração democrática via eleições, por outro, "a apresentação deformada ou escandalosa das imagens de criminalidade pelos meios de comunicação" pode levar ao "alarme social”. O Legislativo

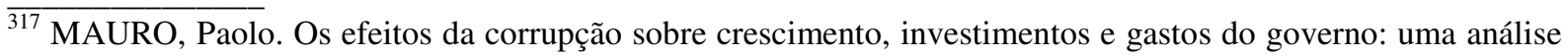
de países representativos. In: ELLIOT, Kimberly Ann (Org.). A corrupção e a economia global. Tradução de Marsel Nascimento Gonçalves de Souza. Brasília: UnB, 2002. p. 138.

318 Ibidem. A literatura especializada também reconhece dificuldades para o esquema adotado no Brasil. "Sistemas de múltiplas taxas de câmbio e esquemas de alocação cambial (cuja importância pode ser substituída por ágios do mercado de câmbio paralelo, como os ágios usados por Levine e Renelt), produzem rendas improdutivas. Por exemplo, suponhamos que, em um dado país, os gerentes de bancos comerciais estatais fazem o câmbio de acordo com prioridades determinadas por eles próprios, o que pode levar os empreendedores do país a concordar em subornar os gerentes para obter câmbio necessário à aquisição de insumos importados." ROSEACKERMAN, Susan. A economia política da corrupção. In: ELLIOT, Kimberly Ann (Org.). A corrupção e a economia global. Tradução de Marsel Nascimento Gonçalves de Souza. Brasília: UnB, 2002. p. 62. "Do mesmo modo, taxas de câmbio múltiplas geralmente não refletem os fundamentos econômicos subjacentes, o que produz incentivos ao pagamento de propinas para obtenção, com boas taxas, de divisas estrangeiras escassas. Por exemplo: um memorando econômico do Banco Mundial, sobre o Paraguai, ressalta que, na década de 1980, o sistema de taxas de câmbio múltiplas desse país causava corrupção (Banco mundial, 1994)."

${ }^{319}$ FURTADO, Celso. Formação econômica do Brasil. 24. ed. São Paulo: Nacional, 1991. p. 222.

${ }^{320}$ Mesmo depois da morte de Vargas, Lacerda continuou a atacá-lo. Em 1957, leu no plenário da Câmara dos Deputados a decifração do telegrama $\mathrm{n}^{\mathrm{o}} 295$, que se referia a um inquérito do exército argentino a respeito de uma transação comercial entre o Brasil e a Argentina com parte do pagamento destinado ao financiamento da campanha de Vargas. Ao ler o telegrama, Lacerda foi acusado do crime de espionagem, uma vez que o documento se encontrava em código secreto do Itamaraty. Ver HUNGRIA, Nélson. Op. cit. p. 403.

${ }^{321}$ LIVIANU, Roberto. Corrupção e direito penal: um diagnóstico da corrupção no Brasil. Coimbra: Coimbra Editora, 2007. p. 170. "O papel das empresas de difusão de informação passa a ser relevante, à medida que possibilita o êxito dos profissionais jornalísticos e pode influir na quebra do monopólio do poder, passando a ser os verdadeiros conselheiros políticos, como relata Beyme, interferindo nos rumos dos partidos políticos e até dos funcionários ministeriais."
} 
pode reagir rapidamente e aprovar "legislação simbólica ou mesmo uma intervenção violenta, sem a observância dos direitos fundamentais do Estado Democrático de Direito". ${ }^{322}$

Exemplo dessa reação ao noticiado "mar de lama" dos anos 1950, a Lei no $3.502 / 58^{323}$ ampliou subjetiva e objetivamente o conceito de improbidade administrativa, que poderia levar ao sequestro e perdimento de bens do agente público. Em seu art. $1^{\circ}$, o rol de sujeitos ativos da improbidade engloba aqueles que atuam em entes da administração indireta ou entidade que receba ou aplique contribuições parafiscais. Ademais, amplia a noção de improbidade para todos e quaisquer atos que decorram de abuso de poder ou influência do cargo público. De acordo com Bernardi, a honestidade administrativa foi elevada ao rol dos bens jurídicos tutelados pelo ordenamento. ${ }^{324}$ Uma vez mais, firma-se no direito posto o princípio geral de direito que afirma decorrer o poder de uma atribuição legal e que o poder só deve ser exercido para esse fim.

O período 1945-1964 caracterizou-se por acelerado crescimento econômico e elevados investimentos estatais em obras públicas, ambiente em que a contratação de empreiteiras sempre esteve cercada de suspeitas. A construção de Brasília em si está envolta numa série de críticas sobre as irregularidades na sua execução: custos superfaturados, fraudes a licitações e outros tipos de manobras perniciosas para o patrimônio e interesse público tomaram corpo maior devido ao vulto dos investimentos. No bojo da desarticulação do voto de cabresto, o crescente custo para se eleger fecha o círculo obras superfaturadas financiamento das campanhas eleitorais. No ambiente de crescente escamoteamento do Estado patrimonialista, o adesismo social a tais práticas começa a se manifestar na popularização de bordões do tipo "rouba, mas faz", associado a Ademar de Barros. ${ }^{325}$ Não é à toa que datam dessa época as primeiras campanhas moralistas de combate à corrupção: a feita por Jânio Quadros para sua eleição à Presidência da República em 1960 teve como mascote uma vassoura para varrer a corrupção do país. ${ }^{326}$

\footnotetext{
322 Idem, ibidem.

${ }^{323}$ BRASIL. Lei n⿳⺈ 3.502, de 21 dez. 1958.

324 BERNARDI, Ovídio. Ação de enriquecimento ilícito e ação popular. Revista dos Tribunais, São Paulo, n. 314, p. 30-36, dez. 1961.

325 MOTTA, Rodrigo Patto Sá. Corrupção no Brasil República: 1954-1964. In: AVRITZER, Leonardo et al. (Org.). Op. cit. p. 245.

326 QUADROS NETO, Jânio; GUALAZZI, Eduardo Lobo Botelho. Jânio Quadros: memorial à história do Brasil. São Paulo: Rideel, 1996. p. 124. Vide trecho do discurso de posse de Jânio Quadros na Presidência da Republica em 31 de janeiro de 1961. "Derrogarei até o extremo limite das minhas forças a contrafação do sistema político-administrativo que infelicitou a Pátria em alternância de ações irresponsáveis e de omissões inconscientes. No combate a essa adulteração, a essa corrupção que infecciona e debilita o regime, não darei quartel. A vassoura, que o povo me confiou nas assembléias, trago-a comigo para os serviços empreitados. Usála-ei em consonância com o que prometi e com o que me reclamam, mas em caráter da ais estrita impessoalidade."
} 


\title{
3.4.4 Aperfeiçoamento normativo e incentivo estatal à formação do poder econômico no ambiente de repressão da ditadura militar
}

No período da República populista entre 1945 e 1964, o Congresso Nacional funcionava como caixa de reverberação para as demandas locais, menos fortes do que na República Velha, e, ao mesmo tempo, torna "legítimo" o limitado uso da intervenção militar do tipo moderador. Essa corrupção do sistema democrático solaparia as instituições a tal ponto que, às vésperas do golpe de 1964, o descrédito nas instituições democráticas era bastante disseminado. A partir de 1964, o Congresso deixou de exercer explicitamente esse papel, e a sua existência e permanência derivam do próprio poder revolucionário ${ }^{327}$ - isso se comprova pelo fato de que nenhum Ato Institucional fundamentou a utilização do poder militar na fórmula institucional da República populista, a saber, o Congresso Nacional. ${ }^{328}$

Em 1964, a corrup̧̧ão dos políticos da República populista assume o papel das elites locais. A semelhança com o diagnóstico feito pelos tenentistas é grande:

\begin{abstract}
Já a noção de corrupção assimilada pelas forças armadas sempre esteve associada à identificação de uma desonestidade específica: o mau trato do dinheiro público. Reduzia-se a furto. Na fantasmagoria do quartel, corrupção era resultado dos vícios produzidos por uma vida política de baixa qualidade moral e vinha associada, às vésperas do golpe, ao comportamento viciado dos políticos diretamente vinculados ao regime nacional-desenvolvimentista. No meio militar, em geral, o juízo era sempre o mesmo: um problema de ordem moral, fácil de detectar e medir, e a qualidade de seu controle, razoavelmente simples de ser obtida: diante da corrupção dos dinheiros, a honestidade se fazia força e, se os velhos padrões de demagogia e desonestidade continuavam vigorando na parte corrupta do país - o Estado, a vida política -, sempre era possível regenerar a sociedade. Uma sociedade vista por eles, diga-se de passagem, como incapaz de solucionar para por si o que o regime nacional-desenvolvimentista não queria ou não conseguia resolver: os políticos desonestos podiam trocar de cargos, mas continuavam os mesmos; a democracia não alcançava destituí-los. ${ }^{329}$
\end{abstract}

Por esse motivo, a ditadura militar não enxergava corrupção em outras formas mais sutis de confusão entre o espaço público e o privado. O diagnóstico sobre a empresa de capital nacional a relegava à posição de fragilidade, desprovida de capitais para adquirir escala e competir globalmente - tornava-se necessário criar grandes conglomerados nacionais privados para evitar a internacionalização ou a estatização da economia. ${ }^{330}$ A fórmula

\footnotetext{
${ }^{327}$ LAFER, Celso. Op. cit. p. 72.

${ }^{328}$ BRASIL. Ato Institucional n⿳ำ 1, de 9 abr. 1964. "Era explícito o Ato Institucional nº 1/64: "Fica assim, bem claro, que a revolução não procura legitimar-se através do Congresso. Este é que recebe deste Ato Institucional, resultante do exercício do Poder Constituinte, inerente a todas as revoluções, a sua legitimação"

${ }^{329}$ STARLING, Heloísa Maria Murgel. Ditadura militar. In: AVRITZER, Leonardo et al. (Org.). Op. cit. p. 251252.

${ }^{330}$ SIMONSEN, Mário Henrique. A nova economia brasileira. São Paulo: José Olympio, 1971. p. 205.
} 
encontrada pelo Estado para esse diagnóstico já havia sido utilizada antes, mas não na escala que se verifica nesse momento: auxiliar o desenvolvimento da empresa de capital nacional, o que aconteceu de vários modos que revelam um privilégio patrimonial da esfera privada em detrimento da pública. No âmbito fiscal, houve incentivos para a distribuição de lucros das empresas holdings. ${ }^{331}$ Outra estratégia foi a participação do Estado via Banco Nacional de Desenvolvimento Econômico (BNDE) como acionista de empresas. ${ }^{332}$

O mais contundente mecanismo de auxílio à empresa privada nacional, porém, foi o Programa de Apoio à Capitalização da Empresa Privada Nacional (Procap), que estendeu os benefícios fiscais aos financiamentos do BNDE. ${ }^{333}$ Carvalhosa identificou três características do Procap:

\begin{abstract}
A primeira é que os capitais administrados pelo governo serão repassados aos principais grupos bancários de forma extremamente subsidiada, em termos de juros ( $4 \%$ ou $5 \%$ ao ano) e de correção monetária (teto de $20 \%$ ao ano). E, ainda, de prazo de pagamento (4 anos). A segunda é conseqüência da primeira: os grupos financeiros poderão adquirir o controle das companhias produtivas sem o dispêndio de qualquer recurso próprio. A terceira é que os Bancos obterão essa participação no controle das companhias que serão alinhadas em seu conglomerado com apenas uma ínfima aquisição de ações, graças aos instrumentos contidos na nova lei de S.A. ${ }^{334}$
\end{abstract}

Essas preocupações relacionadas à corrupção na regulamentação macrojurídica não incomodavam os militares. A corrupção que surge como uma das preocupações dos militares no Ato Institucional $\mathrm{n}^{\mathrm{o}} 1 / 64,{ }^{335}$ época em que foi criada a Comissão Geral de Investigação

\footnotetext{
$\overline{331}$ CARVALHOSA, Modesto. A nova lei de sociedades anônimas. São Paulo: Paz e Terra, 1976. p. 157. "Por esse dispositivo, não mais ficam sujeitos ao desconto do Imposto sobre a Renda na fonte os lucros, dividendos e bonificações em dinheiro e quaisquer outros interesses distribuídos por pessoa jurídica a outra pessoa jurídica, em decorrência de participação societária ou acionária. Com essa revogação, voltou-se ao regime tributário anterior à Lei 4.154, de 28 de novembro de 1962 (art. $8^{\circ}$ ), que estabeleceu o sistema de antecipação do imposto sobre lucros distribuídos pelas holdings a outras companhias do grupo. Procurava-se naquela ocasião (1962) estancar a evasão tributária que o regime, agora novamente instaurado, permitia. Essa evasão se dava através do diferimento sucessivo do momento de pagamento do tributo sobre dividendos. Esses dividendos iam sendo sucessivamente transferidos de uma para outras holdings, sendo nessa cadeia desbastados por despesas 'operacionais' de cada companhia. A outra fórmula de evasão consistia em manter indefinidamente o valor dos dividendos recebidos pela holding no giro de seus negócios, Jamais distribuindo tais proventos aos acionistas desta última. Doravante essa antecipação por conta de futura distribuição de lucros aos acionistas não mais existe, podendo as holdings manter indefinidamente ou transferir sucessivamente a outras sociedades os dividendos recebidos, sem qualquer ônus de pagamento ou antecipação dos lucros auferidos." ${ }^{332}$ Idem, p. 46-49.

${ }^{333}$ BRASIL. Decreto no 77.834 , de 16 jun. 1976. “Art. $1^{\circ}$. O sistema de incentivo fiscal previsto nos artigos $1^{\circ}, 2^{\circ}$ e $3^{\circ}$ do Decreto-lei $\mathrm{n}^{\mathrm{o}}$ 1542, de 30 de março de 1964, será aplicável também a financiamentos que o Banco Nacional de Desenvolvimento Econômico - BNDE venha a conceder, com a finalidade exclusiva de subscrição, por estes, de ações em aumentos de capital de empresas privadas nacionais. Art. $2^{\circ}$ Os limites e as condições das operações enquadráveis no benefício estabelecido no artigo anterior serão fixados em resolução da diretoria do BNDE, sujeita a homologação do ministro-chefe da Secretaria de Planejamento da Presidência da República."

${ }^{334}$ CARVALHOSA, Modesto. Op. cit. p. 160.

${ }^{335}$ BRASIL. Ato Institucional no 1 , de 9 abr. 1964. “Art $8^{\circ}$ Os inquéritos e processos visando à apuração da responsabilidade pela prática de crime contra o Estado ou seu patrimônio e a ordem política e social ou de atos de guerra revolucionária poderão ser instaurados individual ou coletivamente."
} 
(CGI), é de natureza diversa: no Ato Institucional nº 2/65 aflora o objetivo de "erradicar uma situação e um Governo que afundavam o País na corrupção e na subversão". ${ }^{336}$ Essas notas se refletiriam nos movimentos de reforma administrativa posteriores que intencionaram aperfeiçoar o direito administrativo. ${ }^{337}$

Parte considerável do modelo tecnocrático de administração pública era levada ao extremo. Conforme explica Lafer, "o pós-64 criou condições para uma profissionalização maior da máquina administrativa, na medida em que inexistia a necessidade de conciliar a cultura política do Brasil subdesenvolvido com a do Brasil desenvolvido. Disso resultou o Decreto-lei n⿳ำ 200". ${ }^{338}$ Nessa direção, várias mudanças institucionais na organização políticoadministrativa dos municípios foram implementadas via Atos Institucionais, tais como a exigência do requisito da viabilidade econômica financeira para criação de municípios e a submissão destes ao controle dos Tribunais de Contas estaduais. Outras mudanças, mais voltadas para o fortalecimento da dicotomia público-privado, também foram implementadas por meio do Decreto-lei $n^{0}$ 200/67, tais como um regramento específico para compras públicas e acesso às carreiras do serviço público - o art. 94 estabelecia, entre outros objetivos, a "Profissionalização e aperfeiçoamento do servidor público; fortalecimento do Sistema do Mérito para ingresso na função pública, acesso a função superior e escolha do ocupante de funções de direção e assessoramento". 339

Do ponto de vista do direito posto, o período 1964-1985 pode ser caracterizado como de aperfeiçoamento no combate à corrupção. Ainda que o tom moralista tenha prevalecido, do ponto de vista institucional o efeito foi o firmamento da profissionalização da máquina burocrática em alguns bolsões de eficiência. Por outro lado, a falta de transparência, juntamente com a busca de legitimidade política para o exercício do poder, típica de regimes autoritários (vide Pacote de Abril de 1977), agravou o acobertamento das feições do Estado patrimonialista. Nesse sentido, durante a ditadura militar, várias lideranças políticas, especialmente nas áreas menos desenvolvidas, lograram obter favores do Estado. A

\footnotetext{
$\overline{{ }^{336} \text { Ato Institucional no }}$ 2/65, de 27 out. 1965. Preâmbulo.

337 BUCCI, Maria Paula D. Op. cit. p. 10. "Os grandes movimentos de organização do Estado e da Administração Pública brasileiros, como a reforma administrativa de 1967 e a reforma em curso, a chamada reforma gerencial, a partir de 1996, têm ocorrido quase à margem do direito público, à conta de economistas, planejadores, técnicos de outras áreas e reduzida atuação dos juristas. Isso resultou talvez não só da conjuntura política - o direito e a justiça costumam atrapalhar os avanços do poder - mas também de limitações epistemológicas do nosso direito administrativo, tal como se estruturou na sua formação, no século XIX, construção que perdura ainda hoje."

${ }^{338}$ LAFER, Celso. Op. cit. p. 78-79.

${ }^{339}$ BRASIL. Decreto-lei no $200 / 67$. Art. 91, III.
} 
centralização de recursos na União se acentua, e, como reação, prefeitos e governadores aceleram a peregrinação em busca de recursos em Brasília.

Como a corrupção era equiparada ao comunismo na condição de um dos principais males a molestar o país, ${ }^{340}$ a repressão criminal se endureceu no plano jurídico. As investigações ainda se restringiam às feitas por órgãos de inteligência do governo e eram usadas pela CGI com fins eminentemente políticos - o aparelho estatal autoritário usou o discurso do combate à corrupção como pretexto para a perseguição a alguns dos opositores do governo. $\mathrm{O}$ art. $8^{\circ}$ do Ato Institucional $\mathrm{n}^{0}$ 5/68 é um bom exemplo do modo autoritário de repressão à corrupção: após investigação, o presidente da República poderia decretar o confisco dos bens; se posteriormente ficasse comprovada a inocência, os bens do acusado seriam restituídos. ${ }^{341}$ Logo, é difícil diferenciar políticos tiveram o mandato cassado por corrupção, uma vez que os atos revolucionários eram injustificados. ${ }^{342}$

O Decreto-lei $\mathrm{n}^{\mathrm{o}}$ 359/68 instrumentalizava as regras de confisco criadas com o Ato Institucional $\mathrm{n}^{\mathrm{o}} 5 / 68$, aumentando ainda mais o conceito de improbidade administrativa para se referir a "qualquer evolução patrimonial desproporcional", ${ }^{343}$ de modo que sua constatação inverteria o ônus da prova. Em outras palavras, aquele que apresentasse sensível evolução patrimonial deveria comprovar a legitimidade das aquisições.

O resultado dos trabalhos da CGI pode ser considerado pífio. Mais do que isso, a CGI perdeu o foco de seu trabalho no afã de investigar tudo e todos:

[...] seja por estar convencida da capacidade de acionar racionalmente os mecanismos de constrangimento de que dispunha, seja por acreditar na possibilidade de operar sobre uma sociedade que definia como redutível a uma multiplicidade enumerável e controlável de indivíduos, a CGI tratou de alargar, ao máximo, sua

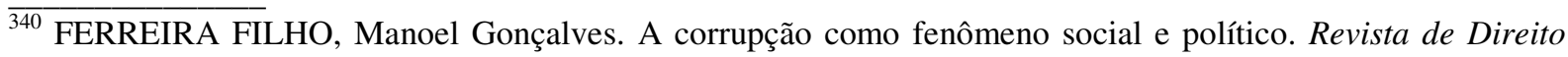
Administrativo, Rio de Janeiro, n. 185, p. 13, jul./set. 1991.

341 BRASIL. Ato Institucional $\mathrm{n}^{\mathrm{o}}$ 5, de $13 \mathrm{dez}$. 1968. “Art 8. O Presidente da República poderá, após investigação, decretar o confisco de bens de todos quantos tenham enriquecido, ilicitamente, no exercício de cargo ou função pública, inclusive de autarquias, empresas públicas e sociedades de economia mista, sem prejuízo das sanções penais cabíveis. Parágrafo único - Provada a legitimidade da aquisição dos bens, far-se-á sua restituição."

${ }^{342}$ FERREIRA FILHO, Manoel Gonçalves. A corrupção como fenômeno social e político. Revista de direito Administrativo, Rio de Janeiro, n. 185, p. 13, jul./set. 1991.

${ }^{343}$ BRASIL. Decreto-lei no 259, de 17 set. 1968. Art. 60. "Considera-se enriquecimento ilícito, para os efeitos dêste decreto-lei, a aquisição de bens, dinheiros ou valôres, por quem tenha exercido ou exerça cargo ou função pública da União, Estados, Distrito Federal, Territórios e Municípios, assim como das respectivas autarquias, emprêsas públicas ou sociedades de economia mista, sem que, à época da aquisição, dispusesse de idoneidade financeira para fazê-lo, à vista da declaração de rendimentos apresentada para fins de pagamento do imposto de renda. Parágrafo único. Considera-se, também, enriquecimento ilícito a aquisição de bens, dinheiros ou valôres por quem tenha exercido ou ainda exerça cargo ou função pública da União, Estados, Distrito Federal, Territórios ou Municípios, assim como das respectivas autarquias, empresas públicas ou sociedades de economia mista, e que, embora dispondo, à época da aquisição, de idoneidade financeira para fazê-lo, não haja comprovado a sua legitimidade perante a Comissão.”
} 
área de atuação. Passo seguinte, a Comissão submergiu na própria mediocridade, enredada em um campo de ação cujas fronteiras ela mesma demarcou e que incluía investigar, por exemplo, o atraso dos salários das professoras municipais de São José do Mipibu, no Rio Grande do Norte; a compra de adubo superfaturado pela Secretaria de Agricultura de Minas Gerais; o aumento de salário dos auditores e procuradores do Paraná; a cobrança de taxas escolares no Espírito Santo; as acusações de irregularidades na Federação Baiana de Futebol; a alta do preço da carne em Manaus. Entre os anos de 1968 e 1973 os integrantes da CGI produziram cerca de 1.153 processos. Desse conjunto, 1000 foram arquivados; 58 foram efetivamente transformados em propostas de confisco de bens por enriquecimento ilícito; 41 casos foram alvo de decreto presidencial. ${ }^{344}$

Ainda na esteira do discurso moralista que impregnava a época, um novo Código Penal entrou em vigor em 1969, mas foi revogado em 1978 devido às fortes críticas que recebeu. Pelo curto período em que vigorou, o Código alterou a sistemática dos crimes contra a administração pública, trazendo aspectos positivos e negativos. Como explicam Pagliaro e Costa Jr., havia um tipo que previa a punição para o peculato de uso ${ }^{345}$ - havia um tipo e uma pena para as hipóteses de uso de bem público pelo particular, como uma autoridade pública que leva regularmente seu cachorro para o veterinário no carro oficial. Para caracterizar o peculato, seria "necessário que o uso, por sua natureza e por sua duração, seja tal que comprometa a utilidade da coisa para a Administração Pública ou para outro sujeito ao qual pertença". ${ }^{346}$ No regime posterior ao Código de 1969, tal conduta não foi tipificada.

Por se tratar de diploma legal aprovado durante o regime militar, alguém poderia cogitar que as penas seriam mais rígidas. Todavia, não se pode esquecer que o Código Penal atualmente vigente data da ditadura Vargas, embora as penas tenham sido agravadas sob o regime democrático pós-1985. A Tabela 2 compara as penas existentes para alguns dos crimes relacionados à corrupção no Código Penal de 1969 às do atual Código Penal, demonstrando que inexiste diferença substancial no que diz respeito às penas em abstrato impostas para tais tipos.

Tabela 2 - Análise comparativa das penas para certos tipos de crimes contra a administração pública nos Códigos Penais de 1969 e atual.

\begin{tabular}{|l|c|l|}
\hline \multicolumn{1}{|c|}{ Tipo } & Pena no atual Código Penal & Pena no Código Penal de 1969 \\
\hline Peculato & Prisão (2 a 12 anos) e multa & $\begin{array}{l}\text { Prisão (3 a 15 anos) e pagamento } \\
\text { (20 a 100) dias-multa }\end{array}$ \\
\hline
\end{tabular}

\footnotetext{
${ }^{344}$ STARLING, Heloísa Maria Murgel. Ditadura militar. In: AVRITZER, Leonardo et al. (Org.). Op. cit. p. 256. 345 BRASIL. Código Penal (1969). Art. 346. "Usar, para fins alheios ao serviço, ou permitir que outrem, indevidamente, faça uso de veículos ou qualquer outra coisa infungível de não pequeno valor, que, pertencente à Administração ou sob sua guarda, lhe tenha sido entregue em razão do cargo. Pena: detenção, até 1 (um) ano, ou pagamento não excedente a vinte (20) dias-multa."

346 PAGLIARO, Antonio; COSTA JÚNIOR, Paulo José. Dos crimes contra a administração pública. 4. ed. São Paulo: Atlas, 2009. p. 40. Os autores lamentam que esta conduta não seja mais tipificada, pois seu conteúdo era "altamente moralizador [...]. Não entendemos por que não foi ele reproduzido na reforma da Parte Especial".
} 


\begin{tabular}{|l|l|l|}
\hline Peculato culposo & Detenção (3 meses a 1 ano) & Detenção (3 meses a 1 ano) \\
\hline Concussão & Prisão (2 a 8 anos) e multa & $\begin{array}{l}\text { Prisão (2 a 12 anos) e multa e } \\
\text { pagamento (10 a 30) dias-multa }\end{array}$ \\
\hline Corrupção passiva & $\begin{array}{l}\text { Prisão (2 a 12 anos) e multa. Antes } \\
\text { de 12.11.2003: reclusão (1 a 8 anos) } \\
\text { e multa }\end{array}$ & $\begin{array}{l}\text { Prisão (2 a 8 anos) e multa e } \\
\text { pagamento (15 a 30) dias-multa }\end{array}$ \\
\hline $\begin{array}{l}\text { Hipótese de corrupção passiva } \\
\text { em que o funcionário retarda } \\
\text { ou deixa de praticar qualquer } \\
\text { ato de ofício ou o pratica } \\
\text { infringindo dever funcional }\end{array}$ & $\begin{array}{l}\text { Detenção Prisão (3 meses a 1 ano) } \\
\text { ou multa }\end{array}$ & Detenção (3 meses a 1 ano) \\
\hline $\begin{array}{l}\text { Corrupção ativa } \\
\text { Prisão (2 a 12 anos) e multa. Antes } \\
\text { de 12.11.2003: reclusão (1 a 8 anos) } \\
\text { e multa }\end{array}$ & $\begin{array}{l}\text { Prisão (até 8 anos) e pagamento } \\
\text { (15 a 30) dias-multa }\end{array}$ \\
\hline
\end{tabular}

Fonte: Códigos Penais de 1969 e atual.

Outra medida prevista no Código Penal de 1969 e ausente no atual é a diferenciação da pena conforme o grau de impacto causado pela conduta. Assim, no peculato, a pena deveria ser aumentada em um terço "se o objeto da apropriação ou desvio é de valor superior a vinte vezes o salário mínimo". ${ }^{347}$ Igualmente curiosa é a circunstância atenuante de um terço da pena no crime de corrupção passiva prevista para as hipóteses em que o funcionário público é pressionado ou atende pedido de outrem. ${ }^{348}$ Do mesmo modo, quando o funcionário público age com culpa no peculato, mas repara o dano, há benefícios decorrentes de tal conduta. ${ }^{349}$

\footnotetext{
7 BRASIL. Código Penal (1969). Art. 348, § $1^{\circ}$. "As penas aumentam-se de um têrço, se o objeto da apropriação ou desvio é de valor superior a vinte vêzes o salário mínimo. (Aumento de pena)."

348 BRASIL. Código Penal (1969). Art. $357 \S 2^{\circ}$. "Se o funcionário pratica, deixa de praticar ou retarda ato de ofício, com infração de dever funcional, cedendo a pedido ou influência de outrem: (Diminuição de pena)". Pena - detenção, de três meses a um ano, ou multa de três a dez dias-multa.

${ }^{349}$ BRASIL. Código Penal (1969). Art. 348, § $3^{\circ}$. "Se o funcionário contribui culposamente para qualquer dos crimes acima: (Peculato culposo) Pena - detenção, de três meses a um ano. $\S 4^{\circ}$ No caso do parágrafo anterior, a reparação do dano, se precede à sentença irrecorrível, extingue a punibilidade; se lhe é posterior, reduz de metade a pena imposta."
} 


\section{PARTE II}

\section{A PERSPECTIVA MICROJURÍDICA NO COMBATE À CORRUPÇÃO}

\section{CAPÍTULO 4 - A CORRUPÇÃO NO DIREITO POSTO}

A ciência política, a sociologia e a economia não se preocupam com a busca de um conceito de corrupção do mesmo modo que o direito. A ênfase de pesquisa dessas ciências está mais focada na identificação das causas, na avaliação dos efeitos e na busca de soluções para o problema. Um conceito de corrupção tenderia a ser abstrato e dificultaria as análises; uma abordagem categórica interessaria mais à religião, à moral e à ética.

Por outro lado, na área jurídica, especialmente para o chamado operador do direito, tais aproximações não são suficientes. Por sua própria natureza, o direito se vincula à necessidade de segurança, e definições mais precisas, ainda que abstratas, são capazes de desempenhar essa função. Mesmo o direito penal, em que a noção de tipo legal é pivotal, trata de precisá-los com maior afinco que as demais ciências sociais mencionadas antes - doutrina e jurisprudência se esforçam por dar a maior clareza possível aos tipos penais, de tal forma que, ao fim do processo, se garante a segurança jurídica. Por isso, os tipos penais não se afastam tanto das tradicionais definições - "a definição só é necessária quando é preciso estabelecer limites exatos, claros e firmes para um conceito, quando o direito pretende criar condições para uma subsunção que não deixe lugar para dúvidas, quando interesse um código binário bem evidente, de sim ou não". ${ }^{350}$ Aliás, apesar de originários da identificação de "algumas formas de comportamento humano", os tipos penais sofrem "um processo de reversão" para deles se extrair "igualmente certo significado que silogisticamente" é atribuído, de modo interativo, ao que é agrupado. ${ }^{351}$

Ora, o direito positivado opera com a identificação, na realidade, de determinadas ações humanas (condutas) que são valoradas e recebem determinadas consequências

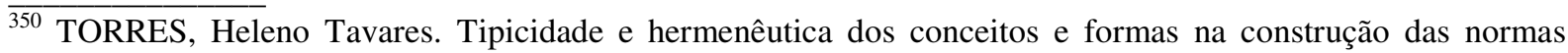
jurídicas. In: LIMA, Martonio M. B.; ALBUQUERQUE, Paulo A. M. Democracia, direito e política: estudos internacionais em homenagem a Friedrich Müller. São José: Conceito, 2006. p. 364.

351 TOLEDO, Francisco de Assis. Princípios básicos de direito penal: de acordo com a Lei no 7.209, de 11-71984 e com a Constituição de 1988. 5. ed. São Paulo: Saraiva. 1994. p. 126.
} 
atribuídas pelo direito. Assim, "a comunidade jurídica quando, tomando os fatos sociais, sobre eles edita normas jurídicas, o faz com o objetivo de que a conduta por ela prevista seja adotada por seus destinatários". ${ }^{352}$

Logo, é intuitiva a conclusão de que existe um processo de seleção de quais ações humanas devem ser valoradas negativamente pela sociedade e, consequentemente, proibidas esse processo, associado ao estudo da política legislativa, é negligenciado normalmente pelo direito. Como explica Larenz,

\begin{abstract}
A selecção das notas distintivas, que hão de ser recolhidas quando da formação de um conceito abstracto na sua definição, é essencialmente co-determinada pelo fim que a ciência em causa persegue com a formação do conceito. Daí resulta que o conceito jurídico que designa uma determinada classe de objectos nem sempre se identifica plenamente com o conceito correspondente de outra ciência, ou nem sequer com o que o uso lingüístico corrente por ele entende. ${ }^{353}$
\end{abstract}

Nessa lacuna, há um espaço para o uso do direito econômico, especialmente no que diz respeito à corrupção. Além de constituir um fato regulamentado pelos direitos penal, administrativo e político-constitucional, a corrupção possui efeitos que se irradiam sobre um plano macrojurídico. Esses três ramos do direito não abarcam a totalidade do fato corrupção, parte do qual é atípico em sentido amplo - são aquelas condutas ilegítimas, porém admitidas ou, ao menos, não vetadas pelo direito.

Para que se reconheça a existência de deslocamento entre o que a sociedade julga como corrupção e o que a ordem jurídica efetivamente rotula como tal, é necessário partir do estudo das condutas proibidas expressamente. Mesmo algumas dessas condutas não vetadas explicitamente seriam banidas pelo ordenamento jurídico em virtude de interpretação dos princípios constitucionais da impessoalidade e da moralidade administrativa. Todavia, a identificação das condutas expressamente proibidas revela-se sugestiva de como os interesses privados dos políticos podem ter moldado o processo legislativo. Em seguida, o papel de cada um dos atores no combate à corrupção será objeto de análise, inclusive no que tange às competências e à eficácia da atuação, esta última causadora de impacto direto sobre o fato corrupção.

\footnotetext{
${ }^{352}$ MELLO, Marcos Bernardes de. Teoria do fato jurídico: plano da existência. 7. ed. atual. São Paulo: Saraiva, 1995. p. 12.

${ }^{353}$ LARENZ, Karl. Metodologia da ciência do direito. Tradução de José Lamego. 3. ed. Lisboa: Fundação Calouste Gulbenkian, 1997. p. 625.
} 


\subsection{Delimitação jurídica do conceito "corrupção"}

Juridicamente, o caráter plurívoco da palavra "corrupção" apresenta desdobramentos palpáveis. Há alguns tipos criminais que envolvem corrupção, mas fora do espectro políticoadministrativo: corrupção de menores, corrupção de água potável, corrupção de substância alimentícia e corrupção de substância medicinal são tipos que povoam o Código Penal. Nestes, corrupção se aproxima ou de depravação de hábitos ou de deterioração física.

Entretanto, é no âmbito do espaço público que a corrupção mais se aproxima daquilo que a mídia noticia diariamente. A maioria dos estudos foca exatamente essa seara, ignorando a nota comum entre o problema nas esferas pública e privada, mesmo quando o fazem de modo amplo. ${ }^{354}$

No espaço público, a regulamentação jurídica trata da corrupção em vários ramos do direito posto. Muitas vezes, um diploma trata acidentalmente do fato corrupção ou, ao redefinir o desenho institucional, produz efeitos sobre o fato corrupção, sem que haja referencia explícita ao mesmo. Por exemplo, acredita-se que a criação e disseminação da modalidade "pregão" nas compras públicas tenha reduzido a possibilidade de ocorrência da corrupção, muito embora esta não seja mencionada nos dispositivos pertinentes da Lei $n^{0}$ $10.520 / 02.35$

Dessa forma, uma primeira aproximação ao tema revela a existência de pelo menos três principais sistemas de repressão à corrupção pela regulamentação microjurídica em sentido amplo: (i) a legislação penal, (ii) a legislação administrativa e (iii) a legislação político-constitucional.

\subsubsection{Identificação e localização do fato corrupção no direito penal}

Um primeiro aspecto que necessariamente se deve reconhecer é a reprovação social das condutas que caracterizam corrupção na esfera pública, fato que nem sempre foi reconhecido em sua totalidade no Brasil, nem o é de modo idêntico ou equivalente em outras culturas. Muitos até mesmo evitam chamar de crimes tais condutas típicas, como aponta

\footnotetext{
$\overline{354}$ JOHSTON, Michael. Agentes públicos, interesses particulares e democracia sustentável: quando política e democracia se unem. In: ELLIOT, Kimberly Ann (Org.). A corrupção e a economia global. Tradução de Marsel Nascimento Gonçalves de Souza. Brasília: UnB, 2002. p. 105.

${ }^{355}$ BRASIL. Lei n⿳⺈ 10.520, de 17 jun. 2002.
} 
Sutherland. ${ }^{356}$ A criminalização dessas condutas se insere no contexto de aperfeiçoamento da burocracia estatal, ocorrido gradativamente desde o século XIX. Não que inexistisse alguma repressão criminal - pelo contrário, no Brasil, mesmo no período colonial, a corrupção sempre foi reprimida de alguma forma pela regulamentação microjurídica. Entretanto, o que existia na história do Brasil Colônia e em período do Brasil Império foi uma repressão que não abarcava parte substancial das condutas corruptas nessa perspectiva microjurídica.

Parcela desse atraso pode ser imputada aos interesses prevalentes à época, os quais transparecem no direito pressuposto da sociedade rural agrária. Mesmo hoje, embora a detecção dos crimes de colarinho branco como a corrupção seja difícil, o maior desafio da repressão criminal, na perspectiva da regulamentação microjurídica, reside no polo processual passivo, em que figuram frequentemente servidores públicos de alto escalão, políticos e detentores de poder econômico. Tais categorias têm capacidade não somente para moldar as regras às quais se sujeitam, mas também influenciar, sutilmente ou não, na sua aplicação, ${ }^{357}$ situação oposta à da maioria dos criminosos comuns. ${ }^{358}$

No direito penal, a noção de "crimes contra a administração pública" volta-se para "o interesse da normalidade funcional, prestígio, incolumidade e decoro da Administração Pública". ${ }^{359}$ No Estado intervencionista, a administração pública desempenha a maioria das tarefas e manipula grandes orçamentos, o que proporcionam maior área para a incidência de corrupção. Todavia, tanto o Legislativo quanto o Judiciário também são esferas de atuação em

\footnotetext{
${ }^{356}$ SUTHERLAND, Edwin H. White collar crime: the uncut version. New Haven: Yale University Press, 1983. p. 5. "White-collar crime is real crime. It is not ordinarily called crime, and calling it by this name does not make it worse, just as refraining from calling it crime does not make it better than it otherwise would be. It is called crime here in order to bring it within the scope of criminology, which is justified because it is in violation of the criminal law. [...] When it is supplemented, the criterion of the crimes of one class must be kept consistent in general terms with the criterion of the crimes of the other class. The definition should not be the spirit of the law for white-collar crimes and the letter of the law for other crimes, or in other respects be more liberal for one class than for the other." Nos países da Common Law, é comum se referir aos crimes de colarinho branco como "offences" em vez de "crimes"; embora em sentido amplo as "offences" abarquem os crimes, em sentido estrito se referem àqueles crimes em que inexiste vítima identificável.

357 Servidores públicos de alto escalão, políticos e detentores de poder econômico exercem influência e autonomia, restritas às relações entre pessoas naturais, mas que, de modo reflexo, impactam as instituições. Influência é uma relação entre atores tal que "os desejos, preferências ou intenções de um ou mais atores afetem a conduta ou a disposição de agir de um ou mais atores distintos". A autonomia, por seu turno, é a capacidade de um ator compor um querer próprio: quanto menos influenciado em determinado assunto por outro ator, maior a sua autonomia; quanto mais influenciado em determinado assunto, menor a sua autonomia. DAHL, Robert A. Análise política moderna. Brasília: UnB, 1981. p. 26 e 33.

${ }^{358}$ SUTHERLAND, Edwin H. White collar criminality. American Sociological Review, vol. 5, n. 1, p. 7, Feb. 1940. "It means only that the upper class has greater influence in moulding the criminal law and its administration to its own interests than does the lower class. The privileged position of white-collar criminals before the law results to a slight extent from bribery and political pressures, principally from the respect in which they are held and without special effort on their part."

${ }^{359}$ HUNGRIA, Nélson. Comentários ao Código Penal (Dec.-Lei no 2.848, de 7 de dezembro de 1940). v. 9. Art. 250 a 361. 2. ed. Rio de Janeiro: Forense, 1959. p. 313.
} 
que se podem verificar práticas corruptas. Quer seja eleito, quer seja concursado, o servidor público que detenha posição de comando pode perfeitamente ser corrupto ao agir mediante pagamento para fazer algo que deveria de ofício ou cobrar propina para favorecer uma empresa num processo licitatório. O art. 327 do Código Penal ${ }^{360}$ define o conceito de funcionário público de modo bastante amplo, a fim de não diferenciar se o sujeito trabalha para o Executivo, Legislativo ou Judiciário. ${ }^{361}$

O Código Penal até mesmo tipifica alguns fatos como "crimes contra a administração da justiça" - tais crimes se verificam majoritariamente na esfera do Judiciário e, em virtude de sua especificidade, são regulados de modo separado. No que tange ao Legislativo, haveria uma omissão que pode ser explicada pela sujeição dos legisladores, mesmo que eleitos, a outros preceitos normativos, mas que não os afasta da sistemática da legislação penal. ${ }^{362}$

A estreita definição de "crimes contra a administração pública", ainda que englobando eventualmente por extensão o Legislativo e o Judiciário, ignora uma pletora considerável de ações classificáveis como corrupção ${ }^{363}$ - afinal, nem sempre o sistema repressivo penal é capaz de punir atos corruptos, quer seja ou devido à não detecção ou a questões jurídicas (prescrição, instrução probatória insuficiente etc.). Essa discussão sobre o alcance da aplicabilidade de certos tipos penais expõe quão problemáticas são a criação e a

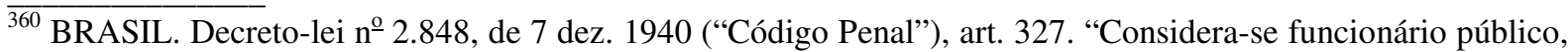
para os efeitos penais, quem, embora transitoriamente ou sem remuneração, exerce cargo, emprego ou função pública. $\S 1^{\circ}$ - Equipara-se a funcionário público quem exerce cargo, emprego ou função em entidade paraestatal, e quem trabalha para empresa prestadora de serviço contratada ou conveniada para a execução de atividade típica da Administração Pública. $\S 2^{\circ}$ - A pena será aumentada da terça parte quando os autores dos crimes previstos neste Capítulo forem ocupantes de cargos em comissão ou de função de direção ou assessoramento de órgão da administração direta, sociedade de economia mista, empresa pública ou fundação instituída pelo poder público."

${ }^{361}$ ALMEIDA, Fernando H. M. Dos crimes contra a administração pública. São Paulo: Saraiva, 1955. p. 9. “Os delitos, de que tratam os arts. 312 a 326, constituem violação do interêsse público no sentido mais amplo possível, ao qual intimamente está ligado o prestígio da administração pública. Esta expressão, por sua vez, está empregada no texto não como a significar um pouco mais do que o aparelhamento do Executivo, atingido por um preceituário específico, como seja o Estatuto. Vai além. Abrange as funções legislativa e jurisdicional, bem como os poderes respectivos." No mesmo sentido, veja-se PAGLIARO, Antonio; COSTA JÚNIOR, Paulo José. Dos crimes contra a administração pública. 4. ed. São Paulo: Atlas, 2009. p. 5-9. LIVIANU, Roberto. Corrupção e direito penal: um diagnóstico da corrupção no Brasil. Coimbra: Coimbra Editora, 2007. p. 179.

${ }^{362}$ HUNGRIA, Nélson. Op. cit. p. 313-314. "Tome-se, por exemplo, o crime de corrupção (peita ou suborno, do antigo Código): quer se trate de um inspetor fiscal, quer de um juiz ou de um deputado, o corrompido incorrerá no art. 317 (corrupção passiva), do mesmo modo que o corruptor, em qualquer caso, incidirá no art. 333 (corrupção ativa)." ALMEIDA, Fernando H. M. Op. cit. p. 9-10.“Por função pública entender-se-á, para efeitos penais, o complexo de pensamento, vontade e ação, como atributos da autoridade, nas esferas dos poderes legislativo, executivo e judiciário, o que evidentemente pressupõe numeroso pessoal não limitado àqueles conceitos formais que os estatutos estabelecem acerca de funcionários."

363 SUTHERLAND, Edwin H. White collar criminality. American Sociological Review, v. 5, n. 1, p. 5, Feb. 1940 5. "The crucial question in this analysis is the criterion of violation of the criminal law. Conviction in the criminal court, which is sometimes suggested as the criterion, is not adequate because a large proportion of those who commit crimes are not convicted in criminal courts. This criterion, therefore, needs to be supplemented."
} 
manipulação adequada dessa ferramenta repressiva da regulamentação microjurídica. Com frequência, a proliferação desordenada de novos tipos e penas tem o condão de minar a já frágil eficácia na repressão criminal.

Quanto aos tipos penais relacionados à corrupção, estes se encontram situados principalmente no Título XI do Código Penal ("Dos crimes contra a administração pública"). Por seu turno, este se subdivide em cinco capítulos: Capítulo I ("Dos crimes praticados por funcionário público contra a administração em geral”); Capítulo II ("Dos crimes praticados por particular contra a administração em geral”); Capítulo II-A ("Dos crimes cometidos por particular contra a administração pública estrangeira"); Capítulo III ("Dos crimes contra a administração da justiça”) e Capítulo IV (“Dos crimes contra as finanças públicas”).

No Capítulo I, podem-se encontrar vários dos tipos associados à corrupção praticada por funcionário público, tais como (i) a apropriação de bens e recursos públicos, denominada peculato, (ii) a propina, denominada concussão, e (iii) suborno, denominado corrupção passiva. O mesmo ocorre no Capítulo II, que trata dos crimes praticados pelo particular encontra-se o reverso da medalha para o suborno, só que de iniciativa do particular, denominada corrupção ativa. Já no Capítulo III, a preocupação se volta mais para o funcionamento do Judiciário - há uma tipificação especial do suborno, denominado exploração de prestígio. ${ }^{364}$

O centro das denominadas práticas corruptas pode ser localizado nos crimes de peculato, concussão e corrupção ativa e passiva. Embora não se confundam, em comum "eles revelam atmosfera de corrupção geral na burocracia em que acontece a repetição dos fatos que se manifestam". ${ }^{365}$ Apesar de tais tipos conterem notas semelhantes, é bastante frequente a confusão $0^{366}$ - a Tabela 3 sintetiza as principais características normativas dos tipos relacionados às práticas corruptas.

\footnotetext{
$\overline{364}$ BRASIL. Decreto-lei no 2.848, de 7 dez. 1940 (“Código Penal”), art. 357. "Solicitar ou receber dinheiro ou qualquer outra utilidade, a pretexto de influir em juiz, jurado, órgão do Ministério Público, funcionário de justiça, perito, tradutor, intérprete ou testemunha: Pena - reclusão, de um a cinco anos, e multa.”

${ }^{365}$ ALMEIDA, Fernando H. M. Op. cit. p. 62.

${ }^{366}$ Idem, p. 62. "São, todavia, delitos que não se devem confundir, já porque já não há razão para baralhá-los, como também não aproveita dispensar o discernimento que os distancia e os delimita."
} 
Tabela 3 - Síntese dos principais tipos criminais ligados à corrupção

\begin{tabular}{|c|c|c|c|}
\hline Tipo & Descrição & Pena & Observações \\
\hline $\begin{array}{l}\text { Peculato } \\
\text { (art. 312) }\end{array}$ & $\begin{array}{l}\text { Apropriar-se o funcionário } \\
\text { público de dinheiro, valor ou } \\
\text { qualquer outro bem móvel, } \\
\text { público ou particular, de que } \\
\text { tem a posse em razão do } \\
\text { cargo, ou desviá-lo, em } \\
\text { proveito próprio ou alheio }\end{array}$ & $\begin{array}{l}\text { Prisão ( } 2 \text { a } 12 \text { anos) } \\
\text { e multa }\end{array}$ & $\begin{array}{l}\text { Aplica-se a mesma pena, se o } \\
\text { funcionário público, embora não tendo a } \\
\text { posse do dinheiro, valor ou bem, o } \\
\text { subtrai, ou concorre para que seja } \\
\text { subtraído, em proveito próprio ou } \\
\text { alheio, valendo-se de facilidade que lhe } \\
\text { proporciona a qualidade de funcionário } \\
\left(\text { art. } 312, \S 1^{\circ}\right)\end{array}$ \\
\hline $\begin{array}{c}\text { Peculato } \\
\text { culposo } \\
\left(\text { art. 312, } \$ 2^{\circ}\right)\end{array}$ & $\begin{array}{l}\text { Se o funcionário concorre } \\
\text { culposamente para o crime de } \\
\text { outrem }\end{array}$ & $\begin{array}{l}\text { Detenção ( } 3 \text { meses a } \\
\text { lano) }\end{array}$ & $\begin{array}{l}\S 3^{\circ} \text { - No caso do parágrafo anterior, a } \\
\text { reparação do dano, se precede à } \\
\text { sentença irrecorrível, extingue a } \\
\text { punibilidade; se lhe é posterior, reduz de } \\
\text { metade a pena imposta }\end{array}$ \\
\hline $\begin{array}{c}\text { Concussão } \\
\text { (art. 316) }\end{array}$ & $\begin{array}{l}\text { Exigir, para si ou para } \\
\text { outrem, direta ou } \\
\text { indiretamente, ainda que fora } \\
\text { da função ou antes de assumi- } \\
\text { la, mas em razão dela, } \\
\text { vantagem indevida }\end{array}$ & $\begin{array}{l}\text { Prisão ( } 2 \text { a } 8 \text { anos) e } \\
\text { multa }\end{array}$ & \\
\hline Art. 316, $\S 2^{\circ}$ ) & $\begin{array}{l}\text { Se o funcionário desvia, em } \\
\text { proveito próprio ou de } \\
\text { outrem, o que recebeu } \\
\text { indevidamente para recolher } \\
\text { aos cofres públicos }\end{array}$ & $\begin{array}{l}\text { Prisão ( } 2 \text { a } 12 \text { anos) } \\
\text { e multa }\end{array}$ & \\
\hline $\begin{array}{c}\text { Excesso de } \\
\text { exação } \\
\left(\text { art. 316, } \$ 1^{\circ}\right)\end{array}$ & $\begin{array}{l}\text { Se o funcionário exige tributo } \\
\text { ou contribuição social que } \\
\text { sabe ou deveria saber } \\
\text { indevido, ou, quando devido, } \\
\text { emprega na cobrança meio } \\
\text { vexatório ou gravoso, que a } \\
\text { lei não autoriza }\end{array}$ & $\begin{array}{l}\text { Prisão ( } 3 \text { a } 8 \text { anos) e } \\
\text { multa }\end{array}$ & \\
\hline $\begin{array}{l}\text { Corrupção } \\
\text { passiva } \\
\text { (art. 317) }\end{array}$ & $\begin{array}{l}\text { Solicitar ou receber, para si } \\
\text { ou para outrem, direta ou } \\
\text { indiretamente, ainda que fora } \\
\text { da função ou antes de assumi- } \\
\text { la, mas em razão dela, } \\
\text { vantagem indevida, ou aceitar } \\
\text { promessa de tal vantagem }\end{array}$ & $\begin{array}{l}\text { Prisão ( } 2 \text { a } 12 \text { anos) } \\
\text { e multa. Antes de } \\
\text { 12.11.2003: prisão } \\
\text { (1 a } 8 \text { anos) e multa }\end{array}$ & $\begin{array}{l}\text { A pena é aumentada de um terço, se, em } \\
\text { consequência da vantagem ou promessa, } \\
\text { o funcionário retarda ou deixa de } \\
\text { praticar qualquer ato de ofício ou o } \\
\text { pratica infringindo dever funcional (art. } \\
\left.317, \S 2^{\circ}\right)\end{array}$ \\
\hline Art. $317, \S 2^{\circ}$ & $\begin{array}{l}\text { Se o funcionário pratica, } \\
\text { deixa de praticar ou retarda } \\
\text { ato de ofício, com infração de } \\
\text { dever funcional, cedendo a } \\
\text { pedido ou influência de } \\
\text { outrem }\end{array}$ & $\begin{array}{l}\text { Detenção ( } 3 \text { meses a } \\
1 \text { ano) ou multa }\end{array}$ & \\
\hline $\begin{array}{l}\text { Corrupção } \\
\text { ativa } \\
\text { (art. 333) }\end{array}$ & $\begin{array}{l}\text { Oferecer ou prometer } \\
\text { vantagem indevida a } \\
\text { funcionário público, para } \\
\text { determiná-lo a praticar, omitir } \\
\text { ou retardar ato de ofício }\end{array}$ & $\begin{array}{l}\text { Prisão ( } 2 \text { a } 12 \text { anos) } \\
\text { e multa. Antes de } \\
\text { 12.11.2003: prisão } \\
\text { (1 a } 8 \text { anos) e multa }\end{array}$ & $\begin{array}{l}\text { A pena é aumentada de um terço, se, em } \\
\text { razão da vantagem ou promessa, o } \\
\text { funcionário retarda ou omite ato de } \\
\text { ofício, ou o pratica infringindo dever } \\
\text { funcional (art. } 333, \S \text { único) }\end{array}$ \\
\hline
\end{tabular}

Fonte: Código Penal.

Os Capítulos I, II e III encontravam-se desde a origem no Código Penal, em 1940, e refletem as preocupações da época, representando um aperfeiçoamento da atividade da 
administração pública então em curso. Embora alguns delitos relacionados a práticas corruptas já estivessem previstos no Código Penal de 1890, somente no Código de 1940 foi tipificada a corrupção ativa; em outras palavras, antes de 1940, não se punia o corruptor, mas apenas o corrupto. ${ }^{367}$

Já o Capítulo V, adicionado recentemente por meio da Lei $\mathrm{n}^{\mathrm{o}}$ 10.028/00, reforça uma preocupação já existente, ampliando as hipóteses de crimes relacionados à administração financeira do Estado.

À semelhança do que ocorre com vários outros dispositivos penais, os crimes contra as finanças públicas arrolados no Capítulo $\mathrm{V}$ não se referem diretamente às práticas corruptas. Todavia, as práticas ali vetadas podem ser consideradas como anteparo contra o exercício abusivo da máquina pública para o interesse privado do político que deseja manter-se no poder. O artigo 359-G, por exemplo, veta a concessão de aumento salarial para o funcionalismo 180 dias antes do término da legislatura, período que coincide com o eleitoral, quando tal poderia ser encarado como um agrado à parcela do eleitorado. Do mesmo modo, a prevaricação ${ }^{368}$ serve de anteparo para evitar a prática de propina - afinal, uma das formas de exigir propina é "criar dificuldades para vender facilidades".

Apesar de a listagem acima englobar grande parte das condutas associadas à corrupção, muitas ainda podem ser encontradas na legislação extravagante. É o caso do art. 90 da Lei $\mathrm{n}^{\mathrm{o}} 8.666 / 93,{ }^{369}$ que trata da fraude ao caráter competitivo da licitação em troca de vantagem para o funcionário público. Igualmente, práticas que podem esconder tentativas de propina ou corrupção também são reprimidas, como se verifica no art. 94 da mesma lei. ${ }^{370}$

Por trás desse aparente viés positivo de expansão na repressão de práticas corruptas, esconde-se um processo de balcanização crescente do direito penal, o qual perde seus referenciais contidos nas regras simples que exprimem condutas ilícitas. Compare-se o já citado artigo 90 da Lei n⿳⺈ 8.666 ao $335^{371}$ do Código Penal: a dicção de ambos possui pontos

\footnotetext{
${ }^{367}$ Idem, p. 196.

${ }^{368}$ BRASIL. Código Penal. Art. 319. "Retardar ou deixar de praticar, indevidamente, ato de ofício, ou praticá-lo contra disposição expressa de lei, para satisfazer interesse ou sentimento pessoal: Pena - detenção, de três meses a um ano, e multa."

369 BRASIL. Lei no 8.666, de 21 jun. 1993. Art. 90. "Frustrar ou fraudar, mediante ajuste, combinação ou qualquer outro expediente, o caráter competitivo do procedimento licitatório, com o intuito de obter, para si ou para outrem, vantagem decorrente da adjudicação do objeto da licitação: Pena-detenção, de 2 (dois) a 4 (quatro) anos, e multa."

370 BRASIL. Lei $\mathrm{n}^{\mathrm{o}}$ 8.666, de 21 jun. 1993. Art. 94. "Devassar o sigilo de proposta apresentada em procedimento licitatório, ou proporcionar a terceiro o ensejo de devassá-lo: Pena-detenção, de 2 (dois) a 3 (três) anos, e multa."

371 BRASIL. Código Penal. Art. 335. "Impedir, perturbar ou fraudar concorrência pública ou venda em hasta pública, promovida pela administração federal, estadual ou municipal, ou por entidade paraestatal; afastar ou
} 
de contacto e sobreposição, criando dúvidas e incertezas sobre qual regra seria aplicável diante de um caso concreto, inclusive quanto ao aspecto temporal.

A abundância de tipos penais pode ser interpretada como uma resposta do Legislativo aos anseios da população por uma repressão mais efetiva da corrupção. De fato, desde os anos 1990, tem-se verificado a proliferação acelerada de normas de caráter criminal, inclusive sobre o âmbito da administração pública. Perde-se o princípio segundo o qual o direito penal deveria ser a ultima ratio legislativa, utilizável somente em situações excepcionais em que medidas mais contundentes seriam necessárias. Souza explica que

[...] o direito penal é, assim, trazido à baila para que o Estado - ou, muitas vezes, o governante do momento, com a constante propaganda política - possa demonstrar uma imediata e aparente resposta. Atende-se então ao anseio social. No mais das vezes, o caminho escolhido é o da produção dos mais diversos tipos penais, o agravamento das penas já existentes ou a supressão de direitos e garantias no âmbito processual penal ou executório de penas. ${ }^{372}$

No que tange ao combate à corrupção, a face mais recente desse fenômeno de proliferação das regras de direito penal é a introdução, em vários ordenamentos jurídicos, dos tipos que criminalizam a corrupção cometida em outros Estados.

\subsubsection{A globalização no combate à corrupção microjurídica}

As pressões para trazer o tema da corrupção à agenda internacional estavam latentes desde os anos 1970. Embora a legislação britânica previsse a repressão a ilícitos cometidos no exterior desde o início do século XX, sua aplicação permaneceu muito aquém do esperado. ${ }^{373}$ Assim, no processo de globalização, a liderança ao combate à corrupção coube aos Estados Unidos, abalados por uma série de escândalos nos anos 1970, especialmente aqueles envolvendo o pagamento de propinas a governantes estrangeiros pela Lockheed Martin, que culminaram na aprovação de uma legislação de repressão a esse tipo de ilícito, cometido por empresas norte-americanas no exterior. Embora a legislação norte-americana contenha

procurar afastar concorrente ou licitante, por meio de violência, grave ameaça, fraude ou oferecimento de vantagem: Pena - detenção, de seis meses a dois anos, ou multa, além da pena correspondente à violência."

372 SOUZA, Luciano Anderson. Expansão do direito penal e globalização. São Paulo: Quartier Latin, 2007. p. 154.

${ }^{373}$ GLYNN, Patrick; KOBRIN, Stephen J.; NAÍM, Moisés. A globalização da corrupção. In: ELLIOT, Kimberly Ann (Org.). Op. cit. p. 48. "Um grande avanço aconteceu em 1995, quando os britânicos desenterraram a Lei de Prevenção da corrupção, datada de 1906 e há muito esquecida, a qual proibia o suborno em condições muito parecidas com as da lei estadunidense de 1977." 
"brechas" para o pagamento de propina no exterior pelas empresas transnacionais, ${ }^{374}$ essas regras passaram a ser consideradas como um fator contrário à competitividade internacional de tais empresas. ${ }^{375}$

Corroborando esse temor do empresariado norte-americano, vários países, especialmente europeus, permitiam, para fins de imposto de renda, a dedução de pagamento de propina como se fosse despesa. ${ }^{376}$ A despeito da resistência inicial de alguns países, ${ }^{377}$ os anos 1990 propiciaram o surgimento da corrupção como um tema de destaque nos foros internacionais. Em 1993, a Organização Mundial do Comércio (OMC) emitiu declaração com sugestão de medidas de prevenção à corrupção na área fiscal relacionadas ao comércio exterior. $^{378}$

O combate à corrupção, porém, também pressupõe uma coordenação elevada entre as nações, de modo que atribuir as mudanças somente aos interesses específicos de um país seria míope. A concatenação das ações anticorrupção é fundamental, pois aqueles países que não adotam tal postura se convertem rapidamente em refúgio de capitais ilicitamente obtidos -

\footnotetext{
$\overline{374}$ Idem, p. 42-43. “[...] [a legislação americana anticorrupção] aceita três casos excepcionais. O mais importante deles é facilitar ou agilizar pagamentos a autoridades de escalão inferior (muitas vezes chamados de 'molhar a mão') com o objetivo de garantir a realização de ações governamentais de rotina. Exceções são feitas também se o pagamento for legal, de acordo com as leis e regulamentações escritas do país sede, ou se o pagamento constituir desembolso de boa-fé, por exemplo para viagem e acomodação relativas à demonstração de um produto ou à execução contratual. Essa segunda disposição abre obviamente uma brecha: atribuíram a uma autoridade americana, por exemplo, a expressão de surpresa quanto à crescente importância da Disneylândia como "centro de treinamento' internacional."

375 JAPIASSÚ, Carlos Eduardo Adriano. A corrupção em uma perspectiva internacional. Revista Brasileira de Ciências Criminais, São Paulo: Revista dos Tribunais, p. 40 jan./fev., 2007.

376 Idem, p. 40. "Dentre as medidas impostas às empresas norte-americanas, figuraram a exigência de transparência no aspecto contábil dos seus investimentos externos, considerando que o pagamento de suborno, em regra, é feito mediante fundos ocultos em filiais fora do alcance da jurisdição do país sede, bem como a exigência daquilo que pode ser considerado o ponto nuclear da política criminal de prevenção da corrupção internacional, qual seja, e não-dedutibilidade dos subornos pagos no estrangeiro."

377 GLYNN, Patrick; KOBRIN, Stephen J.; NAÍM, Moisés. A globalização da corrupção. In: ELLIOT, Kimberly Ann (Org.). A corrupção e a economia global. Tradução de Marsel Nascimento Gonçalves de Souza. Brasília: UnB, 2002. p. 46. "Como seria de prever, Alemanha, França e Grã-Bretanha se opuseram vigorosamente ao esforço estadunidense nos bastidores, muito embora os britânicos tenham demonstrado a partir de então um maior apoio ao posicionamento dos Estados Unidos. Nos conselhos realizados pela OCDE, em 1993, os europeus levantaram diversas objeções à posição estadunidense. Eles alegavam que a responsabilidade primordial de controle do suborno cabia aos países - na maioria em desenvolvimento - cujas autoridades tinham o costume de aceitar propinas, e não às empresas ocidentais que talvez as oferecessem."

378 JAPIASSÚ, Carlos Eduardo Adriano. A corrupção em uma perspectiva internacional. Revista Brasileira de Ciências Criminais, São Paulo: Revista dos Tribunais, p. 41 jan./fev., 2007. "Em 1993, foi elaborada a Declaração de Arusha sobre a Cooperação e Integridade Aduaneira, no seio da Organização Mundial do Comércio, que estabeleceu medidas de combate à corrupção na área alfandegária. Como exemplo, dentre outras, podem ser citadas as seguintes medidas: a necessária rotatividade entre os funcionários das alfândegas, a existência de critérios rígidos e objetivos de seleção, a redução da esfera de discricionariedade de tais agentes, o pagamento de remuneração compatível com a importância do cargo e a existência de mecanismos efetivos de controle, em especial na órbita disciplinar”. Para uma síntese dos acordos internacionais sobre corrupção, ver ACOSTA, Fernando. La corruption politique dans le cadre du nouvel ordre mondial. Revista Brasileira de Ciências Criminais, São Paulo: Revista dos Tribunais, p. 286-290.
} 
veja-se o caso das Ilhas Seychelles, que em 1995 até aprovou uma legislação que legalizava a lavagem de dinheiro ilícito obtido em outras jurisdições. ${ }^{379}$ Tendo em vista situações dessa natureza, em 1994, a Organização das Nações Unidas organizou a Declaração de Nápoles, assinada por 138 países, inclusive o Brasil, a fim de combater a criminalidade transnacional. ${ }^{380}$

Como desdobramento desse movimento, o Brasil teve de adaptar sua legislação penal, pois, à época do Código Penal de 1940, “ainda não se vislumbrava o alcance da corrupção" no futuro ${ }^{381}$ - não era nada fácil remeter fundos ao exterior, nem transferi-los, tampouco os negócios transnacionais eram tão frequentes como hoje. Para lidar com essas situações fáticas não tipificadas criminalmente, a adição do Capítulo II-A ao Código Penal expandiu o alcance das regras de repressão à corrupção, criando tipos dotados de efeitos extraterritoriais, tais como corrupção ativa em transação internacional ${ }^{382}$ e tráfico de influência em transação comercial internacional. ${ }^{383}$ Entretanto, a mera proliferação de acordos internacionais não é garantia de eficácia no combate à corrupção, embora revele um compromisso a respeito ${ }^{384}$ - vários países, paraísos físcais ou não, continuam a oferecer refúgio aos capitais oriundos de práticas corruptas, mesmo após a adesão a tais acordos internacionais.

Essa emenda ao Código Penal reflete a mudança geopolítica operada com o fim da Guerra Fria, fato que possibilitou trazer à tona assuntos politicamente inconvenientes para

\footnotetext{
$\overline{379}$ GLYNN, Patrick; KOBRIN, Stephen J.; NAÍM, Moisés. Globalização da corrupção. In: ELLIOT, Kimberly Ann (Org.). Op. cit. p. 54 . "Trata-se, o caso Seychelles, de um exemplo flagrante dos três tópicos principais deste capítulo. Em primeiro lugar: a globalização alterou drasticamente as feições da corrupção. Segundo: mesmo que mudanças recentes tenham aberto novos caminhos para a corrupção, em contrapartida elas criaram também condições que propiciam oportunidades nunca antes vistas para a contenção e até a redução dela. Terceiro: já que a corrupção se tornou um problema inerentemente global, os governos que agirem isoladamente só poderão obter pequenas conquistas. A colaboração e a coordenação sistemáticas entre as autoridades de diferentes países passaram a ser um pré-requisito indispensável para o sucesso na batalha contra a corrupção."

${ }^{380}$ Idem, p. 40.

${ }^{381}$ LIVIANU, Roberto. Op. cit. p. 178.

382 BRASIL. Código Penal. Art. 337-B. "Prometer, oferecer ou dar, direta ou indiretamente, vantagem indevida a funcionário público estrangeiro, ou a terceira pessoa, para determiná-lo a praticar, omitir ou retardar ato de ofício relacionado à transação comercial internacional: Pena - reclusão, de 1 (um) a 8 (oito) anos, e multa.”

383 BRASIL. Código Penal. Art. 337-C. "Solicitar, exigir, cobrar ou obter, para si ou para outrem, direta ou indiretamente, vantagem ou promessa de vantagem a pretexto de influir em ato praticado por funcionário público estrangeiro no exercício de suas funções, relacionado a transação comercial internacional: Pena - reclusão, de 2 (dois) a 5 (cinco) anos, e multa."

384 ACOSTA, Fernando. La corruption politique dans le cadre du nouvel ordre mondial. Revista Brasileira de Ciências Criminais, São Paulo: Revista dos Tribunais, p. 285. “[...] on constate que la prolifération d'instruments de lutte contre la corruption n'est pas un gage d'efficacité. Leur valeur assurée, tout semble l'indiquer, est avant tout symbolique, et à ce titre ils font état d'une volonté commune et partagée de reconnaître l'existence d'un problème qui afflige de manière par ailleurs fort distincte les membres de ce que l'on appelle la communauté internationale."
} 
nações capitalistas e socialistas. ${ }^{385}$ Assim, "essas mudanças no ambiente internacional trouxeram consigo pressões internas por reformas, decorrentes do crescimento da própria democracia". 386

\subsubsection{Identificação e localização do fato corrupção no direito administrativo}

Inexiste uma definição formal de corrupção no direito administrativo, o qual se contenta com as definições contidas no Código Penal. Essa interdependência teria reflexos, não fosse o fato de que "a absolvição na área criminal não implica a mesma solução para o processo administrativo, político ou civill". ${ }^{387}$ De fato, a diferença entre a repressão criminal e a administrativa "[...] não é ontológica: somente de grau. A falta disciplinar representa um minus com respeito ao crime. E a pena criminal um plus em relação à sanção disciplinar". ${ }^{388}$ Até mesmo as finalidades do combate à corrupção no direito administrativo são mais amplas: enquanto no direito penal a ênfase é principalmente na punição com objetivos de dissuasão, o direito administrativo também estabelece mecanismos de controle e de reparação dos danos.

Essas características adicionais defluem do princípio republicano. Se o regime de governo é o republicano, haverá responsabilização daqueles que, agindo de modo corrupto, causarem prejuízo patrimonial ao Estado. No caso dos ocupantes eleitos, a responsabilização pode, em tese, atingir as decisões puramente políticas que estiverem contaminadas pela corrupção e houverem causado prejuízo ao erário - se se reconhece que a decisão "manifestamente imprudente" enseja responsabilização do agente político ${ }^{389}$ o mesmo se deve admitir com relação ao ato praticado motivado pela corrupção.

\footnotetext{
385 GLYNN, Patrick; KOBRIN, Stephen J.; NAÍM, Moisés. A globalização da corrupção. In: ELLIOT, Kimberly Ann (Org.). Op. cit. p. 30-31. "O fim da Guerra Fria e o surgimento de uma economia internacional integrada de fato também contribuíram para a consciência generalizada acerca da corrupção como um problema dotado de ramificações inerentes globais. Com o fim da divisão do mundo em dois grandes blocos, a noção de interdependência em âmbito global ampliou-se."

${ }^{386}$ Idem, p. 32.

${ }^{387}$ LIVIANU, Roberto. Op. cit. p. 194. Hungria informa a respeito de certa divergência doutrinária sobre os efeitos da decisão penal sobre a esfera administrativa. Alguns como Temístocles Cavalcanti defendiam a completa independência. Por seu turno, Hungria subordina a esfera administrativa à penal, a fim de evitar a "incongruência de decisões". Assim, "a autonomia do poder disciplinar só se entende com os fatos que constituem, exclusivamente, faltas disciplinares. Fora daí, só é admissível a ação disciplinar no caso de absolvição do acusado no juízo penal, quando, embora afastada a identificação do fato imputado como crime, persista, residualmente, uma falta disciplinar. Apenas por este residuum poderá subsistir ou funcionar a instância administrativo disciplinar". HUNGRIA, Nélson. Comentários ao Código Penal (Dec.-Lei nº 2.848, de 7 de dezembro de 1940). v. 9, Art. 250 a 361. 2. ed. Rio de Janeiro: Forense, 1959. p. 325.

388 PAGLIARO, Antonio; COSTA JÚNIOR, Paulo José. Op. cit. p. 11. No mesmo sentido, ver HUNGRIA, Nélson. Op. cit. p. 317.

389 ATALIBA, Geraldo. Instituições de direito público e república. 1984. 215 f. Tese (Professor Titular)Faculdade de Direito, Universidade de São Paulo, São Paulo. p. 80. "Os excessos e os desvios de poder, porém,
} 
Durante o processo de separação entre as esferas pública e privada, uma das formas de evolução paralela foi a redução gradual da noção de irresponsabilidade estatal - o Estado era irresponsável, mas não os seus agentes, exceção feita ao soberano. ${ }^{390}$ Em princípio, a irresponsabilidade era ampla, mas se reduziu a partir do século XIX, restringindo-se apenas aos atos de conteúdo meramente político. ${ }^{391}$ Como desdobramento dessa restrição, houve também a redução do campo de atividade administrativa discricionária, que embute em si a noção de irresponsabilidade estatal, na medida em que o juízo de conveniência e oportunidade dos atos administrativos discricionários escaparia ao escrutínio do Judiciário - caminhou-se do direito privado aplicável para um regime especial à administração pública, norteado pelo interesse público.

A responsabilidade dos agentes públicos remete aos seus superiores no interior do próprio ente da máquina burocrática e, em última instância, quanto à chefia do Executivo. ${ }^{392} \mathrm{~A}$ responsabilidade perante os demais poderes cabe ao Chefe do Executivo, que é quem responde pela estrutura administrativa direta e indireta. Esse ponto é crucial para que se compreenda a distinção entre o tratamento dado às práticas corruptas pelo direito administrativo e pelo direito político-constitucional. $\mathrm{O}$ primeiro se refere à repressão e à prevenção administrativa, alheia e independente da esfera penal, à prática de improbidade administrativa, inclusive corrupção, por parte de funcionários públicos, entre os quais se pode incluir o Chefe do Executivo. No que tange ao direito político-constitucional, igualmente independente das esferas criminal e administrativa, questiona-se a responsabilidade política dos altos cargos do Estado, tais como presidente da República, ministros de Estado e ministros do Supremo Tribunal Federal (STF).

Esse regime de responsabilização no direito administrativo deflui da confiança sobre a qual se assenta o desempenho da atividade administrativa pelo funcionário publico, e a linha divisória do que é uma traição à confiança é dada pela dicotomia público-privado.

ao lado de decisões manifestamente imprudentes, dão ensejo a responsabilização civil: seja regressiva, seja originária, quando o lesado é o patrimônio público."

${ }^{390}$ MELLO, Celso Antônio Bandeira de. Curso de direito administrativo. 19. ed. São Paulo: Malheiros, 2005. p. 437.

${ }^{391}$ ATALIBA, Geraldo. Op. cit. p. 80. “A atenta consideração das exigências do regime leva à convicção de que também são passíveis os chefes do executivo de responderem civilmente, pelos danos que alguns de seus atos possam eventualmente provocar ao estado, ou a terceiros. Evidentemente, as decisões puramente políticas, adotadas no desempenho de competências regularmente exercitadas, ainda que danosas (guerra, atos que causam tumultos danosos, anulação de contratos, revogação de medidas de cunho financeiro, sanção ou veto de leis etc.), não podem acarretar nenhuma responsabilidade."

${ }^{392}$ Idem, p. 134. "Consubstancia-se a responsabilidade dos servidores no dever de responder (e correspondente submissão às sanções disciplinares) perante os escalões hierárquicos internos da Administração até o escalão máximo, o chefe do Poder Executivo. Isto porque a responsabilidade última perante o Legislativo e o Judiciário - pela fiel observância e acatamento das leis administrativas - é do próprio chefe do Executivo." 
Constitucionalmente, a vedação à corrupção pode ser associada a vários princípios constantes do art. 37 , tais como legalidade, impessoalidade, moralidade administrativa e publicidade. ${ }^{393}$

Ao lado dos mecanismos de controle interno da administração pública que preveem sanções aos infratores, tais como a Lei Complementar $\mathrm{n}^{\mathrm{o}}$ 101/2000 394 e o Estatuto do Funcionalismo Público, ${ }^{395}$ bem como algumas leis extravagantes mais antigas, ${ }^{396}$ um dos principais diplomas vigentes no direito administrativo, referencial em matéria de repressão da corrupção, ${ }^{397}$ é a Lei n⿳0 8.429/92 ("Lei de Improbidade Administrativa"). A probidade administrativa caracteriza-se por um padrão de comportamento que orienta como o funcionário público deve agir, ligando-se ao princípio da moralidade administrativa conforme explica Tácito, "a moralidade administrativa tem como diretrizes o dever de boa administração, a preservação dos bons costumes e a noção de equidade no confronto entre os interesse público e o dos administradores". ${ }^{398}$

A Lei $n^{0}$ 8.429/92 dispõe sobre as sanções aplicáveis aos agentes públicos, servidores ou não, nos casos de enriquecimento ilícito e improbidade administrativa no exercício de mandato, cargo, emprego ou função na administração direta, indireta ou fundacional de qualquer dos poderes da União, dos estados, do Distrito Federal, dos municípios ou, ainda, de empresa incorporada ao patrimônio público. ${ }^{399}$ Logo, ela é aplicável a todo agente público amplamente definido, ${ }^{400}$ reafirmando o princípio básico de que o causador do dano deverá

\footnotetext{
$\overline{393}$ BRASIL. Constituição (1988). Art. 37. "A administração pública direta e indireta de qualquer dos Poderes da União, dos Estados, do Distrito Federal e dos Municípios obedecerá aos princípios de legalidade, impessoalidade, moralidade, publicidade e eficiência e, também, ao seguinte."

${ }^{394}$ BRASIL. Lei Complementar $\mathrm{n}^{\mathrm{o}}$ 101, de 4 maio 2000.

${ }^{395}$ BRASIL. Lei $\mathrm{n}^{\mathrm{o}} \mathrm{8.112}$, de 11 dez. 1990.

${ }^{396}$ Ver itens 3.4.3 e 3.4.4, supra.

${ }^{397}$ Para uma relação de outros diplomas aplicáveis, ver itens 3.4 .3 e 3.4.4, supra.

398 TÁCITO, Caio. Improbidade administrativa como forma de corrupção. Revista Diálogo Jurídico, Salvador: CAJ - Centro de Atualização Jurídica, v. 1, n. 8, p. 1, nov. 2001.

399 BRASIL. Lei $\mathrm{n}^{\mathrm{O}}$ 8.429/92, de 2 jun. 1992. Art. $1^{\text {o }}$. "Os atos de improbidade praticados por qualquer agente público, servidor ou não, contra a administração direta, indireta ou fundacional de qualquer dos Poderes da União, dos Estados, do Distrito Federal, dos Municípios, de Território, de empresa incorporada ao patrimônio público ou de entidade para cuja criação ou custeio o erário haja concorrido ou concorra com mais de cinquienta por cento do patrimônio ou da receita anual, serão punidos na forma desta lei. Parágrafo único. Estão também sujeitos às penalidades desta lei os atos de improbidade praticados contra o patrimônio de entidade que receba subvenção, benefício ou incentivo, fiscal ou creditício, de órgão público, bem como daquelas para cuja criação ou custeio o erário haja concorrido ou concorra com menos de cinquienta por cento do patrimônio ou da receita anual, limitando-se, nestes casos, a sanção patrimonial à repercussão do ilícito sobre a contribuição dos cofres públicos."

${ }^{400}$ BRASIL. Lei $\mathrm{n}^{\mathrm{o}}$ 8.429/92, de 2 de jun. 1992. Art. $2^{\circ}$. "Reputa-se agente público, para os efeitos desta lei, todo aquele que exerce, ainda que transitoriamente ou sem remuneração, por eleição, nomeação, designação, contratação ou qualquer outra forma de investidura ou vínculo, mandato, cargo, emprego ou função nas entidades mencionadas no artigo anterior. Art. $3^{\circ}$. "As disposições desta lei são aplicáveis, no que couber, àquele que, mesmo não sendo agente público, induza ou concorra para a prática do ato de improbidade ou dele se beneficie sob qualquer forma direta ou indireta."
} 
indenizá-lo, ${ }^{401}$ bem como repetindo a tradicional pena de perdimento dos bens do infrator ${ }^{402} \mathrm{e}$ possibilitando o pedido de indisponibilidade dos bens do investigado. ${ }^{403}$ Institui, também, mecanismo preventivo destinado a conferir transparência à evolução patrimonial dos agentes públicos, exigindo apresentação da declaração de bens e valores que compõem seu patrimônio privado. ${ }^{404}$

Em sua sistemática, a Lei $\mathrm{n}^{\underline{0}} 8.429 / 92$ classifica os atos de improbidade administrativa naqueles (i) que importem em enriquecimento ilícito ("a obtenção de qualquer tipo de vantagem patrimonial indevida e sem justa causa, em razão do exercício do cargo, mandato, função ou emprego nas entidades às quais a lei se refere"), (ii) que causem prejuízos ao erário público ("a perda patrimonial, desvio, apropriação, malbaratamento ou dilapidação dos bens ou haveres das entidades às quais a lei faz referência”) e (iii) que atentem contra os princípios da administração pública ("qualquer ação ou omissão que viole os deveres de honestidade, imparcialidade, legalidade, e lealdade às instituições"). O diploma legal ainda arrola atos que caracterizam enriquecimento ilícito, ${ }^{405}$ prejuízo ao erário público ${ }^{406}$ e atentado

$\overline{{ }^{401} \text { BRASIL. Lei } \mathrm{n}^{\mathrm{O}}}$ 8.429/92, de 2 jun. 1992. Art. 5. "Ocorrendo lesão ao patrimônio público por ação ou omissão, dolosa ou culposa, do agente ou de terceiro, dar-se-á o integral ressarcimento do dano."

${ }^{402}$ BRASIL. Lei no ${ }^{\circ} 8.429 / 92$, de 2 jun. 1992. Art. $6^{\circ}$. "No caso de enriquecimento ilícito, perderá o agente público ou terceiro beneficiário os bens ou valores acrescidos ao seu patrimônio."

${ }^{403}$ BRASIL. Lei no $8.429 / 92$, de 2 jun. 1992. Art. $7^{\circ}$. "Quando o ato de improbidade causar lesão ao patrimônio público ou ensejar enriquecimento ilícito, caberá a autoridade administrativa responsável pelo inquérito representar ao Ministério Público, para a indisponibilidade dos bens do indiciado. Parágrafo único. A indisponibilidade a que se refere o caput deste artigo recairá sobre bens que assegurem o integral ressarcimento do dano, ou sobre o acréscimo patrimonial resultante do enriquecimento ilícito."

${ }^{404}$ BRASIL. Lei $\mathrm{n}^{\mathrm{o}}$ 8.429/92, de 2 jun. 1992. Art. 13.

${ }^{405}$ BRASIL. Lei $\mathrm{n}^{\mathrm{O}}$ 8.429/92, de 2 jun. 1992. Art. $9^{\circ}$. "Constitui ato de improbidade administrativa importando enriquecimento ilícito auferir qualquer tipo de vantagem patrimonial indevida em razão do exercício de cargo, mandato, função, emprego ou atividade nas entidades mencionadas no art. $1^{\circ}$ desta lei, e notadamente: I receber, para si ou para outrem, dinheiro, bem móvel ou imóvel, ou qualquer outra vantagem econômica, direta ou indireta, a título de comissão, percentagem, gratificação ou presente de quem tenha interesse, direto ou indireto, que possa ser atingido ou amparado por ação ou omissão decorrente das atribuições do agente público; II - perceber vantagem econômica, direta ou indireta, para facilitar a aquisição, permuta ou locação de bem móvel ou imóvel, ou a contratação de serviços pelas entidades referidas no art. $1^{\circ}$ por preço superior ao valor de mercado; III - perceber vantagem econômica, direta ou indireta, para facilitar a alienação, permuta ou locação de bem público ou o fornecimento de serviço por ente estatal por preço inferior ao valor de mercado; IV - utilizar, em obra ou serviço particular, veículos, máquinas, equipamentos ou material de qualquer natureza, de propriedade ou à disposição de qualquer das entidades mencionadas no art. $1^{\circ}$ desta lei, bem como o trabalho de servidores públicos, empregados ou terceiros contratados por essas entidades; $\mathrm{V}$ - receber vantagem econômica de qualquer natureza, direta ou indireta, para tolerar a exploração ou a prática de jogos de azar, de lenocínio, de narcotráfico, de contrabando, de usura ou de qualquer outra atividade ilícita, ou aceitar promessa de tal vantagem; VI - receber vantagem econômica de qualquer natureza, direta ou indireta, para fazer declaração falsa sobre medição ou avaliação em obras públicas ou qualquer outro serviço, ou sobre quantidade, peso, medida, qualidade ou característica de mercadorias ou bens fornecidos a qualquer das entidades mencionadas no art. $1^{\circ}$ desta lei; VII - adquirir, para si ou para outrem, no exercício de mandato, cargo, emprego ou função pública, bens de qualquer natureza cujo valor seja desproporcional à evolução do patrimônio ou à renda do agente público; VIII - aceitar emprego, comissão ou exercer atividade de consultoria ou assessoramento para pessoa física ou jurídica que tenha interesse suscetível de ser atingido ou amparado por ação ou omissão decorrente das atribuições do agente público, durante a atividade; IX - perceber vantagem econômica para intermediar a 
contra os princípios da administração pública. ${ }^{407}$ Embora este não caracterize diretamente uma confusão entre o público e o privado, algumas das condutas podem sê-lo, em particular quando insertas na dinâmica do jogo político. Cada um desses tipos de improbidade administrativa é sancionado diferentemente e independe da verificação de dano ao patrimônio público ou da aprovação ou rejeição das contas pelo órgão de controle interno ou pelo Tribunal de Contas. ${ }^{408}$ Criou-se também o tipo criminal de falsa denúncia de improbidade. ${ }^{409}$

liberação ou aplicação de verba pública de qualquer natureza; X - receber vantagem econômica de qualquer natureza, direta ou indiretamente, para omitir ato de ofício, providência ou declaração a que esteja obrigado; XI - incorporar, por qualquer forma, ao seu patrimônio bens, rendas, verbas ou valores integrantes do acervo patrimonial das entidades mencionadas no art. $1^{\circ}$ desta lei; XII - usar, em proveito próprio, bens, rendas, verbas ou valores integrantes do acervo patrimonial das entidades mencionadas no art. $1^{\circ}$ desta lei."

406 BRASIL. Lei $\mathrm{n}^{\mathrm{o}}$ 8.429/92, de 2 jun. 1992. Art. 10. "Constitui ato de improbidade administrativa que causa lesão ao erário qualquer ação ou omissão, dolosa ou culposa, que enseje perda patrimonial, desvio, apropriação, malbaratamento ou dilapidação dos bens ou haveres das entidades referidas no art. $1^{\circ}$ desta lei, e notadamente: I - facilitar ou concorrer por qualquer forma para a incorporação ao patrimônio particular, de pessoa física ou jurídica, de bens, rendas, verbas ou valores integrantes do acervo patrimonial das entidades mencionadas no art. $1^{\circ}$ desta lei; II - permitir ou concorrer para que pessoa física ou jurídica privada utilize bens, rendas, verbas ou valores integrantes do acervo patrimonial das entidades mencionadas no art. $1^{\circ}$ desta lei, sem a observância das formalidades legais ou regulamentares aplicáveis à espécie; III - doar à pessoa física ou jurídica, bem como ao ente despersonalizado, ainda que de fins educativos ou assistências, bens, rendas, verbas ou valores do patrimônio de qualquer das entidades mencionadas no art. $1^{\circ}$ desta lei, sem observância das formalidades legais e regulamentares aplicáveis à espécie; IV - permitir ou facilitar a alienação, permuta ou locação de bem integrante do patrimônio de qualquer das entidades referidas no art. $1^{\circ}$ desta lei, ou ainda a prestação de serviço por parte delas, por preço inferior ao de mercado; V - permitir ou facilitar a aquisição, permuta ou locação de bem ou serviço por preço superior ao de mercado; VI - realizar operação financeira sem observância das normas legais e regulamentares ou aceitar garantia insuficiente ou inidônea; VII - conceder benefício administrativo ou fiscal sem a observância das formalidades legais ou regulamentares aplicáveis à espécie; VIII - frustrar a licitude de processo licitatório ou dispensá-lo indevidamente; IX - ordenar ou permitir a realização de despesas não autorizadas em lei ou regulamento; X - agir negligentemente na arrecadação de tributo ou renda, bem como no que diz respeito à conservação do patrimônio público; XI - liberar verba pública sem a estrita observância das normas pertinentes ou influir de qualquer forma para a sua aplicação irregular; XII - permitir, facilitar ou concorrer para que terceiro se enriqueça ilicitamente; XIII - permitir que se utilize, em obra ou serviço particular, veículos, máquinas, equipamentos ou material de qualquer natureza, de propriedade ou à disposição de qualquer das entidades mencionadas no art. $1^{\circ}$ desta lei, bem como o trabalho de servidor público, empregados ou terceiros contratados por essas entidades. XIV - celebrar contrato ou outro instrumento que tenha por objeto a prestação de serviços públicos por meio da gestão associada sem observar as formalidades previstas na lei; XV - celebrar contrato de rateio de consórcio público sem suficiente e prévia dotação orçamentária, ou sem observar as formalidades previstas na lei."

${ }^{407}$ BRASIL. Lei $\mathrm{n}^{\mathrm{o}}$ 8.429/92, de 2 jun. 1992. Art. 11. "Constitui ato de improbidade administrativa que atenta contra os princípios da administração pública qualquer ação ou omissão que viole os deveres de honestidade, imparcialidade, legalidade, e lealdade às instituições, e notadamente: I - praticar ato visando fim proibido em lei ou regulamento ou diverso daquele previsto, na regra de competência; II - retardar ou deixar de praticar, indevidamente, ato de ofício; III - revelar fato ou circunstância de que tem ciência em razão das atribuições e que deva permanecer em segredo; IV - negar publicidade aos atos oficiais; V - frustrar a licitude de concurso público; VI - deixar de prestar contas quando esteja obrigado a fazê-lo; VII - revelar ou permitir que chegue ao conhecimento de terceiro, antes da respectiva divulgação oficial, teor de medida política ou econômica capaz de afetar o preço de mercadoria, bem ou serviço."

${ }^{408}$ BRASIL. Lei no 8.429/92, de 2 jun. 1992. Art. 21.

${ }^{409}$ BRASIL. Lei no $8.429 / 92$, de 2 jun. 1992. Art. 19. "Constitui crime a representação por ato de improbidade contra agente público ou terceiro beneficiário, quando o autor da denúncia o sabe inocente. Pena: detenção de seis a dez meses e multa. Parágrafo único. Além da sanção penal, o denunciante está sujeito a indenizar o denunciado pelos danos materiais, morais ou à imagem que houver provocado." 
Tabela 4 - Sanções previstas para os atos de improbidade administrativa

\begin{tabular}{|c|c|}
\hline $\begin{array}{l}\text { Tipo de improbidade } \\
\text { administrativa }\end{array}$ & Sanção \\
\hline Enriquecimento ilícito & $\begin{array}{l}\text { Perda dos bens ou valores acrescidos ilicitamente ao patrimônio, ressarcimento } \\
\text { integral do dano, quando houver, perda da função pública, suspensão dos } \\
\text { direitos políticos de oito a dez anos*, pagamento de multa civil de até três vezes } \\
\text { o valor do acréscimo patrimonial e proibição de contratar com o Poder Público } \\
\text { ou receber benefícios ou incentivos fiscais ou creditícios, direta ou } \\
\text { indiretamente, ainda que por intermédio de pessoa jurídica da qual seja sócio } \\
\text { majoritário, pelo prazo de dez anos** }\end{array}$ \\
\hline $\begin{array}{c}\text { Prejuízo ao erário } \\
\text { público }\end{array}$ & $\begin{array}{l}\text { Ressarcimento integral do dano, perda dos bens ou valores acrescidos } \\
\text { ilicitamente ao patrimônio, se concorrer esta circunstância, perda da função } \\
\text { pública, suspensão dos direitos políticos de cinco a oito anos, pagamento de } \\
\text { multa civil de até duas vezes o valor do dano e proibição de contratar com o } \\
\text { Poder Público ou receber benefícios ou incentivos fiscais ou creditícios, direta } \\
\text { ou indiretamente, ainda que por intermédio de pessoa jurídica da qual seja sócio } \\
\text { majoritário, pelo prazo de cinco anos*** }\end{array}$ \\
\hline $\begin{array}{l}\text { Atentado contra os } \\
\text { princípios da } \\
\text { administração pública }\end{array}$ & $\begin{array}{l}\text { Ressarcimento integral do dano, se houver, perda da função pública, suspensão } \\
\text { dos direitos políticos de três a cinco anos, pagamento de multa civil de até cem } \\
\text { vezes o valor da remuneração percebida pelo agente e proibição de contratar } \\
\text { com o Poder Público ou receber benefícios ou incentivos fiscais ou creditícios, } \\
\text { direta ou indiretamente, ainda que por intermédio de pessoa jurídica da qual seja } \\
\text { sócio majoritário, pelo prazo de três anos. }\end{array}$ \\
\hline
\end{tabular}

* BRASIL. Constituição (1988). “Art. 15. É vedada a cassação de direitos políticos, cuja perda ou suspensão só se dará nos casos de: [...] V - improbidade administrativa, nos termos do art. 37, § $4^{\circ}$ [...] Art. 37, § $4^{\circ}-$ Os atos de improbidade administrativa importarão a suspensão dos direitos políticos, a perda da função pública, a indisponibilidade dos bens e o ressarcimento ao erário, na forma e gradação previstas em lei, sem prejuízo da ação penal cabível."

** BRASIL. Lei $\mathrm{n}^{\circ}$ 8.429/92, de 2 jun. 1992. Art. 12, I.

*** BRASIL. Lei no ${ }^{\circ} 8.429 / 92$, de 2 jun. 1992. Art. 12, II.

**** BRASIL. Lei $\mathrm{n}^{\circ}$ 8.429/92, de 2 jun. de 1992. Art. 12, III.

\subsubsection{Identificação e localização do fato corrupção no direito político-constitucional}

Como no direito administrativo, a esfera político-constitucional não define precisamente os contornos do que seria corrupção. É ponto pacífico "que os exercentes de funções políticas agem debaixo de um estatuto social, viabilizado pelo mandato [...] $\mathrm{O}$ 
administrador continua a gerir coisa alheia. O dono continua sendo o povo". ${ }^{410}$ À semelhança dos deveres dos funcionários públicos não eleitos, essa relação de administração das coisas do povo decorre da confiança depositada para tal tarefa, e a corrupção aparece justamente quando há traição a essa confiança.

De um ponto de vista crítico, no tratamento de crimes de responsabilidade, as injunções de natureza política prevalecem, e, na maioria das ocasiões, o que importa é o jogo de poder. Ao atualizar clássica monografia sobre o impeachment antes da sua aplicação ao então Presidente Fernando Collor de Mello, Brossard manifesta seu ceticismo sobre o arcaico instituto, sugerindo que as mudanças efetuadas pela Constituição de 1988 o tornaram ainda menos aplicável ou de utilização mais difícil ainda. ${ }^{411}$ A responsabilidade de cunho político tem relação intrínseca com o processo de eleição e mesmo depois desta. Politicamente, a não reeleição seria a maior sanção aplicada ao mau administrador, maus políticos ou, ainda, partidos que se desviam de suas matrizes ideológicas e práticas não consoantes com o anunciado durante as eleições ou aquilo determinado pela Constituição. ${ }^{412}$ A solução seria a manutenção do regime democrático com periodicidade das eleições, para renovar o mandato e o compromisso do candidato, e a fidelidade do mandatário para com o eleitorado fica realçada com a breve periodicidade de sua renovação. ${ }^{413}$

A importância da periodicidade dos mandatos conduz ao debate sobre a conveniência da reeleição. Em tese, a reeleição possibilita à população "referendar" o bom desempenho do político, reconduzindo-o para um segundo mandato - os efeitos de renovação do compromisso com a população e fiscalização estariam preenchidos. Todavia - ao menos a realidade brasileira sugere -, se há algum ponto positivo nas eleições para o Legislativo, a reeleição para cargos do Executivo não goza dos mesmos benefícios.

$\mathrm{O}$ primeiro argumento contrário se refere exatamente à forma como a possibilidade de reeleição foi introduzida na Constituição. O presidente Fernando Henrique Cardoso, no

\footnotetext{
$\overline{410}$ ATALIBA, Geraldo. Op. cit. p. 103.

${ }^{411}$ BROSSARD, Paulo. O impeachment: aspectos da responsabilidade política do presidente da república. 3. ed. ampl. São Paulo: Saraiva, 1992. p. IX.

412 Idem, p. 72. "[...] essa responsabilidade política resolve-se, em regra, diante dos mandatários, das urnas. Essencialmente, na verdade, é pela reeleição, pela perda do prestígio, pelo comprometimento do partido - com todas as consequiências políticas, daí advindas - que se punem os desvios políticos, as omissões e os gestos contrários às grandes diretrizes consagradas pelo partido ou pela própria constituição."

${ }^{413}$ Idem, p. 75. "O próprio processo especial a que sujeito o chefe do executivo demonstra a dificuldade de discernir entre o cunho político e o cunho penal das transgressões cometidas. Daí o regime especial de apuração, processo e julgamento, em atenção à natureza do cargo, às peculiaridades das funções e ao inseparável cunho político que acompanha e informa os atos presidenciais. Daí a denominação sui generis de crime de responsabilidade e o tipo de punição em que desemboca: a perda do cargo (impeachment), com inabilitação [...] para o exercício de função pública."
} 
auge de sua popularidade, apoiado por muitos governadores e prefeitos, conseguiu que o Congresso Nacional aprovasse a reeleição na Emenda Constitucional $\mathrm{n}^{\mathrm{o}}$ 16, de 4 de junho de 1997, em meio a denúncias sobre troca de favores políticos e compra de votos de parlamentares. Além desse problema genético, coloca-se uma questão estrutural: ao não prever o afastamento do ocupante do Executivo, a reeleição se transforma, na maioria das vezes, no uso da máquina administrativa a favor do ocupante-candidato. Em que pese a vedação legal existente, tal prática ocorre em todos os partidos políticos, pelo menos de maneira velada. Uma vez mais, o espaço público é usado pelos interesses privados dos que ocupam o poder em nome do povo. No resumo de Rosas, "a reeleição não faz parte do processo político brasileiro e sempre foi repudiada, por ser uma fonte de barganha política para a manutenção do cargo"." ${ }^{414}$

Além disso, a concepção de que apenas as eleições teriam efeito depurador é parcialmente correta. Políticos podem praticar atos incompatíveis com os cargos para os quais foram eleitos, e a espera pelo ciclo eleitoral não oferece uma resposta rápida. De fato, crimes de responsabilidade e crimes comuns podem ocorrer ao mesmo tempo, ${ }^{415}$ embora processualmente o julgamento do primeiro deva ocorrer antes do segundo. ${ }^{416}$ Concordando com Tobias Barreto, Hungria prefere a expressão "crimes funcionais", uma vez que são "praticados pelos próprios exercentes do cargo, emprego ou função pública". ${ }^{417}$

Fora do processo eleitoral, o art. 85 da Constituição da República arrola as hipóteses de responsabilização política do presidente. ${ }^{418}$ Como ocorre em relação à responsabilização administrativa, a responsabilidade política é distinta da criminal, e muitas das condutas ali descritas se enquadram também em tipos criminais. ${ }^{419}$ Ainda, tais responsabilidades são independentes entre si: uma se dá por via de ação criminal, proposta pelo procurador-geral da República perante o STF, e a outra, a política, pelo procedimento de impeachment, conforme

\footnotetext{
$\overline{414}$ ROSAS, Roberto. A corrupção eleitoral. In: ZILVETI, Fernando Aurélio; LOPES, Silvia. O regime democrático e a corrupção política. São Paulo: Atlas, 2004. p. 146.

${ }^{415}$ LIVIANU, Roberto. Op. cit. p. 171.

${ }^{416}$ HUNGRIA, Nélson. Op. cit. p. 315.

${ }^{417}$ Idem, p. 315. A doutrina sugere a distinção entre crimes funcionais próprios, nos quais o exercício da função pública faz parte do tipo legal (v.g. prevaricação), e os impróprios, que constituiriam outros crimes que independem da condição de funcionário público ( $v . g$. violência arbitrária).

${ }^{418}$ BRASIL. Constituição (1988). Art. 85. "São crimes de responsabilidade os atos do Presidente da República que atentem contra a Constituição Federal e, especialmente, contra: I - a existência da União; II - o livre exercício do Poder Legislativo, do Poder Judiciário, do Ministério Público e dos Poderes constitucionais das unidades da Federação; III - o exercício dos direitos políticos, individuais e sociais; IV - a segurança interna do País; V - a probidade na administração; VI - a lei orçamentária; VII - o cumprimento das leis e das decisões judiciais."

${ }_{419}$ BROSSARD, Paulo. O impeachment: aspectos da responsabilidade política do presidente da república. 3. ed. ampl. São Paulo: Saraiva, 1992. p. 75.
} 
detalhada no procedimento da Lei $\mathrm{n}^{\mathrm{o}}$ 1.079/50, denominada Lei de Crimes de Responsabilidade. ${ }^{420}$ De fato, conforme ensina Ataliba, para o Executivo,

[...] certas responsabilidades surgem de modo diferente, põem-se de modo diverso. Efetivamente, responsabilidade penal, em razão das funções, só os exercentes de função executiva (chefe do executivo e secretários) a têm. O formidável poder pessoal do presidente, inerente ao presidencialismo, engendra a possibilidade de desvios gravíssimos; cria uma potencialidade danosa - seja às instituições, seja ao patrimônio público - incomensurável. ${ }^{421}$

Originariamente aplicável a atos cometidos pelo presidente da República, pelos ministros de Estado, pelos ministros do STF e pelo procurador-geral da República, mais tarde sua aplicação se estende a uma categoria bem mais ampla. A Constituição da República enquadra outros sujeitos ativos de crime de responsabilidade, tais como prefeitos, presidentes das câmaras de vereadores, ${ }^{422}$ membros do Conselho Nacional de Justiça e do Conselho Nacional do Ministério Público, ${ }^{423}$ membros do Ministério Público ${ }^{424}$ membros dos Tribunais Superiores, os do Tribunal de Contas da União e os chefes de missão diplomática de caráter permanente, ${ }^{425}$ bem como os governadores dos estados e do Distrito Federal, os desembargadores dos Tribunais de Justiça dos estados e do Distrito Federal, os membros dos Tribunais de Contas dos estados e do Distrito Federal, os dos Tribunais Regionais Federais, dos Tribunais Regionais Eleitorais e do Trabalho, os membros dos Conselhos ou Tribunais de Contas dos municípios e os do Ministério Público da União que oficiem perante tribunais. ${ }^{426} \mathrm{O}$ episódio do impeachment de Fernando Collor de Mello e vários outros casos nos diversos entes federativos afastam qualquer crítica quanto ao desuso dessa legislação, embora ela fique condicionada, em boa parte dos casos, à conjunção das forças políticas em dado momento.

Do ponto de vista material, os crimes de responsabilidade mais relacionados à corrupção figuram nos arts. 9 ("probidade administrativa"), ${ }^{427} 10$ ("lei orçamentária”) ${ }^{428}$ e 11

\footnotetext{
$\overline{{ }^{420}{\text { BRASIL. Lei } \mathrm{n}^{\mathrm{o}}}^{-}} 1.079$, de 10 abr. 1950.

${ }^{421}$ ATALIBA, Geraldo. Op. cit. p. 74.

${ }^{422}$ BRASIL. Constituição (1988). Art. 29.

${ }^{423}$ BRASIL. Constituição (1988). Art. 52, II.

${ }^{424}$ BRASIL. Constituição (1988). Art. 95, III.

425 BRASIL. Constituição (1988). Art. 102, I.

${ }^{426}$ BRASIL. Constituição (1988). Art. 105, I.

${ }^{427}$ BRASIL. Lei no $1079 / 50$, de 10 abr. 1950. Art. 9'. "São crimes de responsabilidade contra a probidade na administração: 1 - omitir ou retardar dolosamente a publicação das leis e resoluções do Poder Legislativo ou dos atos do Poder Executivo; 2 - não prestar ao Congresso Nacional dentro de sessenta dias após a abertura da sessão legislativa, as contas relativas ao exercício anterior; 3 - não tornar efetiva a responsabilidade dos seus subordinados, quando manifesta em delitos funcionais ou na prática de atos contrários à Constituição; 4 expedir ordens ou fazer requisição de forma contrária às disposições expressas da Constituição; 5 - infringir no provimento dos cargos públicos, as normas legais; 6 - Usar de violência ou ameaça contra funcionário público
} 
("guarda e o legal emprego dos dinheiros públicos") ${ }^{429}$ da Lei no ${ }^{\circ}$ 1079/50. Os outros tipos se referem mais a atentados contra as liberdades públicas e a organização estatal. Em geral, as condutas reprimidas não se referem somente à obtenção de vantagem pecuniária, mas trata principalmente de ações que visem dificultar a ação de fiscalização da administração pública por meio de práticas que distorcem a função pública, gerando vantagens mais de caráter político do que pecuniário.

Em matéria de controle preventivo da corrupção, há que citar o Código de Alta Conduta da Administração Federal, ${ }^{430}$ aplicável a ministros, secretários de Estado e ocupantes de cargos de primeiro escalão em entidades da administração indireta. ${ }^{431}$ Seu objetivo principal é esclarecer exatamente em que situações existe conflito de interesses - como reconhece a sua exposição de motivos, "o setor público passou a depender cada vez mais do recrutamento de profissionais oriundos do setor privado, o que exacerbou a possibilidade de conflito de interesses e a necessidade de maior controle sobre as atividades privadas do administrador público". Ainda que desnecessário, o Código esclarece que, "no exercício de suas funções, as autoridades públicas deverão pautar-se pelos padrões da ética, sobretudo no que diz respeito à integridade, à moralidade, à clareza de posições e ao decoro, com vistas a motivar o respeito e a confiança do público em geral". ${ }^{432}$

Apesar de a aplicação das sanções ter caráter eminentemente político, ${ }^{433}$ há várias regras de controle da atuação dos membros do alto escalão da administração pública, tais como os impedimentos imputados à autoridade pública após sua saída do cargo, entre os quais se encontram atuar, por quatro meses, em benefício ou em nome de pessoa física ou jurídica

para coagi-lo a proceder ilegalmente, bem como utilizar-se de suborno ou de qualquer outra forma de corrupção para o mesmo fim; 7 - proceder de modo incompatível com a dignidade, a honra e o decôro do cargo."

${ }^{428}$ BRASIL. Lei n⿳0 1079/50, de 10 abr. 1950. Art. 10. "São crimes de responsabilidade contra a lei orçamentária: 1 - não apresentar ao Congresso Nacional a proposta do orçamento da República dentro dos primeiros dois meses de cada sessão legislativa; 2 - exceder ou transportar, sem autorização legal, as verbas do orçamento; 3 realizar o estorno de verbas; 4 - infringir, patentemente, e de qualquer modo, dispositivo da lei orçamentária."

${ }^{429}$ BRASIL. Lei no ${ }^{\circ} 1079 / 50$, de 10 abr. 1950. Art. 11. "São crimes contra a guarda e legal emprego dos dinheiros públicos: 1 - ordenar despesas não autorizadas por lei ou sem observância das prescrições legais relativas às mesmas; 2 - abrir crédito sem andamento em lei ou sem as formalidades legais; 3 - Contrair empréstimo, emitir moeda corrente ou apólices, ou efetuar operação de crédito sem autorização legal; 4 - alienar imóveis nacionais ou empenhar rendas públicas sem autorização legal; 5 - negligenciar a arrecadação das rendas impostos e taxas, bem como a conservação do patrimônio nacional."

${ }^{430}$ BRASIL. Código de Conduta da Alta Administração Federal, de 22 ago. 2000.

${ }^{431}$ BRASIL. Código de Conduta da Alta Administração Federal, de 22 ago. 2000.

${ }^{432}$ BRASIL. Código de Conduta da Alta Administração Federal, de 22 ago. 2000.

${ }^{433}$ BRASIL. Código de Conduta da Alta Administração Federal, de 22 ago. 2000. Art. 17. "A violação das normas estipuladas neste Código acarretará, conforme sua gravidade, as seguintes providências: I - advertência, aplicável às autoridades no exercício do cargo; II - censura ética, aplicável às autoridades que já tiverem deixado o cargo. Parágrafo único. As sanções previstas neste artigo serão aplicadas pela CEP, que, conforme o caso, poderá encaminhar sugestão de demissão à autoridade hierarquicamente superior." 
que tenham tido sua participação em negócio ou procedimento administrativo, ou com quem tenha tido relação direta por conta de seu cargo. ${ }^{434}$ A quarentena é particularmente importante para cargos em que os critérios políticos se sobrepuseram aos técnicos e para os responsáveis por compras governamentais, quer em razão do seu poder decisório, quer em razão das informações privilegiadas detidas. ${ }^{435}$ No mesmo sentido, estabelece-se o dever às autoridades de declarar seu patrimônio na posse no $\operatorname{cargo}^{436}$ e "alterações relevantes no patrimônio da autoridade pública", ${ }^{437}$ bem como a vedação ao recebimento de favores, presentes ou remunerações não autorizados em lei. ${ }^{438}$ Também é traçada uma distinção entre presente e brinde, ${ }^{439}$ expurgando dúvidas eventuais sobre presentear autoridades com jet-skis seria permitido, como já aconteceu no passado.

A análise empreendida focou as hipóteses em que a corrupção se dá quando o seu ocupante já exerce o poder. Há, porém, mecanismos que atuam para o acesso ao poder, a saber o regime jurídico aplicável às inelegibilidades, ${ }^{40}$ que se dividem em absolutas e relativas. As inelegibilidades absolutas se referem aos analfabetos e aos que não podem ser alistados como eleitores. ${ }^{441}$ Já as inelegibilidades relativas decorrem de certas situações em que se reconhece a necessidade de limitar a participação de alguns candidatos - por motivos funcionais, não podem concorrer a um terceiro mandato os chefes do Executivo, ${ }^{442}$ bem como

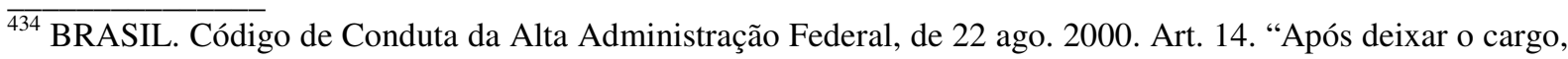
a autoridade pública não poderá: I - atuar em benefício ou em nome de pessoa física ou jurídica, inclusive sindicato ou associação de classe, em processo ou negócio do qual tenha participado, em razão do cargo; II prestar consultoria a pessoa física ou jurídica, inclusive sindicato ou associação de classe, valendo-se de informações não divulgadas publicamente a respeito de programas ou políticas do órgão ou da entidade da Administração Pública Federal a que esteve vinculado ou com que tenha tido relacionamento direto e relevante nos seis meses anteriores ao término do exercício de função pública."

${ }^{435}$ FEOLI, Ludovico. Quarentena. In: AVRITZER, Leonardo et al. (Org.). Corrupção: ensaios e críticas. Belo Horizonte: UFMG, 2008. p. 583-584.

${ }^{436}$ BRASIL. Código de Conduta da Alta Administração Federal, de 22 ago. 2000. Art. 4. "Além da declaração de bens e rendas de que trata a Lei n⿳0 8.730, de 10 de novembro de 1993, a autoridade pública, no prazo de dez dias contados de sua posse, enviará à Comissão de Ética Pública - CEP [...] informações sobre sua situação patrimonial que, real ou potencialmente, possa suscitar conflito com o interesse público, indicando o modo pelo qual irá evitá-lo."

${ }^{437}$ BRASIL. Código de Conduta da Alta Administração Federal, de 22 ago. 2000. Art. $5^{\circ}$.

${ }^{438}$ BRASIL. Código de Conduta da Alta Administração Federal, de 22 ago. 2000. Art. 80. "É permitido à autoridade pública o exercício não remunerado de encargo de mandatário, desde que não implique a prática de atos de comércio ou quaisquer outros incompatíveis com o exercício do seu cargo ou função, nos termos da lei."

439 BRASIL. Código de Conduta da Alta Administração Federal, de 22 ago. 2000. Art. 9. "É vedada à autoridade pública a aceitação de presentes, salvo de autoridades estrangeiras nos casos protocolares em que houver reciprocidade. Parágrafo único. Não se consideram presentes para os fins deste artigo os brindes que: I não tenham valor comercial; ou II - distribuídos por entidades de qualquer natureza a título de cortesia, propaganda, divulgação habitual ou por ocasião de eventos especiais ou datas comemorativas, não ultrapassem o valor de $\mathrm{R} \$ 100,00$ (cem reais)."

${ }^{440}$ SILVA, José Afonso da. Curso de direito constitucional positivo. 29. ed. São Paulo: Malheiros, 2007. p. 388.

${ }^{441}$ BRASIL. Constituição (1988). Art. 14, § $4^{\circ}$.

${ }^{442}$ BRASIL. Constituição (1988). Art. 14, § 5º
} 
estes somente podem se candidatar a outro cargo caso se afastem seis meses antes das eleições. ${ }^{443}$

Outro mecanismo da legislação eleitoral é a vedação ao abuso do poder econômico nas eleições por meio da limitação de despesas. ${ }^{444}$ A própria Constituição Federal reserva à matéria das inelegibilidades a proteção contra o abuso do poder econômico. ${ }^{445}$ Este constitui um meio muito capaz para influenciar as decisões políticas, conservando o próprio poder político ou atuando como meio para sua obtenção, preocupação existente nos Estados Unidos desde o século XIX que motivou a aprovação da legislação antitruste. Por esse motivo, vários sistemas políticos adotam o financiamento público das campanhas ${ }^{446}$ políticas, o que tem o condão de nivelar a competição entre os diversos candidatos. Ao se vetarem as doações de particulares, reduz-se o espectro que liga o candidato ao seu financiador, a fim de salvaguardar o interesse público dos interesses privados.

\subsection{Os agentes do combate à corrupção}

Os itens precedentes descreveram as principais regras do direito posto aplicáveis à regulamentação microjurídica do fato corrupção, a maioria das quais se volta contra a corrupção-suborno e a corrupção-favorecimento, e algumas das quais, mormente as do direito político-constitucional, enfrentam obliquamente o problema político relacionado à corrupçãosolapamento. Ao se debruçar sobre as regras vigentes, porém, constata-se que as violações à dicotomia público-privado se encontram relativamente bem delineados, embora haja sempre espaço para aperfeiçoamentos - veja-se a regra constante do Código de Conduta da Alta Administração Federal que permite a "participação em seminários, congressos e eventos

\footnotetext{
$\overline{443}$ BRASIL. Constituição (1988). Art. 14, § $6^{\circ}$.

${ }^{444}$ FERREIRA FILHO, Manoel Gonçalves. Corrupção e democracia. Revista de Direito Administrativo, Rio de Janeiro: Renovar, v. 226, p. 217, out./dez. 2001.

${ }^{445}$ BRASIL. Constituição (1988). Art. 14, § 9. "Lei complementar estabelecerá outros casos de inelegibilidade e os prazos de sua cessação, a fim de proteger a normalidade e legitimidade das eleições contra a influência do poder econômico ou o abuso do exercício de função, cargo ou emprego na administração direta ou indireta". BRASIL. Lei $\mathrm{n}^{\mathrm{o}}$ 4.737, de 15 jul. 1965. Art. 237. "A interferência do poder econômico e o desvio ou abuso do poder de autoridade, em desfavor da liberdade de voto, serão coibidos e punidos".

${ }^{446}$ CAGGIANO, Monica Herman S. Corrupção e financiamento das campanhas eleitorais. In: ZILVETI, Fernando Aurélio; LOPES, Silvia. Op. cit. p. 136. Embora o método de financiamento de campanhas eleitorais pelo Estado na Alemanha também esteja sujeito a falhas, "[...] sua mola mestre consiste em impor financiamento público para as campanhas político-eleitorais, o que implica identificar perfeitamente o volume e a origem dos recursos. Quanto aos gastos, prevê um ajuste entre as lideranças para a fixação de limites. Em suma, a solução germânica, que se destaca, também, pelo tratamento menos proibitivo, repousa sobre aportes públicos e, consequentemente, um rígido controle do destino destas verbas. A prestação de contas pública deve realizar-se sob os "princípios da correta contabilidade"".
} 
semelhantes, desde que tornada pública eventual remuneração, bem como o pagamento das despesas de viagem pelo promotor do evento, o qual não poderá ter interesse em decisão a ser tomada pela autoridade", ${ }^{447}$ sem atentar para as implicações. ${ }^{448}$

Entretanto, o problema da corrupção no Estado patrimonialista brasileiro esconde-se atrás das normas e se origina da sua relação com a sociedade. Não se trata de um problema de normas, mas sim de como as normas são operacionalizadas. Não se trata de um problema de direito posto, mas sim de direito pressuposto. Assim, a compreensão das instituições, imersas na teia das relações socioeconômicas, exige a avaliação de como são desempenhadas as funções decorrentes do direito posto de verniz modernizante. Serão analisados sucessivamente (i) o Poder Legislativo, (ii) o Tribunal de Contas, (iii) a polícia judiciária, (iv) o Ministério Público, (v) o Poder Judiciário, (vi) a Controladoria Geral da União, (vii) a recuperação de ativos e o combate à lavagem de dinheiro e (viii) a sociedade civil.

\subsubsection{O Poder Legislativo}

Antes de o Judiciário adquirir independência no desempenho da função jurisdicional e o Executivo criar mecanismos de controle interno, coube ao Poder Legislativo a fiscalização da administração pública. No que tange ao combate à corrupção, é possível identificar duas frentes principais de atuação.

De um lado, incumbe ao Legislativo votar e aprovar normas que desincentivem a prática de corrupção e estimulem a virtude - trata-se de modalidade de controle, voltado para o processo decisório, em que o Legislativo pode "apresentar, modificar, protelar e rejeitar projetos de lei". ${ }^{449}$ De outro lado, historicamente os parlamentares exercem fiscalização e controle sobre as atividades do Executivo. Dentro da noção de que o Executivo desempenha funções em nome do povo, o Legislativo, especialmente nos países em que vige o princípio da supremacia do Parlamento, fiscaliza as ações da administração pública enquanto representante do povo. ${ }^{450}$

\footnotetext{
$\overline{447}$ BRASIL. Código de Conduta da Alta Administração Federal, de 22 ago. 2000. Art. $7^{\circ}, \S$ único.

${ }^{448}$ GLYNN, Patrick; KOBRIN, Stephen J.; NAÍM, Moisés. A globalização da corrupção. In: ELLIOT, Kimberly Ann (Org.). A corrupção e a economia global. Trad. de Marsel Nascimento Gonçalves de Souza. Brasília: UnB, 2002. p. 42-43.

${ }^{449}$ LLANOS, Mariana; MUSTAPIC, Ana María. O controle parlamentar na Alemanha, na Argentina e no Brasil. In: LLANOS, Mariana; MUSTAPIC, Ana María (Org.). Controle parlamentar na Alemanha, na Argentina e no Brasil. Rio de Janeiro: Fundação Konrad Adenauer, 2005. p. 11.

${ }^{450}$ Idem, p. 12.
} 
Nessa segunda frente de atuação do Legislativo, a Constituição de 1988 confere ampla competência para o exercício dessa tarefa. Assim, o art. 70 estabelece que "a fiscalização contábil, financeira, orçamentária, operacional e patrimonial da União e das entidades da administração direta e indireta, quanto à legalidade, legitimidade, economicidade, aplicação das subvenções e renúncia de receitas, será exercida pelo Congresso Nacional, mediante controle externo, e pelo sistema de controle interno de cada Poder". ${ }^{451}$

No âmbito da fiscalização orçamentária, o Sistema Integrado de Administração Financeira do Governo Federal (Siafi), gerido desde 1987 pela Secretaria do Tesouro Nacional, permite que os parlamentares e a sociedade civil acompanhem a execução orçamentária $^{452}$ - o acesso é fácil e pode ser feito através da internet. Ao lado do Siafi, os parlamentares também podem convocar ministros e subordinados para prestar esclarecimentos, bem como requerer informações por escrito. ${ }^{453}$ Por fim, as Comissões Parlamentares de Inquérito (CPIs), dotadas de "poderes de investigação próprios das autoridades judiciais", ${ }^{454}$ apresentam resultados variados conforme a qualidade de seus membros e os interesses políticos que conflitam. Em que pese essa limitação, seus relatórios constituem uma interessante fonte sobre as práticas políticas que caracterizam a corrupção na perspectiva macrojurídica. Ademais, as conclusões das CPIs podem ser encaminhadas ao Ministério Público para que se tomem as providências cabíveis. ${ }^{455}$

\footnotetext{
$\overline{451}$ BRASIL. Constituição (1988). Art. 70.

452 SILVA, Marcos Araujo. A utilização do SIAFI nas atividades de fiscalização do Tribunal de Contas da União. 2008. 52 f. Monografia (Especialização em Orçamento Público)-Instituto Serzedello Corrêa do Tribunal de Contas da União, Centro de Formação, Treinamento e Aperfeiçoamento da Câmara dos Deputados e Universidade do Legislativo Brasileiro, do Senado Federal, Brasília. p. 12. “[...] o SIAFI passou a ser o instrumento da Administração Pública Federal para a execução do orçamento, para o controle das finanças e para o registro de todos os fatos ligados à gestão orçamentária, financeira, contábil e patrimonial da União. As previsões orçamentárias inicial e adicionais das receitas públicas; a fixação inicial e por meio de créditos adicionais das despesas públicas; as transferências constitucionais, legais e voluntárias efetuadas pela União para Estados, Distrito Federal, Municípios e entidades privadas sem fins lucrativos; o registro do recebimento de serviços e materiais; o pagamento a prestadores de serviço e fornecedores; o controle dos recursos arrecadados, dos créditos disponíveis para gasto, das disponibilidades de caixa e tantas outras operações são realizados por intermédio do SIAFI ou são por ele evidenciados."

${ }^{453}$ BRASIL. Constituição (1988). Art. 50. "A Câmara dos Deputados e o Senado Federal, ou qualquer de suas Comissões, poderão convocar Ministro de Estado ou quaisquer titulares de órgãos diretamente subordinados à Presidência da República para prestarem, pessoalmente, informações sobre assunto previamente determinado, importando crime de responsabilidade a ausência sem justificação adequada. [...] § $2^{\circ}$ - As Mesas da Câmara dos Deputados e do Senado Federal poderão encaminhar pedidos escritos de informações a Ministros de Estado ou a qualquer das pessoas referidas no caput deste artigo, importando em crime de responsabilidade a recusa, ou o não-atendimento, no prazo de trinta dias, bem como a prestação de informações falsas."

${ }^{454}$ BRASIL. Constituição (1988). Art. 58, § $3^{\circ}$.

${ }^{455}$ LIVIANU, Roberto. Op. cit. p. 174.
} 
No Brasil, o Legislativo tem sido mais foco de denúncias de corrupção, de modo que sua função de controle e fiscalização, inclusive da corrupção, fica relegada a segundo plano. Em algumas ocasiões, o Legislativo investiga as irregularidades cometidas dentro das suas próprias casas, deixando de investigar o Executivo, o que certamente agrada a seus ocupantes, que invariavelmente tentam, por meio da sua base de apoio, criar empecilhos para o funcionamento das CPIs. Parte dessas investigações diz respeito à forma como se verifica o relacionamento entre o Executivo e o Legislativo - compra de votos, troca de favores e indicação de apadrinhados, típicas situações de confusão entre as esferas pública e privada, ${ }^{456}$ parecem mais importantes para muitos parlamentares do que o desempenho das funções públicas. Talvez a explicação para a atual agenda do Congresso Nacional tenha origem em como, no Estado patrimonialista, foi historicamente estruturada sua relação com o Executivo.

\subsubsection{O Tribunal de Contas da União}

Frequentemente políticos reclamam das medidas de fiscalização tomadas pelo Tribunal de Contas da União (TCU), ao qual se atribui, por exemplo, a paralisação de obras e serviços suspeitos de superfaturamento e a suspensão de repasses a entes federativos que não prestam contas. As funções do TCU em relação ao amplo orçamento da União ampliam sua competência para todas as transferências de recursos, obrigatórias ou voluntárias, o que

\footnotetext{
$\overline{456}$ BRASIL. Congresso Nacional. Relatório parcial da Comissão Parlamentar Mista de Inquérito criada para apurar as denúncias de recebimento de quaisquer vantagens patrimoniais elou pecuniárias indevidas por membros do Congresso Nacional, com a finalidade de aprovar as matérias de interesse do Poder Executivo e as acusações do mesmo teor nas deliberações da Proposta de Emenda à Constituição $n^{\circ}$ 01/1995, que dispõe sobre a reeleição para mandatos executivos. Brasília, novembro de 2005, p. 39 e 70 . "No curso das investigações, sobrevieram descobertas acerca de condutas ilegais por parte de parlamentares e outros personagens que, embora graves, não possuem direta relação com o objeto desta Comissão, qual seja: a apuração da venda de votos por parte de parlamentares em troca de vantagens ou valores. Referimo-nos diretamente às confissões e denúncias da prática de 'caixa 2' nas campanhas de alguns parlamentares. Essas condutas, decerto criminosas e graves, deverão ser apuradas pelo Ministério Público. Todavia, não podem ser compulsadas por esta Comissão, à luz do preceito constitucional que determina que as comissões parlamentares de inquérito devem tratar de objeto determinado. Não será por outro motivo, senão o cívico respeito à Magna Lei Brasileira, que esta Comissão, na sede deste Relatório, não versará sobre esses assuntos. [...] No Relatório conjunto das CPMI, da Compra de Votos e dos Correios, foram relacionados os nomes dos beneficiados por tais cessões de recursos financeiros. O Relatório conjunto, no entanto, restringe-se aos nomes de parlamentares beneficiados, tanto os que não alcançaram justificativas aceitáveis para o recebimento das importâncias recebidas, quanto os poucos que, claramente, as identificavam como financiamento de despesas das respectivas campanhas de que participaram, no âmbito estritamente municipal, no ano de 2004." A CPMI não emitiu relatório final devido a divergências político-partidárias.
} 
significa que uma decisão do tribunal pode impactar não somente ações federais, mas também as municipais e estaduais. ${ }^{457}$

Ao se analisar a estrutura do TCU, as críticas sobre uma eventual atuação predominantemente política nas suas ações parecem improváveis, embora as omissões já tenham sido objeto de crítica na CPMI do Orçamento em 1994. ${ }^{458}$ O TCU tem sede no Distrito Federal, quadro de pessoal próprio e atuação em âmbito nacional. É um órgão autônomo, sem vínculo de subordinação com o Poder Legislativo, apesar de ser auxiliar deste. A origem dos seus nove ministros é mais diversificada, se comparada ao STF: (i) um terço dos ministros é indicado pelo presidente da República com base numa lista tríplice mediante aprovação do Senado Federal, sendo que dois serão, alternadamente, auditores e membros do Ministério Público junto ao TCU; (ii) e dois terços são indicados livremente pelo Congresso Nacional. ${ }^{459}$

Embora não se possam descartar injunções político-partidárias, a composição diversificada do TCU tende a lhe atribuir uma atuação eminentemente técnica no auxílio do Congresso Nacional no controle externo fiscalizatório a posteriori da União. Tal assistência é necessária devido à grande envergadura das funções desempenhas pelo Estado e à complexidade das questões orçamentárias - já nos anos 1950, Almeida alertava para as dificuldades de levar a efeito investigações sobre casos complexos, usando como exemplo os ilícitos criminais relacionados à gestão orçamentária. ${ }^{460}$

Basicamente, o TCU desempenha o chamado "controle financeiro público", que consiste no "conjunto de medidas de natureza fiscalizatória, exercidas sobre o movimento de dinheiros e bens valiosos, de natureza econômica, manejados por administradores públicos,

\footnotetext{
$\overline{457}$ Devido a essa repercussão mais ampla, a análise se foca apenas no TCU, embora todos os estados e os municípios de São Paulo e Rio de Janeiro também possuam Tribunais de Contas.

458 BRASIL. Congresso Nacional. Relatório final da Comissão Parlamentar Mista de Inquérito. Congresso Nacional. Criada através do Requerimento $n^{\circ}$ 151/93-CN, destinada a "apurar fatos contidos nas denúncias do Sr. José Carlos Alves dos Santos, referentes às atividades de parlamentares, membros do Governo e representantes de empresas envolvidas na destinação de recursos do Orçamento da União". Vol. III, Brasília, janeiro de 1994, p. V.III - 15. "Infelizmente, verificam-se inúmeros casos de irregularidades que, não vindo a público, compõem processos que permanecem estacionados por longo tempo, até que, ao serem julgados, findam por ser arquivados, muitas vezes pela prescrição do direito de ressarcimento ou pelo próprio falecimento do responsável pela irregularidade. O acompanhamento dos resultados apresentados pelo Tribunal de Contas da União pode ser tarefa atribuída às comissões de fiscalização e controle do Senado e da Câmara.”

${ }^{459}$ BRASIL. Constituição (1988). Art. 73.

${ }^{460}$ ALMEIDA, Fernando H. M. Op. cit. p. 49. Ao se referir ao crime previsto no artigo 315 do Código Penal, discorre Almeida: "Mas quem poderia, na maioria das vezes, sair a campo com a acusação fundamentada de que o se fala é, em direito penal, apenas um crime? Em verdade, uma denúncia tal sobre corre o risco de ver-se diluída pelos artifícios de algum hábil contabilista, não aproveitaria a um pequeno funcionário que tivesse ciência do fato. Quanto aos grandes funcionários, porque receiem eles, ainda que deliberadamente, vir a cair no mesmo delito e porque, geralmente, são obumbrados pela mais desatinada paixão pela chamada 'política', calam-se. E a tutela penal, já de si irrisória, porque prevê pena leve e de caráter optativo, redunda em inutilidade, salvo se, por vingança de 'política partidária', houver interesse subalterno de um alto funcionário, desavido com outro, de, então, transformar a justiça em arma do seu revide.”
} 
debaixo da relação de administração. Fiscalizar significa contrastar - para averiguar de sua adequação - uma atividade com as normas que a disciplinam". ${ }^{461} \mathrm{Na}$ Constituição de 1988, as prerrogativas do TCU foram substancialmente ampliadas, se comparadas às das Constituições anteriores, notadamente a de 1967, devido ao aumento de atribuições do Poder Legislativo. O TCU recebeu poderes para auxiliar o Congresso Nacional na fiscalização contábil, financeira, orçamentária, operacional e patrimonial da União e das entidades da administração direta e indireta, quanto à legalidade, legitimidade, economicidade, aplicação das subvenções e renúncia de receitas. ${ }^{462}$

As competências do TCU estão estabelecidas nos arts. 71 e $74^{463}$ da Constituição. ${ }^{464}$ Com o objetivo de dar diretrizes para a atividade do TCU, foi editada a Lei $n^{0}$ 8.443/92, que dispõe sobre a sua organização e a sua administração interna, bem como especifica as competências previstas na Constituição. ${ }^{465}$ Aprovada pouco antes das investigações da CPMI do Orçamento, a Lei $\mathrm{n}^{\mathrm{o}}$ 8.443/92 não incorporou as sugestões feitas no relatório final e apresenta até mesmo algumas inconsistências que indicam que sua elaboração talvez tenha sido influenciada pela "Máfia do Orçamento". ${ }^{466}$ Nesse sentido, o $§ 1^{\circ}$ do art. 55 dispunha que "ao decidir, caberá ao Tribunal manter ou não o sigilo quanto ao objeto e à autoria da denúncia". O STF decidiu que a expressão "manter ou não o sigilo quanto ao objeto e à autoria da denúncia" é inconstitucional, o que motivou o Senado a suspender sua execução. ${ }^{467}$

A função de controle financeiro público confere ao TCU as seguintes atribuições: apreciar, para fins de registro, a legalidade: (i) dos atos de admissão do pessoal, a qualquer título, na administração direta e indireta e nas fundações instituídas e mantidas pelo Poder

\footnotetext{
${ }_{461}$ ATALIBA, Geraldo. Op. cit. p. 84.

462 BRASIL. Constituição (1988). Art. 70.

${ }^{463}$ BRASIL. Constituição (1988). Art. 74. “Os Poderes Legislativo, Executivo e Judiciário manterão, de forma integrada, sistema de controle interno com a finalidade de: I - avaliar o cumprimento das metas previstas no plano plurianual, a execução dos programas de governo e dos orçamentos da União; II - comprovar a legalidade e avaliar os resultados, quanto à eficácia e eficiência, da gestão orçamentária, financeira e patrimonial nos órgãos e entidades da administração federal, bem como da aplicação de recursos públicos por entidades de direito privado; III - exercer o controle das operações de crédito, avais e garantias, bem como dos direitos e haveres da União; IV - apoiar o controle externo no exercício de sua missão institucional."

${ }^{464}$ DI PIETRO, Maria Sylvia Zanella. Direito administrativo. 20. ed. São Paulo: Atlas, 2007. p. 688. Di Pietro classifica as funções do TCU da seguinte maneira: (a) fiscalização financeira propriamente dita, (b) de consulta, (c) de informação e de julgamento, (d) sancionatórias (e) corretivas; e (f) de ouvidor, podendo, ainda, ser acrescida a função de denúncia de irregularidades.

${ }^{465}$ BRASIL. Lei no 8.443 , de 16 jul. 1992.

${ }^{466}$ Ver item 7.5.1.2, infra.

${ }^{467}$ BRASIL. Senado Federal. Resolução no 16 , de 14 mar. 2006. Art. 1 . "É suspensa a execução da expressão 'manter ou não o sigilo quanto ao objeto e à autoria da denúncia' constante do $\S 1^{\circ}$ do art. 55 da Lei Federal $n^{\circ}$ 8.443, de 16 de julho de 1992 e do contido no disposto no Regimento Interno do Tribunal de Contas da União, quanto à manutenção do sigilo em relação à autoria de denúncia, em virtude de declaração de inconstitucionalidade em decisão definitiva do Supremo Tribunal Federal, nos autos do Mandado de Segurança n 24.405-4 - Distrito Federal."
} 
Público, excetuadas as nomeações para cargo de provimento em comissão; (ii) das concessões de aposentadorias, reformas e pensões, ressalvadas as melhorias posteriores que não alterem o fundamento legal do ato concessório; ${ }^{468}$ realizar, por iniciativa própria, da Câmara dos Deputados, do Senado Federal, de comissão técnica ou de inquérito, inspeções e auditorias de natureza contábil, financeira, orçamentária, operacional e patrimonial, nas unidades administrativas dos poderes Legislativo, Executivo e Judiciário e da administração indireta, incluídas as fundações e sociedades instituídas e mantidas pelo Poder Público federal; fiscalizar as contas nacionais das empresas supranacionais de cujo capital social a União participe, de forma direta ou indireta, nos termos do tratado constitutivo; e fiscalizar a aplicação de quaisquer recursos repassados pela União mediante convênio, acordo, ajuste ou outros instrumentos congêneres, a estado, ao Distrito Federal ou a município. ${ }^{469}$

No que diz respeito à função de consulta, compete ao TCU apreciar as contas prestadas anualmente pelo presidente da República, mediante parecer prévio que deverá ser elaborado em 60 dias a contar de seu recebimento. ${ }^{470}$ Adicionalmente, a legislação infraconstitucional prevê as seguintes atribuições ao TCU relacionadas a essa função: decidir sobre consulta que lhe seja formulada por autoridade competente, a respeito de dúvida suscitada na aplicação de dispositivos legais e regulamentares concernentes a matéria de sua competência. ${ }^{471} \mathrm{~A}$ resposta à consulta tem caráter normativo e constitui prejulgamento da tese, mas não do fato ou caso concreto. Ademais, as contas prestadas anualmente pelo presidente da República consistirão nos balanços gerais da União e no relatório do órgão central do sistema de controle interno do Poder Executivo sobre a execução dos orçamentos de que trata o $\S 5^{\circ}$ do art. 165 da Constituição Federal. ${ }^{472}$

A função de informação diz respeito à competência do TCU para prestar as informações solicitadas pelo Congresso Nacional, por qualquer de suas Casas, ou por

\footnotetext{
$\overline{468}$ SILVA, José Afonso da. Op. cit. p. 755.

${ }^{469}$ BRASIL. Constituição (1988). Art. 71, inc. III a VI. Ao prever as atribuições ao TCU relacionadas à função de fiscalização financeira, os arts. $1^{\circ}$ e 41 da Lei $n^{0} 8.443 / 92$ repetem as atribuições constitucionais, dentre as quais se destacam: (i) acompanhar a) a lei relativa ao plano plurianual, a lei de diretrizes orçamentárias, a lei orçamentária anual e a abertura de créditos adicionais; b) os editais de licitação, os contratos, inclusive administrativos, e os convênios, acordos, ajustes ou outros instrumentos congêneres; (ii) realizar inspeções e auditorias; (iii) fiscalizar as contas nacionais das empresas supranacionais de cujo capital social a União participe; (iv) fiscalizar a aplicação de quaisquer recursos repassados pela União mediante convênio, acordo, ajuste ou outros instrumentos congêneres, a estado, ao Distrito Federal ou a município.

${ }^{470}$ BRASIL. Constituição (1988). Art. 71, I.

${ }^{471}$ BRASIL. Lei $\mathrm{n}^{\mathrm{o}} 8.443$, de 16 jul. 1992. Art. $1^{\text {o }}$, inc. XVII.

${ }^{472}$ BRASIL. Lei $\mathrm{n}^{\mathrm{o}}$ 8.443, de 16 jul. 1992. Art. 36. "Ao Tribunal de Contas da União compete, na forma estabelecida no Regimento Interno, apreciar as contas prestadas anualmente pelo Presidente da República, mediante parecer prévio a ser elaborado em sessenta dias a contar de seu recebimento. Parágrafo único. As contas consistirão nos balanços gerais da União e no relatório do órgão central do sistema de controle interno do Poder Executivo sobre a execução dos orçamentos de que trata o $§ 5^{\circ}$ do art. 165 da Constituição Federal.”
} 
qualquer das respectivas comissões, sobre a fiscalização contábil, financeira, orçamentária, operacional e patrimonial e sobre resultados de auditorias e inspeções realizadas. ${ }^{473}$ Segundo a legislação infraconstitucional, compete também ao TCU emitir pronunciamento conclusivo sobre matéria que seja submetida a sua apreciação pela comissão mista permanente de senadores e deputados, bem como auditar, por solicitação da Comissão Mista de Orçamento ${ }^{474}$ ou de comissão técnica de qualquer das Casas do Congresso Nacional, projetos e programas autorizados na lei orçamentária anual, avaliando os seus resultados quanto à eficácia, eficiência e economicidade.

No que concerne à função de julgamento, ao TCU incumbe decidir sobre as contas dos administradores e demais responsáveis por dinheiros, bens e valores públicos da administração direta e indireta, incluídas as fundações e sociedades instituídas e mantidas pelo Poder Público federal, e as contas daqueles que derem causa a perda, extravio ou outra irregularidade de que resulte prejuízo ao erário público. ${ }^{475}$ As contas dos administradores e responsáveis serão anualmente submetidas a julgamento do tribunal, sob forma de tomada ou prestação de contas, organizadas de acordo com as normas estabelecidas em instrução normativa. ${ }^{476}$ Além disso, a autoridade administrativa competente deverá imediatamente adotar providências com vistas à instauração da tomada de contas especial para apuração dos fatos, identificação dos responsáveis e quantificação do dano nos seguintes casos, sob pena de responsabilidade solidária: (a) diante da omissão no dever de prestar contas; (b) da não comprovação da aplicação dos recursos repassados pela União, na forma prevista em lei; (c) da ocorrência de desfalque ou desvio de dinheiros, bens ou valores públicos; ou, ainda, (d) da prática de qualquer ato ilegal, ilegítimo ou antieconômico de que resulte dano ao erário. ${ }^{477} \mathrm{O}$ tribunal decidirá se as contas são regulares, regulares com ressalva ou irregulares. ${ }^{478}$ Por esse motivo, o TCU expediu as Súmulas $n^{\circ} 78$ e 88:

\footnotetext{
$\overline{473}$ BRASIL. Constituição (1988). Art. 71, inc. VII.

${ }^{474}$ BRASIL. Constituição (1988). Art. 166.

${ }^{475}$ BRASIL. Constituição (1988). Art. 71, inc. II.

${ }^{476}$ BRASIL. Lei no ${ }^{\circ}$ 8.443, de 16 jul. 1992. Art. $7^{\circ}$, caput. "As contas dos administradores e responsáveis a que se refere o artigo anterior serão anualmente submetidas a julgamento do Tribunal, sob forma de tomada ou prestação de contas, organizadas de acordo com normas estabelecidas em instrução normativa."

477 BRASIL. Lei $\mathrm{n}^{\mathrm{O}}$ 8.443, de 16 jul. 1992. Art. 8. "Diante da omissão no dever de prestar contas, da não comprovação da aplicação dos recursos repassados pela União, na forma prevista no inciso VII do art. $5^{\circ}$ desta Lei, da ocorrência de desfalque ou desvio de dinheiros, bens ou valores públicos, ou, ainda, da prática de qualquer ato ilegal, ilegítimo ou antieconômico de que resulte dano ao Erário, a autoridade administrativa competente, sob pena de responsabilidade solidária, deverá imediatamente adotar providências com vistas à instauração da tomada de contas especial para apuração dos fatos, identificação dos responsáveis e quantificação do dano."

478 BRASIL. Lei no 8.443, de 16 jul. 1992. Art. 15. “Ao julgar as contas, o Tribunal decidirá se estas são regulares, regulares com ressalva, ou irregulares."
} 
Com o sistema de controle externo, instituído pela Constituição de 1988 e disciplinado em legislação ordinária pertinente, não compete ao Tribunal de Contas da União julgar ou aprovar previamente contratos, convênios, acordos ou ajustes celebrados pela Administração Pública. Pode, todavia, o Tribunal, no exercício da auditoria financeira e orçamentária e com vistas ao julgamento das contas dos responsáveis ou entidades sob a sua ilegalidade ou irregularidade, adotar providências no sentido de saná-la ou evitar a sua reincidência. ${ }^{479}$

Não é da competência do tribunal de Contas da União o julgamento ou a aprovação, prévia ou a posteriori, de minutas ou termos de convênios, ajustes, acordos, e contratos de abertura de crédito, financiamentos, ou empréstimo, celebrados, com a vinculação, em garantia, de quotas dos Fundos de Participação. Pode, todavia, o Tribunal, no exercício da auditoria financeira e orçamentária e com vistas ao julgamento da regularidade das contas relativas à movimentação e aplicação dos recursos provenientes daqueles Fundos, expedir Instruções sobre a matéria ou, ainda, tomar conhecimento dos respectivos termos, para verificar ilegalidade ou irregularidade, adotar providências no sentido de saná-la ou evitar a sua reincidência. ${ }^{480}$

A função sancionatória atribui ao TCU a competência de aplicar aos responsáveis, em caso de ilegalidade de despesa ou irregularidade de contas, as sanções previstas em lei, que estabelecerá, entre outras cominações, multa proporcional ao dano causado ao erário. ${ }^{481}$ As decisões do TCU de que resulte imputação de débito ou multa terão eficácia de título executivo. ${ }^{482}$ Nessa hipótese, o responsável será notificado para recolher o valor devido em 15 dias. Caso o responsável não recolha tempestivamente a importância devida, será formalizado processo de cobrança executiva, que será encaminhado ao Ministério Público junto ao TCU para, por meio da Advocacia-Geral da União ou das unidades jurisdicionadas ao TCU, realizar a cobrança judicial da dívida ou o arresto dos bens.

Quando o responsável for julgado em débito, o TCU poderá aplicar-lhe multa de até $100 \%$ do valor atualizado do dano causado ao erário. ${ }^{483}$ O TCU poderá aplicar multas aos responsáveis por: (i) contas julgadas irregulares de que não resulte débito; (ii) ato praticado com grave infração à norma legal ou regulamentar de natureza contábil, financeira, orçamentária, operacional e patrimonial; (iii) ato de gestão ilegítimo ou antieconômico de que resulte injustificado dano ao erário; (iv) não atendimento, no prazo fixado, sem causa justificada, a diligência do relator ou a decisão do Tribunal; (v) obstrução ao livre exercício

\footnotetext{
$\overline{{ }^{479} \text { BRASIL. Tribunal de Contas da União. Súmula no }}{ }^{\text {7 }}$ 78, de 25 nov. 1976. Presidente do TCU Ministro Wagner Estelita Campos. Relator: Ministro Luiz Octávio Gallotti. Diário Oficial da União. Brasília 16 dez. 1976.

${ }^{480}$ BRASIL. Tribunal de Contas da União. Súmula no 88, de 25 nov. 1976. Presidente do TCU Ministro Wagner Estelita Campos. Relator: Ministro Luiz Octávio Gallotti. Diário Oficial da União. Brasília 16 dez. 1976.

${ }^{481}$ BRASIL. Constituição (1988). Art. 71, inc. VIII.

${ }^{482}$ BRASIL. Constituição (1988). Art. 71. § $3^{\circ}$. "As decisões do Tribunal de que resulte imputação de débito ou multa terão eficácia de título executivo."

${ }^{483}$ BRASIL. Lei no 8.443/92. Art. 57. "Quando o responsável for julgado em débito, poderá ainda o Tribunal aplicar-lhe multa de até cem por cento do valor atualizado do dano causado ao Erário.”
} 
das inspeções e auditorias determinadas; (vi) sonegação de processo, documento ou informação, em inspeções ou auditorias realizadas pelo TCU; (vii) reincidência no descumprimento de determinação do TCU. ${ }^{484}$ Sem prejuízo das sanções previstas e das penalidades administrativas, aplicáveis pelas autoridades competentes, por irregularidades constatadas pelo TCU, sempre que este, por maioria absoluta de seus membros, considerar grave a infração cometida, o responsável ficará inabilitado, por um período que variará de cinco a oito anos, para o exercício de cargo em comissão ou função de confiança no âmbito da administração pública.

A função corretiva é uma das mais relevantes do TCU. Quando verificar ilegalidade em atos administrativos, o TCU poderá determinar prazo para que o órgão ou entidade adote as providências necessárias ao exato cumprimento da lei - se não atendido, o TCU pode sustar a execução do ato impugnado, comunicando a decisão à Câmara dos Deputados e ao Senado Federal. ${ }^{485}$

No entanto, essa atribuição do TCU é enfraquecida em relação aos contratos administrativos, pois o ato de sustação será adotado diretamente pelo Congresso Nacional nessas hipóteses. Quando isso ocorrer, o Congresso tem a competência para solicitar ao Executivo as medidas cabíveis. Se dentro de 90 dias o Congresso Nacional ou o Executivo não efetivar as medidas previstas, o TCU decidirá a respeito ${ }^{486}$ - Torres critica essa competência do TCU por ferir a separação entre os poderes. ${ }^{487}$ Quanto às licitações e aos

\footnotetext{
$\overline{484}$ BRASIL. Lei $\mathrm{n}^{\mathrm{o}}$ 8.443, de 16 jul. 1992. Art. 58. "O Tribunal poderá aplicar multa de Cr\$ 42.000.000,00 (quarenta e dois milhões de cruzeiros), ou valor equivalente em outra moeda que venha a ser adotada como moeda nacional, aos responsáveis por: I - contas julgadas irregulares de que não resulte débito, nos termos do parágrafo único do art. 19 desta Lei; II - ato praticado com grave infração à norma legal ou regulamentar de natureza contábil, financeira, orçamentária, operacional e patrimonial; III - ato de gestão ilegítimo ou antieconômico de que resulte injustificado dano ao Erário; IV - não atendimento, no prazo fixado, sem causa justificada, a diligência do Relator ou a decisão do Tribunal; V - obstrução ao livre exercício das inspeções e auditorias determinadas; VI - sonegação de processo, documento ou informação, em inspeções ou auditorias realizadas pelo Tribunal; VII - reincidência no descumprimento de determinação do Tribunal.”

${ }^{485}$ BRASIL. Constituição (1988). Art. 71, incisos IX e X.

486 BRASIL. Constituição (1988). Art. 71, §§ $1^{\circ}$ e $2^{\circ}$. Quanto aos atos sujeitos a registro, ainda no que diz respeito à função corretiva, a Lei $\mathrm{n}^{\mathrm{o}}$ 8.443/92 prevê que o relator presidirá a instrução do processo, determinando, mediante despacho singular, por sua ação própria e direta, ou por provocação do órgão de instrução ou do Ministério Público junto ao Tribunal, a adoção das providências consideradas necessárias ao saneamento dos autos, fixando prazo, na forma estabelecida no Regimento Interno, para o atendimento das diligências, após o que submeterá o feito ao Plenário ou à Câmara respectiva para decisão de mérito. BRASIL. Lei $\mathrm{n}^{\mathrm{o}}$ 8.443, de 16 jul. 1992. Art. 40. "O Relator presidirá a instrução do processo, determinando, mediante despacho singular, por sua ação própria e direta, ou por provocação do órgão de instrução ou do Ministério Público junto ao Tribunal, a adoção das providências consideradas necessárias ao saneamento dos autos, fixando prazo, na forma estabelecida no Regimento Interno, para o atendimento das diligências, após o que submeterá o feito ao Plenário ou à Câmara respectiva para decisão de mérito."

${ }^{487}$ TORRES, Ricardo Lobo. Tratado de direito constitucional, financeiro e tributário. v. 5. (O orçamento na Constituição). 3. ed. atual. Até 31.12.2007, incluindo a Emenda Constitucional nº 56, de 20.12.2007. Rio de Janeiro: Renovar, 2008. p. 479.
} 
contratos, a mesma lei dispõe que o TCU comunicará às autoridades competentes o resultado das inspeções e auditorias que realizar, para que sejam tomadas as medidas saneadoras das impropriedades e das faltas identificadas. ${ }^{488}$ Verificada a ilegalidade de ato ou contrato, o TCU assinará prazo para que o responsável adote as providências necessárias ao exato cumprimento da lei, fazendo indicação expressa dos dispositivos a observar - se for ato administrativo, o TCU sustará a execução do ato impugnado e, se for contrato, comunicará o fato ao Congresso Nacional, ao qual compete adotar o ato de sustação e solicitar ao Executivo as medidas cabíveis. ${ }^{489}$ Por esse motivo, Grau sustenta que

[...] as decisões tomadas pelo Tribunal de Contas na apreciação e no julgamento de contas, na realização de inspeções e auditorias e no empreendimento de Fiscalizações [incisos I, II, IV, V e VI do artigo 71] não obrigam imediatamente a Administração. Elas apenas a vincularão após terem sido acolhidas pelo Poder Legislativo, titular do exercício do controle externo. Este, contudo, pode não acolhêlas. ${ }^{490}$

Mesmo assim, o STF já decidiu que o TCU deve determinar ao órgão ou entidade que promova a anulação dos contratos, ${ }^{491}$ inclusive reconhecendo poder geral de cautela para prevenir lesão ao erário e garantir a efetividade de suas decisões. ${ }^{492}$

\footnotetext{
$\overline{{ }^{488} \text { BRASIL. Lei no }}$ 8.443, de 16 jul. 1992. Art. 41, § 2º "O Tribunal comunicará às autoridades competentes dos poderes da União o resultado das inspeções e auditorias que realizar, para as medidas saneadoras das impropriedades e faltas identificadas."

${ }^{489}$ BRASIL. Lei $\mathrm{n}^{\mathrm{o}}$ 8.443, de 16 jul. 1992. Art. 45. "Verificada a ilegalidade de ato ou contrato, o Tribunal, na forma estabelecida no Regimento Interno, assinará prazo para que o responsável adote as providências necessárias ao exato cumprimento da lei, fazendo indicação expressa dos dispositivos a serem observados. $\S 1^{\circ}$ No caso de ato administrativo, o Tribunal, se não atendido: I - sustará a execução do ato impugnado; II comunicará a decisão à Câmara dos Deputados e ao Senado Federal; III - aplicará ao responsável a multa prevista no inciso II do art. 58 desta Lei. $\S 2^{\circ}$ No caso de contrato, o Tribunal, se não atendido, comunicará o fato ao Congresso Nacional, a quem compete adotar o ato de sustação e solicitar, de imediato, ao Poder Executivo, as medidas cabíveis. $\S 3^{\circ}$ Se o Congresso Nacional ou o Poder Executivo, no prazo de noventa dias, não efetivar as medidas previstas no parágrafo anterior, o Tribunal decidirá a respeito da sustação do contrato."

${ }^{490}$ GRAU, Eros Roberto. Tribunal de Contas - Decisão - Eficácia. Revista de Direito Administrativo, Rio de Janeiro: Renovar, n. 210, p. 354,1997. Em sentido oposto, ver OLIVEIRA, Régis Fernandes de; HORVATH, Estevão. Manual de direito financeiro. 6. ed. São Paulo: Revista dos Tribunais, 2003. p. 213. MILESKI, H. S. $O$ controle da gestão pública. São Paulo: Revista dos Tribunais, 2003. p. 284. "Nesta competência de julgamento, diferentemente do papel que representa no julgamento das Contas do Chefe do Poder Executivo, o Tribunal de Contas desempenha uma atividade controladora de muito maior relevância jurídica. Enquanto nas contas do Chefe do Poder Executivo apenas emite parecer prévio, de caráter técnico-opinativo, no julgamento das contas que realiza, é terminativa no âmbito administrativo, na medida em que se trata de uma atividade de jurisdição administrativa, cuja revisão judicial fica adstrita aos aspectos de ilegalidade manifesta e erro formal. Desse modo, pode-se afirmar que a competência constitucional de julgar contas corresponde ao exercício de uma jurisdição administrativa determinada constitucionalmente [...]. Trata-se de competência de caráter administrativo, mas com a qualificação do poder jurisdicional administrativo, que deriva de competência constitucional previamente estabelecida, com a delimitação do poder de conhecer e julgar as contas pelos administradores públicos."

491 BRASIL. Supremo Tribunal Federal. Mandado de segurança nº 23.550. Rel. Min. Sepúlveda Pertence. Decisão publicada em 31 out. 2001. "O Tribunal de Contas da União, embora não tenha poder para anular ou
} 
Quanto à função de ouvidor, a Constituição de 1988 estabelece que os responsáveis pelo controle interno, ao tomarem conhecimento de qualquer irregularidade ou ilegalidade, dela darão ciência ao TCU, sob pena de responsabilidade solidária. Além disso, qualquer cidadão, partido político, associação ou sindicato é parte legítima para, na forma da lei, denunciar irregularidades ou ilegalidades perante o Tribunal. $^{493}$ A legislação infraconstitucional dispõe que compete ao TCU decidir sobre denúncia que lhe seja encaminhada por qualquer cidadão, partido político, associação ou sindicato. A Lei $\mathrm{n}^{\mathrm{o}}$ 8.443/92 tratou timidamente esse dispositivo que poderia ampliar a atuação da sociedade civil na fiscalização das contas públicas. ${ }^{494}$

No que diz respeito à função de denúncia de irregularidades, compete ao TCU representar à autoridade competente sobre irregularidades ou abusos apurados, indicando o ato inquinado e definindo responsabilidades, inclusive as de ministro de Estado ou autoridade de nível hierárquico equivalente.

\subsubsection{A ação policial de combate à corrupção}

No Estado de Direito, o sucesso de qualquer política de repressão mais eficaz à corrupção depende de uma boa ação policial. Associada normalmente à repressão do deliquente pobre e violento, a polícia enfrenta dificuldades adicionais para lidar com a criminalidade sofisticada de colarinho branco, especialmente na atualidade, quando os bens decorrentes do enriquecimento ilícito não mais são dados a parentes, mas sim legalizados em sofisticados esquemas de lavagem de dinheiro à disposição dos infratores.

Nesse contexto, a coleta probatória assume papel nodal na eficiência do trabalho policial, pois as provas coletadas por ela servirão de base para o trabalho posterior de

sustar contratos administrativos, tem competência, conforme o art. 71, IX, para determinar à autoridade administrativa que promova a anulação do contrato e, se for o caso, da licitação de que se originou."

492 BRASIL. Supremo Tribunal Federal. Mandado de segurança nº 24.510. Rel. Min. Ellen Gracie. Decisão publicada em 31 nov. 2003.

${ }^{493}$ BRASIL. Constituição (1988). Art. 74. $\S 1^{\circ}$ e $\S 2^{\circ}$.

494 TORRES, Ricardo Lobo. Op. cit. p. 479. "[...] o tratamento dado à matéria foi excessivamente cauteloso e até preconceituoso. Em alguns aspectos faz lembrar a velha figura da denúncia fiscal, em que o denunciante procurava obter vantagem própria - a participação na multa - e era tratado com certo desdém pelo seu ofício de delator. Mantém-se o sigilo 'no resguardo dos direitos individuais', sem que se saiba quem é o titular de tais direitos - o denunciante ou o denunciado. Nas ações coletivas não há tal restrição, até porque nelas se discute a respeito de direitos fundamentais e difusos. Aliás, num País como o nosso, com sérios problemas financeiros, com enorme extensão territorial e populações crescente, no qual predominam a falta de zelo no trato da coisa pública e a corrupção generalizada, não se pode esperar que os Tribunais de Contas, apenas com as suas auditorias e com a sua estrutura burocrática, possam descobrir as irregularidades e ilegalidades que campeiam por toda a parte. Daí a necessidade de melhor regulamentação do uso dos novos instrumentos.” 
promotores públicos e juízes. Escutas telefônicas, invasão de computadores, escuta ambiental, interceptação de correspondência, quebra de sigilo bancário e fiscal, cooperação com autoridades internacionais e prisão provisória são alguns dos instrumentos jurídicos à disposição para a busca da prova. Novamente, os instrumentos jurídicos encontram-se à disposição, mas mesmo assim permanece a sensação de impunidade.

O uso abusivo de pedidos de prisão temporária e preventiva, endossados pelo Ministério Público e aprovados pelo Judiciário, tem sido apontado como "técnica" para punir ex ante os acusados pelas investigações, sem que haja o regular desenvolvimento do devido processo legal. Existe um verdadeiro temor de que as provas sejam insuficientes ou ilegítimas para fundamentar uma condenação penal, circunstância que conduz à antecipação da condenação nas prisões preventivas e temporárias, constantemente cercadas de ampla cobertura midiática.

De fato, os resultados da repressão à corrupção tendem a ser pífios sem as provas de qualidade. Apontada uma das principais alegações sobre as causas do elevado número de absolvições do Judiciário, seria ingênuo pensar que esta seria a causa do problema da ineficiência policial - na realidade, a instrução probatória deficiente nada mais é do que um sintoma de condições estruturais da própria organização da polícia brasileira.

Não se pretende discorrer sobre todos os sérios problemas enfrentados pela polícia. Contudo, dois fatores mais fortemente relacionados às práticas corruptas precisam ser mencionados.

Primeiro, a polícia é estruturalmente uma instituição cujas funções a levam a um constante contato com infratores. Estudos demonstram que existe uma correlação entre corrupção policial e contato com criminosos. ${ }^{495}$ As próprias polícias brasileiras reconhecem a existência de elevados índices de corrupção. ${ }^{496}$ Se existe essa maior suscetibilidade para a corrupção na polícia, o contato com criminosos envolvidos em práticas de corrupção aumenta consideravelmente as chances de corrupção policial.

\footnotetext{
$\overline{495}$ Sobre a relação de causalidade entre contatos com criminosos e corrupção policial, ver item 5.4, infra.

496 FRANÇA, Reinaldo. Sem medo da verdade. Veja, São Paulo, 2 dez. 2009. Disponível em: <http://veja.abril.com.br/021209/sem-medo-verdade-p-154.shtml>. Acesso em: 24 dez. 2009 às 18 h01.
} 
Tabela 5 - Percepção da existência de corrupção pela própria polícia

\begin{tabular}{|c|c|c|c|c|c|c|}
\cline { 2 - 7 } \multicolumn{1}{c|}{} & \multicolumn{4}{c|}{ Existe corrupção na polícia civil? } & \multicolumn{3}{c|}{ Existe corrupção na polícia militar? } \\
\cline { 2 - 7 } \multicolumn{1}{c|}{ Respostas da polícia militar (em \%) } & \multicolumn{2}{c|}{ Respostas da polícia civil (em \%) } \\
\hline Capital & Muita & Pouca & Nenhuma & Muita & Pouca & Nenhuma \\
\hline Brasília & 10 & 70 & 0 & 10 & 62 & 4 \\
\hline Belo Horizonte & 40 & 50 & 4 & 32 & 50 & 8 \\
\hline Recife & 30 & 62 & 2 & 26 & 52 & 8 \\
\hline Rio de Janeiro & 46 & 40 & 2 & 52 & 36 & 6 \\
\hline São Paulo & 39 & 53 & 2 & 12 & 78 & 5 \\
\hline
\end{tabular}

Fonte: Pesquisa Veja CNT/Sensus, realizada com apoio das Secretarias de Segurança Pública do Distrito Federal e dos estados de Minas Gerais, Pernambuco, Rio de Janeiro e São Paulo. Disponível em: <http://veja.abril.com.br/021209/sem-medo-verdade-p-154.shtml>. Acesso em: 24 dez. 2009 às 18 h01.

Segundo, funcionalmente, a polícia não goza das mesmas garantias constitucionais que membros do Judiciário e do Ministério Público. Desse modo, os delegados e investigadores de polícia encontram-se mais sujeitos à ingerência política dos ocupantes do Executivo - pode ser que haja interesse em não investigar a corrupção praticada por um aliado político ou pelos próprios ocupantes do Executivo. A aparente eficiência da Polícia Federal esbarra justamente nas denúncias sobre o direcionamento político das investigações.

\subsubsection{O Ministério Público}

Com base no trabalho desempenhado pela polícia judiciária, quando a corrupção se configurar como crime, cabe ao Ministério Público a propositura privativa da ação penal pública conforme o art. 129 da Constituição. ${ }^{497}$ Somente por essa função, quer seja no âmbito federal, quer seja no âmbito estadual, ao Ministério Público já se atribui um papel fulcral na fiscalização da administração pública e, indiretamente, no combate à corrupção.

A Constituição de 1988 ampliou ainda mais essa competência, ao constitucionalizar regra já existente na legislação infraconstitucional que atribuía ao Ministério Público a competência para "promover o inquérito civil e a ação civil pública, para a proteção do patrimônio público e social, do meio ambiente e de outros interesses difusos e coletivos". ${ }^{498}$ De qualquer forma, é função genérica do Ministério Público a defesa da ordem jurídica, do

\footnotetext{
$\overline{497}$ BRASIL. Constituição (1988). Art. 129. "São funções institucionais do Ministério Público: I - promover, privativamente, a ação penal pública, na forma da lei."

${ }^{498}$ BRASIL. Constituição (1988). Art. 129, III.
} 
regime democrático e dos interesses sociais e individuais indisponíveis, ${ }^{499}$ o que, por si só, já o incluiria como importante órgão de combate a práticas desvirtuadas na administração pública. Há até quem argumente que o Ministério Público poderia atuar preventivamente para evitar que algum nomeado para cargo público suspeito tomasse posse. ${ }^{500}$

Por gozar de garantias similares às dos juízes, tais como acesso ao cargo por meio de concurso de títulos e documentos e independência funcional, o Ministério Público se encontra insulado de pressões políticas e pode desempenhar com maior desenvoltura suas tarefas constitucionais. ${ }^{501}$ Com razão, Sadek lembra que "o administrador público, o servidor público, o legislador e também setores privados têm sido constrangidos, obrigados a levar em conta a probabilidade de que um integrante do Ministério Público venha a exercer vigilância". ${ }^{502}$

Em princípio, cabe ao Ministério Público aplicar a Lei $\mathrm{n}^{0}$ 8.429/92, a qual apenas aparentemente restringe sua atuação à representação de autoridade administrativa encarregada de apurar as irregularidades. ${ }^{503} \mathrm{~A}$ atuação do Ministério Público se daria das seguintes formas: qualquer pessoa poderia representar ao Ministério Público, mesmo que a autoridade administrativa tenha rejeitado a representação, hipótese em requererá instauração de inquérito policial ou procedimento administrativo. Adicionalmente, o Ministério Público atuará fiscalizando as investigações, junto à Comissão Processante, no caso de procedimento administrativo. ${ }^{504}$ No processo judicial, quando não for parte, o Ministério Público poderá atuar como fiscal da lei, sob pena de nulidade. ${ }^{505}$

Um ponto que chama a atenção na Lei $n^{0}$ 8.429/92 é não ter apresentado ao Ministério Público as possibilidades de atuação via inquérito civil e ação civil pública. ${ }^{506}$ Todavia, por constituir sua prerrogativa constitucional, é facultado ao Ministério Público valer-se desses meios para apurar, sobretudo, irregularidades que envolvam prejuízo ao

\footnotetext{
$\overline{499}$ BRASIL. Constituição (1988). Art. 127. “O Ministério Público é instituição permanente, essencial à função jurisdicional do Estado, incumbindo-lhe a defesa da ordem jurídica, do regime democrático e dos interesses sociais e individuais indisponíveis."

${ }^{500}$ FIGUEIREDO, Lúcia Valle. Corrupção administrativa. Revista Eletrônica de Direito do Estado, Salvador: Instituto de Direito Público da Bahia, n. 6, abr./maio/jun. 2006.

${ }^{501}$ Para uma avaliação positiva do trabalho desempenhado pelo Ministério Público, ver LIVIANU, Roberto. Op. cit. p. 200.

${ }^{502}$ SADEK, Maria Teresa. Ministério Público. In: AVRITZER, Leonardo et al. (Org.). Op. cit. p. 546.

${ }^{503}$ BRASIL. Lei n⿳0 8.429/92. Art. 14, § $2^{\circ}$. Art. 22.

${ }^{504}$ BRASIL. Lei $\mathrm{n}^{\mathrm{O}}$ 8.429/92. Art. 15. “A comissão processante dará conhecimento ao Ministério Público e ao Tribunal ou Conselho de Contas da existência de procedimento administrativo para apurar a prática de ato de improbidade. Parágrafo único. O Ministério Público ou Tribunal ou Conselho de Contas poderá, a requerimento, designar representante para acompanhar o procedimento administrativo."

${ }^{505}$ BRASIL. Lei $\mathrm{n}^{\mathrm{o}} 8.429 / 92$. Art. 17. $\S \S 3^{\circ}$ e $4^{\circ}$.

506 GATTO, Ruy Alberto. A atuação do Ministério Público em face da Lei no 8429/92 (Lei Anticorrupção). Justitia, São Paulo, v. 55, n. 161, p. 58, jan./mar. 1993.
} 
patrimônio público. Assim, provou-se de todo descabida a interpretação que retirava do Ministério Público a prerrogativa de valer-se de tais meios nos casos de corrupção. ${ }^{507}$

\subsubsection{O Poder Judiciário}

$\mathrm{Na}$ tradicional teoria da separação entre os poderes, nada caberia ao Judiciário além de aplicar imparcialmente a lei aprovada pelo Legislativo - a máxima "o juiz não utiliza adjetivos" é o corolário dessa imparcialidade. Operacionalmente, o juiz seria um mero aplicador de silogismos, e qualquer desvio dessa função seria considerado arbitrariedade. ${ }^{508}$ Dessa perspectiva, não se poderia considerar o Judiciário como um agente do combate à corrupção, uma vez que o nemo procedat iudex ex officio obstaria a posição ativista pelo Judiciário.

Entretanto, tem havido crescentes manifestações de ativismo judicial, especialmente em matéria de repressão à corrupção. Decisões baseadas no "clamor público", declarações públicas, suspeitas de interferência ativa de magistrados nas investigações policiais e decisões judiciais adjetivadas endossam essa alegação comum aos advogados criminalistas, colocando em xeque a noção de imparcialidade dos juízes e a legitimidade de todo o processo judicial.

Outro aspecto da atuação do Judiciário diz respeito às ações judiciais, propostas por aqueles investigados, que restringem a divulgação de informações pelos órgãos da mídia. ${ }^{509}$ Tais decisões estariam em contradição com o art. 220 da Constituição, ${ }^{510}$ mas a fundamentação utilizada se baseia, principalmente, no direito à intimidade e à necessidade de evitar a condenação dos acusados antes de uma sentença judicial. Ao diminuírem a

\footnotetext{
${ }^{507}$ Idem, p. 59.

${ }^{508}$ BECCARIA, Cesare. Dos delitos e das penas. Trad. de J. Cretella Jr. e Agnes Cretella. 3. ed. rev. São Paulo: Revista dos Tribunais, 2006. p. 27. "Em cada crime, o juiz deverá estruturar um silogismo perfeito: a premissa maior deve ser a lei geral; a premissa menor, a ação, conforme ou não à lei: a conclusão é a liberdade ou a pena. Quando o juiz for coagido, ou quiser formular apenas dois silogismos, a porta à incerteza estará aberta.”

509 ASSOCIAÇÃO BRASILEIRA DE IMPRENSA. Jornal da ABI. Rio de Janeiro, n. 307-B. abr. 2006 , p. 6. Disponível em: <http://www.abi.org.br/contasdaabi/relatorio\%202005-2006.pdf>. Acesso em: 25 dez. 2009. Veja-se o seguinte relato: "4.5. A Justiça, aliás, em sua primeira instância, no âmbito dos chamados juízos monocráticos, foi uma das fontes permanentes de preocupação da ABI, pelas tropelias cometidas contra a liberdade de imprensa por magistrados desatentos às prescrições do artigo 220 da Constituição da República, cujo parágrafo $2^{\circ}$ veda expressamente a censura prévia. Ordem de censura, porém, partiu do Juiz Sílvio Luiz Ferreira da Rocha, da $5^{\text {a }}$ Vara Federal Criminal de São Paulo, que vetou a divulgação pela Folha Online de matéria publicada pelo jornal. Já o Desembargador Pedro Valle Feu Rosa, do Tribunal de Justiça do Espírito Santo, autorizou a Polícia a grampear telefones da Rede Gazeta de Comunicações, para espionar jornalistas da Rádio CBN, do Estado, do jornal A Gazeta e da TV Gazeta, afiliada da TV Globo".

510 BRASIL. Constituição (1988). Art. 220. “A manifestação do pensamento, a criação, a expressão e a informação, sob qualquer forma, processo ou veículo não sofrerão qualquer restrição, observado o disposto nesta Constituição."
} 
visibilidade de práticas corruptas, as decisões judiciais dessa natureza conseguem evitar o dano à imagem daqueles envolvidos, o que, em determinadas circunstâncias, pode interferir no processo eleitoral e a formação da opinião pública.

\subsubsection{O papel da Controladoria-Geral da União}

A Controladoria-Geral da União (CGU) é o ministério encarregado de auxiliar diretamente o presidente da República em assuntos relacionados à defesa do patrimônio público e ao incremento da transparência da gestão âmbito do Executivo federal. No desempenho de suas funções, a CGU realiza atividades de controle interno, correição, auditoria pública e ouvidoria, entre outras medidas de prevenção e combate à corrupção. ${ }^{511}$ Ademais, a CGU também exerce a supervisão dos órgãos que compõem o Sistema de Controle Interno e o Sistema de Correição e das unidades de ouvidoria do Poder Executivo Federal.

Criada em abril de $2001,{ }^{512}$ a CGU atuava como um órgão de correição interna, mas suas atividades foram gradualmente expandidas ao longo da década de 2000. O Decreto $\mathrm{n}^{\mathrm{o}}$ 4.177/2002 transferiu à CGU funções de controle interno e auditoria pública da Casa Civil e da ouvidoria do Ministério da Justiça. ${ }^{513}$ A Lei $\mathrm{n}^{\mathrm{o}}$ 10.683/2003 transformou a CGU em ministério, e o seu titular passou a ser denominado ministro de Estado do Controle e da Transparência. $^{514}$ Posteriormente, esse diploma foi alterado novamente pela Lei $\mathrm{n}^{\mathrm{o}}$ $11.204 / 2005,^{515}$ e mais competências foram atribuídas à instituição. $\mathrm{O}$ Decreto $\mathrm{n}^{\mathrm{o}}$ $5.683 / 2006^{516}$ consolidou os anteriores, conferindo maior sistematicidade à estrutura da CGU

\footnotetext{
$\overline{511}$ BRASIL. Lei $\mathrm{n}^{\mathrm{o}}$ 11.204. Art. 17. "À Controladoria-Geral da União compete assistir direta e imediatamente ao Presidente da República no desempenho de suas atribuições quanto aos assuntos e providências que, no âmbito do Poder Executivo, sejam atinentes à defesa do patrimônio público, ao controle interno, à auditoria pública, à correição, à prevenção e ao combate à corrupção, às atividades de ouvidoria e ao incremento da transparência da gestão no âmbito da administração pública federal."

512 BRASIL. Medida Provisória nº 2.143-31/2001, de 2 abr. 2001.

${ }^{513}$ BRASIL. Decreto $\mathrm{n}^{\mathrm{O}}$ 4.177, de 28 mar. 2002.

${ }^{514}$ BRASIL. Lei n⿳o 10.683 , de 28 maio 2003.

${ }^{515}$ BRASIL. Lei $\mathrm{n}^{\mathrm{O}} 11.204$, de 5 dez. 2005.

516 BRASIL. Decreto $\mathrm{n}^{\mathrm{o}}$ 5.683, de 24 jan. 2006. Art. 3․ "A Controladoria-Geral da União tem a seguinte estrutura organizacional: I - órgãos de assistência direta e imediata ao Ministro de Estado: a) Gabinete; b) Assessoria Jurídica; e c) Secretaria-Executiva: 1. Diretoria de Desenvolvimento Institucional; 2. Diretoria de Gestão Interna; e 3. Diretoria de Sistemas e Informação; II - órgãos específicos singulares: a) Secretaria Federal de Controle Interno: 1. Diretoria de Auditoria da Área Econômica; 2. Diretoria de Auditoria da Área Social; 3. Diretoria de Auditoria da Área de Infra-Estrutura; 4. Diretoria de Auditoria da Área de Produção e Emprego; 5. Diretoria de Planejamento e Coordenação das Ações de Controle; e 6. Diretoria de Auditoria de Pessoal e de Tomada de Contas Especial; b) Ouvidoria-Geral da União; c) Corregedoria-Geral da União: 1. CorregedoriaGeral Adjunta da Área Econômica; 2. Corregedoria-Geral Adjunta da Área de Infra-Estrutura; e 3. Corregedoria-
} 
e concentrando o caráter preventivo de sua atuação em uma secretaria específica, a Secretaria de Prevenção da Corrupção e Informações Estratégicas (SPCI). Essa concentração possibilitou o aumento dos esforços na fiscalização das transferências de recursos federais para entidades privadas sem fins lucrativos. Por fim, o Decreto $\mathrm{n}^{\mathrm{o}}$ 6.656/08 criou 448 cargos comissionados e funções gratificadas. ${ }^{517}$

Dentre as competências conferidas à CGU pela Lei $\mathrm{n}^{0}$ 10.683/2003, destacam-se suas atribuições de dar o devido andamento às representações ou denúncias fundamentadas relativas a lesão ou ameaça de lesão ao patrimônio público. Sempre que constatar omissão da autoridade competente, a CGU deve requisitar a instauração de sindicância, procedimentos e processos administrativos outros, bem como avocar aqueles já em curso em órgão ou entidade da administração pública da União, a fim de corrigir o andamento, inclusive promovendo a aplicação da penalidade administrativa cabível. A CGU realiza trabalhos de auditoria em órgãos da administração direta e indireta da União e ações de fiscalização da aplicação de recursos públicos federais por organizações não governamentais, estados, municípios, além de ser responsável pelo sítio "Portal da Transparência".

De acordo com a CGU, entre janeiro de 2003 e outubro de 2009, a União aplicou penalidades de expulsão a 2.315 agentes públicos por envolvimento em práticas ilícitas. Desse total, as demissões de cargos efetivos somaram 2.000 casos, as destituições de cargos em comissão, 177, e as cassações de aposentadorias, $138 .{ }^{518} \mathrm{O}$ Gráfico 1, abaixo, agrupa os tipos de condutas que causaram as referidas exonerações, feita a ressalva de que a soma das expulsões pelos motivos que as geraram supera o total de expulsões, porque há casos em que há mais de um motivo gerador da punição. Embora a quantidade possa parecer expressiva, o

Geral Adjunta da Área Social; d) Secretaria de Prevenção da Corrupção e Informações Estratégicas: 1. Diretoria de Informações Estratégicas; e 2. Diretoria de Prevenção da Corrupção; III - unidades descentralizadas: Controladorias Regionais da União nos Estados; IV - órgãos colegiados: a) Conselho de Transparência Pública e Combate à Corrupção; b) Comissão de Coordenação de Controle Interno; e c) Comissão de Coordenação de Correição."

${ }^{517}$ BRASIL. Decreto $\mathrm{n}^{\mathrm{o}}$ 6.656, de 20 nov. 2008. A criação de tantos cargos comissionados e funções gratificadas para o desempenho de tarefas essencialmente administrativas é inconsistente. Se os funcionários são efetivamente necessários, estes deveriam ser ocupados por meio de concurso público, não por indicação subjetiva, ainda que entre aqueles que já fazem parte do funcionalismo. Ver item 7.2, infra.

518 BRASIL. Controladoria-Geral da União. Governo Federal já expulsou 2,3 mil servidores por práticas ilícitas. Disponível em: <http://www.cgu.gov.br/Imprensa/Noticias/2009/noticia21009.asp> Acesso em: 30/11/2009 às 23h31. De acordo com a CGU, "a intensificação do combate à impunidade na administração pública federal é resultado do trabalho do Sistema de Correição da Administração Pública Federal, que conta hoje com uma unidade em cada ministério e é coordenado pela Corregedoria-Geral da União, órgão integrante da estrutura da Controladoria-Geral da União (CGU). [...] A CGU destacou um corregedor para supervisionar os processos em cada ministério e quando a situação envolve casos mais delicados ou complexos, avoca-se o processo e instaurase diretamente na controladoria". 
número de servidores civis ativos totalizava 542.843 em maio de 2009 - entre 2003 e 2009, a União contratou 57 mil servidores.

\section{Gráfico 1 - Número de expulsões por tipo de conduta}
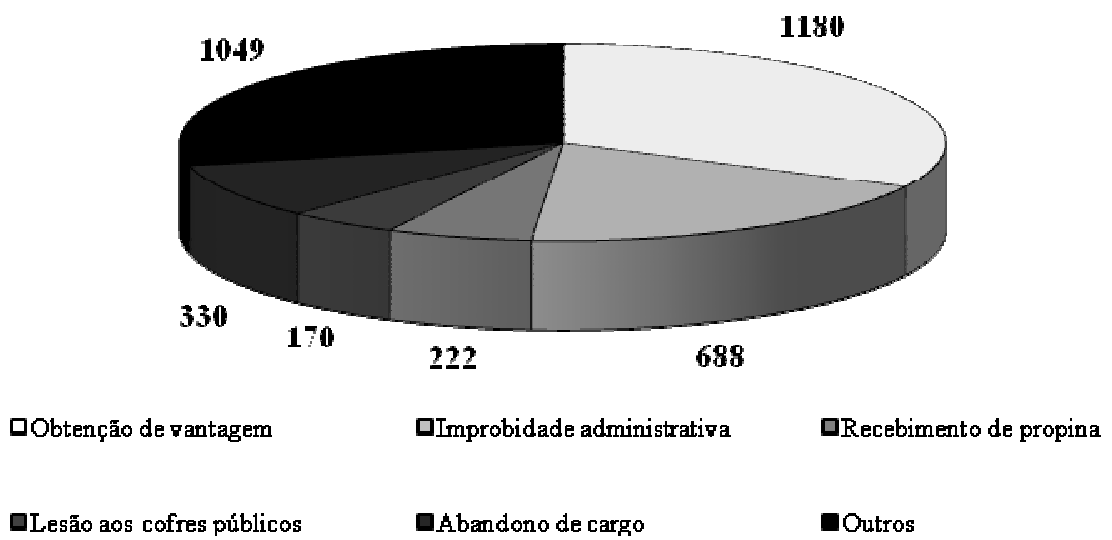

Fonte: Elaboração própria.

Diante de um universo tão vasto a ser investigado, a principal ferramenta de atuação da CGU é o programa de fiscalização a partir de sorteios públicos. Instituído em 2003, esse programa tem como propósito inibir e dissuadir a corrupção. Tal técnica de fiscalização parte do pressuposto de que o processo estimularia práticas mais rigorosas de controle entre os governantes, assegurando a correta aplicação do dinheiro público. Mesmo assim, esse método pode produzir alguns resultados não esperados. Um estudo comparativo elaborado para testar os efeitos da fiscalização sobre o comportamento do político que governava durante a primeira auditoria e permaneceu no governo durante a segunda auditoria comparou a média do indicador de eficiência administrativa também para dois grupos, os que permaneceram e os que não permaneceram no governo. Em geral, prefeitos que estavam na primeira auditoria da CGU e continuaram no governo durante a segunda provavelmente duvidaram que seriam fiscalizados outra vez, o que levou os municípios a apresentar menor eficiência na segunda fiscalização. ${ }^{519}$

Por fim, em razão de suas competências, a CGU ocupa uma posição de destaque nas articulações do combate à corrupção, devendo encaminhar os casos que configurem improbidade administrativa e todos aqueles que necessitem da decretação judicial de indisponibilidade de bens, o ressarcimento ao erário e outras providências a serem tomadas

\footnotetext{
$\overline{519}$ SANTANA,Victor Leal. O impacto das auditorias da CGU sobre o desempenho administrativo local. Revista da CGU/Presidência da República, Controladoria-Geral da União, Brasília: CGU, ano 3, n. 5, dez. 2008.
} 
pela Advocacia-Geral da União, bem como provocar, sempre que necessária, a atuação do Tribunal de Contas da União, da Secretaria da Receita Federal, dos órgãos do Sistema de Controle Interno do Poder Executivo Federal. Quando houver indícios de responsabilidade penal, deve comunicar à Polícia Federal e ao Ministério Público.

\subsubsection{Combate à lavagem de dinheiro e recuperação de ativos}

$\mathrm{Na}$ contabilidade motivadora dos jogadores corruptos, a manutenção das vantagens financeiras obtidas é um dos objetivos principais, mesmo quando os criminosos são detectados e punidos. A lógica é simples: se a vantagem econômica auferida é ainda mantida, o caráter dissuasório da ação repressiva estatal é enfraquecido. Alterar essa variável é peçachave do combate à corrupção pela regulamentação microjurídica.

Exceção feita aos casos de ostentação de riqueza, os corruptos lançam mão de técnicas para "esconder" os ganhos auferidos, prática denominada "lavagem de dinheiro". Essa expressão sintetiza as mais diversas práticas cuja finalidade é a ocultação ou dissimulação da origem de ativos financeiros ou bens patrimoniais provenientes de práticas ilícitas, dificultando a detecção destas.

Na esteira do que se verifica com a repressão aos ilícitos de corrupção, a lavagem de dinheiro é um problema transnacional, cuja criminalização é recomendada por diversas organizações internacionais e agrupamentos informais de países, tais como a Organização das Nações Unidas e o Grupo de Ação Financeira sobre Lavagem de Dinheiro (Gafi/FATF). Além da corrupção, há várias práticas ilícitas comumente associadas à lavagem de dinheiro, tais como o tráfico de entorpecentes, a evasão fiscal, o estelionato, o crime organizado e o terrorismo. No Brasil, o combate à lavagem de dinheiro adquiriu maior relevância com a assinatura da Convenção de Viena em 1988. ${ }^{520}$

Para aperfeiçoar a cooperação internacional na matéria, foi aprovada a Lei $\mathrm{n}^{\mathrm{o}}$ 9.613/98, ${ }^{521}$ que define o crime de lavagem de dinheiro e estabelece medidas preventivas e repressivas para combatê-lo. Nesse sentido, o referido dispositivo legal criou o Departamento de Combate a Ilícitos Cambiais e Financeiros no Banco Central e o Conselho de Controle de Atividades Financeiras (Coaf), vinculado ao Ministério da Fazenda. O Coaf autointitula-se

\footnotetext{
$\overline{520}$ A execução e cumprimento no Brasil da Convenção de Viena de 1988 foram determinados pelo Decreto $\mathrm{n}^{\mathrm{o}}$ 154, de 26 jun. 1991.

${ }^{521}$ BRASIL. Lei $\mathrm{n}^{\mathrm{0}}$ 9.613, de 3 mar. 1998. A Lei $\mathrm{n}^{\mathrm{o}}$ 9.613/98 introduziu no ordenamento jurídico brasileiro várias iniciativas internacionais que têm origem na Convenção de Viena, na Convenção de Palermo, na Convenção das Nações Unidas contra o Financiamento ao Terrorismo e nas 40 Recomendações Gafi/FATF.
} 
uma Unidade de Inteligência Financeira, expressão existente em diversos países, que corresponde a um órgão nacional centralizador de informações, o qual é responsável por receber, examinar e dar encaminhamento às denúncias sobre práticas suspeitas de lavagem de dinheiro. Nos termos da Lei $\mathrm{n}^{\mathrm{o}}$ 9.613/98, o Coaf foi incumbido de disciplinar e aplicar penas administrativas, bem como coordenar e propor mecanismos de cooperação e de troca de informações que viabilizem ações rápidas no combate à ocultação ou dissimulação de bens, direitos e valores.

O Coaf é formado por um presidente, nomeado pelo presidente da República, por indicação do ministro de Estado da Fazenda, e por onze conselheiros, além de um representante convidado da Advocacia-Geral da União. Estão representados no Coaf vários órgãos que dão a exata dimensão da complexidade do tema: a Controladoria- Geral da União (CGU), o Banco Central, a Comissão de Valores Mobiliários (CVM), a Superintendência de Seguros Privados (Susep), a Procuradoria-Geral da Fazenda Nacional, a Secretaria de Receita Federal, o órgão de Inteligência do Poder Executivo (Abin), o Departamento da Polícia Federal, o Ministério das Relações Exteriores, o Ministério da Previdência Social e o Ministério da Justiça.

No âmbito da Lei $\mathrm{n}^{\mathrm{o}}$ 9.613/98, o principal mecanismo de detecção de práticas de lavagem de dinheiro é o sistema de comunicação de operações suspeitas. Esse sistema é fundado na obrigação de informar que é atribuída a alguns agentes econômicos-chave, tais como instituições que operam no mercado financeiro e de capitais, administradoras de cartão de crédito, factorings, incorporadoras de imóveis, imobiliárias, empresas de comércio de joias, metais preciosos e artigos de luxo, seguradoras, fundos de pensão, entre diversas outras. ${ }^{522}$ Perante o Coaf, estes sujeitos são legalmente obrigados a implementar políticas e procedimentos internos de controle para colaborar com a prevenção e detecção de lavagem de dinheiro por parte de seus clientes, ${ }^{523}$ o que inclui a identificação de clientes e manutenção de cadastros atualizados (política know your costumer) e a obrigatoriedade de comunicação de atividades suspeitas às autoridades competentes.

\footnotetext{
$\overline{522}$ BRASIL. Lei no ${ }^{0} 9.613$, de 3 mar. 1998. Art. $9^{\circ}$.

${ }^{523}$ O Projeto de Lei do Senado $\mathrm{n}^{\mathrm{o}}$ 476/2003 pretende emendar a Lei $\mathrm{n}^{\mathrm{o}}$ 9.613/98, com vistas a ampliar o conceito de crime de lavagem de dinheiro para criminalizar a ocultação ou dissimulação da natureza, origem, localização, disposição, movimentação ou propriedade de bens, direitos ou valores oriundos de qualquer infração penal. Para facilitar a identificação de operações suspeitas, o Projeto de Lei do Senado n⿳o 476/2003 adiciona várias outros sujeitos no rol dos obrigados a colaborar com o Coaf, tais como as juntas comerciais, os cartórios, as empresas transportadoras de valores, as organizações não governamentais sem fins lucrativos, as pessoas físicas ou jurídicas que prestem serviços de advocacia, consultoria ou auditoria, e os leiloeiros de obras de arte, automóveis, embarcações, aeronaves, joias e animais.
} 
Embora exista certa discussão a respeito da definição do que configuraria uma atividade suspeita e o que constituiria "sérios indícios" para os fins de comunicação obrigatória, ${ }^{524}$ no caso das denominadas "pessoas politicamente expostas" (politically exposed persons) há uma preocupação maior: a Resolução Coaf n⿳o 16/2007 dispõe que qualquer operação que envolva essas pessoas deve ser comunicada à unidade de inteligência financeira nacional - por estarem em posições sensíveis de comando dentro da administração pública, as "pessoas politicamente expostas" probabilisticamente possuem maior chance de se envolverem com corrupção de maior envergadura. De fato, a Resolução Coaf n⿳⺈ 16/2007 considera "pessoas politicamente expostas" todos os agentes públicos, seus representantes, familiares e estreitos colaboradores que desempenham ou tenham desempenhado cargos, empregos ou funções públicas relevantes nos últimos cinco anos no Brasil ou exterior. ${ }^{525}$ Essa disposição atende à Convenção das Nações Unidas contra a Corrupção de 2003, cuja execução e cumprimento no Brasil foram determinados pelo Decreto $\mathrm{n}^{\mathrm{o}} 5.687 / 06 .{ }^{526}$ No mesmo sentido, o Banco Central do Brasil já havia baixado a Circular $n^{\mathrm{o}} 3.339 / 06,{ }^{527}$ dispondo acerca dos procedimentos a serem observados por instituições financeiras para o acompanhamento das movimentações de pessoas politicamente expostas.

O sigilo de informações bancárias é um ponto sensível relacionado ao combate à lavagem de dinheiro. No exercício das funções de supervisão, as autoridades competentes têm acesso a informações bancárias, com a obrigação de sigilo e de utilização exclusiva para fins

\footnotetext{
$\overline{524}$ A Lei $\mathrm{n}^{\mathrm{o}}$ 9.613/98 estabelece que somente as transações acompanhadas de "sérios indícios" devem ser obrigatoriamente comunicadas. Ao utilizar essas palavras, a lei estabeleceu um juízo de valor que deve ser formulado a cada transação - esse critério deve ser formulado pelo intérprete da lei. Para esclarecer mais a questão, o Banco Central do Brasil editou a Carta-Circular no 2.826/98, a Comissão de Valores Mobiliários (CVM) editou a Instrução no 301/99, a Superintendência de Seguros Privados (Susep) publicou a Circular n. 89/99, e a Secretaria de Previdência Complementar publicou a Instrução Normativa n⿳ำ 22/99.

${ }^{525}$ BRASIL. Resolução/Coaf no ${ }^{\circ}$ 16, de 28 mar. 2007. Art. $1^{\circ}, \S 2^{\circ}$. "No caso de pessoas politicamente expostas brasileiras, para efeito do $\S 1^{\circ}$ devem ser abrangidos: I - os detentores de mandatos eletivos dos Poderes Executivo e Legislativo da União; II - os ocupantes de cargo, no Poder Executivo da União: a) de Ministro de Estado ou equiparado; b) de Natureza Especial ou equivalente; c) de presidente, vice-presidente e diretor, ou equivalentes, de autarquias, fundações públicas, empresas públicas ou sociedades de economia mista; d) do Grupo Direção e Assessoramento Superiores - DAS, nível 6, e equivalentes; III - os membros do Conselho Nacional de Justiça, do Supremo Tribunal Federal e dos Tribunais Superiores; IV - os membros do Conselho Nacional do Ministério Público, o Procurador-Geral da República, o Vice-Procurador-Geral da República, o Procurador-Geral do Trabalho, o Procurador-Geral da Justiça Militar, os Subprocuradores-Gerais da República e os Procuradores-Gerais de Justiça dos estados e do Distrito Federal; V - os membros do Tribunal de Contas da União e o Procurador-Geral do Ministério Público junto ao Tribunal de Contas da União; VI - os governadores de Estado e do Distrito Federal, os presidentes de Tribunal de Justiça, de Assembléia Legislativa e de Câmara Distrital e os presidentes de Tribunal e de Conselho de Contas de Estado, de Municípios e do Distrito Federal; VII - os Prefeitos e Presidentes de Câmara Municipal de capitais de Estados."

${ }^{526}$ BRASIL. Decreto n⿳0 5.687, de 31 jan. 2006.

${ }^{527}$ BRASIL. Banco Central do Brasil. Circular nº 3.339, de 22 dez. 2006.
} 
de supervisão, sob pena de responsabilização administrativa e penal. O Decreto $\mathrm{n}^{\mathrm{o}} 2.799 / 98^{528}$ permite ao Coaf solicitar informações bancárias ou mesmo requisitar documentos. Adicionalmente, a Lei Complementar $n^{0}$ 105/2001 ampliou o acesso do Coaf a informações bancárias. ${ }^{529} \mathrm{Se}$, por um lado, essas medidas podem representar avanços no combate à corrupção, por outro, argumenta-se que há violação à proteção constitucional da inviolabilidade da vida privada e de dados. ${ }^{530}$

Os resultados da atuação do Coaf ainda são tímidos, mas o número de rastreamentos tem apresentado elevado crescimento nos últimos anos. O Gráfico 2, abaixo, aponta as operações rastreadas pelo Coaf entre 2003 e 2008.

\section{Gráfico 2 - Operações rastreadas pelo Coaf entre 2003 e 2008}

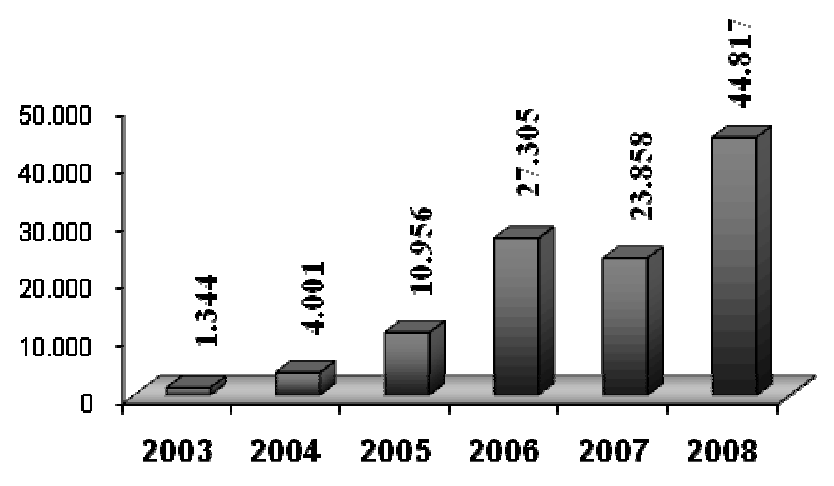

Fonte: Relatórios de atividade do Coaf de 2003 a 2008. Disponível em: $<$ https://www.coaf.fazenda.gov.br/destaques/downloads/relatorioscoaf/Relatorio\%20de\%20Atividades\%202008.pdf>. Acesso em: 25 dez. 2009 às $20 \mathrm{~h} 23$.

Ainda que esse resultado possa indicar melhorias na capacidade de rastreamento do órgão, eles não permitem mensurar em que medida o rastreamento de operações é eficiente na efetiva detecção de condutas de corrupção, pois isso depende do que outras autoridades fazem com as informações recebidas. Eis aqui um possível Calcanhar de Aquiles do Coaf: como todos os que compõem o órgão são indicados pelo presidente da República, é possível que se façam vistas grossas para uma "pessoa politicamente exposta" por razões políticas, em desacordo com o interesse público. De qualquer modo, as informações disponíveis ao Coaf

\footnotetext{
$\overline{528}$ BRASIL. Decreto ${ }^{\circ}$ 2.799/98, de 8 out. 1998. Art. $7^{\circ}$.

${ }^{529}$ BRASIL. Lei Complementar $\mathrm{n}^{\mathrm{o}}$ 105, de 10 jan. 2001. Art. $2^{\circ}$, § 6 . "O Banco Central do Brasil, a Comissão de Valores Mobiliários e os demais órgãos de fiscalização, nas áreas de suas atribuições, fornecerão ao Conselho de Controle de Atividades Financeiras - COAF, de que trata o art. 14 da Lei oㅜ 9.613, de 3 de março de 1998, as informações cadastrais e de movimento de valores relativos às operações previstas no inciso I do art. 11 da referida Lei."

${ }_{530}$ BRASIL. Constituição (1988). Art. $5^{\circ}$, incisos X e XII.
} 
também têm ampla utilidade $a$ posteriori como provas após a detecção da conduta por outras autoridades - vários órgãos responsáveis por investigações de ilícitos fazem requisições para fins instrutórios ao Coaf com grande frequência.

Gráfico 3 - Participação de autoridades no intercâmbio de informações
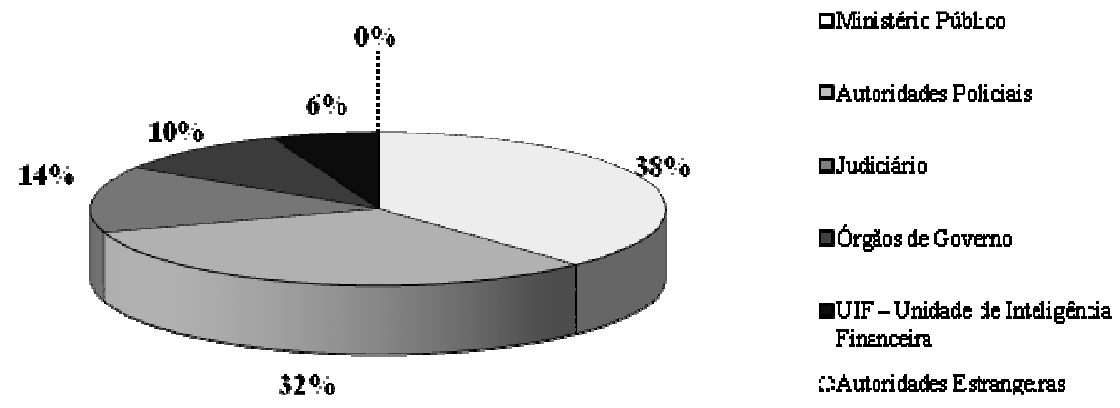

Fonte: Relatório de atividade do Coaf - 2008, p. 24. Disponível em: $<$ https://www.coaf.fazenda.gov.br/destaques/downloads/relatorios-

coaf/Relatorio\%20de\%20Atividades\%202008.pdf>. Acesso em: 25 dez. 2009 às 22 h03.

Ao lado do Coaf, o Departamento de Recuperação de Ativos e Cooperação Jurídica Internacional (DRCI), criado pelo Decreto $\mathrm{n}^{\mathrm{o}} 4.991 / 2004,{ }^{531}$ precisa ser citado. Subordinado à Secretaria Nacional de Justiça, do Ministério da Justiça, o DRCI possui as atribuições de analisar cenários, identificar ameaças, desenvolver e aperfeiçoar instrumentos normativos e desenvolver a cultura de prevenção e combate à lavagem de dinheiro. Em outras palavras, se o Coaf existe para detectar a lavagem de dinheiro, o DRCI visa recuperar os ativos ganhos com as práticas ilícitas. No caso específico da corrupção, a recuperação do ilegalmente auferido é essencial, na medida em que o potencial jogador corrupto provavelmente decidirá participar ou não do jogo dependendo da chance de vir a perder o que houver obtido como ganho.

O DRCI é encarregado de articular a atividade estatal de recuperação de ativos de origem ilícita, por meio de sua Coordenação-Geral de Recuperação de Ativos (CGRA) em consonância não só com os princípios de direito público brasileiro, mas também com os acordos internacionais - no que tange à Convenção da ONU contra Corrupção, existe regra explícita que "prevê a repatriação de ativos obtidos a partir de práticas ilícitas e transferidos para diferentes países". ${ }^{532}$ A CGRA é responsável por articular e colaborar com as polícias, o

\footnotetext{
$\overline{531}$ BRASIL. Decreto no ${ }^{\mathrm{o}}$ 4.991, de 18 fev. 2004.

${ }^{532}$ LIVIANU, Roberto. Op. cit. p. 175. "O texto determina que o dinheiro e bens públicos enviados para o exterior retornem ao país de origem sempre que o país solicitante comprove ser o proprietário legítimo dos bens
} 
Ministério Público, o Judiciário e os órgãos competentes para recuperar, no Brasil e no exterior, ativos derivados de atividades ilícitas.

No contexto dos esforços nacionais pelo combate à corrupção, a atividade de articulação do DRCI é bastante concentrada na capacitação e treinamento dos agentes públicos para a condução de investigações relacionadas à corrupção e ao crime de lavagem de dinheiro. Por isso, o DRCI participa da Estratégia Nacional de Combate à Corrupção e à Lavagem de Dinheiro (Enccla) e do Programa Nacional de Capacitação e Treinamento para o Combate à Corrupção e à Lavagem de Dinheiro (PNLD) - havia pouco esforço na recuperação dos ganhos ilegais decorrentes das práticas corruptas, e tais iniciativas surgiram como um meio de coordenação entre os agentes públicos, a partir de cursos e treinamentos nas necessidades especiais requeridas por esse tipo de investigação, com o intuito de fomentar na burocracia o aprendizado contra a lavagem de dinheiro.

O DRCI tem difundido a necessidade de implementação das recomendações do Banco Mundial e do Escritório das Nações Unidas sobre Drogas e Crime (UNODC), as quais foram recentemente consubstanciadas num guia de boas práticas. ${ }^{533} \mathrm{O}$ DRCI endossa as sugestões de recuperação de ativos por alienação antecipada, por meio de um regime legal que prevê a apreensão e confisco (extinção de domínio) de ativos de origem ilícita por meio de uma ação cível que dispensaria a necessidade de condenação penal à semelhança do que ocorria durante a ditadura militar. ${ }^{534}$

Os resultados concretos da atuação do DRCI tem sido pouco perceptíveis, uma vez que as autoridades encontram dificuldades na definição de indicadores que possibilitem comprovar os avanços e resultados obtidos na área. Dessa forma, uma das metas do Enccla de 2005 foi desenvolver um sistema para produzir estatísticas sobre inquéritos, procedimentos investigatórios criminais, denúncias, sentenças, réus, condenações e apreensões sobre lavagem de dinheiro no âmbito federal e estadual. O DRCI considera como resultados

ou valores e que o país requerido reconheça a existência dos danos causados pelas práticas ilícitas ao país solicitante."

${ }^{533}$ GREENBERG, Theodore S. et al. Stolen asset recovery: a good practices guide for non-conviction based asset forfeiture. Washington: Banco Mundial \& UNODC, 2009. Disponível em: < http://siteresources.worldbank.org/EXTSARI/Resources/NCBGuideFinalEBook.pdf>. Acesso em: 27 nov. 2009 às $18 \mathrm{~h} 20$.

${ }^{534}$ Ver item 3.4.4, supra. 
positivos a consolidação de informações dos diversos órgãos, a elaboração de anteprojetos de lei e o treinamento de agentes públicos. ${ }^{535}$

\subsubsection{O papel da sociedade civil}

Os agentes analisados anteriormente fazem parte do aparato do Estado. Um crítico menos atento poderia observar que, se a corrupção está localizada no interior do Estado, não faria sentido estudar o papel da sociedade civil no combate às práticas corruptas. Tal raciocínio possui dois equívocos.

Primeiro, apesar de a teoria política de inspiração liberal ter criado uma distinção aparentemente rígida entre Estado e sociedade civil, mesmo assim cabe à sociedade civil a função de direcionar os ocupantes do poder para a direção do bem comum. Nusdeo resume a visão liberal sobre o papel a ser desempenhado pela sociedade civil:

Tal esquema, entendia-se e ainda, em parte, se entende, permitiria, sem maiores desvios, a abertura dos representantes, às proposições dos grupos de cidadãos, os quais, legitimamente, poderiam ter a possibilidade de convencê-los a produzir o tipo de legislação necessário ao desenvolvimento de suas atividades privadas, objetivo esse, em ultima análise, coincidente com o do país como um todo, interessado, sempre, no progresso e melhor atuação de todos os seus cidadãos.

O "The Federalist" definia o grupo de interação, por ele chamado de "faction", como a "number of citizens, whether amounting to a majority or minority of the whole who are united and actuated by some common impulse of passion, or of interest, adverse to the right of other citizens, or to permanent and aggregate interests of the community", acrescentando, adiante, que o equacionamento desses interesses intervenientes constituía a principal tarefa da moderna legislação. ${ }^{536}$

Segundo, a cisão entre Estado e sociedade civil é apenas aparente e não se sustenta na realidade, uma vez que o primeiro encontra-se imerso na segunda. ${ }^{537}$ Portanto, em ambas as visões sobre o relacionamento entre Estado e sociedade civil, há pontos de contato entre ambos, o que justifica incluí-lo no estudo da corrupção. Em realidade, enquanto imersos no emaranhado de relações sociais, a sociedade civil e o Estado se influenciam reciprocamente, de modo que é complicado identificar em qual dos dois repousa a real origem do problema da

\footnotetext{
$\overline{535}$ Para maiores informações a respeito das metas do Enncla, sugere-se a visita ao site. Disponível em: <http://www.mj.gov.br/data/Pages/MJ7AE041E8ITEMIDC13D03AB776B414A98E45A765FF1E912PTBRNN. htm>. Acesso em: 12 nov. 2009 às $11 \mathrm{~h} 15$.

${ }^{536}$ NUSDEO, Fábio. Fundamentos para uma codificação do direito econômico. 1993. 226 f. Tese (Titular)Faculdade de Direito, Universidade de São Paulo, São Paulo. p. 59-60.

${ }^{537}$ Para uma discussão sobre o assunto, ver ALVES, Alaôr Caffé. Estado e ideologia: aparência e realidade. Apresentação de Dalmo de Abreu Dallari. São Paulo: Brasiliense, 1987.
} 
corrupção. A consciência de que os recursos públicos se originam dos tributos pagos pela sociedade acentua esse sentimento de ligação da sociedade civil com o Estado.

No direito posto, a legislação outorga uma ampla legitimidade processual na defesa do interesse público - veja-se a Lei da Ação $\operatorname{Popular}^{538}$ e a Lei da Ação Civil Pública. ${ }^{539}$ A partir de meados dos anos 1990, grande parte das agências reguladoras foi instituída por leis que estabelecem a necessidade de realizar consultas e/ou audiências públicas, anteriormente a tomadas de decisões. Assim, a Lei $n^{0} 9.427 / 96^{540}$ fixou a necessidade de que todas as decisões da Aneel que possam afetar direitos dos agentes econômicos do setor elétrico ou dos consumidores devem ser precedidas de audiência pública. No mesmo sentido, a Lei $\mathrm{n}^{\mathrm{o}}$ 9.472/97541 estabeleceu que a Anatel deve realizar consultas públicas prévias aos seus atos relevantes, inclusive, expressamente, os de natureza normativa.

Essa abertura maior à participação da sociedade presente nas agências reguladoras representa uma tendência perceptível de compensar formalmente compensar o déficit democrático no processo decisório das agências reguladoras. Ainda que não vinculativas, as consultas à sociedade civil são uma forma de restringir a discricionariedade no processo decisório pela administração pública, na medida em que a legitimidade das medidas deve ser interpretada à luz do que for sugerido.

\footnotetext{
${ }^{538}$ BRASIL. Lei no ${ }^{\circ}$ 4.717, de 29 jun. 1965. Art. 1º "Qualquer cidadão será parte legítima para pleitear a anulação ou a declaração de nulidade de atos lesivos ao patrimônio da União, do Distrito Federal, dos Estados, dos Municípios, de entidades autárquicas, de sociedades de economia mista (Constituição, art. 141, § 38), de sociedades mútuas de seguro nas quais a União represente os segurados ausentes, de empresas públicas, de serviços sociais autônomos, de instituições ou fundações para cuja criação ou custeio o tesouro público haja concorrido ou concorra com mais de cinqüenta por cento do patrimônio ou da receita ânua, de empresas incorporadas ao patrimônio da União, do Distrito Federal, dos Estados e dos Municípios, e de quaisquer pessoas jurídicas ou entidades subvencionadas pelos cofres públicos."

539 BRASIL. Lei n⿳o 7.347, de 24 jul. 1985. Art. 5. "Têm legitimidade para propor a ação principal e a ação cautelar: V - a associação que, concomitantemente: a) esteja constituída há pelo menos 1 (um) ano nos termos da lei civil; b) inclua, entre suas finalidades institucionais, a proteção ao meio ambiente, ao consumidor, à ordem econômica, à livre concorrência ou ao patrimônio artístico, estético, histórico, turístico e paisagístico.”

${ }^{540}$ BRASIL. Lei no 9.427 , de 26 dez. 1996. Art. $4^{\circ}$, §3º "O processo decisório que implicar afetação de direitos dos agentes econômicos do setor elétrico ou dos consumidores, mediante iniciativa de projeto de lei ou, quando possível, por via administrativa, será precedido de audiência pública convocada pela ANEEL."

${ }^{541}$ BRASIL. Lei no ${ }^{\circ}$ 9.472, de 16 jul. 1997. Art. 19. “À Agência compete adotar as medidas necessárias para o atendimento do interesse público e para o desenvolvimento das telecomunicações brasileiras, atuando com independência, imparcialidade, legalidade, impessoalidade e publicidade, e especialmente: I - implementar, em sua esfera de atribuições, a política nacional de telecomunicações; II - representar o Brasil nos organismos internacionais de telecomunicações, sob a coordenação do Poder Executivo; III - elaborar e propor ao Presidente da República, por intermédio do Ministro de Estado das Comunicações, a adoção das medidas a que se referem os incisos I a IV do artigo anterior, submetendo previamente a consulta pública as relativas aos incisos I a III. Art. 42. As minutas de atos normativos serão submetidas à consulta pública, formalizada por publicação no Diário Oficial da União, devendo as críticas e sugestões merecer exame e permanecer à disposição do público na Biblioteca. Art. 195. O modelo de reestruturação e desestatização das empresas enumeradas no art. 187, após submetido a consulta pública, será aprovado pelo Presidente da República, ficando a coordenação e o acompanhamento dos atos e procedimentos decorrentes a cargo de Comissão Especial de Supervisão, a ser instituída pelo Ministro de Estado das Comunicações."
} 
Entretanto, a visão otimista sobre a participação desinteressada da sociedade civil não prevalece ao teste da realidade. Já no século XIX, Jhering considerava que toda ação individual pressupunha um interesse - a visão romântica de indivíduos agindo desinteressadamente é equivocada: o agir desinteressado terá sempre uma finalidade, oculta ou não. ${ }^{542}$

Quando esses espaços para a participação da sociedade civil perante o Estado não são ocupados por grupos de interesse, sinceramente motivados pela busca do interesse público, os interesses privados prevalecem incontestes. Tal realidade é particularmente aguda no Estado patrimonialista brasileiro. A imprensa independente e as associações de defesa do interesse público possuem papel decisivo nesse jogo e devem ser incentivadas ${ }^{543}$ como estratégia de fortalecimento de grupos capazes de vocalizar contrários aos interesses dos detentores do poder econômico e político, interessados na manutenção do usufruto das benesses do Estado.

A essa dificuldade se adicionam ameaças a esses grupos constituintes da sociedade civil. Comumente, a mídia escrita é intimidada e proibida de divulgar informações sobre os interesses contrariados, ${ }^{544}$ o que é incompatível com a liberdade de imprensa. De igual maneira, a prática de venda de matérias jornalísticas para fins de propaganda ou a serviço de interesses políticos específicos, forma de corrupção da atividade jornalística, é frequente no Brasil. $^{545}$

Já no que tange aos grupos de interesse, tem-se verificado que a denominação ONG (organização não governamental) é inadequada, pois parte considerável delas recebe recursos

\footnotetext{
$\overline{542}$ JEHRING, Rudolf von. A evolução do direito. Trad. de O. de Meulenaere. Salvador: Livraria Progresso, 1953. p. 61. "A própria abnegação supõe um interesse, mas se reveste de um caráter diferente do egoísmo. A bem nítida distinção que a língua estabeleceu é perfeitamente justa: opõe o espírito de desinteresse e de abnegação ao espírito egoísta, interesseiro, pessoal. O egoísta que age em proveito de outrem permanece indiferente ao resultado obtido pelo terceiro, de tal modo que preferia atingir o seu fim sem ele. Esse resultado é para ele apenas um meio. No ato de abnegação, pelo contrário, é precisamente esse resultado que o seu autor pretende. Se este fim lhe escapa ele abstém-se."

${ }^{543}$ ROSE-ACKERMAN, Susan. A economia política da corrupção. In: ELLIOT, Kimberly Ann (Org.). Op. cit. p. 85.

${ }^{544}$ ASSOCIAÇÃO BRASILEIRA DE IMPRENSA. Jornal da ABI, Rio de Janeiro, n. 307-B, abr. 2006 , p. 6. Disponível em: <http://www.abi.org.br/contasdaabi/relatorio\%202005-2006.pdf>. Acesso em: 25 dez. 2009. Vejam-se os fatos relatados de intimidação da mídia escrita a seguir descritos: “4.4.3. em princípio de fevereiro [de 2006], A Gazeta do Povo, de Curitiba, Paraná, denunciou à ABI a perseguição que passou a sofrer do Governador do Estado, Roberto Requião, que, em represália a noticiário do jornal, fez seu partido, o PMDB, espalhar pela capital outdoors com a inscrição A Gazeta do Povo mente e, segundo o jornal, determinou o corte na inserção de publicidade oficial no jornal."

${ }^{545}$ LIMA, Venício A. de. Mídia. In: AVRITZER, Leonardo et al. (Org.). Op. cit. p. 532. Numa pesquisa feita em 66 países, o Brasil figura na $47^{\mathrm{a}}$ posição, o que demonstraria certa independência da mídia. Por outro lado, as disparidades regionais influenciam a independência dos grupos regionais de mídia, os quais, nas regiões mais afastadas dos grandes centros, tendem a ser vinculados aos grupos políticos detentores do poder. Ver ABRAMO, Claudio Weber. Brazil: a portrait of disparities. Brazilian Journalism Research, Brasília: UnB, v. 3, n. 1, Semestre 12007.
} 
públicos para sua subsistência. De fato, uma CPI voltada para a investigação das atividades das ONGs esclarece que, pelo menos desde 1993, existe regulamentação da Secretaria do Tesouro Nacional que permite às ONGs terem "acesso a recursos públicos para realização de projetos por meio da celebração de convênios, requerendo para tanto uma série de documentos, além do registro no Conselho de Assistência Social - CNAS". A preocupação não é exagerada, pois mesmo entidades pequenas,

[...] quando se envolvem com o Poder Público, o fazem tão-somente quando necessitam financiar suas atividades com recursos públicos. Muitas delas, no entanto, são dotadas de estrutura para captação de recursos privados, inclusive no exterior; não necessitam de recursos públicos brasileiros para financiar suas atividades. $^{546}$

Em cenários dessa natureza, é difícil acreditar que inexista conflito de interesses, mesmo porque a dependência financeira de uma ONG em relação ao Estado dificulta o exercício das atividades de crítica e defesa do interesse público, desempenhadas pela sociedade civil. ${ }^{547}$

\subsection{Existe um sistema nacional de combate à corrupção?}

Em ciências sociais, um sistema pode ser definido como "um conjunto de fenômenos sócio-culturais configurados por normas, valores e instrumentos distintos dos que pertencem a outro conjunto de fenômenos causalmente significativos". Externamente, um sistema aflora "em certos fundamentos ideológicos, certas funções concretas e uma estrutura ou forma de como se organizam e praticam aquelas funções e os instrumentos ou meios correspondentes". ${ }^{548}$

Normalmente, a palavra sistema é associada certa ideia de organização e ordem entre as diversas partes envolvidas. ${ }^{549} \mathrm{O}$ legislador brasileiro tomou a expressão emprestada e a

\footnotetext{
${ }^{546}$ BRASIL. Senado Federal. Relatório final da Comissão Parlamentar de Inquérito, destinada a apurar, no prazo de 180 (cento e oitenta) dias, as denúncias veiculadas a respeito da atuação irregular de Organizações Não-Governamentais - ONG's, nos termos do Requerimento no 22, de 2001-SF. Brasília, 2002, p. 28 e 31.

547 Vide o potencial conflito de interesses da ONG Transparência Brasil, que tem por objeto o combate à corrupção estatal, mas em 2006 recebeu mais de R\$ 180 mil da CGU. Informação obtida no blog do Presidente da ONG Transparência Brasil. Disponível em: <http://colunistas.ig.com.br/claudioabramo/2009/06/23/a-luz-dosol/>. Acesso em: 25 dez. 2009.

${ }^{548}$ CARDONA, Alejandro Ramírez. Sistema de hacienda pública. Bogotá: Temis, 1970. p. 1. "Un sistema es un conjunto de fenómenos socio-culturales configurados por normas, valores e instrumentos distintos de los que pertenecen a otro conjunto de fenómenos causal-significativos. Esa identidad del sistema se manifiesta por unos fundamentos ideológicos, unas funciones concretas y una estructura o formas de como se organizan y practican aquellas funciones y los instrumentos o medios correspondientes."

${ }^{549}$ DE CHIARA, José Tadeu. Instituições financeiras. In: FRANÇA, R. M. Enciclopédia Saraiva do direito. São Paulo: Saraiva, 1977, v. 47. p. 47. "Traduzindo o vocábulo 'sistema' a idéia de conjunto, de harmonia, de atuação conjugada entre partes de um todo [...]."
} 
utilizou em vários diplomas legais. $\mathrm{O}$ art. $1^{\circ}$ da Lei $\mathrm{n}^{\mathrm{o}}$ 4.595/64 estabelece "o Sistema Financeiro Nacional, estruturado e regulado pela presente lei", ${ }^{550}$ ao passo que o art. 105 da Lei $\mathrm{n}^{\mathrm{o}} 8.078$ determina que "integram o Sistema Nacional de Defesa do Consumidor (SNDC) os órgãos federais, estaduais, do Distrito Federal e municipais e as entidades privadas de defesa do consumidor" ${ }^{551}$ A própria Constituição de 1988 utilizou a palavra 59 vezes e criou ou mencionou um grande número de sistemas (sistema confederativo de representação sindical, sistema nacional de gerenciamento de recursos hídricos, sistema nacional de viação, sistema nacional de emprego, sistema eleitoral, sistema tributário nacional, sistema financeiro nacional, sistema de seguridade social, sistema único de saúde, sistema de ensino, entre outros). ${ }^{552}$ Há, inclusive, referências constitucionais a sistema em matéria de controle - o art. 31 se refere aos "sistemas de controle interno" dos Executivos municipais, ${ }^{553}$ expressão repetida nos arts. $70^{554}$ e $74 . .^{55}$

Por certo, um sistema não precisa estar positivado em lei para sê-lo. Nesse sentido, pode-se reformular a questão inicial: em que medida as entidades arroladas e descritas se articulam dentro de um sistema nacional de combate à corrupção? Nenhuma delas possui por função articular ou organizar a ação dos diversos atores envolvidos, mesmo porque alguns são dotados de independência para decidir sua pauta de ação, tais como o Ministério Público, o Judiciário, os Tribunais de Contas e o Legislativo. No âmbito do Executivo, são frequentes as críticas quanto à atuação "desarticulada” dos órgãos responsáveis por essas tarefas, em especial os Tribunais de Contas - a suspensão de obras é objeto de protestos dos políticos, talvez preocupados com o calendário eleitoral.

Contudo, no direito posto, há algumas normas que sugerem ação coordenada. Um interessante exemplo de coordenação é dado pela Lei $\mathrm{n}^{-0}$ 8.429/92. Do ponto de vista processual, a Lei $\mathrm{n}^{\mathrm{o}}$ 8.429/92 dispõe de amplos meios repressivos e dissuasórios, inclusive permitindo a medida cautelar de sequestro de bens. Qualquer pessoa tem legitimidade para

\footnotetext{
$\overline{550}$ BRASIL. Lei $\mathrm{n}^{\mathrm{o}} 4.595 / 64$, art. $1^{\mathrm{o}}$.

${ }^{551}$ BRASIL. Lei no ${ }^{\circ} 8.078 / 90$, art. 105.

552 BRASIL. Constituição (1988).

553 BRASIL. Constituição (1988). Art. 31. “A fiscalização do Município será exercida pelo Poder Legislativo Municipal, mediante controle externo, e pelos sistemas de controle interno do Poder Executivo Municipal, na forma da lei."

${ }^{554}$ BRASIL. Constituição (1988). Art. 70.

555 BRASIL. Constituição (1988). Art. 74. “Os Poderes Legislativo, Executivo e Judiciário manterão, de forma integrada, sistema de controle interno com a finalidade de: I - avaliar o cumprimento das metas previstas no plano plurianual, a execução dos programas de governo e dos orçamentos da União; II - comprovar a legalidade e avaliar os resultados, quanto à eficácia e eficiência, da gestão orçamentária, financeira e patrimonial nos órgãos e entidades da administração federal, bem como da aplicação de recursos públicos por entidades de direito privado; III - exercer o controle das operações de crédito, avais e garantias, bem como dos direitos e haveres da União; IV - apoiar o controle externo no exercício de sua missão institucional."
} 
apresentar a denúncia na administração pública, ${ }^{556}$ o que não afasta a participação do Ministério Público, ${ }^{557}$ embora somente este e a pessoa jurídica interessada possam propor ação judicial. ${ }^{558}$ Uma vez instaurado o procedimento administrativo, a notificação ao Tribunal ou Conselho de Contas e ao Ministério Público se torna obrigatória. ${ }^{559}$

Excluídos esses atores que atuam em arenas distintas por serem dotados de independência funcional, a CGU apresenta certas características de coordenação, incumbindolhe "assistir direta e imediatamente ao Presidente da República no desempenho de suas atribuições quanto aos assuntos e providências que, no âmbito do Poder Executivo, sejam atinentes à defesa do patrimônio público, ao controle interno, à auditoria pública, à correição, à prevenção e ao combate à corrupção, às atividades de ouvidoria e ao incremento da transparência da gestão no âmbito da administração pública federal". ${ }^{560}$ Mesmo assim, a CGU tem limitado papel de coordenação, quer por causa da sua falta de competência nas ações dos demais membros da federação, quer devido ao fato de algumas competências estarem fora de suas atribuições (v.g. as relacionadas à recuperação de ativos são coordenadas pelo DRCI, e não está claro o grau de coordenação entre as repartições públicas).

A função de coordenação deve ser exercida com prudência. Enxergar uma missão institucional com messianismo ou sebastianismo pode conduzir a arbitrariedades, especialmente com a oposição ao governo. Por isso, dotar um ministério, órgão eminentemente político como a CGU, de atribuições de agência reguladora com superpoderes, sugestão comum de alguns organismos internacionais, representa risco para a própria democracia. ${ }^{561}$ No Brasil, o Ministério Público, dotado de independência funcional, já desempenha essas funções e sempre é criticado por causa dos seus supostos excessos. ${ }^{562}$

\subsection{Existe uma política nacional de combate à corrupção?}

Ora, se inexiste uma clareza na articulação formal entre os agentes institucionalmente incumbidos do combate à corrupção, deve-se indagar se ao menos existe

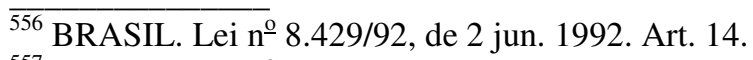

${ }^{557}$ BRASIL. Lei $\mathrm{n}^{\mathrm{o}} 8.429 / 92$, de 2 jun. 1992. Art. 14, $\S 2^{\circ}$.

${ }^{558}$ BRASIL. Lei no 8.429/92, de 2 jun. 1992. Art. 17.

${ }^{559}$ BRASIL. Lei $\mathrm{n}^{\mathrm{o}}$ 8.429/92, de 2 jun. 1992. Art. 15 .

${ }^{560}$ BRASIL. Lei $\mathrm{n}^{\mathrm{o}}$ 10.683, de 28 maio 2003. Art. 17.

${ }^{561}$ ROSE-ACKERMAN, Susan. A economia política da corrupção. In: ELLIOT, Kimberly Ann (Org.). Op. cit. p. 84. "Órgãos externos de inspeção, como a Comissão Independente de Honk Kong contra a Corrupção, podem ser úteis. Porém um órgão dessa natureza corre o risco de ser arbitrário se estiver subordinado somente ao governante do país, o qual poderia tornar-se tendencioso contra rivais políticos."

${ }^{562}$ SADEK, Maria Teresa. Ministério Público. In: AVRITZER, Leonardo et al (Org.). Op. cit. p. 545.
} 
uma diretriz mais objetiva a ser obedecida. Reformulando a questão: reconhecidos os efeitos nefastos da corrupção, existiria uma política de combate à corrupção por parte do Estado brasileiro? O questionamento é conveniente, pois o Estado patrimonialista tratou de positivar regras que diferenciam o público do privado e, ao mesmo tempo, proporciona condições para que as mesmas sejam sabotadas - a articulação dos atores engajados no combate à corrupção poderia ser uma resposta ao problema.

Quando se refere a políticas públicas, tem-se em mente um ato administrativo, na medida em que uma política pública nada mais é do que um conjunto de atos administrativos tomados pelo Estado para atingir dada finalidade, normalmente estatuída ou na Constituição ou na lei. Atos administrativos são "a manifestação de vontade do Estado, por seus representantes, no exercício regular de suas funções, ou por qualquer pessoa que detenha, nas mãos, fração de poder reconhecido pelo Estado, que tem por finalidade imediata criar, reconhecer, modificar ou extinguir situações jurídicas subjetivas em matéria administrativa". ${ }^{563}$

Como se pode deduzir da definição apresentada, os atos são inerentes às atividades da administração pública. Desse modo, o ato administrativo atua como um canal de comunicação entre as pessoas públicas e o povo. ${ }^{564}$ É por meio dos atos administrativos que as medidas anticorrupção podem ser tomadas individualmente - cada vez que a CGU e o TCU tomam alguma medida de combate à corrupção, o fazem por meio de atos administrativos.

Todavia, essa comunicação não é desprovida de propósito. É conferida pelas normas que expressam os valores tutelados pelo direito. Assim,

\begin{abstract}
Como categoria analítica, as políticas públicas envolveriam sempre uma conotação valorativa; de um lado, do ponto de vista de quem quer demonstrar a racionalidade da ação governamental, apontando os vetores que a orientam; de outro lado, da perspectiva dos seus opositores, cujo questionamento estará voltando à coerência ou à eficácia da ação governamental. Essa dimensão axiológica das políticas públicas aparece nos fins da ação governamental, os quais se detalham e se concretizam em metas e objetivos. 565
\end{abstract}

Não bastam atos administrativos para formar uma política pública, "definida por sua finalidade enquanto conjunto de atos e normas" ${ }^{\$ 66}$ - é necessário identificar uma finalidade, valorada pelo ordenamento jurídico, que repila a corrupção. Indiretamente existe a finalidade

\footnotetext{
$\overline{563}$ CRETELLA JÚNIOR, José. Direito administrativo brasileiro. Rio de Janeiro: Forense, 1999. p. 229.

564 Idem, p. 221.

${ }^{565}$ BUCCI, Maria Paula D. Direito administrativo e políticas públicas. São Paulo: Saraiva, 2002. p. 252.

${ }^{566}$ COMPARATO, Fábio Konder. Ensaio sobre o juízo de constitucionalidade de políticas públicas. Revista dos Tribunais, São Paulo, ano 86, n. 737, p. 17, mar. 1997.
} 
bem comum que exige eficiência na gestão da coisa pública, o que permite conceber a existência de uma política nacional de combate à corrupção.

Uma política nacional de combate à corrupção deflui da concepção de Loewenstein sobre a separação entre os poderes. Loewenstein argumenta que, para a livre formação da “vontade estatal” garantidora das liberdades públicas, faz-se necessário que cada função seja exercida por um sujeito diferente. ${ }^{567}$ Diversamente da separação subjetiva entre os poderes de Montesquieu, Loewenstein sustenta que a divisão das funções deveria ser o novo paradigma. Três seriam as funções estatais: policy determination (determinação de políticas), policy execution (execução de políticas) e policy control (controle das políticas). A atividade de planejamento, implementadora de políticas, é uma "forma de atuação estatal, caracterizada pela previsão de comportamentos econômicos e sociais futuros, pela formulação explícita de objetivos e pela definição de meios de ação coordenadamente dispostos, mediante a qual se procura ordenar, sob o ângulo macroeconômico, o processo econômico, para melhor funcionamento da ordem social, em condições de mercado". 568

Vista desse ângulo, uma política nacional de combate à corrupção seria o elemento orientador da ação estatal, capaz de articular todos os entes envolvidos na repressão ao ilícito nas formas de corrupção suborno e corrupção-favorecimento. No ordenamento jurídico, haveria elementos determinadores de política (valor confiança depositada nas várias regras que sedimentam a dicotomia público-privado) e controladores de política (as regras de controle mais diversas).

Essa tarefa é complexa, uma vez que os agentes do sistema nacional de combate à corrupção se encontram desarticulados e haveria a necessidade de avaliação conjuntural constante, ${ }^{569}$ impondo ao seu formulador a constante reconfiguração da estratégia a ser seguida - na história recente, houve momentos em que se teve a impressão de que avanços eram feitos, mas estes se desmancharam no momento seguinte, ante a possível falta dessa coordenação. Beccaria apontava a clareza na ação repressora como um dos fatores do sucesso

\footnotetext{
${ }^{567}$ LOEWENSTEIN, Karl. Teoría de la constitución. Traducción y studio sobre la obra por Alfredo Gallego Anabitarte. Barcelona: Ariel, 1970. v. 1. p. 50.

${ }^{568}$ GRAU, Eros Roberto. Planejamento econômico e regra jurídica. São Paulo: Revista dos Tribunais, 1997. p. 145.

${ }^{569}$ LAFER, Celso. O sistema político brasileiro. São Paulo: Perspectiva, 1975. p. 45. "A policy, muito mais que a administração, envolve riscos e conjuntura porque representa uma escolha entre atos futuros. Daí a complexidade da decisão política, que é basicamente uma opção de policy, uma decisão que estabelece parâmetros optando entre diversos riscos, com base numa apreciação que varia de indivíduo para indivíduo sobre uma determinada conjuntura."
} 
da repressão criminal, ${ }^{570}$ e tal mudança de objetivos poderia criar incertezas. Do ponto de vista dos instrumentos disponíveis, há até mesmo quem os considere eficazes. ${ }^{571} \mathrm{O}$ que o combate à corrupção enfrenta é dificuldades em seara diversa do direito positivo. ${ }^{572}$

A existência de uma política nacional de combate à corrupção, expressa por meio das instâncias político-decisórios do Estado patrimonialista, também se limita e é determinada pelo direito pressuposto. Os influxos deste podem atrapalhar a implementação dos mecanismos de controle - afinal, os fatores da infraestrutura econômica conspirariam contra a aplicação pura e simples dos instrumentos repressivos microjurídicos.

\footnotetext{
$\overline{570}$ BECCARIA, Cesare. Op. cit. p. 109-110. "Quereis prevenir os delitos? Fazei com que as leis sejam claras, simples e que toda a força da Nação se coordene em defendê-las e nenhuma parte seja empregada em destruí-las. Fazei com que as leis favoreçam menos as classes dos homens do que os próprios homens."

${ }^{571}$ LIVIANU, Roberto. Op. cit. p. 205. No mesmo sentido, ver ROSAS, Roberto. A corrupção eleitoral. In: ZILVETI, Fernando Aurélio; LOPES, Silvia. O regime democrático e a corrupção política. São Paulo: Atlas, 2004. p. 146. "A legislação está muito bem aquinhoada: há um capítulo sobre crimes eleitorais, a lei de improbidade administrativa, a ação civil pública, a lei da ação popular, há o princípio da moralidade administrativa no art. 37 da Constituição, há um capítulo no Código Penal de crimes contra a Administração Pública etc."

${ }^{572}$ ROSAS, Roberto. A corrupção eleitoral. In: ZILVETI, Fernando Aurélio; LOPES, Silvia. O regime democrático e a corrupção política. São Paulo: Atlas, 2004. p. 146. Por exemplo, Rosas argumenta que "não basta, na verdade, apenas a legislação. [...] O que falta, na realidade, é a ação dos indivíduos, dos segmentos jurídicos do País, das instituições culturais jurídicas, no sentido de levar elementos para a discussão e o debate para impedir o progresso da corrupção".
} 


\section{CAPÍTUlO 5}

\section{O FATO CORRUPÇÃO TOMADO COMO FUNDAMENTO DA REGULAMENTAÇÃO MICROJURÍDICA DOS DIREITOS PENAL, ADMINISTRATIVO E POLÍTICO-CONSTITUCIONAL}

As dificuldades expostas para o funcionamento do aparato repressivo microjurídico têm raízes na evolução histórica do Estado brasileiro. Mesmo assim, há outros aspectos ligados às práticas corruptas que influenciam a sua repressão, tais como as dificuldades inerentes para lidar com os crimes do colarinho branco, sempre envoltos em elevadas cifras negras. Por isso, há linha de investigação que pretende compreender melhor as várias nuances da corrupção, desvendando suas características nucleares e traçando relações, a fim de poder estabelecer respostas mais eficazes ao problema.

Criticamente, deve-se ter em mente que o fato corrupção não é atemporal, como sugere parte desses estudos. Logo, para serem válidas para fins da política nacional de combate à corrupção, as conclusões precisam ser temperadas com as circunstâncias que informaram a formação nacional e constituem o direito pressuposto. Para essa finalidade, também precisam ser investigados o comportamento e a atitude específica de parcela da sociedade e classe política brasileira.

\subsection{Abordagem tipológica da corrupção}

Na concepção metodológica que inspira este trabalho, as ciências sociais possuem a função de fornecer subsídios sobre como a corrupção se manifesta: embora o direito possa julgar a corrupção perante os tribunais, encontra-se fora do seu objeto de estudo principal investigar outros aspectos do fato corrupção. Assim, não é objeto a priori do direito relacionar o fato corrupção com as práticas entre os partidos políticos, as percepções sobre o espaço público-privado e os seus danos econômicos. Entretanto, essas informações precisam ser conhecidas e manipuladas, caso se deseje construir um trabalho jurídico ligado à realidade. Para que haja uma seleção de qual melhor de lege ferenda a ser transformada em de lege lata, o confinamento aos limites do formalismo jurídico é insuficiente. 
Isso significa dizer que os dados obtidos pelas ciências sociais não devem e não podem ser considerados mero ex cursus em relação ao método adotado. Essa ressalva é importante, pois grande parte dos trabalhos produzidos sobre a corrupção a partir dos anos 1990 tende a não dar a necessária ênfase multidisciplinar ao fato corrupção. ${ }^{573} \mathrm{~A}$ perfeita compreensão do fato corrupção nos mais variados aspectos ajuda a definir melhor seus contornos na regulamentação microjurídica, bem como suas causas e seus pontos vulneráveis. Esses dados permitem desenhar estratégias de combate à corrupção que sejam consistentes com a realidade brasileira.

A principal dificuldade encontrada é identificar traços gerais do tratamento conferido por tais ciências ao problema. Embora a literatura produzida seja ampla, sua resenha demonstra que diversas linhas de pesquisa foram adotadas, muitas das quais se confundem entre si - isso é patente entre a ciência política e a sociologia. Os itens seguintes constituem apenas um panorama geral das obras e ideias mais significativas, condensando as preocupações mais significativas em torno da corrupção.

Uma nota comum entre a ciência política, a sociologia e a economia é a ausência de preocupação com o estabelecimento de uma definição ou conceito de corrupção. Embora muito se tenha escrito sobre possíveis definições e conceitos, as ciências sociais não lograram atingir um consenso. Essas ciências lidam principalmente com aproximações, quase que intuitivas, sobre o que seria corrupção, criando tipos para cada estudo específico em comum, todas partem da noção de que corrupção seria o uso inadequado do titular do Poder Público para obtenção de benefícios privados. Ao tratar da tipologia específica da corrupção policial, Barker e Roebuck alertam para o fato de que "normas, regras e processos sancionatórios relativos ao comportamento policial corrupto são relativos no tempo e espaço; portanto, a tipologia deveria ser empiricamente testada, retestada e modificada conforme o caso". ${ }^{574}$

Ainda que seja apresentada uma definição por tais ramos do conhecimento, sua utilização se restringiria a trabalhos específicos e, mais importante, se adaptaria conforme as

\footnotetext{
$\overline{573}$ HEIDENHEIMER, Arnold J.; JOHNSTON, Michael (Org.). Political corruption: concepts and contexts. 3. ed. New Brunswick: Transaction Publishers, 2002. p. xiii. "Some of the extensive corruption literature published by social scientists in the 1990s has been mono-disciplinary, as in the case of most publications by international lending and development agencies. Other parts of that literature have been so directed toward policy lessons that key conceptual and definitional questions have been largely ignored, as in many of the publications produced or sponsored by reform groups."

574 BARKER, T.; ROEBUCK, J. B. Typology of police corruption. Social Problems, Berkeley: University of California Press, v. 21, n. 3, p. 435,1974.
} 
circunstâncias. Em grande parte, essa delimitação decorreria do objetivo traçado para a pesquisa a ser realizada. Por exemplo, a economia se preocupa com o suborno na contratação de obras públicas e, dentro dos modelos simplificadores da realidade da microeconomia, analisa se essa prática poderia causar prejuízo ao bem- estar social: da perspectiva econômica, o importante é a existência desse prejuízo ao bem-estar social, haja ou não prática proibida juridicamente.

A ausência de consenso não significa a existência de uma ampla liberdade que impossibilitaria a intercomunicação e o diálogo interdisciplinar. O fato de um conceito, abstrato por natureza, não atender às necessidades metodológicas específicas de tais ciências impõe-lhes o recurso ao tipo, mais concreto e próximo à realidade. A solução para estabelecer o diálogo interdisciplinar reside no recurso ao tipo como referencial teórico. Afinal, a corrupção é uma prática multifacetada que comporta vários aspectos e caracteres distintos.

Empregado há muito tempo pelo direito penal, Assis reconhece que o tipo "é utilizado em todas as áreas do conhecimento para separar e agrupar classes de objetos particulares que apresentem algo de comum". ${ }^{575}$ Já do ponto de vista das ciências sociais, o tipo permite a delimitação individual de práticas corruptas que, em princípio, pouco têm em comum entre si a não ser o uso do Estado para obtenção de benefícios privados - para um jurista do direito penal, o que as ciências sociais utilizam provavelmente nem sequer seria considerado como um tipo, posto que demasiado aberto.

Afastado do direito penal, o uso de tipos para definir corrupção parece tornar os limites e fronteiras menos precisos do que os de um conceito. Ao partirem do concreto para o abstrato, os tipos das ciências sociais abrem a possibilidade de as escolhas feitas serem, de certo modo, arbitrárias. É perfeitamente aceitável a crítica quanto à falta de consistência de alguns tipos - por que diferenciar a corrupção em que o particular oferece dinheiro daquela em que o particular oferece presentes para obter uma vantagem do Poder Público? Essa diferenciação se explica na medida em que os incentivos e as causas sejam distintos, o que, por seu turno, justificaria estratégias de combate diferenciadas.

O método indutivo, presente na construção dos tipos de corrupção, adiciona riqueza ao significado da palavra e possibilita que os estudos sejam feitos livres de restrições. Mais do que isso, em vez de se deter numa discussão estéril sobre um possível conceito ou

\footnotetext{
575 TOLEDO, Francisco de Assis. Princípios básicos de direito penal: de acordo com a Lei no ${ }^{\mathrm{o}}$ 7.209, de 11-71984 e com a Constituição de 1988. 5. ed. São Paulo: Saraiva. 1994. p. 126.
} 
definição de corrupção, pode-se avançar para a forma como a corrupção se manifesta no cotidiano.

Os seguintes tipos relacionados à corrupção serão objeto de estudo: (i) suborno, (ii) presentes, (iii) clientelismo, (iv) nepotismo, (v) favorecimento de amigos em cargos públicos, (vi) apropriação de bens e recursos públicos, (vii) propina e (viii) envolvimento com o crime organizado. A lista abaixo apresenta os tipos mais genéricos e não possui caráter exaustivo. ${ }^{576}$ Também se deve ressaltar que várias das práticas corruptas envolvem uma combinação de vários tipos arrolados e a sua melhor compreensão pode necessitar a combinação desses tipos.

\subsubsection{Suborno}

Subornar significa dar algum dinheiro a alguém para que faça algo ilícito, pouco importando se o aceitante está investido de função pública ou não. Quando o aceitante é pessoa desprovida de qualquer função pública, as repercussões patrimoniais se restringem predominantemente às partes envolvidas. Por seu turno, quando o aceitante ou extorquinte é detentor de função pública, toda a sociedade é afetada indiretamente por sua ação ilegal. Essa distinção justifica o fato de as maiores preocupações sobre corrupção focarem o espaço público.

Outro aspecto a destacar é a inexistência de prévio acordo entre o oferente e o aceitante do suborno - este é oferecido sem a certeza de sua aceitação. ${ }^{577}$ Tal grau de incerteza adiciona risco à sua prática, de modo que esse seria um ponto fraco a ser explorado no seu combate. Isso ocorre principalmente quando o ocupante do cargo público tenta extorquir o particular.

O seu grau e a sua intensidade variam de um lugar ao outro. Enquanto algumas sociedades consideram tal prática repulsiva no relacionamento dos particulares com a esfera pública, outras a enxergam como normal e corriqueira - os bons modos impõem o pagamento de suborno como retribuição pela licença, pela não imposição de multa ou pelo voto. Especialmente quando o suborno é de pequena monta, a sua condenação, pura e

\footnotetext{
$\overline{576}$ WEBER, Max. Economia e sociedade: fundamentos da sociologia compreensiva. Vol. 1. Tradução de Regis Barbosa e Karen Elsabe Barbosa. Revisão técnica de Gabriel Cohn. Brasília: UnB, 1999. p. 142. Ao traçar os três tipos de dominação, Weber também se defrontou com o problema: "Nem de longe se cogita aqui sugerir que toda a realidade histórica pode ser 'encaixada' no esquema conceitual desenvolvido no que segue".

577 Compare-se o suborno à propina. Ver item 5.1.7, infra.
} 
simples, pode ferir suscetibilidades em várias culturas, o que levanta questões acerca de um relativismo cultural nessa área - pagar um guarda de trânsito para evitar uma multa seria aceitável, mas aceitar suborno para favorecer a contratação de uma empresa para uma obra de grande porte não o seria.

\subsubsection{Presentes}

A prática de presentear autoridades públicas pode ser considerada uma subespécie de suborno, pois o presenteador visa, ao menos indiretamente, à obtenção de uma vantagem. Quer seja porque a aceitação de presentes valiosos sugira fortemente a contraprestação por algum favor, quer porque é uma questão de etiqueta sociocultural, a prática de troca de presentes envolvendo particulares e agentes públicos constitui um caso análogo ao suborno. Obviamente, se o agraciado com o presente não exerce nenhuma função pública, a troca de presentes não suscita maiores preocupações.

Não se pode ignorar que a prática de relações sociais comumente pode se caracterizar pela troca de presentes. Em certas culturas, é de gesto de educação presentear o anfitrião com algum mimo - no Japão, visitar alguém e não lhe oferecer um presente é visto como séria falta de etiqueta social. O ponto, porém, é saber diferenciar quando o presente cruza a linha do razoável e culturalmente aceitável, de modo que o agraciado se sente ou compelido a retribuir o favor ou "encobre um suborno". Nos Estados Unidos e no Brasil, respectivamente presentes ao presidente em valor superior a US\$ 200 e a R\$ 100 são considerados presentes ao gabinete - se desejar ficar com o presente, o presidente deverá comprá-lo. Na história política recente brasileira, jet-skis foram presenteados a autoridades e estas não tiveram nenhum constrangimento em recebê-los.

Um subtipo de troca de presentes é o financiamento privado de campanhas eleitorais. Apesar de serem permitidas na legislação de vários países, as doações privadas podem criar um relacionamento entre o doador e o donatário mais forte do que seria desejável da perspectiva do interesse público. Os interessados em obter recursos privados poderiam se tornar defensores irredutíveis ou críticos ferozes de determinada ação estatal a despeito do interesse público envolvido.

\subsubsection{Clientelismo}


O clientelismo consiste na concessão de privilégios no seio da máquina da administração pública aos apoiadores daqueles que detêm o poder. Isso se dá principalmente por meio da nomeação para cargos públicos, embora outros tipos de favores também possam ser associados, tal como concessão de licenças, financiamentos ou isenções. Sob certo prisma, à semelhança do que ocorre na Sicília e na Grécia, o clientelismo se torna parte integrante do sistema político ao fornecer "um canal de comunicação com o governo" 578 inegável reconhecer que o mesmo sucede em partes do Brasil. Há manipulação das "recompensas" proporcionadas pela apropriação da máquina estatal, utilizada pelo detentor do poder de modo a assegurar a sua manutenção no longo prazo, inclusive nos regimes democráticos. ${ }^{579}$

Nessas regiões, mesmo nas democracias, o clientelismo sobrevive frequentemente associado a práticas políticas de manutenção no poder de oligarquias. Esses traços revelam que o clientelismo se estrutura de modo assimétrico entre o patrão, concessor de favores, e os clientes, beneficiários dos favores e devedores de algum grau gratidão para com o patrão. ${ }^{580}$

Esse ponto merece uma nota distintiva em relação a certas práticas assemelhadas ao clientelismo, mas que não são necessariamente caracterizadas como uma forma de corrupção. Num regime democrático, a indicação de apoiadores para ocupar cargos da administração pública até pode ser considerada como um mecanismo legítimo: na medida em que um partido político se sagra vitorioso nas eleições, as suas propostas e ideias precisam ser implementadas e, para tanto, a indicação dos apoiadores para cargos-chave do Estado é esperada. Todavia, essa prática pode caracterizar um tipo corrupção se a quantidade

\footnotetext{
$\overline{578}$ BOISSEVAIN, J. Patronage in Sicily. In: HEIDENHEIMER, Arnold J. Op. cit. p. 149. "For in such a society the lines of communication are tenous and difficult to follow because of the social distance between those who wish to make their voices heard on high, and those who control the channels through which such messages necessarily must pass. Those desiring to communicate are faced by the rigid apparatus of a ponderous bureaucratic system."

579 JOHSTON, Michael. Agentes públicos, interesses particulares e democracia sustentável: quando política e democracia se unem. In: ELLIOT, Kimberly Ann (Org.). A corrupção e a economia global. Tradução de Marsel Nascimento Gonçalves de Souza. Brasília: UnB, 2002. p. 121. “[...] uma elite bem arraigada no poder pode manipular recompensas econômicas escassas, com vistas a controlar a concorrência política, e mesmo onde existam significativas oportunidades políticas, por intermédio do tipo de organização de clientelismo disciplinado, outrora conhecido nas cidades dos Estados Unidos como máquinas políticas. [...] Uma elite que tenha domínio sobre o clientelismo e elimine gradualmente as facções concorrentes pode controlar o governo, explorar interesses econômicos, extrair valor econômico de alternativas políticas existentes (ou chegar perto disso) e criar um esquema de clientelismo disciplinado. A política permanece como o caminho para a riqueza; o séquito, porém, pode ser controlado por um monopólio sobre o clientelismo: ele não precisa ser subornado repetidas vezes, mas precisa contentar-se com recompensas pequenas, as quais apresentam, porém, um alto preço político. A liderança da máquina tira proveito, política e economicamente, do statu quo; sua atuação se dá a longo prazo, pois aquinhoa favores com o interesse de manter seu domínio, e não de saquear o Estado.”

${ }^{580}$ BOISSEVAIN, J. Patronage in Sicily. In: HEIDENHEIMER, Arnold J. Op. cit.. p. 138.
} 
de cargos a distribuir for elevada e se a partilha deles não obedecer a critérios técnicos mínimos, perdendo-se na mera barganha por cargos. Sob essas circunstâncias, o que é legítimo na democracia pode ser caracterizado como corrupção.

Um subtipo de clientelismo é o coronelismo. A expressão "coronelismo" é usada para designar a forma como as relações sociais no interior brasileiro, fortemente atreladas à economia rural e agropecuária, subvertem a distinção entre o espaço público e privado. A figura do coronel, normalmente um grande e rico proprietário rural, monopoliza o aparelho estatal em determinada região, de modo a utilizá-lo para seus próprios interesses privados. Tal apropriação do aparelho estatal decorre da manipulação do processo político-eleitoral, bem como da omissão das autoridades judiciárias. A manutenção do coronelismo decorria da prática de troca de favores políticos com outras autoridades, e pode-se defini-lo como uma espécie de clientelismo praticada pelas oligarquias rurais brasileiras. ${ }^{581}$ Práticas similares ao coronelismo se repetem em vários países da América Latina.

\subsubsection{Nepotismo}

Uma quarta forma que a corrupção pode assumir é o favorecimento de parentes mediante a concessão de cargos pelos detentores de funções públicas. Prática comum em sociedades em que vigora o clientelismo, o nepotismo é típico de sociedades em que os laços de solidariedade familiar ainda são bastante fortes, e, por conta desse vínculo, existe um dever recíproco de proteger e beneficiar os parentes. Em algumas sociedades, o nepotismo pode até mesmo ser considerado prática obrigatória para os detentores de cargos públicos, pelo menos da perspectiva dos parentes destes. ${ }^{582}$

$\mathrm{O}$ nepotismo não se confunde com o clientelismo. Embora ambos possam se utilizar do nepotismo para a consecução de objetivos privados, o nepotismo sobrevive mesmo fora do contexto clientelista. Onde o coronelismo não está presente, um político pode nomear a esposa para ocupar um cargo público sob o argumento parnasiano de que "não há pessoa melhor para deter esta posição de confiança".

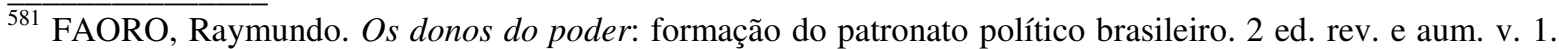
Porto Alegre: Globo; São Paulo: Edusp, 1975. p. 242. O coronelismo tem expandido seu significado. Como nota Faoro, "ao lado do coronel legalmente sagrado, prosperou o 'coronel tradicional', também o chefe político e também o senhor dos meios capazes de sustentar o estilo de vida de sua posição. O conceito entrou na linguagem corrente por via do estilo social, inclusive na vida urbana, com predominância sobre sua função burocrática e política".

${ }^{582}$ LA PALOMBARA, Joseph G. A política no interior das nações. Tradução do $1^{\circ}$ ao $5^{\circ}$ capítulo de Marilu Seixas Correa e do $6^{\circ}$ em diante de Oswaldo Biato. Brasília: UnB, 1982. p. 370
} 


\subsubsection{Favorecimento de amigos em cargos públicos}

Enquanto o favorecimento de parentes até mesmo possui denominação em português (nepotismo), não há uma palavra específica que designe o favorecimento de amigos dos detentores do poder - nos países de língua inglesa, existe a palavra cronyism para se referir a esta prática. Tanto isso é verdade que a indicação de amigos para ocupar cargos públicos, independentemente de qualificação técnica ou experiência prévia, nem sequer é questionada pela sociedade brasileira, a qual, muitas vezes, considera que o detentor do poder tem o direito de escolher seus assessores. Está-se diante da figura caricata do compadre, forma afetiva de se referir a amigos íntimos. O compadre tem o dever moral de ajudar o outro compadre, independentemente da licitude da conduta - num contexto em que os âmbitos público e privado se misturam, os compadres nem sequer consideram moralmente reprovável a entrega de cargos públicos. Diversamente do clientelismo, cujo móvel imediato é a perpetuação no poder, no favorecimento de amigos os detentores do poder desejam precipuamente privilegiar os que lhes são próximos.

Outra manifestação de favorecimento de amigos é a concessão de privilégios e favores a agentes econômicos privados que se beneficiam de rendas. ${ }^{583}$ Esses favores não caracterizam necessariamente corrupção na regulamentação microjurídica, mas consistem na concessão de vantagens anticompetitivas para as empresas privilegiadas: barreiras alfandegárias específicas, subsídios à produção, empréstimos oficiais com juros subsidiados e distribuição de cotas de importação constituem exemplos desse favorecimento, que frequentemente tem efeitos muito mais abrangentes do que boa parte dos outros tipos de corrupção.

\subsubsection{Apropriação de bens e recursos públicos}

A apropriação pura e simples de bens públicos pode ser considerada como uma forma de corrupção. Nesse caso, o detentor do poder simplesmente se apropria de bens públicos, utilizando-os em benefício próprio, de familiares ou de amigos. Por vezes, pode-se confundir com outros tipos - a nomeação, por um agente público, de muitos parentes e

\footnotetext{
$\overline{583}$ KANG, David C. Crony capitalism: corruption and development in South Korea and the Philippines. Cambridge: Cambridge University Press, 2002. p. 12-13.
} 
amigos para determinado setor da administração pode torná-la mera extensão de sua casa, privatizando por completo esse setor. No passado medieval, presente na maioria da Europa ocidental, essa prática, denominada prebentarismo, era bastante comum, sendo associada a um bom rendimento sem muito trabalho.

Tal forma de corrupção é mais usual nas sociedades em que nem sequer existe uma noção teórica da separação entre o público e o privado, tal como ocorre em vários países africanos - os governantes simplesmente transferem recursos financeiros do Poder Público para suas contas pessoais, comportamento que se reflete em todas as instâncias de poder. Aliás, nessas sociedades, a apropriação de bens e recursos públicos tende a não ser considerada como um ilícito ou ação moralmente reprovável.

\subsubsection{Propina}

No uso ordinário, propina significa bonificação ou gorjeta. Em sentido figurado, corresponde à quantia destinada ao agente público que, desde o princípio de um procedimento, conspira com o particular. Diferentemente do que acontece na prática de suborno, em que não há acordo prévio entre o agente público e o particular quanto ao favorecimento deste último, na propina existe acordo desde o princípio: ou as partes se conhecem de contatos anteriores, ou são apresentadas por intermediários, ou já possuem informações recíprocas umas sobre as outras. Trata-se de um jogo em que as cartas são marcadas e o agente público tem a deliberada intenção de lesar o patrimônio público e, com isso, obter sua propina.

Nesse contexto, a gravidade das ações do agente público é mais preocupante do que no suborno, uma vez que, ao se apropriar de dado setor da administração, utiliza-o de modo sistemático para proveito próprio. Em sua origem, suborno e propina podem-se confundir é difícil saber se foi o particular ou o agente público quem iniciou o processo. Entretanto, à medida que o agente público implementa um esquema de extorsão dos particulares, caracteriza-se o tipo propina. Numa concepção essencialmente mercantilista do combate à corrupção, a diferenciação tem impactos na definição de medidas que alterem incentivos para a sua prática. 


\subsubsection{Envolvimento com o crime organizado}

O envolvimento de agentes públicos com o crime organizado prescinde de um corruptor - o agente público pratica alguma conduta que é vedada por lei e se beneficia com o fruto dessa conduta. Normalmente, há repulsa generalizada a essa prática, inclusive daqueles segmentos políticos que consideram normais alguns tipos de práticas corruptas. ${ }^{584}$ Mais sério é o risco de a corrupção relacionada ao crime organizado expandir-se para outros setores da atividade econômica, bem como para o sistema político. ${ }^{585}$

A associação de agentes públicos com o crime organizado não é fenômeno recente. Por paradoxal que possa parecer, os agentes públicos, que deveriam reprimir atividades ilícitas, se associam aos criminosos para favorecê-los. Em realidade, há crimes que, atualmente, necessitam de apoio estatal para prosperar: a repressão estatal adiciona incerteza aos negócios ilícitos, e, por isso, ao minimizá-la, criminosos aumentam sua rentabilidade veja-se a venda de proteção, prática bastante comum nas organizações policiais. ${ }^{586}$ Tráfico de drogas ilegais, tráfico de armas, jogos ilegais e lavagem de dinheiro são os exemplos mais contundentes de condutas que apresentam menores riscos de detecção se houver algum grau de apoio estatal e, consequentemente, maior atratividade para os criminosos.

O envolvimento da corrupção com o crime organizado não se dá apenas nesses tipos de crimes, que naturalmente inspiram repulsa. Pelo contrário, parte significativa da criminalidade ocorre no âmbito dos crimes do colarinho branco. A lavagem de dinheiro garante aos envolvidos em práticas corruptas, mesmo depois de descobertos, os benefícios financeiros dos seus ilícitos. Na maioria dos casos, a modernização ocorrida no sistema financeiro nas últimas décadas, ao permitir transferência instantânea de recursos entre diversos países, facilita o mascaramento dos recursos ilícitos. ${ }^{587}$ Do ponto de vista da

\footnotetext{
${ }^{584}$ BARKER, T.; ROEBUCK, J. B. Typology of police corruption. Social Problems, Berkeley, University of California Press, v. 21, n. 3 , p. 433,1974.

${ }^{585}$ ROSE-ACKERMAN, Susan. Corruption and government: causes, consequences and reform. Nova York: Cambridge University Press, 1999. p. 25.

${ }^{586}$ BARKER, T.; ROEBUCK, J. B. Typology of police corruption. Social Problems, Berkeley, University of California Press, v. 21, n. 3, p. 431, 1974.

${ }^{587}$ GLYNN, Patrick; KOBRIN, Stephen J.; NAÍM, Moisés. Globalização da corrupção. In: ELLIOT, Kimberly Op. cit. p. 28 e ss. "Torna-se cada vez mais difícil nos nossos dias traçar uma linha definida entre capital legal e ilegal, separar propinas e dinheiro das drogas de transações menos criminosas, mas ainda assim dúbias, de companhias e de pessoas físicas idealizadas para, por exemplo, minimizar uma carga tributária. É natural que esse sistema financeiro internacional integrado e digital sob o controle de autoridades nacionais expanda somente em parte a oportunidade de transmissões e de seus efeitos potenciais."
} 
regulamentação microjurídica, a partir de meados dos anos 1990, tem havido um consenso internacional crescente no sentido de aumentar a cooperação entre as diversas jurisdições. ${ }^{588}$

Também deve ser citado o fenômeno da criminalidade de Estado, vista não como os crimes isolados praticados pelos agentes públicos, mas quando há "organizações incrustadas no aparato do Estado de forma intencional e até institucional". ${ }^{589} \mathrm{O}$ fenômeno de "vampirização" do Estado pelo soberano pode-se manifestar, ${ }^{590}$ mas não necessariamente no grau máximo, em que existe a confusão total entre o público e o privado.

\subsection{Características criminológicas dos ilícitos de colarinho branco}

Um dos objetivos da criminologia é aplicar suas conclusões para além dos limites do direito penal, uma vez que as repercussões de muitos dos tipos associados à corrupção, ainda que não tipificados, possuem caracteres similares aos crimes de colarinho branco.

Em sua origem, a criminologia se voltou para o denominado microcriminoso, “encarado como um indivíduo à parte, um marginal da vida societária, sendo o fulcro do sistema jurídico-penal embasado na teoria pura do direito". ${ }^{591}$ Por muitos anos, essa ênfase no microcriminoso moldou a agenda da política criminal, ignorando quase que por completo a existência da macrocriminalidade, caracterizada pela "delinqüência em bloco conexo e compacto, incluída no contexto social de modo pouco transparente (crime organizado) ou sob rotulagem econômica lícita (crime de colarinho branco)". ${ }^{592}$

Curiosamente, foi um estudo crítico dessa criminologia tradicional que originou a expressão crimes do colarinho branco. Foi Sutherland ${ }^{593}$ quem forjou a expressão "crime do

\footnotetext{
$\overline{588}$ Ver item 4.1.1.1, supra.

589 WERNER, Guilherme Cunha. O crime organizado transnacional e as redes criminosas: presença e influência nas relações internacionais contemporâneas. 2009. 241 f. Tese (Doutorado em Ciência Política) Faculdade de Filosofia, Ciências Humanas e Letras, Universidade de São Paulo, São Paulo. p. 90.

${ }^{590}$ ROSE-ACKERMAN, Susan. A economia política da corrupção. In: ELLIOT, Kimberly Ann (Org.). Op. cit.. p. 62.

${ }^{591}$ FERNANDES, Newton; FERNANDES, Valter. Criminologia integrada. 2. ed. rev. e atual. São Paulo: Revista dos Tribunais, 2002. p. 505.

592 Idem, ibidem.

593 Desde os fins dos anos 1920, Sutherland estudava o tema e utilizou a expressão "crime do colarinho branco" (white-collar crime) no encontro anual da American Sociological Association em 1939. No ano seguinte, Sutherland publicou o artigo "White collar criminality" na American Sociological Review, ocasião em que antecipou muitas de suas conclusões sobre o tema. Em 1949, o seu livro White collar crime foi publicado, mas teve expurgada de sua edição original uma série de descrições pormenorizadas de vários casos de crimes de colarinho branco, especialmente as referências literais àquelas empresas cujos processos judiciais foram julgados improcedentes. Mesmo assim, o livro foi objeto de forte oposição, uma vez que muitos dos casos tiveram ampla repercussão na mídia da época e facilmente podiam ser identificados, ainda que abstratamente. Somente em 1985 uma versão completa foi publicada.
} 
colarinho branco" para se referir aos "crimes cometidos por uma pessoa de status social elevado e respeitabilidade no curso de sua ocupação". ${ }^{594}$

Seu livro representou um dos marcos da ruptura com a pesquisa criminológica anterior, ao defender que o crime "não é necessariamente correlacionado com a pobreza ou com as condições de psicopata ou sociopata associadas à pobreza, de modo que uma explicação adequada do comportamento criminoso deve proceder com linhas bem diferentes". Para Sutherland, a pesquisa até então realizada estava enviesada, pois não analisa a conduta de empresários e profissionais liberais. ${ }^{595}$

Para sua teoria da ação diferencial, as causas da criminalidade seriam outras que a pobreza:

[...] o crime não pode ser definido simplesmente como uma disfunção ou inadaptação de pessoas de classe menos favorecidas, não sendo ele exclusividade destas. [...] A vantagem dessa teoria é que, ao contrário do positivismo, que estava centrado no perfil biológico do criminoso, tal pensamento traduz uma grande discussão dentro da perspectiva social. O homem aprende a conduta desviada e associa-se com referência nele.

A Teoria da Associação Diferencial assenta-se na consideração de que o processo de comunicação é determinante para a prática delitiva. Os valores dominantes no seio do grupo "ensinam" o delito. Uma pessoa converte-se em delinqüente quando as definições favoráveis à violação superam as desfavoráveis. ${ }^{596}$

Os trabalhos de Sutherland despertaram também o interesse da sociologia. Uma das obras de sociologia mais significativas a tratar do tema corrupção de forma sistemática, a partir de uma perspectiva do Terceiro Mundo, foi A sociologia da corrupção: a natureza, função, causas e prevenção da corrupção, de autoria de Syed Hussein Alatas, de 1968. ${ }^{597}$ Desde então, a sociologia tem-se debruçado sobre o tema, investigando as repercussões das práticas tradicionais sobre o funcionamento dos regimes democráticos, a relatividade da noção de corrupção conforme culturas, lugares e tempos diferentes e os desdobramentos da importação de regras morais sobre o tema para países em desenvolvimento.

Desta maneira, juntamente com a psicologia, a sociologia influencia os estudos da criminologia. Esta última tem sua agenda pautada pelas decisões governamentais acerca dos

\footnotetext{
${ }^{594}$ SUTHERLAND, Edwin H. White collar crime: the uncut version. New Haven: Yale University Press, 1983. p. 7.

595 SUTHERLAND, Edwin H. White Collar Criminality. American Sociological Review, v. 5, n. 1, p. 2, Feb. 1940.

${ }^{596}$ SHECAIRA, Sérgio Salomão. Criminologia e direito penal: um estudo das escolas sociológicas do crime. São Paulo. 2002. 406 f. Tese (Livre-Docência em Direito Penal)-Faculdade de Direito, Universidade de São Paulo, São Paulo. p.185-186.

597 ALATAS, S. H. The sociology of corruption: the nature, functions, causes and prevention of corruption. Kuala Lumpur: S. Abdul Majed and Co., 1991.
} 
crimes que deverão ser reprimidos. Com isso, estabelecem-se as conexões que fazem fluir as conclusões da academia para a política pública de combate à criminalidade.$^{598}$

Entre tais conclusões, figura a identificação de algumas características dos crimes de colarinho branco que, via de regra, se aplicam às práticas corruptas. Primeiro, deve-se apontar a complexidade das condutas devido à crescente sofisticação das ações da administração pública - muitas vezes, restrições e exigências num edital encobrem o direcionamento da compra pública sem que haja suspeita aparente sobre a legitimidade do procedimento. ${ }^{599}$

Os crimes de colarinho branco não acontecem nas ruas (in the streets), mas sim nas suítes (in the suites). Enquanto os ilícitos in the streets envolvem o uso de violência ou grave ameaça, o mesmo não se verifica com os in the suites. Estes se concretizavam em ambientes reservados, sem atrair a atenção do público e sem lesar pessoas identificáveis prontamente, de modo que a publicidade dos crimes de colarinho branco é menor. ${ }^{600}$ Inclusive no aspecto repressivo, o tratamento é distinto - os ilícitos in the streets são investigados por autoridades policiais, ao passo que parte considerável dos ilícitos in the suites apresenta repressão administrativa. ${ }^{601}$ Como os crimes de colarinho branco não envolvem violência explícita, alguns doutrinadores propugnam pelo tratamento essencialmente na esfera administrativa. ${ }^{602}$

\footnotetext{
${ }^{598}$ FERNANDES, Newton; FERNANDES, Valter. Op.cit. p. 116-117.

${ }^{599}$ Nesse sentido, ver SILVEIRA, Renato de Mello Jorge da. Direito penal econômico como direito penal de perigo. São Paulo: Revista dos Tribunais, 2006. p. 29-30.

${ }^{600}$ FERNANDES, Newton; FERNANDES, Valter. Criminologia integrada. Op.cit. p. 505. No mesmo sentido, ambos os autores identificam essa característica, mas substituem a nomenclatura pela diferenciação entre micro e macrocriminalidade.

${ }^{601}$ SUTHERLAND, Edwin H. White collar criminality. American Sociological Review, v. 5, n. 1, p. 6, Feb. 1940.

602 SANTOS, Cláudia Cruz. O crime de colarinho branco, a (des)igualdade e o problema dos modelos de controlo. In: PODVAL, Roberto (Org.). Temas de direito penal econômico. São Paulo: Revista dos Tribunais, 2001. p. 195. Santos pode ser tomada como exemplo de abordagem que reitera a necessidade de preferencialmente se reprimir com o direito administrativo os crimes de colarinho branco sempre que possível. "[...] para evitarmos as acusações de desigualdade tão correntemente esboçadas, há dois vectores a seguir: quanto às condutas mencionadas em primeiro lugar, devemos relembrar os ensinamentos do direito penal mínimo e cingir a intervenção do direito criminal às situações em que ela é legítima, necessária e eficaz - a descriminalização talvez se devesse impor, portanto, em alguns casos; quanto ao segundo grupo de condutas, há que dotar o sistema dos meios necessários à garantia da efectividade do sancionamento penal. Pelo que, sempre que white-collar crime merecer qualificação jurídico-penal de crime e houver necessidade de punição, não poderá ser o poderio dos seus agentes a condicionar o funcionamento das instâncias de controlo, sob pena de estarmos a incorrer numa desigualitária dualidade de critérios." No mesmo sentido, ver CERVINI, Raúl. Os processos de decriminalização. Vários tradutores. Apresentação, notas e referências de Luiz Flávio Gomes. 2. ed. rev. da tradução. São Paulo: Revista dos Tribunais, 2002. p. 215 e ss. O autor reconhece que a criminalização tem sido a tendência legislativa predominante apesar do predomínio das teses descriminalizados na doutrina.
} 
Mesmo quando há sucesso das investigações, é complicado estabelecer quem seria o responsável pelo ilícito, pois muitos se envolveram em atos de apoio, alguns dos quais sem ter conhecimento. De acordo com as ponderações de Livianu,

[...] a divisão do trabalho, determinada pelos novos métodos introduzidos pela Revolução Industrial, torna difícil uma responsabilização individualizada pelo resultado da ação criminosa. Esta responsabilidade é dividida, e, como este tipo de crime envolve uma organização, haverá a tentativa de isenção de responsabilidade com argumentos relacionados aos equívocos na atuação, descuido, despreparo $[\ldots] .^{603}$

No suborno de um funcionário público em procedimento de compras, seria culpado o proprietário que deseja o lucro acima de tudo, o presidente que leva a cabo a decisão de pagar ou o representante comercial que instiga o pagamento para ganhar sua comissão? Ou seria culpado apenas o funcionário público?

Entretanto, esse raciocínio pode conduzir à inviabilização da organização estatal, se levado ao extremo - no caso dos crimes de corrupção, a adoção de teses penais minimalistas pode redundar no completo fracasso das políticas anticorrupção em virtude das motivações dos agentes corruptos. Uma postura crítica mais condizente com a realidade visaria exatamente à correção dessas distorções, a fim de trazer os instrumentos repressivos da regulamentação microjurídica, incluindo o direito penal, para mais próximo dos objetivos de uma sociedade democrática. Esse movimento não significa aprioristicamente uma opção impensada pela renúncia pura e simples à repressão criminal, especialmente no que tange às práticas corruptas.

O combate mais efetivo aos crimes do colarinho branco, entre os quais se incluem as várias formas de corrupção, pode ser interpretado como uma resposta às críticas sobre deslegitimidade ou ilegitimidade do direito penal. ${ }^{604} \mathrm{Em}$ vez de simplesmente descartar a repressão criminal por ser comprometida ideologicamente, coloca-se o corruptor, por meio de seus bens, e os políticos, por meio do Estado, a serviço do bem comum, limitando-se

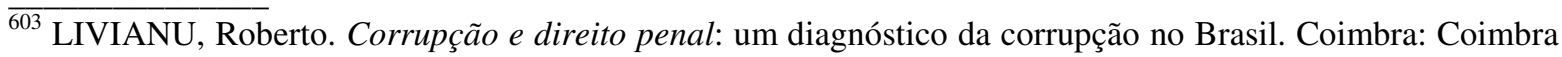
Editora, 2007. p. 144.

${ }^{604}$ QUEIROZ, Paulo de Souza. Do caráter subsidiário do direito penal: lineamentos para um direito penal mínimo. Belo Horizonte: Del Rey, 2002. p. 40. Para os mais críticos, as diferenças acima apontadas expõem o caráter ideológico do direito penal, retirando-lhe legitimidade mesmo num regime democrático. Em diferentes graus, as chamadas teorias abolicionistas e minimalistas reconhecem implicações normativas para as conclusões acima e sugerem a abolição ou redução da repressão criminal. Como explica Queiroz, ambas “coincidem [...] quanto à 'deslegitimidade' (ou ilegitimidade) deste mecanismo formal de controle social. Ambos são, enfim, movimentos político-criminais deslegitimadores do sistema penal. Vêem, tanto o abolicionismo quanto o minimalismo, o sistema penal como um subsistema funcional de reprodução material e ideológica (legitimação) do sistema social global, é dizer, das relações de poder e da propriedade existentes".
} 
práticas que se afastem desse intento mediante sua criminalização - a legitimação também se verificaria, uma vez que o direito penal se voltaria não apenas para a repressão dos que se encontram desprovidos do poder político-econômico, mas também para seus detentores.

\subsection{Algumas variáveis normalmente associadas à corrupção}

A corrupção manifesta-se com intensidades diversas conforme as diferentes regiões geográficas, situações político-institucionais e substrato cultural. Essa diferenciação tem levado os cientistas sociais a questionar a sua causa - afinal, sabendo-se o que diminui a incidência da corrupção, podem-se adotar políticas voltadas para criar tais condições. Ao mesmo tempo em que tal diferenciação é estudada, aumenta-se a compreensão sobre como a corrupção se manifesta.

Os tipos descritos, bem como seu viés criminológico, ajudam na compreensão do que seriam as práticas corruptas, mas não esgotam o rol das características pertinentes para o estudo - por exemplo, não incluem certas negociações políticas de troca de favores em que o móvel está mais no interesse pessoal do agente do que no interesse público. Mesmo assim, esse conhecimento serve de ponto de partida para uma melhor compreensão do modus operandi da corrupção - a utilidade de um estudo pormenorizado da corrupção ajuda no desenho das melhores estratégias para combatê-la. A partir dessa premissa, será aprofundado o entendimento da corrupção por meio de traços característicos que servem de ponto de partida para algumas reflexões com vistas a extrair desdobramentos práticos para o combate à corrupção.

A ideia é estabelecer possíveis relações de causalidade entre aspectos pertinentes a um dado grupo e a incidência maior ou menor de corrupção. Tais estudos poderiam confirmar ou não certos mitos a respeito da corrupção. Apesar de tantos estudos, muitos dos resultados ainda não são satisfatórios ou conclusivos. ${ }^{605}$ Ademais, quando se logra obter

\footnotetext{
605 GERRING, J.; THACKER, S. Do neoliberal policies deter political corruption?. International Organization, Cambridge: University of Toronto, n. 59, p. 233, Winter 2005. "Why are some countries more corrupt than others? Many have attempted to answer this question in recent years, and the subject of political corruption has rightly captured a rapidly growing share of public and academic attention, in part because of the recognition of its intrinsic importance and also because of its close relationship with economic growth, investment, the rule of law, political accountability, political institutions, and democratic governance more generally."
} 
algum nexo relacional, muitas vezes é difícil determinar em que sentido esse nexo atua: é o corruptor quem seduz o corrupto ou seria o corrupto quem seduz o corruptor? ${ }^{606}$

A despeito dessa dificuldade, o objetivo por trás dessa linha de raciocínio é simples. Com base em estudos lastreados em conclusões científicas, seriam desenhadas políticas públicas mais adequadas para o combate à corrupção. Maior racionalidade e objetividade seriam conferidas na política de combate à corrupção, deixando-se de lado ações que se mostrassem ineficazes.

Um primeiro grupo de fatores está relacionado direta ou indiretamente à cultura presente em cada sociedade. Em realidade, há muito que são traçadas relações entre corrupção e cultura - tanto os estudos de Alam $^{607}$ quanto os de Bayley ${ }^{608}$ sugerem que a corrupção em países em desenvolvimento decorre do choque entre valores tradicionais arcaicos e regras jurídicas importadas pela modernização. Para superar a corrupção, a cultura deveria ser levada em consideração - como explica Lambsdorff,

[...] países onde o poder é distribuído de modo desigual e onde a hierarquia é aceita requererão um tratamento diferenciado. Em tais países, abordagens de cima para baixo no combate à corrupção podem ter melhor perspectivas se comparadas a movimentos de base da sociedade. ${ }^{609}$

Além da relação entre confiança e corrupção, ${ }^{610}$ há aqueles que relacionam determinadas religiões a maior ou menor incidência da corrupção. Religiões em que o componente hierárquico seria mais acentuado, tal como se verifica no catolicismo, cristianismo ortodoxo e islamismo, não favoreceriam o engajamento da sociedade civil e,

\footnotetext{
${ }^{606}$ MAURO, Paolo. Os efeitos da corrupção sobre crescimento, investimentos e gastos do governo: uma análise de países representativos. In: ELLIOT, Kimberly Ann (Org.). A corrupção e a economia global. Tradução de Marsel Nascimento Gonçalves de Souza. Brasília: UnB, 2002. p. 160. "Na verdade, o sentido da casualidade é indistinto em alguns casos. Por exemplo, não fica claro se a existência de leis faz que os burocratas peçam subornos para que se ajudem os empresários a driblá-las, ou, em vez disso, se há uma maior probabilidade de os burocratas corruptos multiplicarem as leis como mecanismo para a criação de oportunidades de suborno. [...] da mesma maneira que a existência da corrupção pode gerar uma composição subótima dos gastos do governo, pode ser também que altos dispêndios públicos em atividade de difícil fiscalização criem oportunidades para a corrupção. [...] Entretanto, a questão da causalidade não foi - e pode nunca chegar a ser - inteiramente resolvida, visto que a causalidade pode muito bem atuar nos dois sentidos."

607 ALAM, M. S. Anatomy of corruption: an approach to the political economy of underdevelopment. American Journal of Economics and Sociology, Boston, Blackwell Publishing, v. 48, n. 4, p. 441 e ss, 1989.

${ }^{608}$ BAYLEY, D. H. The effects of corruption in a developing nation. The Western Political Science Quarterly, Salt Lake City, University of Utah, v. 19, n. 4, p. 719 e ss, dez. 1966

${ }^{609}$ LAMBSDORFF, Johann Graf. The institutional economics of corruption and reform: theory, evidence, and policy. Cambridge: Cambridge University Press, 2008. p. 29. "Countries where power is distributed unequally, and where hierarchy is accepted, will require different treatment than others. In such countries, a top-down approach to anticorruption may have better prospects as compared with a grassroots movement"

${ }^{610}$ Ver item 2.1, supra.
} 
por vias indiretas, aumentariam a incidência de corrupção. ${ }^{611}$ Para Treisman, a redução decorrente de percentual maior de protestantes resultaria de maior desenvolvimento econômico ou da estabilidade democrática. ${ }^{612}$

No que tange aos valores, alguns destes influenciariam positiva ou negativamente a incidência de corrupção. Há valores mais presentes em certas culturas do que em outras relações familiares mais intensas tendem a aumentar a incidência de corrupção, uma vez que corrompem a distinção entre os espaços público e privado. O relativismo cultural poderia ser considerado para moldar diferentes visões sobre o que seria público e o que seria privado. ${ }^{613}$

Tais observações reforçam a crítica feita às generalizações no combate à corrupção - por vezes, como se a corrupção fosse um fenômeno universal e atemporal, a ausência de uma análise focada num determinado contexto pode levar à aplicação de soluções não apropriadas para ele. Rotular o nepotismo como corrupção pode dificultar o avanço do combate à corrupção em outros setores, como o de compras públicas - afinal, o mero fato de haver contratação de parentes não significa que haverá corrupção automaticamente em compras públicas. Logo, pode ser recomendável a observância de questões culturais no delineamento de políticas de combate à corrupção.

Intimamente relacionada ao problema dos valores, à semelhança do que ocorre com a percepção da corrupção por estrangeiros, há os dilemas oriundos do relativismo cultural. No exemplo de Filgueiras,

[...] não levando em consideração, na análise empírica, as diferenças nos padrões de sociabilidade e nos padrões culturais, a sociologia americana contribui para lançar mais cortina de fumaça sobre o problema da corrupção. Por exemplo, em vista dos valores americanos, o familismo é imoral e fonte de enorme corrupção. Do ponto de vista de uma sociedade como a chinesa, o familismo é fator de agregação e solidariedade no conjunto da sociedade como um todo, não sendo considerado, por parte dos chineses, uma fonte de corrupção na política. ${ }^{614}$

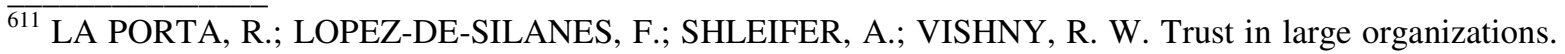
National Bureau of Economic Research. NBER Working Paper n. 5864, Cambridge, 1996, p. 8. Disponível em $<$ http://www.nber.org/papers/w5864.pdf>. Acesso em: 1 dez. 2008 às $18 \mathrm{~h} 36$.

${ }^{612}$ TREISMAN, D. The causes of corruption: a cross-national study. Journal of Public Economics, v. 76, n. 3 , p. 344-345, June 2000. "As La Porta et al. have found (1999), the percentage of Protestants in the population is a robust predictor of lower corruption. The evidence in this paper suggests that this effect works both via Protestantism's positive impact on economic development (the Weber argument) and on stable democracy and via some additional pathway. This may have to do with greater tolerance for dissent in Protestant societies-or, by contrast, a more intense and unforgiving moralism. It may also reflect an institutional fact-that Protestant churches often developed in counterpoint rather than in fusion with the state and may thus have stimulated a more autonomous civil society."

${ }^{613}$ LA PALOMBARA, Joseph G. Op. cit. p. 370-372.

${ }^{614}$ FILGUEIRAS, Fernando. O problema da corrupção e a sociologia americana. Working paper. Juiz de Fora: Centro de Pesquisas Estratégicas Paulino Soares de Souza, 2006, p. 13. Disponível em $<$ http://www.ecsbdefesa.com.br/fts/PCSA.pdf>. Acesso em: 8 dez. 2008 às 16h59.
} 
Nepotismo e dar presentes ilustram bem esses dilemas, uma vez que não há unanimidade global sobre se tais práticas configuram corrupção. O que pode ser corrupção num dado lugar e época pode não sê-lo noutras condições. Todavia, La Palombara alerta que a tentativa de relativizar a corrupção pode ser "tão estéril intelectualmente como afetado e paternalista politicamente". ${ }^{615}$

De similar maneira, há certa crença de que a corrupção diminuiria à medida que o papel das mulheres na sociedade aumentasse. Se essa afirmação fosse verdadeira, uma das estratégias de combate à corrupção deveria incentivar a diminuição de desigualdades entre homens e mulheres. Tal assertiva, porém, não parece se sustentar. Ao criticar dois estudos que associavam menor corrupção à participação das mulheres no mercado de trabalho e à presença feminina no Parlamento, Sung conclui que a corrupção diminui quando há obediência à lei, liberdade de imprensa e democracia, fatores normalmente associados à maior presença feminina na sociedade..$^{616}$

Também há estudos que buscam enfatizar aspectos geográficos relacionados à corrupção. Países mais afastados do Equador tenderiam a ser menos corruptos. ${ }^{617}$ Outros trabalhos concluíram que existe uma relação entre a abundância de recursos minerais e petrolíferos e corrupção. Leite e Weidman concluem que, quanto maior a abundância de recursos naturais em determinado país, maior tende a ser a corrupção, especialmente em países subdesenvolvidos. ${ }^{618}$ Ambos sugerem que descobertas de recursos naturais abundantes exigem instituições fortes ou fortalecidas, de modo a geri-los. ${ }^{619}$ A tese é endossada por Mauro, para quem a "abundância de recursos naturais é um exemplo clássico de fonte de rendas improdutivas, já que tais recursos geralmente podem ser vendidos a preços superiores aos custos de extração" - o comportamento parasítico teria mais oportunidades para se desenvolver se o volume de matérias-primas exportadas fosse proporcionalmente alto, o que poderia impactar negativamente a eficiência administrativa e, de modo indireto, os níveis de

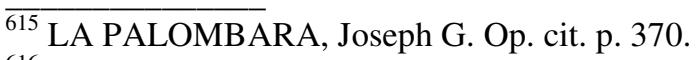

616 SUNG, Hung-En. Fairer sex or fairer system? Gender and corruption revisited. Social Forces International Journal of Social Research, Chapel Hill: University of North Carolina Press, v. 82, n. 2, p. 720, Dec. 2003.

617 GERRING, J.; THACKER, S. Do neoliberal policies deter political corruption?. International Organization, Cambridge, University of Toronto, n. 59, p. 247, Winter 2005.

${ }^{618}$ A razão disso decorreria do fato de serem os recursos naturais uma renda improdutiva.

${ }^{619}$ LEITE, C.; WEIDMAN, J. Does mother nature corrupt? Natural resources, corruption, and economic growth. IMF working paper n. WP/99/85, Washington: FMI. Julho de 1999, p. 31. Disponível em <http://www.imf.org/external/pubs/ft/wp/1999/wp9985.pdf>. Acesso em: 1 nov. 2008 às 20h48.
} 
corrupção. ${ }^{620}$ Essas colocações são bastante oportunas no momento em que se discute como as ricas reservas petrolíferas do pré-sal serão exploradas no Brasil.

Ainda, do ponto de vista geográfico, tendem a ser mais corruptos países cercados por vizinhos corruptos $^{621}$ e os mais fechados ao comércio internacional. ${ }^{62}$ Azfar e Knack chegam a conclusões diferentes, argumentando que parte dos trabalhos apresentados anteriormente possui falhas metodológicas: países maiores não são necessariamente mais corruptos do que países menores, bem como o comércio internacional parece ter influência desprezível sobre o nível de corrupção. Ambos os autores recomendam aprofundar os estudos de "modo mais rigoroso para testar hipóteses sobre o impacto do tamanho do país sobre a sua governança e outros resultados". ${ }^{623}$

O último exemplo leva a um questionamento: em que medida certas conclusões podem ser consideradas cientificamente isentas e não mera investigação sobre estereótipos dos seus autores? Muitos dos estudos relatados partem de certos preconceitos e mitos em torno da corrupção e procuram provas sobre a sua veracidade ou não. Há certa impressão de que pouco parece ser retido com alguma utilidade - talvez somente permaneça inteiramente válida a afirmação de Shecaira: "o crime do colarinho branco não pode ser explicado pela pobreza, nem por má habitação, carências de recreação, falta de educação etc., enfim,

\footnotetext{
$\overline{{ }^{620}}$ MAURO, Paolo. Os efeitos da corrupção sobre crescimento, investimentos e gastos do governo: uma análise de países representativos. In: ELLIOT, Kimberly Ann (Org.). A corrupção e a economia global. Tradução de Marsel Nascimento Gonçalves de Souza. Brasília: UnB, 2002. p. 139.

621 SANDHOLTZ, W.; GRAY, M. International integration and national corruption. International Organization, Cambridge, The IO Foundation e Cambridge University Press, v. 57, p. 777, 2003,: "If one country, for instance, interacts extensively with a second country that is pervasively corrupt, those international links might tend to foster corruption in the first country. [...] That border relationship, we argue, exercises its effects primarily through normative channels. [...] First, countries often share cultural affinities with their immediate neighbors; that is, there are shared values, norms, and practices within geographic regions. On average, countries are likely to share values and norms with their closest neighbors. [...]. Second, people are more likely to travel to, or meet people from, neighboring countries. These kinds of personal contacts are also modes of cultural and normative transmission, and attitudes toward corrupt practices can follow those channels."

${ }^{622}$ WEI, S. Natural openness and good government. World Bank Policy Research. Working Paper n. 2411, Aug. 2000. Washington: World Bank. Jul. 1999, p. 1. Disponível em <http://wwwwds.worldbank.org/servlet/WDSContentServer/WDSP/IB/2000/09/01/000094946_00082205414670/Rendered /PDF/multi_page.pdf>. Acesso em: 1 nov. 2008 às 20h58. "The amount of resources that a society devotes to building good institutions is endogenous; and depends on marginal cost and marginal benefits comparison. Since international traders and investors are more footloose (i.e., have better outside options) than domestic ones, bad governance and bureaucratic corruption in a country reduces international trade and investment more than domestic trade and investment. A country that is naturally more open - as determined by its size, geography and other factors - would find it optimal to devote more resources to building good institutions. In equilibrium, such economies may display less corruption and a higher quality of government than naturally less open economies."

${ }^{623}$ AZFAR, Omar; KNACK, Stephen. Are larger countries really more corrupt? World Bank Policy Research. Working Paper n. 2470. Washington: World Bank, Nov. 2000, p. 20. Disponível em $<$ http://ssrn.com/abstract=632540>. Acesso em: 23 nov. 2008 às 22 h34.
} 
aqueles critérios tradicionais explicativos da criminalidade". ${ }^{24}$ Diante das hipóteses estudadas, alguns resultados confirmaram tais preconceitos e mitos, ao passo que outros os desmentem. Essa contradição remete ao questionamento do que deve ser tomado como ponto de partida numa área em que a Weltanschauung dos pesquisadores parece influenciar consideravelmente a agenda das pesquisas realizadas.

\subsection{Desenhos político-administrativos e sua relação com a corrupção}

Outra vertente de estudo sobre a corrupção a relaciona com diferentes formas de arranjo político-administrativo, tentando-se estabelecer em que medida determinado desenho político ou dada organização administrativa favorecem ou não favorecem o surgimento ou extinção de práticas corruptas. Como a estrutura e o aparelhamento administrativo são fruto de decisão política, provavelmente, ao menos na perspectiva microjurídica, ela é mais facilmente alterável para atender às demandas sociais do que aspectos culturais e geográficos.

Kanti Dey traça uma análise microeconômica da origem da corrupção e estabelece dois caminhos possíveis para sua ocorrência: (i) a oferta cria a própria demanda e (ii) a demanda cria a própria oferta. No primeiro cenário, o agente público (fornecedor dos serviços corruptos) cria condições em que o suborno parece ser a melhor alternativa entre as possíveis e, ao mesmo tempo, oferece o serviço corrupto. ${ }^{625} \mathrm{Um}$ cenário possível seria a criação de dificuldades materiais e, especialmente, formais, não previstas em lei, para a prestação do serviço - isso poderia decorrer de uma interpretação restritiva da norma aplicável, a famosa "criação de dificuldades para a venda de facilidades".

No segundo cenário, aqueles que demandam o serviço corrupto fazem um investimento inicial para os agentes públicos corruptos, a fim de que o processo se torne autossustentável e "o investimento inicialmente feito se pague quando a bola começar a rolar". ${ }^{626}$ Depois de certo tempo, a situação tende a atingir um equilíbrio. Então, "quando a corrupção se torna estabelecida, pode-se observar os demandantes procurando por fornecedores, e vice-versa, como se estivessem num mercado organizado. Parte disso se

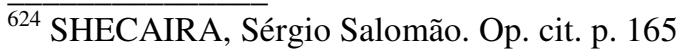

${ }^{625}$ KANTI DEY, Harendra. The genesis and spread of economic corruption: a microtheoretic interpretation. World Development, Montreal: Elsevier, v. 17, n. 4, p. 504, 1989.

${ }^{626}$ Idem, p. 505.
} 
deve ao efeito de se aprender executando ações de um jogo repetido". ${ }^{627}$ Tal cenário é mais apropriado para descrever hipóteses de contato permanente entre ofertantes e demandantes de práticas corruptas, como ocorre com as agências reguladoras que tratam de setores específicos.

Estabelecida a corrupção generalizada, é muito difícil eliminar um ambiente corrupto, ou mesmo evitar seu crescimento continuado. Por essa razão, é preciso impedir a criação da corrupção antes da formação de uma atmosfera de desconfiança pública, em que se acredita que todos são corruptos. No contexto patrimonialista, esse problema é parte rotineira da sociedade, sendo encontrado em todos os níveis responsáveis pela tomada das decisões das mais diversas organizações e poderes, independentemente de orientação político-partidária. Como afirmado por Kroll e Transparência Brasil, ${ }^{228}$ "aceitação de suborno e política de nepotismo são consideradas freqüentes ou quase freqüentes em quase todas áreas investigadas [Licenciamento e Inspeção, Polícia, Concorrência Pública, Poder Judiciário, Comércio Exterior, Taxas, Tributos e Privatizações]”.

Ademais, pesquisas enfatizam os crescentes riscos para uma regulação eficiente quando há contato frequente entre reguladores e violadores, ${ }^{629}$ troca frequente de funcionário ${ }^{630}$ e grande poder discricionário. ${ }^{631}$ Muitos dos entes da administração pública, inserida num processo de modernização formal, em desacordo com o direito pressuposto, enfrentam essa realidade.

De outra perspectiva, Kanti Dey lista três condições para que essa situação de corrupção-suborno e corrupção-favorecimento endêmicas ocorram: (i) exercício do poder de monopólio; (ii) insuficiência de honestidade; e (iii) problemas de implementação. ${ }^{632}$

A primeira condição (exercício do poder de monopólio) está ligada a problemas de autonomia e controle. Nesses casos, há condições para que um agente público ofereça

\footnotetext{
${ }^{627}$ Ibidem.

${ }^{628}$ KROLL BRASIL; TRANSPARÊNCIA BRASIL. Fraude e corrupção no Brasil: a perspectiva do setor privado. 2. ed. São Paulo, 2002. p. 16 e ss. Disponível em $<$ http://www.krollamericalatina.com/pesquisas/documents/fraudsurvey_2002_PT.pdf>. Acesso em: 12 dez. 2008 às $16 \mathrm{~h} 10$.

${ }^{629}$ SIMPSON, Antony E. The literature of police corruption. Nova York: John Hay Press, 1977. v. 1. p. 88108.

${ }^{630}$ GRABOSKY, Peter. BRAITHWAITE, John. Of manners gentle: enforcement strategies of Australian business regulatory agencies. Melbourne: Oxford University Press, 1986. p. 198. KAUFMAN, Herbert. The forest ranger behaviour: a study of administrative behavior. Baltimore, Johns Hopkins University, Press, 1960. ${ }^{631}$ DAVIS, Kenneth Culp. Discretionary justice. Urbana: University of Illinois Press, 1969. LOWI, Theodore. The end of liberalism: ideology, policy, and the crisis of public authority. Nova York: Norton, 1969. F. HANDLER, Joel. Dependent people, the state and the modern/postmodern search for the dialogic community. UCLA Law Review, Los Angeles, n. 35, 1988, p. 1027.

${ }^{632}$ KANTI DEY, H. The genesis and spread of economic corruption: a microtheoretic interpretation. World Development, Montreal: Elsevier, v. 17, n. 1, 1989, p. 506.
} 
serviços corruptos e receba dinheiro, e inexistem mecanismos de controle da organização hierárquica, como se houvesse um "monopólio" de suas decisões. A ausência de grupos ativos de defesa do interesse público torna essa situação mais difícil - o adesismo social e a cooptação das ONGs pelos recursos governamentais restringem o que se espera da ação de tais grupos. Para evitar a corrupção, "funcionários superiores devem ser honestos e cumprir seus deveres, e também livres de pressões internas e externas para não cumprirem sua obrigação, ou fazê-la seletivamente" ${ }^{633}$ - desse modo, deve-se dar mais atenção ao processo de acesso aos cargos públicos comissionados que respondam por posições de chefia.

A segunda condição (insuficiência de honestidade) diz respeito aos incentivos e desincentivos à honestidade. ${ }^{634}$ Esses incentivos e desincentivos têm causas mais profundas do que a mera configuração institucional, sendo ligados ao grau de confiança existente nas relações sociais. Logo, não se deve esperar uma variação no curto prazo, uma vez que a insuficiência de honestidade se relaciona a mudanças sociais mais profundas.

Quanto à terceira situação (problemas de implementação), a causa pode decorrer de "uma assimetria de informação entre subordinados e superiores (o primeiro sabe mais do que o último)" ${ }^{635}$ É verdade que há um forte elemento cultural na existência dessa assimetria. O crescente número de funcionários em cargos comissionados distorce o funcionamento da máquina administrativa, de modo que uma das formas de anular essa característica negativa é aumentar o grau de profissionalismo da administração pública com a garantia institucional adequada para o desempenho de suas funções, especialmente por meio da redução dessas posições demissíveis ad nutum.

As contratações governamentais também são uma das áreas mais sujeitas aos problemas de implementação que geram corrupção, particularmente levando-se em consideração que os volumes e valores elevados fornecem atrativos para os agentes corruptos. A habilitação, a preparação do edital, o controle de qualidade e a execução retardada constituem etapas envoltas em risco. ${ }^{636}$ De igual maneira, as vendas de ativos

\footnotetext{
${ }^{633}$ Idem.

${ }^{634}$ Ibidem. "One would then cultivate honesty, if one can expect rewards. Likewise, one would shun dishonesty if one expects it to bring unacceptable punishment. For many, the time horizon of this expectation will not extend beyond the job-life."

${ }^{635}$ Ibidem, p. 507.

${ }^{636}$ ROSE-ACKERMAN, Susan. A economia política da corrupção. In: ELLIOT, Kimberly Ann (Org.). A corrupção e a economia global. Tradução de Marsel Nascimento Gonçalves de Souza. Brasília: UnB, 2002. p. 64. "Quando o governo está na posição de comprador ou na de fornecedor, surgem diversas razões para o pagamento de propinas aos agentes públicos. Primeira: uma companhia pode pagar para que seja incluída no rol de concorrentes habilitados. Segunda: essa companhia pode pagar para que agentes organizem as especificações da concorrência de tal modo que a empresa corrupta seja a única a atender os requisitos.
} 
públicos, em especial durante processos de privatização, criam grandes oportunidades para práticas corruptas. ${ }^{637}$

Nos cenários de interface entre o público e o privado inicial, a autoridade pública frequentemente possui amplo poder discricionário ou para reprimir uma conduta privada, criando um custo para o particular, ou para conceder um benefício para o particular. ${ }^{638}$ Isso justifica a restrição da discricionariedade, e, com isso, a capacidade de a administração pública negociar como se fosse um ente da esfera privada decorre do fato de que essa proibição geral pode evitar negócios ilícitos. Bardach e Kagan sintetizam a crítica contra a discricionariedade, a qual pode erodir a "capacidade de dissuasão do direito", de modo a "criar imprevisibilidade, tratamento desigual, um alto risco de corrupção e, em última instância, prejudicar seriamente os cidadãos desprotegidos". Os dois concluem que "a legalidade estrita, com todos os seus defeitos, é preferível à discricionariedade de agentes públicos imperfeitos". ${ }^{639}$

A remuneração paga aos agentes públicos também é reconhecida como um fator ligado à propensão às práticas corruptas. Argumenta-se que, quanto maior a remuneração paga aos agentes públicos, tanto menor seria a incidência de corrupção: ${ }^{640}$ se bem remunerado, o agente público não teria tanto interesse em aumentar oportunisticamente sua renda. ${ }^{641}$ Caso o nível de corrupção seja elevado na carreira, há até mesmo chance de fraude no acesso por concursos públicos, uma vez que os prospectos de ganhos para os futuros funcionários públicos são elevados e compensariam eventuais riscos ${ }^{642}$ - as denúncias constantes de irregularidades em concursos públicos endossam essa visão. Também interferiria no grau de corrupção a expectativa de perder o emprego - se baixo for o risco de perdê-lo, o agente público tenderia a aceitar mais facilmente os riscos associados à prática

Terceira: a companhia pode pagar para ser selecionada como a vencedora da concorrência. Finalmente: uma vez selecionada, a empresa pode pagar para obter preços inflacionados ou para poupar em qualidade."

637 Nesse sentido, ver BRASIL. Congresso Nacional. Relatório final da Comissão Parlamentar Mista de Inquérito, criada através do Requerimento $n^{\circ}$ 002/1993-CN, destinada a investigar fatos decorrentes da execução do Programa Nacional de Desestatização, do Relator Deputado Rubem Medina, bem como a declaração de voto vencido em separado do senador Amir Lando. Brasília, 1994.

${ }^{638}$ ROSE-ACKERMAN, Susan. Op cit., 2002. p. 59.

${ }^{639}$ BARDACH, E.; KAGAN, R. Going by the book: the problem of regulatory unreasonableness. 2. ed. New Brunswick: Transaction, 2003. p. 35. "[...] resulting in unpredictability, unequal treatment, a high risk of corruption, and ultimately serious harm to unprotected citizens; the rule of law, whatever its defects, is preferable to the discretionary rule of imperfect officials."

${ }^{640}$ ROSE-ACKERMAN, Susan. Op cit., 2002. p. 83. "Os países irão se deparar com a escolha entre um equilíbrio muito corrupto, com baixos salários, e um Estado pouco corrupto, com altos salários."

${ }^{641}$ ROSE-ACKERMAN, Susan. Op. cit., 1999, p. 71 e ss.

${ }^{642}$ ROSE-ACKERMAN, Susan. A economia política da corrupção. In: ELLIOT, Kimberly Ann (Org.). A corrupção e a economia global. Tradução de Marsel Nascimento Gonçalves de Souza. Brasília: UnB, 2002. p. 69. 
de corrupção. ${ }^{643}$ De igual maneira, reformas liberalizantes para aumentar a competitividade da economia, tais como diminuição das restrições ao comércio exterior e fomento à concorrência, são vistas como geradoras de desincentivos para a corrupção. ${ }^{644}$

Tabela 6 - Corrupção vis-à-vis o risco de perder o emprego e a remuneração do funcionário público

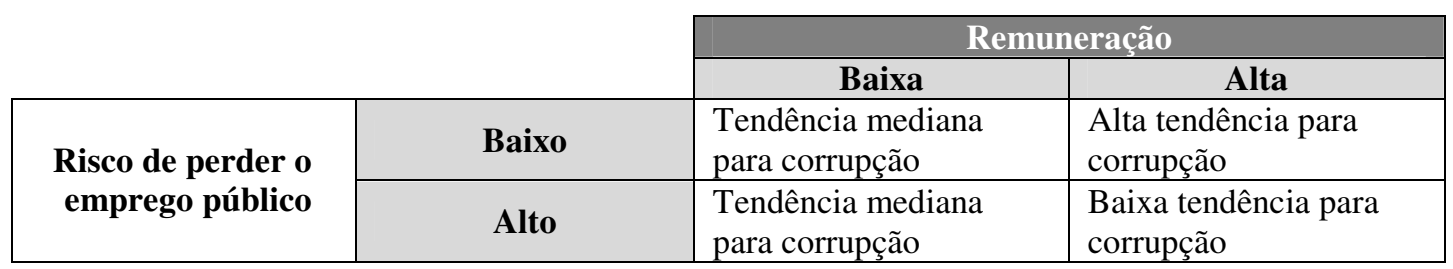

Fonte: Elaboração própria.

Há outros fatores relacionados ao funcionalismo que são apontados como associados à corrupção. Os frequentes contatos com aqueles que violam a lei foram identificados como situação de risco - há décadas a literatura a respeito da corrupção policial atesta a causalidade existente. ${ }^{645}$ A substituição constante dos funcionários ${ }^{646}$ e a concessão de amplos poderes discricionários ${ }^{647}$ podem ser apontadas também como propiciadores de potenciais oportunidades para o afloramento da corrupção, ainda que indiretamente.

No contexto de redução da presença estatal direta na economia via privatizações, sustenta-se que, quanto menor a presença do Estado, tanto menor seria a chance de haver oportunidades para a corrupção no setor público:

\begin{abstract}
A demanda por serviços corruptos - ou seja, a oferta de subornos - depende do porte e da estrutura do Estado. Os subornos são pagos por duas razões: para obter benefícios do governo e para evitar custos. Uma estratégia anticorrupção eficiente deve não apenas reduzir os benefícios e os custos sob o controle de agentes públicos, como deve também limitar os poderes de que dispõem para alocar ganhos e provocar prejuízos. ${ }^{648}$
\end{abstract}

\footnotetext{
$\overline{{ }^{643}}$ MAURO, Paolo. Os efeitos da corrupção sobre crescimento, investimentos e gastos do governo: uma análise de países representativos. In: ELLIOT, Kimberly Ann (Org.). A corrupção e a economia global. Tradução de Marsel Nascimento Gonçalves de Souza. Brasília: UnB, 2002. p. 139. "Quando os funcionários públicos não recebem remuneração suficiente para que se mantenham, é possível que sejam obrigados a fazer valer suas posições para a coleta de propinas, principalmente quando a expectativa de custo flagrante e de demissão é baixa. Os países deveriam ter essas considerações em mente ao se verem diante da difícil escolha de reduzir as excessivas contas com folha de pagamento do funcionalismo público mediante a diminuição de salários ou o corte no quadro de pessoal."

${ }^{644}$ ROSE-ACKERMAN, Susan. Op cit., 2002. p. 88.

${ }^{645}$ SIMPSON, A. E. Op. cit. p. 88-108.

${ }^{646}$ GRABOSKY, P.; BRAITHWAITE, J. Op. cit. p. 198. KAUFMAN, H. Op. cit.

${ }^{647}$ DAVIS, K. C., Discretionary justice. Op. cit. LOWI, T. Op. cit.. HANDLER, J. F. Dependent people, the state and the modern/postmodern search for the dialogic community. UCLA Law Review, Los Angeles, n. 35, p. 1027, 1988.

${ }^{648}$ ROSE-ACKERMAN, Susan. A economia política da corrupção. In: ELLIOT, Kimberly Ann (Org.). A corrupção e a economia global. Tradução de Marsel Nascimento Gonçalves de Souza. Brasília: UnB, 2002. p. 64.
} 
Essa linha de raciocínio, porém, ignora que as empresas recém-privatizadas possuem grandes incentivos para obter regras de tratamento favoráveis, por órgãos reguladores, aos seus interesses privados. ${ }^{649}$ Em realidade, "qualquer medida de desregulamentação ou de privatização deve ser implementada com cautela. A desregulamentação de um setor pode simplesmente elevar a corrupção de outros" ${ }^{650}$ A crítica neoliberal remete a outro interessante questionamento: é necessário identificar as hipóteses em que a corrupção é uma patologia social em si, geradora da perda de bem- estar social, daquelas em que a corrupção constitui uma reação a um funcionamento estatal distorcido. ${ }^{651}$

Também há vertente de investigação que estabelece conexões entre o regime democrático a maior ou menor incidência de corrupção. Ao reunirem sob sua égide a exigência de transparência no trato da coisa pública e a liberdade de imprensa, os regimes democráticos serviriam de coibidores das práticas corruptas. ${ }^{652}$ Por outro lado, partindo-se da ideia de que um regime representativo necessita de políticos que busquem a reeleição, até mesmo para manter a eficiência do governo, a eleição deve gerar insegurança quanto à possibilidade de reeleição, mas não em excesso. A segurança excessiva proporciona a confiança de que a manutenção no poder dificultaria a detecção de atividades corruptas, gerando um incentivo para sua prática, ao passo que a insegurança em excesso, igualmente, geraria incentivos para atividades corruptas devido à necessidade de "aproveitar" ao máximo o aparelho estatal enquanto o político estiver no poder. ${ }^{653}$

Outras pesquisas relacionam a menor incidência de corrupção em regimes parlamentaristas do que em regimes presidencialistas. A causa estaria associada à forma menos hierarquizada do parlamentarismo, bem como a uma abertura à participação de um maior número de pessoas na tomada de decisões. Logo, haveria uma vantagem comparativa dessa forma de organização política. ${ }^{654}$

Mesmo quando as análises descritas anteriormente possuem caráter qualitativo, existem critérios objetivos para avaliar a pertinência, a frequência e o impacto das condutas estudadas. Por isso, alguns países identificam os setores mais vulneráveis à corrupção e, com

\footnotetext{
${ }^{649}$ Idem, p. 67.

${ }^{650}$ Ibidem, p. 88.

${ }^{651}$ Ibidem, p. 81.

${ }^{652}$ LAMBSDORFF, Johann Graf. Op. cit. p. 39-40.

${ }^{653}$ ROSE-ACKERMAN, Susan. Op. cit., 1999, p. 127.

${ }^{654}$ LAMBSDORFF, Johann Graf. Op. cit., p. 41.
} 
isso, podem adotar medidas condizentes. Nesse sentido, a Transparência Brasil e a CGU elaboraram conjuntamente o documento intitulado "Metodologia de mapeamento de riscos de corrupção", o qual consiste em ferramenta de gestão que permite aos agentes públicos mapear os processos organizacionais das instituições que integram, de forma a identificar fragilidades que possibilitem a ocorrência de atos de corrupção. No momento posterior, "implementam-se mecanismos preventivos que minimizem as vulnerabilidades e evitem a prática de corrupção". ${ }^{655}$

\subsection{A mensuração dos níveis de corrupção}

Sabe-se que o Zimbábue é mais corrupto do que a Finlândia. Poucos discutiriam a veracidade dessa afirmação, mas também poucos saberiam demonstrar os motivos que a tornam verdadeira. Raciocínio similar pode ser aplicado a diferentes estados brasileiros: uns são considerados mais corruptos do que outros. Na maioria das vezes, essa visão decorre de um sentimento subjetivo de quem emite essas opiniões, originário de experiências pessoais e relatos de conhecidos.

Essa indução assistemática é insuficiente para permitir o uso de dados aptos a servir de base para estudos e comparações posteriores. Enquanto espécie de fenômeno humano, a compreensão da corrupção exige interpretação do sujeito, a qual "é sempre feita a partir de um determinado ponto de vista, de uma perspectiva que é sempre impregnada de subjetividade". ${ }^{656}$ A essa dificuldade inerente aos fenômenos sociais adicione-se que a “corrupção é difícil de ser estudada empiricamente", porque "suas muitas variáveis prováveis se inter-relacionam de modo complicado". Conforme explica Treisman, "algumas destas variáveis podem rapidamente mudar e ser causadas pela corrupção ou o ser a causa da corrupção. Como ocorre com outros tipos de atividades criminosas, é difícil observá-las diretamente e os pesquisadores precisam confiar em pesquisas a partir das vítimas de corrupção, cuja precisão é difícil de avaliar". ${ }^{657}$

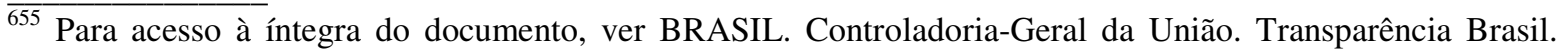
Metodologia de mapeamento de riscos de corrupção. Disponível em: <http://www.cgu.gov.br/AreaPrevencaoCorrupcao/Arquivos/Metodologia.pdf>. Acesso em: 26 dez. 2009 às $13 \mathrm{~h} 42$.

${ }^{656}$ ALVES, Alaôr Caffé. Estado e ideologia: aparência e realidade. Apresentação de Dalmo de Abreu Dallari. São Paulo: Brasiliense, 1987. p. 365.

${ }^{657}$ TREISMAN, D. The causes of corruption: a cross-national study. Journal of Public Economics, v. 76, n. 3, June 2000, p. 44.
} 
Para superar ou confirmar certas preconcepções a respeito do tema, há vários índices que balizam o grau de corrupção conforme o país. Existe uma grande quantidade desses índices, baseados "em respostas a questionários padronizados fornecidos por consultores de vários países, os quais, portanto, possuem a desvantagem de ser subjetivos", ${ }^{658}$ mas "nenhuma fonte única ou método de pesquisa foi desenvolvida que combine um espectro de amostras perfeito, uma cobertura nacional suficiente e um método totalmente convincente para produzir resultados comparáveis". ${ }^{659}$ Para lidar com essas dificuldades, uma estratégia é condensar as várias avaliações, tal como o faz o Índice de Percepção da Corrupção (Corruption Perception Index), publicado anualmente desde 1995 pela Transparência Internacional. ${ }^{660}$ Nele, vários referenciais sobre a corrupção alimentam a aplicação de fórmulas estatísticas, para expurgar eventuais distorções causadas pela subjetividade dos informantes. O resultado final é uma nota atribuída a cada país, que pode variar de 0 a 10.

Para mitigar o risco de subjetivismo, o Índice de Percepção de Corrupção utiliza três espécies de dados. O primeiro grupo consiste de opiniões de não residentes sobre outros países, e a maioria dos respondentes origina-se da América do Norte e da Europa ocidental. O segundo grupo se compõe de opiniões de não residentes sobre outros países, mas a maioria dos partícipes provém de países não desenvolvidos. Já o terceiro grupo coleta as opiniões de residentes sobre seu próprio país.

Entretanto, o Índice de Percepção da Corrupção não está isento de críticas. A primeira delas se dirige ao fato de que se trata de uma mensuração da percepção e não da realidade - uma percepção, ainda que generalizada, pode corresponder a uma distorção da realidade. Se o noticiário da mídia predominante se referir à corrupção, a percepção sobre ela será muito mais acentuada do que a realidade.

Outra crítica se refere à base de dados utilizada. Como o Índice de Percepção da Corrupção é formado a partir da avaliação subjetiva daqueles que participam da pesquisa, a distorção pode resultar de percepções preconcebidas da realidade. ${ }^{61}$ Imagine-se um

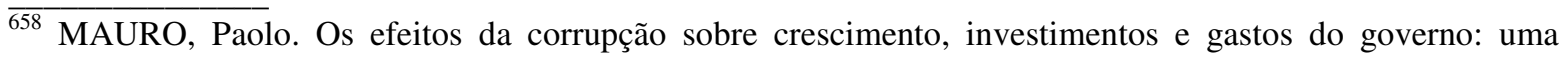
análise de países representativos. In: ELLIOT, Kimberly Ann (Org.). A corrupção e a economia global. Tradução de Marsel Nascimento Gonçalves de Souza. Brasília: UnB, 2002, p. 135.

${ }^{659}$ LAMBSDORFF, Johann Graf. Op. cit., p. 21.

${ }^{660}$ A Transparência Internacional é uma organização não governamental, sediada em Berlim, na Alemanha, criada em 1993 e presente em vários países, inclusive o Brasil. Seu objetivo principal é a luta contra a corrupção e, para tanto, financia uma série de pesquisas acadêmicas sobre o tema. Em virtude de sua intensa atividade política e acadêmica, vários relatórios e estudos produzidos pela Transparência Internacional serão utilizados nesta tese.

${ }^{661}$ Idem, ibidem, p. 22.
} 
participante da pesquisa originário de um país em que a troca de presentes é prática comercial comum: provavelmente, esse respondente avaliará a prática de modo diferente. Da mesma forma, respondentes de países que adotam o financiamento público das campanhas eleitorais podem enxergar corrupção se políticos de países sem o financiamento público os procurarem para obter recursos para as campanhas eleitorais, ainda que isso seja feito por meios lícitos. No exemplo mencionado por Abramo, uma pessoa questionada sobre a corrupção no Chile e no Brasil pode responder o questionário sem ter tido nenhum contacto com a realidade dos dois países. ${ }^{662}$ Para lidar com essa observação, utilizam-se as já mencionadas três espécies de dados. A comparação das bases de dados distintas revela que os dados se relacionam bem entre si. Como sintetiza Lambsdorff,

[...] residentes podem, portanto, possuir padrões éticos universais e posicionar adequadamente seu país em relação a outros. Do mesmo modo, os respondentes que analisam países estrangeiros parecem dotados de boa percepção sobre a cultura do país e fornecem avaliações apropriadas em vista disso. ${ }^{663}$

Em que pese a pertinência de tais críticas, não se deve perder de vista que os índices fornecem referenciais que, apesar de passíveis de falhas e deturpações, ainda assim fornecem um panorama geral da corrupção. Discutir se a Finlândia é mais ou menos corrupta do que a Noruega pode ser tão difícil quanto discutir se o Zimbábue é mais corrupto do que o Chade. Todavia, pouca dúvida há que Finlândia e Noruega sejam menos corruptos do que o Zimbábue e o Chade. Nisto reside uma das possíveis utilidades dos índices de percepção da corrupção: ao identificar menores índices de corrupção, deve-se investigar quais circunstâncias influenciam no resultado, de modo a mitigá-las, se forem causa da corrupção, ou acentuá-las, se forem impeditivas.

Outros apontam que o Índice de Percepção da Corrupção pode ser usado como orientador para investidores estrangeiros. Ao tomarem suas decisões, estes poderiam direcionar seus recursos para países em que o Índice fosse menor. Parece haver alguma prova de que isso ocorra, especialmente para empresas dos Estados Unidos. ${ }^{664}$ Vários países utilizam boas colocações como forma de atrair investidores estrangeiros, tal como ocorre

\footnotetext{
$\overline{662}$ ABRAMO, Claudio Weber. Percepções pantanosas: a dificuldade de medir a corrupção. Novos Estudos, São Paulo: Cebrap, n. 73, p. 34, nov. 2005.

${ }^{663}$ LAMBSDORFF, Johann Graf. Op. cit. p. 23.

${ }^{664}$ SANYAL, Rajib; SAMANTA, Subarna. Effect of perception of corruption on outward US foreign direct investment. Global Business and Economics Review, Worcester, v. 10, n. 1, p. 123-140, 2008
} 
com o Chile, que obteve nota similar à dos Estados Unidos em 2006. ${ }^{665}$ Mauro informa que, "os altos preços cobrados pelas agências de avaliação (em geral, empresas multinacionais e bancos estrangeiros) para o acesso a tais índices são evidência indireta de que as informações são valiosas". ${ }^{666}$

Abramo critica a finalidade do Índice de Percepção da Corrupção, pois haveria pouca utilidade em saber que o Zimbábue é mais corrupto do que a Finlândia: o autor questiona qual seria a relevância dessa informação para um cidadão desses países. Ademais, a margem de erro seria excessivamente grande, de modo que a posição de um país poderia variar bastante dentro de um espectro. De outra perspectiva, critica-se a intenção do governo norte-americano de utilizar o Índice de Percepção da Corrupção como parâmetro para a concessão de ajuda para o desenvolvimento - haverá diminuição na ajuda àqueles que mais necessitam de apoio para o desenvolvimento, pois os países mais pobres normalmente são os mais corruptos. ${ }^{667}$ Abramo ainda aponta possíveis inclinações ideológicas envolvidas no Índice, citando o Chile, país que teria melhorado sua posição após alinhar-se comercialmente com os Estados Unidos. ${ }^{668}$

Por fim, uma última restrição pode ser dirigida a esses índices: seu caráter genérico, que não diferencia entre a corrupção do alto e do baixo escalão, bem como se ocorre de modo organizado ou não. ${ }^{669}$ É possível que somente um desses segmentos padeça de problemas relacionados à corrupção - um importante executivo, ao responder o questionário, terá em mente apenas e tão-somente sua experiência com o setor público, ocorrida majoritariamente com o alto escalão, não com o baixo.

\footnotetext{
665 CHILE. Foreign Investment Committee. Transparency is the rule. Disponível em $<$ http://www.foreigninvestment.cl/index/plantilla2.asp?id_seccion=3\&id_subsecciones=78>. Acesso em: 18 nov. 2008 às 08 h30.

${ }^{666}$ MAURO, Paolo. Os efeitos da corrupção sobre crescimento, investimentos e gastos do governo: uma análise de países representativos. In: ELLIOT, Kimberly Ann (Org.). A corrupção e a economia global. Tradução de Marsel Nascimento Gonçalves de Souza. Brasília: UnB, 2002. p. 135.

667 ABRAMO, Claudio Weber. Percepções pantanosas: a dificuldade de medir a corrupção. Novos Estudos, São Paulo: Cebrap, n. 73, p. 35, nov. 2005.

668 Idem, ibidem.

${ }^{669}$ MAURO, Paolo. Os efeitos da corrupção sobre crescimento, investimentos e gastos do governo: uma análise de países representativos. In: ELLIOT, Kimberly Ann (Org.). A corrupção e a economia global. Tradução de Marsel Nascimento Gonçalves de Souza. Brasília: UnB, 2002. p. 136. "Os índices também não diferenciam corrupção bem organizada de corrupção mal organizada. Nessa última não fica claro qual seria o valor necessário de um suborno e nem qual seria o receptor adequado dele, e, além disso, o pagamento não é garantia de que o benefício desejado será obtido. A incerteza do sistema de corrupção mal organizado pode torná-lo o mais nocivo dos dois.”
} 


\subsubsection{Alguns desdobramentos do Índice de Percepção da Corrupção}

Não é exagerada a preocupação com a corrupção no cenário brasileiro, em que o Índice de Percepção da Corrupção (IPC) é elevado. Além dos efeitos políticos e econômicos negativos da corrupção, deve-se atentar para a possibilidade de que um IPC elevado já reflita uma situação irreversível ou de difícil superação.

Em geral, estudos baseados na teoria dos jogos voltados para a explicação do racional por trás da corrupção concluem que, ao penetrar uma determinada organização, tais práticas tendem a se proliferar de modo incontrolável. No linguajar da teoria dos jogos, a corrupção se torna a estratégia dominante dos jogadores, ou seja, nenhuma outra estratégia a ser adotada lhes gerará ganhos maiores do que a corrupção. A adoção da estratégia dominante corrupta ocorre a despeito de todas as distorções e ineficiências resultantes. ${ }^{670}$ Para Andvig e Moene "a corrupção pode contaminar outros e levar a uma situação de corrupção disseminada", ${ }^{671}$

\section{Conforme explica Mishra,}

[...] a universalização da corrupção contribui para sua persistência de modo significativo. Quando há muitos indivíduos corruptos na sociedade, torna-se ótimo ser corrupto a despeito da presença de políticas e incentivos contrários à corrupção. Este modo de comportamento corrupto torna-se o comportamento de equilíbrio ou a regra social. ${ }^{672}$

Afinal, quando se questiona se a corrupção é apenas uma manifestação isolada de um comportamento desviante da norma ou se é a norma em si, Mishra sustenta que, naquelas condições, "a corrupção não é um desvio, mas a norma em si. Entretanto, é fácil verificar se ela é uma situação ineficiente". ${ }^{673}$ Ora, tal cenário se manifesta com mais probabilidade quando o Índice de Percepção de Corrupção é elevado.

O problema causado por esse contexto é que a mera proibição legal e a existência de severas punições não constituem mais a solução para a corrupção, uma vez que esta

\footnotetext{
${ }^{670}$ MACRAE, J. Underdevelopment and the economics of corruption: a game theory approach. World Development, Montreal, Elsevier, v. 10, n. 8, p. 677-687,1982.

671 ANDVIG, J. C.; MOENE, K.. How corruption may corrupt. Journal of Economic Behavior and Organization, Montreal, Elsevier, v. 13, n. 1, p. 63-76, Jan. 1990

${ }^{672}$ MISHRA, A. Persistence of corruption: some theoretical perspectives. World Development, Montreal, Elsevier, v. 34, n. 2, 2006, p. 349.

${ }^{673}$ Idem, ibidem.
} 
depende da sua detecção. Mais do que na mera detecção, as dificuldades residem numa punição eficiente. ${ }^{674}$

\subsubsection{O Índice de Percepção da Corrupção e o Brasil}

Desde a década de 1990, o Brasil é um dos países selecionados por várias pesquisas de opinião sobre a percepção da corrupção, numa ampla base de dados disponível a respeito. Uma dessas pesquisas resultou numa série de relatórios, elaborados conjuntamente pela Kroll e Transparência Brasil, os quais revelaram que 70\% das empresas consultadas já teriam se sentido compelidas a contribuir para campanhas eleitorais. Entre estas, 58,5\% declararam que os favores que os políticos, se eleitos, poderiam fazer para as empresas foram explicitamente citados durante a abordagem - mencione-se que nenhuma das empresas pesquisadas respondeu negativamente a esse questionamento. ${ }^{675}$

Em razão da disponibilidade de informações, diversamente do que ocorreu com muitos países incluídos somente nos últimos anos no Índice de Percepção da Corrupção, o Brasil consta dele desde 1995, ano em que foi criado. A Tabela 7, infra, sintetiza a evolução das notas obtidas pelo país.

A variação da nota brasileira revela o que seria de esperar: não houve grandes avanços no combate à corrupção que é percebida - a nota brasileira variou entre o mínimo de 2.7, em 1995, e o máximo de 4.1, em 1999. A posição relativa do Brasil declinou de $37^{\circ}$ colocado, em 1995, para $80^{\circ}$, em 2008, movimento em grande parte devido ao aumento do número de países pesquisados. A quantidade de pesquisas utilizadas para a montagem da nota brasileira variou ao longo do tempo entre 4 e 12, fato que pode ser criticado apesar do uso de métodos para isolar eventuais discrepâncias.

\footnotetext{
${ }^{674}$ MACRAE, J. Underdevelopment and the economics of corruption: a game theory approach. World Development, Montreal: Elsevier, v. 10, n. 8, p. 677-686, 1982. “[...] legal solutions are unlikely to be effective in solving a problem which has its roots in the day-to-day operation of society from the lowest to highest levels of decision-making."

${ }^{675}$ KROLL BRASIL; TRANSPARÊNCIA BRASIL. Fraude e corrupção no Brasil: a perspectiva do setor privado. 2. ed. São Paulo, 2002. p. 16 e ss. Disponível em $<$ http://www.krollamericalatina.com/pesquisas/documents/fraudsurvey_2002_PT.pdf>. Acesso em: 12 dez. 2008 às $16 \mathrm{~h} 10$.
} 
Tabela 7 - Evolução do índice de percepção da corrupção no Brasil

\begin{tabular}{|c|c|c|c|}
\hline Ano & $\begin{array}{c}\text { Índice de Percepção da } \\
\text { Corrupção }\end{array}$ & Pesquisas utilizadas & $\begin{array}{c}\text { Posição no } \\
\text { ranking/total de } \\
\text { países pesquisados }\end{array}$ \\
\hline $\mathbf{1 9 9 5}$ & 2.7 & 4 & $37 / 41$ \\
\hline $\mathbf{1 9 9 6}$ & 2.96 & 7 & $40 / 54$ \\
\hline $\mathbf{1 9 9 7}$ & 3.56 & 6 & $36 / 52$ \\
\hline $\mathbf{1 9 9 8}$ & 4.0 & 9 & $46 / 85$ \\
\hline $\mathbf{1 9 9 9}$ & 4.1 & 11 & $45 / 99$ \\
\hline $\mathbf{2 0 0 0}$ & 3.9 & 8 & $49 / 90$ \\
\hline $\mathbf{2 0 0 1}$ & 4.0 & 9 & $46 / 91$ \\
\hline $\mathbf{2 0 0 2}$ & 4.0 & 10 & $45 / 102$ \\
\hline $\mathbf{2 0 0 3}$ & 3.9 & 12 & $54 / 133$ \\
\hline $\mathbf{2 0 0 4}$ & 3.9 & 11 & $59 / 146$ \\
\hline $\mathbf{2 0 0 5}$ & 3.7 & 10 & $62 / 159$ \\
\hline $\mathbf{2 0 0 6}$ & 3.3 & 7 & $70 / 163$ \\
\hline $\mathbf{2 0 0 7}$ & 3.5 & 7 & $72 / 179$ \\
\hline $\mathbf{2 0 0 8}$ & 3.5 & 7 & $80 / 180$ \\
\hline $\mathbf{2 0 0 9}$ & 3.7 & $75 / 180$ \\
\hline $\mathbf{2}$ & & 7 & \\
\hline
\end{tabular}

Fonte: Relatórios da International Transparency de 1995 até 2009

Desde a sua criação, o Índice de Percepção da Corrupção tem sido amplamente divulgado pela imprensa brasileira. Apesar de o alcance das suas conclusões ser bastante restrito nas regiões menos avançadas do país, altos círculos governamentais com frequência se manifestam negativamente sobre os seus resultados. ${ }^{676}$

\footnotetext{
$\overline{676}$ JORGE Hage diz que ranking da corrupção é "leviano e irresponsável". O Globo, Rio de Janeiro, 23 set. 2008 às $18 \mathrm{~h} 41$ Disponível em <http://oglobo.globo.com/pais/mat/2008/09/23/jorge_hage_diz_que_ranking_da_corrupcao_leviano_irrespons avel_-548346374.asp>. Acesso em: 9. nov. 2008 às 23h04. "O ministro-chefe da Controladoria-Geral da União (CGU), Jorge Hage, criticou nesta terça-feira a organização não-governamental Transparência Internacional que indicou o Brasil na $80^{\mathrm{a}}$ posição no ranking que mede a percepção na sociedade do nível de corrupção entre seus políticos e autoridades. Ele considerou 'leviano e irresponsável' o ranking elaborado pela entidade. - A Transparência Internacional não conhece nada do Brasil, nunca vem aqui, ignora completamente o que aqui se faz e fica dando palpite à distância, sem fazer nenhuma pesquisa real sobre corrupção nem sobre o combate à corrupção - disse o ministro. Segundo Jorge Hage, o levantamento é feito sem um critério unificado adequado, sendo que a percepção aumenta quando se ouve falar mais do assunto. Ele defende que no Brasil o combate à corrupção passou a ser uma prioridade de governo. - O que eles dizem medir (e nem isso medem, pois o que fazem é uma salada de cálculos incoerentes a partir de medições de terceiros, de outras instituições, cada uma com seus próprios e diferentes critérios) são apenas 'percepções' sobre corrupção."
} 


\subsection{A indignada visão popular sobre a corrupção}

Quando se trata de um tema técnico de repercussão e eco na sociedade, é comum que a população possua opiniões simplistas e enviesadas, frutos da manipulação de meios de comunicação, preconceitos relacionados a cultos religiosos, superstições imemoriais ou falhas no sistema de ensino. Aborto, criminalidade urbana, criacionismo e vida extraterrestre são, ao mesmo tempo, objeto de acirradas conversas e opiniões inconsistentes, as chamadas "conversas de botequim".

Nesta seara, também é equivocada boa parte da visão popular sobre a função dos políticos: a maioria da população associa corrupção a uma ação errada feita por algum político, o que se traduz pela confusão entre corrupção e escândalo. ${ }^{677} \mathrm{Um}$ amplo aspecto de condutas é incluído no que se entende por ação errada: um senador infiel ao casamento; um deputado que vota a favor do governo em troca de propina; um prefeito que recebe propina de uma agência de publicidade em troca de favores em dada licitação; um fiscal de administração regional que faz vistas grossas à instalação irregular de camelôs na via pública em troca de presentes; um administrador que não cumpre o orçamento público e gasta menos do que o devido em educação; o juiz que usa o carro oficial para levar o neto à escola e um lobista que recebe comissão por facilitar a liberação de recursos que seriam devidos pela União ao município são algumas das condutas díspares associadas à corrupção que povoam o imaginário popular. Se houver algo errado no "governo", assim compreendido como todo e qualquer parte do Estado, haverá corrupção.

Logo, há uma forte dimensão moral associada à censura da corrupção pela população. Mesmo sem saber exatamente o que a lei estabelece, há um sentimento de indignação e revolta quando tais práticas são noticiadas pela imprensa, responsável principal pela emergência do tema à agenda do dia. Embora os interesses da mídia sejam relevantes nas pautas dos meios de comunicação, o regime da Nova República pós-1985 franqueou ampla liberdade de imprensa e manifestação de pensamento, permitindo que o povo

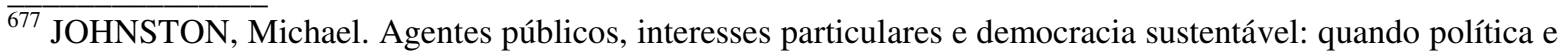
corrupção se unem. In: ELLIOT, Kimberly Ann (Org.). A corrupção e a economia global. Tradução de Marsel Nascimento Gonçalves de Souza. Brasília: UnB, 2002. p. 106. “A corrupção é uma questão política acalorada: apesar de - ou por causa de? - suas dimensões morais ela é usada de formas controversas e politizadas, e pode provocar fortes reações do público. Corrupção e escândalo são duas coisas diferentes, e ambas podem ocorrer uma na ausência da outra. Por essas razões saber a relevância da corrupção, sua aplicação em certos casos, e aquém cabe o direito de decidir isso pode levantar questões da acalorada contestação."
} 
soubesse a real dimensão que a corrupção ocupa na vida pública brasileira. ${ }^{678}$ Assim, ainda que haja uma substancial convergência de interesses entre os grandes órgãos de comunicação em dar mais importância a dados temas do que a outros, a opinião pública com frequência atropela tais preferências e traz à tona o inconveniente noticioso. Mesmo contaminada com as falhas que os cientistas políticos já identificaram há muito tempo, a democracia permite aos poucos conferir transparência à administração pública.

Esse atropelamento da mídia ocorre independentemente da relevância social, política ou econômica do fato noticiado. Como desdobramento de um desconhecimento do que seria corrupção propriamente, a população pode-se indignar muito mais por fatos sem repercussão do que por outros mais importantes. Algumas práticas políticas seriam corruptas, mas a avaliação da seriedade das condutas é, na maioria das vezes, distorcida. Propostas de aumentos salariais de parlamentares, legais ainda que possam ser consideradas ilegítimas ou imorais, são vistas com muito mais reprovação do que a politicagem envolvendo "questiúnculas" legislativas, tais como o processo de elaboração do orçamento público e a respectiva liberação de verbas do orçamento. Por meio desses processos, ocorre um verdadeiro escamoteamento da corrupção que assola e impregna a administração pública. Entretanto, reconhece-se que há corrupção.

Independentemente das causas e intensidade da corrupção, há consenso aparente de que esta não é punida devidamente. Isso em nada contrasta com o que acontece na repressão aos crimes de colarinho branco no Brasil - Lopes aponta que são punidos apenas 3\% dos crimes de colarinho branco tipificados na Lei $\mathrm{n}^{\mathrm{o}}$ 7.492/86, entre os identificados pelo Banco Central do Brasil e processados pelo Ministério Público. ${ }^{679}$ Essas conclusões são reconhecidas pela população, de modo que até mesmo os cordelistas Sebastião e Pedro Nunes Batista as sintetizaram nos anos 1960:

\footnotetext{
${ }^{678}$ ABRAMO, Claudio Weber. Brazil: a portrait of disparities. Brazilian Journalism Research, Brasília: UnB, v. 3, n. 1, Semestre 1 2007, p. 95. Para o autor, há uma diferença entre os grandes grupos de mídia imprensa, de repercussão e alcance nacionais, e os pequenos grupos, economicamente inviáveis e voltados para o fortalecimento político dos seus proprietários. "The immediate political interests of these groups might appear with varying frequency in the news they publish, but it cannot be said that this is what characterise them. The strongest groups in particular (Globo, Folha, Estado) are in permanent competition in the markets they occupy. Blatant political alignments are bound to alienate parts of their readership, and that is something they cannot afford in the long run."

${ }^{679}$ LOPES, J. R. L. Direitos humanos e tratamento igualitário: questões de impunidade, dignidade e liberdade. Revista Brasileira de Ciências Sociais, São Paulo: Anpocs, v. 42, n. 15, p. 77.
} 


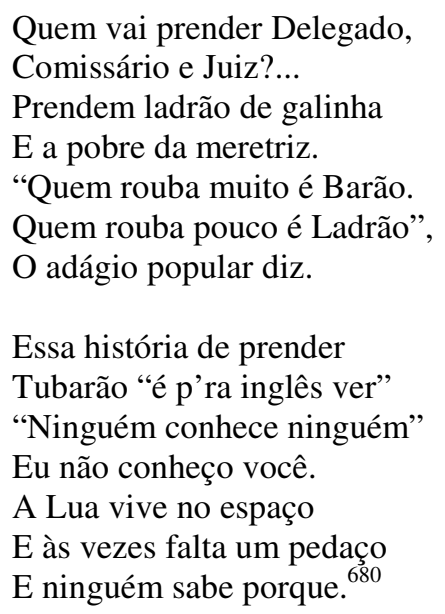

Semelhante pano de fundo sugere o risco de uma descrença da população nas instituições. Mais do que um componente moralista exclusivo da classe média, a corrupção é associada à impunidade, especialmente daqueles que detêm o poder. Paradoxalmente, parcelas da população associam a corrupção à democracia, que possibilitou as críticas às práticas corruptas florescerem na imprensa. Sob os regimes autoritários, a corrupção certamente existe, mas os mecanismos de repressão à oposição política e à livre manifestação do pensamento impedem que o assunto seja discutido de modo transparente. Ingenuamente, a esperança não foi perdida. Ulisses Higino da Silva, outro cordelista, faz versos que retratam essa esperança popular no episódio do escândalo do orçamento em 1993:

\footnotetext{
Estava se alastrando $\mathrm{O}$ vírus da corrupção Milhares contaminados Sem nenhuma solução A C.P.I do orçamento Minimizou o sofrimento De toda população. ${ }^{681}$
}

Afinal, qual seria a importância de questionar o que a população considera como corrupção, uma vez que há uma distorção na sua concepção?

Esse descolamento quase sempre existe quando se analisa a forma de aplicação das leis e aquilo que a população gostaria que fosse aplicado, dando espaço para críticas comuns ao regime democrático: a negação da competência do povo para se autogovernar. Enquanto

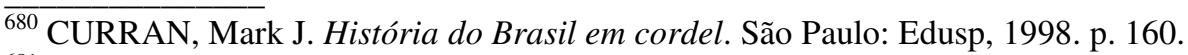

${ }^{681}$ Idem, p. 245.
} 
houver discussões sobre a dicotomia direito-moral, esse descompasso entre o que é norma e o que a população considera que deveria ser norma permanecerá no centro do debate das sociedades democráticas, permitindo o reaparecimento de concepções platônicas sobre como a esfera pública seria mais bem gerida por especialistas.

Entretanto, não se trata de elogiar ou criticar a sabedoria dos operadores do direito em relação ao que a população conversa nas ruas. Num regime democrático, a determinação das políticas públicas deve refletir, em alguma medida, o desejo da população. Mais do que isso, Dahl apresenta quatro contra-argumentos a essa visão platônica que retira legitimidade popular: (i) "delegar determinadas decisões secundárias a especialistas não é o mesmo que ceder o controle decisivo nas grandes decisões"; (ii) "decisões pessoais tomadas por indivíduos não equivalem a decisões tomadas e impostas pelo governo de um estado"; (iii) "governar um estado exige muito mais do que um conhecimento rigorosamente científico"; (iv) "governar bem exige mais do que o conhecimento". ${ }^{62}$

Tampouco é objetivo elogiar ou criticar a ignorância da população sobre o que está nos dicionários e compêndios jurídicos. Essa ignorância, problema sério no Brasil, fragiliza a democracia e coloca a população à mercê de interesses que não os seus. Os males de um sistema educacional de má qualidade já são bastante conhecidos e não precisam ser relembrados. A corrupção só se aproveita deles para se perpetuar.

A importância da identificação desse descompasso se liga às implicações que defluem da aplicação do princípio da maioria, um dos pilares do próprio regime democrático. Aristóteles já argumentava que a regra da maioria é traço marcante do regime democrático, ${ }^{683} \mathrm{e}$, já no século XIX, Lincoln a definiu como o "governo do povo, pelo povo e para o povo". O reconhecimento de que o regime democrático se assenta na vontade do povo remete à necessidade de compreender o que a população julga como prática corrupta. Essa melhor compreensão se torna mais importante após o alargamento da participação popular no processo eleitoral, o qual se reflete no processo legislativo. É indesejável a criação de uma oligarquia político-jurídica capaz de decidir o que seja corrupção em detrimento dos anseios da população.

Portanto, constata-se a existência de um descolamento entre percepção das pessoas comuns e o que tecnicamente se considera corrupção. A existência dessa incongruência repercute diretamente na conceituação técnico-jurídico da corrupção, fazendo com que

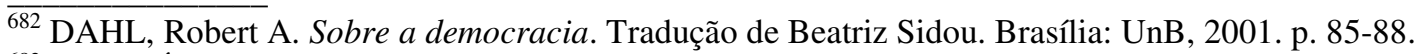

${ }^{683}$ ARISTÓTELES. A política. Tradução de Nestor Silveira Chaves. Introdução de Ivan Lins. Rio de Janeiro: Ediouro, [s.d.]. p. 56-57.
} 
certas práticas consideradas corruptas pela população não sejam reprimidas pelo sistema jurídico - os antigos romanos já afirmavam que nem tudo que é lícito é moralmente belo ("non omne quod licet honestum est").

Essas considerações revelam quais são os interesses motivadores dos potenciais adversários do princípio democrático quando se pretende estudar modos de aperfeiçoamento do combate à corrupção. Não são apenas a corrupção-suborno e a corrupção-favorecimento que subvertem a lógica e a legitimidade do Estado de Direito. Também a corrupçãosolapamento, nitidamente impregnada no modo de pensar dos políticos, depõe contra a depuração das práticas do Estado patrimonialista.

\subsubsection{Visão dos políticos sobre a corrupção}

A exposição precedente demonstra como a percepção popular sobre corrupção não se coaduna com as significações atribuídas por certos segmentos da sociedade ou até por aqueles que a estudam. $\mathrm{O}$ mesmo pode ser dito a respeito da percepção jurídica em relação à política e à popular. Esse descasamento é comum, uma vez que a vivacidade de uma língua falada faz com que o sentido das palavras se afaste do que consta nos dicionários, na prática política e nos tratados jurídicos. ${ }^{684}$

A chamada moral pública é formada a partir das visões individuais da moral de cada indivíduo, constituindo "concepções predominantes (opinião pública) sobre o moralmente correto". ${ }^{685}$ Sob certa perspectiva, ela brota da sociedade, independentemente de classe ou condição social. Como explica Romano,

[...] as pessoas menos esclarecidas mostram, por seus discursos e sua conduta, que têm idéias muito corretas em matéria de moral, embora nem sempre possam desenvolvê-las muito bem, nem exprimir com clareza tudo o que sentem; mas os que possuem maior penetração devem ser capazes de adquirir, de modo distinto, todas as luzes das quais necessitam para se conduzir. ${ }^{686}$

\footnotetext{
$\overline{684}$ ALVES, Alaôr Caffé. Lógica, pensamento formal e argumentação: elementos para o discurso jurídico. Bauru: Edipro, 2000. p. 26. “[...] o pensamento não se identifica com a linguagem, não é idêntico a ela, mas também não é possível a sua existência em expressões simbólicas sem a formulação pertinente da linguagem. [...] A linguagem é um processo que se caracteriza essencialmente como fenômeno intersubjetivo, sob condições humanas biologicamente singulares e sociais. Isso significa que se o pensamento depende da linguagem para existir, e esta depende das relações intersubjetivas das relações e práticas sociais, não há como deixar de concluir que aquilo que temos de mais íntimo, ou seja, o pensamento, depende de relações sociais. Assim, não há pensamento, nem sua expressão formal, sem sociedade, sem a comunidade falante."

${ }^{685}$ HORN, Norbert. Introdução à ciência do direito e à filosofia jurídica. Tradução da $2^{\mathrm{a}}$ edição alemã de Elisete Anoniuk. Porto Alegre: Sérgio Fabris Editor, 2005. p. 41.

${ }^{686}$ ROMANO, Roberto. Contra o abuso da ética e da moral. Educação \& Sociedade, Campinas: Cedes, ano 22, n. 76 , p. 98, out. 2001.
} 
Esse aspecto da opinião pública explica o porquê da grande indignação popular decorrente das declarações do Deputado Sérgio Moraes (PTB-RS) em maio de 2009: ao analisar um caso no Conselho de Ética da Câmara dos Deputados, o congressista afirmou que "se lixava" para a opinião pública e a mídia e que faria o relatório como bem lhe conviesse. ${ }^{687}$

Tal reação, ocorrida no Brasil, faz parte de algo mais amplo. Existe um questionamento global quase que generalizado a respeito da corrupção, o qual coloca em xeque a legitimidade dos sistemas políticos democráticos. ${ }^{688}$ Especialmente a partir dos anos 1990, a corrupção tem sido objeto de preocupações da maioria das sociedades, inclusive as não democráticas. Como explicam Glynn, Kobrin e Naím, há transformações sociais que fomentam esse questionamento global:

\begin{abstract}
As forças motrizes primordiais dessa mudança são o crescimento da riqueza e da educação, e o surgimento da era da informação. A crescente disponibilidade e o consumo mundial da informação, a influência cada vez maior dos meios de comunicação e os avanços tecnológicos que dão prioridade ao conhecimento e à informação na vida econômica contribuíram, todos, para um contexto rico em informações, no qual os líderes, quer queiram quer não, são mais que nunca forçados a vir a público para prestar contas mais detalhadas dos seus atos. ${ }^{69}$
\end{abstract}

Independentemente de haver ou não uma opinião pública global, políticas como a pretendida pelas Ilhas Seychelles em 1995, objetivando legitimar a lavagem de dinheiro ilegal ${ }^{690}$ não encontram eco, mas sim feroz oposição em outros países. Aliás, esse exemplo demonstra como o direito nem sempre acolhe na íntegra tais concepções predominantes, mas

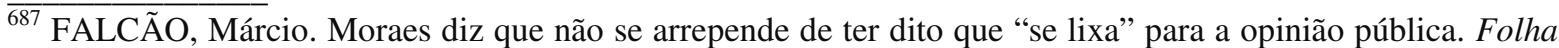
de S.Paulo, São Paulo, 16 maio 2009. Disponível em: <http://www1.folha.uol.com.br/folha/brasil/ult96u564539.shtml>. Acesso em: 2 dez. 2009 às 19 h19.

${ }^{688}$ GLYNN, Patrick; KOBRIN, Stephen J.; NAÍM, Moisés. Globalização da corrupção. In: ELLIOT, Kimberly Ann (Org.). A corrupção e a economia global. Tradução de Marsel Nascimento Gonçalves de Souza. Brasília: UnB, 2002. p. 29. "A revolução anticorrupção de hoje pode ser considerada uma continuação da crise de legitimação em andamento que tornou o motivo condutor da polícia global durante o último quarto do século XIX. Desde as mais avançadas democracias até os Estados mais repressivos, a proporção do poder entre os líderes e a população tem mudado, e a continua a mudar, em favor de uma governança transparente e democrática."

${ }^{689}$ Idem, p. 29.

${ }^{690}$ Idem, p. 53-54. "No final de 1995, o governo das Ilhas Seychelles promulgou uma lei aparentemente inocente, chamada Lei do Desenvolvimento Econômico. Uma das disposições dessa lei oferece imunidade penal de quaisquer crimes àqueles estrangeiros que realizarem investimentos superiores a US\$10 milhões. O teto da lei chega a determinar que ela somente poderá ser alterada por meio de plebiscito nacional e de emenda constitucional. Em suma, trata-se de um convite escancarado, oficial e desavergonhado, a lavadores de dinheiro e a chefões da droga: 'Tragam seu dinheiro sujo para as Ilhas Seychelles'. Embora a lei ainda não tenha sido revogada, a reação internacional muito provavelmente já afugentou alguns dos investidores aos quais o governo de Seychelles esperava seduzir. Parece questionável, a longo prazo, que a lei sobreviva a tamanho ataque internacional."
} 
com frequência o faz com a positivação de regras - às vezes, até mesmo com discordância total entre os preceitos predominantes e o que é positivado. ${ }^{691}$

Todavia, a percepção popular sobre corrupção também não se harmoniza com a visão que um segmento particular da população possui sobre o tema: alguns políticos são pródigos em desenvolver explicações para comportamentos reprovados pela maioria da população, tal como o nepotismo. "Não vejo nada de errado nisso" é afirmação comum dos políticos, antecipando uma defesa jurídica calcada no formalismo de uma definição - no caso específico do nepotismo, inexiste uma vedação legal expressa, de forma que ele seria admissível. Tal descompasso sugere até mesmo a existência de uma moralidade distinta dos políticos em relação à sociedade. Não se trata de um cinismo aberto e declarado sobre a aceitação da corrupção, ${ }^{692}$ mas de uma tentativa de justificar condutas inaceitáveis.

Ilustrativo desse descompasso é o que se infere da entrevista concedida à revista Carta Capital, em 3 de fevereiro de 2006, pelo ex-deputado Roberto Jefferson, protagonista do escândalo do mensalão. Para Roberto Jefferson, “o recurso não sai do caixa da empresa [Furnas]. Isso é da relação com as empresas que fornecem serviços à empresa. É assim em todas as estatais. Por isso os partidos se digladiam pelas nomeações. Sempre foi assim". ${ }^{693}$

A singeleza do argumento pode até seduzir os mais incautos, de modo que algumas vezes raciocínios dessa natureza podem até mesmo invadir a seara jurídica. ${ }^{694}$ Se comparada à tradicional apropriação da coisa pública pelos detentores do poder, ${ }^{695}$ existe uma

\footnotetext{
${ }^{691}$ HORN, Norbert. Op. cit. p. 43-44.

${ }^{692}$ SUTHERLAND, Edwin H. White collar criminality. American Sociological Review, v. 5, n. 1, p. 2 , Feb. 1940. "Their attitudes are illustrated by these statements: Colonel Vanderbilt asked, 'You don't suppose you can run a railroad in accordance with the statutes, do you?' A. B. Stickney, a railroad president, said to sixteen other railroad presidents in the home of J. P. Morgan in 1890, 'I have the utmost respect for you gentlemen, individually, but as railroad presidents I wouldn't trust you with my watch out of my sight.' Charles Francis Adarns said, 'The difficulty in railroad management [...] lies in the covetousness, want' of good faith, and low moral tone of railway managers, in the complete absence of any high standard of commercial honesty."

693 CARTA CAPITAL. As donzelas furadas. Entrevista concedida por Roberto Jefferson em 3 de fevereiro 2006. São Paulo, n. 279, 8 fev. 2006, n. 279, p. 19.

${ }^{694}$ ALMEIDA, Fernando H. M. Dos crimes contra a administração pública. São Paulo: Saraiva, 1955. p. 1920. Num curto trecho, o jurista antevê que o peculato poderia se tornar incriminável pelo costume. "O costume pode, nalgumas vezes, legitimar um fato que, sem ele, seria incriminável. Com isto não se deseja significar que o costume é hábil para invalidar a norma de direito penal. Quer dizer, apenas, que ele pode temperá-la quanto à ocorrência e, quiçá, excluir o aspecto antijurídico de que se revestiria. O uso de papel de cartas de repartição, por exemplo, é do costume. Quando moderado e restrito, de modo que não comprometa o decoro da administração pública, não pode ter incriminação." Políticos engajados em práticas tradicionais se identificariam com esta assertiva, mas o próprio autor admite a contradição de seu raciocínio adiante: "O difícil é saber, precisamente, quando há aí um uso, ou um abuso. É o que se chama costume aquilo que se faz e não aquilo que se deveria fazer, dentro dos limites da razoabilidade."

${ }^{695}$ Vide exemplo típico dessa apropriação do patrimônio público: BRASIL. Tribunal de Justiça de São Paulo. Acórdão por maioria da $2^{a}$ Câmara Criminal na apelação criminal $\mathrm{n}^{\mathrm{o}}$ 108.761, originária da Comarca de Itápolis. Relator: Desembargador Acácio Rebouças. Voto vencido do Desembargador Odyr Porto. Decisão em 21 fev. 1972. In: Revista dos Tribunais 442/258. "Crime de responsabilidade - Peculato de uso - Delito
} 
sofisticação que lhe confere ares de legalidade. Entretanto, o sentimento ético e moral acertado no trato da res publica não deixa dúvidas. Em realidade, conforme continua a se explicar Roberto Jefferson,

[...] o dinheiro do suborno sai, sim, dos cofres da estatal, na forma do superfaturamento, refletindo-se, no caso de Furnas, no custo da energia elétrica (e em menor capacidade de investimento e menor distribuição de dividendos aos acionistas, pois Furnas é uma sociedade anônima), o qual aparece direitinho na conta de luz que pagamos no final de todos os meses. ${ }^{696}$

Típico político do Estado patrimonialista que não enxerga com clareza a distinção entre o público e o privado, Roberto Jefferson ignora peremptoriamente esse nexo causal conducente à imoralidade administrativa. Intuitivamente, mesmo sem analisar em detalhes a legislação de combate à corrupção, pode-se concluir que, à semelhança do nepotismo, alguns dos tipos relacionados não são explicitamente vedados pelo ordenamento brasileiro. Essa situação seria até mesmo esperada no contexto brasileiro, em que os políticos e, em especial, os legisladores tendem a proteger os próprios interesses privados em detrimento do interesse público.

Nesses momentos, vem à superfície o caráter patrimonialista do Estado brasileiro, escondido sob a aparência modernizada da dicotomia público-privado. Alves explica como se dá o fenômeno:

[...] como a relação de poder se realiza no interior de um processo que abrange avanços e recuos de todas as forças sociais em jogo, não se pode afirmar que o falseamento ideológico na elaboração teórica dependa deste ou daquele setor ou classe social, mas sim das circunstâncias históricas decorrentes do dinamismo das classes em luta, do empenho dos agentes coletivos com interesses divergentes ou antagônicos na linha da transformação da realidade social. Por isso, a ideologia se instala com mais força quando a consciência de classe se mostra não como consciência crítica, senão como consciência justificadora. ${ }^{697}$

Qual seria a relevância de constatar esse descompasso entre a aparência e a realidade?

caracterizado - Prefeito Municipal que desvia, voluntária e conscientemente, trabalhadores braçais do serviço para prestar serviço em propriedades particulares, inclusive na sua - Remuneração devida aos mesmos não recolhida aos cofres públicos - Hipótese punida com reclusão e não mera detenção - Apelação provida - Voto vencido - Inteligência do art. $1^{\circ}, \mathrm{n}^{\circ}$ II, do Decreto-lei $\mathrm{n}^{\mathrm{o}}$ 201, de 1967. O trabalho, a energia física dos servidores públicos, constitui serviço público, enquanto custeados pelos cofres públicos e sua utilização em benefício de particulares, sem o prévio depósito estipulado, configura o peculato de uso, tão relevante quanto o desvio de objetos materiais."

${ }^{696}$ ABRAMO, Claudio Weber. Acham que somos idiotas? Folha de S.Paulo, São Paulo, 17 fev. 2006.

${ }^{697}$ ALVES, Alaôr Caffé. Op. cit., 1987. p. 41. 
De uma perspectiva democrática, esse descompasso é uma prova do déficit democrático no sistema político brasileiro. Este não tem sido eficaz em receber inputs da sociedade e transformá-los em ações aplicáveis aos políticos e à administração pública. Vendo-se de outra perspectiva, os políticos eleitos, principalmente aqueles que ocupam posições no Congresso Nacional, deveriam fazer eco desses reclamos da população e vedar certas condutas, mas legislam em causa própria. Em virtude da magnitude do descaramento de setores políticos, as causas dessas práticas estão profundamente arraigadas no sistema político-administrativo.

$\mathrm{O}$ atrito entre as diversas versões e percepções de corrupção, muitas destas permeadas de interesse próprio dos políticos, faz com que a efetivação dos reclamos populares seja imperfeita. A perfeita simetria entre o que é desejado pela população e o que é legislado é difícil de ser atingida, da mesma forma que nem todas as ações moralmente reprováveis serão objeto de sanção pela regulamentação microjurídica. Sob certa perspectiva, atribui-se ao próprio sistema representativo a função de filtrar as paixões da população e implementar ações mais adequadas.

Quando tal descompasso é sério demais, a própria natureza do sistema político é desvirtuada pela quantidade de inconsistências. Consequentemente, o sistema político, em especial por meio do Poder Legislativo, não responde às insistentes demandas sociais, perdendo a legitimidade.

\subsubsection{Adesismo social e corrupção}

Quando se trata da interpretação dos limites e contornos da dicotomia públicoprivado, legisladores, operadores do direito e população nutrem profunda incompreensão uns dos outros. Legisladores, intérpretes autênticos, alegam que operadores do direito, intérpretes não autênticos, distorcem o sentido e alcance das regras democraticamente aprovadas, ao passo que operadores do direito acusam os legisladores de ofensa a direitos e garantias consagrados na Constituição ${ }^{698}$ - em outros termos, legisladores e operadores do direito travam uma batalha pela prevalência de interesses defendidos por cada lado. Dessa

\footnotetext{
$\overline{698}$ GRAU, Eros Roberto. Ensaio e discurso sobre a interpretação/aplicação do direito. São Paulo: Malheiros, 2002. p. 76. “Aqui se coloca um grave problema, pois a norma é a manifestação de poder. Quem produz uma norma exerce um ato de poder. E é certo ainda que não apenas o intérprete autêntico interpreta. Também o fazem os advogados, os juristas, o administrador público e os cidadãos, até o momento anterior ao da definição da norma de decisão. Ora, se as normas nascem da interpretação, também esses intérpretes, não autênticos, produzem normas."
} 
perspectiva, é mais fácil compreender a razão pela qual o legislado se afastar do que o legislador, representante do povo, desejava em princípio. Não raro, leis produzem efeitos diametralmente opostos aos pretendidos pelo legislador em virtude de interpretação criativa dos operadores do direito.

Tal metamorfose, típica dos regimes jurídicos em países democráticos, não pode ser valorada aprioristicamente como positiva ou negativa. Suas causas precisam ser investigadas com cuidado. Por que houve a "adaptação" do direito posto? Seria isso um influxo do direito pressuposto? Por que a corrupção praticada por alguns causa mais indignação do que a praticada por outros?

Especialmente no Estado patrimonialista, o legislador pode ter feito leis em causa própria, e o operador do direito, não comprometido com os mesmos interesses ou a ideologia do legislador, as impugna em virtude de ofensa ao princípio da moralidade administrativa. Também pode o operador do direito, comungando os mesmos interesses ou ideologia do legislador, interpretar uma norma para preservar o status quo a despeito do desejo de mudanças da sociedade, e o legislador aprova uma lei interpretativa da já previamente aprovada mudança normativa, visando justamente refletir um avanço demandado pela sociedade. Sabendo-se que legislador e operador do direito defendem interesses, o escrutínio valorativo deve ser cauteloso. Uma valoração sobre tal embate pressupõe o conhecimento de tais interesses e ideologias, uma vez que os interesses podem justificar certas decisões e consequências.

Tome-se o caso do Congresso Nacional, que pode ser expandido provavelmente para parcela considerável da esfera pública no Brasil. De acordo com pesquisa do Instituto FSB, feita com 247 congressistas em 2009, 17,3\% dos parlamentares julgam alto o nível de corrupção no Congresso Nacional, e 48,9\%, mediano. Por si sós, tais números levam ao questionamento do que está sendo feito a respeito do problema. Não bastasse essa crueza da aceitação da corrupção-suborno, também há profunda incompreensão por parte da população sobre a separação entre os espaços público e privado, permitindo que a corrupçãofavorecimento se desenvolva. Apesar de condenado, parcela da população considera normal o recebimento de favores dos políticos, favores que se encontram muito distantes das funções típicas deles enquanto ocupantes de cargos. Em pesquisa realizada em junho de 2008 pelo Instituto Vox Populi, 42\% dos entrevistados considera dever dos vereadores "ajudar a resolver problemas que as pessoas têm em órgãos públicos" e "pagar despesas de 
hospital e enterro para pessoas necessitadas", e $22 \%$ consideram que deveriam "patrocinar ônibus para viagens de passeio e festas de formatura". ${ }^{699}$

Esse paradoxo entre o que se acha e o que se faz não é totalmente estranho. Apesar de a corrupção ser repudiada pela sociedade civil, os mecanismos típicos do Estado patrimonialista cooptam ideologicamente a população, quer esteja ela ao abrigo dos detentores do poder, quer esteja ela sedenta por estar abrigada. As práticas políticas desnudam essa tolerância à corrupção, pois existe uma "conexão entre valores e politicidade", e algumas pessoas são responsáveis pela transmissão de tais valores para a política. $^{700}$

Um dos mecanismos dessa cooptação de parcela da população é a "criação de dificuldades para a venda de facilidades". A síntese de Ataliba é perfeita sobre o que pode caracterizar as dificuldades sob o olhar de um jurista:

\begin{abstract}
Delega-se alusivamente faculdades normativas inaugurais a toda sorte de órgãos e funcionários. Já não sabe o administrado donde virão os próximos constrangimentos. Os deveres se multiplicam. Os comandos se contradizem, se superpõem, se somam. $\mathrm{O}$ administrado se sente inseguro, indefeso. A multiplicidade o surpreende. Desaparece toda veleidade de participação. Não há sequer aparência de lealdade do Estado no fazê-lo saber do que se trama, que se lhe pretende, que se lhe vai exigir. [...] Nessa balbúrdia, a crítica, a colaboração não cabem. A deslealdade da autoridade, acostumada à impunidade, se faz regra. Desaparece a legalidade, olvida-se a relação de administração. Desvanece-se o espírito republicano. ${ }^{701}$
\end{abstract}

Quando o espírito republicano se esgota por completo, então a facilidade é vendida. Por esse motivo, não é de surpreender que, entre 18 países da América Latina -Brasil inclusive -, 41,8\% da população estaria disposta a pagar suborno para que "as coisas funcionem". ${ }^{702}$ Mais do que tolerância, um número tão elevado revela um adesismo social de parte da população a tais práticas e, de acordo com Pareto, também se justifica pela “correlação entre o nível da moralidade da população e dos políticos" ${ }^{703} \mathrm{O}$ dualismo moral

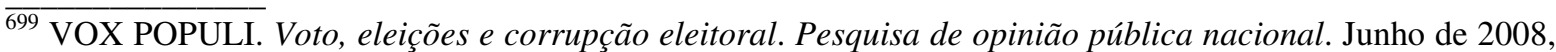
p. 28. Disponível em www.amb.com.br/portal/docs/pesquisa/pesquisa_perfil_eleitor.pdf. Acesso em: 28 set. 2008 às $16 \mathrm{~h} 23$.

${ }^{700}$ SALDANHA, Nelson. Ética e história. 2. ed. rev. e ampl. Rio de Janeiro: Renovar, 2007. p. 14. "Esta conexão entre valores e politicidade não descarta, certamente, a referência à pessoa (algo distinto do indivíduo humano mas não 'separado' dele). A pessoa é que dá sentido à política; os valores políticos dependem de um entendimento, ou uma interpretação, que é afinal obra de determinadas pessoas. Os valores que se atribuem à pessoa, para revelá-la ou para enriquecê-la, são entretanto referências cuja significação mais objetiva se acha na dimensão institucional: língua, parentesco, ordem social, crenças."

701 ATALIBA, Geraldo. Instituições de direito público e república. 1984. 215 f. Tese (Professor Titular)Faculdade de Direito, Universidade de São Paulo, São Paulo. São Paulo. p. 9.

${ }^{702}$ PNUD. A democracia na América Latina rumo a uma democracia de cidadãs e cidadãos. Tradução de Mônica Hirts. Santana de Parnaíba: LM\&X, 2004. p. 88.

${ }^{703}$ FERREIRA FILHO, Manoel Gonçalves. Corrupção e democracia. Revista de Direito Administrativo, Rio de Janeiro: Renovar, v. 226, p. 218 out./dez., 2001.
} 
não é exclusivo do Brasil - ao menos a Rússia, outro país de formação historicamente patrimonialista, também o apresenta. ${ }^{704}$

Weber explicou esse processo de coexistência de dois comportamentos morais, diferenciando a moral interna da externa. A primeira se baseia nos laços familiares e comunitários, ao passo que a segunda decorre da divisão do trabalho mais sofisticada. Antes da sofisticação da divisão do trabalho, predominavam os comportamentos pautados pela moral interna. À medida que ocorreu um distanciamento do indivíduo em relação à família e à comunidade próxima, a moral externa passou a predominar. Em algumas sociedades, ambas as morais caminham conjuntamente, ao passo que, em outras, tais como as estruturadas em torno de um Estado patrimonialista, se verifica um descompasso. ${ }^{705}$

Também há outras formas de cooptação ideológica. A distribuição de recursos públicos para a sociedade civil é outra estratégia que o Estado patrimonialista utiliza para minar a sua independência. Sindicatos recebem, ONGs recebem, movimentos sociais recebem, movimentos estudantis recebem. Num cenário dessa natureza, não ocorre somente adesão às políticas do governo momentâneo, mas também cumplicidade. Aqueles que deveriam atuar como defensores do interesse público são capturados pelos recursos do Estado.

Essas técnicas têm sido aperfeiçoadas ao longo da evolução política. Há quem alegue que o uso de políticas de inclusão social tenha por efeito desviar o apoio de movimentos sociais do movimento de combate à corrupção, mudança perceptível a partir do impedimento de Fernando Collor em 1992. As elites também não teriam interesse em mudanças estruturais, pois são beneficiadas pelo sistema, quer pelos favorecimentos específicos à custa do Estado, quer pelo descomprometimento com uma ação política. ${ }^{706}$

\footnotetext{
${ }^{704}$ SUHARA, Manabu. Corruption in Russia: a historical perspective. In: Hayashi, Tadayuki. Democracy and market economics in Central and Eastern Europe: are new institutions being consolidated?. Sapporo: Slavic Research Center, Hokkaido University, 2004. p. 393-394. "Firstly, it was not considered to be an ethical issue that merchants cheated others. [...] That is to say, Moscow merchants' attitudes towards a person depended on whether or not he or she belonged to the same community as they did. In other words, different morals were applied inside and outside the community. Secondly, the credit system was still in a rudimentary stage and most trade was conducted in cash, which could also be explained by distrust of outsiders. Thirdly, [...] they demonstrated total devotion to the tsar, but on the other hand, displayed profound hostility towards state officialdom, which arbitrarily exploited them using law as an administrative weapon. The same dualism is found in the moral code that operated among the peasants. The peasants deemed it 'immoral' to deceive a neighbor or relative, but to deceive a government official or landlord was quite a different matter - indeed, that was a moral deed worthy of encouragement. [...] the peasants had one morality when dealing with members of their own commune and quite another for outsiders, especially those who were not peasants."

${ }^{705}$ WEBER, Max. The sociology of religion. Introdução de Talcott Parsons. Prefácio de Ann Swindler. Boston: Beacon Press, 1993. p. 164 e ss.

${ }^{706}$ CARVALHO, José Murilo de. Passado, presente e futuro da corrupção brasileira. In: AVRITZER, Leonardo et al. (Org.). Corrupção: ensaios e críticas. Belo Horizonte: UFMG, 2008. p. 240. "Daí que hoje, à diferença da época da eleição e do processo de impedimento de Collor, a classe média está sozinha, não tem a cumplicidade dos pobres, nem dos ricos. O desencontro entre classe média e setores populares pode ser
} 


\section{CAPÍTULO 6}

\section{RESPOSTAS ALTERNATIVAS DA REGULAMENTAÇÃO MICROJURÍDICA NO COMBATE À CORRUPÇÃO}

No capítulo 5, foram analisadas as tradicionais respostas da regulamentação microjurídica no combate à corrupção. As legislações essencialmente repressivas e pouco flexíveis e adaptáveis, parte do que se pode definir como regras de comando e controle (command and control), apresentam vantagens, dentre as quais podem ser mencionadas as seguintes: (i) são percebidas como mais facilmente aplicáveis ao estabelecer padrões claros de comportamento; (ii) deixam evidente quando uma ação é requerida; e (iii) determinam sanções a serem aplicadas na hipótese de verificada a violação. ${ }^{707}$ Esse tipo de resposta, forjada no âmbito da igualmente tradicional dicotomia público-privado, se encontra dentro do figurino fattispecie $\rightarrow$ sanção e constitui a primeira reação esperada do Estado no combate à corrupção.

Por outro lado, a estrutura das regras de comando e controle apresenta imperfeições que sofreram crítica mais intensa a partir dos anos 1970 no bojo do processo de liberalização econômica, igualmente sentido no direito. Roth analisa as críticas a esse tipo de regras, consubstanciadas no Estado moderno, o qual “já não está em capacidade de impor soluções, seja de um modo autoritário ou seja em negociação com os principais atores sócio-político nacionais, aos problemas sociais e econômicos atuais". ${ }^{708}$ Captura estatal, excesso de burocracia, critérios inadequados e dificuldades na aplicação das regras de comando e controle são as críticas feitas com maior freqüência. ${ }^{709}$

Por oposição às regras de comando e controle, o movimento liberalizante sugeriu a adoção de mecanismos autorregulatórios e de regulação assistida pelo Estado. Também se recomendaram políticas públicas menos intervencionistas e contundentes, tais como as baseadas em incentivos e desincentivos, bem como o apelo a mecanismos jurídicos, contratuais ou não, típicos da regulamentação do espaço privado, tais como as leis de defesa

caracterizado como um distanciamento entre a opinião pública e a opinião popular. Um deputado mensaleiro justificou assim seu comportamento: 'a opinião pública me condena, mas a opinião popular me absolve'."

${ }_{707}$ BALDWIN, R.; CAVE, M. Understanding regulation: theory, strategy and practice. Oxford: Oxford University Press, 1999. p. 35.

${ }^{708}$ ROTH, André-Noël. O direito em crise: fim do Estado moderno?. In: FARIA, José Eduardo (Org.). Direito e globalização econômica: implicações e perspectivas. São Paulo: Malheiros, 1996. p. 17-18.

${ }^{709}$ BALDWIN, R.; CAVE, M. Op. cit. p. 36-39. 
da concorrência, franquias, regulação via contratual e autorizações comercializáveis. ${ }^{710}$ Até mesmo por causa dessa mutação na forma de atuação estatal, alguns autores sugerem ter havido certa redefinição da dicotomia público-privado, a qual teria por efeito "abalar sua pedra angular - a noção de interesse público". ${ }^{711}$

Tal discussão se encontra implicitamente presente quando se trata do combate à corrupção. Associa-se o menor intervencionismo estatal a menores possibilidades para os agentes corruptos. Em realidade, partindo-se do reconhecimento da reduzida eficácia dos mecanismos baseados no estilo comando e controle, são desenvolvidas novas propostas, supostamente mais adequadas ao mundo pós-liberalização econômica.

Em seguida, será analisado o substrato teórico por trás desse soft law e como as suas várias vertentes podem ser articuladas no combate à corrupção nos termos da teoria da regulação responsiva. Em linhas gerais, o modelo teórico apresenta recomendações aplicáveis em várias jurisdições - desde já, fica registrada uma de suas fragilidades na tendência a ignorar peculiaridades socioculturais locais. Embora o aperfeiçoamento institucional deva evoluir até mesmo para lidar com questões localizadas, essa agenda está impregnada de uma visão sistêmica inerentemente redutora da realidade e tendente a ignorar boa parte do direito pressuposto. Mesmo assim, reconhece-se que as diretivas das estratégias adotadas tendem a agir contra a permanência de práticas corruptas microjurídicas. Ao término, serão traçadas considerações sobre a teoria da regulação econômica e corrupção.

\subsection{A teoria da regulação responsiva enquanto modelo para formulação e implementação de políticas públicas}

No contexto de liberalização econômica descrito, a regulação responsiva pode ser apontada como uma nova forma de conceber uma atuação estatal menos baseada em regras de comando e controle. Diferentemente da mera preocupação com a aplicação de sanções a certas hipóteses de fato, típica das regras de comando e controle, a regulação responsiva tem pretensões mais ambiciosas, voltando-se não somente para a maneira como as instituições

\footnotetext{
$\overline{{ }^{710} \text { Idem, p. 39-48. }}$

${ }^{711}$ MARQUES NETO, Floriano Peixoto de Azevedo. Regulação estatal e interesses públicos. São Paulo: Malheiros, 2002. p. 133-143. O autor resume os fenômenos que caracterizam tal abalo como relacionados à globalização econômica. Embora se reconheça a pertinência da argumentação, a ênfase desta tese é diversa: parte-se da premissa de que as bases da dicotomia público-privado e, por via reflexa, do que se entende por interesse público não foram historicamente assentadas no Brasil do mesmo modo que nos países da Europa ocidental e nos Estados Unidos. Logo, parece imprescindível discutir esse ponto antes de adentrar no abalo do interesse público decorrente da globalização, tal como propugnado por Marques Neto.
} 
devem ser concebidas, mas também para a forma como elas devem se comportar diante de dada situação. Por isso, em certa medida, associa-se a teoria da regulação responsiva ao movimento de busca por melhores práticas de governança pública. ${ }^{712}$

De antemão, relembre-se que a palavra "regulação" é plurívoca, e é necessário um esclarecimento sobre o sentido empregado ao se referir à regulação responsiva. Do ponto de vista técnico, regulação apresenta pelo menos três sentidos: (i) conjunto específico de regras de comando, (ii) um estado de influência deliberado; e (iii) todas as formas de controle social ou influência. O primeiro é fortemente relacionado ao direito, contendo a noção de um comando direto e preciso, o qual pode se traduzir numa ação ou omissão. O segundo é mais sutil, relacionando-se com os incentivos diretos e indiretos para que um sujeito se comporte de um modo ou de outro. O terceiro sentido é o mais amplo de todos, aproximando-se da própria definição de poder. ${ }^{713}$ Quando se trata de regulação responsiva, os seus teóricos têm em mente o segundo sentido: não se refere às regras de comando e controle, tampouco de um sinônimo de poder, mas sim de como atingir dado resultado manipulando as variáveis disponíveis, que podem ser tanto as regras de comando e controle quanto outras manifestações do poder, estatal ou privado.

Embora a regulação responsiva vise substituir regras impostas unilateralmente ou concebidas na ignorância dos incentivos e desincentivos por relações baseadas na interação, de modo a "economizar motivação, mas não somente motivação virtuosa", ela também lança mão dessas regras de comando e controle, se necessário. A regulação responsiva não se baseia apenas no modelo do bom cidadão, honesto cumpridor de seus deveres, à semelhança do bonus paterfamilias, e, por isso, sempre tem as "armas" do aparato regulatório "prontas para serem usadas". Do mesmo modo, a regulação responsiva não sabota a virtude desse bonus paterfamilias, uma vez que as referidas "armas" sempre estão de prontidão, bem como não se baseia exclusivamente nos atores economicamente racionais, posto que "uma variedade de formas de persuasão está disponível". ${ }^{714}$

A primeira premissa da regulação responsiva é entender as motivações dos sujeitos sobre os quais se pretende induzir determinados comportamentos. Obviamente, as

\footnotetext{
$\overline{712}$ PIETH, Mark. Cooperação internacional no combate à corrupção. In: ELLIOT, Kimberly Ann (Org.). A corrupção e a economia global. Trad. de Marsel Nascimento Gonçalves de Souza. Brasília: UnB, 2002. p. 194. "Com a recente ênfase na importância da 'boa governança' do desenvolvimento, o Banco Mundial freqüentemente exige um amplo leque de reformas do setor público com vistas a aumentar a transparência, o senso de responsabilidade e a participação dos países financiadores."

${ }^{713}$ BALDWIN, R.; CAVE, M. Op. cit. p. 2.

${ }^{714}$ AYRES, I.; BRAITHWAITE, J. Responsive regulation: transcending the deregulation debate. Nova York: Oxford University Press, 1992. p. 50.
} 
motivações de cada um, indivíduos, empresas e associações, variam, e qualquer tentativa de generalização está fadada ao fracasso. A racionalidade econômica nem sempre está presente: (i) algumas empresas oferecerão suborno, mesmo que isso possa custar mais do que obedecer à lei, ou (ii) um funcionário público que negocia propina numa situação pode não repeli-la em outra - os agentes podem se comportar de modo imprevisível, o que dificulta a adoção de uma única solução para o combate à corrupção.

Para tentar lidar com a multiplicidade de motivações, pensar em termos da teoria dos jogos tem sido uma alternativa para conceber cenários com que se defrontarão os responsáveis pelo combate à corrupção. O "olho por olho" (tit-for-tat) e até a hipótese do "vingativo olho por olho" (vindictive tit-for-tat) podem ser adaptados para implementar-se uma política pública que antecipe a melhor resposta do agente público em relação às ações dos corruptos.

Às vezes, a corrupção envolve variações do jogo do tipo ultimato, ${ }^{715}$ no qual as complexidades são maiores. Essa constatação parte da premissa de que os participantes de uma atividade corrupta estão sempre sujeitos a trapaças recíprocas: a qualquer momento, um deles pode renegar suas promessas e/ou reportar o incidente a autoridades anticorrupção, colocando tudo a perder.

Como não há nenhuma proteção legal para uma parte "traída" em um pacto corrupto, visto que todos estão descumprindo a lei, participantes envolvidos em atividades corruptas dependem muito do elemento "confiança" - o fato de que nenhum deles é exatamente confiável só torna o problema ainda mais complexo. À primeira vista, as probabilidades de um participante reportar o ato de corrupção a um superior hierárquico ou a um órgão de fiscalização seriam insignificantes: na maioria dos casos, a delação implicaria

\footnotetext{
$\overline{715}$ LAMBSDORFF, Johann Graf; FRANK, Björn. Corrupt reciprocity: an experiment. Working Paper. Sept. 2007. Disponível em: <http://www.wiwi.unipassau.de/fileadmin/dokumente/lehrstuehle/lambsdorff/downloads/Disc_Corrupt_Reciprocity.pdf>. Acesso em: 10 jan. 2010 às 13h10. Segundo Lambsdorff e Frank, é possível enquadrar o jogo de participantes de uma transação corrupta num jogo do tipo ultimato: "In these games a first mover can propose a division of a cake and a second mover can accept or reject, inducing a zero-payoff for both. Preferences for fairness and reciprocity motivate players to deviate from the payoff-maximizing Nash equilibrium. A second mover may reject, either because he dislikes inequality or because of negative reciprocity, that is, the willingness to retaliate. First movers may share fairly with second movers, either because they anticipate the second mover's willingness to reject or because they themselves dislike inequality. While preferences for fairness and reciprocity operate hand in hand in regular ultimatum games, they are conflicting in corruption games. Reciprocity is a force that induces players to share with each other, even involving the allotment of illegal earnings. This is no longer the case for fairness, which may also involve sentiments of civic-mindedness and altruism. It may go along with preferences for sharing with third parties. Corrupt actions are known to be unfair to the population at large, inducing fair actors to refrain from participating. This suggests that a corrupt framing of an ultimatum game may impact on the outcome."
} 
autodenúncia, e isso por si só preveniria as traições. No entanto, há pelo menos dois argumentos que contestam essa conclusão.

O primeiro se baseia na eficácia dos instrumentos de incentivos para a denúncia às autoridades, tais como a delação premiada e os programas de leniência. Esse argumento pressupõe que a traição entre os parceiros corruptos é uma coisa boa do ponto de vista da sociedade em geral e que esses instrumentos poderiam até induzir que potenciais participantes se abstenham de se envolver em atividades corruptas pelo receio de oportunismo e vazamento de informações por meio de outros participantes para as autoridades com responsabilidades no combate à corrupção.

Por seu turno, o segundo deriva de estudos empíricos com variações do jogo do ultimato, os quais indicam que em determinadas circunstâncias os jogadores, quando motivados por sentimentos de raiva ou desgosto, poderiam colocar tudo a perder, ainda que esta não fosse a alternativa mais racional. ${ }^{716}$ No caso da corrupção, Lambsdorff sugere que um fator determinante para as denúncias é a reciprocidade negativa (negative reciprocity): um participante, desapontado por algum motivo, pode retaliar denunciando os demais, por vingança $^{717}$. Dessa perspectiva, o processo regulatório habilita o agente envolvido na repressão à corrupção a decidir seu plano de ação levando em consideração a ampla gama de cenários em que ocorrem as ações na esfera privada.

A segunda premissa da regulação responsiva é o uso das pirâmides de coação. $\mathrm{O}$ primeiro tipo de pirâmide é formado por camadas de sanções desde as menos severas até as mais severas, isto é, desde meras notificações até a prisão. A cooperação entre o implementador de política pública e aquele que deve obedecer a ela, entre o regulador e o regulado ou, em sentido lato, entre a esfera pública e a privada será mais facilmente alcançada quando o primeiro puder incrementar as sanções como resposta à resistência do segundo. A tática é adaptar-se do consentimento para a restrição e, quando esta falhar, para a

\footnotetext{
$\overline{716}$ ABBINK, K. Staff rotation as an anti-corruption policy: an experimental study. European Journal of Political Economy, v. 20, n. 4, p. 887-906, 2004. ABBINK, K. An experimental bribery game. Journal of Law, Economics and Organization, v. 18, n. 2, 2002, p. 428-454. ANDVIG, J. (2005), Experimental economics and corruption: survey of budding research. In: Global Corruption Report. Berlim: Transparency International, 2005. p. 265-267. Para uma síntese dos recentes estudos de "neuroeconomia" ligados ao jogo do ultimato, ver: STANTON, Angela A. Evolving economics: synthesis. MPRA Paper n. 767, posted 7. Nov. 2007. Disponível em: http://mpra.ub.uni-muenchen.de/767/. Acesso em: 10 jan. 2010, às 01:20.

${ }^{717}$ LAMBSDORFF, Johann Graf; FRANK, Björn. Corrupt reciprocity: an experiment. Working Paper. Sept. 2007. Disponível em: <http://www.wiwi.unipassau.de/fileadmin/dokumente/lehrstuehle/lambsdorff/downloads/Disc_Corrupt_Reciprocity.pdf>. Acesso em: 10 jan. 2010 às 13 h10.
} 
incapacitação. ${ }^{718}$ Além disso, a pirâmide deve ter um vasto conjunto de sanções, para que cada violação não seja excessiva nem insuficientemente punida.

A outra pirâmide consiste em camadas de estratégias que contenham desde as menos intervencionistas às mais intervencionistas, ou seja, da autorregulação a regras de comando e controle. Essa organização precisa ser flexível - deve-se ter poderes para agir de acordo com as prescrições do "olho por olho" e do "vingativo olho por olho", para que ele possa aprender o nível apropriado de sanções e intervenção ao longo do tempo. ${ }^{719}$

Quanto maior poder persuasório estiver disponível, tanto maior será a credibilidade da política pública para falar convincentemente e tanto menor será a necessidade de usar seus poderes dissuasórios. Consequentemente, pode-se conversar de modo maleável com aqueles a quem se pretende induzir certos comportamentos. ${ }^{720}$ A existência de “superpunições” pode, inclusive, produzir cooperação dos regulados. Baseados nessa teoria, Aires e Braithwaite forjaram a expressão "grande arma benigna" (benign big gun).

Como parte da estratégia, a imagem da invencibilidade do agente público não deve ser esquecida. A sua reputação pode determinar o comportamento dos regulados: se o agente público sempre perde seus casos nos tribunais, haverá um incentivo para que os regulados se recusem a cumprir qualquer decisão adversa sobre seus interesses. Além disso, as punições devem ser usadas dentro de seus próprios critérios, para que a vontade de cooperar seja mantida. $^{721}$

Entre as aproximações responsivas alternativas às regras de comando e controle, a "grande arma benigna" pretende fornecer uma diretriz abrangente para que se obtenha a obediência dos destinatários. Apesar de ser inicialmente admitido apenas como tipologia, ${ }^{722}$ o conceito desenvolveu-se em instruções a serem seguidas pelos agentes públicos, tomados em sentido amplo, que desejassem maximizar seus resultados. ${ }^{723}$

Um exemplo de como a "grande arma benigna" pode funcionar é a regulação do setor nuclear nos Estados Unidos. O Institute of Nuclear Power Operations (INPO) é um

\footnotetext{
$\overline{718}$ PARKER, C. BRAITHWAITE; J. STEPANENKO, N. ACCC Enforcement and Compliance Project: report on ACCC Compliance Education and Liaison Strategies. Canberra: Australian National University, 2004. p. 3. ${ }^{719}$ AYRES, I.; BRAITHWAITE, J. Op. cit.. p. 39-40.

${ }^{720}$ Idem, p. 19.

${ }^{721}$ Idem, p. 44-49.

${ }^{722}$ BRAITHWAITE, J.; GRABOSKY, P. Of manners gentle: enforcement strategies of Australian business regulatory agencies. Melbourne: Oxford University Press, 1986. p. 222.

${ }^{723}$ PARKER, C.; BRAITHWAITE, J.; STEPANENKO, N. ACCC Enforcement and Project: report on ACCC compliance education and liaison strategies. Canberra: Centre for Competition and Consumer Policy, RegNet e Australian National University, 2004, p. 12. Disponível em: $<$ http://www.cccp.anu.edu.au/projects/compliancereportapril2004.pdf>. Acesso em: 24 ago. 2009 às 20 h30.
} 
ente autorregulatório da indústria, encarregado de monitorar os próprios critérios de segurança, desenvolvendo sua tarefa primeiramente de maneira cordial, mediante a persuasão das empresas para que as mesmas atendam aos critérios sugeridos. Se o INPO não convencer uma usina nuclear, o discurso se endurece progressivamente até que se recorre, em última instância, ao encaminhamento do caso ao ente regulador estatal, a Nuclear Regulatory Commission, o "gorila regulatório" (regulatory gorilla) que reforça as regulações. ${ }^{724}$ Note-se que há uma escala tanto na pirâmide de sanções disponíveis quanto na pirâmide de estratégias seguidas.

\subsection{Alguns aspectos da aplicação da teoria da regulação responsiva no combate à corrupção no Brasil}

Em linhas gerais, as considerações anteriores explicam como se dá o funcionamento da regulação responsiva. Enquanto modelo teórico, a regulação responsiva não pode ser sempre aplicada na íntegra para todos os setores das atividades desempenhadas no espaço público - o modus operandi se volta mais para setores regulados, e, à medida que o escopo da aplicação se expande, torna-se difícil encaixá-la em contextos mais amplos.

Entretanto, as diretrizes e linhas gerais permanecem aplicáveis com os princípios de orientação de ação para os formuladores e implementadores de políticas públicas. A ausência de um fator ou outro, ainda que possa comprometer parcialmente a eficácia, deve ser vista como acrescentadora de resultados à estratégia baseada unicamente nas regras de comando e controle.

Mais interessante do que saber da sua aplicação fragmentária é conhecer os variados instrumentos que, presentes no ordenamento jurídico brasileiro, possibilitam sua aplicação parcial. Desmentindo a crença de que os direitos de tradição romano-germânica são ineficientes e inflexíveis por definição, uma análise diferenciada de certas regras sugere que talvez seja o modo de aplicar o direito à realidade que resulte nessa condição. ${ }^{725}$ Dessa

\footnotetext{
${ }_{724}$ REES, J. The development of communitarian regulation in the chemical industry. Law and policy, Hoboken: Blackwell Publishing, v. 19, n. 4, p. 514-519, Oct. 1997.

${ }^{725}$ ROSA, Christian Fernandes. Eficiência como axioma da teoria econômica do direito. 2008. $108 \mathrm{f}$. Dissertação (Mestrado em Filosofia do Direito)-Faculdade de Direito, Universidade de São Paulo, São Paulo. p. 75-76. Essa também é a conclusão de Rosa, para quem “[...] menos do que a adoção por um ou outro sistema jurídico, é todo o cenário institucional - sócio-econômico e cultural - que prepondera no estabelecimento de circunstâncias em que o desenvolvimento econômico é facilitado. Por tal razão, há estados de tradição consuetudinária que não puderam consolidar instituições nem criar os pressupostos mínimos para o desenvolvimento sustentado de suas economias; a mera adoção da Common Law pouco lhes foi favorável”.
} 
maneira, serão tratados alguns aspectos da teoria da regulação responsiva que teriam a capacidade de incrementar a ação estatal no combate à corrupção, notadamente a "grande arma benigna" e a possibilidade de cooperação com as autoridades anticorrupção, a compreensão da motivação dos agentes e a reputação de invencibilidade no contexto de impunidade.

\subsubsection{A benign big gun e a possibilidade de cooperação com as autoridades de combate à corrupção}

A ideia da "grande arma benigna" se coaduna com o modo como o ordenamento repressivo jurídico induz aos comportamentos. ${ }^{726}$ Logo, deve-se esperar encontrar essas condições no direito brasileiro.

A disponibilidade de um amplo leque de sanções está presente no combate à corrupção no Brasil: perda de cargo, indenização pelos prejuízos causados ao erário e a pena privativa de liberdade constam do rol de consequências jurídicas à disposição das autoridades públicas. Tome-se como pano de fundo para a análise o caso das penas impostas pelo direito penal.

Do ponto de vista da "grande arma benigna", que pressupõe uma gradação das penas, não parece haver problema nas penas em abstrato impostas aos crimes relacionadas às práticas corruptas. A Tabela 8 apresenta as penas cominadas aos tipos básicos de corrupção, ao passo que a Tabela 9 resume as penas aplicáveis aos mesmos delitos em algumas jurisdições, em algumas das quais a incidência da corrupção é reconhecidamente baixa.

Os dados da Tabela 8 revelam que os crimes cometidos contra a administração pública possuem penas proporcionalmente maiores do que aqueles cometidos contra o patrimônio dos particulares. Logo, não haveria espaço para a crítica de que, no sistema criminal brasileiro, os crimes contra o patrimônio seriam apenados mais seriamente do que os crimes contra a administração pública. Pelo contrário, as ações que envolvem dano ao erário são mais duramente punidas do que as que prejudicam os particulares - veja-se o peculato, espécie de apropriação indébita especial feita pelo agente público à custa do Estado, apenada mais gravemente do que a mera apropriação indébita, simples ou previdenciária, cometida em detrimento de um particular.

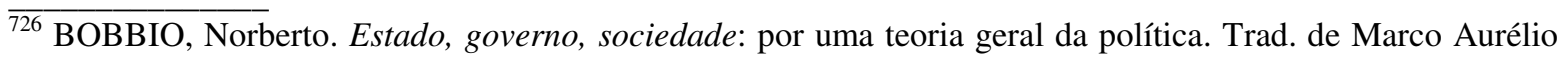
Nogueira. Rio de Janeiro: Paz e Terra, 1987. p. 15. "Para atingir o fim próprio, um ordenamento repressivo efetua operações de três tipos e graus, uma vez que existem três modos típicos de impedir uma ação não desejada: torná-la impossível, torná-la difícil ou torná-la desvantajosa. De modo simétrico, pode-se afirmar que um ordenamento promocional busca atingir o próprio fim pelas três operações contrárias, isto é, buscando tornar a ação desejada necessária, fácil e vantajosa.”
} 
Tabela 8 - Penas de alguns crimes no Código Penal Brasileiro

\begin{tabular}{|c|c|c|c|c|c|}
\hline Corrupção & Pena & $\begin{array}{l}\text { Outros } \\
\text { crimes }\end{array}$ & Pena & $\begin{array}{l}\text { Outros } \\
\text { crimes }\end{array}$ & Pena \\
\hline $\begin{array}{l}\text { Peculato } \\
\text { (art. 312) }\end{array}$ & $\begin{array}{c}\text { Reclusão } \\
\text { (2 a } 12 \text { anos) } \\
\text { e multa }\end{array}$ & $\begin{array}{c}\text { Furto simples } \\
(\text { art. 155) }\end{array}$ & $\begin{array}{c}\text { Reclusão } \\
\text { (1 a } 4 \text { anos) } \\
\text { e multa }\end{array}$ & $\begin{array}{l}\text { Extorsão } \\
\text { (art. 158) }\end{array}$ & $\begin{array}{c}\text { Reclusão } \\
\text { (4 a } 10 \text { anos) } \\
\text { e multa }\end{array}$ \\
\hline $\begin{array}{l}\text { Concussão } \\
\text { (art. 316) }\end{array}$ & $\begin{array}{c}\text { Reclusão } \\
\text { (2 a } 8 \text { anos) } \\
\text { e multa }\end{array}$ & $\begin{array}{c}\text { Furto } \\
\text { qualificado } \\
\left(\text { art. 155, } \$ 4^{\circ}\right)\end{array}$ & $\begin{array}{c}\text { Reclusão } \\
\text { (1 a } 4 \text { anos) } \\
\text { e multa }\end{array}$ & $\begin{array}{l}\text { Apropriação } \\
\text { indébita } \\
\text { (art. 168) }\end{array}$ & $\begin{array}{c}\text { Reclusão } \\
\text { (1 a } 4 \text { anos) } \\
\text { e multa }\end{array}$ \\
\hline $\begin{array}{c}\text { Corrupção } \\
\text { passiva } \\
\text { (art. 317) }\end{array}$ & $\begin{array}{c}\text { Reclusão } \\
\text { (2 a } 12 \text { anos) } \\
\text { e multa }\end{array}$ & $\begin{array}{c}\text { Furto de } \\
\text { veículo levado } \\
\text { a outro estado } \\
\text { ou exterior } \\
\left(\text { art. } 155, \S 5^{\circ}\right)\end{array}$ & $\begin{array}{l}\text { Reclusão } \\
\text { (3 a } 8 \text { anos) }\end{array}$ & $\begin{array}{c}\text { Apropriação } \\
\text { indébita } \\
\text { previdenciária } \\
\text { (art. 168-A) }\end{array}$ & $\begin{array}{c}\text { Reclusão } \\
\text { (2 a } 5 \text { anos) } \\
\text { e multa }\end{array}$ \\
\hline $\begin{array}{c}\text { Corrupção } \\
\text { ativa } \\
\text { (art. 333) }\end{array}$ & $\begin{array}{c}\text { Reclusão } \\
\text { (2 a } 12 \text { anos) } \\
\text { e multa }\end{array}$ & $\begin{array}{c}\text { Roubo } \\
\text { (art. 157) }\end{array}$ & $\begin{array}{c}\text { Reclusão } \\
\text { (4 a } 10 \text { anos) } \\
\text { e multa }\end{array}$ & $\begin{array}{c}\text { Homicídio } \\
\text { simples } \\
\text { (art. 121) }\end{array}$ & $\begin{array}{c}\text { Reclusão } \\
\text { (6 a } 20 \text { anos) }\end{array}$ \\
\hline
\end{tabular}

Fonte: Código Penal.

Ao se analisar as informações da Tabela 9, constata-se que o direito penal brasileiro possui penas que, em tese, são tão ou mais severas do que as de outros países com níveis de corrupção menor. A China, onde as várias formas de corrupção podem ser apenadas até mesmo com a morte do infrator, e o Brasil possuem penas em abstrato mais elevadas e, simultaneamente, piores colocações no ranking de percepção de corrupção preparado pela Transparência Internacional, se comparados à Suécia e à Finlândia. Certamente a mera observação dessa realidade necessita ser comprovada e testada por estudos econométricos, mas esse traço é bastante interessante, sugerindo que talvez a pena em abstrato não seja tão determinante da dissuasão efetiva. Por outro lado, baseados nas condenações feitas nos Estados Unidos nos níveis municipal, estadual e federal no período entre 1970 e 1983, Goel e Rich sustentam que, nas jurisdições em que a severidade da punição penal em concreto é maior, há menor incidência de práticas corruptas. ${ }^{727}$

$\overline{727}$ GOEL, Rajeev K.; RICH, Daniel P. On the economic incentives for taking bribes. Public Choice,Amsterdam, n. 61, p. 269-275, jun. 1989 
Tabela 9 - Sanções criminais para concussão, corrupção passiva e corrupção ativa em algumas jurisdições

\begin{tabular}{|c|c|c|c|}
\hline Jurisdição & $\begin{array}{l}\text { Concussão } \\
\text { (art. 316) }\end{array}$ & $\begin{array}{c}\text { Corrupção passiva } \\
\text { (art. 317) }\end{array}$ & $\begin{array}{l}\text { Corrupção ativa } \\
\text { (art. 333) }\end{array}$ \\
\hline Alemanha & & $\begin{array}{c}\text { Prisão } \\
\text { (6 meses a } 5 \text { anos) } \\
\text { Em casos menos graves, } \\
\text { prisão (máximo: } 3 \text { anos) } \\
\text { ou multa }\end{array}$ & $\begin{array}{c}\text { Prisão } \\
\text { (3 meses a } 3 \text { anos) } \\
\text { Em casos menos graves, } \\
\text { prisão (máximo: } 2 \text { anos) } \\
\text { ou multa }\end{array}$ \\
\hline Argentina & & \multicolumn{2}{|c|}{ Prisão (1 a 6 anos) } \\
\hline Brasil & $\begin{array}{l}\text { Prisão (2 a } 8 \text { anos) } \\
\quad \text { e multa }\end{array}$ & \multicolumn{2}{|c|}{$\begin{array}{l}\text { Prisão (2 a } 12 \text { anos) } \\
\text { e multa }\end{array}$} \\
\hline Dinamarca & \multicolumn{2}{|c|}{ Multa ou prisão por não mais do que 6 anos } & $\begin{array}{l}\text { Multa ou prisão por não } \\
\text { mais do que } 3 \text { anos }\end{array}$ \\
\hline EUA & \multicolumn{3}{|c|}{$\begin{array}{l}\text { Multa de não mais do que } 3 \text { vezes o valor monetário do objeto do crime ou prisão (até } \\
15 \text { anos), ou ambos. O condenado também fica proibido de exercer qualquer cargo de } \\
\text { direção, de confiança ou negociar nos Estados Unidos }\end{array}$} \\
\hline Finlândia & \multicolumn{3}{|c|}{ Multa ou prisão (máximo: 2 anos) } \\
\hline França & & \multicolumn{2}{|c|}{ Prisão (até 5 anos) e multa de até $€ 75.000$} \\
\hline Holanda & & \multicolumn{2}{|c|}{ Prisão (2 a 6 anos) } \\
\hline Luxemburgo & \multicolumn{3}{|c|}{ Prisão (5 a 10 anos) e multa de $€ 500$ a $€ 187.500$} \\
\hline Suíça & & \multicolumn{2}{|c|}{$\begin{array}{c}\text { Prisão (até } 5 \text { anos) ou multa de até } 360 \text { dias de trabalho } \\
\text { no valor máximo de CHF } 3.000 \text { por dia }\end{array}$} \\
\hline Reino Unido & & \multicolumn{2}{|c|}{$\begin{array}{l}\text { Prisão temporária (até } 6 \text { meses), ou multa que não } \\
\text { exceda o máximo legal, ou ambos. Prisão, no } \\
\text { julgamento final, (até } 7 \text { anos) ou multa, ou ambos }\end{array}$} \\
\hline
\end{tabular}

Fonte: Elaboração própria a partir de dados consolidados em BORSODI, Benjamin; FORKMAN, Anders. Is corruption still the second oldest business in the world? Joint report of the Commercial Fraud, International Business, Banking, Finance \& Securities Law, Future of the Profession and Corporate Counsel Commissions (WS07 General Report) of the Association Internationale des Jeunes Avocat. Paris, 31 May 2008.

Ainda que a tese das superpunições efetivamente apresente eficácia limitada no combate à corrupção, o que ainda precisa ser comprovado por mais estudos, faltaria ao Brasil instrumentos que permitissem a colaboração entre o infrator e o responsável pela punição. Constatada a prática corrupta, uma série de instituições iniciaria seus 
procedimentos repressivos quase que simultaneamente, ${ }^{728}$ e não haveria como coordenar a ação entre os diversos agentes em virtude da ausência de um sistema ou uma política nacional de combate à corrupção bem articulados. Na hipótese de todos os procedimentos redundarem em punição em tempo hábil, existe o risco de se estar talvez diante de um excesso de repressão. $\mathrm{Na}$ análise responsiva, esse cenário seria indesejável, na medida em que limita o campo de cooperação do investigado com a autoridade - ainda que o direito processual penal apresente alguns mecanismos limitados de composição, o mesmo não se verifica em outras esferas, como a administrativa. Aliás, nesta, o diálogo com o infrator é até mais desejável, uma vez que poderia contribuir para a reparação dos danos causados ao patrimônio público, auxiliando, por exemplo, na localização dos ativos remetidos ao exterior.

Além disso, a colaboração deve ser cuidadosamente ponderada, a fim de evitar que seja afetado negativamente o objetivo da apresentação espontânea do criminoso, que, no caso brasileiro, se consubstancia na delação premiada. Esta apresenta aspectos positivos e negativos, ${ }^{729}$ tendo-se revelado como um instrumento necessário no combate à criminalidade. Tanto isso é verdade que vários diplomas criminais a preveem explicitamente. ${ }^{730}$ Entretanto, as normas mais plausíveis de serem utilizadas pelo Ministério

\footnotetext{
$\overline{728}$ Estes agentes podem ser considerados parte do sistema nacional de combate à corrupção. Ainda que desarticulados, sua maior coordenação é possível e desejável. Por esse motivo, esta tese irá agrupá-los genericamente sob o rótulo de autoridades responsáveis pelo combate à corrupção ou autoridades anticorrupção.

${ }^{729}$ BECCARIA, Cesare. Dos delitos e das penas. Trad. de J. Cretella Jr. e Agnes Cretella. 3. ed. rev. São Paulo: Revista dos Tribunais, 2006. p. 101. "Alguns tribunais oferecem a impunidade ao cúmplice de grave delito que delatasse os companheiros. Tal expediente tem inconvenientes e vantagens. Os inconvenientes são que a nação estaria autorizando a delação, detestável mesmo entre criminosos, porque são menos fatais os delitos de coragem do que os de vilania: porque o primeiro não é freqüente, já que só espera uma força benéfica e motriz que os faça conspirar contra o bem público, enquanto a segunda é mais comum e contagiosa, e sempre se concentra mais em si mesma. Além disso, o tribunal mostra a própria incerteza, a fraqueza da lei, que implora ajuda de quem a infringe. As vantagens consistem na prevenção dos delitos relevantes, que, por terem efeitos evidentes e autores ocultos, atemorizam o povo. Além disso, contribui para mostrar que quem não tem fé nas leis, isto é, no poder público, é provável que também não confie no particular. Parece-me que a lei geral, que prometesse impunidade ao cúmplice delator de qualquer delito, seria preferível a uma declaração especial em caso particular, porque assim preveniria as uniões pelo temor recíproco que cada cúmplice teria de expor-se ao tribunal não tornaria audaciosos os criminosos a prestar socorro num caso particular."

${ }^{730}$ Uma série de dispositivos na legislação penal prevê a delação premiada: (i) o $§ 4^{\circ}$ do art. 159 do Código Penal para os crimes de extorsão mediante sequestro ("Se o crime é cometido em concurso, o concorrente que o denunciar à autoridade, facilitando a libertação do sequiestrado, terá sua pena reduzida de um a dois terços."); (ii) o $§$ único do art. 16 da Lei $\mathrm{n}^{\mathrm{0}}$ 8.137, de 27 de dezembro de 1990 ("Nos crimes previstos nesta Lei, cometidos em quadrilha ou co-autoria, o co-autor ou partícipe que através de confissão espontânea revelar à autoridade policial ou judicial toda a trama delituosa terá a sua pena reduzida de um a dois terços.”); (iii) o $\S$ único do art. 8 da Lei $\mathrm{n}^{\mathrm{o}}$ 8.072, de 25 de julho de 1990 ("O participante e o associado que denunciar à autoridade o bando ou quadrilha, possibilitando seu desmantelamento, terá a pena reduzida de um a dois terços."); (iv) o art. 14 da Lei n ${ }^{\circ}$ 9.807, de 13 de julho de 1999 (“O indiciado ou acusado que colaborar voluntariamente com a investigação policial e o processo criminal na identificação dos demais co-autores ou partícipes do crime, na localização da vítima com vida e na recuperação total ou parcial do produto do crime,
} 
Público em casos de corrupção são a Lei $\mathrm{n}^{0}$ 9.034/95, que trata do crime organizado, ${ }^{731}$ e a Lei $\mathrm{n}^{\mathrm{o}}$ 9.613/98, que trata da lavagem de dinheiro. ${ }^{732}$ Caso os jogadores corruptos predispostos a optar por delação premiada considerem que os custos seriam elevados e a colaboração resultaria em condições desfavoráveis, os efeitos da política de estímulo à apresentação espontânea seriam substancialmente subvertidos, o que levaria poucos infratores a procurar esses benefícios. De fato, essa situação parece ocorrer no Brasil, onde, em alguns dos casos, infratores preferem contatar a mídia ao Ministério Público. Jogadores corruptos dispostos a buscar o benefício da delação premiada não teriam incentivos suficientes para fazê-lo, aumentando as vantagens de continuarem com as práticas corruptas. Mais uma vez, a manipulação perfeita dessas condições depende de uma série de fatores ligados à capacidade institucional de cada jurisdição em manipular os instrumentos jurídicos à disposição.

Sob a ótica da pirâmide de coação, a mudança no funcionamento das regras sancionatórias não deveria ocorrer no quantum, mas sim no modus operandi. À já referida desarticulação dos diversos entes incumbidos do combate à corrupção se adicionaria a impossibilidade de as sanções por práticas corruptas serem articuladas para garantir cooperação mais atuante dos investigados. Essas observações conduzem à inquirição sobre a compreensão motivacional dos agentes corruptos, pois o conhecimento de tais motivos ajudaria a desenhar a reação dos envolvidos e, assim, possibilitar uma resposta mais adequada das autoridades.

\subsubsection{A compreensão das possíveis motivações dos agentes corruptos}

Outro aspecto envolvido na teoria da regulação responsiva diz respeito ao que motiva os corruptos e corruptores a agir. É a percepção individual dos riscos e as motivações

no caso de condenação, terá pena reduzida de um a dois terços.”); (v) o $§ 5^{\circ}$ do art. $1^{\text {o }}$ da Lei no 9.613 , de 3 de março de 1998 (“A pena será reduzida de um a dois terços e começará a ser cumprida em regime aberto, podendo o juiz deixar de aplicá-la ou substituí-la por pena restritiva de direitos, se o autor, co-autor ou partícipe colaborar espontaneamente com as autoridades, prestando esclarecimentos que conduzam à apuração das infrações penais e de sua autoria ou à localização dos bens, direitos ou valores objeto do crime.”); (vi) o art. 41 da Lei $\mathrm{n}^{\mathrm{o}}$ 11.343, de 23 de agosto de 2006 ("O indiciado ou acusado que colaborar voluntariamente com a investigação policial e o processo criminal na identificação dos demais co-autores ou partícipes do crime e na recuperação total ou parcial do produto do crime, no caso de condenação, terá pena reduzida de um terço a dois terços."); e (vii) art. $6^{\circ}$ da Lei n⿳ ${ }^{\circ}$ 9.034, de 3 de maio de 1995 ("Nos crimes praticados em organização criminosa, a pena será reduzida de um a dois terços, quando a colaboração espontânea do agente levar ao esclarecimento de infrações penais e sua autoria.").

${ }^{731}$ BRASIL. Lei n. 9.034, de 3 de maio de 1995.

${ }^{732}$ BRASIL. Lei n. 9.613, de 3 de março de 1998. 
de cada jogador que induz um jogador racional econômico a como se comportar quando se trata de se corromper. Com base nesse conhecimento, seria possível adaptar responsivamente a ação anticorrupção a cada motivação e, com isso, forçar os agentes corruptos a redefinir suas estratégias. $\mathrm{O}$ foco é aumentar a eficiência da ação anticorrupção, o que poderia dar margem à crítica de que se ignora o dano público causado pelo infrator. ${ }^{733}$

De acordo com a regulação responsiva, um dos fatores que contribuem para o sucesso de uma política de combate à corrupção depende da identificação adequada da motivação por trás de cada agente. No raciocínio típico da teoria dos jogos, as autoridades envolvidas no combate à corrupção devem indagar a razão do comportamento corrupto de alguns para reagir melhor e para atuar sobre as causas. Conforme conclusões de Sutherland, os criminosos de colarinho branco agem de modo semelhante aos criminosos comuns. $\mathrm{Na}$ síntese de Shecaira, Sutherland

[...] observou, ainda, que, quando os representantes dessas corporações queriam se encontrar para suas decisões, procuravam sempre hotéis de província e usavam um jargão específico que não pudesse ser identificado por aqueles que não pertencessem àquela esfera de produção. Assim, ao invés de falarem em lista de preços, utilizavam expressões como "lista de natal". Telefonavam-se através de telefones públicos, registravam-se em hotéis não indicando as companhias por ele representadas etc. Sutherland considerou todas essas atitudes como similares às dos chamados criminosos convencionais, ainda que não tivessem todas aquelas características. $^{734}$

No cenário, em que inexiste possibilidade de alterar as regras do jogo por meio de reforma institucional ou de uma colaboração com os infratores, as expectativas dos agentes corruptos podem ser resumidas na Tabela 10.

Tabela 10 - Possíveis consequiências para as práticas corruptas

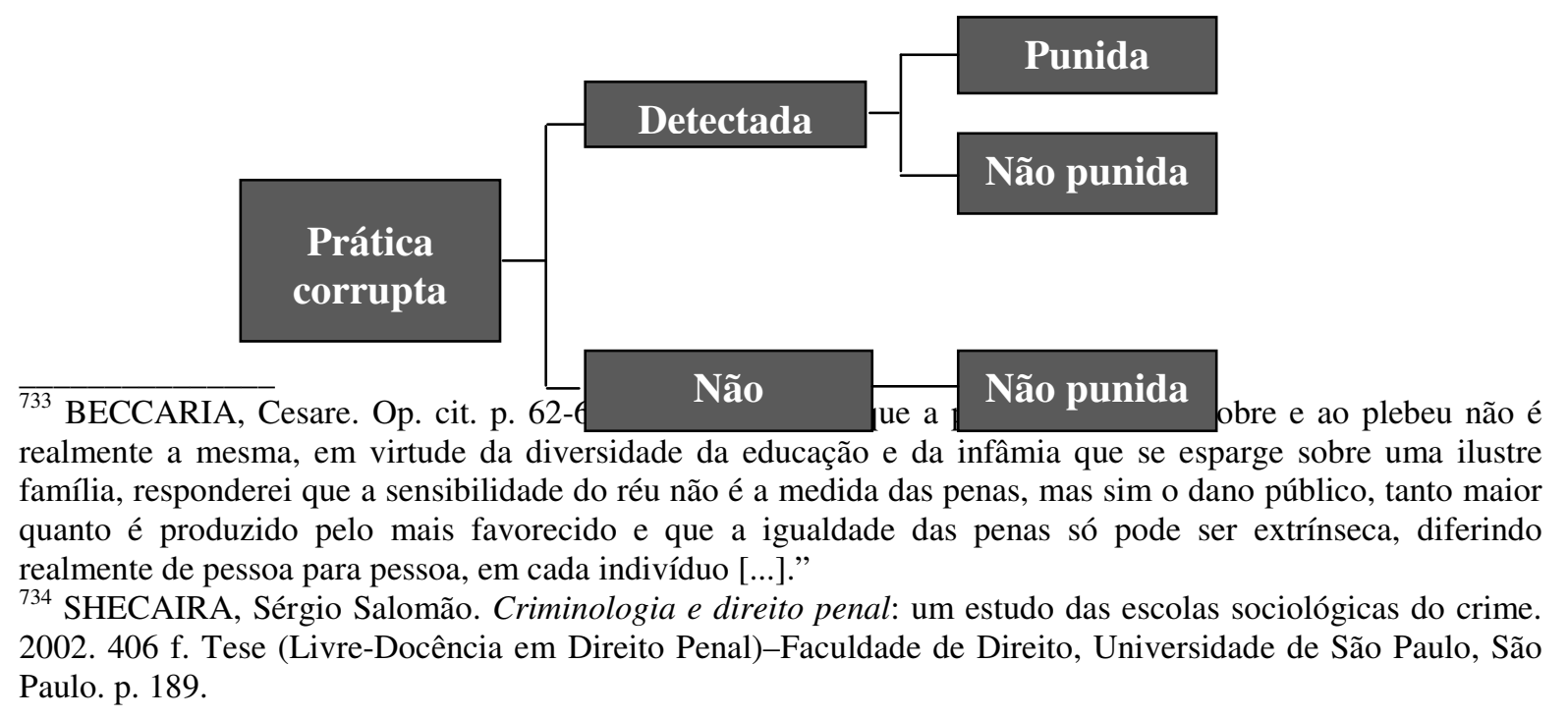


Fonte: Elaboração própria.

Agentes corruptos, quer atuem na esfera pública ou na privada, correm o risco de ser detectados pelas autoridades responsáveis pela repressão à corrupção. Se não houver detecção, a corrupção permanecerá impune e lucrativa. Com certeza, esse é o pior cenário para o combate à corrupção e, por essa razão, as autoridades anticorrupção sempre tentam aumentar a probabilidade de detecção. Se forem bem-sucedidas nessa tarefa, as autoridades anticorrupção aumentarão o custo de uma prática corrupta, desestimulando a decisão sobre a sua consumação. Em outras palavras, aumentando a possibilidade de detecção e, consequentemente, a punição da corrupção sem uma variação compensatória em face de benefícios a alcançar, potenciais jogadores corruptos hesitariam em continuar com a corrupção.

Contudo, a detecção da corrupção não significa necessariamente que ela será punida, embora essa situação já apresente certos custos para os agentes corruptos, especialmente os danos associados à imagem, sérios tanto para políticos quanto para empresas, e as despesas com a defesa jurídica. A falta de punição pode resultar de várias razões (prazo de prescrição, erros procedimentais, incompetência na obtenção de provas pela polícia judiciária, do TCU e das autoridades administrativas, entre outras.). Mesmo se os corruptos forem punidos, a punição pode ser inferior aos benefícios obtidos, o que seria desprovido de efeito dissuasivo sobre o comportamento dos potenciais jogadores corruptos afinal, se os jogadores corruptos forem detectados (o que nem sempre é certo), eles podem manter parte dos benefícios obtidos pela lavagem de dinheiro, por exemplo.

O raciocínio que gira em torno do comportamento esperado se baseia no comportamento de ambos os jogadores corruptos, sejam eles das esferas pública ou privada, e autoridades anticorrupção. De acordo com a teoria dos jogos, normalmente se utilizam os parâmetros do agente maximizador dos resultados, comportamento em que se admite um modelo de ação racional, desde que todos os agentes (i) tentem maximizar a satisfação dos seus interesses e (ii) sejam completamente amorais e neutros em matéria de julgamentos morais. ${ }^{735}$ Esses pressupostos, simplificadores da realidade, são úteis na medida em que a análise econômica precisa estabelecer um padrão específico de comportamento para prever resultados e chegar a determinadas conclusões.

\footnotetext{
$\overline{735}$ WILLIAMSON , Oliver E. The economic institutions of capitalism. Nova York: Free Press, 1985. p. $43-67$.
} 
Por outro lado, quando a análise visa somente estudar iniciativas concretas empreendidas pelos agentes (nesse caso, agentes corruptos), estes nem sempre agem apenas com base no interesse esperado pela teoria dos jogos. Esse viés, frequentemente negligenciado nas análises pelos economistas, tem fundamento na realidade, uma vez que as premissas sobre uma racionalidade econômica generalizada nem sempre são reais, tanto no que respeita aos agentes corruptos como às autoridades anticorrupção: aqueles podem agir sem pensar a respeito de seus ganhos, ao passo que estas podem se afastar do meticuloso planejamento prévio para responder aos apelos midiáticos. Nesse sentido, deve-se levar em conta o papel das várias motivações dos agentes econômicos, pois ponderações sobre o ponto de vista de outros padrões de comportamento humano, que não sejam as normas de um agente maximizador de resultados, não atraíram muita atenção da teoria econômica. ${ }^{736} \mathrm{~A}$ propósito, o contato frequente do operador do direito com os infratores lhe possibilita contribuir para essa discussão mediante a identificação do modus operandi dos agentes corruptos.

Arriscando uma simplificação, Kagan e Scholz identificam pelo menos três protótipos básicos de motivações, a saber, o calculador amoral, o cidadão político e o organizacionalmente incompetente. ${ }^{737} \mathrm{Um}$ quarto protótipo, o infrator irracional, pode ser adicionado a esses. ${ }^{738}$ A exposição que se segue se baseia nas análises e raciocínios contidos nesses textos, aos quais se adicionam considerações próprias sobre as práticas corruptas.

Tabela 11 - Protótipos de comportamento dos agentes econômicos

\begin{tabular}{|c|c|c|}
\cline { 2 - 3 } \multicolumn{1}{c|}{} & Mal-intencionado & Bem-intencionado \\
\hline Mal-informado & Infrator irracional & Oganizacionalmente incompetente \\
\hline Bem-informado & Calculador amoral & Cidadão político \\
\hline
\end{tabular}

Fonte: BALDWIN, Robert. Rules and regulation. Oxford: Oxford University Press, 1995. p. 148-152.

\footnotetext{
$\overline{736}$ Esse alerta já foi feito nos anos 1920 por MARSHALL, A. Principles of economics. 2. ed. Londres: Macmillan, 1920. p. 3. "But ethical forces are among those of which the economist has to take account. Attempts have indeed been made to construct an abstract science with regard to the actions of an 'economic man', who is under no ethical influences and who pursues pecuniary gain warily and energetically, but mechanically and selfishly. But they have not been successful, nor even thoroughly carried out." Atualmente, tem havido uma crescente preocupação com essa omissão.

737 KAGAN, R. A.; SCHOLZ, J. T. The criminology of the corporation and the regulatory enforcement strategies. In: HAWKINS, K.; THOMAS, J. M. Enforcing regulation. Boston: Kluwer-Nijhoff, 1984. p. 6768.

${ }^{738}$ BALDWIN, Robert. Rules and regulation. Oxford: Oxford University Press, 1995. p. 149.
} 


\subsubsection{Calculador amoral}

$\mathrm{O}$ agente mal-intencionado e bem-informado pode ser denominado calculador amoral. Como ele compreende os incentivos e reage a eles mais rapidamente, é apto para jogar o tit-for-tat (TFT) - jogo caracterizado por situações possibilitadoras de infinitas repetições, em que os agentes decidem cooperar desde o primeiro instante e, na hipótese de traição, a represália tende a ser de força igual e proporcional, restabelecendo-se, em seguida, a estratégia cooperativa. ${ }^{739}$

No entanto, o calculador amoral aparenta ser mais uma ameaça, pois pode se comportar de modo oportunista sempre que identificar uma oportunidade de ganhar uma vantagem sem que exista um risco correspondente de punição - o calculador amoral tenta se aproveitar das autoridades repressoras da corrupção enquanto aparenta colaborar, com o intuito de manter a maior parte dos lucros auferidos pela corrupção. Para o calculador amoral, o acordo é apenas uma questão de análise custo-benefício, inexistindo preocupação efetiva com o cumprimento da lei.

A rigor, esse agente pode ser considerado o maximizador de resultados nos moldes dos pressupostos típicos da teoria econômica - grosso modo, o calculador amoral corresponde ao homo oeconomicus da economia clássica. Empresas e indivíduos que se comportam de forma aética, corruptos até o último momento, e, em seguida, procuram um acordo oportunista são um exemplo de calculador amoral, porque esse protótipo é capaz de avaliar cientificamente todos os riscos razoáveis decorrentes do descumprimento da lei. Em vista da existência de outros jogadores com diferentes motivações, é muito difícil para as autoridades repressoras identificar os calculadores amorais. Em certa medida, o calculador amoral pode até saber que não pagar propina resultaria numa melhor situação para todos, mas, como todos os jogadores lançam mão desse artifício, a corrupção torna-se a regra do jogo. ${ }^{740}$

\footnotetext{
$\overline{739}$ BAIRD, Douglas G.; GERTNER, Robert H.; PICKER, Randal C. Game theory and the law. Harvard: Harvard University Press, 1998. p. 316.

${ }^{740}$ ROSE-ACKERMAN, Susan. A economia política da corrupção. In: ELLIOT, Kimberly Ann (Org.). A corrupção e a economia global. Tradução de Marsel Nascimento Gonçalves de Souza. Brasília: UnB, 2002. p. 92. 'As multinacionais competentes se vêem diante do 'dilema do prisioneiro' quando executam suas transações em países de regime corrupto. Cada uma delas acredita que precisa pagar subornos para fazer negócios, mas cada uma sabe que todas estariam em melhor situação se nenhuma delas os pagasse. O tabuleiro pende a favor das empresas inescrupulosas, porém, menos competentes, que não teriam desempenho tão bom em um sistema honesto."
} 


\subsubsection{Cidadão político}

O agente bem-intencionado e bem-informado, descrito como cidadão político, cumpre a lei porque considera ser a coisa certa a fazer. Esse comportamento não significa exatamente renunciar ao próprio interesse: a maximização dos interesses só poderá ser considerada se estiver de acordo com as disposições legais. Assim, o cidadão político é indiferente aos riscos da detecção de seu comportamento ilegal, que nem sequer figura entre as suas opções de ação $a$ priori. Esse grupo pode ser identificado na direção de uma empresa ou gestão da administração pública que descobre a existência de práticas corruptas envolvendo alguns setores e informa as autoridades responsáveis sem necessariamente esperar nenhum tipo de benefício.

Para o cidadão político, a lei é a prioridade maior, mesmo que seja mais vantajoso não segui-la. Ele conhece as leis e pode gastar mais dinheiro seguindo-as do que violandoas, o bem-estar social é considerado por ele mais relevante do que o próprio interesse. Em princípio, essas empresas e agentes públicos dificilmente seriam réus em uma investigação de corrupção. Indiretamente, quanto maior a presença desse protótipo na sociedade, maior será o grau de confiança, o que redunda, também, numa menor incidência de corrupção.

No que tange à aplicação da regulação responsiva, deve-se ponderar sobre a conveniência de aplicar uma punição substancial para os cidadãos políticos. À semelhança do que se verifica com o calculador amoral, as autoridades anticorrupção têm dificuldades em identificar um cidadão político, mas o comportamento de um empresário investigado ou administrador público durante todo o processo poderia ser usado como circunstância atenuante: o colaborador poderia ser compensado de algum modo. Essa atenuante seria um incentivo à autodenúncia e à delação premiada, aumentando ainda mais o número de investigações iniciadas, ${ }^{741}$ bem como os custos para aqueles que consideram economicamente atrativa a saída pela corrupção. A humilhação pública perante os pares pode ser punição dura o bastante, desde que ressarcido o prejuízo ao erário. Lembre-se que,

\footnotetext{
${ }^{741}$ ALMEIDA, Fernando H. M. Dos crimes contra a administração pública. São Paulo: Saraiva, 1955. p. 49. Já em meados dos anos 1950, Almeida sugeria o uso de mecanismos assemelhados aos da delação premiada para os ilícitos relacionados ao orçamento público. "O verdadeiro seria que o legislador penal, de futuro, pusesse no artigo uma pena não optativa, mas, efetivamente, cumulativa e pesada. Assim, um mínimo de dois anos de detenção, para que os responsáveis pela execução fiel do orçamento começassem de temer pelos desmandos. Outrossim, seria preciso que qualquer pessoa (funcionário ou não) que soubesse do emprego irregular de verba ou renda pública fosse hábil a, mediante queixa, dirigir a juízo, sem qualquer prejuízo de sua situação pessoal, a exposição do fato delituoso."
} 
no Japão, a humilhação dos políticos corruptos e a reprovação ao comportamento social são tamanhas que, com frequência, levam o infrator a cometer suicídio.

\subsubsection{Organizacionalmente incompetente}

Por sua vez, o agente bem-intencionado e mal-informado, rotulado como organizacionalmente incompetente, necessita de uma abordagem educativa. Incluem-se nessa categoria empresas e órgãos públicos que não estão conscientes do fato de que alguns comportamentos se caracterizam como corrupção apesar de, em princípio, essa situação parecer estranha. Os organizacionalmente incompetentes não têm conhecimento das vedações legais e podem cometer atos de corrupção devido à falta de informação. Confusão sobre os contornos da dicotomia público-privado e desinformação sobre conflito de interesses $^{742}$ podem ser apontadas como situações enfrentadas pelos agentes organizacionalmente incompetentes que resultarão em corrupção. Nos anos 1940, Leal informava sobre um ato do então governador de Minas Gerais Milton Campos:

Teve grande divulgação o ato do Governador Milton Campos, chamando os exprefeitos de muitos municípios mineiros a regularizarem suas contas, onde se inscreviam grossas despesas eleitorais. Dizia a exposição do diretor do Departamento de Municipalidades: 'numerosos prefeitos já haviam perdido o senso da fazenda pública, confundindo-a com a fazenda particular, ou com a caixa do partido oficial'. Em folheto editado por aquela repartição, sob o título Regularização das Contas Municipais, vêm especificados os gastos suspeitos. ${ }^{743}$

Naquele momento, certamente muitos não viam nada de errado no uso do dinheiro público para fins privados - pelo contrário, até o utilizavam abertamente. Talvez nem sequer houvesse consciência de que havia uma finalidade na ação estatal. Do mesmo modo, a população pouco esperava da ação do Estado.

Muito se passou desde os eventos relatados por Leal: atualmente, a existência desse tipo de jogadores é incomum, e as alegações sobre o desconhecimento da lei devem ser vistas com cautela. Agentes de ex-países socialistas ou de países com um Estado patrimonialista como o Brasil podem não compreender perfeitamente a separação entre as esferas pública e privada por causa da mera falta de informação, embora a ignorância da lei

\footnotetext{
$\overline{742}$ SPECTOR, Bertram I. Fighting corruption. In: Fighting corruption in developing countries: strategies and analysis. Bloomsfield: Kumarian Press, 2005. p. 8.

${ }^{743}$ LEAL, Victor Nunes. Coronelismo, enxada e voto: o município e o regime representativo no Brasil. Nota do Prof. Basílio de Magalhães e prefácio de Barbosa Lima Sobrinho. 2. ed. São Paulo: Alfa-Ômega, 1975. p. 46.
} 
não seja justificativa para descumpri-la. Ainda que esteja impregnada de cinismo, no Brasil essa confusão pode aflorar em afirmações como "se não posso entregar um cargo de confiança a um parente, a quem eu poderia?" ou "não vi mal nenhum em meu cachorro usar o carro oficial para ir ao veterinário - afinal, se eu vou ao médico, por que ele não pode?”. Trata-se de cômoda forma que a autoridade investida de poder o enxerga: ignora-se que o poder existe para o desempenho de uma função, não para mera satisfação pessoal do detentor. ${ }^{744}$

Autoridades chinesas, que operam em uma economia em parte capitalista e em parte socialista, podem ficar confusas quanto ao que pertence ao público e ao privado, porque (i) até pouco tempo não havia nenhuma lei de propriedade privada e (ii) há forte interferência do Estado no sistema de mercado. Nesse contexto, pode-se atribuir parcialmente a incompetência organizacional a um regime que historicamente não reconhece ou explicita muito bem as fronteiras entre as esferas pública e privada. Não se pretende expurgar o princípio de que "não se pode alegar o desconhecimento da lei para não cumprila”, mas sim interpretá-lo de modo condizente com o contexto. ${ }^{745}$ Por essa razão, o combate à corrupção deve andar de mãos dadas com algum tipo de colaboração dos investigados, com garantia de adoção de medidas para evitar a reincidência, o que é mais importante do que a imposição de severas punições, sem prejuízo de reparar os danos causados.

\subsubsection{Infrator irracional}

Finalmente, o agente mal-intencionado e mal-informado, que pode ser rotulado de infrator irracional, exige medidas drásticas. Um agente público ou privado que ignora a separação entre o público e privado, mas que deseja violar a lei por prazer, se enquadra nessa categoria. É difícil imaginar um infrator irracional sinceramente imbuído da intenção

\footnotetext{
$\overline{744}$ Ver item 7.1, infra.

${ }^{745}$ Vide este julgado. BRASIL. Tribunal de Alçada Criminal do Estado de São Paulo. Acórdão unânime da $1^{\text {a }}$ Câmara Criminal na apelação criminal no 50.499. Relator: Juiz Toledo de Assumpção. Decisão em 14 set. 1972. In: RT 448/403. "Crime de responsabilidade - realização de despesas sem prévia emissão de notas de empenho - Acusação feita a prefeito de pequeno município, recém-criado, sem recurso para contratar pessoal técnico para assessorá-lo - Ausência de dolo - Idoneidade e honorabilidade do mesmo destacada no processo falta de prejuízo para o erário público - Absolvição decretada - Inteligência dos arts. $1^{\circ}, \mathrm{n}^{\mathrm{O}} \mathrm{V}$. do Decreto-lei $\mathrm{n}^{\mathrm{o}}$ 201, de 1967, 60 e 61 da Lei Federal nº 4.320, de 1964. Alçar à gravidade de conduta delituosa a irregularidade na realização de despesas sem prévia emissão de notas de empenho, em matéria intrincada e difícil de contabilidade pública, por parte de um Prefeito cuja honorabilidade é destacada no processo, sem prova de dolo ou de má-fé, sem prova de qualquer prejuízo ao erário municipal ou à execução orçamentária, seria interpretar 'ad urgem' a lei, atento, exclusivamente ao seu aspecto formalístico. Seria desestimular que pessoas de bem, mas leigas, se arriscassem a servir seu município, dando muitas vezes, o melhor de si, para terminar apenas com o prêmio de um processo de crime, quando não de um decreto condenatório."
} 
de colaborar com o combate à corrupção se seu plano inicial é continuar a violar a lei talvez seja esse o caso do milionário bem-sucedido e cleptomaníaco que entra para a política e enriquece ainda mais de modo corrupto, sem nenhuma necessidade de obter tais recursos. Mesmo que se tentasse qualquer tipo de colaboração com o infrator irracional, este insistiria no erro.

Punições extremas como a prisão poderiam ser usadas contra esses agentes, pois excluí-los do jogo seria a única maneira de impedir o descumprimento da lei, mesmo que seja economicamente mais vantajoso segui-la. ${ }^{76}$ De maneira maliciosa, esses agentes acreditam que infringir as leis é sempre mais vantajoso, mesmo gastando mais dinheiro violando-a do que gastariam obedecendo-a.

Se necessária a colaboração com esse protótipo, toda tentativa deve ser cercada de cuidados redobrados, uma vez que o infrator irracional estaria apenas se preparando para enganar as autoridades anticorrupção. Aliás, uma abordagem colaborativa nem sequer é a estratégia mais adequada.

\subsubsection{Diferentes estratégias para diferentes motivações}

A descrição das várias motivações dos agentes corruptos corrobora as alegações de que nem sempre é fácil identificar o seu perfil no dia a dia. Embora seja difícil prever quando esses agentes aparecerão, a descrição sugere que "confiar em uma única teoria para obter a obediência à lei é provavelmente errado e, quando isso se traduz numa estratégia de implementação, é provavelmente contraproducente". ${ }^{747} \mathrm{Em}$ teoria, a resposta estatal à motivação de cada agente é concebida na medida para atingir a máxima eficiência dissuasória. Nesse particular, a política sugerida pela regulação responsiva em nada difere da sugerida por Beccaria:

O fim da pena, pois, é apenas o de impedir que o réu cause novos danos aos seus concidadãos e demover os outros de agir desse modo.

É, pois, necessário selecionar quais penas e quais modos de aplicá-la, de tal modo que, conservadas as proporções, causem a impressão mais eficaz e mais duradoura no espírito dos homens, e a mais tormentosa no corpo do réu. ${ }^{748}$

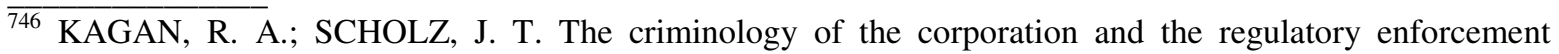
strategies. In: HAWKINS, K.; THOMAS, J. M. Enforcing regulation. Boston: Kluwer-Nijhoff, 1984. p. 85.

${ }^{747}$ PARKER, C. BRAITHWAITE, J. STEPANENKO, N. Op. cit. p. 5. "[...] Reliance on any single theory of compliance is likely to be wrong, and when translated into an enforcement strategy, it is likely to be counterproductive."

${ }^{748}$ BECCARIA, Cesare. Op. cit. p. 43.
} 
No contexto da colaboração com os infratores, é útil verificar a existência dos vários padrões de comportamento, pois estes revelam os objetivos dos agentes e os riscos da persistência do comportamento, mesmo depois de iniciada a colaboração. Tais conclusões podem ser agrupadas conforme a tabela abaixo.

Tabela 12 - Protótipos de agentes e seus incentivos para colaborar

\begin{tabular}{|c|c|c|}
\cline { 2 - 3 } & Motivos para colaborar & Possibilidade de reincidência \\
\hline Cidadão político & $\begin{array}{c}\text { Para ser declarado inocente ou } \\
\text { minimizar o dano à sua imagem }\end{array}$ & Nenhuma \\
\hline $\begin{array}{c}\text { Organizacionalmente } \\
\text { incompetente }\end{array}$ & $\begin{array}{c}\text { Para receber sanções menores que a } \\
\text { vantagem auferida e se organizar }\end{array}$ & Baixa \\
\hline Calculador amoral & $\begin{array}{c}\text { Para receber sanções menores que a } \\
\text { vantagem auferida }\end{array}$ & Média \\
\hline Infrator irracional & Para receber sanções pequenas & Alta \\
\hline
\end{tabular}

Fonte: Elaboração própria.

Com base no padrão que reconhece essa complexidade por trás de motivações individuais, Ayres e Braithwaite desenvolveram a ideia de usar diferentes estratégias de repressão. Uma única pessoa pode ter motivações diferentes de acordo com sua posição. O mesmo acontece com um agente público ou privado: um calculador amoral pode-se transformar em um cidadão político; um infrator irracional pode atuar com responsabilidade; e um organizacionalmente incompetente pode adquirir informação e se transformar em cidadão político. ${ }^{749}$ Assim, a reação das autoridades encarregadas de combater a corrupção que propõem colaboração deveria variar com a motivação identificável daqueles de que se aproximam.

Em um ambiente tão complexo, Ayres e Braithwaite alegam que a TFT seria a estratégia mais adequada. ${ }^{750}$ Caso a TFT seja aplicada na luta contra a corrupção, as autoridades responderiam com uma ação equivalente à do agente corrupto na jogada anterior - o possível engano seria depois compensado com outro jogador corrupto; assim, um eventual "erro" de lance da autoridade anticorrupção poderia ser compensado mais tarde, a fim de se manter a imagem de invencibilidade. Note-se que a estratégia resultante é dependente do perfil psicológico do agente público ou privado sob investigação por

\footnotetext{
$\overline{749}$ AYRES, I. BRAITHWAITE, J. Op. cit. p. 21-27.

${ }^{750}$ Idem, p. 33-34.
} 
envolvimento em corrupção. Essa estratégia é bastante maleável, a ponto de se adaptar a qualquer uma das motivações que as autoridades anticorrupção possam enfrentar.

Tabela 13 - Análise da motivação dos agentes vis-à-vis as autoridades anticorrupção

\begin{tabular}{|c|c|c|c|}
\hline & \multicolumn{2}{|c|}{ Colaboradores } & \multirow{2}{*}{$\begin{array}{l}\text { Autoridades anticorrupção } \\
\text { Aceitaria a colaboração se }\end{array}$} \\
\hline & $\begin{array}{l}\text { Propõe-se a } \\
\text { colaborar se }\end{array}$ & Sanção & \\
\hline $\begin{array}{l}\text { Infrator } \\
\text { irracional }\end{array}$ & $\begin{array}{l}\text { houver provas } \\
\text { altamente } \\
\text { incriminatórias. }\end{array}$ & Mínima possível & $\begin{array}{l}\text { o custo pecuniário da sanção tender a } \\
\text { incapacitar e a dissuasão criminal existir } \\
\text { efetivamente. }\end{array}$ \\
\hline $\begin{array}{l}\text { Calculador } \\
\text { amoral }\end{array}$ & $\begin{array}{c}\text { houver probabilidade } \\
\text { de uma sanção } \\
\text { elevada. }\end{array}$ & $\begin{array}{l}\text { Não pode exceder } \\
\text { a vantagem } \\
\text { auferida }\end{array}$ & $\begin{array}{l}\text { o custo pecuniário exceder a vantagem } \\
\text { auferida e houver probabilidade ou } \\
\text { possibilidade de dissuasão criminal. }\end{array}$ \\
\hline $\begin{array}{c}\text { Organizacionalmente } \\
\text { incompetente }\end{array}$ & $\begin{array}{l}\text { houver possibilidade } \\
\text { de punição. }\end{array}$ & $\begin{array}{l}\text { Baixa, mas } \\
\text { razoável }\end{array}$ & $\begin{array}{l}\text { o custo pecuniário se igualar com a } \\
\text { vantagem auferida, se buscar o } \\
\text { aprimoramento institucional e se mitigar } \\
\text { o risco de dissuasão criminal. }\end{array}$ \\
\hline $\begin{array}{l}\text { Cidadão } \\
\text { político }\end{array}$ & $\begin{array}{c}\text { houver remotas } \\
\text { chances de punição. }\end{array}$ & Mínima possível & $\begin{array}{c}\text { o custo pecuniário se igualar com a } \\
\text { vantagem auferida e se mitigar o risco de } \\
\text { dissuasão criminal. }\end{array}$ \\
\hline
\end{tabular}

Fonte: Elaboração própria.

Essas premissas permitem conceber estratégias diferentes para lidar com os diferentes perfis de corruptos e corruptores (ver tabela 14).

Tabela 14 - Estratégias recomendadas para o combate à corrupção vis-à-vis as ferramentas disponíveis

\begin{tabular}{|c|c|c|}
\cline { 2 - 3 } \multicolumn{1}{c|}{} & Estratégia & Ferramentas disponíveis \\
\hline Cidadão político & Persuasão e adaptação à lei & Uso de mecanismos consensuais \\
\hline $\begin{array}{c}\text { Organizacionalmente } \\
\text { incompetentes }\end{array}$ & Educação & $\begin{array}{c}\text { Disseminar a informação correta sobre } \\
\text { a dicotomia público-privado }\end{array}$ \\
\hline Calculador amoral & Punições extremas & $\begin{array}{c}\text { Sanções escaladas e graduadas } \\
\text { Infrator irracional }\end{array}$ \\
\hline
\end{tabular}

Fonte: Adaptação a partir de AYRES, I. BRAITHWAITE, J. Responsive regulation: transcending the deregulation debate. Oxford: Oxford University Press, 1992, p. 146-157.

Esse raciocínio precisa ser testado no contexto brasileiro, embora se reconheça que várias críticas lhe podem ser endereçadas. A primeira diz respeito à ampla maleabilidade do interesse público por parte dos responsáveis pela repressão à corrupção, o que não se coaduna exatamente com a forma como o direito administrativo e o Judiciário brasileiros 
tratam o tema. É irrelevante se houve restituição do proveito econômico para estabelecimento da sanção criminal, bem como nega-se aplicação ao princípio da insignificância. ${ }^{751}$ Ademais, as hipóteses de recompensa para os que colaboram com as autoridades, mormente em direito penal, são reduzidas, o que torna necessárias reformas normativas para conferir maior maleabilidade. ${ }^{752}$ Por esse motivo, Livianu lembra que "a pena de confisco de bens é pouco utilizada no Brasil” e poderia ser objeto de negociação com os envolvidos em corrupção. ${ }^{753}$ Outro fator a restringir a utilização desse modelo é a ausência de coordenação das agências anticorrupção: para que a exata medida de punição seja transmitida aos infratores, haveria necessidade de que todos os envolvidos na repressão se articulassem, para transmitir a exata proporção de dissuasão recomendada a cada protótipo.

\subsubsection{Manipulação institucional de incentivos e desincentivos à corrupção}

Certos fatores dificilmente podem ser alterados por políticas públicas, mesmo no longo prazo, uma vez que dependem de mudanças mais profundas na sociedade - o grau de confiança nas relações sociais é um deles.

Por outro lado, tem-se apontado que há outros elementos determinantes dos incentivos e desincentivos de comportamentos dos agentes corruptos, tais como o risco de detecção e punição, a discricionariedade das autoridades públicas e a correlação de forças

\footnotetext{
1 FAZZIO JÚNIOR, Waldo. Corrupção no poder público: peculato, concussão, corrupção passiva e prevaricação. São Paulo: Atlas, 2002. p. 83-84.

${ }^{752}$ LIVIANU, Roberto. Corrupção e direito penal: um diagnóstico da corrupção no Brasil. Coimbra: Coimbra Editora, 2007. p. 162. "Por isso, outra solução possível visando a responsabilização dos líderes da prática do crime de corrupção, poderia ser a amplificação das hipóteses dos acordos penais, permitindo-se o Ministério Público ter mais discricionariedade no exercício do poder punitivo, facultando-lhe o não oferecimento de denúncia em face de criminoso menor que colaborasse para a obtenção de provas incriminadoras em face dos grandes responsáveis pelas condutas, à semelhança da plea bargaining estadunidense."

${ }^{753}$ Idem, ibidem. "A pena de confisco de bens, pouco utilizada no Brasil e de aplicação restrita pela legislação, poderia representar um caminho punitivo a ser utilizado entre nós, sendo necessário redimensioná-la na legislação para que pudesse ser utilizada como alternativa à privação de liberdade.” Em sentido contrário, ver BECCARIA, Cesare. Op. cit. p. 68. "Não é esse, porém, o pormenor que me leva a censurar o confisco de bens. Se alguns já sustentaram que o confisco era o freio às vinganças e às prepotências privadas, não perceberam que, embora boas penas produzam um bem, nem sempre são justas, pois, para serem justas, precisariam ser necessárias, e uma injustiça útil não pode ser tolerada pelo legislador que pretendesse fechar todas as portas à vigilante tirania, a qual seduz com um bem do momento e com a felicidade de alguns notáveis, desprezando o extermínio futuro e as lágrimas de muita gente obscura. O confisco coloca a prêmio a cabeça dos fracos e faz recair sobre o inocente a pena do culpado, deixando-o na desesperada necessidade de cometer delitos. Que espetáculo mais triste do que o da família arrastada à infâmia e à miséria pelos crimes do chefe, cujos atos, por causa da submissão imposta pelas leis, ela não poderia impedir mesmo que dispusesse dos meios de fazê-lo?"
} 
entre o corrupto e o corruptor, os quais podem ser manipulados por políticas públicas: ${ }^{754}$ quanto maiores as chances de recompensa, maiores serão os atrativos para os jogadores corruptos. Tais fatores interagem para estabelecer os incentivos.

Há aspectos que se contrapõem aos benefícios, atuando como custos que servem de desincentivos. Entre estes, dois podem ser ressaltados: a probabilidade de detecção e a probabilidade de punição. À semelhança do que ocorre com outros crimes, o agente corrupto vislumbra os benefícios e pondera as chances de ser detectado e punido. Quanto maiores as chances de ser detectado, menores serão os benefícios, uma vez que a detecção impõe uma série de custos, entre os quais se pode apontar os danos à imagem e as despesas com a defesa jurídica. Todavia, com frequência, detecção não significa punição automática, e o jogador corrupto pode, ainda assim, reter partes dos ganhos com a corrupção. Mesmo que punido, nem sempre a sanção tem força suficiente para dissuadir o corrupto e aqueles que pretendem sê-lo. ${ }^{755}$ Uma política consistente deveria buscar alterar esses fatores. ${ }^{756}$ A Tabela 15 resume o cenário.

Tabela 15 - Probabilidade de detecção e punição vis-à-vis os benefícios do agente corrupto

\begin{tabular}{|c|c|c|c|}
\cline { 3 - 4 } \multicolumn{2}{c|}{} & \multicolumn{2}{c|}{ Probabilidade de detecção } \\
\cline { 3 - 4 } \multicolumn{2}{c|}{} & Baixa & Alta \\
\hline \multirow{2}{*}{ Probabilidade de punição } & Baixa & Benefícios altos & Benefícios medianos \\
\cline { 2 - 4 } & Alta & Benefícios medianos & Benefícios baixos \\
\hline
\end{tabular}

Fonte: Elaboração própria.

\footnotetext{
$\overline{754}$ ROSE-ACKERMAN, Susan. A economia política da corrupção. In: ELLIOT, Kimberly Ann (Org.). A corrupção e a economia global. Tradução de Marsel Nascimento Gonçalves de Souza. Brasília: UnB, 2002, p. 81. "[...] a dimensão e a incidência da corrupção dependiam de quatro fatores: do nível geral de benefícios públicos disponíveis, do poder discricionário das autoridades, do risco de transações corruptas e do relativo poder de negociação do corruptor e do corrompido. As estratégias anticorrupção podem ser categorizadas da mesma maneira: as que diminuem os benefícios sob o controle das autoridades, as que reduzem os seus poderes, as que elevam os custos do suborno e as que limitam o poder de negociação das autoridades."

755 Idem, p. 72. "Quanto maior a probabilidade de se detectar e de se punir a corrupção menor é a disponibilidade de benefícios eficientes. Se a possibilidade de detecção e de castigo é alta, a oferta ou a demanda por suborno pode cair a zero. A análise pode prosseguir de forma bastante semelhante a qualquer discussão sobre os aspectos econômicos do crime (Becker e Stingler, 1974; Rose-Ackerman, 1978, capítulo 6). A expectativa de custo do suborno é igual à probabilidade de ser pego multiplicada pela probabilidade de ser condenado multiplicada pelo castigo imposto. $\mathrm{O}$ corruptor ou agente público isento de riscos compara essa expectativa de custo com a expectativa de benefício, e só age corruptamente se o saldo for positivo. $\mathrm{O}$ agente avesso a riscos deve também receber uma compensação pelo elemento de incerteza existente nas transações corruptas. Segundo a versão mais simplificada desse modelo, o corruptor e o funcionário são tomadores de preço de suborno, os quais não negociam o valor do suborno ou do serviço prestado em retorno."

756 Idem, p. 81. "A política governamental pode aumentar os benefícios de quem é honesto, ampliar a probabilidade de detecção e de castigo e elevar as penalidades impostas àqueles que forem pegos."
} 
Tome-se o caso das propinas exigidas por funcionários públicos. As reformas institucionais devem-se voltar contra os ganhos marginais auferidos pelos que recebem e pagam propinas - até que ponto compensa aceitar o risco adicional de ser detectado e punido pelo benefício que será desfrutado? Uma possível resposta seria a seguinte:

Independentemente da sanção imposta pela lei penal a alguém condenado por corrupção, os custos de se perder um cargo governamental por conduta ilícita deverão ampliar-se. [...] as penalidades devem ser atreladas aos benefícios marginais das propinas recebidas. Até certo ponto, essa é uma tarefa que cabe à lei penal e a processos de monitoramento interno. Há dois aspectos envolvidos aqui: as probabilidades de detecção e de castigo e a intensidade do castigo dada à condenação. ${ }^{757}$

Portanto, essa manipulação das instituições, alternando os incentivos e desincentivos, é ferramenta útil para aperfeiçoar a regulamentação microjurídica no combate à corrupção.

\subsection{A necessária imagem de invencibilidade na repressão à corrupção vis-à-vis a impunidade nos ilícitos de colarinho branco}

A utilização da "grande arma benigna" pressupõe que haja uma repressão efetiva e bem-sucedida às infrações que se pretende dissuadir - a possibilidade de uma sanção substancial, escudada na quase certeza da sua imposição, é a chave para evitar o ilícito, inclusive os relacionados à corrupção. A propósito, diversamente do que o senso comum afirma ocorrer, pelo menos nos Estados Unidos, quando punidos, os crimes de colarinho branco tendem a ser sancionados com maior severidade. ${ }^{758}$

A essa imagem se deve acrescentar o caráter simbólico do direito penal, o qual por vezes pode ter influência muito mais efetiva para fins de prevenção. ${ }^{759} \mathrm{Em}$ tese, a dissuasão

\footnotetext{
${ }^{757}$ Idem, p. 83.

758 SANTOS, Cláudia Cruz. O crime de colarinho branco, a (des)igualdade e o problema dos modelos de controlo. In: PODVAL, Roberto (Org.). Temas de direito penal econômico. São Paulo: Revista dos Tribunais, 2001. p. 199. Os resultados de um estudo norte-americano se justificariam "[...] com o forte sentimento de reprovação dos juízes - e do público em geral - contra os crimes 'de ganância', por oposição à criminalidade justificada pela necessidade. $\mathrm{O}$ que, apesar de ter sido exacerbado pelo fenómeno Watergate, a ele não se deverá exclusivamente. Conclui-se, em suma, que existe uma relação 'consistente e positiva' entre o estatuto sócio-económico do agente e a severidade da condenação, pelo que se tornaria imperativa uma reformulação do corrente entendimento de que os white-collar criminals são tratados com especial brandura pela justiça."

${ }^{759}$ Não se pode concordar com a tese de que o caráter simbólico do direito penal não atinge o efeito desejado, tal como defendido por Livianu. Embora essa situação possa ocorrer para alguns crimes, a generalização é exagerada, especialmente no caso dos crimes de colarinho branco, em que a reputação de seus autores é um grande bem jurídico. Em sentido oposto, ver LIVIANU, Roberto. Op. cit. p. 168. "Os efeitos simbólicos da legislação penal, muito utilizados na atualidade como resposta do Estado aos conflitos sociais determinados pela criminalidade complexa, em que se inclui o crime de corrupção, não atingem o efeito desejado, uma vez
} 
exercida pela "grande arma benigna" só é eficaz se o conjunto das ações, levadas a cabo pelas diversas autoridades anticorrupção, for considerado altamente eficaz pelos que pretendem praticar atos corruptos. Como defende Beccaria, o objetivo do sistema criminal não deveria ser a crueldade ou severidade da pena, mas a certeza de sua aplicação. ${ }^{760}$

Assim, o ponto não é exatamente defender o uso brutal da força de dissuasão. Pelo contrário, a "grande arma benigna" pressupõe que a força seja usada em situações excepcionais, tentando-se sempre atingir o resultado do modo mais colaborativo possível. Certamente, o aparato dissuasório estatal não é descartado, mas precisa ser usado de modo racional para combater a impunidade. ${ }^{761}$

Todavia, os órgãos responsáveis pela imposição de tais sanções carecem de tal imagem, situação esta comum à maioria dos ilícitos de colarinho branco. Sadek relata que, entre 1988 e 2007, “de um total de 130 ações no STF contra agentes públicos protegidos pelo foro privilegiado, nenhuma teve condenação; no STJ, de um total de 33 processos, houve punição em cinco". ${ }^{762}$

Ao se indagar sobre as causas desta impunidade, uma grande variedade se apresenta e não é objetivo esgotá-las, mas apenas chamar atenção para alguns aspectos específicos dos crimes de colarinho branco. Outra causa associada à impunidade diz respeito ao ímpeto investigativo. Diversamente do que ocorre com os crimes comuns, nos casos de colarinho branco existe sempre a tendência a restringir as investigações aos principais

que não conseguem modificar a realidade, nem mesmo proteger os bens jurídicos a que se propõem. A função do direito penal deve ser encarada com um efeito expressivo e integrador, que é um pilar da utilização da pena, pois esta se caracteriza pelo seu efeito intimidatório, individual e coletivo, aliado à prevenção geral positiva que se pretende como motivação ao cumprimento dos conteúdos básicos da ordem social. Nesta linha de pensamento, não se deve atribuir ao direito penal a única função de controle social, mas seu caráter interdisciplinar característico de qualquer iniciativa social para atender aos reclamos sociais com relação aos danos causados pelo crime de corrupção. A intervenção simbólica não deve ser totalmente afastada, uma vez que, em muitos casos e situações emergenciais, atende à expectativa social, podendo ser adequada no momento da expedição de determinada lei."

${ }^{760}$ BECCARIA, Cesare. Op. cit. p. 72. "Um dos maiores freios dos delitos não é a crueldade das penas, mas sua infalibilidade, e como conseqüência, a vigilância dos magistrados e a severidade de um juiz inexorável que, para ser uma virtude útil, deve ser acompanhada de uma legislação branda".

761 LOPES, José Reinaldo de Lima. Direitos humanos e tratamento igualitário: questões de impunidade, dignidade e liberdade. Revista Brasileira de Ciências Sociais, São Paulo: Anpocs, v. 15, n. 42, p. 77, 2000. Disponível em: <http://www.scielo.br/scielo.php?script=sci_arttext\&pid=S010269092000000100006\&lng=en\&nrm=iso>. Acesso em: $28 \mathrm{dez}$. 2009. A crítica de Lopes ao apelo social pelo uso do poder discricionário é pertinente, pois este subverte o próprio Estado de Direito. "A resposta adequada, segundo elas, é que a autoridade aja contra a lei, ou acima da lei. A fórmula é simples, e significa que o sistema legal não deve ser mais encarado com a perspectiva de que o poder precisa ser constituído e controlado. Passase a defender o poder discricionário e o uso imediato da violência. Há uma parte considerável da opinião pública, de todas as classes e estratos sociais, pode-se dizer, acreditando que o aumento da violência é fruto da 'pouca energia' da polícia. Os números disponíveis, de fato, não mostram isto. Ao contrário, parece que há uma escalada de violência policial paralela à escalada da violência geral, sem que uma tenha sido capaz de conter a outra." Como Lopes constata, até mesmo um pensador autoritário como Oliveira Vianna intui que a impunidade é antidemocrática, na medida em que desnuda o privilégio de uns em relação aos outros.

${ }^{762}$ SADEK, Maria Teresa. Ministério Público. In: AVRITZER et al. (Org.). Corrupção: ensaios e críticas. Belo Horizonte: UFMG, 2008. p. 549-550. 
envolvidos, ou seja, os funcionários públicos. Em outras palavras, aqueles que pagam para obter vantagem são considerados vítimas e tendem a ser deixados de lado $^{763}$. Embora essa afirmação possa estar correta, nem sempre está e a ausência de sanção aos corruptores acrescenta ainda mais sensação de impunidade. Já nos anos 1950, Almeida alertava para as dificuldades de se levar a efeito investigações sobre casos complexos, usando como exemplo os relacionados à gestão orçamentária ${ }^{764}$.

À semelhança do que se verifica com criminosos violentos e poderosos, que podem “influenciar" testemunhas e agentes do Estado, os envolvidos em corrupção contam com seu status social para neutralizar ou minimizar animosidades. ${ }^{765}$ Esse personalismo na relação com a lei pode explicar por que alguns associam o cumprimento da lei à impunidade. Essa associação, feita, inclusive, nos casos de corrupção, é intuída pela população. Afinal,

esta sensação generalizada de impunidade - que todos nós começamos a sentir dos bancos escolares, quando a cola pode correr solta, ou que testemunhamos no dia-a-dia do trânsito - resulta em descrença nas instituições e, para aqueles que menos refletem criticamente, em demanda para que a autoridade aja sem lei. Nesta ordem de idéias, associa-se a impunidade à legalidade: a lei é o que impede a justiça de se realizar da perspectiva destas vozes. ${ }^{766}$

\footnotetext{
763 SUTHERLAND, Edwin H. White collar criminality. American Sociological Review, v. 5, n. 1, p. 5-6, Feb. 1940. "Fourth, persons who are accessory to a crime should be included among white collar criminals as they are among other criminals. When the Federal Bureau of Investigation deals with a case of kidnapping, it is not content with catching the offenders who carried away the victim; they may catch and the court may convict twenty-five other persons who assisted by secreting the victim, negotiating the ransom, or putting the ransom money into circulation. On the other hand, the prosecution of white-collar criminals frequently stops with one offender. Political graft almost always involves collusion between politicians and business men but prosecutions are generally limited to the politicians. Judge Manton was found guilty of accepting $\$ 664,000$ in bribes, but the six or eight important commercial concerns that paid the bribes have not been prosecuted. Pendergast, the late boss of Kansas City, was convicted for failure to report as a part of his income \$3 15,000 received in bribes fiom insurance companies but the insurance companies which paid the bribes have not been prosecuted. In an investigation of an embezzlement by the president of a bank, at least a dozen other violations of law which were related to this embezzlement and involved most of the other officers of the bank and the officers of the clearing house, were discovered but none of the others was prosecuted."

${ }^{764}$ ALMEIDA, Fernando H. M. Op. cit. p. 49. Ao se referir ao crime previsto no artigo 315 do Código Penal, discorre Almeida: "Mas quem poderia, na maioria das vezes, sair a campo com a acusação fundamentada de que o de que se fala é, em direito penal, apenas um crime? Em verdade, uma denúncia tal sobre correr o risco de ver-se diluída pelos artifícios de algum hábil contabilista, não aproveitaria a um pequeno funcionário que tivesse ciência do fato. Quanto aos grandes funcionários, porque receiem eles, ainda que deliberadamente, vir a cair no mesmo delito e porque, geralmente, são obumbrados pela mais desatinada paixão pela chamada 'política', calam-se. E a tutela penal, já de si irrisória, porque prevê pena leve e de caráter optativo, redunda em inutilidade, salvo se, por vingança de 'política partidária', houver interesse subalterno de um alto funcionário, desavido com outro, de, então, transformar a justiça em arma do seu revide."

765 SUTHERLAND, Edwin H. White collar criminality. American Sociological Review, v. 5, n. 1, p. 5, Feb 1940. "Gangsters and racketeers have been relatively immune in many cities because of their pressure on prospective witnesses and public officials, and professional thieves, such as pickpockets and confidence men who do not use strong-arm methods, are even more frequently immune. The conventional criminologists do not hesitate to include the life histories of such criminals as data, because they understand the generic relation of the pressures to the failure to convict. Similarly, white-collar criminals are relatively immune because of the class bias of the courts and the power of their class to influence the implementation and administration of the law."

${ }^{766}$ LOPES, José Reinaldo de Lima. Direitos humanos e tratamento igualitário: questões de impunidade, dignidade e liberdade. Revista Brasileira de Ciências Sociais, v. 15, n. 42, p. 77-100, 2000. Disponível em:
} 


\subsection{Teoria da regulação econômica: a tênue diferença entre captura e corrupção}

A análise precedente tece considerações realistas sobre o relacionamento entre agentes públicos e privados. A origem dessa linha de abordagem se localiza na teoria da regulação econômica, estudada pelos economistas liberais a partir dos anos 1970 - à diferença dos juristas liberais, estes não hesitaram em trazer os interesses novamente ao centro das atenções. Como o tema também guarda relações evidentes com a problemática da corrupção e como ajuda na compreensão do modus operandi da interface entre os interesses público e privados, inclusive no estado patrimonialista brasileiro, ele será analisado a seguir.

A teoria da regulação econômica se desenvolveu a partir de artigo publicado em 1971 por Stigler. ${ }^{767}$ À época, havia "um idealismo profundo impregnado no pensamento econômico sobre regulação". No contexto das críticas ao intervencionismo estatal feito por meio da regulação excessiva, Stigler admite a existência de pressões em defesa de interesses privados sofridas pelo Legislativo ou órgãos normativos e, ao mesmo tempo, enfatiza que os políticos encontram-se pressionados pelos eleitores, posicionados como consumidores no mercado - num modelo microeconômico teórico, pode-se contrapor uma oferta e uma demanda por regulação, de modo que haveria um mercado de regulação. Considerando que os interesses privados dos produtores se organizam melhor, os eleitores tenderiam a perder sempre a disputa. Para camuflar a transferência de renda, os subsídios não são preferidos pelos interesses privados, mas são utilizados eventualmente. A estratégia preferida na proteção dos interesses privados seria o protecionismo que limitaria a entrada de competidores no mercado mediante licenças, taxas e restrições à concorrência, entre outros meios.

Nessa concepção neopluralista, os grupos defensores de interesses privados são denominados rent-seeking, que constituem "grupos cujo escopo seria, em essência, a

$<$ http://www.scielo.br/scielo.php?script=sci_arttext\&pid=S0102-69092000000100006\&lng=en\&nrm=iso $>$. Acesso em: 28 dez. 2009. "Seria fácil, mas incompleto e por isso mesmo enganoso, imaginar que a questão da autoridade diz respeito a um problema vertical da relação do 'governo' com o 'povo', ou de pura obediência. É mais adequado perceber que se trata de um problema horizontal: da relação dos cidadãos entre si, ou de uma parte do povo com a outra parte, ou de uma parte com todos. O tema é o do respeito recíproco, que implica uma noção universal de liberdade e dignidade. J. S. Mill (1974, pp. 128-132) notara que uma vez estabelecidos os princípios da liberdade política sob a forma da soberania popular, surgia imediatamente a questão da liberdade civil, ou seja, da opressão recíproca que os membros do povo exerceriam sobre si. Muito embora sua preocupação fosse com a tirania da maioria sobre as minorias em termos de opinião, costumes ou vida privada, faz sentido pensar que na sociedade democrática, em que os estados (status) e a honra não devem contar, a discriminação na aplicação da lei, a criação de grupos impunes, resulta em uma forma de opressão de uma parte do povo por outra."

${ }^{767}$ STIGLER, G. J. The economic theory of regulation. Bell Journal of Economics and Management Science, Rand Corporation, v. 2, n. 1, p. 3-21, Spring 1971. 
obtenção de vantagens de diferente ordem, mas que redundariam, por uma ou outra forma, em procurar na esfera pública em acréscimo de renda para os seus integrantes. Essa renda é procurada na esfera pública porque não foi conseguida ou seria insuscetível de o ser no mercado". ${ }^{768}$ A análise econômica do mercado de regulação se torna sofisticada com a transposição da noção de rent-seeking também para a esfera pública. Enquanto indivíduo maximizador de seu próprio interesse, o político se depara com duas necessidades:

A primeira necessidade a impor norte a seus atos é a de conseguir satisfazer as expectativas mínimas de seus eleitores de maneira que, em próximos pleitos, ele consiga novamente reunir votos suficientes para se manter no cargo. É importante esclarecer que, no limite, basta que se promova a aparência de que o representante persegue minimamente o interesse de seus representados. O que de fato ocorre nos bastidores das votações parlamentares - e não vem a público - tem pouca relevância.

A segunda necessidade que afeta as ações do agente político é a de oferecer privilégios a pequenos grupos de modo a que, com a extração de recursos destes, consiga financiar suas campanhas eleitorais e talvez até mesmo incrementar sua renda, o que certamente configura uma conduta pouco reta, mas previsível uma vez que se assuma a capacidade preditiva da instrumentalização do tipo individual conforme descrito pela sociologia econômica. ${ }^{769}$

Essa "denúncia” explícita de um economista liberal como Stigler deixa claro como interesses privados perseguem seus objetivos dentro da legalidade democrática. Talvez ainda imbuídos de certo apego à visão romântica sobre a interação entre os grupos de interesse, Stigler e outros economistas da mesma escola parecem ignorar o desdobramento lógico da teoria da regulação, hesitando em relacionar o mercado de regulação à corrupção. Todavia, a proximidade entre os interesses privados e os públicos proporciona as condições para corrupção nos mesmos cenários analisados pela teoria da regulação econômica: quando a demanda de legislação não é atendida pela oferta e os jogadores envolvidos não se restringem ou se limitam pelas regras do mercado, surge espaço para a corrupção.

A escassez de subsídios suficientes pode fazer com que agentes privados pressionem ou até corrompam os agentes governamentais. ${ }^{770}$ Essa corrupção em torno de

\footnotetext{
${ }^{768}$ NUSDEO, Fábio. Fundamentos para uma codificação do direito econômico. 1993. 226 f. Tese (Titular)Faculdade de Direito, Universidade de São Paulo, São Paulo. p. 70. "Naturalmente, a expressão 'rent seeking' é propositadamente vaga, querendo significar qualquer tipo de prestação pelo Estado apta a satisfazer uma procura do particular e cujo custo não será por ele suportado. Mais do que isso, tal custo para a comunidade será superior ao benefício proporcionado aos membros do grupo, o que em linguagem da 'Welfare Economics' implicaria um afastamento do ponto de Ótimo de Pareto."

769 ROSA, Christian Fernandes. Eficiência como axioma da teoria econômica do direito. 2008. $108 \mathrm{f}$. Dissertação (Mestrado em Filosofia do Direito)-Faculdade de Direito, Universidade de São Paulo, São Paulo. p. 69.

${ }^{770}$ ROSE-ACKERMAN, Susan. A economia política da corrupção. In: ELLIOT, Kimberly Ann (org.). A corrupção e a economia global. Tradução de Marsel Nascimento Gonçalves de Souza. Brasília: UnB, 2002. p. 65. "Com a escassez de um determinado serviço, há quem pague para ser agraciado pelo benefício, ou o
} 
subsídios pode ser mais visível, e, por isso, os interesses privados preferem o protecionismo. O mais óbvio caso é o monopolista que paga a agentes governamentais para manter elevadas as barreiras à entrada de concorrentes. ${ }^{771}$ Existem outros cenários em que a interface entre os interesses público e privado pode redundar em corrupção, tais como atrasos em mudanças normativas e interpretações mais ou menos gravosas das normas, hipóteses em que há impacto adverso sobre o grau de competição entre as empresas e, indiretamente, sobre sua rentabilidade. ${ }^{772}$

O desdobramento mais sofisticado da análise da teoria da regulação ocorre com a captura do ente regulador pelos interesses privados. No capítulo 1 foi exposto que uma das técnicas do Estado Moderno para eficientemente atingir o bem comum é a separação entre os espaços público e privado, no meio da qual se insere a noção de supremacia do interesse público. Em alguns países, especialmente após o movimento de liberalização econômica do pós-1970, proliferaram órgãos governamentais especializados em determinados setores da ação estatal, dotados de várias garantias para a independência funcional, de modo a evitar ingerências políticas sobre decisões técnicas. Muitas das ingerências políticas que se buscava afastar refletiam interesses essencialmente privados dos políticos, ao passo que outros seriam anseios legítimos da população - temia-se o populismo regulatório.

Entretanto, apesar de relativo sucesso no afastamento destes interesses, uma série de outras críticas pode ser endereçada a essa técnica de desenho institucional, inclusive quanto à responsabilização, ${ }^{773} \mathrm{o}$ que dá azo às críticas do déficit democrático dos entes reguladores. Um modelo policêntrico de organização do Estado, insulado do sistema político-representativo, não parece ser automaticamente melhor do que outro permeado, podendo propiciar a prevalência do interesse privado, não político, mas econômico.

\footnotetext{
serviço pode ser um direito dado a todos aqueles que para ele se habilitam, de modo que as pessoas pagam para ser incluídas no grupo dos merecedores."

${ }^{771}$ Idem, p. 66. "Assim, se as companhias pagam para preservar o poder de monopólio do empreendimento depois que ele passa a mãos privadas, o resultado pode se resumir em uma transferência de rendimentos do Estado para os novos proprietários."

${ }^{772}$ Idem, p. 66-67. "Os governos impõem regulamentações, arrecadam impostos e aplicam leis penais. As autoridades podem retardar ou incomodar aqueles com quem lida. Podem impor custos, seletivamente, de modo que afete a posição competitiva das empresas de um determinado segmento [...] Condicionadas a esquemas normativos do governo, as empresas podem pagar para obter uma interpretação favorável das leis, ou para conseguir um julgamento discricionário em seu favor. É possível que as empresas paguem para evitar ou abrandar as obrigações normativas, ou mesmo para esclarecer requisitos normativos quando as leis estiverem ambíguas."

${ }^{773}$ TREBILCOCK, Michael J.; IACOBUCCI, Edward M. Designing competition law institutions. World Competition, Amsterdã: Kluwer, v. 25, n. 3, p. 364. "Notwithstanding the virtues of independence, it is difficult in a representative democracy to defend institutional independence without some form of accountability."
} 
No bojo do movimento liberalizante, a noção de captura regulatória foi desenvolvida para explicar uma série de desvirtuamentos na busca do interesse público por parte das agências reguladoras. Contudo, muitos de seus raciocínios e conclusões podem ser aplicados a toda administração pública direta, indireta e fundacional, posto que as influências dos interesses privados não são exclusivas das agências reguladoras. Ademais, a ação de interesses privados é determinante na formação do interesse público num regime democrático.

Uma das facetas da regulação estatal em sentido amplo, não importa por quem ela seja produzida, é a troca de informações entre reguladores e regulados num processo de comunicação constante. ${ }^{774}$ Isso nem poderia ser diferente, pois "a própria natureza da regulação com frequiência permite a participação direta dos interesses privados afetados no processo de decisão administrativa". ${ }^{775}$ Todavia, a captura do regulador não se limita à mera participação do regulado no processo regulatório: ela acontece sempre que houver influência lato sensu da parte regulada de modo tão poderoso que molda o comportamento do regulador de acordo com seus interesses. Em outras palavras, a captura regulatória é um fenômeno por meio do qual os reguladores se tornam, consciente ou inconscientemente, ligados aos interesses dos setores regulados, afastando-se dos objetivos institucionais que deveriam perseguir. ${ }^{776}$ Definição tão ampla suscita questionamentos sobre em que proporção a captura é universal ou não e, subsidiariamente, se haveria arranjos institucionais mais suscetíveis a ela. Mais ainda, pode-se questionar onde deve ser traçada a linha entre o que é legítimo e o que representa corrupção. Muitas vezes, captura se torna apenas um eufemismo de corrupção.

Para estabelecer onde essa linha deve ser traçada, é necessário focar quatro pontos relacionados à extensão da captura regulatória: o tipo de custos e benefícios decorrentes da regulação, a influência do ambiente institucional sobre as agências reguladoras, o espectro

\footnotetext{
$\overline{774}$ CLUNE, G. A. Implementation as autopoietic interaction of autopoietic organizations. In: TEUBNER, G.; FEBBRAJO, A. (Org.). State, law and economy as autopoietic systems: regulation and autonomy in new perspective. Milão: Giuffrè, 1992. p. 486-487.

${ }_{775}$ HORN, M. J. The political economy of public administration: institutional choice in the public sector. Cambridge: Cambridge University Press, 1985. p. 40. "[...] the very nature of regulation often allows for direct participation of the affected private interests in administrative decision making."

${ }^{776}$ HOOD, C. Explaining economic policy reversals. Buckingham: Open University Press, 1994. p. 21. Um regulador pode ser capturado por outros grupos que não o das indústrias reguladas, o que acontece com freqüência no campo da defesa do consumidor e do meio ambiente. Entretanto, levando-se em consideração que a Teoria da Regulação Econômica, conforme proposta por Stigler, parte do pressuposto de que a "regulação é adquirida pela indústria e é desenhada e operada primariamente no seu interesse, o caráter da captura do regulador segue esta argumentação. Ver STIGLER, G. J. The economic theory of regulation. Bell Journal of Economics and Management Science, Rand Corporation, v. 2, n. 1, p. 3, Spring 1971.
} 
dos setores regulados e o comportamento das agências. Estes pontos esclarecem quando surge a corrupção no relacionamento entre as esferas pública e privada.

O tipo de interesses regulados desempenha papel importante na avaliação da probabilidade de um órgão governamental ser capturado ou não. Nesse sentido, é preciso determinar a diferenciação entre os custos gerados e os benefícios advindos da regulação produzida por certa agência em relação àqueles que deverão suportar os primeiros e gozar dos segundos. Tanto os custos quanto os benefícios podem ser concentrados ou dispersos. Se concentrados, há incentivo à participação, porque os custos de transação para reunir os interesses são comparativamente baixos. Se dispersos, semelhante incentivo inexiste, uma vez que os custos de transação são mais altos, dificultando organizar um grupo de defesa do interesse público e facilitando a captura por interesses privados. ${ }^{777}$

Essa lógica custos concentrados-custos dispersos pode ser explicitada com o auxílio de dois exemplos. Considere-se inicialmente um órgão concebido para executar uma política de proteção aos consumidores. É relativamente fácil para os consumidores organizarem-se para pressionar por seus interesses perante o órgão governamental consumerista como os Procons, o que lhes permite participação mais ativa. Esse órgão pode tender a ser mais receptivo à proteção dos consumidores, pois é a sua própria raison d'être grupos de defesa do consumidor consideram razoável receber não só um bom tratamento, mas também respostas adequadas às suas demandas.

Todavia, esse quadro dificilmente corresponde à realidade, pois os benefícios aos consumidores encontram-se muito dispersos tanto no tempo quanto no espaço. O espectro dos assuntos sujeitos à atuação governamental é muito amplo e, por causa disso, muitos setores podem fazer lobby a favor de seus interesses privados de modo consistente com a análise custo-benefício: na maioria das vezes, é preferível suportar uma decisão negativa a gastar recurso com a participação perante uma agência antitruste como o Conselho Administrativo de Defesa Econômica (Cade), que se caracteriza pela tutela de benefícios dispersos para a sociedade, mas cuja atuação ininterrupta em todos os setores da economia torna proporcionalmente altos seus custos de participação para facilitar a captura por um

\footnotetext{
$\overline{777}$ WILSON, James Q. The politics of regulation. In: FERGUSON, Thomas; ROGERS, Joel. The political economy: readings in the politics and economics of American public policy. 4. ed. Nova York: Basic Books, 1984. p. 384.
} 
agente econômico ou grupo. Sob essas circunstâncias, há baixa probabilidade de que qualquer setor econômico seja bem-sucedido na captura de órgão antitruste ${ }^{778}$.

Tomando-se como base para a análise outros tipos de agências, tais como aquelas encarregadas de regular o setor de energia como a Agência Nacional de Energia Elétrica (Aneel) ou de telecomunicações como a Agência Nacional de Telecomunicações (Anatel), nas quais os benefícios para os consumidores continuam dispersos, a relação dos reguladores e regulados se altera. Mesmo se os consumidores fizerem lobby junto ao órgão governamental, o que nem sempre ocorre sistematicamente devido aos elevados custos envolvidos, eles teriam de competir com outras preocupações regulatórias, como o fornecimento regular de energia, a universalização da internet de banda larga e a proteção ao investidor. ${ }^{779}$ Quanto mais dispersos forem os benefícios para os consumidores, mais fácil será para os interesses privados defenderem seus interesses e capturarem o regulador. Embora "o custo de obter acesso efetivo ao processo político se tenha reduzido dramaticamente", ${ }^{780}$ a situação de assimetria entre custos e benefícios da regulação continuar válida, pois os grupos possivelmente afetados além da indústria podem não estar interessados ou organizados para fazer lobby.

Outro ponto que impacta o grau de independência dos órgãos governamentais em relação aos interesses privados é o ambiente institucional no qual estão imersas. A independência também se aplica em relação aos interesses privados que são regulados e é um dos elementos de governança regulatória. Assim, "escolhas sobre governança regulatória são limitadas pelos dons institucionais específicos da nação, o que determina a forma e a severidade dos problemas regulatórios do país e a gama de opções para resolvê-los" ${ }^{781}$ A assertiva significa que não importa quão geniosa uma estrutura regulatória possa ser para evitar captura, pois esta pode acontecer se o país não possuir instituições que apoiem o regime adotado. O Brasil é um país em que o seu histórico patrimonialista o credencia para

\footnotetext{
$\overline{778}$ Talvez isso explique o porquê de o Cade não estar envolvido em muitas denúncias de corrupção, muito embora lide com interesses privados consideráveis. PAGOTTO, L. U. C. To what extent will the possibility of executing agreements with cartel members impact on the Brazilian Antitrust Policy?. In: FOX, E. M.; SOKOL; D. D. Competition policy in Latina America. Oxford \& Portland: Hart Publishing, 2009. p. 117 e ss.

${ }^{779}$ WILSON, James Q. The politics of regulation. In: FERGUSON, Thomas; ROGERS, Joel. The political economy: readings in the politics and economics of American public policy. 4. ed. Nova York: Basic Books, 1984. p. 385.

${ }^{780}$ Idem, ibidem. "[...] the cost of obtaining effective access to the political process has been dramatically lowered."

${ }^{781}$ LEVY, B.; SPILLER, P. T. A framework for resolving the regulatory problem. In: LEVY, B.; SPILLER, P. T. (Org.). Regulations, institutions, and commitment: comparative studies of telecommunications. Cambridge: Cambridge University Press, 1996. p. 4. "[...] choices about regulatory governance are constrained by the specific institutional endowment of the nation, which determines the form and the severity of the country's regulatory problems and the range of options for resolving them."
} 
que qualquer órgão administrativo seja extremamente suscetível a tais pressões. ${ }^{782}$ Seria ingenuidade defender uma ou outra repartição pública sob o argumento de que se é imune à captura: a história política demonstra um impressionante grau de permanência dessas práticas. $^{783}$

A assertiva também significa que, dependendo do ambiente institucional do país, as agências reguladoras independentes podem ser desnecessárias para levar a efeito políticas públicas com sucesso e eficácia. Adicionalmente, as instituições do Legislativo, do Executivo e do Judiciário, "normas que tacitamente limitem a ação dos indivíduos ou instituições", os interesses sociais em disputa e seu balanceamento, bem como a máquina administrativa pública, ${ }^{784}$ interagem como variáveis numa equação cujo resultado pode ser previsto com certa precisão, tendo-se em vista o comportamento pretérito. Uma burocracia fraca pode ser susceptível à captura e à corrupção, mas isso pode não ocorrer onde houver um Judiciário independente, que deseja executar políticas públicas mediante provocações de grupos de defesa do interesse público ou do Ministério Público. Essas combinações são múltiplas e apresentam correlações com a vida política real. Na França, a implementação de uma política industrial muito forte demandou o envolvimento íntimo entre o governo e os interesses privados, e, conseqüentemente, o estabelecimento de agências tendeu a ser influenciado pelas tradições históricas, traduzindo-se num grau muito alto de captura regulatória. Ao contrário, o Reino Unido, onde as conexões entre os setores público e

\footnotetext{
$\overline{782}$ Nesse sentido, ver LEAL, Victor Nunes. Op. cit. O correr dos anos levou a sucessivas atualizações da obra por ocasião de sua reedição, na medida em que a influência crescente da televisão e o crescimento das cidades com o despovoamento dos campos produziram uma nova situação social no país. O coronelismo diminuiu como prática política e se retirou para longe dos grandes centros, enquanto ao mesmo tempo entrava cena a figura do populista. Sua persistência, enquanto instituição de direito público costumeiro brasileiro, é impressionante, podendo ser constatada grandemente no Nordeste e no Centro-Oeste. Contudo, a simbiose entre os espaços público e privado permanece.

783 VIANNA, Francisco José de Oliveira. Instituições políticas brasileiras. Brasília: Conselho Editorial do Senado Federal, 1999. v. 1. p. 94. Referindo-se ao Brasil, Viana explica que "a estabilidade e a resistência às inovações caracteriza, destarte, os complexos culturais. Estes instalam-se na própria personalidade do homem. Quaisquer mudanças apresentam a tendência a influir só no aspecto exterior, deixando os elementos imanentes (sentimentos, emoções, idéias, julgamentos de valor) intactos. Quando algum elemento cultural é transplantado de fora da cultura, caso venha com grande força, ocupa a crosta do complexo cultural. O núcleo, porém, resta ileso. Assim, o decreto de Estado (lei), que estabelece a norma, cria apenas a norma - e isto não é bastante, porque a norma, elemento objetivo, é apenas um elemento do complexo - e não todo o complexo."

${ }^{784}$ LEVY, B.; SPILLER, P. T. A framework for resolving the regulatory problem. In: LEVY, B.; SPILLER, P. T. (Org.). Regulations, institutions, and commitment: comparative studies of telecommunications. Cambridge: Cambridge University Press,1996. p. 4.
} 
privado foram fracas ao longo da história, tende a possuir um grau mais baixo de captura do regulador pela indústria. ${ }^{785}$

A idéia de responsabilização final (accountability) permeia a relação entre captura e instituições ${ }^{786}$. Quanto mais houver transparência e responsabilização, mais fácil é para a sociedade civil perceber a captura das instituições. Especificamente quanto às agências reguladoras, a questão democrática é objeto de críticas à descentralização dos centros de tomada de decisão na estrutura estatal. ${ }^{787}$ Quanto mais restrita a participação popular na agência reguladora, mais fácil a indústria poderia capturá-la, porque ninguém estaria prestando atenção ao que acontece na máquina burocrática. Bons indicadores de transparência podem ser a justificação de suas decisões e a participação popular - ambos refletiriam indiretamente se houver indícios de captura e talvez corrupção. Neste aspecto, a participação efetiva deve ser considerada: a mera abertura de consulta pública é insuficiente, caso haja uma predisposição para defender com afinco as posições previamente assumidas pelo regulador. Esta parece ter sido a prática no Brasil, onde o respeito às formalidades supera o respeito às finalidades condizentes com o interesse público.

Tanto a responsabilização final quanto as questões democráticas constituem diferentes aspectos do mesmo problema. Segundo o raciocínio de Majone, "o meio mais simples e mais básico de melhorar a transparência é a responsabilização final de uma agência e requerer que os reguladores apresentem justificativas de suas decisões". ${ }^{788} \mathrm{Tal}$ prática permite avaliar o grau de influência dos interesses privados sobre o guardião do interesse público.

A amplitude dos setores regulados também influencia a existência de captura regulatória. Conforme sua atuação, os órgãos governamentais, incluindo as agências reguladoras podem ser divididas em duas categorias: horizontais e verticais. A primeira está encarregada de regular uma grande amplitude de setores, ao passo que a segunda tem ênfase mais restrita, geralmente voltada para apenas uma atividade ou setor econômico

\footnotetext{
$\overline{785}$ THATCHER, Mark. From industrial policy to a regulatory state: contrasting institutional change in Britain and France. In: HAYWARD, J. E. S.; MENON, A. Governing Europe. Oxford: Oxford University Press. p. 324-325.

786 BALDWIN, R.; CAVE, M. Understanding regulation: theory, strategy and practice. Oxford: Oxford Universitu Press, 1999. p. 313.

${ }^{787}$ MAJONE. G. From the positive to the regulatory state: causes and consequences of changes in the mode of governance. Journal of Public Policy, Cambridge: Cambridge University Press, n. 17, p. 159-163.

${ }^{788}$ Idem, p. 160. "[...] the simplest and most basic means of improving agency transparency and accountability is to require regulators to give reasons for their decisions." O artigo 50 da Lei n. 9.784, de 21 de janeiro de 1999, não prevê explicitamente a necessidade de justificar o ato administrativo de escolha de uma dada regulação, muito embora tal dever possa defluir do princípio geral.
} 
específico. ${ }^{789}$ Um exemplo de agência horizontal é a agência antitruste, que é responsável por monitorar o comportamento de todos os mercados relevantes e, por isso, seria menos vulnerável à captura pelos interesses regulados. Como Wilks e Bartle descrevem, "as agências de defesa da concorrência são relativamente impermeáveis ao lobby das indústrias e não priorizam as opiniões dos líderes e organizações industriais". ${ }^{790}$ Os autores fundamentam sua opinião descrevendo o funcionamento das agências de defesa da concorrência em países desenvolvidos como não influenciado pela indústria e enfatizando sua independência política.

Em sentido oposto, aqueles órgãos com atuação vertical tendem a ser mais facilmente capturadas, trabalham mais próximo dos interesses regulados e dependem mais da colaboração destes para ter acesso às informações relevantes, sem as quais não podem desempenhar sua função. ${ }^{791}$ Os reguladores segmentados dos mercados financeiros, criados para substituir a "auto-regulação cavalheiresca" (gentlemanly self-regulation) em alguns países, ${ }^{792}$ são provavelmente o outro extremo. Seu objetivo é manter a estabilidade, o que quase sempre significa regular o mercado para manter o status quo - pouco importa se a manutenção do status quo significa perseguir algum tipo de interesse público maior ou não.

A diferença entre esta classificação e aquela baseada no tipo dos interesses regulados reside no fato de a última focar apenas a estrutura da agência, enquanto a primeira considera os custos e os benefícios da regulação. Embora algumas vezes as conclusões possam ser as mesmas, elas se diferenciam metodologicamente. Ainda assim, pode-se imaginar um órgão governamental vertical não capturado, cujos benefícios estejam dispersos e os custos para se fazer lobby sejam concentrados - um único órgão regulador para todo o setor financeiro poderia ser um exemplo, pois continua como regulador vertical do setor, mas com competência expandida a todos os mercados financeiros e não apenas a parte deles.

Por fim, o comportamento do órgão governamental também deve ser mencionado quando a captura do regulador está sob análise. Num texto clássico sobre as agências reguladoras, Bernstein descreve o processo de envelhecimento das agências, que tendem a sofrer uma perda no seu entusiasmo à medida que o tempo passa, identificando quatro fases do seu ciclo de vida: o estágio preparatório, denominado gestação; a juventude, em que são

\footnotetext{
$\overline{789}$ WILKS, S.; BARTLE, I. The unanticipated consequences of creating independent competition agencies. West European Politics, Abingdon: Routledge, v. 25, n. 1, p. 149.

${ }^{790}$ Idem, p. 170. "Competition agencies are relatively impervious to industrial lobbying and do not give priority to views from leading industrialists and industrial organisations."

${ }^{791}$ BALDWIN, R.; CAVE, M. Op. cit., p. 2.

${ }^{792}$ HOOD, C. Op. Cit. p. 29
} 
inexperientes e manobráveis apesar do forte desejo de perseguir seus objetivos institucionais; a idade madura, quando já adquiriram conhecimento técnico e começam a prestar atenção às demandas da indústria, mas o apoio político já findou; e, finalmente, a idade senil, quando perdem todo o entusiasmo e tendem a servir mais aos interesses privados do que aos do público em geral. Nessa fase, a indústria dita a agenda do órgão e a captura se torna nítida - é a fase em que a corrupção pode se institucionalizar no órgão. Quanto mais velha a agência, mais provável a captura. ${ }^{793}$ Todavia, o valor da teoria do ciclo da vida repousa na identificação da atuação estatal mutante no decorrer do tempo, mas tais transformações não seguem necessariamente o ciclo da vida. Uma agência pode nascer muito ativa, perder vitalidade e, algum tempo depois, recuperar poder e vontade para se afastar da influência da indústria. Do mesmo modo, não se pode ignorar o impacto que as diretrizes do governo possuem sobre a administração pública - os responsáveis pelas agências reguladoras podem ditar ou não uma agenda positiva. Por essa razão, uma regra melhor para o comportamento das agências seria a seguinte: quanto mais proativa a agência, menos provável será a captura.

Com algumas modificações, o raciocínio pode ser transposto aos demais setores da administração pública que não são dotados de independência como as agências reguladoras. Ao mostrar os vários elementos que influenciam o comportamento das agências, bem como as relações entre elas e os setores econômicos, demonstra-se que, para que se dê consoante a teoria tradicional das agências reguladoras, a captura do regulador depende de certas circunstâncias. É difícil dissociar o interesse público do privado, particularmente no contexto do estado patrimonialista brasileiro, no qual esses comportamentos se encontram acirrados.

$\overline{793}$ BERNSTEIN, M. H. Regulating business by independent commission. Westport, Conn.: Greenwood Press, 1977. p. 1-25. 


\title{
PARTE III \\ PREMISSAS PARA O COMBATE À CORRUPÇÃO NO PLANO MACROJURÍDICO
}

\section{CAPÍTULO 7 \\ O FATO CORRUPÇÃO VISTO SOB A ÓTICA DO DIREITO ECONÔMICO}

$\mathrm{Na}$ Parte I, demonstrou-se de que maneira o direito pressuposto brasileiro opera atualmente para moldar o Estado patrimonialista e subverter a lógica da separação entre público e privado. Particularmente o capítulo 3 identificou como afloram no direito posto influxos socioculturais subterrâneos que, historicamente articulados, desacreditam a legitimidade estatal - tratou-se do fato corrupção. O resultado foi uma importação deformada do próprio Estado de Direito pela formação peculiar de uma máquina burocrática e de positivismo jurídico. Grau e Belluzzo sintetizam a lógica que motivou o estudo, ao expor como se estruturou a formação do Estado com base nos interesses revelados:

\begin{abstract}
O Estado é descrito como deve ser, jamais como é. Isso, entre inúmeras outras distorções, conduz à radicalização do princípio da presunção da legitimidade dos atos administrativos. Quando não se comprove que o ato não passa de uma farsa, a esconder o escuso interesse particular travestido em interesse público, o desvio de finalidade não é questionado e supõe-se que o Estado esteja a atuar em nome do interesse público.

O Estado brasileiro, como produto histórico, cumpriu sua tarefa com grande brilhantismo, dentro dos limites impostos pelas formas de estratificação e de dominação social que o engendraram. ${ }^{794}$
\end{abstract}

$\mathrm{Na}$ Parte II, utilizando-se a típica visão multidisciplinar do direito econômico, analisaram-se as ferramentas tradicionais de combate à corrupção e sua aplicação, bem como se apresentaram algumas plausíveis formas de aumentar a eficiência do combate à corrupção - na terminologia do direito econômico, tratou-se do fato corrupção isoladamente, "tomado

\footnotetext{
$\overline{794}$ BELLUZZO, Luiz Gonzaga de Mello; GRAU, Eros Roberto. A corrupção no Brasil. Revista Brasileira de Estudos Políticos, Belo Horizonte: UFMG, n. 80, p. 13, jan. 1995.
} 
como fundamento do Direito", no qual "se coloca a relação entre o Direito e a Ciência Econômica". 795

O fato corrupção desdobra-se tanto em fato isolado, tomado como fundamento do direito penal, administrativo e político-constitucional, quanto em fato que escapa a essa regulamentação. Os problemas de fundo, especialmente os relacionados ao aspecto político da corrupção, conducentes à corrupção-solapamento, escapam a esse viés repressivo do direito posto penal, administrativo e político-constitucional.

A abordagem da regulamentação microjurídica possui sua utilidade e relevância. A alteração formal de instituições facilitadoras da prática da corrupção contribui, indiretamente, para a depuração do que se deve entender por confiança, bem como para a melhor visualização das fronteiras entre o público e o privado. Todavia, a corrupção também possui causas de outra natureza, associadas aos fundamentos estruturais e funcionais do próprio Estado brasileiro, e não podem ser somente extirpadas, v.g., por meio de mudanças no sistema de compras públicas. Assim, certas soluções microjurídicas podem não produzir os efeitos esperados, na medida em que outras causas permanecem intocadas. O influxo positivo proveniente de eventuais avanços no plano microjurídico é subvertido pelas condicionantes que envolvem as práticas macrojurídicas. A capacidade desagregadora da ausência de valores associados à confiança dessas práticas histórico-culturais contamina toda a distinção entre as esferas pública e privada, realimentando a prática da corrupção. Compreender como tais práticas contaminam o funcionamento da República é o primeiro passo para conceber estratégias de combate à corrupção.

É justamente essa parcela de corrupção não regulada pelo direito que se torna objeto de crítica do direito econômico. ${ }^{796} \mathrm{~A}$ sua não regulamentação não a exclui da preocupação do direito econômico. Trata-se de área que possivelmente demanda alguma regulamentação

\footnotetext{
$\overline{795}$ GRAU, Eros Roberto. Elementos de direito econômico. São Paulo: Revista dos Tribunais, 1981, p. 25.

${ }^{796}$ NUSDEO, Fábio. Fundamentos para uma codificação do direito econômico. 1993. 226 f. Tese (Titular) Faculdade de Direito, Universidade de São Paulo, São Paulo. p. 37-38. Nusdeo sintetiza as duas concepções principais sobre o direito econômico que são utilizadas neste capítulo: "As normas de Direito Econômico, para a maioria dos autores, constituem, não propriamente um ramo independente da árvore jurídica, ao lado dos tradicionais Direito Administrativo, Comercial, Civil e todos os outros, mas, muito mais, um conjunto de normas com vetorialidade especial, as quais se inserem de permeio a esses outros ramos, marcando-os com sua presença. Esse entendimento do Direito Econômico não discrepa daquele outro, segundo o qual ele é muito mais um método de interpretação e de análise do Direito do que propriamente um conjunto de normas, muito menos, é claro, um ramo autônomo. E não discrepa porque, em última análise, esse método decorre ou se faz necessário em virtude das diretrizes básicas de política econômica, que nenhum país deixa de adotar, diretrizes essas que acabam por seccionar todos os ramos do Direito, matizando as normas até aqui vistas como próprias a cada um deles. Gera-se, por essa forma, um método próprio de interpretação legal, abrangente e específico ao mesmo tempo, pois não se atém às peculiaridades de cada ramo, mas à visão mais ampla daqueles princípios e daquelas diretrizes que informam os objetivos e os instrumentos da política econômica."
} 
macroeconômica, embora não haja consenso a respeito. ${ }^{797}$ Como a referência histórica ao problema é insuficiente, faz-se necessário investigar como a corrupção solapa o interesse público traçado pela Constituição de 1988.

Uma crítica possível a essa abordagem do direito econômico seria a de que a ampliação excessiva do que é estudado (fato corrupção) levaria à perda da centralidade do objeto. A corrupção vista pela regulamentação microjurídica é bem identificada e delimitada, quer seja pelo direito propriamente dito, quer seja pelas ciências informativas da sua ação - o pagamento puro e simples de propina a um funcionário público para obter uma vantagem, devida ou não, caracteriza corrupção na maioria dos ordenamentos jurídicos modernos. Ao se expandir o que se entende por corrupção, porém, a polêmica sobre seus contornos exatos se instala. "Isso faz parte do jogo político" é a alegação mais comum para desviar o foco e repelir a qualificação de corrupta para certa prática em que há subversão do valor confiança e confusão entre as esferas do público e do privado.

Essa ampliação ilumina o outro lado da moeda do fato corrupção. A mercantilização do estudo sobre a corrupção reduziu a problemática a mero jogo matemático em que as ações dos agentes podem ser medidas, estimuladas e desestimuladas por instituições circundantes. ${ }^{798}$ Os incentivos e desincentivos por trás da motivação dos agentes evidenciam os fatores que alteram os interesses envolvidos, mas compreendem apenas parte do fato corrupção.

Em realidade, o que se pode criticar é a redução ocorrida no que se entende por corrupção. Aristóteles associava a corrupção à deterioração do sistema político em relação a um modelo idealizado, concepção que prevaleceu na teoria política até o século XIX - no Brasil Império, “corruptos eram os sistemas, monárquico ou republicano, por serem, na visão dos acusadores, despóticos, oligárquicos, e não promoverem o bem comum" ${ }^{799}$ Em outras palavras, o foco era a corrupção na perspectiva da regulamentação macrojurídica.

\footnotetext{
${ }_{797}$ FERREIRA FILHO, Manoel Gonçalves. Corrupção e democracia. Revista de Direito Administrativo, Rio de Janeiro: Renovar, v. 226, p. 216, out./dez. 2001. “A corrupção que se há de combater na democracia é aquela que se envolve retribuição material. Esta, sim, perverte as suas instituições e seus mecanismos. É a que tem que ser reprimida, é a que deve ser prevenida. Outras práticas poderão não ser a-éticas, não configuram corrupção. Estender a estas o labéu de corrupção é alargar de tal forma o conceito que este se torna impreciso e inútil. Pode servir a objetivos políticos, ou da videodemocracia, foge a um tratamento objetivo da questão."

${ }^{798}$ Ver análise empreendida no capítulo 6, supra.

${ }^{799}$ CARVALHO, José Murilo de. Passado, presente e futuro a corrupção brasileira. In: AVRITZER, Leonardo et al. (Org.). Corrupção: ensaios e críticas. Belo Horizonte: UFMG, 2008. p. 238. "As acusações de corrupção dirigidas ao Império e à Primeira República não se referiam a pessoas, mas principalmente ao sistema. Nenhum republicano acusava D. Pedro II de presidir uma administração corrupta ou de ser ele mesmo corrupto. Em 1930, quando os revolucionários chamavam de carcomidos aos políticos da Velha República, não queriam dizer que eram ladrões. Nos dois casos, a acusação era dirigida ao sistema, não às pessoas."
} 
Todavia, essa associação da corrupção ao sistema político não excluía a responsabilidade pessoal dos corruptos; pelo contrário, boa medida da corrupção do sistema devia-se à corrupção na perspectiva microjurídica, que não era percebida necessariamente como algo nefasto em razão da mentalidade da época. O Estado era usado como propriedade particular de seus detentores, mas esse comportamento não era concebido como corrupção - a sociedade não esperava nada do Estado, de modo que inexistia a ideia de que seu fim era a busca do bem comum. Tampouco essa associação excluía a existência de relações recíprocas entre o que se reprimia no microjurídico e o que se verificava no macrojurídico.

Esse descasamento se acentua quando o Brasil se urbaniza e a modernização da máquina burocrática se acentua a partir do Estado Novo; nesse momento, o verniz modernizante do direito posto começa a ter apelo para parcela da sociedade civil. Entretanto, a noção de Estado de Direito não se verifica na realidade como a doutrina jurídica importada da Europa sugeria. O discurso político oposicionista da UDN nos anos 1950 atacava o "mar de lama" do governo de Vargas, encontrando eco mais forte na nascente classe média, pagadora dos tributos. Nesse momento, a velha noção aristotélica de corrupção cede lugar a uma visão mais restrita. Não obstante, ambas continuam a se relacionar simbioticamente.

Mesmo metamorfoseados, ainda é possível encontrar traços de persistência desse Estado patrimonialista no pós-1988, quer seja no plano sociocultural, quer seja no plano jurídico-institucional. Na terminologia de Grau, no pós-1988 o direito pressuposto do Estado patrimonialista se encontra presente em vários institutos do direito posto ou no modo como estes são instrumentalizados formalmente - não há nada de errado na aparência, mas, funcionalmente, esses institutos não atendem aos valores e finalidades para os quais foram criados. Um aspecto para o qual a literatura sobre corrupção não dá tanta ênfase é a relação entre o processo de construção de uma nação e a corrupção.

No que diz respeito à herança colonial, certos países colonizadores teriam transmitido heranças culturais e institucionais menos propensas à corrupção do que outros. $\mathrm{O}$ caso mais explorado é o das antigas colônias britânicas, que seriam menos corruptas do que as de outros países europeus - veja-se a abundante literatura sobre a superioridade dos valores da Common Law sobre os da Civil Law. Os dados estatísticos sugerem que ex-colônias britânicas exibem menores índices de corrupção, ${ }^{800}$ mas estudos adicionais são necessários para se concluir algo.

\footnotetext{
$\overline{800}$ TREISMAN, D. The causes of corruption: a cross-national study. Journal of Public Economics, v. 76, n. 3, p. 345-346, June 2000. "Countries that were British colonies (or the UK) have significantly lower perceived
} 
Embora esse determinismo pareça impregnado de uma visão ideologizada e centrada no mundo anglo-saxão, cada sociedade experimentou um processo de formação distinto. Furtado ressalta que diferenças no processo de colonização entre as colônias inglesas, as quais deram origem aos Estados Unidos e ao Canadá, e o ocorrido com as colônias luso-espanholas, que resultaram nas nações latino-americanas, redundaram em diferentes graus de desenvolvimento na atualidade. ${ }^{801}$ Há até quem tenha observado que a primeira construção numa cidade norte-americana era uma escola, ao passo que numa cidade do Brasil colonial tal construção seria o pelourinho, um lugar de castigo para criminosos e escravos rebeldes, símbolo do poder do Estado ou do senhor. Esses distintos modos de colonizar tiveram influência significativa na formação de variados aspectos da organização social, inclusive no que diz respeito às relações entre as esferas pública e privada.

No histórico brasileiro, boa parcela da estruturação do Estado patrimonialista se deu em bases conceituais formalmente semelhantes aos processos de afirmação das nacionalidades europeias, apesar de o substrato sociocultural ser distinto. Contudo, a importação da dicotomia público-privado não foi acompanhada de uma correspondente mudança no substrato sociocultural. Os interesses privados de certos grupos, não necessariamente idênticos aos dos que se apossaram do Estado patrimonialista, conseguiram se sobrepor aos interesses públicos, quer seja pela apropriação pura e simples de parcelas do patrimônio público via corrupção-suborno, quer pela impessoalização das relações estatais com a sociedade via corrupção-favorecimento. Ambas as formas, já abarcadas e reprimidas pela regulamentação microjurídica do direito posto, alimentam e são alimentadas pela corrupção em sentido aristotélico, que, na maioria dos casos, solapa as instituições, passa ao largo do sancionamento jurídico e semelhantemente corrói a dicotomia público-privado, talvez até com maior perversidade do que as duas primeiras.

Se não parece provável que haja uma regulamentação adequada do fato corrupção nessa amplitude macrojurídica, este capítulo mostrará como o direito posto brasileiro, inspirado pela dicotomia público-privado, se encontra em confronto com o direito pressuposto, ainda fortemente impregnado socioculturalmente pelos traços do Estado

corruption. This might reflect the fact that most former British colonies have common law legal systems. Slightly stronger evidence suggests, however, that the British heritage effect is linked to a distinct 'legal culture' governing the way the law is administered and enforced: a preoccupation with procedural fairness even at the expense of social hierarchy. The lower perceived corruption among former British colonies was significant not just in the older settlement colonies, but also in more recently acquired African and Asian crown colonies and mandates."

${ }^{801}$ FURTADO, Celso. Formação econômica do Brasil. 24. ed. São Paulo: Nacional, 1991, p. 19-23. 
patrimonialista, inclusive após a Constituição de $1988 .{ }^{802}$ Como todas as divisões de fases e períodos históricos, a escolha de 5 de outubro de 1988, data em que a atual Constituição foi promulgada, pode ser criticada. Por que escolher a Constituição de 1988 como divisor de um período se certas práticas corruptas existiam desde antes e continuam a existir mesmo após sua promulgação ${ }^{803}$ No cenário pós-1988 se encontram consolidadas algumas características normalmente associadas ao desenvolvimento político e econômico: em que pesem a má distribuição de renda e indicadores sociais ruins, a atual Constituição tem garantido o pleno funcionamento do regime republicano e democrático num país urbano e industrial, bem diferente da realidade associada ao Estado patrimonialista brasileiro por Faoro e Leal, mas ainda marcado por profundas desigualdades sociais e baixos níveis de escolaridade.

Ao longo da exposição, serão estudados alguns aspectos sutis do funcionamento e da prática do direito brasileiro que, apesar de aceitos socialmente em virtude de processos ideológicos como o adesismo social, se encontram contaminados pela corrupção-solapamento. Sob o manto do legal, o processo de utilização do Estado pelos interesses privados produz profundos impactos sob vários aspectos da ação do mesmo Estado, desvirtuando-se a busca do bem comum. Para tanto, serão analisados (i) o funcionalismo público e sua relação com o corporativismo; (ii) a transparência das decisões estatais; (iii) os riscos decorrentes da discricionariedade; (iv) a assimetria entre as atribuições e meios dos entes federados; e (v) o orçamento da União enquanto locus de tensão entre os diferentes interesses. Antes, porém, a questão da autoridade no Estado patrimonialista deve ser abordada em face da teoria geral do direito, a fim de fornecer um referencial para a análise crítica.

\subsection{Poder, dever e autoridade na teoria geral do direito e na realidade do Estado patrimonialista}

No Estado de Direito, o poder é um dos modos como se manifesta para os cidadãos o princípio da soberania do interesse público. Entretanto, essa faceta não encerra a totalidade do aspecto fático do fenômeno poder. Em sua essência ontológica, o fato poder se manifesta sob diversas maneiras, tais como no uso da coação ou da coerção, na força, na pressão social

\footnotetext{
$\overline{802}$ BELLUZZO, Luiz Gonzaga de Mello; GRAU, Eros Roberto. A corrupção no Brasil. Revista Brasileira de Estudos Políticos, Belo Horizonte: UFMG, n. 80, p. 18 jan 1995. "O sistema de forças, que se abrigava sob a pele do regime militar, sobreviveu incólume à transição democrática. Pior que isso, durante estes anos de observância das regras democráticas, cresceu sem parar o poder do veto e de bloqueio destas forças sobre qualquer iniciativa política ou econômica capaz de alterar o status quo."

${ }^{803}$ Para uma síntese dos escândalos da Nova República, ver RIBEIRO, Antonio Silva Magalhães. Corrupção e controle na administração pública brasileira. São Paulo: Atlas, 2004. p. 53-78.
} 
difusa, no enquadramento coletivo e na propaganda ${ }^{804}$ nos recursos ou provisões ${ }^{805}$ e, também, na possibilidade de um grupo ou pessoa limitar as opções de comportamento de outros grupos ou pessoas, visando a objetivos próprios. ${ }^{806}$ Importante manifestação poder - enquanto fenômeno isolado ${ }^{807}$ - consiste na "capacidade de um indivíduo ou grupo de indivíduos de levar a cabo sua vontade, mesmo com a resistência de outros indivíduos ou grupos" ${ }^{808}$ Não deve ser tido como uno ou indivisível, ou seja, a titularidade do poder por uma pessoa ou grupo não exclui a possibilidade de outra pessoa ou grupo ter o mesmo ou maior poder. ${ }^{809}$

Fica claro que o fato poder (fenômeno isolado) não é exclusivo da organização política e está presente em todos os aspectos da vida social, inclusive no âmbito do direito privado, como na grande empresa, na família e no condomínio. O coronel do interior, o presidente de uma estatal, o deputado federal e o chefe do Executivo possuem poder, seja do ponto de vista social, político, econômico ou cultural; onde quer que haja alguma diferença entre os indivíduos ou entidades, a desigualdade fática gerará uma relação em que um se encontrará em posição de superioridade ao outro. Quando essa relação extrapola os limites do quanto o direito (no sentido de direito posto) a concebe, se está diante do que se pode denominar dominação.

Possivelmente em virtude das consequências políticas do exercício do fato poder, este foi mais investigado pelos interessados no Estado. Como explica Weber, a comunidade política reservou para si um âmbito de ação dentro do qual age por meio de uma pessoa ou de

\footnotetext{
$\overline{804}$ DUVERGER, Maurice. Ciência política: teoria e método. Rio de Janeiro: Zahar, 1976.

${ }^{805}$ ARON, Raymond. Paz e guerra entre as nações. Tradução de Sérgio Bath. Apresentação de Vamireh Chacon. 2. ed. Brasília: UnB, 1986.. p. 99-103. O sociólogo francês diferencia o poder (pouvoir), exercido no seio das unidades politicamente organizadas, da potência (puissance), característica externa das unidades políticas. Todavia, em português, o uso permite atribuir poder tanto aos Estados quanto às pessoas e aos grupos internos; a potência refere-se somente às unidades políticas.

${ }^{806}$ DAHL, Robert A. Análise política moderna. Brasília: UnB, 1981. p. 24-25.

${ }^{807}$ FERRAZ JR. Tercio Sampaio. "Teoria da norma jurídica: um modelo pragmático". In: FERRAZ, Sérgio (org.) A norma jurídica. Rio de Janeiro: Freitas Bastos, 1980. p. 14. "A doutrina costuma encará-lo, porém, como simples fato extrajurídico, o que ocorre sobretudo no direito privado, mas também no direito público, onde a noção de poder é esvaziada pelas limitadas e restritivas concepções vigentes nos currículos jurídicos em termos de Teoria Geral do Estado. Tradicionalmente, a noção de poder costuma ser assinalada nos processos de formação do direito, na verdade como um elemento importante, mas, que esgota sua função quando o direito surge, passando, daí por diante, a contrapor-se a ele nos termos da dicotomia do poder e direito, como se, nascido o direito, o poder se mantivesse um fenômeno isolado (em termos de arbítrio, força) ou então um fenômeno esvaziado (poder do Estado, juridicamente limitado). Como fenômeno isolado ele aparece, assim, como algo que põe em risco o próprio direito; como fenômeno esvaziado surge como um arbítrio castrado, cujo exercício se confunde com a obediência e a conformidade às leis. Nessa dicotomia aflora uma concepção limitada do próprio poder, tido como uma constante transmissível, como algo que se tem, que se ganha, que se perde, que se divide, que se usa, perdendo-se, com isto, uma dimensão importante do problema, localizado na relação à complexidade social e às exigências de formas de organização a ela compatíveis."

${ }^{808}$ BODENHEIMER, Edgar. Teoría del derecho. 2. ed. Tradução de Vicente Herrero. México: Fondo de Cultura Económica, 1946. p. 20. "En sentido sociológico, el poder es la capacidad de un individuo o grupo de individuos de llevar a la práctica su voluntad, incluso a pesar de la resistencia de otros individuos o grupos."

${ }^{809}$ DAHL, Robert A. Op.cit. p. 24-25.
} 
um grupo de pessoas, no interesse do conjunto, e, se necessário, faz uso da força para efetivar tal ação $0^{810}$ - o uso da força é a forma mais marcante do fato poder, mas não precisa sempre se verificar para que se reconheçam situações de sujeição. O poder, utilizado imperativamente pelo Estado enquanto comunidade política, para fazer prevalecer sua ação sobre tudo e todos que se encontrem em seu território, inclusive outras comunidades, políticas ou não, ${ }^{811}$ denomina-se imperium ou soberania. ${ }^{812}$

Há limitações ao fato poder descrito acima e, neste momento, o fato poder deve ser diferenciado do poder, tal como entendido pela teoria geral do direito. O sociólogo Weber observa que as normas jurídicas e os direitos subjetivos o restringem. ${ }^{813}$ Fora desse âmbito, estabelecido por vários processos sociais, tais como o costume, a religião e a legislação, o Estado não interfere, e as demais forças sociais podem exercer seu poder até os limites da lei. Com o surgimento da comunidade política denominada Estado, o poder constituinte, proveniente do corpo social, ergue barreiras contra possíveis abusos futuros do poder constituído. ${ }^{814}$ Ao impor ao "detentor do poder a observância de certas normas" ou "regras gerais de conduta", o direito caracteriza-se como um dos limitadores do poder, razão pela qual é um dos instrumentos de controle do poder. ${ }^{815} \mathrm{O}$ exercício do poder como fenômeno esvaziado (limitado juridicamente) confunde-se com a obediência e a conformidade às leis.

Contrapondo-se a tendência limitadora do direito (no sentido do direito posto) ao caráter expansivo do fato poder, vislumbra-se um foco constante de tensão entre ambos que se extravasa no Estado patrimonialista brasileiro. De fato, as relações de poder manifestam-se sob várias formas e condições, muitas das quais escapam à apreciação jurídica por constituírem fatos ou atos não abarcados por qualquer fattispecie. Quando tratado pelo direito, o fato poder surge como algo a ser controlado. ${ }^{816}$ No Estado patrimonialista, esses limites tornam-se frouxos.

\footnotetext{
$\overline{810}$ WEBER, Max. Economia e sociedade: fundamentos da sociologia compreensiva. Tradução de Regis Barbosa e Karen Elsabe Barbosa. Revisão técnica de Gabriel Cohn, v. 2, 3. ed. Brasília: UnB, 1999. p. 155.

${ }^{811}$ FARIA, José Eduardo. O direito na economia globalizada. São Paulo: Malheiros, 2000. p. 18.

${ }^{812}$ DALLARI, Dalmo de Abreu. Elementos de teoria geral do Estado. 19. ed. atual. São Paulo: Saraiva, 1995. p. 93-94.

${ }^{813}$ WEBER, Max. Op. cit. p. 3-4.

814 FERRAZ, Anna Cândida da Cunha. O poder constituinte do Estado-membro. São Paulo: Revista dos Tribunais, 1979. p. 15.

${ }^{815}$ BODENHEIMER, Edgar. Teoría del derecho. Op. cit. p. 29. "Para evitar la anarquía, el Derecho limita el poder de los individuos particulares; para evitar el despotismo, enfrena el poder del gobierno. [...] Pero no toda limitación del poder puede ser denominada Derecho. Es posible que el poder se vea limitado por otro poder igual o superior en fuerza, por la fuerza pura o por hechos naturales. Solo una limitación que imponga al detentador del poder la observancia de ciertas 'normas', es decir, reglas generales de conducta, es Derecho."

${ }^{816}$ FERRAZ JR., Tercio Sampaio. Introdução ao estudo do direito: técnica, decisão e dominação. 2. ed. São Paulo: Atlas, 1994. p. 346. "[...] a dogmática da decisão constrói um sistema conceitual que capta a decisão como um exercício controlado do poder, como se as relações sociais de poder estivessem domesticadas.
} 
Um dos reflexos de como as autoridades agem no Estado patrimonialista impacta o exercício do poder. Desdobramento quase que lógico da evolução histórica do patrimonialismo no Brasil, as autoridades investidas de poder usam-no de forma pessoalizada em várias circunstâncias que requereriam impessoalidade: viagens oportunistas, obras associadas a políticos, autopromoção por realizações do próprio Estado e uso de recursos públicos para fins políticos são algumas dessas situações que, aliás, em parte dos casos, recebem o beneplácito da população. Em realidade,

[...] a situação é pelo menos ambígua, quando o uso do poder se desvia do interesse geral para atender a interesses de grupos ou mesmo a interesses pessoais. Isto é, quando busca favorecer um segmento da sociedade, eventualmente atendendo a suas reivindicações, ou visa a promover o prestígio do governante, ou mesmo a criar a base de sustentação de que este necessita para executar uma política governamental. Numa visão rígida, o governante que leva uma obra, ou investimento, para a sua base eleitoral, ou promove uma medida para aumentar sua popularidade, estaria incidindo em corrupção. Da mesma forma, o parlamentar que insere num projeto disposição que beneficia grupo que o prestigia ou apóia, ou obtém do governo o atendimento de uma reivindicação. E neste caso também o governante que o atende, por exemplo para contar no futuro com seu voto nas deliberações congressuais. ${ }^{817}$

No Estado patrimonialista, o detentor do poder considera como um direito seu (no sentido de direito subjetivo) o exercício do poder estatal. Traduzido em termos de teoria geral do direito, o detentor do poder se enxerga tal como o proprietário de um bem que possui direitos erga omnes em relação à coisa, bem como certas obrigações decorrentes dessa propriedade. Como desdobramento dessa situação, o detentor do fato poder transforma-se em proprietário do Estado e, nessa condição, trata desigualmente os iguais, criando bolsões de privilegiados. A apresentação do detentor do fato poder não faz surgir tantos questionamentos na relação vertical Estado-cidadão, mas sim na relação horizontal entre os cidadãos:

Seria fácil, mas incompleto e por isso mesmo enganoso imaginar que a questão da
autoridade diz respeito a um problema vertical da relação do "governo" com o
"povo", ou de pura obediência. É mais adequado perceber que se trata de um
problema horizontal: da relação dos cidadãos entre si, ou de uma parte do povo com
a outra parte, ou de uma parte com todos. O tema é o do respeito recíproco, que
implica uma noção universal de liberdade e dignidade. J.S. Mill notara que, uma vez
estabelecidos os princípios da liberdade política sob a forma da soberania popular,
surgia imediatamente a questão da liberdade civil, ou seja, da opressão recíproca que
os membros do povo exerceriam sobre si. Muito embora sua preocupação fosse com
a tirania da maioria sobre as minorias em termos de opinião, costumes ou vida
privada, faz sentido pensar que na sociedade democrática, em que os estados (status)
e a honra não devem contar, a discriminação na aplicação da lei, a criação de grupos
impunes, resulta em uma forma de opressão de uma parte do povo por outra. ${ }^{818}$

Sublinha-se a força e, com isso, se diminui a carga emocional da presença da violência do direito. Torna-se possível falar da violência não como vis física, concreta e atual, mas no sentido simbólico de ameaça."

${ }^{817}$ FERREIRA FILHO, Manoel Gonçalves. Corrupção e democracia. Revista de Direito Administrativo, Rio de Janeiro: Renovar, vol. 226, p. 215, out./dez. 2001.

${ }^{818}$ LOPES, José Reinaldo de Lima. Direitos humanos e tratamento igualitário: questões de impunidade, dignidade e liberdade. Revista Brasileira de Ciências Sociais. [online]. 2000, v. 15, n. 42, p. 77-100. Disponível 
Tais considerações sociológicas se referem ao aspecto fático do poder. Contudo, sob o viés do direito, a sua qualificação jurídica precisa ser elaborada.

O processo de modernização do Estado brasileiro, realizado por meio da importação da dicotomia público-privado, reposicionou a relação entre as autoridades e o poder. Num Estado de Direito, minimamente assentado sobre as premissas da racionalidade e da dominação burocrática, não há espaço para o personalismo. Por isso, numa organização social, seja ela estatal ou privada, torna-se relevante a definição de função enquanto "um cargo de trabalho na sociedade, o qual consiste em colocar sua atividade à disposição do público para uma tarefa determinada". ${ }^{819}$ Se a função é desenvolvida independentemente, fora de uma organização, ela se submete às regras ordinárias do direito privado. Dentro de uma organização, estatal ou não, a função apresenta um caráter dependente, na medida em que seu exercente, titular de prerrogativa, vocaliza a mesma organização da qual é dependente. ${ }^{820}$

Com a modernização do Estado, muitas das manifestações do fato poder são canalizadas pelo ordenamento jurídico e colocadas num caminho a ser seguido para a busca de uma finalidade. Dentro do Estado moderno, não cabem os fins egoístas, "que têm por objeto a sua própria pessoa com exclusão da sociedade, isto é, de qualquer outra pessoa, de qualquer outro fim superior". ${ }^{821}$ Conforme explica Roubier, da perspetiva da teoria geral do direito, os altos mandatários das organizações políticas não adquirem direitos subjetivos em seu benefício em virtude do exercício de sua função e correm o risco de perder a função a cada pleito. ${ }^{822}$ Somente há espaço para "fins sociais", voltados para a "vida em comum e aos quais se liga também a missão do Estado". ${ }^{823}$ Se os titulares da prerrogativa agem em desconformidade com a sua função, isso caracteriza uma forma de corrupção. Para Kelsen, a domesticação do poder será uma das contribuições do direito a auxiliar na formação da sociedade. ${ }^{824} \mathrm{O}$ poder, apresentado como o "elemento de luta, guerra e sujeição", cede espaço, nos campos historicamente considerados mais significativos pela sociedade, ao direito,

em: <http://www.scielo.br/scielo.php?script=sci_arttext\&pid=S0102-69092000000100006\&lng=en\&nrm=iso $>$. Acesso em: 28 dez. 2009.

${ }^{819}$ ROUBIER, Paul. Droits subjectifs et situations juridiques. Paris: Dalloz, 1963. p. 179. "On appelle fonction un poste de service dans la societé, qui consiste à mettre son activité à la disposition du public pour une tâche determinée."

${ }^{820}$ Idem, ibidem. p. 186.

${ }^{821}$ JEHRING, Rudolf von. A evolução do direito. Tradução de O. de Meulenaere. Salvador: Livraria Progresso, 1953. p. 64.

${ }^{822}$ ROUBIER, Paul. Op. cit. p. 184-185

${ }^{823}$ JEHRING, Rudolf von. Op.cit. p. 65.

${ }^{824}$ KELSEN, Hans. Teoria pura do direito. Tradução de João Baptista Machado. 6. ed. São Paulo: Martins Fontes, 1998. p. 39-40. 
"elemento de compromisso, paz e concordância" ${ }^{825} \mathrm{O}$ modo como se deu essa mudança pouco importa: contratualismo, autoconsciência dos governantes, democratização ou qualquer outra explicação sobre tal processo não se preocupam com a sua dinâmica na sociedade, embora possam fornecer uma justificativa e uma explicação plausíveis para o seu processo de legalização e legitimação. Há, porém, teorias e movimentos para os quais essa submissão não ocorreu na integridade, permitindo-se o desenvolvimento equilibrado dos vários membros da sociedade que não são tolhidos inteiramente do exercício de seu poder, mas apenas da parcela que ameaça os demais. Conquanto referindo-se ao político, Acton tem razão ao afirmar que "o poder corrompe e o poder absoluto corrompe absolutamente": quando isso ocorre e a sociedade assim o percebe, o direito começa a desempenhar seu papel limitador do poder, condicionando-o para o desempenho de uma função.

Conforme explica Jhering, a coação pública e a norma são "insuficientes para criar o Estado de Direito". ${ }^{826} \mathrm{O}$ viés personalista tende a impregnar a aplicação da norma e da coação pública - lembre-se de como as forças policiais foram usadas até recentemente na história brasileira para fins políticos pessoais. A visão idealizada e personalista do interesse coletivo tutelado pelo Estado é frequente objeto de críticas pelos liberais: "Sugere-se com frequiência, erroneamente, que todos os interesses coletivos são interesses gerais da sociedade; mas, em muitas circunstâncias, a satisfação de interesses coletivos de certos grupos pode ser decididamente contrária aos interesses gerais da sociedade". ${ }^{827}$

Para evitar que o uso das prerrogativas estatais seja arbitrário, o Estado de Direito pressupõe a submissão do próprio Estado ao direito voltado para um fim. ${ }^{828} \mathrm{Com}$ isso,

[...] o acaso desaparece na aplicação das normas, o arbítrio dá lugar à uniformidade, à certeza, à visibilidade da lei. É o que chamamos de ordem jurídica, é o que temos em vista quando falamos de soberania do direito e da lei. Eis aí o que nos deve dar o direito se ele quiser corresponder ao que dele esperamos. É a tarefa do Estado segundo o direito. Portanto o direito, nesta acepção lata, implica a força bilateralmente obrigatória da lei, a submissão do próprio Estado às leis que ele promulga. ${ }^{829}$

\footnotetext{
$\overline{825}$ BODENHEIMER, Edgar. Teoría del derecho. Op.cit. p. 30. "El poder representa, en el mundo de la vida social, el elemento de lucha, guerra y sujeción. Por el contrario, el Derecho representa el elemento do compromiso, paz y acuerdo."

${ }^{826}$ JEHRING, Rudolf von. Op. cit. p. 280.

827 HAYEK, F. A. Direito, legislação e liberdade: uma nova formulação dos princípios liberais de justiça e economia política. São Paulo, Visão, 1985. v. 2. p. 7.

${ }^{828}$ JEHRING, Rudolf von. Op. cit. p. 280. "O que ainda falta é o elemento que assinalamos sob a designação de norma bilateralmente obrigatória, em virtude da qual o próprio Estado se inclina diante das regras que ditou, e às quais concede de fato, enquanto existem, o império que em princípio lhes atribuiu."

${ }^{829}$ Idem, ibidem.
} 
$\mathrm{O}$ ponto é que as limitações legais, frequentemente, deveriam se basear nos interesses juridicamente tutelados daqueles que se encontram sujeitos ao poder. Essa é a base de limites legais ao exercício do poder, o que acaba por implicar que, em teoria geral do direito, toda situação de poder é mista, isto é, ativa e passiva ao mesmo tempo, porque encontra deveres que limitam a sua estrutura, que são correlatos a direitos submetidos ao poder, em um esquema que implica a funcionalização dos direitos subjetivos e dos poderes. Por isso, o direito, até mesmo como sinônimo de justiça, "floresce somente numa atmosfera de igualdade aproximada e não onde o poder está distribuído desigualmente". ${ }^{830}$ Conforme sintetiza Roubier,

[...] o que caracteriza o poder em relação ao direito é que o titular deste poder não deve agir de acordo com seu interesse pessoal, mas sim de acordo com o interesse do grupo ou da pessoa no nome de quem ele age. Esta é a contrapartida obrigatória do poder; só se pode avançar sobre a esfera jurídica de outrem no interesse de outrem, e não no seu próprio interesse. ${ }^{831}$

No momento em que o ordenamento jurídico atribui uma função ao poder, a técnica jurídica o canaliza, afastando-o do "acaso" da vontade do governante e do seu arbítrio. A noção bilateral direito-obrigação se torna incompatível para reger as relações, em que o Estado é parte - do contrário, o princípio da supremacia do interesse público se transforma em mero pretexto para o uso arbitrário do poder para fins privados de seu detentor. Afastado o personalismo, o detentor do poder deve agir de acordo com a busca da finalidade - o poder surge apenas como instrumental necessário para o cumprimento do dever de atingi-la. Num Estado de Direito, organizado racionalmente, despido de personalismos, pressupõe-se "necessariamente o poder como estrutura governante encarregada de regular, coordenar, gerenciar, decidir, definir e garantir os critérios da ordem. O poder político é uma condição necessária da ordem, um instrumento indispensável para sua realização". 832

Em direito público, o binômio direito-obrigação é substituído pelo binômio poderdever. O próprio princípio da supremacia do interesse público se liga a esse binômio poderdever como instrumento para atingimento dos fins do Estado. Na terminologia da teoria geral do direito,

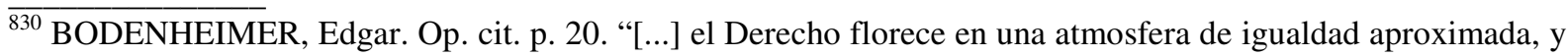
no donde el poder está distribuido desigualmente."

${ }^{831}$ ROUBIER, Paul. Op. cit. p. 186. "On verra bientôt que ce qui caractérise le pouvoir par rapport au droit, c'est que le titulaire de ce pouvoir ne doit pas agir pour son interêt personnel, mais dans l'interêt du groupement ou de la personne au nom de qui il s'agit. C'est la rançon obligatoire du pouvoir; on ne peut empiéter sur la sphére juridique d'autrui que dans l'iinterêt d'autrui, et non pas dans son propre interêt."

${ }_{832}$ DROMI, Roberto. Sistema jurídico e valores administrativos. Porto Alegre: Sergio Fabris Editor, 2007. p. 44.
} 
[...] tem-se função apenas quando alguém está sujeito ao dever de buscar, no interesse de outrem, o atendimento de certa finalidade. Para desimcumbir-se de tal dever, o sujeito de função necessita manejar poderes, sem os quais não teria como atender à finalidade que deve perseguir para a satisfação do interesse alheio. ${ }^{833}$

Esses traços constituem marcas características do direito do Estado Moderno - no entanto, como será demonstrado a seguir, esse binômio não foi integralmente incorporado pelo direito pressuposto brasileiro.

\subsection{Funcionalismo público entre o profissionalismo e o corporativismo}

O processo de consolidação das prerrogativas necessárias à profissionalização da burocracia weberiana, iniciado com o Estado Novo, foi reafirmado na ordem constitucional de 1988 no art. 37 mediante a exigência de concurso público. ${ }^{834} \mathrm{~A}$ esse anteparo contra o uso privado da administração pública se adicionam a estabilidade dos servidores, também prevista na Constituição de $1988^{835}$ e as garantias especiais para algumas carreiras, tais como a vitaliciedade e inamovibilidade para a magistratura. ${ }^{836}$

Simultaneamente a esse viés moderno e profissional da máquina burocrática, presente no direito posto brasileiro, convivem dois outros aspectos: o empreguismo e o corporativismo. Historicamente, esses aspectos representam a permanência de características do Estado patrimonialista e influenciam de modo negativo a eficiência estatal ${ }^{837}$ - coexistem $^{2}$

\footnotetext{
$\overline{833}$ MELLO, Celso Antônio Bandeira de. Curso de direito administrativo. 19. ed. São Paulo: Malheiros, 2005. p. 45. No mesmo sentido, TÁCITO, Caio. Improbidade administrativa como forma de corrupção. Revista Diálogo Jurídico, Salvador: CAJ - Centro de Atualização Jurídica. v. I, n. 8, nov. 2001. "[...] o desvio de poder, sob a aparência da legalidade, viola o ato administrativo, caracterizando corrupção." No mesmo sentido, ver FAZZIO JÚNIOR, Waldo. Corrupção no poder público: peculato, concussão, corrupção passiva e prevaricação. São Paulo: Atlas, 2002. p. 14-16.

834 BRASIL. Constituição (1988). Art. 37. "II - a investidura em cargo ou emprego público depende de aprovação prévia em concurso público de provas ou de provas e títulos, de acordo com a natureza e a complexidade do cargo ou emprego, na forma prevista em lei, ressalvadas as nomeações para cargo em comissão declarado em lei de livre nomeação e exoneração."

${ }^{835}$ BRASIL. Constituição (1988). Art. 41. "São estáveis após três anos de efetivo exercício os servidores nomeados para cargo de provimento efetivo em virtude de concurso público."

${ }^{836}$ BRASIL. Constituição (1988). Art. 95. "Os juízes gozam das seguintes garantias: I - vitaliciedade, que, no primeiro grau, só será adquirida após dois anos de exercício, dependendo a perda do cargo, nesse período, de deliberação do tribunal a que o juiz estiver vinculado, e, nos demais casos, de sentença judicial transitada em julgado; II - inamovibilidade, salvo por motivo de interesse público, na forma do art. 93, VIII [...]."

${ }^{837}$ LAFER, Celso. $O$ sistema político brasileiro. São Paulo: Perspectiva, 1975. p. 66 e 67. "A cultura política do Brasil subdesenvolvido cobrou um preço, em termos de diminuição da eficiência do aparelho estatal, exigida pelo Brasil desenvolvido. Isto se traduziu, por exemplo, na diluição do sistema de mérito pelo emprego público como favor político. Entretanto, à medida que foi crescendo a preponderância do Estado em relação à sociedade civil, pari passu com este tipo de demandas, solicitadas pelas necessidades de acomodação do pacto de dominação, tornaram-se mais complexas as tarefas da administração pública, que passaram a exigir um
} 
lado a lado bolsões de eficiência e práticas corruptas. No neopatrimonialismo, não há inocência quanto ao fato de uns grupos se beneficiarem mais do Estado, ainda que haja eficiência da máquina burocrática. ${ }^{838}$ Com esses caracteres, o poder da máquina burocrática não é utilizado para o desempenho das funções a que se destina. Até mesmo o lobby da indústria tem dificuldades para impor certas medidas que visam ao aumento da competitividade empresarial, possivelmente em virtude da agenda própria do patrimonialismo, a qual tornou o empresariado parceiro privilegiado, diversamente de outros países, em que o Estado se encontra à serviço dos interesses industriais. ${ }^{839}$

Por empreguismo deve-se entender a tendência de contratar funcionários públicos em excesso, desdobrando-se em várias manifestações: empreguismo por questões meramente eleitorais, para atendimento aos reclamos sindicais, para usufruto de cargos de confiança excessivos, entre outros. As distorções causadas pelo empreguismo subvertem o espírito burocrático a ponto de inverter os incentivos para a eficiência. Os cargos de confiança podem ser usados tanto para empregar os "aliados" do político ou acrescentar remuneração adicional aos servidores públicos subservientes, transformando a busca pela excelência do serviço público na adulação ao político de plantão, o qual, por vezes, deseja cooptar os funcionários de carreira para usá-los para seus interesses privados. ${ }^{840}$ Por vezes, os candidatos a cargos comissionados pagam para ocupar posições disponíveis, destinando parte de seus proventos ao que o indicou ou para o partido político ao qual é filiado.

Dados constantes da Pesquisa de Informações Básicas Municipais - Perfil dos Municípios, feita pelo IBGE, revelam a magnitude que os cargos de confiança ocupam na

aprimoramento da burocracia, para garantia a viabilidade operacional do pacto de dominação. A coexistência destas duas necessidades explica, nesse período, tanto os esforços no sentido da reorganização do Estado através da forma administrativa, quanto a sua diluição pelas pressões do 'cartorialismo', para usar a fórmula cunhada por Hélio Jaguaribe. O resultado das duas tendências foi o aparecimento, no corpo administrativo do Estado, de bolsões de eficiência, que tiveram condições, dadas as características do modelo econômico, de assegurar, operacionalmente, o papel do Estado no controle da economia."

${ }^{838}$ DOMINGUES, José Maurício. Patrimonialismo e neopatrimonialismo. In: AVRITZER, Leonardo et al. (Org.). Corrupção: ensaios e críticas. Belo Horizonte: UFMG, 2008. p. 189.

${ }^{839}$ MANCUSO, Wagner Pralon. O lobby da indústria no Congresso Nacional: empresariado e política no Brasil contemporâneo. Apresentação de Maria Hermínia Tavares de Almeida. São Paulo: Humanitas/Edusp, 2007. p. 192-197.

${ }^{840}$ FIGUEIREDO, Lúcia Valle. Corrupção administrativa. Revista Eletrônica de Direito do Estado, Salvador: Inst. de Direito Público da Bahia. n. 6, abr./maio/jun. 2006. "Pior ainda ocorre na escolha dos ocupantes de cargos em comissão dos diversos escalões. Os cargos são distribuídos rigorosamente dentro dos apoios políticos. As exonerações são feitas quando alguma rebeldia ocorre. E o que deve ser escolha técnica passa a ser de um casuísmo terrivelmente chocante. Ou, então, prêmio para a fidelidade particular do candidato àquele que vai servir. Na verdade, tudo resulta do erradíssimo entendimento de que a nomeação não deve traduzir critérios técnico-jurídicos, mas, antes, a escolha deve-se dar por preferências pessoais, ao alvedrio, ao bel talante do administrador do momento. Os cargos, que deveriam ser técnicos, como já dito, passam a ser de quota partidária. Apenas alguns são da escolha dos Chefes dos Executivos, e, aliás, também, não guardam o devido critério técnico." 
administração pública. No período 2004-2008, quando houve aumento substancial no número de pessoas empregadas, ${ }^{841}$ houve um crescimento acima da média para os cargos comissionados em municípios de todos os tamanhos (ver tabelas 16 e 17).

Tabela 16 - Percentual do pessoal ocupado na administração direta, por vínculo empregatício, segundo as Grandes Regiões - 2004/2008

\begin{tabular}{|c|c|c|c|c|c|c|}
\hline \multirow{2}{*}{\multicolumn{2}{|c|}{$\begin{array}{l}\text { Grandes } \\
\text { Regiões }\end{array}$}} & \multicolumn{5}{|c|}{$\begin{array}{c}\text { Percentual de pessoal ocupado na administração } \\
\text { direta por vínculo empregatício }(\%)\end{array}$} \\
\hline & & $\begin{array}{l}\text { Total } \\
\text { (1) }\end{array}$ & Estatuários & CLT & $\begin{array}{l}\text { Somente } \\
\text { comissionados }\end{array}$ & $\begin{array}{l}\text { Sem vínculo } \\
\text { permanente }\end{array}$ \\
\hline \multirow{6}{*}{2004} & & 100,0 & 64,3 & 18,5 & 7,9 & 9,4 \\
\hline & Norte & 100,0 & 58,0 & 19,2 & 7,2 & 15,6 \\
\hline & Nordeste & 100,0 & 61,2 & 17,6 & 9,0 & 12,3 \\
\hline & Sudeste & 100,0 & 63,0 & 21,8 & 6,7 & 8,5 \\
\hline & Sul & 100,0 & 71,4 & 17,4 & 7,1 & 4,1 \\
\hline & Centro-Oeste & 100,0 & 74,1 & 9,3 & 10,9 & 5,7 \\
\hline \multirow{6}{*}{2005} & & 100,0 & 64,0 & 11,4 & 8,5 & 16,1 \\
\hline & Norte & 100,0 & 56,8 & 5,5 & 8,5 & 29,3 \\
\hline & Nordeste & 100,0 & 59,2 & 8,6 & 9,9 & 22,3 \\
\hline & Sudeste & 100,0 & 63,3 & 17,8 & 7,4 & 11,6 \\
\hline & Sul & 100,0 & 73,3 & 11,2 & 8,4 & 7,1 \\
\hline & Centro-Oeste & 100,0 & 75,5 & 2,6 & 7,9 & 14,0 \\
\hline \multirow{6}{*}{2006} & & 100,0 & 60,9 & 11,1 & 8,8 & 19,2 \\
\hline & Norte & 100,0 & 58,1 & 5,3 & 8,5 & 28,2 \\
\hline & Nordeste & 100,0 & 56,3 & 7,5 & 9,7 & 26,5 \\
\hline & Sudeste & 100,0 & 60,6 & 17,9 & 7,7 & 13,8 \\
\hline & Sul & 100,0 & 69,3 & 10,9 & 8,2 & 11,6 \\
\hline & Centro-Oeste & 100,0 & 68,9 & 1,6 & 11,8 & 17,7 \\
\hline \multirow{6}{*}{2008} & & 100,0 & 64,7 & 10,9 & 9,0 & 15,4 \\
\hline & Norte & 100,0 & 60,8 & 5,7 & 8,7 & 24,8 \\
\hline & Nordeste & 100,0 & 60,9 & 6,4 & 9,9 & 22,9 \\
\hline & Sudeste & 100,0 & 63,7 & 18,0 & 7,8 & 10,4 \\
\hline & Sul & 100,0 & 75,1 & 10,9 & 8,3 & 5,7 \\
\hline & Centro-Oeste & 100,0 & 72,3 & 3,7 & 12,1 & 11,8 \\
\hline
\end{tabular}

Fonte: IBGE, Diretoria de Pesquisas, Coordenação de População e Indicadores Sociais, pesquisa de Informações Básicas Municipais 2004/2008

(1) Inclusive os servidores sem declaração de vínculo empregatício.

$\overline{{ }^{841} \text { IBGE. Pesquisa }}$ de Informações Básicas Municipais - Perfil dos Municípios Brasileiros. Rio de Janeiro, 2008, p. 24 "O número de pessoas ocupadas na administração direta municipal brasileira foi de 4281 923, em 2004; 4 494 154, em 2005; 4794 844, em 2006; e 5015 729, em 2008 - o que corresponde a um crescimento de, aproximadamente, $5,0 \%$, entre 2004 e 2005; 6,7\%, entre 2005 e 2006; e 4,6\%, entre 2006 e 2008." 
Tabela 17 - Percentual de pessoal ocupado na administração direta, por vínculo empregatício, segundo as classes de tamanho da população dos municípios - Brasil 2004/2008

\begin{tabular}{|c|c|c|c|c|c|c|}
\hline \multirow{2}{*}{\multicolumn{2}{|c|}{$\begin{array}{c}\text { Classes de tamanho da } \\
\text { população dos } \\
\text { municípios }\end{array}$}} & \multicolumn{5}{|c|}{$\begin{array}{c}\text { Percentual de pessoal ocupado na administração } \\
\text { direta por vínculo empregatício }(\%)\end{array}$} \\
\hline & & $\begin{array}{c}\text { Total } \\
(1)\end{array}$ & Estatuários & CLT & $\begin{array}{l}\text { Somente } \\
\text { comissionados }\end{array}$ & $\begin{array}{l}\text { Sem vínculo } \\
\text { permanente }\end{array}$ \\
\hline \multirow{8}{*}{2004} & Total & 100,0 & 64,3 & 18,5 & 7,9 & 9,4 \\
\hline & Até 5.000 & 100,0 & 64,5 & 14,9 & 10,1 & 10,5 \\
\hline & De 5.001 a 10.000 & 100,0 & 62,0 & 18,7 & 8,8 & 10,6 \\
\hline & De 10.001 a 20.000 & 100,0 & 60,1 & 20,3 & 8,2 & 11,4 \\
\hline & De 20.001 a 50.000 & 100,0 & 60,0 & 20,9 & 8,0 & 11,2 \\
\hline & De 50.001 a 100.000 & 100,0 & 59,3 & 22,1 & 8,5 & 10,1 \\
\hline & De 100.001 a 500.000 & 100,0 & 60,1 & 22,7 & 8,1 & 9,1 \\
\hline & Mais de 500.000 & 100,0 & 83,2 & 7,3 & 5,6 & 3,9 \\
\hline \multirow{8}{*}{2005} & Total & 100,0 & 64,0 & 11,4 & 8,5 & 16,1 \\
\hline & Até 5.000 & 100,0 & 63,0 & 10,9 & 12,0 & 14,0 \\
\hline & De 5.001 a 10.000 & 100,0 & 62,5 & 10,3 & 9,9 & 17,3 \\
\hline & De 10.001 a 20.000 & 100,0 & 59,6 & 12,2 & 9,4 & 18,9 \\
\hline & De 20.001 a 50.000 & 100,0 & 59,3 & 13,4 & 8,8 & 18,6 \\
\hline & De 50.001 a 100.000 & 100,0 & 59,5 & 13,7 & 8,9 & 17,9 \\
\hline & De 100.001 a 500.000 & 100,0 & 58,7 & 16,1 & 8,4 & 16,8 \\
\hline & Mais de 500.000 & 100,0 & 82,6 & 2,9 & 5,5 & 9,0 \\
\hline \multirow{8}{*}{2006} & Total & 100,0 & 60,9 & 11,1 & 8,8 & 19,2 \\
\hline & Até 5.000 & 100,0 & 61,3 & 9,8 & 12,8 & 16,1 \\
\hline & De 5.001 a 10.000 & 100,0 & 59,7 & 10,3 & 10,7 & 19,3 \\
\hline & De 10.001 a 20.000 & 100,0 & 57,5 & 11,0 & 9,8 & 21,6 \\
\hline & De 20.001 a 50.000 & 100,0 & 57,5 & 11,8 & 9,1 & 21,6 \\
\hline & De 50.001 a 100.000 & 100,0 & 57,7 & 13,0 & 8,7 & 20,5 \\
\hline & De 100.001 a 500.000 & 100,0 & 55,4 & 15,7 & 9,0 & 20,0 \\
\hline & Mais de 500.000 & 100,0 & 77,7 & 4,0 & 5,2 & 13,1 \\
\hline \multirow{8}{*}{2008} & Total & 100,0 & 64,7 & 10,9 & 9,0 & 15,4 \\
\hline & Até 5.000 & 100,0 & 65,1 & 10,0 & 12,5 & 12,4 \\
\hline & De 5.001 a 10.000 & 100,0 & 63,5 & 10,4 & 10,4 & 15,7 \\
\hline & De 10.001 a 20.000 & 100,0 & 62,9 & 10,2 & 9,5 & 17,4 \\
\hline & De 20.001 a 50.000 & 100,0 & 61,9 & 11,1 & 9,1 & 17,9 \\
\hline & De 50.001 a 100.000 & 100,0 & 62,0 & 12,1 & 9,3 & 16,6 \\
\hline & De 100.001 a 500.000 & 100,0 & 60,3 & 14,6 & 9,3 & 15,8 \\
\hline & Mais de 500.000 & 100,0 & 78,7 & 6,0 & 6,1 & 9,3 \\
\hline
\end{tabular}

Fonte: IBGE, Diretoria de Pesquisas, Coordenação de População e Indicadores Sociais, pesquisa de Informações Básicas Municipais 2004/2008

(2) Inclusive os servidores sem declaração de vínculo empregatício. 
Os dados acima se referem aos municípios, mas o problema se espraia por todos os entes da federação (municípios, estados, Distrito Federal e União) e poderes (Executivo, Legislativo e Judiciário). Na União, há mais de 22 mil cargos comissionados. ${ }^{842}$

Tabela 18 - Quantitativo dos ocupantes de cargos comissionados na União

\begin{tabular}{|}
\begin{tabular}{|c|c|c|c|c|c|c|c|c|c|c|c|}
\hline $\begin{array}{c}\text { Nível } \\
\text { da } \\
\text { Função }\end{array}$ & 1997 & 1998 & 1999 & 2000 & 2001 & 2002 & 2003 & 2004 & 2005 & 2006 & 2007 \\
\hline DAS-1 & 6.820 & 6.554 & 5.681 & 6.503 & 6.665 & 6.733 & 6.551 & 6.761 & 7.054 & 6.821 & 6.836 \\
\hline DAS-2 & 5.943 & 5.678 & 5.313 & 5.442 & 5.615 & 5.703 & 4.658 & 5.213 & 5.480 & 5.366 & 5.550 \\
\hline DAS-3 & 2.472 & 2.490 & 2.690 & 2.826 & 2.828 & 2.954 & 3.055 & 3.420 & 3.509 & 3.588 & 3.703 \\
\hline DAS-4 & 1.682 & 1.716 & 1.810 & 1.886 & 2.073 & 2.158 & 2.341 & 2.651 & 2.785 & 2.886 & 2.946 \\
\hline DAS-5 & 558 & 607 & 666 & 606 & 662 & 672 & 772 & 852 & 911 & 943 & 951 \\
\hline DAS-6 & 132 & 138 & 146 & 146 & 152 & 154 & 182 & 186 & 186 & 193 & 201 \\
\hline
\end{tabular}
\end{tabular}

\begin{tabular}{|l|l|l|l|l|l|l|l|l|l|l|l|}
\hline Total & 17.607 & 17.183 & 16.306 & 17.306 & 17.995 & 18.371 & 17.559 & 19.083 & 19.925 & 19.797 & 20.187 \\
\hline
\end{tabular}

Fonte: Secretaria de Recursos Humanos - Ministério do Planejamento

1 - Inclui os servidores civis da administração indireta, autarquia e Fundações do Poder Executivo

2 - Posição: dezembro/2007

Poder-se-ia defender tais cargos de confiança com o argumento de que constituem prática corriqueira em todos os países, o que é verdade. Contudo, o que diferencia o quadro brasileiro não é só o alto percentual de participação dos comissionados, mas sim sua finalidade no Estado patrimonialista. Há um momento em que a quantidade influencia a qualidade da prática: quanto maior o número de comissionados, maior será o poder de usar a máquina administrativa para os interesses pessoais do detentor do poder. Afinal, não se conhece até o momento se houve contratação de comissionados para lecionar em escolas públicas e auxiliar enfermos em hospitais. Logo, a elevada quantidade se explica pela finalidade que os detentores do poder atribuem aos cargos comissionados.

$\mathrm{Na}$ maioria das ocasiões, escamoteiam-se tais ofensas à dicotomia público-privado sob o véu da legalidade. Os chamados "trens da alegria" - denominação conferida a projetos de lei que visam ou incorporar ao funcionalismo aqueles contratos sem concurso público ou criar mais cargos comissionados para serem ocupados por apaniguados políticos ${ }^{843}$ - são uma marca constante da atuação dos poderes Legislativo e Executivo. Consegue-se a proteção às

\footnotetext{
$\overline{842}$ GAETANI, Francisco. Funcionalismo público. In: AVRITZER et al. (Org.). Corrupção: ensaios e críticas. Belo Horizonte: UFMG, 2008. p. 492.

${ }^{843}$ Idem, p. 486.
} 
críticas com apoio na ampla noção de discricionariedade legislativa. Às vezes, nem sequer existe o esforço de se submeter ao processo legislativo. ${ }^{844}$

O adesismo social se manifesta na aceitação implícita desses comportamentos por meio de tentativas de "regulamentar" o acesso aos cargos de confiança - veja-se o município do Rio de Janeiro, que aprovou lei destinando $10 \%$ dos cargos de confiança aos negros e $10 \%$ às negras. ${ }^{845}$ Não se trata de discutir a legitimidade de ações afirmativas, mas sim de reconhecer que o adesismo social à corrupção dificulta os avanços efetivos da divisão público privado: ${ }^{846}$ inexistiu qualquer tentativa de os vereadores restringirem o número dos cargos comissionados.

Esses traços do Estado patrimonialista atingem também o funcionalismo concursado. Existe uma apropriação do aparato estatal por alguns setores do funcionalismo descomprometidos com as finalidades para as quais foram contratados. Algumas das práticas do fiscalismo, insertas no Estado patrimonialista, ainda permanecem na atualidade. ${ }^{847}$ Outro exemplo disso se verifica nas argumentações de sindicatos ligados à arrecadação tributária que pleiteiam aumentos salariais proporcionais ao aumento da carga tributária, como se fossem remunerados por uma espécie de "participação nos lucros". ${ }^{848}$ O governo encampa

AGÊNCIA ESTADO. Senado fez "trem da alegria" secreto. 19 jul. 2009. Disponível em $<$ http://www.estadao.com.br/nacional/not_nac405069,0.htm>. Acesso em 2 dez. 2009 às 19h23.

${ }^{845}$ RIO DE JANEIRO. Lei municipal no 4.978, de 9 de dezembro de 2008. Art. 3'. "Todos os órgãos da Administração Direta e Indireta da Prefeitura do Rio de Janeiro estão obrigados a disponibilizar, em seus quadros de cargos em comissão, o limite mínimo de vinte por cento de vagas para afro-descendentes dos respectivos gêneros, sendo dez por cento das vagas reservadas para homens dez por cento para mulheres."

${ }^{846}$ DANTAS, P. Câmara do Rio aprova cotas raciais para cargos de confiança: Texto especifica que $10 \%$ das vagas sejam para negras e outros $10 \%$ para negros nas nomeações e contratações. O Estado de S. Paulo, São Paulo, 12 dez. 2008 às 16h10. Disponível em <http://www.estadao.com.br/nacional/not_nac281044,0.htm>. Acesso em: 28 out. 2009 às 11h39. "Espero que ele não faça nada contra a lei que é afirmativa. Trata-se de uma contribuição do Estado para a sociedade atingir a igualdade racial', disse o vereador Roberto Monteiro (PC do B), que é autor do projeto."

${ }^{847}$ WEHLING, Arno. História administrativa do Brasil: administração portuguesa no Brasil, de Pombal a D. João. Coordenação de Vicente Tapajós, Brasília: Fundação Centro de Formação do Servidor Público, 1986. v. 6. p. 120. A comparação com o período colonial é esclarecedora. O autor assim sintetiza as dificuldades enfrentadas pelas mesas de inspeção, órgão da administração fazendária: "O contrabando, o suborno e a comercialização dos produtos adulterados ou de má qualidade, no entanto, frustraram os objetivos das mesas de inspeção. No documento entregue ao marquês de Valença, quando foi governar a Bahia, o secretário Martinho de Melo e Castro criticou severamente a mesa de inspeção local, acusando seus membros de omissão e conivência com as fraudes e determinando ao governador medidas rigorosas, inclusive com a destituição do presidente, o desembargador supranumerário da relação da Bahia João Ferreira Bittencourt e sua sujeição a um juízo de residência, para a apuração da procedência dos seus bens."

848 SINDICATO NACIONAL DOS AUDITORES-FISCAIS DA RECEITA FEDERAL. Subsídios para campanha salarial 2005/2006. 3. ed. Brasília, março de 2006, p. 16. Disponível em <http://www2.unafisco.org.br/campanhas/camp_salarial_2006/arquivos/caderno3.0.pdf>. Acesso em: $2 \mathrm{dez}$. 2009 às 19h35. "Pela tabela 7 (p. 15) percebe-se que cada AFRF [Auditor da Fiscal da Receita Federal] autuou, em média, pessoas físicas e jurídicas, $\mathrm{R} \$$ 6,082 milhões em 2001, cifra esta que aumentou para $\mathrm{R} \$ 10,287$ milhões em 2004, em valores deflacionados pelo IPCA. Interessante observar que esse valor, de R\$10,287 milhões, representa nada menos que 80 vezes o salário anual de um AFRF ao final da carreira. Portanto, um 
essa tese ao propor bonificação para aqueles fiscais que atingissem metas específicas de arrecadaçãa. ${ }^{849}$ Embora a Constituição de 1988 preveja a possibilidade de avaliação periódica de rendimento, ${ }^{850}$ a utilização desse tipo de avaliação para que servidores estáveis ineficientes percam o cargo é amplamente ignorada - na visão impregnada pelo adesismo social, os mecanismos garantidores da função pública somente são positivos naquilo que convém aos interesses do funcionalismo público. A apropriação do interesse público por parcela do funcionalismo também transparece na ampliação da responsabilidade objetiva do Estado, a qual teve o condão de mitigar a responsabilidade pessoal do funcionário público ${ }^{851}$ - são raras as ações de regresso contra o servidor faltoso. Assim, parcela do funcionalismo público age como se o Estado fosse seu e contribui para a confusão entre os espaços público e privado.

Nesse ambiente burocrático distorcido, traços associados à dominação racional não podem ser automaticamente identificados com uma visão otimista sobre o funcionamento do Estado. Há efeitos colaterais decorrentes da imersão das regras profissionalizantes num ambiente patrimonialista. Por exemplo, as regras garantidoras de maior estabilidade para o exercício da função pública podem-se transformar em incentivos para a prática de corrupção, na medida em que o menor risco de exoneração pode-se traduzir na maior propensão para a prática de corrupção-suborno ou corrupção favorecimento.

\subsection{A transparência e os interesses privados nas decisões estatais}

Em sua origem, a ideia de uma burocracia legitimada racionalmente não pressupunha a transparência das decisões político-administrativas. Estava implícita uma tendência tecno-

\footnotetext{
AFRF gera, em créditos tributários, 80 vezes aquilo que recebe de salário. De forma que são plenamente justificáveis a valorização e o aumento do quantitativo dos auditores da Receita Federal."

${ }^{849}$ BOMPAN, F. Meta para fiscais da Receita gera polêmica. Diário do Comércio e Indústria, São Paulo, 28 out. 2009 às 12h04. Disponível em:

$<$ http://www.sindifisconacional.org.br/index.php?option=com_content\&view=article\&id=5111:POL\%C3\%8DT ICA\%20ECON\%C3\%94MICA\&catid=45:na-midia\&Itemid=73>. Acesso em: 28 out. 2009 às 16h24.

${ }^{850}$ BRASIL. Constituição (1988). Art. 41 "§ $1^{\circ}$ O servidor público estável só perderá o cargo: I - em virtude de sentença judicial transitada em julgado; II - mediante processo administrativo em que lhe seja assegurada ampla defesa; III - mediante procedimento de avaliação periódica de desempenho, na forma de lei complementar, assegurada ampla defesa."

${ }^{851}$ BUCCI, Maria Paula D. Direito administrativo e políticas públicas. São Paulo: Saraiva, 2002. p. 96. "A quarta contradição baseia-se na segunda objeção formulada por Dicey ao droit administratif (a primeira era às prerrogativas, por oposição ao direito comum) quanto à irresponsabilidade dos funcionários públicos na origem do direito administrativo francês. Essa postura teria evoluído para a responsabilidade subjetiva e posteriormente para a responsabilidade objetiva da Administração Pública, com base na teoria do risco. Não haveria um antagonismo entre a propalada busca de eficiência administrativa e o modo de acionar a responsabilidade objetiva que no Brasil teria sido banalizada e instituída como forma de esvaziar a responsabilidade pessoal, subjetiva, dos agentes públicos, em todos os níveis?"
} 
burocrática, tendente a excluir a participação da sociedade na tomada de decisões. Como lembrava Bismarck, "leis são como salsichas: é melhor não ver como são feitas". Contudo, dentro do espírito republicano que inspira a dicotomia público-privado, a transparência deflui do Estado Democrático de Direito, no qual a participação popular na fiscalização das ações se torna característica do sistema político.

Afora essa ligação com a democracia, a transparência é considerada inimiga da corrupção. Se esta é um ilícito que se perfaz em recintos fechados ou "nas suítes" (in the suites), como explicam os estudiosos dos crimes de colarinho branco, o simples ato de abrir as portas desses recursos já tem efeito inibidor. $\mathrm{O}$ efeito ocorre tanto pela ausência de reuniões ou deliberações secretas quanto pelo amplo acesso dos cidadãos às informações. Por certo, a corrupção reprimida juridicamente continuará a existir. Já no que concerne àquela corrupçãosolapamento, em que predomina a antiga noção aristotélica, a transparência tem a finalidade de dissuadir os políticos de suas práticas corruptas, desde que a população se posicione contra elas. Uma vez mais, o adesismo social a certas práticas se apresenta como um possível inimigo do processo de depuração do sistema político representativo. Nesse sentido, uma imprensa livre e independente pode desempenhar um papel relevante. ${ }^{852}$

Entretanto, na formação do Estado patrimonialista, transparência nunca foi a escolha a perseguir. A modernização formalista do Estado brasileiro herdou essa repulsa à transparência, transmitida especialmente pela cultura política autoritária. Com o advento da Nova República, apesar da exigência constitucional de transparência ao se elencar a publicidade como um dos princípios da administração pública, ${ }^{853}$ a efetividade de tais normas fica comprometida pelo substrato sociocultural de cada localidade e órgão do Estado. $\mathrm{O}$ comprometimento com a transparência, bem como o significado e o alcance que lhe é atribuído, varia do mesmo modo. Mais genericamente, podem-se identificar três planos distintos de crítica à falta de transparência.

\footnotetext{
$\overline{852}$ ABRAMO, Claudio Weber. Brazil: a portrait of disparities. Brazilian Journalism Research. Brasília: UnB, vol. 3, n. 1, Semestre 1 2007, p. 93-108. O autor analisa quão frequentemente os leitores de jornais de diferentes estados brasileiros recebem informações sobre corrupção e constata que os de estados menos desenvolvidos têm acesso muito mais limitado ao tema do que os dos estados mais desenvolvidos. Em sua conclusão, Abramo explica que "[...] in the states where private firms do not produce enough to justify advertising the picture is much worse. Naturally, the regional distribution of gross revenues from advertising in newspapers replicates the Brazilian imbalances. In 2005, papers from the State of São Paulo alone accounted for $41 \%$ of the national total and Rio de Janeiro had 25\%. The South and South-East (except Rio and São Paulo) accounted for 17\%, the North-East $11 \%$ and the Center-West $6 \%$. The newspapers that do exist in the poorer states either exist precariously or are bound to serve other purposes than generating profits for their owners by selling information. Such objectives are invariably political. Changing that situation would require profound economic change in Brazil's poorest states. Few would say that such an endeavor is achievable in the foreseeable future."

${ }^{853}$ BRASIL. Constituição (1988). Art. 37.
} 
Num primeiro plano, numa afronta explícita ao direito posto, há os atos aos quais se deveria dar publicidade, mas não se dá. O exemplo caricato são os atos secretos do Senado. Inicialmente revelados numa breve passagem de um relatório preparado pela Fundação Getulio Vargas, ${ }^{854}$ pareciam restringir-se à organização administrativa, mas posteriormente se revelaram possuir outras naturezas, tais como "desdobramento ou criação de cargos em comissão e a nomeação ou exoneração de seus ocupantes". ${ }^{855}$ Todavia, não há somente exemplos caricatos: o "Esquema do Orçamento", objeto de investigação em 1993 e 1994 de uma Comissão Parlamentar Mista de Inquérito, era hábil em utilizar a falta de transparência para seus fins ilícitos, dificultando ao máximo que o público soubesse efetivamente o que acontecia durante o processo de elaboração orçamentário. ${ }^{856}$

Num segundo plano, há os atos para os quais se apresenta uma justificativa -sujeita a críticas devido à sua inconsistência - para a falta de transparência. Podem-se lembrar os gastos com cartões de crédito feitos pelo Palácio do Planalto, tidos como secretos em razão de questões de segurança nacional. ${ }^{857}$ Apenas à guisa de uma breve comparação, é preciso notar

${ }^{854}$ FUNDAÇÃO GETULIO VARGAS. Revisão da Estrutura Organizacional Administrativa e Sistemática de Classificação e Remuneração de Cargos de Provimento em Comissão e Funções Comissionadas. Rio de Janeiro, 6 de maio de 2009. Disponível em <https://intranetsenado.senado.gov.br/ArqG/RelatorioFGV.pdf>. Acesso em: 21 nov. 2009 às 19h35. p. 8. "O próprio Regulamento dispõe que muitas das competências não descritas deveriam ou poderiam ser especificadas por atos da Comissão Diretora e do Diretor-Geral. No entanto, a equipe de consultores da FGV não teve acesso a estes atos, e alguns deles sequer foram publicados."

${ }^{855}$ BRASIL. Senado Federal. Relatório final. Comissão de sindicância. Portaria n⿳0 01/2009, de autoria do Senhor Presidente do Senado Federal (BAP n⿳ - 4.232, de 23 jun. 2009). Processo n. 010788/09, p. 303. "Do que apurou a presente Sindicância, verifica-se que a existência de atos administrativos, não disponibilizados, ou disponibilizados com atraso, não se deveu a qualquer tipo de falha técnica, mas a determinações expressas para que tal procedimento fosse adotado. Essas determinações foram feitas, em sua esmagadora maioria, pelo Gabinete da Diretoria-Geral e, em alguns casos, pelo Gabinete da Secretaria de Recursos Humanos e dirigidas ao responsável pelo Serviço de Publicação daquela Secretaria ou pela unidade que o antecedeu. Merece destaque o fato de que os servidores ouvidos foram unânimes em dizer que, em momento algum, receberam ordens de quaisquer parlamentares."

${ }^{856}$ BRASIL. Congresso Nacional. Relatório final da Comissão Parlamentar Mista de Inquérito. Congresso Nacional. Criada através do Requerimento $n^{\circ}$ 151/93-CN, destinada a "apurar fatos contidos nas denúncias do Sr. José Carlos Alves dos Santos, referentes às atividades de parlamentares, membros do Governo e representantes de empresas envolvidas na destinação de recursos do Orçamento da União”. Vol. III, Brasília, janeiro de 1994, p. III.4. "[...] ao chegar ao Plenário do Congresso, dada a exigüidade do tempo para apreciação, o projeto do orçamento constituía uma verdadeira 'caixa preta', conhecido e compreendido apenas pelos integrantes do esquema e por aqueles poucos parlamentares versados no assunto, não vinculados ao próprio esquema de corrupção."

${ }^{857}$ BRASIL. Congresso Nacional. Relatório final da Comissão Parlamentar Mista de Inquérito - Cartão de Pagamentos do Governo Federal. Relator Deputado Luiz Sérgio. Brasília, junho de 2008, p. 38. De acordo com o então Diretor-Geral da Agência Brasileira de Inteligência (ABIN), Paulo Lacerda, "a figura do Presidente da República, ele é na verdade uma instituição, seja ele quem for, essa instituição que representa o nosso país, que ora é de um partido, ora é de outro partido e que há de ser considerada como tal. E, como instituição que é, o Estado deve dar-lhe toda a garantia para que a sua segurança esteja preservada, para que ele possa, sem nenhum tipo de restrição à sua segurança, se locomover no país e fora dele. Hoje nós não vivemos mais naquele mundo em que a figura de um Presidente da República era possível estar em todos os locais públicos sem ser molestado. Os exemplos estão aí pelo mundo. O Presidente brasileiro não deve ser tratado de maneira diferente de nenhum outro país do mundo. Nós devemos dar-lhe toda a segurança e garantia como uma instituição que é. Hoje é o 
que esse tipo de preocupação também existe em outros países com índices menores de corrupção. No entanto, há mecanismos para evitar abusos: na Nova Zelândia, por exemplo, o Official Information Act de 1982 lista algumas hipóteses de exceção à publicidade, entre as quais se incluem o prejuízo à segurança e a defesa nacional, bem como à segurança ou à privacidade de qualquer pessoa, entre outras. ${ }^{858}$ Contudo, há um ombudsman que investiga e avalia as recusas de pedidos de informação. ${ }^{859}$ Mesmo assim, não há como negar que essas preocupações encontrem relação com o direito pressuposto de uma sociedade: na Suécia, qualquer cidadão tem acesso aos gastos dos membros do Parlamento, pois acredita-se que uma pessoa pública não tem o direito de esconder nada - até os extratos bancários dos parlamentares estão disponíveis na internet. ${ }^{860}$

Num terceiro plano, coloca-se a falta de transparência das ações de defesa de interesses privados perante o Estado. Esse viés, mais difícil de identificar, possui o condão de minar sub-repticiamente a legitimidade e se caracteriza como corrupção-solapamento. Qual é o interesse verdadeiro por trás de certa norma ou de certo ato administrativo? Saber o que motiva as ações estatais é importante para superar as dificuldades inerentes ao escamoteamento dos interesses privados no Estado patrimonialista.

\footnotetext{
Presidente Lula, ontem foi o Presidente Fernando Henrique, amanhã não sabemos quem é, mas deverá ser-lhe dedicado todo o respeito, toda a consideração e o aparato do Estado tem que estar para servir-lhe. Por isso é imprescindível que as questões de despesas relacionadas à sua locomoção, ao seu transporte, ao seu dia-a-dia, sejam absolutamente alvo das cautelas por parte do sistema de segurança que é destinado à sua proteção." Ao término, a CPI somente requereu os dados sigilosos que haviam sido encaminhados ao TCU, mas, acertadamente, o relatório final "apresenta, em capítulo específico, uma proposta de período de tempo adequado após o qual os dados referentes à Presidência da República estejam disponíveis ao público”.

${ }^{858}$ NOVA ZELÂNDIA. Official Information Act. Section 6, "Conclusive reasons for withholding official information. Good reason for withholding official information exists, for the purpose of section 5, if the making available of that information would be likely - (a) to prejudice the security or defence of New Zealand or the international relations of the Government of New Zealand; or (b) to prejudice the entrusting of information to the Government of New Zealand on a basis of confidence by - (i) the Government of any other country or any agency of such a Government; or (ii) any international organisation; or (c) to prejudice the maintenance of the law, including the prevention, investigation, and detection of offences, and the right to a fair trial; or (d) to endanger the safety of any person; or (e) to damage seriously the economy of New Zealand by disclosing prematurely decisions to change or continue government economic or financial policies relating to- (i) exchange rates or the control of overseas exchange transactions: (ii) the regulation of banking or credit: (iii) taxation: (iv) the stability, control, and adjustment of prices of goods and services, rents, and other costs, and rates of wages, salaries, and other incomes: (v) the borrowing of money by the Government of New Zealand: (vi) the entering into of overseas trade agreements."

${ }^{859}$ Para uma análise empírica da efetividade do Official Information Act, ver PRICE, S. The Official Information Act 1982: A Window on government or curtains drawn? The New Zealand Centre for Public Law, Faculty of Law, Victoria University of Wellington. Disponível em: <http://www.victoria.ac.nz/nzcpl/Files/Occ\%20papers/OP_Price.pdf>. Acesso em 04 jan. 2010, às $23 \mathrm{~h} 48$.

860 Jornal Globo.com. "Parlamento sueco dá exemplo de transparência". 23/11/2009. Disponível em: <http://jornalnacional.globo.com/Telejornais/JN/0,,MUL1389703-10406,00-PARLAMENTO+SUECO+～DA +EXEMPLO+DE+TRANSPARENCIA.html> Acesso em 05 jan. 2010, às 00h09.
} 
Essas considerações suscitam questionamentos sobre como os interesses privados influenciam a formação do interesse público. Por um lado, se é impossível impedir que haja a defesa dos interesses privados perante as diversas instâncias do Estado, deve-se, por outro, conferir transparência a essa defesa, a fim de desestimular ou inibir que o interesse público reflita exclusivamente os interesses privados. ${ }^{861}$ Dito de outro modo, os interesses privados devem ser controlados pela transparência para evitar que "sua maior influência conduza ao privilégio" em detrimento do interesse comum ou público. ${ }^{862}$

A questão do relacionamento dos interesses e a organização política sempre preocupou o Estado. Como uma associação necessita de um direcionamento na ação para atingir suas finalidades privadas, partidos, facções e grupos sectários eram tradicionalmente vistos com ressalva pela teoria política. Os governantes custaram muito a admitir certa pluralidade sem pretender erradicá-la. Na visão democrática nascente no século XIX, as minorias e os grupos de interesse têm, sim, um lugar, quer seja no interior do próprio Estado, quer seja na sociedade civil. Nusdeo identifica quatro visões principais sobre como ocorre esse relacionamento do Estado com os interesses privados: a corporativista, a pluralista liberal, a neocorporativista e a neopluralista. ${ }^{863}$

De acordo com a visão corporativista, as associações e sindicatos teriam um lugar definido na própria organização estatal, paralelamente à representação política. Já na visão pluralista liberal, admite-se a existência dos grupos de interesse, cuja interação teria por resultado "uma legislação em princípio apropriada à comunidade pela própria forma de acesso à fonte legiferante e à concorrência que tais grupos fariam entre si" ${ }^{864}$

O neocorporativismo confere status aos grupos de interesse que passam a participar diretamente do processo de elaboração normativa, mas sem a exclusão dos partidos políticos e

\footnotetext{
$\overline{861}$ BUCCI, Maria Paula D. Op. cit. p. 209. "Uma amostra da jurisprudência nessa matéria evidencia que, além da contraposição entre interesse público, de um lado, e interesse particular de outro, pode haver oposição entre o interesse público declarado e o interesse concretamente realizado, este nem sempre coincidindo com aquele. Freqüentemente há um descompasso entre o interesse público que fundamenta a ação administrativa e o interesse efetivamente realizado, que entra em pauta no momento do litígio judicial sobre o dano. O que é, afinal, o interesse público, em nome do qual se impõe sacrifício aos direitos de particulares, sacrifício este que termina por ser indenizado com recursos do Tesouro, o mesmo que custeia todas as ações administrativas? A definição de interesse público - finalidade da atividade administrativa - comporta um juízo de eficiência, isto é, da relação entre meios e fins, ou, dito de outro modo, faz-se o balanço entre os custos de indenização e os benefícios decorrentes do avanço sobre direitos dos particulares?"

${ }^{862}$ CARDONA, Alejandro Ramírez. Sistema de hacienda pública. Bogotá: Temis, 1970. p. 15. "Los 'grupos de presión' que se hacen manifiestos en las sociedades democráticas modernas como portadores de un influjo superior en el gobierno, son producto de aquella organización más eficiente. No obstante, han de ser controlados para evitar que su mayor influencia conduzca al privilegio."

${ }^{863}$ NUSDEO, Fábio. Op. cit. p. 48.

${ }^{864}$ Idem, ibidem. p. 48.
} 
da representação política tradicional ${ }^{865}$ - exemplo dessa técnica é a autorregulação levada a efeito pelas bolsas de valores em colaboração com os entes reguladores. No que tange ao neopluralismo, há um pessimismo quanto à prevalência do interesse público: os agentes privados em busca de renda sempre teriam resultados que se sobreporiam ao interesse público por meio do uso de mecanismos estatais, sem o que tais resultados não seriam obtidos no mercado. ${ }^{866}$

Ciente dessas implicações, depois de ter superado a postura otimista do pluralismo liberal de Madison, já no século XIX parte da sociedade americana começou a criticar o funcionamento do sistema político, que estaria privilegiando os interesses privados. $\mathrm{O}$ movimento Granger combatia o abuso cometido pelas ferrovias contra os pequenos agricultores, ao mesmo tempo em que se descortinavam as relações promíscuas entre os detentores do poder político e o econômico - temia-se que os ricos utilizariam o Estado para instituir uma tirania semelhante à do rei inglês no período colonial. Como resultado, primeiro surgiram as regras de regulação dos serviços públicos, seguidas pelas leis antitruste. Em 1946, foi aprovado o Federal Regulation of Lobbying Act, que determinava:

[...] qualquer pessoa que se ocupe, mediante pagamento ou qualquer outra forma de compensação, de influenciar a aprovação ou reprovação de qualquer legislação perante o Congresso Nacional deverá, antes de fazer qualquer coisa na persecução de seu intento, se registrar perante o Cartório da Câmara dos Deputados ou na Secretaria do Senado, indicando a estes, por escrito e mediante juramento, seu nome e endereço, o nome e endereço de seu empregador e para quais interesses aparece ou trabalha, a duração de tal emprego, quanto é pago e tem a receber, por quem é pago ou deve ser pago, quanto será reembolsado pelas despesas e quais despesas estão inclusas. ${ }^{867}$

Por se tratar de declaração feita sob juramento, a falsidade tipifica perjúrio, punido criminalmente. Alguns anos mais tarde, em 1953, em virtude da procedência de uma ação proposta por alguns lobistas, reduziu-se o âmbito de aplicação da regra acima, mas foi mantida a sua constitucionalidade sob o argumento de (i) que inexistia violação ao direito de petição e (ii) que era direito do cidadão saber que interesses agiam perante o Poder

\footnotetext{
$\overline{865}$ Idem, ibidem. p. 59.

${ }^{866}$ Idem, ibidem. p. 70. Ver item 4.4, supra.

${ }^{867}$ ESTADOS UNIDOS DA AMÉRICA. The Federal Regulation of Lobbying Act of 1946. Secção 308. Tradução livre do seguinte original: “(a) Any person who shall engage himself for pay or for any consideration for the purpose of attempting to influence the passage or defeat of any legislation by the Congress of the United States shall, before doing anything in furtherance of such object, register with the Clerk of the House of Representatives and the Secretary of the Senate and shall give to those officers in writing and under oath, his name and business address, the name and address of the person by whom he is employed, and in whose interest he appears or works, the duration of such employment, how much he is paid and is to receive, by whom he is paid or is to be paid, how much he is to be paid for expenses, and what expenses are to be included".
} 
Legislativo. ${ }^{868}$ A sistemática da Federal Regulation of Lobbying Act possui falhas e já foi objeto de algumas alterações legislativas desde a sua aprovação - mesmo assim, regras similares foram adotadas por vários outros países, tais como França, Reino Unido, Nova Zelândia e México.

No Brasil, desde 1990, tem havido várias tentativas de regulamentar o lobby. A primeira delas foi o Projeto de Lei $\mathrm{n}^{\mathrm{o}}$ 6.132/90, que, proposto pelo então senador pernambucano Marco Maciel, foi aprovado no Senado, mas considerado inconstitucional pela Comissão de Constituição e Justiça da Câmara dos Deputados, sob o argumento de que o tema deveria ser regulamentado por resolução do Congresso Nacional, porque a matéria se referia à organização interna do Legislativo. Posteriormente foram apresentados três projetos de resolução e um projeto de lei, mas nenhum deles logrou ser votado pelo Senado ou pela Câmara dos Deputados. ${ }^{869}$

Nesse cenário, a regulamentação do lobby surge nos debates sobre transparência das ações governamentais: não basta haver publicidade do ato administrativo, é preciso que os

\footnotetext{
$\overline{868}$ ESTADOS UNIDOS DA AMÉRICA. Corte Suprema. United States v. Harriss et al., 347 U.S. 612 (1954). Recurso da United States District Court para a District Court of Columbia n. 32. Proposto em 19 out. 1953. Julgado em 7 jun. $1954 . \quad$ Disponível $<$ http://caselaw.lp.findlaw.com/scripts/getcase.pl?navby=CASE\&court=US\&vol=347\&page=612>. Acesso em: 19 dez. 2009. "Thus construed, 305 and 308 also do not violate the freedoms guaranteed by the First Amendment - freedom to speak, publish, and petition the Government. Present-day legislative complexities are such that individual members of Congress cannot be expected to explore the myriad pressures to which they are regularly subjected. Yet full realization of the American ideal of government by elected representatives depends to no small extent on their ability to properly evaluate such pressures. Otherwise the voice of the people may all too easily be drowned out by the voice of special interest groups seeking favored treatment while masquerading as proponents of the public weal. This is the evil which the Lobbying Act was designed to help prevent. Toward that end, Congress has not sought to prohibit these pressures. It has merely provided for a modicum of information from those who for hire attempt to influence legislation or who collect or spend funds for that purpose. It wants only to know who is being hired, who is putting up the money, and how much. It acted in the same spirit and for a similar purpose in passing the Federal Corrupt Practices Act - to maintain the integrity of a basic governmental process. See Burroughs and Cannon v. United States, 290 U.S. 534, 545. Under these circumstances, we believe that Congress, at least within the bounds of the Act as we have construed it, is not constitutionally forbidden to require the disclosure of lobbying activities. To do so would be to deny Congress in large measure the power of self-protection. [347 U.S. 612, 626] And here Congress has used that power in a manner restricted to its appropriate end. We conclude that 305 and 308, as applied to persons defined in 307, do not offend the First Amendment."

${ }^{869}$ É interessante observar que as propostas de regulamentação do lobby partiram de correntes opostas do espectro partidário. Veja-se dados sobre as cinco propostas em trâmite: (i) Projeto de Lei n⿳o 6.132/1990, de autoria do senador Marco Maciel (PFL/PE): "Dispõe sobre o registro de pessoas físicas ou jurídicas junto às casas do Congresso Nacional, para os fins que especifica"; (ii) Projeto de Resolução do Congresso Nacional $\mathrm{n}^{\mathrm{o}}$ 87/2000, de autoria do deputado Ronaldo Vasconcellos (PFL/MG): "Disciplina a atuação dos grupos de pressão, lobby e assemelhados na Câmara dos Deputados"; (iii) Projeto de Resolução do Congresso Nacional nº 63/2000, de autoria da Comissão Especial da Reforma do Regimento Interno da Câmara dos Deputados; (iv) Projeto de Resolução do Congresso Nacional n⿳o 203/2001, de autoria do deputado Walter Pinheiro (PT/BA): "Disciplina a atuação dos grupos de pressão ou de interesses e assemelhados na Câmara dos Deputados"; (v) Projeto de Lei n⿳亠口冋 1202/2007, de autoria do deputado Carlos Zarattini (PT/SP): "Disciplina a atividade de lobby e a atuação dos grupos de pressão ou de interesses e assemelhados no âmbito dos órgãos e entidades da Administração Pública Federal".
} 
interesses motivadores da aprovação da lei que permitiu a emissão daquele ato administrativo também sejam transparentes. Parte dessa função no desnudamento dos interesses privados já é desempenhada pelo dever de informar os doadores de recursos, inclusive durante a campanha eleitoral ${ }^{870}$ Tal determinação permite à sociedade civil identificar o móvel por trás da atuação do político. Embora nem todos os recursos gastos em campanha sejam efetivamente declarados devido à prática de caixa-dois, a regra pode ser eficaz para inibir que os políticos atuem na defesa de interesses privados. Esse efeito inibidor pode ser comprovado pela recente tendência de as doações serem feitas aos partidos políticos, os quais não se sujeitam a regras de transparência idênticas aos candidatos - por vias indiretas, os partidos transfeririam os recursos doados para as campanhas daqueles candidatos que houverem obtido as doações de particulares.

Se regulamentado o lobby, mesmo assim as regras não confeririam clareza completa ao móvel da ação dos políticos eleitos. Estes ainda poderiam agir de acordo com seus interesses privados e subverter o interesse público. Entra em cena o problema políticopartidário - houvesse um sistema de fidelidade partidária eficiente, os políticos ficariam compelidos em sua ação pelas regras e práticas existentes.

O esclarecimento desse aspecto, negligenciado pelo direito posto, ajuda a compreender como várias feições do Estado patrimonialista corrompem por dentro a dicotomia público-privado. O ponto de partida precisa ser a discricionariedade, que será analisada em três de seus aspectos, a saber, o conceito de mérito administrativo, a discricionariedade técnica e a discricionariedade legislativa.

\footnotetext{
$\overline{{ }^{870} \text { BRASIL. Lei no }}$ 9.504, de 30 set. 1997. Art. 28. “A prestação de contas será feita: I - no caso dos candidatos às eleições majoritárias, na forma disciplinada pela Justiça Eleitoral; II - no caso dos candidatos às eleições proporcionais, de acordo com os modelos constantes do Anexo desta Lei. $\S 1^{\mathrm{o}}$ As prestações de contas dos candidatos às eleições majoritárias serão feitas por intermédio do comitê financeiro, devendo ser acompanhadas dos extratos das contas bancárias referentes à movimentação dos recursos financeiros usados na campanha e da relação dos cheques recebidos, com a indicação dos respectivos números, valores e emitentes. [...] $\S 4^{\circ}$ Os partidos políticos, as coligações e os candidatos são obrigados, durante a campanha eleitoral, a divulgar, pela rede mundial de computadores (Internet), nos dias 6 de agosto e 6 de setembro, relatório discriminando os recursos em dinheiro ou estimáveis em dinheiro que tenham recebido para financiamento da campanha eleitoral, e os gastos que realizarem, em sítio criado pela Justiça Eleitoral para esse fím, exigindo-se a indicação dos nomes dos doadores e os respectivos valores doados somente na prestação de contas final de que tratam os incisos III e IV do art. 29 desta Lei."
} 


\subsection{Discricionariedade, separação entre os poderes e interesses privados}

Para identificar qual interesse está por trás de dada norma ou ato administrativo, deve-se voltar para a sua motivação. É nesta que, em tese, os interesses públicos deveriam vir explicitados.

Em matéria de motivação, deve-se começar pela diferença doutrinária entre atos vinculados e discricionários. Nos primeiros, a administração deve obedecer estritamente à previsão legal sem nenhuma espécie de margem de manobra para exercer a sua arbitrariedade. Já quanto aos atos discricionários, haveria certa liberdade de decisão diante do caso concreto, posto inexistir uma solução única correta, mas sim "vários objetos possíveis para atingir o mesmo fim, sendo todos eles válidos perante o direito". ${ }^{871}$ É exatamente essa "liberdade" que constitui a discricionariedade. Só se pode falar em mérito nos atos discricionários, pois somente nestes há a possibilidade de a autoridade formular juízos de conveniência e oportunidade.

Quando se depara com um ato discricionário, a autoridade pouca ou nenhuma margem de manobra dispõe em realidade, pois está adstrita à finalidade da norma. "Onde há função, pelo contrário, não há autonomia da vontade, nem a liberdade em que se expressa, nem a autodeterminação da finalidade a ser buscada, nem a procura de interesses próprios, pessoais". 872

Em certa medida, isso é deixado de lado pelos debates doutrinários, nos quais o elemento "personalista" da escolha pessoal da autoridade é ignorado. Não há consenso quanto à justificativa para essa discricionariedade, mas algumas podem ser indicadas. A justificativa derivaria do fato de que a ausência de qualquer flexibilidade prejudicaria o bom desempenho das tarefas do Poder Público. Medauar argumenta que

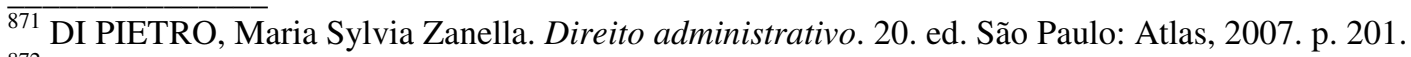

${ }^{872}$ MELLO, Celso Antônio Bandeira de. Op. cit. p. 46.
} 
[...] o Estado contemporâneo, muito complexo, com amplas funções, não pode atuar sem flexibilidade; torna-se fundamental deixar margem de maleabilidade à Administração em época de rápidas mudanças; grandes metrópoles, convivência de massa, problemas sociais, grandes tragédias exigem, por vezes, rapidez de atuação e certa margem de escolha; a discricionariedade atende, portanto, à necessidade institucional. ${ }^{873}$

Outros apontam a impossibilidade de o legislador criar normas para todos os aspectos da vida social em que o Estado age. De acordo com Mello,

[....] a discricionariedade é pura e simplesmente o fruto da finitude, isto é, da limitação da mente humana. À inteligência dos homens falece o poder de identificar sempre, em toda e qualquer situação, de maneira segura, objetiva e inobjetável, a medida idônea para preencher de modo ótimo o escopo legal. ${ }^{874}$

Por meio dessas justificativas, a discricionariedade é aplicada amplamente e, como uma grande avenida, permite que os interesses privados adentrem o interesse público - afinal, os atos discricionários prescindiriam de fundamentação e se contentariam com o personalismo da decisão de seu prolator.

Implicitamente, essa discussão demonstra uma tendência autoritária, quase que arbitrária, sobre o conteúdo de um conceito fulcral do direito administrativo. A discricionariedade não se confunde com a arbitrariedade: ${ }^{875}$ de modo diverso da atividade privada, à qual tudo que não é proibido é permitido, à atividade administrativa somente se

\footnotetext{
${ }^{873}$ MEDAUAR, Odete. Direito administrativo moderno. 7. ed. São Paulo: Revista dos Tribunais, 2003. p. 123. ${ }^{874}$ MELLO, Celso Antônio Bandeira de. Op. cit. p. 894.

875 JEHRING, Rudolf von. Op. cit. p. 281-282. O autor apresenta uma explicação didática sobre o que se deve entender por arbitrariedade. "Aquele que procede segundo o direito, procede legalmente, comete uma injustiça se vai de encontro ao direito. Todos estes termos se aplicam tanto ao Estado como aos súditos. O Estado pode cometer também um ato ilegal, uma injustiça. Contudo o Estado está, em relação ao direito, colocado de modo diferente do súdito. Tendo a missão e o poder de realizar o direito, ele pode e deve constranger à sua observância aqueles que querem afastar-se dele. A única obrigação do súdito é submeter-se ao direito. O Estado rege os atos de outrem, o súdito dirige os seus próprios. O Estado ordena, o súdito obedece. Esta situação diferente imprime à injustiça cometida pelo Estado, comparada com a cometida pelo súdito, um caráter particular. A linguagem compreendeu isto bem, quando designou a injustiça do Estado pelo nome de arbítrio. O súdito que infringe a lei procede ilegalmente e não arbitrariamente. $\mathrm{O}$ arbítrio é a injustiça do superior; distingue-se da do inferior em que o primeiro tem o poder a seu favor, ao passo que o segundo o tem contra ele. Se este último desacata, não a norma abstrata, mas a ordem concreta do superior, comete uma rebelião, uma desobediência. Estes termos não podem aplicar-se ao poder: o termo arbítrio e, como depois veremos, o termo justiça não podem aplicar-se aos atos do interior. A potência de vontade que não é regida por uma lei não é arbítrio, é simples poder. É por isso que ainda não pode tratar-se do arbítrio na história do direito na fase histórica da força unilateralmente obrigatória da norma jurídica, e é essa também a razão por que nós não podíamos falar dele senão aqui. A sombra não precedeu a luz, o arbítrio não podia existir antes do direito. Noção puramente negativa, o arbítrio supõe, como antítese, o direito cuja negação é: não há arbítrio se o povo ainda não reconheceu a força bilateralmente obrigatória das normas públicas. A este respeito a sua situação acima descrita poderia afigurar-senos, na fase inicial do direito, regida pelo arbítrio puro; mas convém não perder de vista que lhe introduzimos aqui um elemento que lhe era estranho."
} 
permite fazer aquilo que é previsto pela lei ${ }^{876}$ Todo e qualquer ato administrativo deve basearse em alguma norma permissiva ${ }^{877}$ Assim, discricionariedade deve ser compreendida não como total liberdade decisória da administração, mas como uma liberdade-vínculo, na medida em que "sujeita-se não só às normas específicas para cada situação, mas a uma rede de princípios que asseguram a congruência da decisão ao fim de interesse geral e impedem seu uso abusivo" ${ }^{878}$ Com razão, ainda hoje, Bucci reconhece a existência dessa contradição no direito administrativo brasileiro:

\begin{abstract}
A segunda contradição está no cerne do que foi a resistência do direito angloamericano ao modelo de direito administrativo francês e diz respeito à estruturação do direito administrativo como um direito estatuário da Administração Pública, baseado na existência de prerrogativas especiais, integrantes do "poder de império" da Administração, poderes exorbitantes aos conferidos pelo direito comum, por oposição à estrutura dos modelos inglês e norte-americano, que não proporciona às respectivas Administrações nenhum poder exorbitante, regendo-se elas pela common law. A finalidade de explorar esta contradição é investigar como a noção de prerrogativa ainda permanece no direito administrativo brasileiro e se a sua permanência é necessária ao desempenho da função administrativa. ${ }^{879}$
\end{abstract}

Até a Constituição de 1988 discutia-se a necessidade de explicitar a motivação dos atos administrativos discricionários. ${ }^{880}$ Essa polêmica abria ampla área para que os interesses privados adentrassem o ato administrativo - há disputas levadas ao Judiciário em que os interesses pessoais presentes no ato administrativo foram anulados. ${ }^{881}$ Ao se motivar o ato administrativo, permite-se verificar "a existência dos pressupostos de fato" e abre-se o mesmo para sujeição à teoria dos fatos determinantes. ${ }^{882}$

\footnotetext{
$\overline{876}$ Por cômico, merece ser lembrado o episódio de uso irregular de passagens aéreas por deputados e senadores, escândalo que veio ao conhecimento público em 2009. Muitos parlamentares argumentaram que os fatos eram lamentáveis, mas que nada podia ser feito, uma vez que inexistia uma regra sobre o uso das passagens aéreas consequentemente, o que não era proibido era permitido e não haveria espaço para punição. Tal sofisma foi repetido exaustivamente, inclusive por jornalistas mal-informados ou mal-intencionados. Ignorava-se que o propósito das passagens aéreas para parlamentares sempre pareceu bem claramente relacionado ao desempenho de suas funções, não a outro fim privado (apoiar as bases eleitorais, ajudar férias de namorada, levar a sogra para fazer exames médicos no exterior etc.).

${ }^{877}$ MELLO, Celso Antônio Bandeira de. Op. cit. p. 890.

${ }^{878}$ MEDAUAR, Odete. Op. cit. p. 122.

${ }^{879}$ BUCCI, Maria Paula D. Op. cit. p. 96.

${ }^{880}$ NOHARA, Irene Patrícia. O motivo no ato administrativo. 2002. 185 f. Dissertação (Mestrado em Direito do Estado) - Faculdade de Direito, Universidade de São Paulo, São Paulo. p. 44.

${ }^{881}$ Idem, p. 47. “[...] o antigo Tribunal Federal de Recursos, em acórdão de 25.09.1950, anulou pena disciplinar aplicada a servidor autárquico por motivos comprovadamente políticos. Também o Tribunal de Justiça do Estado de São Paulo anulou ato de demissão de funcionário público, a título de economia, porque a finalidade real era proporcionar oportunidade para nomeação de outras pessoas [....]."

${ }^{882}$ Idem, p. 49.
} 
Entretanto, após 1988, os tribunais consolidaram posição no sentido de exigir motivação com base no princípio da publicidade. ${ }^{883}$ Ademais, foi positivado o dever de motivar $\mathrm{o}$ ato administrativo, inclusive o discricionário. ${ }^{884}$ Esse novo desenho reduz a discricionariedade, embora possa gerar conflitos entre os poderes em questões consideradas políticas. ${ }^{885}$ Kelsen identificou incoerências produzidas pela aplicação do princípio da separação entre os poderes, argumentando que

[...] este princípio parece exigir que nenhum dos três poderes seja controlado por qualquer um dos outros dois. Não obstante, invoca-se o princípio da separação de poderes para justificar o mais estrito controle da administração pelos tribunais, um estado que é alcançado quando os órgãos administrativos têm de recorrer aos tribunais para a imposição de leis administrativas. ${ }^{886}$

De fato, a tradicional noção de separação entre os poderes impunha ao Legislativo a função de estabelecer as diretrizes estatais. Com o advento do Estado intervencionista, essa tarefa foi assumida, em grande parte, pelo Executivo, o que permaneceu verdadeiro mesmo depois da liberalização econômica e da privatização. Ao Judiciário nenhum papel ativo incumbiria quanto ao delineamento das políticas públicas ou ao exame da legitimidade dos interesses.

Tal como concebida por Montesquieu, a fórmula da separação entre os poderes perde seu referencial prático e seu sentido político com a superação do liberalismo clássico. Mais importante do que uma lei que garanta o equilíbrio entre os poderes é a existência de uma lei de impulsão, que possa garantir a implementação de políticas aptas a atender aos anseios da população. ${ }^{887}$

\footnotetext{
${ }^{883}$ Idem, p. 46.

${ }^{884}$ BRASIL. Lei no 9.784, de 29 jan. 1999. Art. 50. "Os atos administrativos deverão ser motivados, com indicação dos fatos e dos fundamentos jurídicos, quando: I - neguem, limitem ou afetem direitos ou interesses; II - imponham ou agravem deveres, encargos ou sanções; III - decidam processos administrativos de concurso ou seleção pública; IV - dispensem ou declarem a inexigibilidade de processo licitatório; V - decidam recursos administrativos; VI - decorram de reexame de ofício; VII - deixem de aplicar jurisprudência firmada sobre a questão ou discrepem de pareceres, laudos, propostas e relatórios oficiais; VIII - importem anulação, revogação, suspensão ou convalidação de ato administrativo. $§ 1^{\circ}$ A motivação deve ser explícita, clara e congruente, podendo consistir em declaração de concordância com fundamentos de anteriores pareceres, informações, decisões ou propostas, que, neste caso, serão parte integrante do ato."

${ }^{885}$ BARBOSA, Rui. Comentários à Constituição Federal Brasileira. Coligidos e ordenados por Homero Pires. São Paulo: Saraiva, 1933. v. 5. p. 41. "O efeito da interferência da justiça, muitas vezes, não consiste senão em transformar, pelo aspecto com que se apresenta o caso, uma questão política em questão judicial. Mas a atribuição de declarar inconstitucionais os atos da legislatura envolve, inevitavelmente, a Justiça Federal em questões políticas. É, indubitavelmente, um poder, até certa altura, político, exercido sob as formas judiciais."

${ }^{886}$ KELSEN, Hans. Teoria geral do direito e do Estado. São Paulo: Martins Fontes, 2000. p. 400. No mesmo sentido, ver TOJAL, Sebastião Botto de Barros. O controle judicial da atividade normativa das agências reguladoras. Revista da Academia Brasileira de Direito Constitucional, Curitiba. v. 2, 2002. p. 75-103, 2002

${ }^{887}$ FERREIRA FILHO, Manoel Gonçalves. Do processo legislativo. 4. ed. São Paulo: Saraiva, 2001. Ilustrativa dessa mudança na dimensão temporal é o fato de que as leis, no Estado liberal, "visam a um equilíbrio entre a
} 
Ao considerar a lei como instrumento de políticas públicas, Loewenstein delineia três funções do Estado, já referidas anteriormente (policy determination, policy execution e policy control). ${ }^{888}$ Por se tratar de ação administrativa situada nos limites entre o mérito e a legalidade, as políticas públicas sujeitam-se cada vez mais ao controle jurisdicional.

\subsubsection{Revisão judicial do ato administrativo enquanto limitação aos interesses privados, exame da finalidade do ato e teoria do desvio de poder}

A atuação do Judiciário na redução da discricionariedade também precisa ser vista com cautela, uma vez que os tribunais têm atribuído diferentes significados e alcances à palavra "discricionariedade". A auto-outorga de poderes pelo Judiciário poderá somente alterar o locus do problema para o Judiciário, um poder desprovido de legitimidade democrática - se as críticas veladas à atuação do Ministério Público já são consideráveis, elas se reproduzem quando o Judiciário age com certo "ativismo". Além das dificuldades inerentes em detectar práticas que revelem uma confusão entre o público e o privado, uma decisão judicial corrupta também pode esconder esse problema por trás de uma interpretação supostamente baseada no livre convencimento racional do juiz. Permitir que o Judiciário decida nessas circunstâncias em nada seria distinto do exercício da discricionariedade pela administração pública. ${ }^{889}$

Em realidade, o controle jurisdicional de políticas públicas tem sido uma questão das mais recorrentes do direito administrativo brasileiro. A abundância de princípios da Constituição de 1988 teria diminuído o campo da discricionariedade administrativa e, consequentemente, do mérito administrativo. Além disso, a mesma Constituição impôs vários planos implementadores de políticas públicas nos mais diversos setores da vida social e econômica. A legalidade, ampliada para a ideia de juridicidade, alarga o âmbito dos debates, pois passa a fornecer critérios mais objetivos para aferir a adequação da ação administrativa à política pública, seja ela legal ou constitucional.

\footnotetext{
variedade de interesses dos vários grupos que constituem a sociedade", devendo, por isso, ser estáveis, pois "do contrário elas não servirão ao estabelecimento de uma ordem onde haja segurança nas relações sociais". Por outro lado, no Estado intervencionista, esse paradigma se transforma. As leis "se inscrevem como meios para a realização de objetivos determinados, devendo ser flexíveis", porque, se não o forem, "não poderá haver uma resposta pronta e adequada para as dificuldades oriundas de uma economia e de uma sociedade em rápida transformação".

${ }^{888}$ LOEWENSTEIN, Karl. Teoria de la Constitución. Trad. de Alfredo Gallego Anabitarte. Barcelona: Ediciones Ariel, 1970.

889 ÁVILA, Humberto Bergmann. A distinção entre princípios e regras e a redefinição do dever de proporcionalidade. Revista de Direito Administrativo, Rio de Janeiro: Renovar, n. 215, 1999, p. 151-179, 1999.
} 
Tome-se o caso do princípio da proporcionalidade, que pode ser um referencial. ${ }^{890}$ Antes é necessário resolver o impasse sobre qual seu sentido, uma vez que os tribunais têm atribuído diferentes significados à palavra, mantendo grande margem de discricionariedade ao Judiciário. Uma forma de resolver esse impasse é estabelecer uma definição jurisprudencial do que é a proporcionalidade e quais elementos devem ser observados para que reste inquestionável a sua aplicação. A prevalecer as dúvidas, talvez a "discricionariedade judicial" na aplicação dos princípios seja tão arbitrária quanto a administrativa.

Essa mudança tem lentamente começado a produzir efeitos. Apesar de ainda não pacificadas, as discussões judiciais e administrativas sobre moralidade administrativa, razoabilidade, proporcionalidade e eficiência constituem exemplos da transformação verificada. Como desdobramento da redução da discricionariedade administrativa, o mérito administrativo, antes intocado e intocável pelo Judiciário, tem seu campo de abrangência diminuído se comparado ao período pré-1988. Em certa proporção, o Judiciário atua mais como um ator do processo decisório na qualidade de terceiro independente, retirando o ato administrativo dos gabinetes e ampliando o grau de publicidade efetiva a que este está submetido.

Quando se trata do controle judicial da administração, usualmente se desdobra a questão em dois elementos: legalidade e mérito. Ao Judiciário caberia somente a análise da legalidade do ato administrativo, que pode ser definida como a adequação do ato ao disposto pelas normas. Tradicionalmente, o mérito pode ser definido como "o juízo de conveniência e oportunidade da escolha no atendimento do interesse público, juízo esse efetuado pela autoridade à qual se conferiu o poder discricionário". ${ }^{891}$ Nesse sentido, Di Pietro explica que "diz respeito à conformidade do ato com a lei" e esta, por sua vez, estabelece "os limites da atuação administrativa" ${ }^{892}$ - qualquer revisão do mérito pelo Judiciário seria vista como invasão da competência prevista em lei à administração. A divergência observada na doutrina

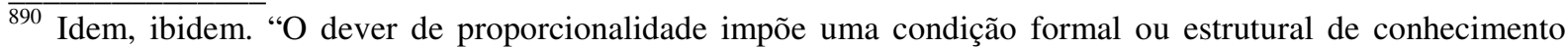
concreto (aplicação) de outras normas. Não consiste numa condição no sentido de que, sem ela, a aplicação do Direito seria impossível. Consiste numa condição normativa para a sua devida aplicação. Sem obediência ao dever de proporcionalidade não há a devida realização integral dos bens juridicamente resguardados. É dizer: ele traduz um postulado normativo aplicativo." Para que seja observado esse "postulado normativo aplicativo", três são os elementos que devem ser verificados: a adequação, a necessidade e a proporcionalidade em sentido estrito. "Uma medida é adequada se o meio escolhido está apto a alcançar o resultado pretendido; necessária, se, dentre todas as disponíveis e igualmente eficazes para atingir um fim, é a menos gravosa em relação aos direitos envolvidos; proporcional ou correspondente, se, relativamente ao fim perseguido, não restringir excessivamente os direitos envolvidos."

${ }^{891}$ MEDAUAR, Odete. Op. cit. p. 122.

${ }^{892}$ DI PIETRO, Maria Sylvia Zanella. Op. cit. p. 58.
} 
dizia respeito ao que poderia ser considerado exame do mérito e ao que poderia ser considerado exame da legalidade. Mello sustenta que

[...] haverá sempre uma zona de certeza positiva, na qual ninguém duvidará do cabimento da aplicação do conceito, uma zona circundante, onde justamente proliferarão incertezas que não podem ser eliminadas objetivamente, e, finalmente, uma zona de certeza negativa, onde será indisputavelmente seguro que descabe a aplicação do conceito [...]. Casos haverá em que, para além de dúvidas ou entredúvidas, qualquer sujeito em intelecção normal, razoável, poderá depreender (e assim também, a fortiori, o Judiciário) que, apesar de a lei haver contemplado discrição, em face de seus próprios termos e da finalidade que lhe presidiu a existência, a situação ocorrida não comportava senão uma determinada providência ou, mesmo comportando mais de uma, certamente não era a que foi tomada. Em situações quejandas, a censura judicial não implicaria invasão do mérito do ato. ${ }^{893}$

Outra postura é a de Meirelles, que admite a divisão entre mérito e legalidade, sendo o primeiro intocável pelo Judiciário. Não se poderia, porém, confundir "o mérito administrativo do ato, infenso à revisão judicial, com o exame de seus motivos determinantes, sempre passíveis de verificação em juízo" ${ }^{894}$ Aliás, Meirelles também minimiza o campo da discricionariedade, a qual seria sempre "relativa e parcial", pois deve haver obediência à competência, forma e finalidade do ato administrativo. ${ }^{895}$ Abre-se campo para análise do interesse público e, possivelmente, afastamento do interesse privado nos atos discricionários. Meirelles explica que "o Judiciário não poderá dizer da conveniência, da oportunidade e justiça da aplicação de uma penalidade administrativa, mas poderá e deverá sempre examinar seu cabimento e a regularidade formal de sua imposição". ${ }^{896}$

Por sua vez, Grau admite a existência de mérito e de legalidade, contrapondo a discricionariedade e a interpretação. Todavia, o alcance dessa discricionariedade é enormemente reduzido se comparado ao que a doutrina costuma lhe conceber: "[...] a doutrina do direito administrativo liberal constrói uma falsa legalidade, na medida em que fragiliza mediante a introdução, nela, deste autêntico Cavalo de Tróia, a discricionariedade". ${ }^{897}$ É por meio desse Cavalo de Troia que os interesses privados podem adentrar a administração pública e moldam o interesse público. Segundo Grau, a discricionariedade consistiria numa "liberdade de eleição entre alternativas igualmente justas ou entre indiferentes jurídicos porque a decisão se fundamenta em critérios extrajurídicos (de oportunidade, econômicos

\footnotetext{
$\overline{893}$ MELLO, Celso Antônio Bandeira de. Op. cit. p. 894.

${ }^{894}$ MEIRELLES, Hely Lopes. Direito administrativo brasileiro. 34. ed. São Paulo: Malheiros, 2008. p. 718.

${ }^{895}$ Idem, p. 104.

${ }^{896}$ Idem, p. 718.

${ }^{897}$ GRAU, Eros Roberto. O direito posto e o direito pressuposto. 7. ed. São Paulo: Malheiros, 2008. p. 195.
} 
etc.), não incluídos na lei e remetidos ao juízo subjetivo da Administração". ${ }^{898}$ A aplicação dos conceitos indeterminados é um caso de aplicação da lei, um caso de interpretação, papel a ser exercido pelo operador do direito. Consequentemente, a interpretação só admite uma única solução justa para cada caso, refletindo-se no papel a ser desempenhado pelo Judiciário, pois, se há apenas uma solução, este pode se manifestar quando a decisão for incorreta. Grau considera o interesse público como conceito indeterminado e, por isso, passível de interpretação e análise. Todo ato administrativo motivado por razões de interesse público pode ser analisado pelos tribunais, o que esvazia a tradicional visão sobre o seu mérito. ${ }^{899}$ Portanto, a restrição da noção de ato discricionário indiretamente também reduz o âmbito de influência dos interesses privados perante o Estado. Isso se dá principalmente pelo exame da finalidade do ato administrativo - quando uso de um ato alcança finalidade diversa da que lhe é própria, costuma-se falar em “desvio de poder" ou "desvio de finalidade”. Segundo Tácito,

\begin{abstract}
A manifestação de vontade do agente público terá, necessariamente, que se dirigir à observância da finalidade específica com a natureza da atividade exercida. Se a autoridade se desvia da finalidade legal específica, o ato administrativo se torna viciado em elemento essencial à sua legalidade. Caracteriza-se, na hipótese, o vício que se conceituou como desvio de finalidade ou desvio de poder. ${ }^{900}$
\end{abstract}

De acordo com Mello, o desvio de poder pode se manifestar de dois modos: “a) quando o agente busca uma finalidade alheia ao interesse público. Isto sucede ao pretender usar de seus poderes para prejudicar um inimigo ou para beneficiar a si próprio ou amigo; b) quando o agente busca uma finalidade - ainda que de interesse público - alheia à categoria do ato que utilizou". ${ }^{901}$

Outro ponto controverso é se seria possível estender a aplicação da teoria do desvio de poder, originariamente dirigida aos atos administrativos, a outros atos que não os

\footnotetext{
$\overline{898}$ GRAU, Eros Roberto. Op. cit. p. 203. Baseado em Dworkin, Grau examina a discricionariedade sob várias perspectivas e constata que a palavra é empregada plurivocamente, fazendo-se necessário analisar o contexto para a definição do seu exato sentido. Num primeiro sentido, discricionariedade indica uma razão que impede alguém de fazer uma atividade mecanicamente, seguindo um padrão predeterminado e sendo-lhe exigido efetuar algum julgamento para realizar esta atividade. "[...] o poder discricionário, neste sentido, fraco, diz apenas com o fato de que a aplicação de qualquer ordem, indicação, conceito etc. reclama alguma interpretação; ou seja, reclama um agente capaz de raciocinar, portanto não imbecil ou idiota. Neste sentido, discricionariedade = capacidade de raciocínio." Igualmente em sentido fraco, discricionariedade é empregada para indicar que alguém possui a capacidade de tomar uma decisão, não podendo ser anulada ou controlada por outros. Por fim, num sentido mais forte, a palavra é aplicada para mostrar que o investido de poder discricionário não está obrigado à observância de restrições impostas por outra autoridade.

${ }^{899}$ Idem, ibidem.

900 TÁCITO, Caio. O desvio de poder no controle dos atos administrativos, legislativos e jurisdicionais. Revista de Direito Administrativo, n. 228, p. 1, abr./jun. 2002.

${ }^{901}$ MELLO, Celso Antônio Bandeira de. Op. cit. p. 379.
} 
praticados pelo Executivo. Há quem expanda a aplicação da teoria do desvio de poder a uma gama ainda mais abrangente de atos praticados pelo Estado. ${ }^{902}$

No tradicional direito constitucional, a produção legislativa seria um ato político e, portanto, gozaria de total liberdade de atuação. Mesmo assim, havia a necessidade de cumprimento de uma finalidade. Tal como argumenta Jhering,

\begin{abstract}
O poder legislativo não está, como o juiz, como o governo, colocado sob a lei, antes está acima da lei. Cada lei que ele proclama, qualquer que seja o seu teor, é, em direito, um ato perfeitamente legal. Portanto, em sentido jurídico, o legislador não pode cometer nunca uma arbitrariedade; sustentar o contrário seria o mesmo que dizer que lhe não assistia o direito de mudar as leis existentes; seria colocar o poder legislativo em contradição consigo mesmo. Mas, assim como o pai deve, senão juridicamente pelo menos moralmente, usar do seu poder em conformidade com o fim da autoridade paternal, ao legislador pelo seu lado cumpre empregar no interesse da sociedade o poder de que dispõe: o seu direito é ao mesmo tempo, como o do pai, um dever; por força da sua própria missão tem que satisfazer a umas certas exigências, que respeitar umas certas normas. Portanto ele pode também abusar do poder que lhe foi confiado. ${ }^{903}$
\end{abstract}

No que tange ao alcance da teoria aos atos políticos, o ponto é se a vinculação a que se submete o ato administrativo em relação à lei é a mesma que se dá entre esta e a Constituição, permitindo a transposição dos conceitos de discricionariedade e desvio de poder dos atos administrativos para os legislativos. Para Canotilho, essa transposição seria possível com algumas ressalvas: apenas no âmbito de uma Constituição Dirigente a "liberdade de conformação do legislador" corresponderia a uma "discricionariedade legislativa", tendo em vista a vinculação do legislador submetido ao controle da jurisdição constitucional, cabendo a esta fiscalizar a conformidade formal e material dos atos legislativos. ${ }^{904}$ Embora essa noção de vinculação do legislador seja muito polêmica, há quem sustenta a transposição da teoria do desvio de poder para os atos do Legislativo.

Haveria uma "discricionariedade peculiar" do Legislativo no exercício de suas funções normativas devido às atribuições políticas desempenhadas. ${ }^{905}$ Para Tácito, "é necessário um temperamento da latitude discricionária de ato do poder legislativo, ainda que

\footnotetext{
$\overline{902}$ Idem, ibidem. "O desvio de poder não é mácula jurídica privativa dos atos administrativos. Pode se apresentar, igualmente, por ocasião do exercício de atividade legislativa ou jurisdicional. Ou seja: leis e decisões judiciais são igualmente suscetíveis de incorrer no aludido vício, porquanto umas e outras são, também, emanações das competências públicas, as quais impõem fidelidade às finalidades que as presidem. Assim, se o legislador ou o juiz delas fizerem uso impróprio, a dizer, divorciado do sentido e direcionamento que lhes concernem, haverão traído as competências que os habilitavam e os atos que produzirem resultarão enodoados pela indelével jaça do desvio de poder."

${ }_{903}$ JEHRING, Rudolf von. Op. cit. p. 284-285

${ }^{904}$ CANOTILHO, José Joaquim Gomes. Constituição dirigente e vinculação do legislador. Coimbra: Coimbra Editora, 1994, p. 260-266.

${ }_{905}$ TÁCITO, Caio. O desvio de poder legislativo. Revista Trimestral de Direito Público, 1993, p. 66.
} 
fundado em competência constitucional e formalmente válida". ${ }^{906}$ Como exemplo, são mencionados dois julgados do STF, nos quais se decidiu pela nulidade de leis estaduais que criavam cargos públicos em número excessivo ao fim de mandatos e tão-somente para o aproveitamento de correligionários ou de seus familiares - à época, o STF reconheceu o abuso do legislativo estadual no exercício da atribuição, em princípio discricionária, da criação de cargos públicos. ${ }^{907} \mathrm{Se}$ a invalidade dos atos administrativos maculados pelo desvio de poder são inválidos, na terminologia do direito constitucional os atos legislativos maculados com o mesmo vício são considerados inconstitucionais, como explica Mendes:

O excesso de poder como manifestação de inconstitucionalidade configura afirmação da censura judicial no âmbito da discricionariedade legislativa ou, como assente na doutrina alemã, na esfera de liberdade de conformação do legislador (gesestzgeberische Gestaltungsfreiheit), permitindo aferir a compatibilidade das opções políticas com os princípios consagrados na Constituição. Nega-se, assim, à providência legislativa o atributo de um ato livre no fim, consagrando-se a vinculação do ato legislativo a uma finalidade. ${ }^{908}$

Um ponto de contradição da extensão da aplicação da teoria do desvio de poder é o problema da responsabilização da autoridade que abusa de poder. Diversamente do passado, quando vigia o princípio da irresponsabilidade do Estado (the king can do no wrong), confundido com o soberano, hoje os atos estatais geram responsabilidade não somente para o Estado, mas também para seu autor, ainda que subsidiariamente - afinal, aquele que usa o poder sem atender a um dever pratica um ilícito. A dificuldade reside no fato de que, em qualquer Estado Democrático, tradicionalmente vigora a noção de que os atos legislativos do Parlamento escapam à toda e qualquer responsabilização, sujeitando-se, apenas de modo difuso, ao escrutínio eleitoral ${ }^{909}$. Dentro do conceito de imunidade parlamentar encontra-se a

\footnotetext{
$\overline{906}$ TÁCITO, Caio. O desvio de poder no controle dos atos administrativos, legislativos e jurisdicionais. Revista de Direito Administrativo, n. 228, abr./jun. 2002, p. 4.

907 Ver BRASIL. Supremo Tribunal Federal. Mandado de segurança no 7.243. Relator: Ministro Luiz Galotti. Decisão em 20 jan. 1969. "Poderes Legislativo e Executivo. Pode anular seus próprios atos, quando os considerem inconstitucionais. Entretanto, a palavra derradeira, a respeito, caberá ao Poder Judiciário, sempre que oportunamente provocado. Lei cearense $n^{\circ} 4.488$, que considerou nulos e de nenhum efeitos os atos de criação, transformação e equiparação de cargos constantes da Lei 4.222. Arts. 123 e 124 da Constituição do Ceará, que, respectivamente, não permitem encargo que onere o Estado sem a atribuição de recursos suficientes para custearlhe as despesas, nem que o Estado despenda, anualmente, com o funcionalismo, inclusive militares e extranumerários, mais de 50\% das suas rendas, excluídas as despesas com o magistério primário e profissional. Não se pode ter como inconstitucional uma lei que anulou a anterior, por sua inconstitucionalidade. A anulação opera ex tunc do ato nulo, em regra, não nasce direito. Segurança negada."

908 MENDES, Gilmar Ferreira. O controle de constitucionalidade: aspectos jurídicos e políticos. São Paulo: Saraiva, 1990, p. 39

${ }^{909}$ HUNGRIA, Nélson. Comentários ao Código Penal (Dec.-Lei n. 2.848, de 7 de dezembro de 1940). v. 9, Art. 250 a 361. 2. ed. Rio de Janeiro: Forense, 1959. p. 402. Por outro lado, "os senadores e deputados são, indiscutivelmente, funcionários públicos. $\mathrm{O}$ ponto de vista contrário ressente-se de obsoleto idealismo democrático, que colocava os parlamentares na ilimitada amplitude de suas imunidades e prerrogativas, acima
} 
imunidade material, também denominada inviolabilidade, consistente na irresponsabilidade absoluta dos parlamentares pelos votos proferidos no exercício do mandato Como a atividade normativa é por excelência política, o objetivo da inviolabilidade é destacar a atuação do parlamentar das pressões do seu eleitorado e de outros poderes, justamente para que atue de acordo com o interesse público.

Como desdobramento deste corolário da irresponsabilidade do Parlamento, o legislador goza de liberdade para decidir o que é melhor para a sociedade - o mandato eletivo não o é para o fiel exercício do que determinar o outorgante, tal como ocorre com o direito privado. O voto, a inviolabilidade das opiniões e as verbas de gabinete dos parlamentares existem para ser utilizadas no cumprimento de um dever funcional para com o Estado e não constituem direito subjetivo dos eleitos.

A indignação popular contra a inviolabilidade parlamentar, embora possa se basear num inconformismo legítimo em relação a leis e até mesmo emendas constitucionais com flagrantes afrontas à Constituição, é incapaz de fornecer uma alternativa mais segura para o problema. Ademais, o Judiciário não tem legitimidade para certas escolhas políticas. Conforme ensina Queiroz,

\begin{abstract}
Sempre que a justiça constitucional ultrapassar a sua medida de controle "as a court" estará a agir inconstitucionalmente e, para mais, no limiar de uma "usurpação" de poderes. A actuação reiterada da Supreme Court ao tempo da concretização do "New Deal", faz pressupor os perigos que comporta uma jurisdição excessivamente "activista", um "governo de juízes" (government by judiciary), capaz de defrontar a vitória eleitoral de um Presidente, Franklin D. Rossevelt, e de um Congresso livremente eleitos pelo povo. [...]

A institucionalização de mecanismos de controle jurídico do poder apresentam-se como um elemento necessário e indefectível do Estado de direito. Mas seria puro engano pressupor que o manejo de todo esse instrumentário jurídico pudesse alguma vez resolver todos os problemas atinentes à justiciabilidade do político. Numa ordem constitucional livre e democrática o controle jurídico não é tudo. Controles "sociais" e "políticos" também se desenvolvem como desde há muito foi notado. ${ }^{910}$
\end{abstract}

O problema é complexo e escapa aos limites desta tese. Contudo, pelas suas implicações nítidas sobre a estruturação do federalismo fiscal e, principalmente, sobre o processo orçamentário da União, precisa ser mencionado.

dos próprios interesses do Estado, de modo que não era concebível sua equiparação aos funcionários públicos em

${ }_{910}^{\text {geral”. }}$ QUEIROZ, Cristina M. M. Os actos políticos no Estado de Direito. O problema do controle jurídico do poder. Coimbra: Almedina, 1990. p. 217. 


\subsubsection{Discricionariedade técnica}

No atendimento ao interesse público, decisões tecnicamente complexas devem ser tomadas por autoridades e funcionários públicos. Esse fenômeno em nada se diferenciaria da "discricionariedade em sentido amplo", objeto de discussão nos itens anteriores, não fosse uma peculiaridade: a complexidade das decisões a serem tomadas. A sofisticação das ações do Estado tornou o processo de tomada de decisões igualmente mais sofisticado.

Diversamente da "discricionariedade em sentido amplo", a discricionariedade técnica já representa um estreitamento do processo decisório pelo Estado - a decisão de fazer algo já foi tomada no momento da escolha da política pública, ${ }^{911}$ e agora restaria apenas a decisão de como fazer o que foi decidido. Por trás da aparente singeleza do ato administrativo se escondem questões macrojurídicas, típicas de direito econômico, que se refletem diretamente sobre a vida econômica de todo o país. Ora, se a discricionariedade técnica representa um estreitamento da "margem de manobra" da autoridade, por que ela causa tanta preocupação?

Diante da necessidade de tomar uma decisão técnica, várias opções igualmente técnicas se abrem, cada uma apresentando justificativas igualmente técnicas. Por vezes, há nítida vantagem de uma opção sobre as demais, perceptível até mesmo para os leigos. Contudo, podem ocorrer hipóteses em que a definição da melhor escolha técnica seja muito complexa, dificultando a participação da sociedade civil, bem como a compreensão do que seria o interesse público. ${ }^{912}$ Haveria uma chance para que os interesses privados adentrassem num ato administrativo que deveria ter por paradigma apenas o interesse público. A alegada complexidade técnica na tomada da decisão a afastaria da revisão judicial: ${ }^{913}$ deveria ser afastada toda e qualquer análise do mérito pelos tribunais. Para Medauar, esse juízo peculiar

\footnotetext{
$\overline{911}$ BUCCI, Maria Paula D. Op. cit. p. 265. “As políticas públicas podem ser entendidas como forma de controle prévio de discricionariedade na medida em que exigem a apresentação dos pressupostos materiais que informam a decisão, em conseqüência da qual se desencadeia a ação administrativa. O processo de elaboração da política seria propício a explicitar e documentar os pressupostos da atividade administrativa e, dessa forma, tornar viável o controle posterior dos motivos."

912 Idem, ibidem, p. 265. "Embora o conceito de discricionariedade técnica seja em si controvertido, até porque a idéia de discricionariedade há muito deixou de ser sinônimo de insuscetibilidade de controle jurisdicional, o seu núcleo permanece sendo um obstáculo à participação dos cidadãos na Administração e ao contraste pleno da atividade administrativa, na medida em que os instrumentos do direito não são aptos, por si sós, a sopesar as escolhas técnicas."

${ }_{913}$ BUCCI, Maria Paula D. Op. cit. p. 265. De fato, Bucci explica que a origem da noção de discricionariedade técnica por Bernatzik, em 1864, se liga ao discurso que tentava afastar questões técnicas do controle judicial, uma vez que somente os administradores deteriam formação técnica capaz de compreender a "elevada complexidade das premissas factuais".
} 
não consiste em tipo diverso de discricionariedade, logo não foge ao controle judicial. ${ }^{914}$ Quando há a obrigatória motivação técnica, não há por que afastar os atos discricionários da revisão judicial. Afinal, uma decisão possui "standards, e muito precisos, a serem estrita e rigorosamente atendidos por quem toma a decisão!". ${ }^{915}$

O afastamento puro e simples da discricionariedade técnica da revisão judicial também apresenta inconvenientes. Tome-se o caso da exigência de capacitação técnicooperacional da pessoa jurídica que participa de um certame licitatório, e não das pessoas que integram seu quadro. Estabelecida no edital de licitação, tal exigência refletiria o que a administração entende ser necessário para dada obra ou serviço e estaria dentro do juízo de conveniência e oportunidade ínsito à ideia de discricionariedade técnica. Vista de outro ângulo, porém, essa exigência reduz drasticamente a competitividade do certame e pode até mesmo permitir que somente se habilitem os membros de um cartel de empresas, que tenham feito obra ou serviço semelhante no passado. ${ }^{916}$

A pretexto de implementar uma política industrial de desenvolvimento, nem sequer existe o esforço de escamotear uma transferência de recursos de uma instituição financeira pública para o privado por meio de juros subsidiados, ${ }^{917}$ os quais podem, aliás, afetar outros aspectos da política monetária. ${ }^{918}$ Ademais, dois exemplos podem demonstrar como os interesses privados são capazes de informar o processo decisório sobre o conteúdo do interesse público.

\footnotetext{
$\overline{914}$ MEDAUAR, Odete. Op. cit. p. 124. "Nem sempre a técnica e a ciência implicam certeza absoluta; no campo da técnica e das ciências exatas, biológicas, matemáticas também há diversidade de entendimentos, controvérsias. Podem existir conhecimentos técnicos aceitos amplamente pela comunidade científica; há juízos prováveis oscilantes, há alternativas técnicas e científicas igualmente válidas para o direito, que justificam escolha. Assim, nem sempre ocorre uniformidade ou concordância total na área técnica e científica. Permanecendo margem de escolha, o poder discricionário aí incide, sem que o uso de conhecimentos técnicos enseje modalidade diferente desse poder. Se houver só uma solução possível, como consequiência da aplicação de pauta científica ou técnica, trata-se de poder vinculado; regras técnicas uniformes remetem ao bloco vinculado."

${ }^{915}$ GRAU, Eros Roberto. Op. cit. p. 214.

${ }^{916}$ Nesse sentido, ver SCHUARTZ, Luís Fernando; POSSAS, Mario Luiz. Habilitação em licitações públicas e defesa da concorrência. Estudos Econômicos da Construção, São Paulo: SindusCon-SP, v. 3, n. 1, 1998.

${ }^{917}$ SIMONSEN, Mário Henrique. A nova economia brasileira. São Paulo: José Olympio, 1971. p. 205 e ss.

${ }^{918}$ MAURO, Paolo. Os efeitos da corrupção sobre crescimento, investimentos e gastos do governo: uma análise de países representativos. In: ELLIOT, Kimberly Ann (Org.). A corrupção e a economia global. Trad. de Marsel Nascimento Gonçalves de Souza. Brasília: UnB, 2002. p. 141. "Ao afetar a coleta de impostos ou o volume de gastos públicos, a corrupção pode trazer consequiências orçamentárias adversas. De modo alternativo, nos casos em que a corrupção assume a forma do uso indevido de financiamentos direcionados, feitos por instituições financeiras públicas a taxas de juros abaixo do valor do mercado, a corrupção pode resultar em uma política monetária frouxa e indesejável."
} 
No primeiro, analisa-se o estabelecimento da taxa de câmbio, uma decisão discricionária e técnica, desempenhada pelo Banco Central do Brasil (BCB). ${ }^{919}$ Como não se fixa mais a taxa de câmbio por meio de ato administrativo, a atuação do BCB se faz por meio da compra e venda de grandes quantidades de moeda estrangeira. Em outras palavras, trata-se de uma atuação direta do Estado sobre a formação do preço da moeda estrangeira.

Em 1999, o país enfrentava uma séria restrição no volume de moeda estrangeira, e o BCB tentou manter a taxa de câmbio em certo patamar. A forte pressão pela saída dos capitais tornou insustentável a manutenção, o que forçou o então presidente do BCB Gustavo Franco a pedir demissão em 13 de janeiro de 1999. O seu sucessor, Francisco Lopes, pôde, então, modificar a política cambial, permitindo que o câmbio flutuasse até a taxa de $\mathrm{R} \$ 1,32$ para cada dólar que houvera sido estabelecida. Em apenas 48 horas, a taxa de R 1,32 se tornou insustentável, e o dólar passou a flutuar livremente, atingindo R\$ 2,16 em março de 1999.

Esses eventos seriam apenas um exemplo de malsucedido uso da discricionariedade técnica não fossem dois detalhes: (i) representaram um custo considerável para o patrimônio público, quer seja em termos de reservas cambiais perdidas, quer seja em termos de elevados juros pagos na tentativa de atrair recursos externos, e (ii) houve encaminhamento de informações privilegiadas de autoridades para certos atores se beneficiarem financeiramente à custa do Estado. Essa situação é comum àqueles casos em que o Estado atua nos mercados, gerando não só oportunidades de corrupção pura e simples, mas também de outorga de privilégios ilegítimos a particulares. ${ }^{920} \mathrm{~A}$ discricionariedade técnica do BCB está vinculada a uma finalidade, informada pelo interesse público - assim, o repasse de informações privilegiadas por funcionários públicos àqueles atuantes no mercado não figura entre os seus deveres funcionais, tampouco causa vultosos prejuízos ao erário. Conforme sintetizou o relatório final da CPI dos Bancos,

\footnotetext{
$\overline{919}$ BRASIL. Lei no 4.595/64. Art. 4 ${ }^{\circ}$ XXI. "Compete ao Conselho Monetário Nacional, segundo diretrizes estabelecidas pelo Presidente da República: [...] XXXI - Baixar normas que regulem as operações de câmbio, inclusive swaps, fixando limites, taxas, prazos e outras condições." Art. 11, III. "Compete ainda ao Banco Central [...] III - Atuar no sentido do funcionamento regular do mercado cambial, da estabilidade relativa das taxas de câmbio e do equilíbrio no balanço de pagamentos, podendo para esse fim comprar e vender ouro e moeda estrangeira, bem como realizar operações de crédito no exterior, inclusive as referentes aos Direitos Especiais de Saque, e separar os mercados de câmbio financeiro e comercial."

${ }^{920}$ ROSE-ACKERMAN, Susan. A economia política da corrupção. In: ELLIOT, Kimberly Ann (Org.). Op.cit. p. 64. "Muitas vezes os governos vendem bens ou serviços a preços abaixo do valor de mercado. Há, em muitos casos, preços duplos: um preço estatal baixo e um preço de livre mercado mais alto. As empresas, então, pagam propinas às autoridades para ter acesso a ofertas estatais com preço abaixo do mercado. Quando a oferta de crédito e a taxa de juros são controladas pelo Estado, subornos podem ser pagos para que acesso a crédito seja obtido."
} 
O fato de o Banco Central demonstrar despreocupação com o resultado não significa que isso seja indiferente às contas públicas. Tampouco o mandato que foi concedido aos diretores daquela Autarquia lhes concede despender verbas desnecessariamente. A estabilidade da moeda, como qualquer outro bem, tem um justo preço, que deve ser mensurado de forma equânime e imparcial, assim como a conduta dos administradores cuja baixa efetividade na prestação de contas ensejou a instauração da CPI. ${ }^{921}$

O segundo exemplo não envolve dano patrimonial explícito do erário público. Embora inexistisse necessariamente ofensa aos princípios da separação público-privado, os interesses privados se manifestaram abertamente em favor de uma das escolhas à disposição das autoridades públicas responsáveis. A eleição do modelo de TV digital foi marcada pela competição entre três modelos distintos: o Advanced Television Systems Commmittee (ATSC), adotado pelos Estados Unidos; o Digital Video Broadcasting (DVB), acolhido pelos países europeus; e o Integrated Service Digital Broadcasting (ISDB), utilizado pelo Japão. Cada um dos modelos apresentava vantagens e desvantagens, e as partes envolvidas fizeram lobby explícito em favor de suas propostas, especialmente quanto aos royalties a serem pagos. ${ }^{922}$ Ao fim, o presidente da República optou pelo modelo ISDB, combinado com algumas inovações peculiares ao Brasil, justificando os motivos da decisão. ${ }^{923}$

Em ambos os exemplos, houve apelo a decisões altamente técnicas, que somente poderiam ser tomadas por funcionários públicos dotados de alta especialização. Sousa ${ }^{924}$

\footnotetext{
$\overline{921}$ CONGRESSO NACIONAL. Relatório final da Comissão Parlamentar de Inquérito, criada através do Requerimento no 127, de 1999-SF, destinada a apurar fatos do conhecimento do Senado Federal, veiculados pela imprensa nacional, envolvendo instituições financeiras, sociedades de crédito, financiamento $e$ investimento que constituem o Sistema Financeiro Nacional. Brasília, 1999. p. 67.

922 Para uma síntese das propostas relativas a cada modelo, ver MOREIRA, Daniela. EUA, Europa e Japão: conheça os três padrões de TV Digital. IDG Now!, São Paulo, 13 fev. 2006. Disponível em: $<$ http://idgnow.uol.com.br/telecom/2006/02/13/idgnoticia.2006-02-13.4003735509/paginador/pagina_1>. Acesso em: 18 dez. 2009 às $15 \mathrm{~h} 32$.

${ }^{923}$ BRASIL. Decreto n⿳0 5.820, de 29 jun. 2006. Exposição de Motivos. "8. Em muitos países a transição de um sistema de televisão aberta baseado na tecnologia analógica para outro baseado na tecnologia digital vem sendo encarada principalmente pelo lado técnico, limitando-se à escolha entre os padrões hoje existentes no mundo: o sistema americano ATSC (Advanced Television Systems Committee), o sistema europeu DVB-T (Digital Video Broadcasting - Terrestrial) e o sistema japonês ISDB-T (Integrated Services Digital Broadcasting - Terrestrial). Cada um deles foi concebido tendo em vista as condições peculiares dos países proponentes, e seguindo objetivos diversos. 9. A escolha do padrão brasileiro de TV digital deve atender aos efetivos requisitos de nossa sociedade, considerando o perfil de renda da população e as possibilidades abertas pela interatividade. Como se enfatiza nesta Exposição de Motivos, a televisão digital não é apenas uma evolução tecnológica da televisão analógica, mas uma nova plataforma de comunicação, cujos impactos na sociedade ainda estão se delineando." ${ }^{924}$ SOUSA, Antônio Francisco de. A discricionariedade administrativa. Lisboa: Danúbio, 1987. p. $308-309$. Apud GRAU, Eros Roberto. $O$ direito posto e o direito pressuposto. Op. cit. p. 214. "[...] i) a definição do que seja 'decisão altamente técnica' é subjetiva, visto que não se pode responder onde começa e onde acaba o caráter 'altamente técnico'; ii) quando se trata de decisões referidas a matérias que o juiz não conheça - até porque não tem o dever de conhecer todas as matérias -, pode e deve ouvir peritos, a fim de que sejam plenamente esclarecidos os fatos a respeito dos quais decidirá; iii) da inegável dificuldade de controle de tais decisões não se pode extrair, a benefício da certeza e da segurança do direito, uma liberdade (autorização) para que a Administração decida ao seu talante; essa liberdade apenas pode ser a ela atribuída diretamente, pela lei; iv) ao
} 
relativiza o que pode ser considerado "altamente técnico", colocando em dúvida até onde a peculiaridade de uma análise "técnica" pode interferir numa decisão - para análises muito específicas, haveria o trabalho e auxílio dos peritos. Também questiona limitar-se o controle jurisdicional ao "erro manifesto", uma vez que a qualidade de "manifesto" é igualmente questionável.

Nesse contexto, provavelmente por causa do ataque à discricionariedade no pós1988, tem ocorrido um aumento na busca por legitimidade dessas decisões pelas autoridades administrativas. Nusdeo reconhece que a legitimidade técnica

[...] não implica a certeza de que um dado fim será atingido com o emprego de determinado instrumento, mas importa numa razoável convicção de haver uma probabilidade naquele sentido. Convicção por parte de quem? Por parte do grupo relevante para cada conjunto de decisões, conforme venha a ser definido por lei, o que envolverá uma convicção, também razoável, para a comunidade como um todo. $^{925}$

Uma das expressões mais visíveis dessa redução na discricionariedade e da busca por legitimidade do ato discricionário reside na crescente participação da sociedade civil no processo de tomada de decisões, num movimento que visa conceder maior legitimação à ação administrativa. Inspirada no neopluralismo liberal, essa forma de cooptação social tenta aumentar a legitimidade de uma decisão que, até os anos 1990, seria tomada com base em critérios estritamente técnicos. Abandona-se um modelo aristocrático de tomada de decisões e move-se na direção de um mais democrático, ${ }^{926}$ na esperança de que isso aumente a transparência e revele os interesses envolvidos na tomada de decisão. Essa tendência é mais acentuada no que tange às agências reguladoras, que possuem diversos mecanismos para viabilizar a participação popular nas tomadas de decisão, inclusive por canais de aproximação com a população.

\footnotetext{
limitar-se o controle jurisdicional ao 'erro manifesto', coloca-se à margem desse controle o 'erro não manifesto'; é certo, porém, que tanto o 'erro manifesto' quanto o 'erro não manifesto' são ilegais e devem ser controlados e corrigidos, jurisdicionalmente; a tolerância do erro, manifesto ou não manifesto, se não concedida pela lei, não pode ser concedida pelo juiz; ademais, também não se pode responder de modo satisfatório onde começa e onde acaba o caráter manifesto do erro."

${ }^{925}$ NUSDEO, Fábio. Op. cit. p. 134-135.

${ }^{926}$ LAFER, Celso. Op. cit. p. 47. "A linha democrática propõe o princípio da unanimidade porque a decisão unânime resulta de um consenso, e este supera a multiplicidade dos pontos de vista diferentes e impede a impopularidade das decisões. Uma segunda linha, que os clássicos chamavam de aristocrática e que hoje se poderia chamar de tecnocrática, é a daqueles que procuram propiciar uma decisão por parte dos mais qualificados em termos de formação e de competência, de tal forma que a decisão tomada seja perfeita e não contenha nem o vício da incompetência, nem o ônus da incoerência."
} 


\subsection{Corrupção e descentralização na federação brasileira}

Um dos principais desafios a superar no estudo de desenhos institucionais desestimuladores da corrupção é a compreensão da relação entre a corrupção e o grau de descentralização da autonomia política e fiscal de um Estado. Tradicionalmente, os estudos sobre as formas de Estado concebem a descentralização como um jogo de soma zero, no qual a transferência de autoridade para governos subnacionais é uma escolha formulada com base em fatores muito mais político-geográficos do que político-econômicos. ${ }^{927}$ No entanto, a literatura produzida desde os anos 1990, voltada para os aspectos mercantis da corrupção, tem oferecido novos enfoques aos estudos sobre as implicações da opção por determinadas formas de Estado, propondo avaliar os efeitos da descentralização sobre crescimento econômico, corrupção, inflação, déficit fiscal, entre outros. ${ }^{928}$

Seguindo essa linha metodológica, apontam Bardhan e Mookherjee, tanto as formas descentralizadas quanto as centralizadas apresentam problemas particulares na questão dos incentivos à corrupção e à captura. As burocracias centralizadas poderiam criar incentivos à corrupção pelo caminho do suborno, ao passo que os governos locais das burocracias descentralizadas seriam capturados mais facilmente pelas elites locais. ${ }^{929}$

\footnotetext{
$\overline{927}$ CAMERON, D. The expansion of the public economy: a comparative analysis. American Political Science Review, Washington, D.C., v. 72, n. 4, Dec. 1978, p. 1243-1261, Dec. 1978. OATES, W. Searching for Leviathan: an empirical study. American Economic Review, Nashville, v. 75, n. 4, Sept. 1985, p. 748-757, Sept. 1985. Dessa tradição decorre a percepção de que a forma unitária de Estado é a mais utilizada no mundo, porque a maioria dos países não possuiria extensão territorial suficiente para justificar a descentralização de poderes em coletividades territoriais autônomas. De fato, grande parte dos Estados não unitários do mundo possui territórios extensos, notadamente os Estados Unidos da América, o Canadá, a Rússia, o Brasil, a Índia e a Austrália. No entanto, a grande extensão territorial não resultará automaticamente na escolha descentralizada (veja-se a China), tampouco a pequena extensão territorial resultará em um sistema centralizado (vejam-se Bélgica e Suíça).

${ }_{928}$ Nesse sentido, ver DAVOODI, H.; ZOU, H. F. Fiscal decentralization and economic growth: a cross-country study. Journal of Urban Economics, San Diego: Elsevier, v. 43, n. 2, p. 244-257, Mar. 1998. FISMAN, R.; GATTI, R. Decentralization and corruption: evidence across countries. Journal of Public Economics, San Diego: Elsevier, v. 83, n. 3, p. 325-345, 2002. TREISMAN, D. The causes of corruption: a cross-national study. Journal of Public Economics, San Diego: Elsevier, v. 76, n. 3,. 344-345, June 2000. TREISMAN, D. Decentralization and inflation: commitment, collective action, or continuity? American Political Science Review, Washington, D.C.: Cambridge University Press. n. 94, p. 837-857. Dec. 2000. WIBBELS, E. Federalism and the politics of macroeconomic policy and performance. American Journal of Political Science, Washington, D. C.: Cambridge University Press, n. 44, p. 687-702, Oct. 2000.

929 BARDHAN, P.; MOOKHERJEE, D. Relative capture of local and central governments: an essay in the political economy of decentralization. Center for International and Development Economics Research (CIDER) Working Papers C99-109, University of California at Berkeley, 1998. Disponível em: <http://www.haas.berkeley.edu/groups/iber/wps/cider/c99-109.pdf>. Acesso em: 20 nov. 2009 às 22 h30. BARDHAN, P.; MOOKHERJEE, D. Decentralization, corruption and government accountability: an overview. Boston University - Department of Economics - Working Papers Series WP2005-023, 2005. Disponível em<http://www.bu.edu/econ/workingpapers/papers/Dilip\%20Mookherjee/wp2005/decorr.pdf>. Acesso em: 20 nov. 2009 às $23 \mathrm{~h} 03$.
} 
Essa literatura chama atenção para uma falha na tradicional concepção do problema, que opõe medidas de descentralização demasiado simples, como se houvesse uma distinção binária entre formas centralizadas e descentralizadas. Assim, essa distinção binária é descartada, pois podem existir disparidades significativas entre os modelos teóricos e a realidade de cada modelo federalista. Deve-se encarar a comparação entre os vários países federalistas com cautela, porque inexiste um modelo estrito de federalismo, como esclarece Bercovici:

[...] o fato de a Constituição definir o Brasil com um Estado Federal não nos poupa do trabalho de analisar detidamente que federalismo é o brasileiro. Afinal, não existe um "modelo" de federalismo ideal, puro e abstrato, que englobe a variedade de organizações existentes nos estados denominados federais. O que existe é uma série de soluções concretas, historicamente variadas, de organização do Estado, dentro de determinadas características comuns entendidas como necessárias a um regime federal. ${ }^{930}$

\subsubsection{Breves notas sobre o federalismo}

Para verificar que tipos de incentivos à corrupção do sistema político são produzidos pela estrutura do Estado federal brasileiro, inicialmente é necessário avaliar se ela é descentralizada ou não. Melhor ainda, deve-se questionar o grau de centralização ou descentralização, uma vez que o federalismo não constitui um modelo binário. De plano, coloca-se uma polêmica cuja resposta implica adotar necessariamente um lado do debate político: enquanto a União reclama da excessiva descentralização, estados, Distrito Federal e municípios sustentam haver centralização excessiva.

Embora qualquer modelo teórico de Estado descentralizado seja apenas um arquétipo, uma vez que o desenho institucional dos Estados federais não é idêntico, ${ }^{931}$ é possível agrupar algumas características comumente associadas ao modelo federativo (descentralizado) em oposição às características relacionadas ao modelo unitário (centralizado). Segundo Afonso da Silva, o cerne do conceito de federação está na repartição legional do poder, de modo que o autor estabelece a dicotomia entre as formas unitária e federativa:

\footnotetext{
$\overline{930}$ BERCOVICI, G. Desigualdades regionais, Estado e Constituição. 1. ed. São Paulo: Max Limonad, 2003. p. 145.

${ }^{931}$ DALlARI, Dalmo de Abreu. O Estado federal. São Paulo: Ática, 1986. p. 50. “Assim é que aparecem Estados, cantões, províncias, semicantões, repúblicas, repúblicas autônomas, territórios, distritos federais, numa grande variedade de arranjos, embora todos se definam como Estados Federais. Essa diversificação é, na realidade, bastante acentuada, tendo sido lembrada de modo bem expressivo pelo autor belga Ludo van Wauwe, que, num livro intitulado Fédéralisme - utopie ou possibilité?, observa que se alguém pergunta: 'Que é federalismo?, é freqüente que ouça como resposta: 'Mas de qual federalismo você está falando?'."
} 
O modo de exercício do poder político em função do território dá origem ao conceito de forma de Estado. Se existe unidade de poder sobre o território, pessoas e bens, tem-se Estado unitário. Se, ao contrário, o poder se reparte, se divide, no espaço territorial (divisão espacial de poderes), gerando uma multiplicidade de organizações governamentais, distribuídas regionalmente, encontramo-nos diante de uma forma de Estado composto, denominado Estado federal ou Federação de Estados. A repartição regional de poderes autônomos constitui o cerne do conceito de Estado federal. Nisso é que se distingue da forma de Estado unitário (França, Chile, Uruguai, Paraguai e outros), que não possuiu senão um centro de poder que se estende por todo o território e sobre toda a população e controla todas as coletividades regionais e locais. ${ }^{932}$

Na doutrina brasileira, há grande convergência de opiniões a definir as linhas gerais de um Estado federal. Mello arrola três características essenciais do Estado federal: (i) a repartição de competências entre a União e os estados membros; (ii) a autonomia dos estados; e (iii) a participação dos estados nas decisões da União. ${ }^{933}$ Com base na Constituição de 1988, Horta enumera nove condições que estariam presentes nos Estados federais:

(i) composição plural dos entes constitutivos; (ii) indissolubilidade do vínculo federativo; (iii) soberania da União; (iv) autonomia do Estado Federado ou Estadomembro; (v) repartição de competências; (vi) intervenção federal; (vii) organização bicameral do Poder Legislativo da União; (viii) repartição tributária; (ix) dualidade do Poder Judiciário e a existência de um Supremo Tribunal, para exercer a função de 'Guarda da Constituição'. 934

No mesmo sentido, Bastos conceitua que "a federação é a forma de Estado pela qual se objetiva distribuir o poder, preservando a autonomia dos entes políticos que a compõem". ${ }^{935}$ Para Ferreira Filho, os pontos que distinguem a forma federativa da unitária são a participação dos governos subnacionais nas decisões centrais e, principalmente, o grau de autonomia conferido às coletividades territoriais estabelecidas em um estado. ${ }^{936}$ É dessa conclusão que se extrai a ideia de "autonomia federativa".

\footnotetext{
${ }^{932}$ SILVA, José Afonso da. Curso de direito constitucional positivo. 31. ed. São Paulo: Malheiros, 2008. p. 9899.

${ }^{933}$ MELLO, Oswaldo Aranha Bandeira de. Natureza jurídica do Estado federal. São Paulo: Prefeitura do Município de São Paulo, 1948. p. 57-67.

${ }^{934}$ HORTA, Raul Machado. As novas tendências do federalismo e seus reflexos na Constituição brasileira de 1988. Revista do Legislativo, Belo Horizonte: Assembléia Legislativa de Minas Gerais, n. 25, p. 14, jan./mar. 1999. Disponível em: <http://www.almg.gov.br/revistalegis/Revista25/raul25.pdf>. Acesso em: 21 nov. 2009 às $13 \mathrm{~h} 22$.

${ }^{935}$ BASTOS, Celso Ribeiro. Curso de direito constitucional. 20. ed. São Paulo: Saraiva, 2001. p. 45.

${ }^{936}$ FERREIRA FILHO, Manoel Gonçalves. Curso de direito constitucional. 31. ed. São Paulo: Saraiva, 2005. p. 52. O autor critica a confusão na distinção entre o Estado Unitário descentralizado e o Estado federal, o que causa dificuldade de fixar a linha separadora entre a descentralização e o federalismo, separação que esta para muitos é arbitrária e artificial. "[...] tentando mantê-la, vale lembrar que, nos Estados federais, a estrutura federativa é posta como intocável. [...] Neles, sempre se dá a participação dos Estados-Membros no Poder Central por meio de uma Câmara que os representa (o Senado). Enfim, aos Estados-Membros se reconhece autoorganização por um poder constituinte próprio. Nesses dois últimos pontos está o cerne da autonomia dos
} 
Em síntese, a autonomia federativa se caracteriza por diversos aspectos, dentre os quais se destacam: (i) auto-organização (inclusive por meio de uma Constituição própria); (ii) autogoverno ou autonomia política (escolha do governo e do legislativo pelo próprio povo da coletividade territorial autônoma); (iii) autolegislação ou autonomia legislativa (poder de editar as próprias leis); (iv) autoadministração ou autonomia administrativa (órgãos governamentais próprios, que não dependam dos órgãos federais quanto à forma de seleção e investidura de cargos); (v) autofinanciamento ou autonomia financeira (poder de tributar na esfera local, possibilitando a captação de recursos financeiros suficientes para desempenhar suas finalidades e gozar de sua autonomia); e (vi) autonomia de gestão de políticas (tomada de decisões na gestão da educação básica, infraestrutura local e a força policial local). ${ }^{937}$

Esses caracteres permitem realçar os contrastes entre o modelo federativo e o unitário. Neste, tanto as normas e ordens emanam substancialmente do poder central, disciplinador da organização de eventuais divisões administrativas e as delegações de autoridade, quanto as despesas são financiadas por meio de um poder tributário central, de modo que as receitas são repartidas entre os territórios. Em contrapartida, no modelo descentralizado cada autoridade local pode se auto-organizar e editar normas sem a ingerência da União, mas o faz tendo em vista sua capacidade econômica oriunda da tributação local. Por esse motivo, presume-se certa autonomia para a escolha dos níveis de tributação. ${ }^{938}$

Mesmo assim, não é possível distinguir entre formas de estado por uma dualidade excessivamente estrita. Há várias gradações de autonomia, conforme ensina Bonavides:

\footnotetext{
Estados-Membros da Federação. Convém notar, porém, que esses critérios são frágeis. Ainda mais o segundo, já que, hoje, na maioria dos Estados Federais, os senadores estão presos a partidos e não propriamente aos Estados em que se elegem. Quando ao terceiro, o âmbito dessa auto-organização pode ser extremamente limitado e de vários modos condicionado, a ponto de se reduzir, na realidade, a quase nada, como ocorre no Brasil."

937 Lista elaborada com base nas classificações propostas em: RODDEN, Johnathan. Federalismo e descentralização em perspectiva comparada: sobre significados e medidas. Revista de Sociologia e Política, Curitiba: UFPR, n. 24, p. 9-27, jun. 2005. MORAES, Alexandre de. Direito constitucional. 4. ed. São Paulo: Atlas, 1998. p. 244-247; e CLÈVE, C. M. Temas de direito constitucional e de teoria do direito. São Paulo: Acadêmica, 1993. p. 63.

938 RODDEN, J. Federalismo e descentralização em perspectiva comparada: sobre significados e medidas. Revista de Sociologia e Política, n. 24, p. 9-27, jun. 2005 "The existing literature has typically modelled a centralized system as one in which public spending is financed by general taxation and all districts receive a uniform level of the local public good. By contrast, a decentralized system is one in which local public goods are financed by local taxation and each district is free to choose its own level. The drawback with a decentralized system is that it produces public good levels which reflect only local benefits and hence results in underprovision when such goods provide significant benefits to the larger community. Centralized decision making, on the other hand, produces a 'one size fits all' outcome, which is insufficiently sensitive to local needs. Such logic underpins Oates' (1972) celebrated Decentralization Theorem stating that, in the absence of spillovers, decentralization is preferable. When spillovers are present, the appropriate level of government depends on a weighing of the benefits of internalizing externalities with the costs of uniformity."
} 
[...] não se põe a ênfase na estrita e obsessiva discriminação de competências, como querem alguns federalistas ultrapassados.

São estes os juristas que só vêem o jurídico. Atormentam-se, pois, com as infrações ao esquema federativo da teoria clássica, por afigurar-se-lhes que só há um regime federativo, e este, quase sempre, o de sua inconfessada predileção ideológica. Deslembrados ficam de que a História não se detém numa doutrina vitoriosa. Realidades outras podem alojar novas condições de equilíbrio social, desfazendo assim a rigidez dos esquemas jurídicos. ${ }^{939}$

Essa conclusão leva inexoravelmente à investigação sobre quais bases o federalismo brasileiro se encontra assentado.

\subsubsection{Qual o grau de descentralização ou centralização da federação brasileira?}

Parte considerável da história brasileira pode ser resumida no embate entre as tendências centralizadoras e descentralizadoras. ${ }^{940}$ Enquanto se caracterizam como períodos centralizados o Império, a Era Vargas e a Ditadura Militar, já a República Velha, a República Populista e a Nova República são normalmente associados a uma maior descentralização. Cada período teve sua peculiaridade e equilíbrio de forças políticas que moldou a organização do federalismo. ${ }^{941}$

Atualmente, a organização político-administrativa da República Federativa do Brasil compreende a União, os estados membros, o Distrito Federal e os municípios, ${ }^{942}$ todos dotados de certa "autonomia federativa". As atribuições conferidas a cada um dos entes da federação estão definidas na Constituição de 1988, motivo pelo qual se afirma que, no direito constitucional brasileiro, a autonomia federativa é o "governo próprio dentro do círculo de competências traçadas pela Constituição Federal". ${ }^{943}$

A aferição do grau de descentralização na federação brasileira resulta de uma interpretação do texto constitucional. Alguns enxergam na Constituição uma visível centralização de poder na União, apontando-a como deformadora da federação brasileira, ao passo que outros veem um movimento de forte descentralização no sistema atual, ao menos comparativamente às constituições anteriores. Entre aqueles que realçam o papel centralizador desempenhado pela União, Oliveira aponta como ponto significativo o processo

\footnotetext{
$\overline{939}$ BONAVIDES, Paulo. Teoria do Estado. 4. ed. São Paulo: Malheiros, 2003. p. 130

${ }^{940}$ Ver capítulo 3, supra.

941 Sobre o contexto nordestino, ver BONAVIDES, Paulo. A constituição aberta: temas políticos e constitucionais da atualidade, com ênfase no federalismo das regiões. 2. ed. São Paulo: Editora Revista dos Tribunais, 1996. p. 362-372 e 390-399.

${ }_{942}$ BRASIL. Constituição (1988). Art. $1^{\circ}$, caput.

${ }^{943}$ SILVA, José Afonso da. Op. cit. p. 100.
} 
de repartição de competências entre a União e as unidades territoriais autônomas. Na Constituição de 1988, seria possível dividir as competências entre as de caráter (i) exclusivo (ou privativo), cujo exercício é vedado às outras esferas federativas; (ii) concorrente (ou facultativo), que permite o exercício enquanto um ente federativo não exercer a competência, o que ocorre geralmente no âmbito legislativo; e (iii) comum (ou paralelo), que podem ser exercidas por mais de uma entidade federativa sem exclusão das demais. ${ }^{944} \mathrm{O}$ vasto rol de competências privativas administrativas, ${ }^{945}$ legislativas $^{946}$ e tributárias ${ }^{947}$ da União evidencia

$\overline{944}$ OLIVEIRA, Régis Fernandes de. Curso de direito financeiro. 2. ed. São Paulo: Revista dos Tribunais, 2008. p. 36 e 40.

945 BRASIL. Constituição (1988). Art. 21. "Compete à União: I - manter relações com Estados estrangeiros e participar de organizações internacionais; II - declarar a guerra e celebrar a paz; III - assegurar a defesa nacional; IV - permitir, nos casos previstos em lei complementar, que forças estrangeiras transitem pelo território nacional ou nele permaneçam temporariamente; $\mathrm{V}$ - decretar o estado de sítio, o estado de defesa e a intervenção federal; VI - autorizar e fiscalizar a produção e o comércio de material bélico; VII - emitir moeda; VIII - administrar as reservas cambiais do País e fiscalizar as operações de natureza financeira, especialmente as de crédito, câmbio e capitalização, bem como as de seguros e de previdência privada; IX - elaborar e executar planos nacionais e regionais de ordenação do território e de desenvolvimento econômico e social; X - manter o serviço postal e o correio aéreo nacional; XI - explorar, diretamente ou mediante autorização, concessão ou permissão, os serviços de telecomunicações, nos termos da lei, que disporá sobre a organização dos serviços, a criação de um órgão regulador e outros aspectos institucionais; XII - explorar, diretamente ou mediante autorização, concessão ou permissão: a) os serviços de radiodifusão sonora, e de sons e imagens; b) os serviços e instalações de energia elétrica e o aproveitamento energético dos cursos de água, em articulação com os Estados onde se situam os potenciais hidroenergéticos; c) a navegação aérea, aeroespacial e a infra-estrutura aeroportuária; d) os serviços de transporte ferroviário e aquaviário entre portos brasileiros e fronteiras nacionais, ou que transponham os limites de Estado ou Território; e) os serviços de transporte rodoviário interestadual e internacional de passageiros; f) os portos marítimos, fluviais e lacustres; XIII - organizar e manter o Poder Judiciário, o Ministério Público e a Defensoria Pública do Distrito Federal e dos Territórios; XIV - organizar e manter a polícia civil, a polícia militar e o corpo de bombeiros militar do Distrito Federal, bem como prestar assistência financeira ao Distrito Federal para a execução de serviços públicos, por meio de fundo próprio; XV organizar e manter os serviços oficiais de estatística, geografia, geologia e cartografia de âmbito nacional; XVI exercer a classificação, para efeito indicativo, de diversões públicas e de programas de rádio e televisão; XVII conceder anistia; XVIII - planejar e promover a defesa permanente contra as calamidades públicas, especialmente as secas e as inundações; XIX - instituir sistema nacional de gerenciamento de recursos hídricos e definir critérios de outorga de direitos de seu uso; XX - instituir diretrizes para o desenvolvimento urbano, inclusive habitação, saneamento básico e transportes urbanos; XXI - estabelecer princípios e diretrizes para o sistema nacional de viação; XXII - executar os serviços de polícia marítima, aeroportuária e de fronteiras; XXIII - explorar os serviços e instalações nucleares de qualquer natureza e exercer monopólio estatal sobre a pesquisa, a lavra, o enriquecimento e reprocessamento, a industrialização e o comércio de minérios nucleares e seus derivados, atendidos os seguintes princípios e condições:a) toda atividade nuclear em território nacional somente será admitida para fins pacíficos e mediante aprovação do Congresso Nacional; b) sob regime de permissão, são autorizadas a comercialização e a utilização de radioisótopos para a pesquisa e usos médicos, agrícolas e industriais; c) sob regime de permissão, são autorizadas a produção, comercialização e utilização de radioisótopos de meia-vida igual ou inferior a duas horas; d) a responsabilidade civil por danos nucleares independe da existência de culpa; XXIV - organizar, manter e executar a inspeção do trabalho; XXV estabelecer as áreas e as condições para o exercício da atividade de garimpagem, em forma associativa."

${ }^{946}$ BRASIL. Constituição (1988). Art. 22. "Compete privativamente à União legislar sobre: I - direito civil, comercial, penal, processual, eleitoral, agrário, marítimo, aeronáutico, espacial e do trabalho; II desapropriação; III - requisições civis e militares, em caso de iminente perigo e em tempo de guerra; IV - águas, energia, informática, telecomunicações e radiodifusão; V - serviço postal; VI - sistema monetário e de medidas, títulos e garantias dos metais; VII - política de crédito, câmbio, seguros e transferência de valores; VIII comércio exterior e interestadual; IX - diretrizes da política nacional de transportes; X - regime dos portos, navegação lacustre, fluvial, marítima, aérea e aeroespacial; XI - trânsito e transporte; XII - jazidas, minas, outros recursos minerais e metalurgia; XIII - nacionalidade, cidadania e naturalização; XIV - populações indígenas; 
uma excessiva concentração de atribuições no poder central em detrimento da autonomia das demais esferas federativas. Por esse motivo, defende Oliveira que "[...] em verdade, parecenos que não temos um Estado Federal, em sua essência, pois este se constituiria no exercício de poderes intangíveis. Temos um Estado unitário descentralizado". ${ }^{948}$

Outros consideram que o federalismo brasileiro experimenta um movimento de descentralização. A Constituição de 1988 atribuiu aos municípios e estados crescentes responsabilidades, mormente na prestação de serviços à população. Nesse sentido, o Sistema Único de Saúde (SUS) tem por princípio a descentralização, ${ }^{949}$ o que reforça o papel do município na prestação dos serviços de saúde. ${ }^{950}$ Igualmente, após a Emenda Constitucional no 53, de 19 de dezembro de 2006, os municípios aumentaram suas atribuições na área de educação, ${ }^{951}$ embora caiba à União e aos estados algumas funções no ensino médio e superior. ${ }^{952}$

XV - emigração e imigração, entrada, extradição e expulsão de estrangeiros; XVI - organização do sistema nacional de emprego e condições para o exercício de profissões; XVII - organização judiciária, do Ministério Público e da Defensoria Pública do Distrito Federal e dos Territórios, bem como organização administrativa destes; XVIII - sistema estatístico, sistema cartográfico e de geologia nacionais; XIX - sistemas de poupança, captação e garantia da poupança popular; XX - sistemas de consórcios e sorteios; XXI - normas gerais de organização, efetivos, material bélico, garantias, convocação e mobilização das polícias militares e corpos de bombeiros militares; XXII - competência da polícia federal e das polícias rodoviária e ferroviária federais; XXIII - seguridade social; XXIV - diretrizes e bases da educação nacional; XXV - registros públicos; XXVI atividades nucleares de qualquer natureza; XXVII - normas gerais de licitação e contratação, em todas as modalidades, para as administrações públicas diretas, autárquicas e fundacionais da União, Estados, Distrito Federal e Municípios, obedecido o disposto no art. 37, XXI, e para as empresas públicas e sociedades de economia mista, nos termos do art. 173, $\S 1^{\circ}$, III; XXVIII - defesa territorial, defesa aeroespacial, defesa marítima, defesa civil e mobilização nacional; XXIX - propaganda comercial."

${ }^{947}$ BRASIL. Constituição (1988). Art. 155.

${ }^{948}$ OLIVEIRA, Régis Fernandes de. Op. cit. p. 36

949 BRASIL. Constituição (1988). Art. 198. "As ações e serviços públicos de saúde integram uma rede regionalizada e hierarquizada e constituem um sistema único, organizado de acordo com as seguintes diretrizes: I - descentralização, com direção única em cada esfera de governo; II - atendimento integral, com prioridade para as atividades preventivas, sem prejuízo dos serviços assistenciais; III - participação da comunidade."

${ }^{950}$ BRASIL. Constituição (1988). Art. 30. "Compete aos Municípios: [...] VII - prestar, com a cooperação técnica e financeira da União e do Estado, serviços de atendimento à saúde da população."

${ }^{951}$ BRASIL. Constituição (1988). Art. 30. "Compete aos Municípios: [...] VI - manter, com a cooperação técnica e financeira da União e do Estado, programas de educação infantil e de ensino fundamental."

952 "BRASIL. Constituição (1988). Art. 211. "A União, os Estados, o Distrito Federal e os Municípios organizarão em regime de colaboração seus sistemas de ensino. § $1^{\circ}$ A União organizará e financiará o sistema federal de ensino e o dos Territórios, e prestará assistência técnica e financeira aos Estados, ao Distrito Federal e aos Municípios para o desenvolvimento de seus sistemas de ensino e o atendimento prioritário à escolaridade obrigatória. § $2^{\circ}$ Os Municípios atuarão prioritariamente no ensino fundamental e pré-escolar. $\S 1^{\circ} \mathrm{A}$ União organizará o sistema federal de ensino e o dos Territórios, financiará as instituições de ensino públicas federais e exercerá, em matéria educacional, função redistributiva e supletiva, de forma a garantir equalização de oportunidades educacionais e padrão mínimo de qualidade do ensino mediante assistência técnica e financeira aos Estados, ao Distrito Federal e aos Municípios; $\S 2^{\circ}$ Os Municípios atuarão prioritariamente no ensino fundamental e na educação infantil. $\S 3^{\circ}$ Os Estados e o Distrito Federal atuarão prioritariamente no ensino fundamental e médio." 
Em linhas gerais, tal movimento se justificaria pela descentralização promovida pela Constituição de 1988 em relação à anterior, oriunda de um regime autoritário centralizador. Nessa linha, Horta argumenta que a Carta de 1988

\begin{abstract}
[...] acrescentou e desenvolveu, na repartição de competências, a competência comum, de caráter cooperativo, da União, dos Estados, do Distrito Federal e dos Municípios (art. 23, I a XII), e a competência concorrente, de natureza legislativa, da União, dos Estados e do Distrito Federal, nela contemplando, entre outras matérias, o direito tributário, o direito financeiro, o direito econômico, o direito urbanístico (art. 24, I), orçamento (art. 24, II), responsabilidade por dano ao meio ambiente, ao consumidor, a bens e direitos de valor artístico, estético, histórico, turístico e paisagístico (art. 24, VIII), criação, funcionamento e processo do juizado de pequenas causas (art. 24, X), procedimentos em matéria processual (art. 24, XI), previdência social, proteção e defesa da saúde (art. 24, XII). No domínio da competência legislativa concorrente, a Constituição limitou a competência da União ao estabelecimento de normas gerais (art. $24, \S \S 1^{\circ}, 2^{\circ}$ e $\left.3^{\circ}\right){ }^{953}$
\end{abstract}

A tendência de descentralização também seria observada na criação de novos estados nas regiões menos desenvolvidas do país durante a década de 1970 (Mato Grosso do Sul e Rondônia) e a partir da Assembleia Nacional Constituinte (Amapá, Roraima e Tocantins). Além disso, a Constituição de 1988 conferiu autonomia política ao Distrito Federal, por meio de representação no Congresso Nacional e criação de Assembleia Legislativa, polícia e sistema judiciário próprios.

Dallari aponta o "artificialismo" desse movimento de descentralização, porque certos estados vizinhos poderiam seguramente compor uma só unidade federativa - o caso do Estado de Tocantins, desmembrado do Estado de Goiás, é paradigmático. ${ }^{954}$ Ademais, com a divisão de municípios, o critério de rateio existente possibilitaria o aumento per capita dos recursos recebidos. ${ }^{955} \mathrm{O}$ artificialismo teria acontecido para atender a interesses privados ou mesmo conveniências políticas, ocasionando o surgimento de estados inviáveis, fracos e

\footnotetext{
${ }^{953}$ HORTA, Raul Machado. As novas tendências do federalismo e seus reflexos na Constituição brasileira de 1988. Revista do Legislativo, Belo Horizonte: Assembléia Legislativa de Minas Gerais, n. 25, p. 17, jan./mar. 1999. Disponível em: <http://www.almg.gov.br/revistalegis/Revista25/raul25.pdf>. Acesso em: 21 nov. 2009 às $13 \mathrm{~h} 22$.

${ }^{954}$ Nos anos 1980, Siqueira Campos tentou se eleger governador do Estado de Goiás, mas perdeu o pleito para o grupo ligado a Íris Rezende. Como sua liderança era forte no norte de Goiás, Siqueira Campos aproveitou sua condição de parlamentar na Assembleia Constituinte de 1988 para pressionar pela criação do Estado de Tocantins. De 1988 até 2010, ele foi eleito quatro vezes governador do Estado de Tocantins.

955 TRISTÃO, J. A. M. A administração tributária dos municípios brasileiros: uma avaliação do desempenho da arrecadação. 2003. 172 f. Tese (Doutorado) - Escola de Administração de Empresas de São Paulo, Fundação Getulio Vargas, São Paulo. p. 166. "Outro aspecto que deve ser observado é o crescimento explosivo do número de municípios, que passou de 3.953 em 1970 para 5.506 em 2000, com um acréscimo de 72\%. [...] as regras de rateio do FPM como um incentivo implícito à criação de pequenos municípios, ao estabelecer um piso dado em função de um parâmetro da ordem de 10.188 habitantes. Isto significa que um município de 5.000 habitantes recebe o mesmo valor de FPM que outro de 10.000, o que representa um estímulo à divisão de um município pequeno em outros dois ainda menores, aumentando, deste modo, o valor per capita recebido por seus habitantes.
} 
economicamente dependentes. ${ }^{956}$ Essas mazelas, associadas ao localismo, sobretudo a alegada falta de visão nacional das elites locais, relegaram as propostas descentralizadoras favoráveis aos municípios e aos estados a um papel marginal a partir de 1930. Ideologicamente, as propostas descentralizadoras foram associadas ao conservadorismo e as centralizadoras, ao progressismo.

Em contrapartida, as alegações de descentralização, especialmente na área fiscal, provêm dos interesses ligados à União. A mudança ocorrida em 1988 teria gerado um desequilíbrio na distribuição das receitas em desfavor da União, o que motivou ampla discussão sobre a ingovernabilidade da nova ordem constitucional: "excessos descentralizantes", "o mesmo erro da centralização com sinal trocado" e "ingovernabilidade provocada pela descentralização exagerada" são alguns dos argumentos utilizados. ${ }^{957}$ Ao lado disso, há quem avalie positivamente o processo de descentralização:

\begin{abstract}
Os indicadores da descentralização fiscal, medidos pelos índices de participação dos governos subnacionais na receita e no gasto total, além da grande autonomia na cobrança de seus tributos e na elaboração de seus orçamentos, situam o Brasil próximo às federações mais desenvolvidas. Entre os países em desenvolvimento, é, sem dúvida, quem mais avançou em termos de autonomia. A esse respeito, é interessante lembrar que Shah (1994) elaborou um índice de autonomia dos governos subnacionais, levando em conta a proporção das despesas que são financiadas por recursos próprios ou recebidos de terceiros mas sem vinculações específicas. Num grupo de dez países, entre ricos e pobres, o maior índice é o do Brasil - superando, mesmo, os Estados Unidos, a Alemanha e o Canadá. ${ }^{958}$
\end{abstract}

\title{
7.5.3 O tridimensionalismo na federação e sua relação com a fragilidade econômica
}

\footnotetext{
$\overline{956}$ DALLARI, Dalmo de Abreu. Op. cit.,1995. p. 62.

957 ZIMMERMANN, Gustavo. Orçamentos municipais paulistas. São Paulo em perspectiva, São Paulo: Fundação Seade, v. 10, n. 3, p. 96, 1996. “[...] esta última reação federal contrária à descentralização foi inédita tanto pela rapidez com que se apresentou quanto pela fragilidade das forças políticas que a apoiaram (e em parte ainda a apóiam). Mesmo antes da vigência dos novos dispositivos constitucionais, forças do governo central, que haviam se mantido no mais absoluto silêncio durante todo o processo constituinte, passaram a clamar contra o que consideraram 'excessos descentralizantes', 'o mesmo erro da centralização com sinal trocado', 'ingovernabilidade provocada pela descentralização exagerada', etc. [...] De fato, enquanto estas centralizações resultaram de rupturas políticas, nas quais a concentração de recursos na esfera federal respondia a objetivos amplos que catalisaram politicamente expressivos segmentos sociais, as atuais propostas não apontam para nenhum projeto de longo alcance." No mesmo sentido, ver SOUZA, Amaury de; LAMOUNIER, Bolívar. O futuro da democracia: cenários político-institucionais até 2022. Revisa Estudos Avançados, São Paulo, Instituto de Estudos Avançados da USP, v. 20, n. 56, p. 53-60, 2006. Para análise detalhada do processo constituinte sobre a divisão de receitas, ver SOUZA, Celina. Federalismo e descentralização na Constituição de 1988: processo decisório, conflitos e alianças. DADOS - Revista de Ciências Sociais, Rio de Janeiro, v. 44, n. 3 , p. 513-560, 2001.

${ }_{958}$ AFONSO, J. R. Rodrigues; SERRA, José. Federalismo fiscal à brasileira: algumas reflexões. Revista do BNDES, Rio de Janeiro: BNDES. v. 6, n. 12, p. 1012. dez. 1999
} 
Outro argumento bastante utilizado para sustentar o movimento de descentralização na federação brasileira é a composição tríplice dos entes federativos - o federalismo brasileiro pode ser caracterizado como um "federalismo tridimensional", visto que se confere autonomia aos municípios. Com a facilitação para a criação de municípios, o seu número foi impulsionado de aproximadamente 4 mil para 5,5 mil unidades. ${ }^{959}$

$\mathrm{Na}$ tentativa de conter a criação de municípios em razão de interesses econômicos locais, a Emenda Constitucional $\mathrm{n}^{\mathrm{o}} 15 / 96,{ }^{960}$ promulgada para restringir a criação, a incorporação, a fusão e o desmembramento de municípios, é considerada a principal resposta aos abusos ocorridos entre 1988 e 1996. Apesar de a Emenda ter condicionado a criação de municípios à consulta prévia plebiscitária às populações dos municípios envolvidos e à divulgação dos Estudos de Viabilidade Municipal, não se pode afirmar que o problema tenha sido sanado por inteiro: casos como o do município baiano Luís Eduardo Magalhães demonstram um ponto de fragilidade no federalismo brasileiro. ${ }^{961}$

A discussão sobre se a federação brasileira é centralizada ou descentralizada admite múltiplas respostas, muitas das quais motivadas pelos interesses pessoais de quem as apresenta. Propõe-se uma solução alternativa que, sem responder ao questionamento, possibilita avançar metodologicamente: as recíprocas reclamações revelam que há um desequilíbrio entre as receitas dos entes federativos mais frágeis economicamente e as atribuições que lhes são atribuídas. ${ }^{962} \mathrm{O}$ aspecto tridimensional do federalismo brasileiro serve

\footnotetext{
959 Idem, ibidem.

${ }^{960}$ BRASIL. Constituição (1988). Nova redação dada pela Emenda Constitucional ao art. 18, § $4^{\text {o } ~ " A ~ c r i a c ̧ a ̃ o, ~ a ~}$ incorporação, a fusão e o desmembramento de Municípios, far-se-ão por lei estadual, dentro do período determinado por lei complementar federal, e dependerão de consulta prévia, mediante plebiscito, às populações dos Municípios envolvidos, após divulgação dos Estudos de Viabilidade Municipal, apresentados e publicados na forma da lei."

961 O nome do município de Luís Eduardo Magalhães, localizado no oeste do estado da Bahia, remete ao falecido deputado, filho do também falecido senador Antônio Carlos Magalhães. Criado em 30 de março de 2000 pela Lei Estadual nº 7619/00 com o desmembramento do município de Barreiras, foi alvo de duras críticas públicas, porque fora criado em ano de eleições municipais, sem que existisse a lei complementar federal prevista pela Emenda Constitucional $n^{0}$ 15/96. Além disso, a consulta prévia constitucionalmente exigida por plebiscito não fora realizada com toda a população afetada pelo processo de emancipação, e os estudos de viabilidade municipal foram publicados em data posterior ao plebiscito, o que contradiz a nova redação dada ao art. $18, \S 4^{\circ}$ da Constituição pela Emenda Constitucional no 15/96. Em 2007, ao julgar a ADI 2.240-BA, o STF posicionou-se favoravelmente ao pedido de inconstitucionalidade. Entretanto, o STF não decretou a nulidade do ato de criação do município sob o argumento de que a extinção traria mais consequências negativas do que benefícios para a população. Assim, a existência do município foi mantida por 24 meses, até que o legislador estadual estabelecesse novo regramento. O desfecho é irônico, pois Luís Eduardo Magalhães foi o autor do projeto que se transformaria na Emenda Constitucional $n^{0} 15 / 96$ - não foram poucos os que alegaram que, da forma como ocorreu, a criação do município em sua homenagem foi uma ofensa à sua memória.

962 OLIVEIRA, Régis Fernandes. Federalismo fiscal e pacto federativo. Revista Tributária e de Finanças Públicas, São Paulo: Revista dos Tribunais, n. 61, p. 189, mar./abr. 2005. Oliveira sugere a existência desse desequilíbrio. "Ao celebrar-se o pacto federativo através da elaboração do pacto político que é a Constituição, deve haver o sopesar das necessidades de cada ente autônomo e os recursos previstos no texto. Se não houver
} 
de ponto de partida para investigar o grau e as repercussões do desequilíbrio entre as receitas e as atribuições dos entes federativos, o que gera oportunidades para o aparecimento de comportamos políticos ilegítimos que podem caracterizar corrupção-solapamento.

A despeito da discussão sobre a impossibilidade de conceber os municípios como entes federativos efetivos, ${ }^{963}$ o problema relaciona-se ao estudo da corrupção principalmente em razão das disparidades geradas pela atribuição de certa autonomia federativa aos municípios, sobretudo os mais frágeis economicamente, fadados a serem "pedintes" de recursos perante as esferas federal e estadual. ${ }^{964}$ Tal situação apresenta forte incentivo para a eleição de cargos políticos voltados para a ocupação de interesses privados locais na administração municipal, o que é agravado pelo fato de as melhores oportunidades de trabalho disponíveis no município se encontrarem em repartições públicas: como há pouca oferta no mercado de trabalho, os gabinetes públicos tornam-se palco de troca de favores e apoios, que na maioria dos casos envolvem os numerosos cargos comissionados. Acertadamente, as tabelas 16, 17 e 18 demonstram que os municípios menos populosos possuem maior percentual de cargos comissionados em relação ao total do funcionalismo.

Nessas hipóteses, a inflação do número de funcionários públicos é tendência quase inexorável. Um notório exemplo de inflação estatal é o de Mira Estrela: embora seja mais lembrado na doutrina jurídica por ser um caso clássico de modulação de efeitos de decisão pelo STF, trata-se, também, de um caso de abuso de autonomia municipal em face da antiga sistemática para determinação do número de vereadores por município. Antes da Emenda Constitucional $\mathrm{n}^{\mathrm{o}}$ 58/09, decorrente do polêmico Projeto de Emenda Constitucional $\mathrm{n}^{\mathrm{o}}$ 20/2008 (a denominada "PEC dos Vereadores”), o art. 29, IV, "a” da Constituição dispunha que as Câmaras Municipais das cidades com até um milhão de habitantes deveriam ser

compatibilidade, o pacto é vesgo. Se não se estabelecer razoabilidade entre fins e meios, perecem as soluções democráticas, criando-se odiosa estrutura de dominação dos entes maiores sobre os menores. Deixando de se atender equitativamente na distribuição de recursos, instaura-se desequilíbrio repugnante entre os centros federativos de poder."

963 José Afonso da Silva afirma que "foi equívoco do constituinte incluir os Municípios como componente da federação. Município é divisão política do Estado-membro. E agora temos uma federação de Municípios e Estados, ou uma federação de Estados? Faltam outros elementos para a caracterização da federação de Municípios”. SILVA, José Afonso da. Op. cit. p. 101. Entre esses elementos, pode-se apontar que (a) os territórios dos municípios são compartilhados com o dos estados; (b) a intervenção nos municípios é da competência dos estados, e não da União; (c) a incorporação, fusão e desmembramento de municípios é feita por lei estadual; (d) os municípios não tem auto-organização mediante Constituições municipais e estão submetidos às Constituições estaduais; (e) não há participação dos municípios nas decisões políticas nacionais; e (f) não há possibilidade de um controle concentrado de constitucionalidade de lei municipal.

964 Sobre o contexto nordestino, ver BONAVIDES, Paulo. A constituição aberta: temas políticos e constitucionais da atualidade, com ênfase no federalismo das regiões. 2. ed. São Paulo: Editora Revista dos Tribunais, 1996. p. 505-506. 
compostas por um número de vereadores variável entre 9 e $21 .{ }^{965}$ Interpretadas em sua literalidade, essas regras viabilizaram uma onda de empreguismo, pois, a pretexto do exercício de autonomia administrativa, municípios pouco populosos estipularam uma quantidade de vereadores desproporcional à sua população.

Em Mira Estrela, município cuja população era pouco superior a 2.600 habitantes, a lei municipal fixou em 11 o número de vereadores. Ao declarar inconstitucional a referida lei, o STF comentou ser comum os municípios menos populosos possuírem mais vereadores do que outros com número de habitantes várias vezes superior. Teria havido flagrante excesso do poder de legislar e afronta ao postulado da isonomia e aos postulados da moralidade, impessoalidade e economicidade dos atos administrativos, uma vez que foram rompidas as fronteiras da autonomia municipal impostas pela Constituição. ${ }^{966}$

\footnotetext{
${ }_{965}$ BRASIL. Constituição (1988). Art. 29. "O Município reger-se-á por lei orgânica, votada em dois turnos, com o interstício mínimo de dez dias, e aprovada por dois terços dos membros da Câmara Municipal, que a promulgará, atendidos os princípios estabelecidos nesta Constituição, na Constituição do respectivo Estado e os seguintes preceitos: [...] IV - número de Vereadores proporcional à população do Município, observados os seguintes limites: a) mínimo de nove e máximo de vinte e um nos Municípios de até um milhão de habitantes; b) mínimo de trinta e três e máximo de quarenta e um nos Municípios de mais de um milhão e menos de cinco milhões de habitantes; c) mínimo de quarenta e dois e máximo de cinqüenta e cinco nos Municípios de mais de cinco milhões de habitantes."

966 BRASIL. Supremo Tribunal Federal. Recurso extraordinário no ${ }^{-197917 / S P . ~ R e l a t o r: ~ M i n i s t r o ~ M a u r i ́ c i o ~}$ Corrêa. Decisão em 5 jun. 2002. Diário de Justiça, 7 maio 2004. p. 8. Recurso extraordinário. Municípios. Câmara de Vereadores. Composição. Autonomia municipal. Limites constitucionais. Número de vereadores proporcional à população. CF, Artigo 29, IV. Aplicação de critério aritmético rígido. Invocação dos princípios da isonomia e da razoabilidade. Incompatibilidade entre a população e $o$ número de vereadores. Inconstitucionalidade, incidenter tantum, da norma municipal. Efeitos para o futuro. Situação excepcional. 1. O artigo 29, inciso IV da Constituição Federal, exige que o número de Vereadores seja proporcional à população dos Municípios, observados os limites mínimos e máximos fixados pelas alíneas a, b e c. 2. Deixar a critério do legislador municipal o estabelecimento da composição das Câmaras Municipais, com observância apenas dos limites máximos e mínimos do preceito (CF, artigo 29), é tornar sem sentido a previsão constitucional expressa da proporcionalidade. 3. Situação real e contemporânea em que Municípios menos populosos têm mais Vereadores do que outros com um número de habitantes várias vezes maior. Casos em que a falta de um parâmetro matemático rígido que delimite a ação dos legislativos Municipais implica evidente afronta ao postulado da isonomia. 4. Princípio da razoabilidade. Restrição legislativa. A aprovação de norma municipal que estabelece a composição da Câmara de Vereadores sem observância da relação cogente de proporção com a respectiva população configura excesso do poder de legislar, não encontrando eco no sistema constitucional vigente. 5. Parâmetro aritmético que atende ao comando expresso na Constituição Federal, sem que a proporcionalidade reclamada traduza qualquer afronta aos demais princípios constitucionais e nem resulte formas estranhas e distantes da realidade dos Municípios brasileiros. Atendimento aos postulados da moralidade, impessoalidade e economicidade dos atos administrativos (CF, artigo 37). 6. Fronteiras da autonomia municipal impostas pela própria Carta da República, que admite a proporcionalidade da representação política em face do número de habitantes. Orientação que se confirma e se reitera segundo o modelo de composição da Câmara dos Deputados e das Assembléias Legislativas ( $\mathrm{CF}$, artigos 27 e 45, § $1^{\circ}$ ). 7. Inconstitucionalidade, incidenter tantun, da lei local que fixou em 11 (onze) o número de Vereadores, dado que sua população de pouco mais de 2.600 habitantes somente comporta 09 representantes. 8. Efeitos. Princípio da segurança jurídica. Situação excepcional em que a declaração de nulidade, com seus normais efeitos ex tunc, resultaria grave ameaça a todo o sistema legislativo vigente. Prevalência do interesse público para assegurar, em caráter de exceção, efeitos pro futuro à declaração incidental de inconstitucionalidade. Recurso extraordinário conhecido e em parte provido."
} 
Um dos fatores que influenciaram na ponderação do STF foi o postulado da economicidade. Teoricamente, a afronta à economicidade não faria sentido num governo descentralizado - os estados tentariam compatibilizar seus orçamentos de acordo com sua capacidade econômica, reduzindo os gastos racionalmente. Entretanto, como os municípios são criados para viver à custa da União e, em menor escala, dos estados, tal preocupação inexiste. Surge, então, um problema de risco moral: como os municípios não possuem riscos devido à fonte externa de receita, agem irresponsavelmente com os recursos recebidos do estado e da União. ${ }^{967}$

Pode-se, possivelmente, expandir o exemplo de Mira Estrela para a maioria dos municípios criados desde 1988: poucos possuem capacidade arrecadatória para fazer frente ao necessário para prover os serviços básicos de saúde e educação da população, mas criam máquinas administrativas onerosas, desnecessárias para o seu pequeno tamanho. À guisa de ilustração, veja-se o município mineiro de Umbaratiba, que se encontra entre os 12 do estado de Minas Gerais com menor arrecadação: em 2008, recolheu aproximadamente $\mathrm{R}$ \$ 3,5 mil em IPTU, R\$ 12,5 mil em ISSQN, R\$ 9,9 mil em ITBI. No total, a arrecadação própria não ultrapassou R\$ 70 mil, mas as transferências da União totalizaram R\$ 4,1 milhões e constituem parte significativa das suas receitas. ${ }^{968}$

Diante dessa constatação, deve-se realizar o exame da relação entre corrupção e federalismo considerando-se as questões que envolvem o federalismo fiscal brasileiro.

\subsubsection{A problemática divisão das receitas sob a ótica do federalismo fiscal}

O federalismo fiscal é uma expressão utilizada para denominar o estudo da distribuição de despesas e receitas entre os entes federativos. Segundo Oates, os estudos do federalismo fiscal têm como objetivo compreender quais funções e instrumentos governamentais funcionariam melhor centralizados e quais deveriam ser alocados para esferas descentralizadas. Em outras palavras, pretende-se estudar de que maneira os poderes tributários (sob a perspectiva das receitas) e as competências (sob a perspectiva das despesas)

\footnotetext{
$\overline{967}$ CAVALCANTI, Márcio Novaes. Fundamentos da lei de responsabilidade fiscal. São Paulo: Dialética, 2001. p. 68 968 MAAKAROUN, Bertha. Mais de $80 \%$ das cidades de Minas só sobrevivem com repasses da União. Estado de Minas, Belo Horizonte, 27 abr. 2009. Disponível em: <http://wwo.uai.com.br/UAI/html/sessao_3/2009/04/27/em_noticia_interna,id_sessao=3\&id_noticia=107981/em noticia_interna.shtml>. Acesso em: 22 dez. 2009 às $23 \mathrm{~h} 14$.
} 
devem ser repartidos entre diferentes níveis verticais da administração pública. ${ }^{969}$ No contexto brasileiro, o estudo compreende também o sistema de transferências intergovernamentais da União para os entes descentralizados.

O federalismo fiscal pressupõe que a alocação de competências tributárias em diferentes esferas de governo não é um jogo de soma zero: algumas competências e instrumentos tributários deveriam ser centralizados, enquanto outros, descentralizados. Fica evidente que as ideias propostas pelos estudos de federalismo fiscal não se dirigem especificamente a estados que adotam a forma federativa de Estado. Como os problemas são analisados apenas sob o ângulo fiscal, em realidade o federalismo fiscal constitui um grupo de princípios orientadores que se propõem a melhorar as relações financeiras entre os governos centrais e os governos subnacionais; por isso, há quem afirme que o termo "federalismo" é inadequado para definir essa situação.

Existe uma intersecção entre as questões do federalismo fiscal e corrupção, na medida em que se tenta compreender quais são os possíveis incentivos e desincentivos à corrupção no contexto da distribuição de competências em dado ordenamento jurídico. Além da análise mercantil da corrupção, o federalismo fiscal permite caracterizar o desequilíbrio existente na federação brasileira. Sob esse ângulo, discutir se uma tarefa seria mais bem desempenhada pela União, pelo estado ou município perde um pouco a utilidade, pois o que importa é identificar se o ente federativo está capacitado financeiramente para desempenhar as funções que lhe foram atribuídas. A problemática em torno do aspecto tridimensional do federalismo brasileiro indica fortemente que, na maioria dos casos, não existe esse equilíbrio, mas sim um desequilíbrio estrutural.

No Brasil, o ponto inicial é compreender como o sistema de transferência de recursos entre esferas governamentais se relaciona e causa abusos na gestão orçamentária por parte de entes federados, cada qual dotado de sua autonomia orçamentária. Na teoria, os entes descentralizados deveriam compatibilizar seus orçamentos de acordo com sua capacidade econômica, reduzindo ou expandindo os gastos racionalmente. Na República Velha, já se

\footnotetext{
$\overline{969}$ OATES, W. An essay on fiscal federalism. Journal of Economic Literature, Nashville, American Economic Association. v. 37, n. 3, p. 1120, Sept. 1999. "But the proper goal of restructuring the public sector cannot simply be decentralization. [...] The basic issue is one of aligning responsibilities and fiscal instruments with the proper levels of government. [...] As a subfield of public finance, fiscal federalism addresses the vertical structure of the public sector. It explores, both in normative and positive terms, the roles of the different levels of government and the ways in which they relate to one another through such instruments as intergovernmental grants."
} 
notava a dificuldade para os estados saldarem suas dívidas, especialmente a externa, ${ }^{970}$ e a irresponsabilidade fiscal dos municípios era atribuída à omissão deliberada sobre os desmandos do coronelismo por parte dos estados. ${ }^{971}$ A experiência pós-1988 revela que a prática foi exatamente oposta:

\begin{abstract}
Essas distorções levaram ao surgimento de ainda outro problema: mecanismos artificiais para aumentar os déficits orçamentários de Estados-Membros. Para desenvolver projetos de infra-estrutura, ou financiar projetos de desenvolvimento, os governadores decidiram emitir títulos ou recorreram aos mercados financeiros. Obviamente, não havia recursos para pagar suas aventuras, mas as receitas recebidas por meio de transferências automáticas descritas acima funcionaram como uma espécie de socorro (bail out) para suas dívidas. Portanto, os mecanismos de transferências fiscais automáticas, destinadas a desempenhar uma função redistributiva, foram transformados em garantia de salvamento (bail out), estimulando o mau comportamento governamental. ${ }^{972}$
\end{abstract}

Esse problema de risco moral decorre das significativas diferenças entre a descentralização fiscal fundada (i) em competências tributárias locais e (ii) em transferências intergovernamentais. ${ }^{973} \mathrm{~A}$ descentralização fiscal fundada em poderes tributários locais possibilita a autonomia financeira dos governos subnacionais, ao passo que a fundada em transferências intergovernamentais mitiga a autonomia financeira dos entes subnacionais, criando disputas internas por recursos verticais (entre os diversos níveis de governo) e horizontais (entre os governos de um mesmo nível). A corrupção política tem um campo mais propício para se desenvolver nessa segunda estratégia.

Num quadro em que parte substancial das receitas não é arrecadada localmente, mas garantida por transferências intergovernamentais, o raciocínio de que entes descentralizados administrariam racionalmente seus gastos para equipará-los às suas receitas encontra obstáculos para corresponder à realidade. Entra em cena o risco moral, consistente na

\footnotetext{
$\overline{970}$ BALEEIRO, Aliomar. Uma introdução à ciência das finanças. 15. ed. rev. e atual. por Dejalma de Campos. Rio de Janeiro: Renovar, 1997. p. 468-469.

${ }^{971}$ LEAL, Victor Nunes. Coronelismo, enxada e voto: o município e o regime representativo no Brasil. São Paulo: Alfa-Ômega, 1976. p. 52. "O argumento, muito usado, de que a autonomia local favorece as administrações perdulárias ou corruptas, pela impossibilidade de um controle do alto, é geralmente documentado com a experiência do regime de 91 na maior parte dos Estados. Mas, se o Estado, no regime de 91, dispunha de completa ascendência política sobre os chefes locais, por que não a exercia no sentido de moralizar a administração municipal? Por que só a utilizava para impor candidatos nas eleições estaduais e federais? Essas perguntas desnudam o fato verdadeiro que o próprio argumento encobre. A 'vista grossa' que os governos estaduais sempre fizeram sobre a administração municipal, deixando de empregar sua influência política para moralizá-la, fazia parte do sistema de compromisso do 'coronelismo'. Estava incluída na carta-branca que recebiam os chefes locais, em troca do seu incondicional apoio aos candidatos do governo nas eleições estaduais e federais."

${ }^{972}$ CAVALCANTI, Márcio Novaes. Op. cit. p. 64.

973 RODDEN, J. Reviving Leviathan: fiscal federalism and the growth of government. International Organization, Boston: Cambrigde University Press, v. 57, n. 4, p. 695-696, 2003.
} 
sensação de irresponsabilidade quanto aos recursos que num primeiro momento parecem infindáveis. Dependência financeira e autonomia orçamentária são ingredientes que, combinados, podem produzir o efeito diametralmente contrário: quanto maior a percepção de que o dinheiro "não é de ninguém", maiores são os gastos e as pressões para a captação de recursos distribuídos pelo poder central. 


\subsubsection{A arrecadação tributária dos entes federados}

No ordenamento jurídico brasileiro, a Constituição de 1988 objetivou garantir a segurança jurídica no âmbito do direito tributário por meio das "limitações constitucionais ao poder de tributar", que utilizam duas estratégias principais: (i) a segurança dos contribuintes em face do Estado pela garantia de direitos fundamentais; e (ii) a segurança dos entes federativos entre si, através da organização de um federalismo fiscal contemplando uma repartição clara de competências e do resultado da arrecadação, bem como a fixação de imunidades, entre outras vedações. ${ }^{974}$

Tabela 19 - Divisão das competências tributárias relativas a impostos

\begin{tabular}{|c|c|}
\hline Competência & Impostos \\
\hline União & $\begin{array}{l}\text { - } \text { sobre operações do comércio exterior - sobre importações (II) e exportações (IE) } \\
\text { de produtos e serviços; } \\
\text { - } \text { sobre a renda e proventos de qualquer natureza (IR); } \\
\text { - } \text { sobre produtos industrializados (IPI); } \\
\text { - } \text { sobre operações de crédito, câmbio e seguro, ou relativas a títulos ou valores } \\
\text { mobiliários (IOF); e } \\
\text { - } \text { sobre a propriedade territorial rural (ITR). }\end{array}$ \\
\hline $\begin{array}{c}\text { Estados e } \\
\text { Distrito } \\
\text { Federal }\end{array}$ & $\begin{array}{l}\text { - de transmissão causa mortis e doação de quaisquer bens ou direitos (ITCD); } \\
\text { - } \text { sobre operações relativas à circulação de mercadorias e sobre a prestação de } \\
\text { serviços de transporte interestadual e intermunicipal e de comunicação (ICMS); e } \\
\text { - } \text { sobre a propriedade de veículos automotores (IPVA). }\end{array}$ \\
\hline $\begin{array}{c}\text { Municípios e } \\
\text { Distrito } \\
\text { Federal }\end{array}$ & $\begin{array}{l}\text { - de propriedade predial e territorial urbana (IPTU); } \\
\text { - sobre a transmissão inter vivos, a qualquer título, por ato oneroso, de bens } \\
\text { imóveis (ITBI); e } \\
\text { - sobre serviços de qualquer natureza (ISS), excluídos aqueles tributados pelo } \\
\text { ICMS. }\end{array}$ \\
\hline
\end{tabular}

Fonte: Tabela adaptada do formato proposto por BRASIL. Secretaria da Receita Federal. Coordenação Geral de Política Tributária. Estudo Tributário nº 08. Sistema e administração tributária: uma visão geral. Brasília, 2002, p. 4.4 Disponível em: <http://www.receita.gov.br/Publico/estudotributarios/estatisticas/20SistemaAdministracaoTributaria.pdf $>$ Acesso em: 23 dez. 2009 à 1 h30.

$\overline{974}$ TORRES, Heleno Tavares. Direito tributário e direito privado: autonomia privada, simulação, elisão tributária. São Paulo: Revista dos Tribunais, 2003. p. 55-56. 
Dessa maneira, os tributos podem ser coletados por cada nível de ente federativo, de modo que cada esfera de governo tem a possibilidade de instituir determinados impostos, taxas (em razão do poder de polícia ou pela utilização de serviços públicos) e contribuições de melhoria (decorrentes de obras públicas). Além disso, as contribuições sociais podem, em sua maioria, ser instituídas pela União. No que diz respeito aos principais impostos brasileiros, a Tabela 19 ilustra as competências tributárias segundo a Constituição de 1988. Apesar de a falta de consenso de 27 estados para mudanças de regras relativas ao ICMS ter sido apontada como um dos fatores do caos tributário desde a promulgação da Constituição de 1988, os interesses da União também poderiam ser afetados se houvesse uma reestruturação financeira e tributária consistente.

Adicionalmente, a União pode instituir empréstimos compulsórios e contribuições sociais, de intervenção no domínio econômico e de interesse das categorias profissionais ou econômicas. Dentre as contribuições sociais vigentes, todas de competência da União, destacam-se a Contribuição para o Financiamento da Seguridade Social (Cofins); a Contribuição para o Programa de Integração Social e para o Programa de Formação do Patrimônio do Servidor Público (PIS/Pasep); a Contribuição Social sobre o Lucro Líquido das Pessoas Jurídicas (CSLL); a Contribuição para o Seguro Social incidente sobre folha de pagamento e sobre o trabalho autônomo; e a Contribuição de Intervenção no Domínio Econômico (Cide-Combustíveis). Os demais entes federativos, por sua vez, podem apenas instituir contribuições para o custeio de sistemas de previdência e assistência social para os seus servidores.

A mera enumeração dos tributos é incapaz de explicar o que ela representa na realidade - um único tributo poderia arrecadar muito mais do que vários outros juntamente, e a aparente menor competência poderia ser compensada do ponto de vista do volume arrecadado. De fato, a análise meramente textual das atribuições arrecadatórias, contida na Constituição, demonstra que a margem de manobra disponível à União para instituir tributos é substancialmente superior à conferida aos estados e municípios. ${ }^{975}$ A grande competência tributária da União confirma que ela é responsável pela maior parte da arrecadação: a evolução percentual da arrecadação de cada ente federativo permaneceu praticamente inalterada entre 2000 e 2007 (ver Gráfico 3, abaixo), o que confirma a consistência das alegações de centralização na arrecadação de tributos pela União.

\footnotetext{
${ }_{975}$ Em sentido contrário, ver TORRES, Ricardo Lobo. Tratado de direito constitucional, financeiro e tributário. v. 5. (O orçamento na Constituição). 3. ed. atual. Até 31.12.2007, incluindo a Emenda Constitucional nº 56, de 20.12.2007. Rio de Janeiro: Renovar, 2008. p. 40. AFONSO, J. R. Rodrigues; SERRA, José. Federalismo fiscal à brasileira: algumas reflexões. Revista do BNDES, v. 6, n. 12, p. 3-30, dez. 1999.
} 
Gráfico 3 - Evolução percentual da arrecadação dos entes federativos (2000-2007)

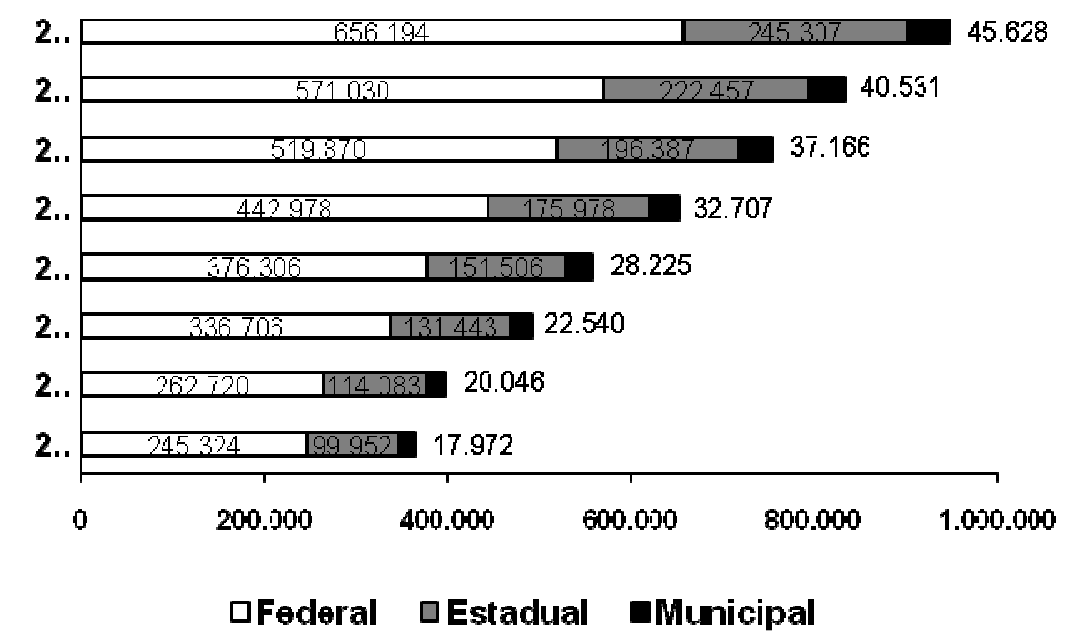

Fonte: CONFEDERAÇÃO NACIONAL DOS MUNICÍPIOS. Estudos fiscais: estimativas da participação dos entes da federação no bolo tributário. Porto Alegre, 2008. p. 2. Disponível em: $<$ http://portal.cnm.org.br/sites/9000/9070/Estudos/Financas/EstudoBoloTributario.pdf > . Acesso em: 31 out. 2009 às $17 \mathrm{~h} 45$.

Um desdobramento desta repartição das receitas tributárias é que, nos municípios, a dependência econômica em relação aos estados e a União é a regra. Conforme apontam Ferreira e Bugarin, menos de $25 \%$ da receita total dos municípios provém de arrecadação tributária própria. ${ }^{976} \mathrm{O}$ paradoxo reside no fato de que saúde e educação, atividades da alçada municipal, exigem vultosos recursos, não tanto para a construção da infraestrutura, mas principalmente para a manutenção do grande número de funcionários especializados necessários. Em realidade, tal fato é corroborado pela dificuldade que os estados e, principalmente, os municípios têm para atingir o equilíbrio entre receitas e despesas. A Tabela 20 mostra que em 2002, ano em que houve restrição generalizada dos gastos públicos, quase a metade dos municípios não conseguiu eliminar o déficit público - no ano anterior, a proporção tinha sido de cerca de 1/3. A tabela indica, ainda, que os municípios mais superavitários se encontram nas regiões Sul e Sudeste, as mais desenvolvidas do país. Os dados segmentados por região e tamanho do município são ainda mais esclarecedores da

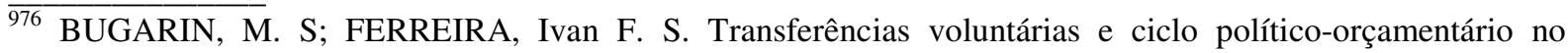
federalismo fiscal brasileiro. Revista Brasileira de Economia, Rio de Janeiro, v. 61, n. 3, jul./set. 2007. Também disponível em: < http://www.scielo.br/pdf/rbe/v61n3/a01v61n3.pdf > Acesso em: 20 dez. 2009 às 22h10.
} 
relação entre menor desenvolvimento econômico e incapacidade de atingir o equilíbrio fiscal. ${ }^{977}$

Tabela 20 - Distribuição dos municípios brasileiros conforme sua situação fiscal em 2002, segundo as grandes regiões

\begin{tabular}{|r|c|c|c|c|c|}
\hline \multirow{2}{*}{ Regiões do Brasil } & Total & \multicolumn{2}{|c|}{ Municípios com superávit fiscal } & \multicolumn{2}{c|}{ Municípios com déficit fiscal } \\
\cline { 2 - 6 } & Número & Número & \% & Número & $\%$ \\
\hline Total & $\mathbf{5 . 5 6 0}$ & $\mathbf{3 . 1 3 7}$ & $\mathbf{5 6 , 0}$ & $\mathbf{2 . 4 2 3}$ & $\mathbf{4 4 , 0}$ \\
\hline Norte & 449 & 209 & 46,5 & 240 & 53,5 \\
\hline Nordeste & 1.792 & 879 & 49,1 & 913 & 50,9 \\
\hline Sudeste & 1.668 & 927 & 55,6 & 741 & 44,4 \\
\hline Sul & 1.189 & 869 & 73,1 & 320 & 26,9 \\
\hline Centro-Oeste & 462 & 253 & 54,8 & 209 & 45,2 \\
\hline
\end{tabular}

Fonte: BREMAEKER, François E. J. A situação fiscal dos municípios brasileiros em 2002. Rio de Janeiro: Instituto Brasileiro de Administração Municipal. Set. 2003. (Série Estudos Especiais no ${ }^{2}$ 55). p. 6 Disponível em: <http://info.worldbank.org/etools/docs/library/229953/Bremaeker\%20Situacao \%20Fiscal.pdf>. Acesso em: 1 jan. 2009 às $16 \mathrm{~h} 36$.

Talvez exista uma tendência para a melhoria do equilíbrio financeiro. Já em 2001, Bremaeker observava que "[...] a situação fiscal dos Municípios brasileiros em 2001 é a melhor de todas, registrando-se um superávit fiscal em 68,5\% deles. No ano de 1995, o primeiro ano pleno do Plano Real, apenas 17,8\% dos Municípios conseguiam apresentar superávit fiscal em suas contas". ${ }^{978}$ A estabilidade da inflação e o crescimento da economia após 2004 certamente atenuaram esse quadro negativo, mas não se pode descartar que existe o risco de a melhora ser apenas conjuntural. Uma interpretação alternativa sugere que a melhora fiscal se deveu mais ao aumento da arrecadação em termos absolutos do que a melhor repartição das receitas. Entre 2000 e 2007, a receita dos municípios e estados aumentou em ritmo elevado em termos absolutos, mas a União ganhou terreno em termos proporcionais, mesmo depois de descontadas as transferências intergovernamentais. Visto desse ângulo, houve uma melhora aparente, mas a estrutura continua a fornecer incentivos para a submissão dos entes economicamente mais frágeis.

Nesse ponto, "gera-se uma tendência irracional no sistema tributário" para burlar a necessidade de divisão das receitas da União com estados e municípios: a criação de

\footnotetext{
$\overline{977}$ Ver BREMAEKER, François E. J. A situação fiscal dos municípios brasileiros em 2001. Rio de Janeiro: Instituto Brasileiro de Administração Municipal. Mar. 2003. (Série Estudos Especiais no 47). p. 7. Disponível em: <http://info.worldbank.org/etools/docs/library/229953/Bremaeker\%20Situacao\%20Fiscal.pdf>. Acesso em: 1 jan. 2009 às 15h30. "Os Municípios da região Sudeste foram responsáveis por 72,2\% deste resultado [de superávit], aparecendo a região Sul em segundo plano com $24,3 \%$. Entretanto, o resultado relativo mais expressivo se deu na região Sul, onde seus Municípios alcançaram um superávit fiscal médio de 5,6\% em relação à receita orçamentária. $\mathrm{O}$ expressivo resultado da região Sudeste se deveu ao desempenho financeiro dos seus Municípios com população superior a 1 milhão de habitantes, que alcançaram um resultado relativo da ordem de $9,5 \%$ em relação à receita orçamentária."

${ }^{978}$ Idem, p. 20.
} 
contribuições. ${ }^{979}$ As diversas contribuições introduzidas, tais como a CPMF, o Cofins e o PIS/Pasep, seriam substancialmente impostos cuja destinação deveria ser dividida pela União com os demais entes federativos, ${ }^{980}$ exceção feita à Cide-Combustíveis, ${ }^{981}$ a qual, a propósito, rompe com o princípio de que somente impostos poderiam ser compartilhados entre os entes federativos. ${ }^{982} \mathrm{O}$ artifício não passou despercebido pela sociedade e gerou grande quantidade de litígios na área tributária, embora em sua maioria as teses tenham sido vencidas.

Como resultado, a maior parte do aumento da carga tributária se verificou na esfera da União, não dos demais entes federativos. ${ }^{983}$ Dessa maneira, o desenho institucional de divisão dos interesses estabelecido na Constituição de 1988 foi desestabilizado, fazendo o pêndulo de receitas fiscais inclinar-se para a União e os entes federados buscarem ali recursos para suprir suas necessidades. ${ }^{984}$

\footnotetext{
${ }^{979}$ SERRA, José. Orçamento no Brasil. 2. ed. rev. e ampl. São Paulo: Atual, 2004. p. 120. “Como a União está especialmente tolhida, gera-se uma tendência irracional no sistema tributário, pois a União tende a elevar impostos típicos de política econômica, que não são transferidos aos Estados e Municípios, além de recorrer a Contribuições Sociais, como forma de defender sua receita."

980 TORRES, Ricardo Lobo. Op. cit. p. 40. "O sistema tributário brasileiro, redesenhado em 1988, trouxe novas desarmonias nas finanças públicas. [...] Introduziu as perversas e exóticas contribuições sociais (CONFINS, PIS/PASEP, CSLL, CPMF), que na realidade são impostos com destinação especial, que geraram enorme contencioso fiscal nos anos seguintes. A União aproveitou essas anômalas contribuições, que não eram repassadas a Estados e Municípios, para ampliar as suas receitas."

${ }^{981}$ PIRES, Adilson Rodrigues; TORRES, Heleno Tavares. Direitos fundamentais, federalismo fiscal e emendas constitucionais tributárias. In: Princípios de direito financeiro e tributário. Estudos em homenagem ao Professor Ricardo Lobo Torres. Rio de Janeiro: Renovar, 2006. p. 68. "Chame-se a atenção para a novidade que é a participação dos Estados na arrecadação da Contribuição de Intervenção no Domínio Econômico - CIDECombustíveis, inaugurada em 25\% com a Emenda Constitucional - EC n ${ }^{\circ}$ 42/2003 e hoje em 29\% desde a EC 44/2004 (artigo 159, III): benfazeja ao Federalismo Fiscal, para o qual parecem ter acordado os Estados, porém ela apenas confirma o diagnóstico de que a CIDE é um verdadeiro imposto disfarçado que distorce o nosso tão desfigurado Sistema Tributário Nacional."

982 CHARNESKI, Heron. Desvio orçamentário de finalidade das contribuições à luz do federalismo fiscal brasileiro: o caso Cide-Combustíveis. Revista Dialética de Direito Tributário, São Paulo: Dialética, n. 128, p. 21, maio 2006.

983 TORRES, Ricardo Lobo. Op. cit. p. 42.

${ }^{984}$ NUSDEO, Fábio. Op. cit. p. 164-165. “[...] certas leis originalmente votadas e promulgadas dentro de uma situação de neutralidade, isto é, com custo e benefícios equanimemente distribuídos pela sociedade, podem com o tempo perder essa neutralidade, passando a representar um caso de captura de seus benefícios por parte de alguns setores ou grupos, fato esse a ser analisado e considerado pelos tribunais a título de balizamento para as suas decisões."
} 
Tabela 21 - Evolução da carga tributária arrecadada por esfera entre 2000-2007 (R\$ milhões)

\begin{tabular}{|r|c|c|c|c|c|c|c|c|}
\hline Esfera & 2000 & 2001 & 2002 & 2003 & 2004 & 2005 & 2006 & 2007 \\
\hline Federal & 245.324 & 262.720 & 336.706 & 376.306 & 442.978 & 519.870 & 571.030 & 656.194 \\
\hline Estadual & 99.952 & 114.083 & 131.443 & 151.506 & 175.978 & 196.387 & 222.457 & 245.307 \\
\hline Municipal & 17.972 & 20.046 & 22.540 & 28.225 & 32.707 & 37.166 & 40.531 & 45.628 \\
\hline
\end{tabular}

Fonte: CONFEDERAÇÃO NACIONAL DOS MUNICÍPIOS. Estudos fiscais: estimativas da participação dos entes da federação no bolo tributário. Porto Alegre, 2008. p. 1. Disponível em: $<$ http://portal.cnm.org.br/sites/9000/9070/Estudos/Financas/EstudoBoloTributario.pdf $>$. Acesso em: 31 out. 2009 às $17 \mathrm{~h} 45$.

Tabela 22 - Carga Tributária Disponível, depois das transferências intergovernamentais entre 2000-2007 (\% do total)

\begin{tabular}{|c|c|c|c|c|c|c|c|c|}
\hline Esfera & $\mathbf{2 0 0 0}$ & $\mathbf{2 0 0 1}$ & $\mathbf{2 0 0 2}$ & $\mathbf{2 0 0 3}$ & $\mathbf{2 0 0 4}$ & $\mathbf{2 0 0 5}$ & $\mathbf{2 0 0 6}$ & $\mathbf{2 0 0 7}$ \\
\hline Federal & 56,70 & 56,79 & 57,18 & 56,85 & 57,58 & 57,72 & 57,34 & 58,14 \\
\hline Estadual & 26,58 & 26,57 & 26,34 & 26,40 & 25,88 & 25,64 & 25,91 & 25,27 \\
\hline Municipal & 16,72 & 16,64 & 16,48 & 16,76 & 16,54 & 16,64 & 16,75 & 16,54 \\
\hline Total & $\mathbf{1 0 0 , 0 0}$ & $\mathbf{1 0 0 , 0 0}$ & $\mathbf{1 0 0 , 0 0}$ & $\mathbf{1 0 0 , 0 0}$ & $\mathbf{1 0 0 , 0 0}$ & $\mathbf{1 0 0 , 0 0}$ & $\mathbf{1 0 0 , 0 0}$ & $\mathbf{1 0 0 , 0 0}$ \\
\hline
\end{tabular}

Fonte: CONFEDERAÇÃO NACIONAL DOS MUNICÍPIOS. Estudos fiscais: estimativas da participação dos entes da federação no bolo tributário. Porto Alegre, 2008. p. 1. Disponível em: $<$ http://portal.cnm.org.br/sites/9000/9070/Estudos/Financas/EstudoBoloTributario.pdf $>$. Acesso em: 31 out. 2009 às $17 \mathrm{~h} 45$.

Ao se compararem os dados da carga tributária em relação ao Produto Interno Bruto (PIB), constata-se que, mesmo depois das transferências intergovernamentais, em sete anos a União ganhou participação de quase $2 \%$, ao passo que estados e municípios tiveram um declínio pequeno nas participações relativas. Durante esse período foram aprovadas três emendas constitucionais (as Emendas Constitucionais n. 42/2003, n. 44/2004 e n. 55/2007), as quais aumentaram a participação dos entes federativos descentralizados nas transferências obrigatórias, e, mesmo assim o quadro não apresentou alterações significativas. Tais dados sugerem que o produto das contribuições, fonte principal do aumento da arrecadação da União, não foi compartilhado com os estados e municípios, pelo menos no mesmo ritmo em que foram arrecadadas pela União. 
Tabelas 23 - Receita tributária e transferência da União entre 2000-2007 (R\$ milhões)

\begin{tabular}{|r|c|c|c|c|c|c|c|c|}
\hline \multirow{2}{*}{ Esfera } & \multicolumn{7}{|c|}{ Receita tributária e transferência da União (R\$ milhões) } \\
\cline { 2 - 11 } & $\mathbf{2 0 0 0}$ & $\mathbf{2 0 0 1}$ & $\mathbf{2 0 0 2}$ & $\mathbf{2 0 0 3}$ & $\mathbf{2 0 0 4}$ & $\mathbf{2 0 0 5}$ & $\mathbf{2 0 0 6}$ & $\mathbf{2 0 0 7}$ \\
\hline Arrecadação & 245.324 & 282.720 & 336.708 & 376.308 & 442.978 & 519.870 & 571.030 & 656.194 \\
\hline Transferências & 39.757 & 45.991 & 56.127 & 60.226 & 67.761 & 83.852 & 92.839 & 105.542 \\
\hline Estados & 21.711 & 24.922 & 30.001 & 32.042 & 35.399 & 43.609 & 48.041 & 53.730 \\
\hline Municípios & 18.045 & 21.069 & 26.126 & 28.184 & 32.362 & 40.243 & 44.798 & 51.811 \\
\hline Disponível & 205.567 & 236.729 & 280.581 & 316.082 & 375.217 & 436.018 & 478.191 & 550.652 \\
\hline
\end{tabular}

Fonte: CONFEDERAÇÃO NACIONAL DOS MUNICÍPIOS. Estudos fiscais: estimativas da participação dos entes da federação no bolo tributário. Porto Alegre. 2008, p. 2. Disponível em: $<$ http://portal.cnm.org.br/sites/9000/9070/Estudos/Financas/EstudoBoloTributario.pdf $>$. Acesso em: 31 out. 2009 às $17 \mathrm{~h} 45$.

Tabelas 24 - Receita tributária e transferência da União entre 2000-2007 (\% do PIB)

\begin{tabular}{|r|c|c|c|c|c|c|c|c|}
\hline \multirow{2}{*}{ Esfera } & \multicolumn{7}{|c|}{ Receita tributária e transferência da União (\% do PIB) } \\
\cline { 2 - 10 } & $\mathbf{2 0 0 0}$ & $\mathbf{2 0 0 1}$ & $\mathbf{2 0 0 2}$ & $\mathbf{2 0 0 3}$ & $\mathbf{2 0 0 4}$ & $\mathbf{2 0 0 5}$ & $\mathbf{2 0 0 6}$ & $\mathbf{2 0 0 7}$ \\
\hline Arrecadação & 20,80 & 21,71 & 22,78 & 22,14 & 22,82 & 24,21 & 24,48 & 25,64 \\
\hline Transferências & 3,37 & 3,53 & 3,80 & 3,54 & 3,49 & 3,91 & 3,98 & 4,12 \\
\hline Estados & 1,84 & 1,91 & 2,03 & 1,88 & 1,82 & 2,03 & 2,06 & 2,10 \\
\hline Municípios & 1,53 & 1,62 & 1,77 & 1,66 & 1,67 & 1,87 & 1,92 & 2,02 \\
\hline Disponível & 17,43 & 18,18 & 18,99 & 18,59 & 19,33 & 20,31 & 20,50 & 21,52 \\
\hline
\end{tabular}

Fonte: CONFEDERAÇÃO NACIONAL DOS MUNICÍPIOS. Estudos fiscais: estimativas da participação dos entes da federação no bolo tributário. Porto Alegre. 2008, p. 2. Disponível em: <http://portal.cnm.org.br/sites/9000/9070/Estudos/Financas/EstudoBoloTributario.pdf>. Acesso em: 31 out. 2009 às $17 \mathrm{~h} 45$.

À guisa de ilustração, pode-se mencionar o cenário do Estado de Minas Gerais: mais de $80 \%$ dos municípios mineiros dependem das transferências constitucionais do Fundo de Participação dos Municípios (FPM). De acordo com levantamento realizado por um consultor da Gerência de Economia e Finanças da Assembleia Legislativa do Estado, 690 municípios participam com menos de $15 \%$ de arrecadação própria no montante total de suas receitas orçamentárias; e, entre os 853 municípios mineiros, 408 contribuem com menos de 7\% no conjunto de suas receitas. Segundo o levantamento, esses municípios apresentam média de 6 mil habitantes e atividade econômica praticamente irrelevante. ${ }^{985}$

\footnotetext{
$\overline{985}$ MAAKAROUN, Bertha. Mais de $80 \%$ das cidades de Minas só sobrevivem com repasses da União. Estado de Minas, Belo Horizonte, 27 abr. 2009. Disponível em: <http://wwo.uai.com.br/UAI/html/sessao_3/2009/04/27/em_noticia_interna,id_sessao=3\&id_noticia=107981/em _noticia_interna.shtml>. Acesso em: $22 \mathrm{dez} .2009$ às 23h14. Um panorama global do problema é fornecido por
} 


\subsubsection{As transferências de recursos entre os entes federativos}

Como mecanismo de compensação ao expressivo poder de tributar conferido à União, foram estipuladas transferências obrigatórias de recursos dos níveis mais centrais de entidades federativas autônomas para os entes mais descentralizados. A Constituição de 1988 define um sistema de transferências entre a União, estados e municípios, as quais podem ser diretas ou mediante a formação de fundos especiais (indiretas). As transferências sempre ocorrem das esferas centralizadas para as descentralizadas: (i) da União para os estados, (ii) da União para os municípios ou (iii) dos estados para seus respectivos municípios.

Tal distribuição se justifica na tentativa de diminuir as diferenças econômicas entre diferentes regiões brasileiras, de modo que a Constituição prevê um sistema de transferências intergovernamentais para restabelecer o equilíbrio entre obrigações e fontes de receita de cada esfera da federação. Acertadamente, a doutrina nacional identifica o sistema de transferências como um dos pilares de um "federalismo cooperativo" estabelecido pela Constituição. Conforme explicam Bercovici, Andrade e Massonetto,

[...] a igualação das condições sociais de vida, em todo o território nacional, é a diretriz fundamental do nosso federalismo cooperativo. Esta homogeneização só é possível se os entes federados possuírem capacidade econômica e política para satisfazerem suas funções essenciais. Portanto, a igualação das condições sociais passa, necessariamente, pela igualação da capacidade dos entes federados. Busca-se, assim, um sistema federativo que responda às exigências de igualdade e solidariedade sem renunciar à sua própria estrutura federal. $\mathrm{O}$ fundamento desta homogeneização é o princípio da solidariedade, cujo conteúdo constitucional essencial é a busca a homogeneidade social. De acordo com a Constituição, o princípio da solidariedade exige o estabelecimento do equilíbrio econômico socialmente adequado e justo entre as várias regiões. A Constituição estabelece a interdependência entre o direito à autonomia e o princípio da solidariedade, ou seja, segundo González Encinar, autonomia e solidariedade são as duas faces da mesma moeda. ${ }^{986}$

Se inexiste dúvida sobre a necessidade de um esquema dessa natureza em razão das desigualdades regionais e do predomínio da União no cômputo geral da arrecadação, o passo seguinte é examinar se o binômio "autonomia/solidariedade", tal como estruturado na Constituição de 1988, evita ou estimula certas práticas corruptas. Não se trata de criticar as

ARAUJO, Érika A.; OLIVEIRA, Paulo A S. Tributação municipal: desigualdades na carga tributária local. Rio de Janeiro: BNDES, 1996.

${ }^{986}$ ANDRADE, J. M. A.; MASSONETTO, L. F.; BERCOVICI, G. Reforma do Estado, prestações de serviços públicos, contribuições especiais e federalismo. Revista do Instituto de Pesquisas e Estudos, Bauru, v. 40, n. 45, p. 192, jan./jun. 2006. 
transferências em si, mas como elas são feitas. A relação das transferências de recursos com a corrupção fica mais clara quando se percebe que, embora existam transferências de recursos obrigatórias, constitucionalmente definidas, estas não garantem a autonomia financeira dos entes federativos. Uma série de mecanismos jurídicos tornam o que era obrigatório não tão obrigatório e o automatismo da fórmula ligada o binômio "autonomia/solidariedade" requer a subserviência política para ser implementada.

A União deve transferir aos estados e ao Distrito Federal o resultado da arrecadação do imposto sobre renda e proventos de qualquer natureza, incidente na fonte, sobre rendimentos pagos, a qualquer título, por eles, suas autarquias e pelas fundações que instituírem e mantiverem. ${ }^{987}$ Há, também, previsão similar em relação aos municípios. Além disso, a União deve transferir aos municípios 50\% da arrecadação do Imposto Territorial Rural (ITR), relativo aos imóveis neles situados. No entanto, se o município optar por fiscalizar e arrecadar o referido imposto, por meio de convênio com a União, fará jus a 100\% de tal arrecadação. O IOF-Ouro (ativo financeiro) é transferido, no montante de 30\%, para o estado de origem e, no montante de $70 \%$, para o município de destino. ${ }^{988}$

No âmbito das transferências diretas entre estados e municípios, cabem aos municípios $50 \%$ da arrecadação do Imposto sobre Propriedade de Veículos Automotores (IPVA) dos veículos licenciados em seus territórios e 25\% da arrecadação do Imposto sobre Circulação de Mercadorias e Serviços (ICMS) (3/4 no mínimo, proporcionalmente ao valor adicionado nas operações feitas em seus territórios e até 1/4 de acordo com a Lei Estadual). ${ }^{989}$

\footnotetext{
987 BRASIL. Constituição (1988). Art. 157. "Pertencem aos Estados e ao Distrito Federal: I - o produto da arrecadação do imposto da União sobre renda e proventos de qualquer natureza, incidente na fonte, sobre rendimentos pagos, a qualquer título, por eles, suas autarquias e pelas fundações que instituírem e mantiverem; II - vinte por cento do produto da arrecadação do imposto que a União instituir no exercício da competência que lhe é atribuída pelo art. 154, I."

988 BRASIL. Constituição (1988). Art. 153. "Compete à União instituir impostos sobre: [...] V - operações de crédito, câmbio e seguro, ou relativas a títulos ou valores mobiliários; [...] $§ 5^{\circ}-\mathrm{O}$ ouro, quando definido em lei como ativo financeiro ou instrumento cambial, sujeita-se exclusivamente à incidência do imposto de que trata o inciso V do "caput" deste artigo, devido na operação de origem; a alíquota mínima será de um por cento, assegurada a transferência do montante da arrecadação nos seguintes termos: I - trinta por cento para o Estado, o Distrito Federal ou o Território, conforme a origem; II - setenta por cento para o Município de origem."

${ }^{989}$ BRASIL. Constituição (1988). Art. 158 "Pertencem aos Municípios: I - o produto da arrecadação do imposto da União sobre renda e proventos de qualquer natureza, incidente na fonte, sobre rendimentos pagos, a qualquer título, por eles, suas autarquias e pelas fundações que instituírem e mantiverem; II - cinqüenta por cento do produto da arrecadação do imposto da União sobre a propriedade territorial rural, relativamente aos imóveis neles situados, cabendo a totalidade na hipótese da opção a que se refere o art. $153, \S 4^{\circ}$, III; III - cinqüenta por cento do produto da arrecadação do imposto do Estado sobre a propriedade de veículos automotores licenciados em seus territórios; IV - vinte e cinco por cento do produto da arrecadação do imposto do Estado sobre operações relativas à circulação de mercadorias e sobre prestações de serviços de transporte interestadual e intermunicipal e de comunicação. Parágrafo único. As parcelas de receita pertencentes aos Municípios, mencionadas no inciso IV, serão creditadas conforme os seguintes critérios: I - três quartos, no mínimo, na
} 
De grande significação, há transferências indiretas, que são realizadas por meio de fundos. O Fundo de Compensação de Exportações (FPEx) é constituído por $10 \%$ da arrecadação total do IPI, enquanto o Fundo de Participação dos Estados e do Distrito Federal (FPE) é integrado por $21,5 \%$ da arrecadação do IPI e do IR. Por seu turno, o Fundo de Participação dos Municípios (FPM) é composto por 22,5\% da arrecadação do IPI e do IR. No entanto, $10 \%$ do fundo ficam reservados para os municípios das capitais.

Por fim, os Fundos Regionais são especificamente destinados a programas de desenvolvimento nas regiões mais carecedoras de recursos: Norte, Centro-Oeste e Nordeste. Esses fundos contam com os recursos correspondentes a $3 \%$ do IPI e do IR. ${ }^{990}$ Assim, as transferências constitucionais indiretas são responsáveis pelo repasse de $47 \%$ do IR e 57\% do IPI aos estados e municípios.

Sintetizando esse esquema de transferências que visa garantir uma repartição mais equânime da arrecadação do Estado, a Tabela 25, abaixo, representa o fluxo das transferências constitucionais diretas e indiretas.

proporção do valor adicionado nas operações relativas à circulação de mercadorias e nas prestações de serviços, realizadas em seus territórios; II - até um quarto, de acordo com o que dispuser lei estadual ou, no caso dos Territórios, lei federal."

990 BRASIL. Constituição (1988). Art. 159. “A União entregará: I - do produto da arrecadação dos impostos sobre renda e proventos de qualquer natureza e sobre produtos industrializados quarenta e oito por cento na seguinte forma: a) vinte e um inteiros e cinco décimos por cento ao Fundo de Participação dos Estados e do Distrito Federal; b) vinte e dois inteiros e cinco décimos por cento ao Fundo de Participação dos Municípios; c) três por cento, para aplicação em programas de financiamento ao setor produtivo das Regiões Norte, Nordeste e Centro-Oeste, através de suas instituições financeiras de caráter regional, de acordo com os planos regionais de desenvolvimento, ficando assegurada ao semi-árido do Nordeste a metade dos recursos destinados à Região, na forma que a lei estabelecer; d) um por cento ao Fundo de Participação dos Municípios, que será entregue no primeiro decêndio do mês de dezembro de cada ano; II - do produto da arrecadação do imposto sobre produtos industrializados, dez por cento aos Estados e ao Distrito Federal, proporcionalmente ao valor das respectivas exportações de produtos industrializados. III - do produto da arrecadação da contribuição de intervenção no domínio econômico prevista no art. 177, § 4º $29 \%$ (vinte e nove por cento) para os Estados e o Distrito Federal, distribuídos na forma da lei, observada a destinação a que se refere o inciso II, $c$, do referido parágrafo. $\S 1^{\circ}-$ Para efeito de cálculo da entrega a ser efetuada de acordo com o previsto no inciso I, excluir-se-á a parcela da arrecadação do imposto de renda e proventos de qualquer natureza pertencente aos Estados, ao Distrito Federal e aos Municípios, nos termos do disposto nos arts. 157, I, e 158, I. § $2^{\circ}$ - A nenhuma unidade federada poderá ser destinada parcela superior a vinte por cento do montante a que se refere o inciso II, devendo o eventual excedente ser distribuído entre os demais participantes, mantido, em relação a esses, o critério de partilha nele estabelecido. $\S 3^{\circ}$ - Os Estados entregarão aos respectivos Municípios vinte e cinco por cento dos recursos que receberem nos termos do inciso II, observados os critérios estabelecidos no art. 158, parágrafo único, I e II. $\S 4^{\circ}$ Do montante de recursos de que trata o inciso III que cabe a cada Estado, vinte e cinco por cento serão destinados aos seus Municípios, na forma da lei a que se refere o mencionado inciso." 
Tabela 25 - Fluxo de transferências constitucionais

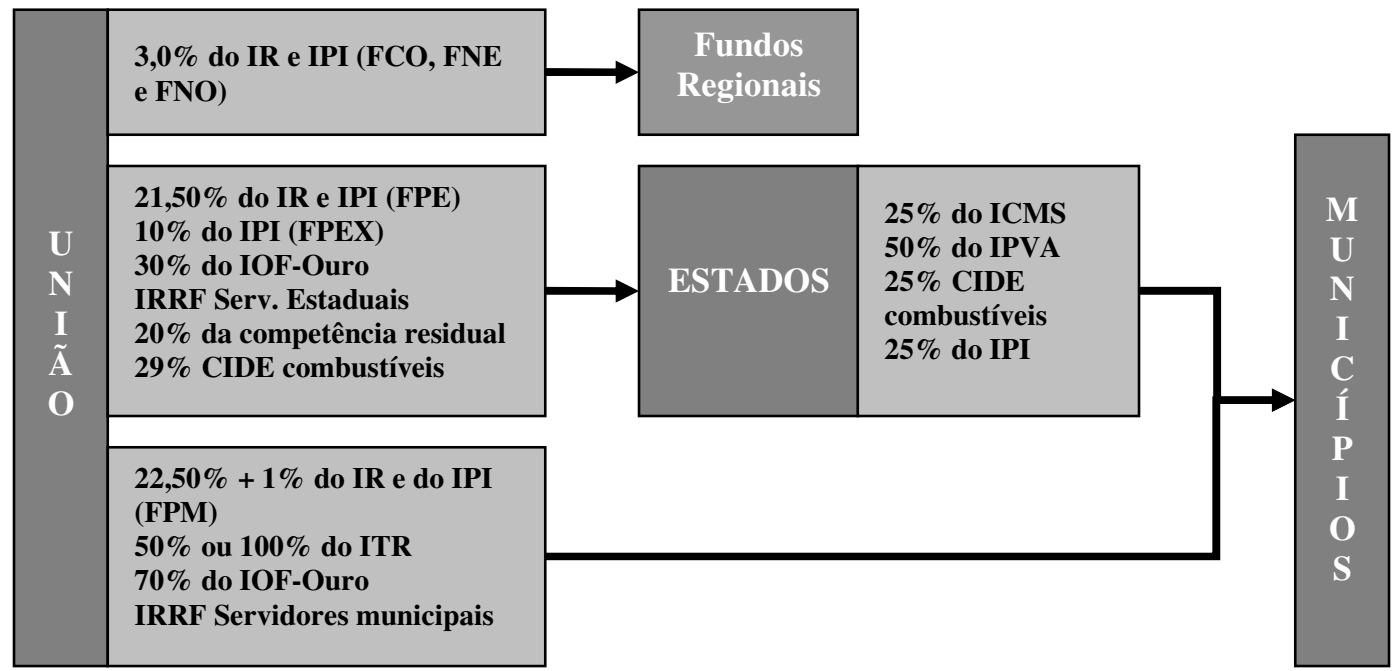

Fonte: Tabela adaptada do formato proposto por BRASIL. Secretaria da Receita Federal. Coordenação Geral de Política Tributária. Estudo Tributário no ${ }^{0}$ 08. Sistema e administração tributária: uma visão geral. Brasília, 2002, p. 11. Disponível em: <http://www.receita.gov.br/Publico/estudotributarios/estatisticas/20SistemaAdministracaoTributar ia.pdf>. Acesso em: 23 dez. 2009 à 1h30.

O critério de rateio das transferências do FPE é diretamente proporcional à população e à superfície e inversamente proporcional à renda per capita de cada ente federativo. ${ }^{991}$ Portanto, o sistema constitucional de transferências resulta em maior participação para os estados mais desprovidos de recursos. A Lei Complementar $n^{\circ}$ 62/89 estabelece a repartição dos recursos do FPE da seguinte maneira: 85\% são destinados para os estados das regiões Norte, Nordeste e Centro-Oeste, e 15\% para os estados das regiões Sul e Sudeste. ${ }^{992}$

Por sua vez, o Fundo de Participação dos Municípios (FPM) tem seus coeficientes fixados pelo $\S 2^{\circ}$ do art. 91 do Código Tributário Nacional. ${ }^{993}$ A Lei Complementar $n^{0}$ 91/97994 visou à correção de certas distorções que tendiam a perpetuar elevadas participações de municípios cuja população diminuiu por êxodo ou criação de outro município, estabelecendo que a distribuição dos recursos contempla um critério proporcional à superfície de cada

\footnotetext{
$\overline{991}$ De acordo com o Código Tributário Nacional (BRASIL. Lei no 5.172, de 25 out. 1966. Art. 92), o TCU é incumbido de calcular as quotas do Fundo de Participação dos Municípios, do Fundo de Participação dos Estados e do Distrito Federal e dos Fundos de Financiamento do Norte, Nordeste e Centro-Oeste. O cálculo elaborado pelo TCU deve respeitar os critérios fixados na legislação complementar e ordinária relativa a cada um desses fundos. Para tanto, o TCU toma como base os dados populacionais fornecidos pela Fundação Instituto Brasileiro de Geografia e Estatística (IBGE), até o último dia de cada exercício (BRASIL. Lei Complementar $\mathrm{n}^{\mathrm{O}}$ 91, de 22 dez. 1997. Art. $5^{\circ}$ ).

992 BRASIL. Lei Complementar $\mathrm{n}^{\mathrm{0}} 62$, de 28 dez. 1989. Art. $2^{\circ}$.

993 BRASIL. Lei no 5.172 , de 25 out. 1966. Art. 91, § $2^{\circ}$.

${ }^{994}$ BRASIL. Lei Complementar no 91, de 22 dez. 1997.
} 
entidade participante e proporcional a um coeficiente individual de participação calculado de maneira proporcional à população e inversamente proporcional à renda per capita de cada entidade participante. A Tabela 26, abaixo, mostra a divisão de recursos do FPE e FPM, ilustrando seu papel na redução das assimetrias regionais; regiões mais pobres recebem mais do que as regiões mais ricas, o que atende ao critério do binômio "autonomia/solidariedade".

Tabela 26 - Divisão de recursos do FPE e FPM por região

\begin{tabular}{|r|c|c|c|c|}
\hline \multicolumn{1}{|c|}{ Região } & FPE & FPM & População & Renda per capita \\
\hline Norte & $25,37 \%$ & $8,53 \%$ & $7,6 \%$ & $\mathrm{R} \$ 3.447$ \\
\hline Nordeste & $52,46 \%$ & $35,27 \%$ & $28,1 \%$ & $\mathrm{R} \$ 2.603$ \\
\hline Sudeste & $8,48 \%$ & $31,18 \%$ & $42,6 \%$ & $\mathrm{R} \$ 7.706$ \\
\hline Sul & $6,52 \%$ & $17,55 \%$ & $14,8 \%$ & $\mathrm{R} \$ 6.611$ \\
\hline Centro-Oeste & $7,17 \%$ & $7,47 \%$ & $6,9 \%$ & $\mathrm{R} \$ 5.681$ \\
\hline
\end{tabular}

Fonte: Tabela adaptada do formato proposto por BRASIL. Secretaria da Receita Federal. Coordenação Geral de Política Tributária. Estudo tributário nº 08. Sistema e administração tributária: uma visão geral.
Brasília,
2002 ,
p.
12.
Disponível
em:

$<$ http://www.receita.gov.br/Publico/estudotributarios/estatisticas/20SistemaAdministracaoTributaria.pdf $>$ . Acesso em: 23 dez. 2009 à 1h30.

Adicionalmente, as regiões menos favorecidas se beneficiam dos recursos do Fundo de Compensação pelas Exportações de Produtos Industrializados: embora a distribuição de recursos seja proporcional ao valor das exportações de produtos industrializados, a participação individual de cada estado é limitada a $20 \%$ do total do fundo. ${ }^{995}$ Há, também, os fundos constitucionais especificamente criados em benefício dessas regiões: os Fundos Constitucionais de Financiamento do Norte, Nordeste e Centro-Oeste (FNO, FNE e FCO). ${ }^{996}$

\footnotetext{
$\overline{995}$ As Leis Complementares no $61 / 89$ e n⿳o 65/91 dispõem que 10\% da arrecadação do Imposto sobre Produtos Industrializados (IPI) deve ser distribuída aos estados e ao Distrito Federal na proporção do respectivo volume de exportação de produtos industrializados. No entanto, tal proporção por ente federado não pode ultrapassar $20 \%$ do total. Os coeficientes de participação no Fundo de Compensação pelas Exportações de Produtos Industrializados (IPI-Exportações) são aprovados pelo TCU.

${ }^{996}$ Os percentuais de participação dos Fundos Constitucionais de Financiamento do Norte, Nordeste e CentroOeste, estabelecidos pela Lei n⿳⺈ 7.827/89, são os seguintes: 0,6\% para o Fundo Constitucional de Financiamento do Norte; 1,8\% para o Fundo Constitucional de Financiamento do Nordeste; 0,6\% para o Fundo Constitucional de Financiamento do Centro-Oeste.
} 
Tabela 27 - Transferências para Municípios entre 2000-2007 (R\$ Milhões)

\begin{tabular}{|r|c|c|c|c|c|c|c|c|}
\hline \multirow{2}{*}{ Esfera } & \multicolumn{7}{|c|}{ Transferências para Municípios (R\$ Milhões) } \\
\cline { 2 - 10 } & $\mathbf{2 0 0 0}$ & $\mathbf{2 0 0 1}$ & $\mathbf{2 0 0 2}$ & $\mathbf{2 0 0 3}$ & $\mathbf{2 0 0 4}$ & $\mathbf{2 0 0 5}$ & $\mathbf{2 0 0 6}$ & $\mathbf{2 0 0 7}$ \\
\hline FPM & 12,816 & 15.024 & 18.595 & 19.343 & 21.322 & 26.676 & 29.503 & 33.935 \\
\hline IOF & 1 & 1 & 2 & 4 & 5 & 2 & 2 & 3 \\
\hline ITR & 112 & 93 & 121 & 133 & 141 & 134 & 152 & 160 \\
\hline Cota IPI - Exp & 375 & 403 & 399 & 383 & 458 & 519 & 585 & 667 \\
\hline Lei Kandir & 811 & 756 & 835 & 864 & 718 & 718 & 415 & 403 \\
\hline FEX & - & - & - & - & 224 & 340 & 599 & 483 \\
\hline CIDE & - & - & - & - & 273 & 438 & 439 & 456 \\
\hline Royalties Hídricos & 110 & 169 & 215 & 264 & 312 & 401 & 440 & 498 \\
\hline Royalties Minerais & 81 & 104 & 121 & 189 & 210 & 265 & 300 & 352 \\
\hline Royalties Petróleo & 775 & 1.071 & 1.520 & 2.232 & 2.523 & 3.179 & 3.963 & 3.727 \\
\hline Salário Educação & 275 & 289 & 331 & 547 & 1.381 & 1.718 & 2.059 & 2.161 \\
\hline Fundef/Funded-U & 2.900 & 3.357 & 4.134 & 4.351 & 5.015 & 6.177 & 6.734 & 9.452 \\
\hline Fundef/Fundeb-E & 4.990 & 5.932 & 7.069 & 8.432 & 10.083 & 11.541 & 13.198 & 15.647 \\
\hline Cota ICMS & 16.893 & 19.152 & 21.640 & 24.536 & 26.278 & 31.600 & 35.127 & 37.589 \\
\hline Cota IPVA & 2.331 & 2.767 & 3.087 & 3.406 & 3.920 & 4.619 & 5.467 & 5.818 \\
\hline Total & $\mathbf{4 2 . 6 3 4}$ & $\mathbf{4 9 . 3 2 4}$ & $\mathbf{5 8 . 3 2 1}$ & $\mathbf{6 4 . 9 4 0}$ & $\mathbf{7 5 . 1 0 1}$ & $\mathbf{8 8 . 5 2 2}$ & $\mathbf{9 9 . 1 7 5}$ & $\mathbf{1 1 1 . 5 3 2}$ \\
\hline
\end{tabular}

Fonte: CONFEDERAÇÃO NACIONAL DOS MUNICÍPIOS. Estudos fiscais: estimativas da participação dos entes da federação no bolo tributário. Porto Alegre. 2008. p. 2. Disponível em: <http://portal.cnm.org.br/sites/9000/9070/Estudos/Financas/EstudoBoloTributario.pdf>. Acesso em: 31 out. 2009 às $17 \mathrm{~h} 45$.

Tabela 28 - Transferências para Municípios entre 2000-2007

\begin{tabular}{|r|c|c|c|c|c|c|c|c|}
\hline \multirow{2}{*}{ Esfera } & \multicolumn{7}{|c|}{ Transferências para Municípios (R\$ milhões) } \\
\cline { 2 - 10 } & $\mathbf{2 0 0 0}$ & $\mathbf{2 0 0 1}$ & $\mathbf{2 0 0 2}$ & $\mathbf{2 0 0 3}$ & $\mathbf{2 0 0 4}$ & $\mathbf{2 0 0 5}$ & $\mathbf{2 0 0 6}$ & $\mathbf{2 0 0 7}$ \\
\hline FPM & 1,09 & 1,15 & 1,26 & 1,14 & 1,10 & 1,24 & 1,26 & 1,33 \\
\hline IOF +ITR & 0,01 & 0,01 & 0,01 & 0,01 & 0,01 & 0,01 & 0,01 & 0,01 \\
\hline IPI+LK+FEX+CIDE & 0,10 & 0,09 & 0,08 & 0,07 & 0,09 & 0,09 & 0,09 & 0,08 \\
\hline Royalties & 0,10 & 0,12 & 0,14 & 0,17 & 0,17 & 0,19 & 0,21 & 0,19 \\
\hline Sal. Educação & 0,02 & 0,02 & 0,02 & 0,03 & 0,07 & 0,08 & 0,09 & 0,08 \\
\hline Fundef / Fundeb & 0,67 & 0,71 & 0,76 & 0,75 & 0,78 & 0,83 & 0,85 & 0,98 \\
\hline ICMS + IPVA & 1,63 & 1,68 & 1,67 & 1,64 & 1,66 & 1,69 & 1,74 & 1,70 \\
\hline
\end{tabular}

Fonte: CONFEDERAÇÃO NACIONAL DOS MUNICÍPIOS. Estudos fiscais: estimativas da participação dos entes da federação no bolo tributário. Porto Alegre. 2008. p. 2. Disponível em: <http://portal.cnm.org.br/sites/9000/9070/Estudos/Financas/EstudoBoloTributario.pdf>. Acesso em: 31 out. 2009 às $17 \mathrm{~h} 45$.

Essas transferências descritas são obrigatórias: não podem a União ou os estados membros deixar de fazê-las. O art. 160 da Constituição dispõe que retenção ou qualquer restrição à entrega dos recursos ora examinados é expressamente vedada. Embora a regra seja a vedação à retenção, há condicionantes para a transferência. O parágrafo único do art. 160 estatui que a vedação à retenção não impede a União e os estados condicionem a transferência de recursos: (i) ao pagamento de seus créditos, inclusive de suas autarquias; e (ii) ao 
cumprimento das regras de aplicação de recursos mínimos em ações e serviços públicos de saúde. ${ }^{997}$

Um raro exemplo de uso da prerrogativa de condicionar a transferência obrigatória ocorreu em 1999, quando o Estado de Minas Gerais deixou de honrar o pagamento de parcelas de sua dívida para com a União, acertadas no Contrato $n^{\circ}$ 004/98/STN/Coafi. Entre outros argumentos utilizados, o Estado de Minas Gerais sustentou que a restrição do art. 160 se refere apenas às transferências voluntárias e que o contrato viola dispositivos constitucionais inerentes ao pacto federativo e à autonomia dos estados membros - diante das graves necessidades de suprir outras despesas mais relevantes, o Estado de Minas Gerais deixou de pagar sua dívida e teve seus repasses bloqueados pela União. Levada a disputa ao STF, o ministro Alves rechaçou em caráter liminar o pleito mineiro, mas não houve decisão de mérito pelo Pleno, pois o Estado de Minas Gerais desistiu da ação. ${ }^{998}$ Em realidade, ao se analisarem as transferências para os estados e municípios, percebe-se que tem havido regularidade nas transferências e que, somente em episódios isolados, não se fazem as transferências obrigatórias.

Há outras possibilidades de limitar a transferência obrigatória de recursos. Ainda que a maioria dos tributos tenha finalidade precípua de arrecadar recursos para o financiamento das ações estatais (função fiscal), alguns deles são utilizados pelo Estado na condição de instrumentos de indução, no contexto da implementação de políticas econômicas (função extrafiscal) - o IOF e o IPI são respectivamente utilizados pelo governo federal como instrumentos na condução de políticas monetária e industrial. Logo, a mera alteração das alíquotas do IOF e do IPI já produz efeitos sobre o FPE e o FPM.

Recentemente, as reduções de alíquotas de IPI, promovidas pela União, bem como o recálculo para baixo dos valores de veículos, promovido pelo Estado de São Paulo, tiveram por efeito indireto a redução das transferências obrigatórias num ano de queda generalizada da arrecadação, como foi 2009. Na esfera da União, essa redução pode ser criticada sob outro

\footnotetext{
997 BRASIL. Constituição (1988). Art. 198, § 2º “A União, os Estados, o Distrito Federal e os Municípios aplicarão, anualmente, em ações e serviços públicos de saúde recursos mínimos derivados da aplicação de percentuais calculados sobre: [...]; II - no caso dos Estados e do Distrito Federal, o produto da arrecadação dos impostos a que se refere o art. 155 e dos recursos de que tratam os arts. 157 e 159, inciso I, alínea a, e inciso II, deduzidas as parcelas que forem transferidas aos respectivos Municípios; III - no caso dos Municípios e do Distrito Federal, o produto da arrecadação dos impostos a que se refere o art. 156 e dos recursos de que tratam os arts. 158 e 159 , inciso I, alínea $b$ e $\S 3^{\circ}$."

${ }_{998}$ BRASIL. Supremo Tribunal Federal. Medida cautelar inominada em procedimento preparatório. Petição no 1665. Requerente: Estado de Minas Gerais. Requerido: União Federal. Relator: Ministro Moreira Alves. Decisão em 15 fev. 1999. A decisão sintetiza os argumentos arrolados pelo Estado de Minas Gerais de forma clara e objetiva, explicitando o racional de se considerar que as cláusulas do Contrato no 004/98/STN/Coaf como inconstitucionais.
} 
aspecto: os benefícios fiscais se concentram principalmente nos impostos, os quais têm sua receita compartilhada com estados e municípios, enquanto há grande resistência em conceder alívio fiscal nas contribuições, cujas receitas permanecem, em sua maioria, com a União.

Nesse contexto, questionar esse sistema de transferências redistributivas é fora de propósito, pois o sistema de fato beneficia as regiões menos desenvolvidas e grande parte dos pequenos municípios do país. Eventuais críticas às transferências soam como censura disfarçada à redistribuição de renda para os menos favorecidos e são incompatíveis com o binômio "autonomia/solidariedade".

Entretanto, a crítica à existência de um sistema de transferência de receitas essencialmente redistributivo não se confunde com eventuais posicionamentos contrários a determinadas características e modus operandi do modelo do federalismo fiscal atual. Assim, são passíveis de reflexão (i) a divisão da competência tributária que, excessivamente, concentra arrecadação na União e impõe a necessidade de um complicado sistema de transferências; (ii) a imposição de atribuições de prestação de serviços pelos municípios, sem que estes disponham de recursos adequados; e (iii) o aumento puro e simples da arrecadação pela União via contribuições sociais, a fim de não compartilhá-las com estados e municípios. Em especial, todos os vieses do problema são criticáveis da ótica da teoria geral do direito: aquele porque impõe um dever ao Município sem que se lhe confira o correspondente poder para exercê-lo; este porque reflete o uso de um poder pela União sem que se lhe imponha um dever.

Portanto, ser contra a corrupção praticada sob o manto da solidariedade é bem diferente de se opor à solidariedade. Poupar o sistema atual de críticas pode ser um grave empecilho à concretização dos objetivos constitucionais de equalização da qualidade de vida em toda a federação, justamente por considerar que o sistema seria perfeito e acabado. Feita essa ressalva, além das dificuldades a serem superadas nos critérios de repartição que podem ser apontados no atual sistema ${ }^{999}$ - entre eles o fato de a "capacidade arrecadatória" dos entes

\footnotetext{
$\overline{999}$ PAMPLONA, K. M. Federalismo fiscal, transferências intergovernamentais constitucionais e desenvolvimento regional: uma análise em prol da efetividade dos direitos humanos. Revista de Direito Tributário da APET, São Paulo: MP, v. 19, p. 115, 2008. "Os critérios tradicionais da população, da renda per capita e do território não conseguem realizar uma distribuição equânime, segundo a real necessidade de gasto de cada ente político para implementar direitos fundamentais sociais prementes, visto que escamoteiam aspectos primordiais como o nível de criminalidade, de educação fundamental e superior, de longevidade, do emprego entre outros. A real e concreta necessidade de gasto das unidades subnacionais não depende apenas do tamanho do território, da quantidade da população ou da renda per capita, mas da demanda de serviços públicos essenciais que as entidades federadas são obrigadas a atender, no intuito de garantir o seu desenvolvimento e o bem-estar de seus cidadãos. O critério de distribuição de renda pautado na quantidade da população é tradicional e arcaico, sendo fruto de uma política macroeconômica, e não se adequada ao paradigma do Estado Democrático de Direito. Deste modo, é urgente e necessária a alteração da legislação brasileira. Seria mais justo e equânime se o critério para a distribuição da receita dos Fundos de Participação se pautasse, principalmente, no atraso econômico-social, haja vista que tornaria mais efetivo o proporcional desenvolvimento regional. Cumpre esclarecer que esse critério é utilizado em alguns países como a Alemanha e a Índia."
} 
federativos ser largamente ignorado -, há dois problemas intimamente relacionados à corrupção do sistema: (i) a insuficiência das transferências obrigatórias para a garantia da autonomia financeira dos entes federativos; e (ii) os impulsos aos gastos irresponsáveis.

\subsubsection{Do Fundo Social de Emergência às Desvinculações de Receita da União: impacto sobre as transferências obrigatórias para os entes federativos}

Um dos princípios tradicionalmente apontados em direito financeiro é a não vinculação das receitas orçamentárias, cujo objetivo é resguardar "a função política do orçamento como plano de governo que o Legislativo aprova para a fiel execução pelo Executivo". ${ }^{1000}$ De fato, os recursos orçamentários disponíveis conferem poderes ao Chefe do Executivo democraticamente eleito para que possa implementar as políticas públicas que defendera durante a campanha eleitoral, a fim de cumprir com a finalidade de busca do bem comum.

Paradoxalmente, na Constituição de 1988, o princípio da não vinculação tinha aplicação limitada, embora estivesse previsto explicitamente. Escrevendo em 1994, antes do aperto fiscalista que se seguiria, Serra reclama que "a despeito de todo o esforço para elevar a arrecadação verifica-se que, no Projeto de Lei do Orçamento Federal para 1994, cerca de 90\% das receitas estão comprometidas com vinculações e gastos específicos". ${ }^{1001}$ Por incomodar tanto, o princípio da não vinculação das receitas foi objeto de três mudanças constitucionais desde 1988, cada qual com objetivo de adicionar uma exceção ao referido princípio.

A ironia é grande: as virtudes de solidariedade do federalismo fiscal brasileiro, sobretudo por meio das transferências obrigatórias, são elogiadas e, ao mesmo tempo, criam o "engessamento" do poder da União, que fica impossibilitada de implementar as próprias políticas públicas. Desse prisma, até soam razoáveis as alegações dos defensores da União. Assim, "depois de tanto vincular a receita a órgãos, fundos e despesas, resolveu a Constituição desvincular parcela da receita da União, o que constitui vinculação às avessas". Entretanto, diversamente do "engessamento" fiscal, o objetivo explícito dessa sístole foi "gerar superávits para o pagamento da dívida pública". ${ }^{1002}$ As leis de diretrizes orçamentárias têm repetido reiteradamente a exigência de superávit primário do setor público. ${ }^{1003}$

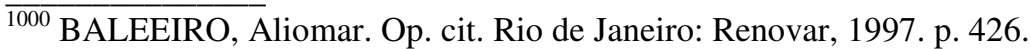

1001 SERRA, José. Op. cit. p. 120.

1002 TORRES, Ricardo Lobo. Op. cit. p. 354-355. PIRES, Adilson Rodrigues; TORRES, Heleno Tavares. Direitos fundamentais, federalismo fiscal e emendas constitucionais tributárias. In: Princípios de direito financeiro e tributário. Estudos em homenagem ao Professor Ricardo Lobo Torres. Rio de Janeiro: Renovar, 2006. p. 69-70. "Ora, decorridos dez anos da primeira investida, as sucessivas e transitórias desvinculações de que se trata, a esta altura, já se constituem em fraude legislativa, configurando manifestação clara de imoralidade fiscal, a merecer total reprovação. [...] as DRUs e as contribuições proliferaram recentemente no País como
} 
Tabela 29 - Evolução da redação do art. 167, IV da Constituição de 1988
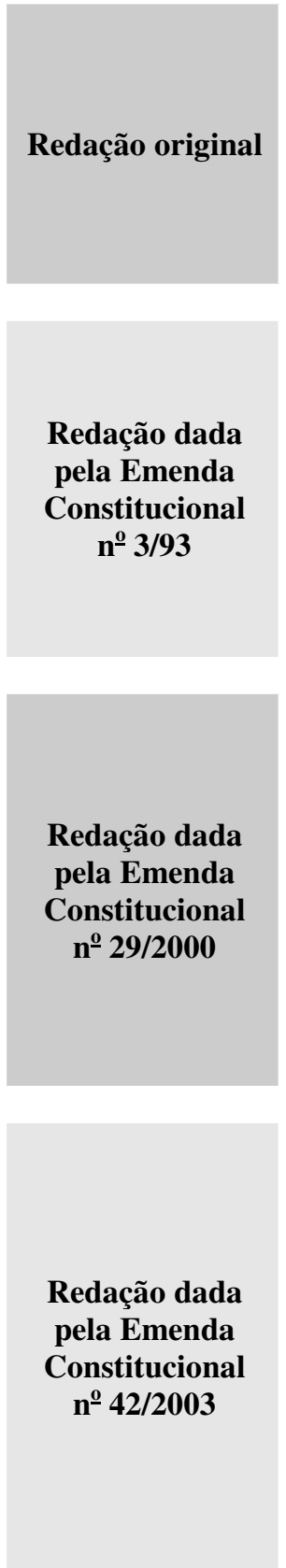

[São vedadas:] a vinculação de receita de impostos a órgão, fundo ou despesa, ressalvadas a repartição do produto da arrecadação dos impostos a que se referem os arts. 158 e 159, a destinação de recursos para manutenção e desenvolvimento do ensino, como determinado pelo art. 212, e a prestação de garantias às operações de crédito por antecipação de receita, previstas no art. $165, \S 8^{\circ}$.

[São vedadas:] a vinculação de receita de impostos a órgão, fundo ou despesa, ressalvadas a repartição do produto da arrecadação dos impostos a que se referem os arts. 158 e 159, a destinação de recursos para manutenção e desenvolvimento do ensino, como determinado pelo art. 212, e a prestação de garantias às operações de crédito por antecipação de receita, previstas no art. $165, \S 8^{\circ}$, bem assim o disposto no $\$ 4^{\circ}$ deste artigo.

[São vedadas:] a vinculação de receita de impostos a órgão, fundo ou despesa, ressalvadas a repartição do produto da arrecadação dos impostos a que se referem os arts. 158 e 159, a destinação de recursos para as ações e serviços públicos de saúde e para manutenção e desenvolvimento do ensino, como determinado, respectivamente, pelos arts. $198, \S \mathbf{2}^{\mathbf{0}}$, e 212 , e a prestação de garantias às operações de crédito por antecipação de receita, previstas no art. $165, \S 8^{\circ}$, bem como o disposto no $\S 4^{\circ}$ deste artigo.

[São vedadas:] a vinculação de receita de impostos a órgão, fundo ou despesa, ressalvadas a repartição do produto da arrecadação dos impostos a que se referem os arts. 158 e 159, a destinação de recursos para as ações e serviços públicos de saúde, para manutenção e desenvolvimento do ensino e para realização de atividades da administração tributária, como determinado, respectivamente, pelos arts. 198, $\$ \mathbf{2}^{\mathbf{0}}, 212$ e $\mathbf{3 7}, \mathbf{X X I I}$, e a prestação de garantias às operações de crédito por antecipação de receita, previstas no art. $165, \S 8^{\circ}$, bem como o disposto no $§ 4^{\circ}$ deste artigo.

Obs.: As partes negritadas correspondem ao acréscimo decorrente de cada emenda constitucional.

Fonte: Elaboração própria.

forma de centralização de recursos na União, de molde a reduzir o déficit orçamentário federal e ensejar o pagamento da dívida externa. Como o horizonte neste tema continua negro, porque o gasto público e a dívida pública continuam fora de controle, não são de esperar propostas de recomposição da racionalidade do Sistema, senão remendos tópicos e casuístas como os que se acabam de criticar."

${ }^{1003}$ BRASIL. Lei $\mathrm{n}^{\mathrm{o}}$ 12.017, de 12 ago. 2009. Art. 20 “A elaboração e a aprovação do Projeto de Lei Orçamentária de 2010, bem como a execução da respectiva Lei deverão ser compatíveis com a obtenção da meta de superávit primário, para o setor público consolidado, equivalente a 3,30\% (três inteiros e trinta centésimos por cento) do Produto Interno Bruto - PIB, sendo 2,15\% (dois inteiros e quinze centésimos por cento) para os Orçamentos Fiscal e da Seguridade Social e 0,20\% (vinte centésimos por cento) para o Programa de Dispêndios Globais, conforme demonstrado no Anexo de Metas Fiscais constante do Anexo IV desta Lei." 
O método utilizado pela União para o acesso aos recursos que deveriam ser transferidos obrigatoriamente para estados e municípios consistiu na propositura e aprovação de uma série de emendas constitucionais, que sempre seriam provisórias, mas, na realidade, sucessivas renovações perpetuaram-nas. Em 1994, a Emenda Constitucional de Revisão n⿳ํㅜ 1, de $1^{\circ}$ de março de 1994, introduziu o art. 71 do Ato das Disposições Constitucionais Transitórias (ADCT), criando o Fundo Social de Emergência (FSE), com objetivo de

[...] saneamento financeiro da Fazenda Pública Federal e de estabilização econômica, cujos recursos serão aplicados no custeio das ações dos sistemas de saúde e educação, benefícios previdenciários e auxílios assistenciais de prestação continuada, inclusive liquidação de passivo previdenciário, e outros programas de relevante interesse econômico e social. ${ }^{1004}$

Várias receitas integravam o FSE, devendo ser destacada a prevista no inc. IV do art. 72 do ADCT: “[...] vinte por cento do produto da arrecadação de todos os impostos e contribuições da União, excetuado o previsto nos incisos I, II e III". ${ }^{1005}$ Na prática, isso significava que $20 \%$ das receitas originariamente destinadas para o FPE e FPM constituiriam o FSE, administrado pela União.

A sistemática tem se repetido desde então. A Emenda Constitucional $n^{\circ} 10$, de 4 de março de 1996, renomeou o FSE como Fundo de Estabilização Fiscal (FEF) e incluiu alguns limites máximos para a arrecadação de imposto de renda a ele destinada. ${ }^{1006}$ Em compensação, intensificou-se o processo de criação de contribuições. A Emenda Constitucional $\mathrm{n}^{\mathrm{o}}$ 27, de 21 de março de 2000, adotou método ligeiramente diferente, ao incluir o art. 76 no ADCT, que estabelecia: "É desvinculado de órgão, fundo ou despesa, no período de 2000 a 2003, vinte por cento da arrecadação de impostos e contribuições sociais da União, já instituídos ou que vierem a ser criados no referido período, seus adicionais e respectivos acréscimos legais". ${ }^{1007}$ Como garantia aos estados e municípios, assegurou-se a manutenção de um piso para o repasse de recursos, o que significa que os valores transferidos pela União não poderiam ser reduzidos. ${ }^{1008}$ As Emendas Constitucionais $n^{\circ}$ 42, de 19 de dezembro de 2003, e n⿳o 56, de 20

\footnotetext{
$\overline{1004}$ Constituição (1988). Ato das Disposições Constitucionais Transitórias. Art. 71. "Fica instituído, nos exercícios financeiros de 1994 e 1995, o Fundo Social de Emergência, com o objetivo de saneamento financeiro da Fazenda Pública Federal e de estabilização econômica, cujos recursos serão aplicados no custeio das ações dos sistemas de saúde e educação, benefícios previdenciários e auxílios assistenciais de prestação continuada, inclusive liquidação de passivo previdenciário, e outros programas de relevante interesse econômico e social. Parágrafo único. Ao Fundo criado por este artigo não se aplica, no exercício financeiro de 1994, o disposto na parte final do inciso II do $§ 9^{\circ}$ do art. 165 da Constituição.”

${ }^{1005}$ Constituição (1988). Ato das Disposições Constitucionais Transitórias. Art. 72, IV.

${ }^{1006}$ Constituição (1988). Ato das Disposições Constitucionais Transitórias. Art. 72, § $5^{\circ}$.

${ }^{1007}$ Constituição (1988). Ato das Disposições Constitucionais Transitórias. Art. 76.

1008 Constituição (1988). Ato das Disposições Constitucionais Transitórias. Art. 76. $\S 1^{\circ}$ "O disposto no caput deste artigo não reduzirá a base de cálculo das transferências a Estados, Distrito Federal e Municípios
} 
de dezembro de 2007, mantiveram a mesma concepção - atualmente a Desvinculação da Receita da União (DRU) está prevista para durar até 31 de dezembro de 2011.

A tecnicidade da matéria dificulta a compreensão de suas verdadeiras implicações. ${ }^{1009}$ Mesmo assim, a DRU é explícita ao referir que $20 \%$ das receitas dos fundos, inclusive o FPM e o FPE, serão retidas e poderão ser utilizadas desvinculadamente pela União. Por consequência, a DRU consiste num golpe no federalismo fiscal concebido pela Constituição de $1988 .{ }^{1010}$

Poder-se-ia argumentar que os recursos da DRU não são utilizados ao livre talante da União, devendo sujeitar-se à lei orçamentária. De fato, isso é verdade: estados e municípios podem tentar recuperar seus recursos por meio das transferências voluntárias. Ainda que os entes federados logrem incluir suas propostas no orçamento da União, o empenho desta ainda é necessário. Em parte considerável dos casos, a recuperação dos recursos tem um custo político: o apoio incondicional a alguma questão de interesse da União. Volta-se ao problema do jogo de interesses, distorcido desde o princípio para favorecer a União, detentora do poder de transferir os recursos sem que haja nenhum dever sobre como fazê-lo. Aqueles que nada têm a oferecer, mormente as pequenas localidades, tendem a ser os grandes perdedores.

\subsubsection{A insuficiência das transferências obrigatórias e o papel das transferências voluntárias}

Ao lado das transferências obrigatórias e dos problemas decorrentes da desvinculação das receitas orçamentárias, há outros fluxos de recursos entre os entes da federação brasileira, dentre os quais se destacam as transferências voluntárias. Segundo Oliveira,

\footnotetext{
na forma dos arts. 153 , $5^{\circ}$; 157, I; 158, I e II; e 159, I, 'a' e ‘b', e II, da Constituição, bem como a base de cálculo das aplicações em programas de financiamento ao setor produtivo das regiões Norte, Nordeste e CentroOeste a que se refere o art. 159, I, 'c', da Constituição."

${ }^{1009}$ CAVALCANTI, Márcio Novaes. Op. cit. p. 61. "Vale notar que diversas emendas constitucionais feitas pela antiga e pela atual legislatura criaram o Fundo de Estabilização Fiscal, pelo qual a receita arrecadada devido ao aumento de vários impostos não será automaticamente repassada, mas permanecerá, ao invés, com o Governo Federal para outros fins de estabilização tais como o desenvolvimento de saúde e educação."

${ }^{1010}$ PIRES, Adilson Rodrigues; TORRES, Heleno Tavares. Direitos fundamentais, federalismo fiscal e emendas constitucionais tributárias. In: Princípios de direito financeiro e tributário. Estudos em homenagem ao professor Ricardo Lobo Torres. Rio de Janeiro: Renovar, 2006. p. 70. "Em conseqüência, o que se vê hoje, e se projeta para o futuro próximo, é a pauperização dos entes locais e o progressivo absenteísmo das instâncias estaduais e municipais nas áreas fundamentais ao exercício da cidadania e do gozo da dignidade humana, quais sejam, educação, saúde e infraestrutura de saneamento e transportes, e o correspondente desestímulo ao investimento privado: e tudo isso substituído pela exclusão, marginalização e favelização, e pelo crime organizado."
} 
Ao lado das transferências obrigatórias, há as receitas transferidas voluntárias, ou seja, receitas que as entidades menores vão buscar junto às maiores, a título de ajuda. É o que se denomina transferência corrente. São dotações às quais não corresponde uma contraprestação e podem ocorrer entre as unidades federadas. É o caso da transferência de um veículo para o Município, tal como uma ambulância, ou da destinação para recuperação de vias, para obras de saneamento etc. ${ }^{1011}$

Diversamente das transferências obrigatórias, essa modalidade de transferência de recursos não obedece a mecanismos preestabelecidos na Constituição: apesar de as mais recentes Leis de Diretrizes Orçamentárias conterem alguns critérios sobre as transferências voluntárias, ${ }^{1012}$ estas são um dos principais objetos de disputa nas jogadas por influência política. Para demonstrar quanto essas transferências ocupam o vazio deixado em razão da insuficiência das transferências obrigatórias constitucionais, veja-se a Tabela 30: em termos relativos, constata-se que houve aumento substancial da participação das transferências voluntárias em relação às obrigatórias entre 1995-2000, período em que ocorreu um grande aumento de arrecadação da União em virtude das contribuições. Aproveitando-se disso, a União começou a utilizar ostensivamente as transferências voluntárias para suprir as demandas por recursos adicionais pelos estados e municípios.

$\overline{1011}$ OLIVEIRA, Régis Fernandes de. Op. cit. p. 115.

${ }^{1012}$ BRASIL. Lei $\mathrm{n}^{\mathrm{O}}$ 12.017, de 12 ago. 2009. Os artigos 39 e 40 regulam as transferências voluntárias para a lei orçamentária de 2010, mas são insuficientes para restringir as práticas descritas. 
Tabela 30 - Participação relativa das transferências voluntárias sobre o total das transferências da União para o os estados e municípios

\begin{tabular}{|c|c|c|c|c|c|}
\hline Ano & $\begin{array}{c}\text { Transferências } \\
\text { Constitucionais } \\
\text { (CT) }\end{array}$ & $\begin{array}{c}\text { Transferências } \\
\text { Voluntárias } \\
\text { (VT)*100 }\end{array}$ & $\begin{array}{c}\text { Participação } \\
\text { Relativa } \\
\text { (VT/CT) }\end{array}$ & $\begin{array}{c}\text { Transferências } \\
\text { Ajustadas pelo } \\
\text { SUS (A VT) }\end{array}$ & $\begin{array}{c}\text { Participação } \\
\text { Relativa Ajustada } \\
\text { pelo SUS } \\
\text { (A VT/CT)*100 }\end{array}$ \\
\hline $\mathbf{1 9 9 5}$ & 23.327 .821 & 5.092 .845 & 18,0 & - & - \\
\hline $\mathbf{1 9 9 6}$ & 29.650 .070 & 7.547 .512 & 25,5 & - & - \\
\hline $\mathbf{1 9 9 7}$ & 32.144 .421 & 9.503 .989 & 26,6 & 3.995 .818 & 12,4 \\
\hline $\mathbf{1 9 9 8}$ & 36.475 .625 & 13.656 .605 & 37,4 & 6.539 .343 & 17,9 \\
\hline $\mathbf{1 9 9 9}$ & 38.190 .489 & 11.877 .612 & 31,1 & 3.164 .650 & 8,3 \\
\hline $\mathbf{2 0 0 0}$ & 37.296 .297 & 13.477 .239 & 36,1 & 3.937 .132 & 10,6 \\
\hline
\end{tabular}

* Os valores absolutos de transferências estão expressos em R \$ Mil a preços de 2000.

Fonte: PRADO, Sérgio. Transferências fiscais e financiamento municipal no Brasil. São Paulo, jul. 2001. (Projeto Descentralização Fiscal e Cooperação Financeira Intergovernamental da ABEP e Fundação Konrad Adenauer). Disponível em: < http://www.cepam.sp.gov.br/arquivos/artigos/TransferenciasFiscais\&FinancMunicipal.pdf>. Acesso em: 1 jan. 2010 às $19 \mathrm{~h} 18$.

Da perspectiva macrojurídica da análise da corrupção, esse fato é peça essencial no quebra-cabeça que liga o federalismo fiscal à corrupção. Enquanto as transferências orçamentárias obrigatórias diminuem a dominação da União no repasse de seus recursos para os entes federados, as transferências voluntárias constituem o locus em que as práticas de barganha política, limítrofes à corrupção-solapamento, acima descrita, se instrumentalizam por meio do orçamento da União.

Como inexiste a mesma vinculação das transferências obrigatórias, essa dominação não está vinculada a uma finalidade e pode ser manejado conforme as conveniências políticas da União. O uso do patrimônio público passa a atender aos fins privados daqueles que ocupam o poder.

No cenário mostrado, é fácil entender por que um bom político no Brasil é aquele com "influência para angariar recursos em Brasília", em vez de ser aquele reconhecido por ser um gestor eficiente e honesto, capaz de racionalizar os custos e maximizar a arrecadação interna. Com isso, há incentivos para a troca de favores entre os ocupantes da chefia do Executivo das esferas da federação, o que ocorre mais facilmente se aquele que procura recursos se mudar para um partido aliado.

Numa época em que as transferências voluntárias ainda não eram tão substanciais quanto hoje, até mesmo a CPMI do Orçamento sugeriu a sua limitação: 
Limitação das transferências federais voluntárias

[...] A Constituição de 1988 não teve o bom senso de proibi-las, ou de definir impositivamente as responsabilidades e obrigações de cada uma das três esferas do Estado, assim como não foi feliz ao estabelecer novas regras na partilha de recursos entre a União, Estados e Municípios. Tanto é assim, que agora, ao iniciar-se o processo de revisão constitucional, encontram-se esses aspectos entre os temas prioritários a merecerem reexame. Impede, pois, limitar tais práticas para conduzir à modernização efetiva do Poder, expressa na descentralização dos recursos arrecadados da sociedade em seu nome geridos.

O pacto federativo não deve ser, no Brasil, apenas uma figura de retórica: as receitas de Estados e Municípios devem ser compatíveis com os encargos constitucionais a eles atribuídos. ${ }^{1013}$

Mais recentemente, a CPMI das Ambulâncias adotou postura mais radical e sugeriu que a "extinção gradual das transferências voluntárias produziria imediatamente diversos benefícios nos âmbitos administrativo e político". ${ }^{1014}$ Isso explica a razão de esses problemas se acentuarem nos ciclos eleitorais. Segundo Ferreira e Bugarin, as transferências voluntárias têm o efeito potencial de quebrar o resultado positivo associado aos ciclos políticoorçamentários:

\begin{abstract}
Mesmo no jogo com informação completa, em que a competência do titular é de conhecimento comum, os eleitores podem decidir racionalmente não reeleger um político administrativamente competente, caso ele não seja apoiado pelo governador. Essa escolha ocorre porque os eleitores entendem que o adicional de transferências que o candidato de oposição receberá caso seja eleito mais do que compensará sua deficiência administrativa. De modo similar, os eleitores podem achar ótimo escolher o titular incompetente que pertença ao mesmo partido do governador para manter o fluxo mais favorável de transferências provenientes do estado. ${ }^{1015}$
\end{abstract}

\footnotetext{
${ }^{1013}$ BRASIL. Congresso Nacional. Relatório final da Comissão Parlamentar Mista de Inquérito. Criada através do Requerimento $n^{-}$151/93-CN, destinada a "apurar fatos contidos nas denúncias do Sr. José Carlos Alves dos Santos, referentes às atividades de parlamentares, membros do Governo e representantes de empresas envolvidas na destinação de recursos do Orçamento da União". Vol. III, Brasília, jan. 1994. p. 17-18. "Nas últimas décadas, a União assumiu, paulatinamente, maior controle sobre os Estados, enfraquecendo-os mais e mais, mercê de crescente centralização, chegando-os quase a implantar, na prática, situação semelhante à verificada no Estado Novo. A fim de manter fidelidade política que lhes garantisse maioria parlamentar, os governos de feição castrense restituíam, mediante as 'transferências voluntárias', parcela dos tributos arrecadados aos Estados, realizando obras ou subvencionando as chamadas ações sociais. Tal sistema facilitou a ação de poderosos agentes econômicos junto àqueles que decidiam, entre quatro paredes, a distribuição dos recursos. As transferências voluntárias se foram avolumando com o tempo: de acordo com estudo realizado pelos professores Deputado José Serra e José Roberto Afonso, correspondiam, em 1970, a apenas 15\% das transferências totais da União aos Estados; e, 1980, elevaram-se a 22\% e, em, 1988, atingiram o percentual de 43\%."

${ }^{1014}$ BRASIL. Congresso Nacional. Relatório dos trabalhos da CPMI das "ambulâncias", criada por meio do Requerimento $n^{-}$77/2006-CN. Vol. I. Brasília, dez. 2006. p. 188. "Tal medida, no entanto, deveria ser acompanhada, necessariamente, da definição de nova sistemática de repasse desses recursos a Municípios e Estados, o que demandaria a criação de mecanismos de controle de recursos públicos nessas instâncias. A esse respeito, propõe-se, portanto, a definição de normas para a promoção da transparência das ações administrativas no âmbito municipal, bem como a reflexão sobre a regulamentação da criação e funcionamento dos conselhos municipais a fim de promover seu funcionamento eficaz."

1015 BUGARIN, M. S.; FERREIRA, Ivan F. S. Transferências voluntárias e ciclo político-orçamentário no federalismo fiscal brasileiro. Revista Brasileira de Economia, Rio de Janeiro, v. 61, n. 3, p. 294, jul./set. 2007.
} 


\subsubsection{Transferências voluntárias na Lei de Responsabilidade Fiscal}

Entre outras finalidades, a Lei Complementar n⿳⺈ 101/00 (Lei de Responsabilidade Fiscal $)^{1016}$ pode ter sido concebida para tentar alterar a relação de incentivos e desincentivos a certos comportamentos políticos na gestão orçamentária, tais como o oportunismo e o risco moral. Quanto às transferências voluntárias, estas foram definidas como a "entrega de recursos correntes ou de capital a outro ente da Federação, a título de cooperação, auxílio ou assistência financeira, que não decorra de determinação constitucional, legal ou os destinados ao Sistema Único de Saúde”. ${ }^{1017}$

Mesmo com o amplo poder conferido à União para reter $20 \%$ das transferências obrigatórias para os estados e municípios, significativo é o fato de a Lei Complementar $n^{\circ}$ 101/00 estabelecer alguns requisitos para a transferência voluntária de recursos financeiros a estados, Distrito Federal e municípios, a saber: (i) existência de "dotação específica" por parte da entidade federativa que transfere; (ii) observância do inciso X do art. 167 da Constituição (vedação de transferência para o financiamento de despesas com pessoal ativo, inativo e pensionistas; (iii) estar "em dia quanto ao pagamento de tributos, empréstimos e financiamentos devidos ao ente transferidor; bem como quanto à prestação de contas de recursos anteriormente recebidos"; (iv) cumprimento dos limites constitucionais no setor educacional e no setor de saúde; e (v) previsão orçamentária de contrapartida do ente recebedor. ${ }^{1018}$

Essas transferências podem ser interrompidas se a entidade recebedora deixar deatender aos requisitos arrolados. Adicionalmente, a Lei Complementar $\mathrm{n}^{\mathrm{o}}$ 101/00 estabelece outras circunstâncias que podem impedir a concretização dessas transferências ou a sua suspensão. Esse mecanismo de coação visa compelir os estados e municípios a se ajustarem às metas de superávit da legislação orçamentária ${ }^{1019}$ e, ao mesmo tempo, desempenharem suas funções constitucionais. Dessa maneira, os entes mais frágeis se tornam reféns da União e dos estados mais ricos por meio da dependência em relação às transferências voluntárias. Reduz-

\footnotetext{
$\overline{1016}$ BRASIL. Lei Complementar $\mathrm{n}^{\mathrm{o}}$ 101, de 4 maio 2000.

${ }^{1017}$ BRASIL. Lei Complementar $\mathrm{n}^{\mathrm{o}}$ 101, de 4 maio 2000. Art. 25.

${ }^{1018}$ BRASIL. Lei Complementar $\mathrm{n}^{\mathrm{o}}$ 101, de 4 maio 2000. Art. 25. $\S 1^{\circ}$. Ressalte-se que estes requisitos não se confundem com as regras estabelecidas comumente pelas Leis de Diretrizes Orçamentárias.

1019 BRASIL. Lei n⿳ 12.017, de 12 ago. 2009. Art. 2 “A elaboração e a aprovação do Projeto de Lei Orçamentária de 2010, bem como a execução da respectiva Lei, deverão ser compatíveis com a obtenção da meta de superávit primário, para o setor público consolidado, equivalente a 3,30\% (três inteiros e trinta centésimos por cento) do Produto Interno Bruto - PIB, sendo 2,15\% (dois inteiros e quinze centésimos por cento) para os Orçamentos Fiscal e da Seguridade Social e 0,20\% (vinte centésimos por cento) para o Programa de Dispêndios Globais, conforme demonstrado no Anexo de Metas Fiscais constante do Anexo IV desta Lei."
} 
se a margem de manobra para o funcionamento equilibrado da federação: se não é possível atender às funções constitucionais fora das limitações impostas, resta apenas a submissão política do mais frágil ao mais forte.

Entretanto, não se podem descartar aspectos positivos na Lei Complementar $\mathrm{n}^{\mathbf{o}}$ 101/00, tal como o mecanismo para incentivar a eficiência tributária nos entes da federação. Mais do que questão de eficiência, cobrar impostos é parte dos deveres da autoridade: “[...] a autorização orçamentária para aplicação das leis de receita vincula os funcionários: nem estes nem os governantes gozam de faculdade discricionária de cobrar ou não cobrar os impostos. São obrigados a arrecadá-los". ${ }^{1020}$ Em pequenos municípios, a relação entre pessoas politicamente expostas e os seus eleitores é muito próxima, de modo que a reação popular à cobrança do imposto é frequente - basta o prefeito sair às ruas. Visto que habitualmente a camaradagem impede que os débitos se transformem na dívida ativa, previu-se um sistema de controle institucional que pune a renúncia de receita com a suspensão de transferências voluntárias. ${ }^{1021}$

Outra hipótese para a suspensão das transferências voluntárias se verifica quando há superação do limite de despesas de pessoal estabelecido no art. 20 da Lei Complementar n $^{0}$ $101 / 00{ }^{1022}$ por qualquer dos poderes da entidade beneficiada, sem sua redução no prazo legal ${ }^{1023}$ - a infração cometida por um dos poderes implica sanção ao ente federativo. A situação descrita leva aos mesmos questionamentos feitos aos limites com despesas de funcionários públicos. De fato, é salutar restringir tais gastos, considerando-se o histórico patrimonialista, impregnado de empreguismo e ou uso político da máquina administrativa. Pode ocorrer, porém, a necessidade de gastar quantias elevadas com pessoal, justamente na prestação de serviços de saúde e educação para suprir carências da população. Salas de aula

\footnotetext{
$\overline{1020}$ BALEEIRO, Aliomar. Op. cit. p. 441.

1021 BRASIL. Lei Complementar no 101, de 4 maio 2000. Art. 11. "Constituem requisitos essenciais da responsabilidade na gestão fiscal a instituição, previsão e efetiva arrecadação de todos os tributos da competência constitucional do ente da Federação. Parágrafo único. É vedada a realização de transferências voluntárias para o ente que não observe o disposto no caput, no que se refere aos impostos."

${ }^{1022}$ BRASIL. Lei Complementar $\mathrm{n}^{\mathrm{0}}$ 101, de 4 maio 2000. Art. 20.

${ }^{1023}$ BRASIL. Lei Complementar n” 101, de 4 maio 2000. Art. 23. "Se a despesa total com pessoal, do Poder ou órgão referido no art. 20, ultrapassar os limites definidos no mesmo artigo, sem prejuízo das medidas previstas no art. 22, o percentual excedente terá de ser eliminado nos dois quadrimestres seguintes, sendo pelo menos um terço no primeiro, adotando-se, entre outras, as providências previstas nos $\S \S 3^{0}$ e $4^{\circ}$ do art. 169 da Constituição. $\S 3^{0}$ Não alcançada a redução no prazo estabelecido, e enquanto perdurar o excesso, o ente não poderá: I receber transferências voluntárias; II - obter garantia, direta ou indireta, de outro ente; III - contratar operações de crédito, ressalvadas as destinadas ao refinanciamento da dívida mobiliária e as que visem à redução das despesas com pessoal. $\S 4^{\circ}$ As restrições do $\S 3^{\circ}$ aplicam-se imediatamente se a despesa total com pessoal exceder o limite no primeiro quadrimestre do último ano do mandato dos titulares de Poder ou órgão referidos no art. 20."
} 
com menos alunos em municípios de população predominantemente jovem e presença de médicos em localidades afastadas dos grandes centros são duas políticas públicas plausíveis que podem ultrapassar os limites de gastos com funcionalismo. Não obstante, o administrador público estará usando seu poder para cumprir com uma finalidade de interesse público.

Outras duas situações que ensejam restrição às transferências voluntárias são: (i) não retorno, no prazo legal, ao limite da dívida consolidada na hipótese de sua superação; ${ }^{1024}$ e (ii) descumprimento de prazos para estados e municípios enviarem ao Executivo da União as suas respectivas contas do exercício anterior para efeito de elaboração da consolidação nacional de contas. ${ }^{1025}$

Por si só, a existência do mecanismo de suspensão de transferências voluntárias já denuncia o papel nodal das transferências voluntárias como fonte de recursos na federação brasileira, condicionando a atuação dos entes mais dependentes financeiramente. Ainda que se argumente que a Lei Complementar $n^{-0}$ 101/00 não estipulou a vedação às transferências obrigatórias em razão da proibição constitucional à retenção de transferências obrigatórias, a previsão pode, sob determinada visão, representar um avanço no ordenamento das finanças públicas. Sob uma perspectiva macrojurídica, porém, a Lei Complementar $\mathrm{n}^{\mathrm{o}}$ 101/00 acirra a dependência político-econômica de alguns entes da federação, o que gera oportunidades para a subversão do funcionamento do sistema político-partidário.

Por fim, vale a pena ressaltar que a Lei Complementar $n^{\underline{0}}$ 101/00 trouxe algumas outras disposições positivas para o controle do fluxo de recursos entre os componentes da federação brasileira. Dentre elas destaca-se a proibição de financiamento dos municípios e dos estados junto ao Banco Central do Brasil ${ }^{1026}$ e de empréstimos da União e dos Estados aos Municípios. ${ }^{1027}$ Houve também restrições para que os entes descentralizados levantem recursos por intermédio das entidades por eles controladas e antecipem receitas tributárias. ${ }^{1028}$

\footnotetext{
${ }^{1024}$ BRASIL. Lei Complementar n⿳o 101 , de 4 maio 2000. Art. 31, § 2º "Vencido o prazo para retorno da dívida ao limite, e enquanto perdurar o excesso, o ente ficará também impedido de receber transferências voluntárias da União ou do Estado."

1025 BRASIL. Lei Complementar n⿳0 101 , de 4 maio 2000. Art. 51, § 2 . "O descumprimento dos prazos previstos neste artigo impedirá, até que a situação seja regularizada, que o ente da Federação receba transferências voluntárias e contrate operações de crédito, exceto as destinadas ao refinanciamento do principal atualizado da dívida mobiliária."

${ }^{1026}$ BRASIL. Lei Complementar nº 101, de 4 de maio de 2000. Art. 34.

1027 BRASIL. Lei Complementar n⿳0 101, de 4 de maio de 2000. Art. 35.

${ }^{1028}$ BRASIL. Lei Complementar no 101, de 4 de maio de 2000. Art. 37.
} 


\subsubsection{Os recursos para as autarquias de fomento de desenvolvimento regional}

Uma questão que guarda problemas semelhantes àqueles apontados no locus de disputa por transferências voluntárias envolve os objetivos de redução das desigualdades regionais: as mudanças de governos implicam mudanças de estratégias nos fluxos de recursos destinados ao fomento de desenvolvimento regional. O exemplo mais expressivo é a quebra de braço institucional envolvendo as autarquias federais criadas para promover o desenvolvimento na Região Nordeste e na Amazônia.

Em 1959, a Superintendência do Desenvolvimento do Nordeste (Sudene) foi criada para desenvolver economicamente o Nordeste ${ }^{1029}$ e, em 1966, já no regime militar, foi instituída a Superintendência de Desenvolvimento da Amazônia (Sudam), nos moldes da Sudene, com o objetivo de desenvolver a Amazônia. ${ }^{1030}$ Nas últimas décadas, essas autarquias foram alvo de denúncias de desvios e fraudes: apesar de um bom mecanismo de desenvolvimento regional, argumenta-se que ambas foram capturadas por oligarquias locais e possibilitaram o surgimento de novas forças políticas, com roupagens diferentes da dominação política encontrada naquelas regiões. ${ }^{1031}$

Dados da CPI do Finor (Fundo de Investimentos do Nordeste), baseados na ação do TCU em 2001, concluíram pela existência de desvios deliberados de recursos públicos. ${ }^{1032}$

\footnotetext{
$\overline{{ }^{1029} \text { BRASIL. Lei no }}{ }^{\mathrm{o}}$ 3.692, de 15 dez. 1959.

${ }^{1030}$ BRASIL. Lei $\mathrm{n}^{\mathrm{0}} 5.173$, de 27 out. 1966.

1031 BURSZTYN, Marcel. O poder dos donos: planejamento e clientelismo no Nordeste. 3. ed. rev e ampl. Rio de Janeiro: Garamond; Fortaleza: BNB, 2008. p. 241. O coronel tradicional, cujo poder defluía do poder de proprietário rural, foi substituído pelo coronel capaz de operar programas governamentais. Após o agravamento da crise fiscal, "distribuição de cestas básicas, vales/cupons de toda a espécie (pão, leite, gás, energia, transporte), mais tarde agregados na Bolsa-Família, e complacência com a ocupação irregular de áreas (públicas e privadas), parecem ser o novo paradigma do velho assistencialismo que resulta em fortalecimento de novos coronéis, urbanos". Padrão similar se repete na região Norte.

1032 BRASIL. Congresso Nacional. Relatório final da Comissão Parlamentar de Inquérito destinada a “investigar a aplicação irregular de recursos do fundo de investimentos do Nordeste - FINOR”. Brasília, 2001. p. 250. "O Relatório de Auditoria [do TCU e da Secretaria Federal de Controle Interno, vinculada ao Ministério da Fazenda - SFC/MF] sobre a gestão FINOR, no período de 01/07/97 a 30/06/98, da Secretaria Federal de Controle do Ministério da Fazenda, constatou, por amostragem, a ocorrência do que os auditores chamaram de uma 'tipologia padrão para as irregularidades' na aplicação de recursos do FINOR. O 'roteiro da fraude', segundo os relatores, inicia-se quando na adesão ao sistema a empresa apresenta-se significativamente maior do que é efetivamente, de forma a ter uma previsão de aporte de recursos muito maior do que seria de fato necessário para implantar-se. Em seguida, o exagerado período de implantação dos projetos perpetua um vínculo da empresa com o sistema FINOR. Verifica-se também que os fornecimentos de equipamentos e serviços são superfaturados, de modo que as contrapartidas dos recursos provenientes do FINOR para essas inversões são, muitas vezes, suficientes para o pagamento total do investimento, livrando o empresário de fazer aportes próprios. Por fim, em todos os casos analisados pelos Auditores, as notas fiscais de serviços ou equipamentos eram fraudadas ('frias') e, na maioria das empresas, os equipamentos constantes dos seus relatórios semestrais para recebimento de contrapartida de recursos estavam desativados desde a sua compra ou instalação,
} 
Posteriormente, constatou-se que cerca de $10 \%$ de todos os recursos desse órgão teriam sido desviados desde o início do Finor, em 1974. À época, havia um "rombo" na Sudene estimado em R $\$ 2,2$ bilhões - estimativas mais recentes apontam prejuízos que superariam $R$ \$ 12 bilhões. ${ }^{1033}$ No bojo do escândalo, a Sudam e a Sudene foram extintas e substituídas, respectivamente, pela Agência de Desenvolvimento da Amazônia (ADA) e pela Agência de Desenvolvimento do Nordeste (Adene). ${ }^{1034}$ No entanto, os problemas não foram resolvidos, como aponta Bercovici:

\begin{abstract}
Ambas as "agências" continuaram ligadas ao Ministério da Integração nacional, fato que, tendo em vista o que, historicamente, se passou com a SUDENE no pós-1964, limita a sua autonomia. A criação da ADA e da ADENE, ainda, repete o mesmo erro cometido na década de 1960: a instituição de órgãos administrativos idênticos para promover o desenvolvimento de regiões totalmente distintas. Ambas as "agências" possuem "natureza autárquica". No entanto, ao contrário da justificativa de criação das demais "agências", os dirigentes da ADA e da ADENE não tinham mandato fixado em lei. ${ }^{1035}$
\end{abstract}

Um dos principais problemas para o fracasso dos órgãos de desenvolvimento regional é a captura de recursos para atendimento de interesses particulares. No caso da ADA e da Adene, Bercovici identifica como ocorria o desvirtuamento dos fundos:

\begin{abstract}
As alterações efetivas nos órgãos de desenvolvimento regional deram-se com a criação de dois fundos de natureza contábil, o Fundo de Desenvolvimento da Amazônia e o Fundo de Desenvolvimento do Nordeste (artigo $3^{\circ}$ das Medidas Provisórias), que deveriam ser geridos pelas "agências" de desenvolvimento regional. O objetivo de ambos os fundos era o de assegurar recursos para a realização de investimentos, recursos estes provenientes, essencialmente, de dotações orçamentárias do Tesouro Nacional. Deste modo, sem qualquer vinculação constitucional de receitas, a certeza e garantia do recebimento destes recursos não existe, podendo ocorrer o mesmo que vitimou a SPVEA: o desvio ou a não entrega dos recursos previstos na lei orçamentária. E, se houvesse, a vinculação
\end{abstract}

evidenciando, segundo a Auditoria, 'que o interesse não era a sua colocação em operação para aprimorar processos ou produzir melhores resultados, mas simplesmente carrear recursos do FINOR para outros fins'."

${ }^{1033}$ MANDL, Carolina. Fundos Finor e Finam têm rombo de R\$ 12,2 bilhões. Jornal Valor Econômico. São Paulo, 18 dez. 2009. p. 14. "Só agora, porém, o governo federal está descobrindo o tamanho do buraco deixado pela antiga política de desenvolvimento regional. São $\mathrm{R} \$ 12,2$ bilhões que as empresas incentivadas não pagaram [...] Os números estão no balanço divulgado pelos fundos em 2008, correspondente ao exercício de 2007. [...] A partir de um levantamento por amostra, a CPI levantou 653 casos de irregularidades nas empresas incentivadas. Porém, o relatório final concluiu que apenas 53 companhias deveriam devolver os recursos tomados."

${ }^{1034}$ BRASIL. Medida Provisória n⿳ำ $2.146-1$, de 4 maio 2001.

${ }^{1035}$ BERCOVICI, Gilberto. Federalismo e desenvolvimento regional no Brasil. In: SHOUERI, Luís Eduardo. Direito tributário: estudos em homenagem a Paulo de Barros Carvalho. São Paulo: Quartier Latin, 2008. p. 899. "A ADA e a ADENE, na realidade, eram 'agências executivas', pois sua administração estava vinculada a um plano estratégico de reestruturação e à celebração de um 'contrato de gestão' com o Ministério da Integração Nacional. O objetivo do 'contrato de gestão' é estabelecer parâmetros e indicadores objetivos para a avaliação da atuação administrativa e do desempenho das 'agências'. O seu descumprimento poderia acarretar, inclusive, a exoneração do Diretor-Geral (artigos 19 e 20 das duas Medidas Provisórias). [...] A idéia básica é a concessão de 'maior autonomia' aos órgãos da Administração Indireta, desde que se submetam ao cumprimento das metas fixadas no 'contrato de gestão'." 
constitucional, estes dois fundos não representariam nada mais do que a repetição dos Fundos Constitucionais do Norte e do Nordeste, previstos no artigo 159, I, "c" da Constituição, limitados ao financiamento do setor produtivo, ou seja, a subsidiar, mais uma vez, a iniciativa privada. Com esta limitação, os fundos regionais serviam aos interesses da iniciativa privada, mas não ao Poder Público, esquecendo-se de que os grandes investimentos necessários (especialmente em relação à Amazônia) são os investimentos em infra-estruturam na sua maior parte realizados pelo Estado. Mas a principal novidade dos fundos criados pelas Medidas Provisórias ${ }^{\circ} 2.156-5$ e 2.1575 era o fato de ser previsto que, além do BASA e do BNB, os agentes operadores dos fundos seriam instituições financeiras federais, a serem definidas em ato do Poder Executivo (leia-se BNDES), cuja competência seria fiscalizar a regularidade dos projetos e propor a liberação de recursos financeiros para os projetos autorizados pelas "agências" de desenvolvimento regional. Ou seja, o efetivo administrador dos fundos de desenvolvimento regional criados não era nenhum dos bancos regionais (BASA ou BNB) ou nenhuma das "agências" (ADA ou ADENE), mas o BNDES. As "agências" de desenvolvimento regional eram meras estruturas intermediárias, encarregadas apenas do estabelecimento de "diretrizes e prioridades" para a nova política federal de "desenvolvimento regional", limitada, como estamos podendo analisar, à aprovação de financiamentos do BNDES para investimentos na região. ${ }^{1036}$

A sutil mudança esvaziou ambos os órgãos recém-criados e transferiu a gestão dos recursos para fora da região que visavam desenvolver. Ao mesmo tempo, essa mudança pode ter ocasionado o acirramento da disputa pelos recursos da União para as regiões Norte e Nordeste e o processo de barganha política de votos parlamentares por recursos. Como a criação das "agências" não trouxe nenhuma mudança significativa no cenário anterior, a Sudene ${ }^{1037}$ e a Sudam ${ }^{1038}$ foram recriadas e recuperaram a estrutura anterior.

Mesmo assim, não há garantia de que o ressurgimento desses órgãos constituirá um novo marco de planejamento regional, substituindo o subsídio a investimentos privados desprovidos de preocupação com a condição socioeconômica da população. ${ }^{1039} \mathrm{O}$ sucesso das autarquias de fomento ao desenvolvimento regional se relacionam diretamente com a insuficiência das transferências obrigatórias e o palco de disputas por transferências voluntárias, as quais permanecem desprovidas de uma finalidade específica e sujeitas, na maioria dos casos, a projetos políticos pessoais. Dessa maneira, o lobby dos interesses

\footnotetext{
${ }^{1036}$ Idem, p. 900.

1037 BRASIL. Lei Complementar nํㅜ 125, de 3 jan. 2007.

1038 BRASIL. Lei Complementar $n^{\mathrm{o}}$ 124, de 3 jan. 2007.

1039 BERCOVICI, Gilberto. Federalismo e desenvolvimento regional no Brasil. In: SHOUERI, Luís Eduardo. Op. cit. p. 901. "Ao extinguir a SUDAM e a SUDENE, o Governo Federal as substituiu pelas 'agências' de desenvolvimento regional. Mais uma vez, perdeu-se a oportunidade de cumprir o previsto no art. 43 da Constituição de 1988, com a criação das Regiões, cujo objetivo é promover o desenvolvimento e reduzir as desigualdades regionais. Ao introduzir a região, a Constituição de 1988 o fez como forma de organização administrativa, não política. A finalidade das Regiões previstas no artigo 43 é a administração dos interesses públicos federais naquela determinada área. Suas atividades são meramente administrativas, ou seja, limitam-se à gestão de serviços e interesses públicos federais. A idéia do artigo 43 da Constituição foi a criação de órgãos administrativos federais com ação e objeto territorialmente delimitados, mantendo a concepção tradicional dos órgãos regionais de desenvolvimento."
} 
privados subverte as finalidades de melhoria das condições de vida da população das regiões a que tais recursos se destinam.

\subsubsection{Efeitos do desequilíbrio entre receitas e despesas dos entes federativos mais fragilizados}

O cenário do federalismo brasileiro impõe uma série de atribuições aos municípios e estados, mas não lhes confere os meios hábeis para o desempenho destas funções. Tal cenário gera um problema similar ao descrito por Leal em meados dos anos 1940: ${ }^{1040}$ a dependência dos municípios e alguns estados, sobretudo os mais fragilizados economicamente, em relação aos Estados e à União. Tendo em vista seus interesses privados de sobrevivência política, os políticos dessas municipalidades se dispõem a adotar práticas para aumentar as chances de se obter sucesso na angariação de recursos financeiros adicionais, quer seja dos estados mais ricos, quer seja da União. ${ }^{1041}$

Contrariamente ao que Lafer argumenta, inexiste um automatismo na divisão entre as regiões mais desenvolvidas e as menos desenvolvidas. Talvez essa afirmação tenha sido válida no passado, mas hoje se observa um certo turvamento das fronteiras: as práticas corruptas, talvez previamente escamoteadas nas regiões mais desenvolvidas, vieram à tona, e vice-versa. O predomínio da União no federalismo fiscal fez com que a corrupção macrojurídica se agravasse.

Dessa forma, os entes descentralizados mais frágeis submetem-se aos mais fortes economicamente. A crueza desse jogo de interesses subverte a representação popular e o sufrágio universal - por vezes, os políticos oportunistas dos municípios trocam de partido apenas e tão-somente para agradar a seu financiador, fato que explica a inexistência, no Brasil, de partidos políticos estruturados claramente com base nos interesses defendidos. $\mathrm{Na}$ ausência de justificativas, não faltará a esses políticos

[...] o grande argumento: não tem direito de impor aos amigos o sacrifício da oposição. E esse argumento, que pode ser insincero, é uma substância verdadeira e

\footnotetext{
$\overline{1040}$ LEAL, Victor Nunes. Op. cit p. 50. "A atrofia dos nossos municípios tem resultado de processos vários: penúria orçamentária, excesso de encargos, redução de suas atribuições autônomas, limitações ao princípio da efetividade de sua administração, intervenção da polícia nos pleitos locais etc."

${ }^{1041}$ Referindo-se ao período da República populista, Lafer identifica o papel de moderador do Congresso Nacional: "A evolução destas tendências começou a pôr em xeque o papel que, no pacto de dominação, o Congresso exercia: o de fiscalizar de modo conservador o núcleo inovador representado pelo executivo e, neste processo, garantir as demandas da cultura política do Brasil subdesenvolvido sem emperrar inconclusivamente as demandas da cultura política do Brasil desenvolvido”. LAFER, Celso. Op. cit. p. 70.
} 
procedente, porque o primeiro dever do chefe local é alcançar a vitória, o que significa obter para sua corrente o apoio da situação estadual. ${ }^{1042}$

A afirmação permanece verdadeira mesmo na atualidade. ${ }^{1043}$ Tudo o que importa na lógica desse sistema é obter recursos para levar a cabo obras e serviços que perpetuem os prefeitos no poder. Não é sem razão que os partidos dos ocupantes dos Executivos estaduais e federal inchem ou encolham de tamanho seus próprios quadros e suas bases parlamentares de apoio depois de vitória ou derrota nas eleições. Aprofunda-se e ganha legitimidade o discurso defensor das distorções no sistema representativo no Congresso Nacional: se as regiões mais frágeis economicamente necessitam de mais recursos, o melhor modo de se garantir isso é com a super-representação no Congresso Nacional. ${ }^{1044} \mathrm{O}$ poder de barganha dos parlamentares destas regiões cresce, mas estes se tornam reféns das necessidades políticas da União. As práticas patrimonialistas sobrevivem por meio daqueles que ocupam eletivamente o poder e servem aos seus interesses pessoais, não ao interesse público. A esse jogo de interesses, devese adicionar o caráter inercial do adesismo social: os prefeitos e governadores observam os políticos bem-sucedidos e constatam que a habilidade em conseguir mais recursos se transforma em votos do eleitorado, os quais podem catapultá-los a melhores posições políticas. Esse solapamento causado pela corrupção macrojurídica na vida política mina a legitimidade do Estado e produz efeitos que se espraiam por todas as vertentes da ação estatal, criando oportunidades para que apareçam a corrupção-suborno e a corrupção-favorecimento.

\footnotetext{
$\overline{1042}$ LEAL, Victor Nunes. Op. cit. p. 42.

1043 Caso alguém se debruce sobre o SIAFI, poderá encontrar infindáveis provas desta alegação. Vide por exemplo levantamento da ONG Contas Abertas, a qual apontou que quase 50\% dos recursos transferidos para a prevenção e reparação de desastres foi destinada para o Estado da Bahia, reduto eleitoral do ocupante do Ministério da Integração Regional, governado pelo mesmo partido da União. COSTA, Amanda; JÚNIOR, Milton. Metade dos recursos de prevenção a desastres foi para a Bahia. ONG Contas Abertas. 06 jan. 2010. Disponível em: <http://contasabertas.uol.com.br/noticias/detalhes_noticias.asp?auto=2949>. Acesso em: 7 jan. 2010 às $11 \mathrm{~h} 20$.

1044 STEPAN, A. "Para uma Nova Análise Comparativa do Federalismo e da Democracia: Federações que Restringem ou Ampliam o Poder do Demos". Disponível em: <http://www.scielo.br/scielo.php?script=sci_arttext\&pid=S0011-52581999000200001> Acesso em 6 jan. 2010 à 1h25. Stepan aponta o grave problema de demos constraining. "O Brasil é uma nova democracia que tem lutado contra uma das piores distribuições de renda do mundo. [...] Na Câmara Alta brasileira, um grupo de senadores que representa menos de $9 \%$ do eleitorado pode criar um grupo 'win-set' capaz de obstruir a aprovação de importantes reformas legislativas. Se as instituições da Câmara dos Deputados americana - mais igualitária - são capazes de produzir equilíbrios induzidos pela estrutura, o federalismo brasileiro, que se caracteriza por uma Câmara Alta de baixíssima proporcionalidade e por uma Câmara Baixa igualmente desproporcional, certamente contribui para a perpetuação estrutural do status quo. Nenhum analista sério do caso brasileiro, após um estudo minucioso das consequiências das regras decisórias e das prerrogativas do Senado, dos estados e dos governadores, defenderia o argumento de que o federalismo é uma variável interveniente de pouca importância relativa." O problema da super-representação é exposto da seguinte maneira: "O Brasil ainda restringe mais o poder do demos do que os Estados Unidos. Em 1991, o menor estado era Roraima, com uma população de 215.790; e o maior era São Paulo, com 31.192.818 habitantes (World Yearbook, 1995:618; Elazar, 1994). Desse modo, um em Roraima pesa 144 vezes mais do que um em São Paulo.”
} 
Em síntese, o federalismo brasileiro está sujeito aos dois grandes problemas de corrupção apontados por Bardhan e Mookherjee: (i) não evita os problemas experimentados pelas burocracias centralizadas, pois o sistema de transferências constitucional não garante a autonomia financeira dos componentes da federação, abrindo espaço para o jogo de influências das transferências voluntárias, e (ii) sofre as consequências negativas da autonomia administrativa e orçamentária dos componentes da federação, especialmente o alto risco de captura da burocracia pelas elites políticas locais.

\subsection{O processo orçamentário como incentivo à subversão da dicotomia entre os espaços público e privado}

Em si, os problemas apontados na exposição sobre o federalismo teriam por consequência desestruturar o funcionamento ideal de um modelo federativo. Todavia, o sistema é altamente instável e força os atores a se adaptar, a fim de lidar com os desequilíbrios. Como estes resultam principalmente da escassez de recursos nos estados e municípios menos desenvolvidos, estes buscam compensações financeiras para arcar com suas despesas - a alternativa dinâmica mais evidente e plausível é angariar tais recursos no orçamento da União. Nesse ponto, a corrupção aflora em seus aspectos macro e microjurídico.

Historicamente, o orçamento vincula-se à origem dos Parlamentos modernos, pois sua elaboração pressupunha a reiterada análise e deliberação acerca das receitas e despesas: de um lado, o soberano necessitava de recursos para a administração do Estado e, de outro, os parlamentares, representantes da sociedade civil, limitavam as suas investidas. ${ }^{1045}$ Muito mais do que lugar para os parlamentares discutirem regras do direito civil, o Parlamento sempre foi o espaço em que se conciliam os diferentes interesses sobre arrecadação e gastos estatais. Aos poucos, à medida que se firmava na sociedade a ideia de que o Estado visava ao bem comum, o Parlamento gradativamente passou a fiscalizar como os tributos eram despendidos. Baleeiro é categórico:

[...] quanto mais se afasta do Estado de Direito, tanto menos o Parlamento decide do conteúdo da tributação e das despesas. Assim nasceu a concepção do orçamento moderno, graças ao qual os representantes dos contribuintes condicionavam sua

\footnotetext{
$\overline{1045}$ TOLDO, Nino Oliveira. O orçamento como instrumento de efetivação das políticas públicas no Brasil. 2006. 205 f. Tese (Doutorado em Direito Econômico-Financeiro)-Faculdade de Direito, Universidade de São Paulo, São Paulo. p. 139. BALEEIRO, Aliomar. Op. cit p. 415. "Pacífico o direito de autorizar as receitas, não foi difícil ao Parlamento britânico obter o reconhecimento de seu poder correlato de também autorizar e controlar as despesas governamentais, discriminados do patrimônio público os haveres pessoais do monarca."
} 
aprovação ao emprego dos fundos aos fins que mais interessavam ao povo representado. ${ }^{1046}$

Num regime federal, há uma complexidade maior, na qual confluem os interesses privados e públicos de representantes dos Executivos dos entes federativos, bem como dos parlamentares $^{1047}$ - os interesses de sucesso político dos eleitos e os de grupos, não necessariamente coincidentes com o interesse público, devem ser conciliados no orçamento público. O orçamento não deflui meramente de uma decisão política sobre como efetuar os gastos e pressupõe objetividade no seu trato, ínsita à noção de legalidade no Estado de Direito, o que é obtido mediante esse processo capaz de "identificar um denominador comum que só a síntese numérica e contábil do orçamento oferece". ${ }^{1048}$ Nesse sentido, a tramitação do orçamento tem por finalidade a maturação política e técnica da proposição feita pelo Executivo. ${ }^{1049}$ Nesse ponto de maturação, a observação da prática sugere que, quanto maior a duração da elaboração do orçamento, tanto maiores serão as demandas apresentadas e tanto maiores as tendências de o orçamento ser maior do que as receitas disponíveis. ${ }^{1050}$

Para que tal amadurecimento ocorra, há uma pletora de regras que precisam ser obedecidas. Em especial desde o advento do Estado de bem-estar social, o processo orçamentário esteve envolto numa aura de mistério para a sociedade, fato que dificulta bastante a sua fiscalização. Numa democracia, a consciência fiscal (tax consciousness), entendida como o "estado de espírito de quem sabe em quanto montam aproximadamente os seus sacrifícios de dinheiro para a manutenção dos serviços públicos", expõe uma percepção do cidadão sobre o interesse público ou comum, ${ }^{1051}$ na medida em que se constata que os recursos privados estão sendo usados pelos políticos no espaço público e não brotam por geração espontânea. Não é à toa que, já no século XVIII, o art. 14 da Declaração Universal dos Direitos do Homem e do Cidadão estabelecia que "todos os cidadãos têm direito de verificar, pessoalmente ou por seus representantes, a necessidade da contribuição pública, de

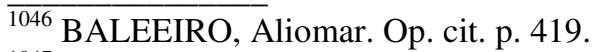

${ }^{1047}$ A análise foca a elaboração do orçamento da União devido aos elevados valores arrecadados e ao poder disso resultante, embora, guardadas as devidas proporções, semelhantes considerações possam ser traçadas para os orçamentos estaduais.

${ }^{1048}$ TORRES, Ricardo Lobo. Op. cit. p. 3.

1049 BENETON, Marco Antonio Hatem. O processo legislativo financeiro. 2007. 256 f. Tese (Doutorado em Direito Econômico e Financeiro)-Faculdade de Direito, Universidade de São Paulo, São Paulo. p. 132.

1050 SANTA HELENA, Eber Zoehler. O processo de alocação de recursos federais pelo Congresso Nacional. Apresentação no Seminário Internacional de Assessoria e Consultoria Institucional do Poder Legislativo, realizado na Câmara dos Deputados de 30 de junho a 4 de julho de 2003. p. 7. Disponível em: $<$ http://apache.camara.gov.br/portal/arquivos/Camara/internet/orcamentobrasil/orcamentouniao/estudos/artigos/ Artigo170.pdf>. Acesso em: 10 dez. 2009.

${ }^{1051}$ BALEEIRO, Aliomar. Op. cit. p. 196.
} 
consentir livremente, de acompanhar a sua aplicação e de determinar a quota, os fundos, a cobrança e a duração". Embora a reprodução pura e simples desse sentimento possa conduzir a uma verdadeira privatização do Estado pelos contribuintes, a democracia também é reforçada pela consciência fiscal, pois aumenta o ímpeto de a sociedade fiscalizar os recursos administrados pelo Poder Público.

Ao se entenderem o alcance e a repercussão de algumas dessas regras, será possível visualizar como a corrupção na perspectiva macrojurídica e, eventualmente, aquelas outras tratadas pelos direitos penal, administrativo e político-constitucional surgem no processo orçamentário. Paradoxalmente, no Brasil a atenção dada à normatização da despesa pública contrasta com a dada à receita pública: em termos de quantidade e grau de detalhamento, a normatização é inversamente proporcional à sua importância política, ${ }^{1052}$ o que faz refletir sobre se esse silêncio seria revelador de algo mais profundo. Baleeiro vaticina:

\footnotetext{
Mas o direito de autorizar as receitas, logo seguido do corolário fatal de controle das despesas, exigia demonstração completa e minuciosa de cada tributo e cada gasto programado, com especificação dos fins e limites, para que os Parlamentos não fossem ludibriados pelos monarcas e ministros. ${ }^{1053}$
}

Tais aspectos ajudam a compreender por que as posições governamentais relacionadas à elaboração e à execução orçamentárias, quer no âmbito do Executivo, quer no do Legislativo, são tão sensíveis à corrupção pela perspectiva da regulamentação microjurídica. Mais do que o aspecto cru da corrupção, há uma grande faixa de condutas corruptas que escapam da regulamentação microjurídica e possivelmente reclamem algum tratamento pelo direito. Não bastasse a corrupção reprimida pela regulamentação microjurídica, há muito mais espaço para aquelas práticas que levam ao solapamento das instituições.

\subsubsection{Visão geral do processo de elaboração orçamentária}

\footnotetext{
${ }^{1052}$ SERRA, José. Op. cit. p. 7. "Curiosamente, têm sido ignorados os dispositivos referentes à organização do gasto público, à transparência e ao planejamento das decisões governamentais sobre alocação de recursos, precisamente os dispositivos para o equilíbrio fiscal e o controle.” A Lei Complementar n⿳ 101/00 supriu parte dessa omissão.

${ }^{1053}$ BALEEIRO, Aliomar. Op. cit. p. 419.
} 
Originariamente, o orçamento era bastante simples, refletindo uma listagem das receitas e das despesas do Estado. ${ }^{1054}$ A gradativa ampliação das funções estatais, mormente na prestação de inúmeros serviços, e a crescente necessidade de transparência da ação da Administração Pública alteraram o cenário inicial, adicionando complexidade à peça orçamentária. No Brasil, houve movimento de igual sofisticação na elaboração do orçamento - à guisa de ilustração, o artigo 165 da Constituição determina a articulação consistente dos objetivos de três leis, a saber, o plano plurianual, ${ }^{1055}$ as diretrizes orçamentárias ${ }^{1056}$ e os orçamentos anuais. ${ }^{1057}$

A propósito, essa sofisticação também pode ser criticada. Tome-se o caso da Lei de Diretrizes Orçamentárias, que inexistia antes da Constituição de 1988 - as decisões básicas eram tomadas pelo Chefe do Executivo. No pós-1988, a lei foi concebida originariamente para operar dentro de um regime parlamentarista, que não veio a ser implantado. Elaborada pelo Executivo, ela transferiu poderes ao Legislativo, aumentando-lhe a capacidade de barganha, o que eleva o custo político da elaboração do orçamento. Para Torres, um efeito colateral dessa importação criativa de um instituto do parlamentarismo para o presidencialismo teria sido o surgimento do "Esquema do Orçamento". ${ }^{1058}$

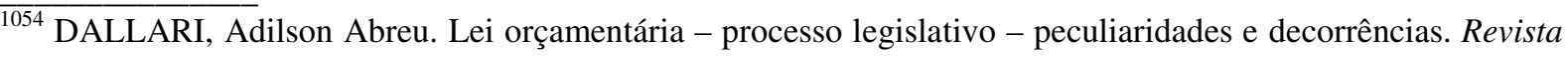
de Informação Legislativa, Brasília, ano 33, n. 129, p. 160, jan./mar. 1996. "No passado, antes de 1964, o orçamento era apenas um rol de números vinculados apenas a categorias orçamentárias, a certos tipos de despesa (como, por exemplo, pessoal, material permanente, obras etc.)."

${ }^{1055}$ BRASIL. Constituição (1988). Art. 165, § 1º. "A lei que instituir o plano plurianual estabelecerá, de forma regionalizada, as diretrizes, objetivos e metas da administração pública federal para as despesas de capital e outras delas decorrentes e para as relativas aos programas de duração continuada".

1056 BRASIL. Constituição (1988). Art. 165, § 2. “A lei de diretrizes orçamentárias compreenderá as metas e prioridades da administração pública federal, incluindo as despesas de capital para o exercício financeiro subseqüente, orientará a elaboração da lei orçamentária anual, disporá sobre as alterações na legislação tributária e estabelecerá a política de aplicação das agências financeiras oficiais de fomento".

1057 BRASIL. Constituição (1988). Art. 165, § 5. "A lei orçamentária anual compreenderá: I - o orçamento fiscal referente aos Poderes da União, seus fundos, órgãos e entidades da administração direta e indireta, inclusive fundações instituídas e mantidas pelo Poder Público; II - o orçamento de investimento das empresas em que a União, direta ou indiretamente, detenha a maioria do capital social com direito a voto; III - o orçamento da seguridade social, abrangendo todas as entidades e órgãos a ela vinculados, da administração direta ou indireta, bem como os fundos e fundações instituídos e mantidos pelo Poder Público. $\S 6^{\circ}$. O projeto de lei orçamentária será acompanhado de demonstrativo regionalizado do efeito, sobre as receitas e despesas, decorrente de isenções, anistias, remissões, subsídios e benefícios de natureza financeira, tributária e creditícia."

1058 TORRES, Ricardo Lobo. Op. cit. p. 90-91. SERRA, José. Op. cit. p. 22. “O sistema presidencialista obstaculiza a participação efetiva e responsável do Congresso. Nele, os parlamentares não têm compromisso com aquelas políticas, tendendo a atitudes polarizadas, de aplauso ou censura, segundo o desempenho do governo. A situação torna-se perversa, pois: a) a força dos parlamentares passa a depender da fragilidade do Executivo; e b) o Congresso vê-se sujeito à manipulação do Executivo, a partir dos recursos que este utiliza com o propósito de obter maioria para seus projetos ou amenizar a fiscalização de que deveria ser seus projetos ou amenizar a fiscalização de que deveria ser objeto. Ambos os problemas foram agravados pela Constituição de 1988, que fortaleceu o Legislativo, mas manteve o presidencialismo. Nesse sentido, só fez ampliar - e enormemente - o poder de barganha do Congresso e reforçar sua adesão ao critério paretiano na avaliação dos diferentes assuntos econômicos."
} 
As regras gerais de direito financeiro constam da Seção II ("Do orçamento") do Capítulo II ("Das finanças públicas”) do Título VI ("Da tributação e do orçamento”) da Constituição de 1988. Podem-se classificar as regras de direito financeiro em dois grupos principais: as que contêm precipuamente disposições substantivas e as que regulam os procedimentos para elaboração do orçamento. Entre as normas de caráter substantivo, encontram-se as dos arts. 167, 168 e 169 da Constituição, bem como as da Lei no ${ }^{\circ}$ 4.320/64 ${ }^{1059}$ e as da Lei Complementar $n^{\mathrm{o}} 101 / 00 .{ }^{1060}$ Entre as regras de caráter procedimental devem ser citadas as dos arts. 165 e 166 da Constituição e uma série de outras normas infraconstitucionais, inclusive algumas constantes da Lei $\mathrm{n}^{-0} 4.320 / 64$, as da Lei Complementar $n^{-0}$ 101/00 e as da Resolução do Congresso Nacional no ${ }^{-0} / 2001 .{ }^{1061}$

Ilustrativo do real papel desempenhado pelo orçamento é a questão das "decisões trágicas" envolvidas em sua elaboração. Dada a escassez de recursos do Estado vis-à-vis as grandes necessidades de bem-estar material de uma população carente como boa parte da brasileira, as decisões sobre o tema são trágicas, na medida em que a despesa em dada rubrica implica automaticamente a exclusão da outra. ${ }^{1062}$ Conforme descreve Torres,

\begin{abstract}
As decisões trágicas, de diferentes graus, consistem nas opções entre as poucas soluções possíveis. As decisões de $1^{\circ}$ grau implicam a escolha entre objetivos genéricos: deve-se privilegiar, na alocação de recursos orçamentários, a saúde e a educação ou os investimentos para o desenvolvimento, máxime por intermédio das empresas estatais permanentemente deficitárias? As decisões de $2^{\circ}$ grau cuidam casuisticamente da distribuição de verbas: qual é o hospital, situado em cidade, que deve receber os recursos para a aquisição da caríssima aparelhagem moderna para exames laboratoriais ou para intervenções cirúrgicas? As escolhas são trágicas porque delas dependem os valores fundamentais, inclusive a própria vida humana. No Brasil das últimas décadas abandonamos inteiramente esse tipo de abordagem ética do orçamento, o que muitas vezes representou escolhas em favor de subvenções a empresas estatais e de incentivos a indústrias obsoletas, com o trágico sacrifício das populações marginalizadas, que deixaram de contar com assistência médica e com educação primária. ${ }^{1063}$
\end{abstract}

Essas ponderações servem para reafirmar que o orçamento possui uma finalidade a ser atendida pelas autoridades, a qual precisa ser atingida com o máximo de eficiência em virtude de os recursos estatais serem escassos. ${ }^{1064}$ A premência por eficiência não deflui

\footnotetext{
$\overline{{ }^{1059} \text { BRASIL. Lei } \mathrm{n}^{\mathrm{o}}}$ 4.320, de 17 mar. 1964.

${ }^{1060}$ BRASIL. Lei Complementar $\mathrm{n}^{\mathbf{0}}$ 101, de 4 maio 2000.

${ }^{1061}$ BRASIL. Congresso Nacional. Resolução noำ 1, de 2001.

1062 CARDONA, Alejandro Ramírez. Op. cit. p. 28.

1063 TORRES, Ricardo Lobo. Op. cit. p. 60.

${ }^{1064}$ CARDONA, Alejandro Ramírez. Op. cit. p. 32. "La escasez de los medios financieros públicos es relativa si se tiene en cuenta que el gasto público, por ejemplo, cuando no es productivo, no hace otra cosa que redistribuir renta, cambiarla de sujeto; y si es productivo, por el contrario, aumenta dicha renta o la reconstruye en beneficio tanto del Estado como de la colectividad, que ve aumentadas sus disponibilidades económicas y su capacidad
} 
necessariamente de uma política neoliberal que pretende a redução do Estado - pelo contrário, deflui da teoria geral do direito, que impõe às autoridades o dever de usar o poder de gastar para atingir a finalidade da norma.

Aliás, a noção de eficiência que orienta o setor privado é distinta da do setor público: enquanto no primeiro há busca do "custo mínimo com o máximo de eficiência ou utilidade individual", no segundo predomina a escolha do "melhor meio com o máximo de bem-estar coletivo". ${ }^{1065}$ Enquanto insuficientes tais recursos, deve a autoridade administrativa extrair o máximo deles para atingir tanto quanto possível os objetivos estatais. O estudo da corrupção no processo orçamentário precisa ser visto sob esse prisma finalístico conjugado com a realidade circundante - nessa seara, a aplicação das regras de direito financeiro positivadas é distorcida na prática em virtude dos influxos do direito pressuposto.

Se a operacionalização do orçamento tem impacto significativo sobre a persecução das finalidades do Estado de bem-estar social, o poder de certas autoridades na elaboração e na gestão orçamentária não existe para ser exercido de modo personalizado. A realização das despesas do orçamento não constitui faculdade da autoridade, dependente única e exclusivamente de sua vontade. Pelo contrário, o poder detido pelos envolvidos existe apenas para o cumprimento dos deveres juridicamente impostos às autoridades.

Perante o Poder Legislativo, o processo financeiro se divide em quatro etapas: apresentação, instrução, deliberação e positivação. ${ }^{1066}$ Essas fases podem se desdobrar ao longo do tempo, da seguinte forma: (i) desde o recebimento da mensagem do Executivo pelo presidente do Congresso Nacional, (ii) que publica e distribui avulsos contendo os respectivos projetos; (iii) assim, o presidente do Congresso encaminha à Comissão Mista de Orçamento; (iv) as Consultorias de Orçamento da Câmara dos Deputados e do Senado Federal elaboram e apresentam nota técnica conjunta, que subsidiará a apreciação do projeto; (v) realizam-se audiências públicas para discutir com a sociedade o projeto em questão, em conformidade com o art. 48, parágrafo único, inciso I, da Lei de Responsabilidade Fiscal; (vi) publica-se o

contributiva. El incremento real de los ingresos de la colectividad por medio del gasto productivo y de la exacción a las rentas ociosas, redunda en el aumento de la capacidad financiera pública." Ver também SABBAG, César de Moraes. Orçamento e desenvolvimento. 2005. 346 f. Tese (Doutorado em Direito do Estado)Faculdade de Direito, Universidade de São Paulo, São Paulo. p. 158-159.

${ }^{1065}$ Idem, p. 11-12. "El principio de las finanzas privadas: la economía del sector privado basa sus finanzas en el principio del mínimo costo con el máximo de beneficio o utilidad individual. De esto se concluye que la actividad económica propia del sector privado no funcionaria sin el incentivo de la rentabilidad o beneficio. El principio de las finanzas públicas: la economía del sector público, por el contrario, se basa en el principio del mejor medio con el máximo de bienestar colectivo. Al ente público no le interesa la realización de utilidades netas en la satisfacción de las necesidades públicas, dada la naturaleza misma de estas".

1066 BENETON, Marco Antonio Hatem. O processo legislativo financeiro. 2007. 256 f. Tese (Doutorado em Direito Econômico e Financeiro)-Faculdade de Direito, Universidade de São Paulo, São Paulo. p. 132. 
parecer preliminar do relator-geral da Comissão Mista; (vii) apresentam-se emendas à proposta, bem como se publicam seus avulsos; (viii) apresentam-se os pareceres setoriais, bem como sua discussão e votação; (ix) apresenta-se, publica-se, discute-se e delibera-se sobre o parecer final da Comissão, que é encaminhado à Mesa do Congresso Nacional; (x) apresentam-se destaques de votação no Plenário e votam-se o parecer final e destaques, que são organizados conforme aprovações; (xi) encaminha-se a redação final para a sanção ou veto parcial; (xii) encaminha-se para a promulgação e publicação e, em caso de veto parcial, este será deliberado pelo Congresso Nacional.

No decorrer do processo, também há oportunidades para eventuais retificações no programa e apreciação de créditos adicionais encaminhados pelo Poder Executivo ao longo do exercício financeiro. ${ }^{1067}$ Parte considerável e relevante do orçamento é vivenciada no âmbito do Poder Executivo. Isso ocorre previamente à apresentação do projeto de lei de proposta orçamentária pelo Executivo ou posteriormente à sua aprovação pelo Legislativo, quando o orçamento começa a ser executado. ${ }^{1068}$

Como em termos proporcionais há pouca margem de manobra no orçamento da União em virtude das transferências obrigatórias e das despesas de custeio da máquina administrativa, o principal embate de interesses se dá exatamente no direcionamento das transferências voluntárias. Ainda assim, depois de descontadas as despesas com a máquina administrativa, em termos absolutos, as quantias disponíveis para transferências voluntárias pela União são consideráveis.

Um conjunto de "brechas", "interpretações" e até mesmo algumas regras sobre as normas de direito financeiro permitem que os entes federativos mais frágeis economicamente tentem suprir suas necessidades e, ao mesmo tempo, se sujeitem a um "jogo político" impregnado de personalismo, que caracteriza essa corrupção macrojurídica. Uma combinação de normas de direito material e processual se articula para criar oportunidades e incentivos para práticas corruptas, muitas vezes consideradas legítimas, mas que enviam sinais negativos para comportamentos corruptos que podem aflorar no âmbito da regulamentação microjurídica.

\footnotetext{
$\overline{1067}$ Síntese a partir de SANTA HELENA, Eber Zoehler. O processo de alocação de recursos federais pelo Congresso Nacional. In: Seminário Internacional de Assessoria e Consultoria Institucional do Poder Legislativo. Câmara dos Deputados, 30 de jun. a 4 de jul. 2003. Disponível em: $<$ http://apache.camara.gov.br/portal/arquivos/Camara/internet/orcamentobrasil/orcamentouniao/estudos/artigos/ Artigo170.pdf>. Acesso em: 10 dez. 2009.

1068 Processo orçamentário não deve ser entendido restritivamente como o processo legislativo de produção da lei orçamentária. Para fins desta tese, o processo orçamentário também compreende o processo legislativo, mas inclui a fase pré e pós-legislativa.
} 


\subsubsection{O processo orçamentário perante o Poder Executivo}

A lei orçamentária, especialmente as dos planos plurianuais, se tornou um instrumento de gestão por meio da qual se viabilizam políticas públicas do governo, traduzindo as necessidades do país. ${ }^{1069}$ Trata-se de uma decisão política, ${ }^{1070}$ e a iniciativa dos projetos orçamentários é exclusiva do Chefe do Poder Executivo, ${ }^{1071}$ de forma que a não apresentação dos projetos nos prazos regulamentares enseja crime de responsabilidade. ${ }^{1072}$

O processo de elaboração da lei orçamentária inicia-se antes de propriamente atingir o procedimento legislativo. Nessa fase, pode-se identificar intensa pressão dos interessados em receber os recursos que podem ser passados por meio das transferências voluntárias. Por vezes, a deturpação do interesse público fica patente na forte influência das empreiteiras "na sugestão de obras a prefeitos e governadores" - tais empresas até elaboram estudos sobre as obras e os repassam às autoridades apenas para assinatura. ${ }^{1073}$

Essa conclusão se coaduna com pesquisas que identificam oportunidades para o surgimento da corrupção reprimida pela regulamentação microjurídica no momento em que se decide como serão gastos os recursos arrecadados pelo Estado. É sabida a predileção de certos políticos por grandes obras e gastos, cujos efeitos sobre o bem-estar são questionáveis, em detrimento de investimentos na melhoria dos serviços de educação e saúde. Afora a visibilidade eleitoral das grandes obras, outro indício de como a corrupção macrojurídica leva à mistura entre o interesse público e o privado, a corrupção-suborno pode estar por trás de certas escolhas, uma vez que as oportunidades para obter propina seriam maiores num projeto dessa natureza:

\footnotetext{
$\overline{1069}$ SILVA, José Afonso da. Processo constitucional de formação das leis. São Paulo: Malheiros, 2007. p. 141142.

${ }^{1070}$ OLIVEIRA, Régis Fernandes de. Manual de direito financeiro. São Paulo: Revista dos Tribunais, 2003. p. 83.

${ }^{1071}$ BRASIL. Constituição (1988). Arts. 84, XXIII c/c 165.

1072 BRASIL. Lei $\mathrm{n}^{\circ}$ 1.079, de 10 abr. 1950. Art. 10. "São crimes de responsabilidade contra a lei orçamentária: 1 - Não apresentar ao Congresso Nacional a proposta do orçamento da República dentro dos primeiros dois meses de cada sessão legislativa."

1073 BRASIL. Congresso Nacional. Relatório final da Comissão Parlamentar Mista de Inquérito. Congresso Nacional. Criada através do Requerimento $n^{\circ}$ 151/93-CN, destinada a "apurar fatos contidos nas denúncias do Sr. José Carlos Alves dos Santos, referentes às atividades de parlamentares, membros do Governo e representantes de empresas envolvidas na destinação de recursos do Orçamento da União”. Vol. III, Brasília, jan. 1994, p. III.6.
} 
Por fim, a corrupção pode afetar a composição das despesas do governo. [...] Os funcionários corruptos do governo podem vir a preferir aqueles tipos de despesa que os permitam coletar subornos e manter-se em segredo. Shleifer e Vishny (1993) postulam que altos gastos em artigos especializados, como mísseis e pontes, cujo exato valor de mercado é difícil de ser determinado, favorecem oportunidades mais rentáveis para a corrupção. É possível também que as oportunidades para a cobrança de subornos sejam mais abundantes em relação a artigos produzidos por empresas que operem em mercados oligopolistas, nos quais há rendas improdutivas disponíveis. Pode-se esperar, a priori, que seja mais fácil coletar subornos substanciais mediante o empreendimento de grandes projetos de infra-estrutura ou de aquisição de equipamentos de defesa de alta tecnologia que por meio de compra de livros escolares e de pagamento de salários de professores. Por exemplo: Hines (1995) afirma que o comércio internacional de aeronaves é bastante suscetível à corrupção. Em outras áreas, como na de saúde, o panorama tem contornos menos nítidos: as oportunidades para a coleta de subornos podem ser abundantes nas aquisições de instalações hospitalares e de equipamentos médicos de última geração; porém, mais limitados no pagamento do salário de médicos e de enfermeiras. ${ }^{1074}$

Em outra frente, as pressões também se repetem perante os Ministérios. Conforme concluiu a CPMI do Orçamento,

[...] a ação dos lobbies - grupos organizados de interesse e pressão - no Orçamento da União se iniciava quando da elaboração da proposta orçamentária pelos diversos Ministérios; prosseguia com a influência junto ao Departamento do Orçamento da União e, ao chegar o Orçamento ao Ministério da Fazenda, em etapa imediatamente subseqüente, já havia sofrido diversas 'modelagens', provocadas pelos grupos de pressão, e as continuava sofrendo enquanto o Ministério da Fazenda negociava cortes nas rubricas próprias de cada Ministério. ${ }^{1075}$

Ainda que de maneira precária, ao antecipar certas discussões e diminuir o espectro da lei orçamentária anual o mecanismo da Lei de Diretrizes Orçamentárias (LDO) reduz um pouco a margem de manobra para tais interesses, muito embora a própria LDO possa ser objeto de manipulação.

\subsubsection{O processo orçamentário perante a Comissão Mista de Planos, Orçamentos Públicos e Fiscalização (CMO)}

Comissões são órgãos especiais dotados de função técnico-política, compostos por um número restrito de parlamentares. Em outras palavras, são o espaço em que se discutem os

\footnotetext{
$\overline{1074}$ MAURO, Paolo. Os efeitos da corrupção sobre crescimento, investimentos e gastos do governo: uma análise de países representativos. In: ELLIOT, Kimberly Ann (org.). Op. cit. p. 141-142.

1075 BRASIL. Congresso Nacional. Relatório final da Comissão Parlamentar Mista de Inquérito. Congresso Nacional. Criada através do Requerimento $n^{\circ}$ 151/93-CN, destinada a "apurar fatos contidos nas denúncias do Sr. José Carlos Alves dos Santos, referentes às atividades de parlamentares, membros do Governo e representantes de empresas envolvidas na destinação de recursos do Orçamento da União”. Vol. III, Brasília, jan. 1994, p. III.3.
} 
projetos de forma especializada conforme a matéria. Trata-se de uma divisão do trabalho parlamentar ${ }^{1076}$ aceita atualmente, mas que no passado já foi vista com desconfiança. ${ }^{1077}$ Se na Alemanha parlamentarista o equivalente da CMO é dotado de amplos poderes, na França semipresidencialista impõe-se-lhe uma série de restrições. ${ }^{1078}$

Hoje as desconfianças diminuíram a ponto de a Constituição de 1988 mencionar tarefas a serem desempenhas por comissões em várias passagens, ${ }^{1079} \mathrm{o}$ que talvez não se devesse aplicar à CMO. ${ }^{1080}$ De fato, esta repetidamente tem sido objeto de denúncias, das quais a mais contundente, apurada na CPMI do Orçamento, rotulou em 1993 parte de seus membros como integrantes da "Máfia do Orçamento", composta pelos "Anões do Orçamento".

Enviada a proposta de lei orçamentária ao Congresso Nacional, seu presidente a remeterá à $\mathrm{CMO},{ }^{1081}$ que "talvez venha a ser a mais poderosa comissão permanente no seio do Congresso Nacional", ${ }^{1082}$ a fim de iniciar a fase instrutória do procedimento. A CMO é instituída com a finalidade de examinar e apresentar pareceres acerca dos projetos de lei orçamentária, ${ }^{1083}$ além de fiscalizar as contas do Executivo. ${ }^{1084}$ Sua competência exclusiva neste aspecto lhe confere papel fulcral no processo, podendo até mesmo oferecer "substitutivo ao projeto original a ser apreciado pelo Plenário". ${ }^{1085}$

A CMO é composta por 84 congressistas - 63 deputados e 21 senadores -, respeitando-se o critério da proporcionalidade partidária. O relator-geral da comissão elaborará um parecer preliminar em que se analisa a receita estimada, comparando-a com

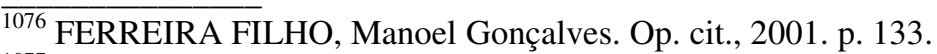

1077 BONAVIDES, Paulo. Op. cit. p. 242. A razão da desconfiança remontaria aos anos do terror da Revolução Francesa, levados a efeito pelo Comitê de Salvação Pública da Convenção Francesa. "A suspeita contra o órgão foi tamanha que o art. 67 da Constituição Francesa de 1795 vedava o estabelecimento dessas comissões em caráter permanente. Admitia apenas seu funcionamento para fins específicos, cumpridos os quais automaticamente se dissolveriam".

1078 TORRES, Ricardo Lobo. Op. cit. p. 62.

1079 SILVA, José Afonso da. Op. cit., 2008. p. 487.

1080 BENETON, Marco Antonio Hatem. Op. cit. p. 165. “A Comissão Mista de Planos, Orçamento Público e Fiscalização, ou CMO, tem vida praticamente 'autônoma' em detrimento das demais comissões parlamentares.”

1081 BRASIL. Congresso Nacional. Resolução n⿳o 01/2001.

1082 SILVA, José Afonso da. Op. cit., 2008. p. 480.

1083 BRASIL. Constituição (1988). Art. 166. "Os projetos de lei relativos ao plano plurianual, às diretrizes orçamentárias, ao orçamento anual e aos créditos adicionais serão apreciados pelas duas Casas do Congresso Nacional, na forma do regimento comum. $\S 1^{\circ}$ - Caberá a uma Comissão mista permanente de Senadores e Deputados: I - examinar e emitir parecer sobre os projetos referidos neste artigo e sobre as contas apresentadas anualmente pelo Presidente da República; II - examinar e emitir parecer sobre os planos e programas nacionais, regionais e setoriais previstos nesta Constituição e exercer o acompanhamento e a fiscalização orçamentária, sem prejuízo da atuação das demais comissões do Congresso Nacional e de suas Casas, criadas de acordo com o art. 58."

${ }^{1084}$ BENETON, Marco Antonio Hatem. Op. cit. p. 166.

1085 BENETON, Marco Antonio Hatem. O processo legislativo financeiro. 2007. 256 f. Tese (Doutorado em Direito Econômico e Financeiro)-Faculdade de Direito, Universidade de São Paulo, São Paulo. p. 169-170.
} 
exercícios anteriores, além de fixar critérios para o recebimento de emendas ao projeto. Tais pareceres possuem viés eminentemente político, e não se vislumbra caráter técnico mais detalhado. ${ }^{1086}$ Elaborados por políticos e não por técnicos, eles visam primordialmente atender aos interesses privados de seus redatores, que podem ser ou não congruentes com o interesse público.

\subsection{As emendas parlamentares}

Desde a República Velha, criticava-se severamente, em virtude de seu oportunismo, a prática de inserir emendas parlamentares (“caudas orçamentárias") sobre o orçamento em leis que dispunham sobre assuntos não relacionados a ele. ${ }^{1087}$ Sob a Constituição de 1946, o amplo poder de fazer emendas conferido aos parlamentares, desvinculadas de planejamento mais coerente e sistemático, dava azo ao uso corporativista e clientelista do orçamento, ${ }^{1088} \mathrm{O}$ que contrastava com a restrição severa imposta pela Constituição de $1967 .{ }^{1089}$

A Constituição de 1988 tentou mitigar esse problema: se a iniciativa do projeto é privativa e vinculada ao Chefe do Executivo, é razoável que haja limites de emendabilidade ${ }^{1090}$ - as emendas devem ser necessariamente compatíveis com o plano plurianual e a lei de diretrizes orçamentárias, ${ }^{1091}$ bem como devem indicar os recursos necessários para o provimento da despesa emendada. ${ }^{1092}$

\footnotetext{
$\overline{1086}$ Idem, p. 168. “[...] esses pareceres, a despeito de inclinarem por serem peças técnicas de orientação e opinião, são, no mais das vezes, pincelados ou motivados com aspectos e conotações de ordem política. Isto porque os membros dessas comissões não são técnicos, mas parlamentares que, em essência, são políticos que defendem os seus e os pontos de vista do partido político a que pertencem, o que fazem, então, vazar opiniões forradas em ideologias e particularismos."

1087 BALEEIRO, Aliomar. Op. cit. p. 442-443.

1088 SERRA, José. Op. cit. p. 11. "Já a Constituição de 1946 abria de tal maneira a possibilidade de emendas que transformava o orçamento em instrumento de nenhuma política coerente, pulverizado em função de pequenos objetos corporativistas ou clientelísticos. Isto, paradoxalmente, enfraquecia o Legislativo, pois, a fim de restabelecer alguma coerência e enquadrar as despesas dentro do limite do possível (o montante aprovado era sempre muito maior), o Executivo utilizava a poderosa arma da não-liberação de verbas, ampliando com isso suas possibilidades de manipulação sobre os parlamentares. A propósito, cabe lembrar o tipo de resposta que o ministro da Fazenda Santiago Dantas, em 1963, costumava dar aos deputados que o procuravam para pedir liberação de uma determinada verba contida no orçamento: 'Existe a verba, senhor deputado, mas não há dinheiro'."

${ }^{1089}$ BRASIL. Constituição (1967). Art. 65. Art. 66.

1090 BENETON, Marco Antonio Hatem. Op. cit. p. 171.

1091 BRASIL. Constituição (1988). Art. 166. "Os projetos de lei relativos ao plano plurianual, às diretrizes orçamentárias, ao orçamento anual e aos créditos adicionais serão apreciados pelas duas Casas do Congresso Nacional, na forma do regimento comum. [...] $\S 4^{\circ}-$ As emendas ao projeto de lei de diretrizes orçamentárias não poderão ser aprovadas quando incompatíveis com o plano plurianual."

1092 BRASIL. Constituição (1988). Art. 166, § $3^{\circ}$. "As emendas ao projeto de lei do orçamento anual ou aos projetos que o modifiquem somente podem ser aprovadas caso: I - sejam compatíveis com o plano plurianual e com a lei de diretrizes orçamentárias; II - indiquem os recursos necessários, admitidos apenas os provenientes de
} 
As emendas podem ser de três tipos: referentes à correção de texto e técnica legislativa; referentes a despesas ou, enfim, à receita estimada. Aquelas que aumentem despesas somente serão admitidas na hipótese de, além de estarem de acordo com as demais leis orçamentárias, apresentarem reestimativa de receitas, isto é, apontando equívocos no projeto ao se estimarem as receitas, de modo a apresentar recursos para a nova despesa.

Neste ponto, surge um inconveniente: o Chefe do Executivo pode encaminhar proposta com receitas propositalmente subestimadas e, ao invés de reapresentar o projeto, concorda que os parlamentares apresentem emendas de reestimativa de receitas, corrigindo o erro ou suprimindo a omissão do Executivo. Em correspondência a esse incremento, apresentam emendas parlamentares de despesas. Por ocasião do encaminhamento para sanção, o Chefe do Executivo veta somente as emendas de despesas e sanciona as de receita. Assim, tem-se uma receita sem destinação, um poder a ser exercido sem um correspondente dever legal, que poderá ser remanejada ao longo do exercício financeiro. ${ }^{1093}$

De fato, o $\S 8^{\circ}$ do art. 166 da Constituição parece legitimar essa manobra do Executivo, ao permitir que "os recursos que, em decorrência de veto, emenda ou rejeição do projeto de lei orçamentária anual, ficarem sem despesas correspondentes poderão ser utilizados, conforme o caso, mediante créditos especiais ou suplementares, com prévia e específica autorização legislativa". ${ }^{1094}$

Essa prática tem sido reiterada na elaboração orçamentária. ${ }^{1095}$ Ora, tal manobra subverte a finalidade do orçamento, corroendo-o pelas bordas e tornando-o desprovido de

anulação de despesa, excluídas as que incidam sobre: a) dotações para pessoal e seus encargos; b) serviço da dívida; c) transferências tributárias constitucionais para Estados, Municípios e Distrito Federal; ou III - sejam relacionadas: a) com a correção de erros ou omissões; ou b) com os dispositivos do texto do projeto de lei."

1093 BENETON, Marco Antonio Hatem. Op. cit. p. 177. “[...] não há que se falar em proibição do aumento de despesa em emendas ofertadas por parlamentares. Há, sim, que se falar em condicionamento de anulação de despesa em detrimento de outra e na correção de erros na quantificação das receitas."

${ }^{1094}$ BRASIL. Constituição (1988). Art. 166, § $8^{\circ}$.

1095 GIAMBIAGI, Fábio. A agenda fiscal. In: URANI, A.; GIAMBIAGI, F.; REIS, José Guilherme (Org.). Reformas no Brasil: balanço e agenda. Rio de Janeiro: Nova Fronteira, 2004. p. 231-257. Apud TOLDO, Nino Oliveira. Op. cit. p. 168-169. "Ao longo dos anos 90, mesmo depois do Plano Real e nos primeiros anos da década atual, o governo especializou-se em gerar superávits primários obtidos por meio de uma prática que o jargão jornalístico denomina de 'controle do gasto na boca do caixa'. Esta 'técnica' segue um habitual 'roteiro': em agosto, o governo encaminha ao Congresso um orçamento para o ano seguinte, relativamente enxuto; em dezembro, o Congresso reestima as receitas e aprova um orçamento modificado a proposta original, com ênfase no incremento dos gastos previdenciários, por conta da concessão de um aumento maior do que o inicialmente previsto para o salário mínimo; sabendo que a execução da despesa total orçada, em um quadro de receitas incertas, daria origem a um superávit primário inferior à meta, no início do ano o governo edita um decreto de reprogramação orçamentária, com receitas e despesas inferiores às estabelecidas no orçamento; com as manchetes, no dia seguinte à decisão, são sempre: 'governo corta tantos bilhões de reais'; e, havendo uma folga de recursos, no final do ano o governo autoriza despesas superiores às previstas no decreto de começo do ano, embora inferiores às que constavam do orçamento. Chega a ser um tanto grotesco analisar o tema 'cortes' à luz dos dados da tabela 3, que mostram um aumento significativo da despesa. A explicação concilia tais manchetes 
finalidade identificável facilmente. A síntese de Beneton explicita como se dá a corrupção política da ideia de controle do Executivo:

\begin{abstract}
Reside neste parágrafo um instrumento de poder muito forte nas mãos do Poder Executivo, principalmente em sede de remanejamento das alocações dos créditos orçamentários. A rejeição neste parágrafo deve ser entendida como aquela proveniente da oposição de veto parcial sobre itens do anexo de despesas do projeto de lei orçamentária. As receitas, que seriam para aquelas destinadas, ficam livres, mas permanecem no texto e no anexo de receitas da proposta que se transforma em lei. O perigo é encontrável naquelas situações em que o Chefe do Poder Executivo vete, propositalmente, uma emenda de aumento de despesa decorrente de reestimativa de receita, sem, contudo, vetar esta. Vislumbra-se uma tática política maquiavélica (no bom sentido da teoria geral da política), porque o Chefe do Executivo poderia, na proposta original, ter escamoteado a real dimensão da receita e esperado do Legislativo a reestimativa dela e a conseqüente destinação a aumentar uma despesa. Mata-se literalmente esta para ficar com o dinheiro... ${ }^{1096}$
\end{abstract}

Propostas as emendas e elaborados os relatórios setoriais, o relator-geral apresenta um parecer final, que compila todas as emendas apresentadas, sistematizando o projeto. Então, o relatório final, aprovado na CMO, é encaminhado ao Plenário, que o aprovará ou não, podendo-se apresentar destaques à votação em separado.

$\mathrm{O}$ excessivo poder do relator-geral da CMO sobre as emendas foi uma das causas que permitiram o desenvolvimento do "Esquema do Orçamento". Como a "emenda do Relator-Geral prescindia de publicação prévia", este "centralizava todas as decisões até, praticamente, o término do prazo disponível". No último momento, o relator-geral apresentava seu parecer sobre as emendas e sugeria as que deveriam ser aceitas, bem como adicionava outras - por causa dos atrasos intencionais no processo orçamentário, as votações se realizavam às vésperas do recesso parlamentar com quórum baixo no Congresso Nacional. ${ }^{1097}$ Ainda que a votação do orçamento ocorresse antes, devido à confusão

com a realidade dos fatos, pois parte da arrecadação prevista no orçamento corresponde ao que o jargão dos técnicos dos Ministérios da área econômica qualifica de 'receita de vento', ou seja, uma superestimação da receita, que a boa técnica orçamentária recomenda que não seja considerada como lastro para a realização da despesa. Note-se então que, ignorando a inflação, se em um ano gastando cem unidades e no ano seguinte o orçamento aprovado pelo Congresso - modificado em relação à proposta original - dispuser uma despesa de 120, das quais, por exemplo, 12 não tiverem fonte de receita assegurada, a decisão oficial limitando a despesa a 108 , eliminando despesas no valor de 12 , com o que as manchetes serão na linha de que o 'Governo corta $10 \%$ do orçamento', embora na realidade o gasto esteja aumentando $8 \%$. A repetição desse ritual tende a gerar uma situação curiosa: aos olhos do público, pela leitura dos jornais, o governo cortaria a despesa de todos os anos, embora no mundo real o gasto possa estar aumentando continuamente. É nisso que reside parte do paradoxo de um governo que aumentou o gasto em termos reais 6\% a.a. durante 1995-2002 ter ficado com a imagem de 'só' se preocupar com a estabilidade' após oito anos de arrocho."

${ }^{1096}$ BENETON, Marco Antonio Hatem. Op. cit. p. 199.

1097 BRASIL. Congresso Nacional. Relatório final da Comissão Parlamentar Mista de Inquérito Congresso Nacional. Criada através do Requerimento $n^{\circ}$ 151/93-CN, destinada a "apurar fatos contidos nas denúncias do Sr. José Carlos Alves dos Santos, referentes às atividades de parlamentares, membros do Governo e representantes de empresas envolvidas na destinação de recursos do Orçamento da União". Vol. III, Brasília, jan. 1994, p. III.3 e 4. "Para que se aquilate a importância da emenda de Relator, como foi empregada, observe- 
deliberadamente criada, poucos tinham capacidade de compreender rapidamente o que significavam aquelas emendas.

Depois de a CPMI do Orçamento ter investigado os eventos, formularam-se várias propostas para limitar o poder de emenda dos parlamentares, ${ }^{1098}$ as quais, entretanto, lograram êxito limitado, restringindo, por exemplo, as possibilidades de destaques durante a leitura e discussão do relatório final pelo relator-geral. ${ }^{1099}$ Mesmo assim, ainda que tivesse sido bemsucedida, o seu conteúdo parece ignorar a dinâmica das práticas orçamentárias que culminaram com o "Esquema do Orçamento": diante da limitação ou dos empecilhos às emendas individuais, as emendas coletivas tenderiam a acirrar o jogo de troca de favores. ${ }^{1100}$

Essa luta pelos recursos da União se dá com o comprometimento de outra função do Parlamento: fiscalizar a execução orçamentária. Transformados em "vereadores federais", os deputados e senadores exacerbam sua atividade de busca de recursos para suas bases eleitorais a ponto de se submeterem passivamente ao Executivo. ${ }^{1101}$ No pós-1988, diante das

se que o Deputado João Alves, em 1990, conseguiu com elas dar destinação a 1,09 bilhões de cruzeiros, de um total de 3,6 bilhões do Ministério da Ação Social, ou seja, nada menos que 30,2\% do total das verbas."

1098 BRASIL. Congresso Nacional. Relatório final da Comissão Parlamentar Mista de Inquérito. Congresso Nacional. Criada através do Requerimento $n^{\circ}$ 151/93-CN, destinada a "apurar fatos contidos nas denúncias do Sr. José Carlos Alves dos Santos, referentes às atividades de parlamentares, membros do Governo e representantes de empresas envolvidas na destinação de recursos do Orçamento da União”. Vol. III, Brasília, jan. 1994, p. VIII.14. "Parece-nos necessário limitar a prerrogativa de emendar a Lei Orçamentária, visto que através desse mecanismo vários desmandos foram praticados, beneficiando entidades supostamente beneficentes mas que escondiam apenas o interesse material do Parlamentar que as havia instituído. Ao se transferir par legislação infra-constitucional o que hoje consta da Carta Magna, referente ao processo de apreciação orçamentária, devem-se permitir unicamente emendas de autoria de Comissão, Bancada e Partido Político, fixados os seus valores através de critérios de proporcionalidade. A medida se mostra recomendável, por instituir um mecanismo que, sem retirar dos Parlamentares o necessário poder de ação em beneficio de seus estados e regiões, limita a possibilidade de emprego irregular da prerrogativa de emendar a Lei de Meios."

${ }^{1099}$ SANTA HELENA, Eber Zoehler. O processo de alocação de recursos federais pelo Congresso Nacional. in: Seminário Internacional De Assessoria E Consultoria Institucional Do Poder Legislativo. Câmara dos Deputados, de 30 jun. a 4 de jul. 2003. p. 13. Disponível em: <http://apache.camara.gov.br/portal/arquivos/Camara/internet/orcamentobrasil/orcamentouniao/estudos/artigos/ Artigo170.pdf $>$. Acesso em: 10 dez. 2009. "Enquanto durar a leitura e discussão do relatório são aceitos destaques à proposta orçamentária ou às emendas apresentadas. Tais destaques são discutidos e votados assim que for aprovado o relatório, ressalvados os destaques apresentados. A Resolução n⿳o 1/01-CN, seguindo tendência de outras resoluções extraordinárias anteriores, restringiu as possibilidades de destaque, sendo vedado o uso desses como substitutos de emendas. Os destaques, na verdade, representam um pedido de reconsideração acerca do parecer das emendas já apresentadas, não podendo, portanto, criar nova ação ou ultrapassar o valor solicitado na emenda ou o valor a ser recomposto do projeto original. Os assessores acompanham e apóiam todas as votações na Comissão. Ao longo dos trabalhos são gerados relatórios parciais e, no encerramento, todas as deliberações são organizadas e implantadas no sistema informatizado."

1100 SERRA, José. Op. cit. p. 1. "Outra idéia ingênua é a de proibir emendas individuais dos parlamentares, permitindo apenas emendas coletivas, de bancadas de partidos ou Estados. Na prática, cada parlamentar faria suas emendas e pediria aos outros para assinarem, e vice-versa. As emendas coletivas seriam, assim, emendas individuais disfarçadas e com uma vantagem para os espertos: seriam diluídas as responsabilidades.”

${ }^{1101}$ Idem, p. 60. "Poder-se-ia argumentar que é universal a tendência dos parlamentares de procurarem sempre atender às regiões que representam, levando-lhes um 'plus' de obras e serviços mesmo quando não prioritários em face de critérios nacionais. No Brasil, porém, essa tendência tem sido exacerbada pela fraqueza do Executivo, que usa a centralização dos gastos como condição para a manipulação e a conquista de votos no 
dificuldades inerentes à obtenção da maioria pelo Executivo no Congresso Nacional, a negociação sobre as emendas se torna moeda de troca no jogo político: o parlamentar deseja recursos para a sua região, ainda que haja necessidade ou oportunidade de melhor gasto em outra região, e, simultaneamente, o Executivo quer apoio para um ponto do seu interesse (projeto de lei, apoio em comissões parlamentares de inquérito, indicação de cargos submetidos à sabatina pelo Senado etc.), ainda que este não seja o mais condizente com o interesse público. Perde-se o interesse pelo debate para o aperfeiçoamento das leis, e o resultado é a barganha pura e simples. Consumado o acordo, fica a questão: quem vai fiscalizar os gastos governamentais, se o parlamentar ainda precisa da liberação efetiva dos recursos constantes do orçamento para a sua região?

\subsubsection{O orçamento novamente perante o Poder Executivo}

Aprovada a proposta de lei orçamentária, ela é encaminhada ao Executivo para a sanção. Embora haja polêmica sobre a possibilidade de veto total, isso dificilmente ocorreria, pois, afinal, é uma lei nitidamente especial, de modo que o atraso resultante de veto total traria grave dano ao Estado, cujos recursos ficariam sem alocação definida. ${ }^{1102}$ Nem sequer o Legislativo pode recusar em absoluto o projeto e quaisquer de seus substitutos. ${ }^{1103}$

Mesmo que a lei orçamentária aprovada não esteja condizente com os interesses do Executivo (por exemplo, ao dificultar a margem de manobra para cooptação dos entes federados mais frágeis economicamente), ainda assim podem ser usados vários artifícios legalmente aceitos para readaptar o orçamento. Além das já citadas (i) capacidade de vetar despesas e não vetar receitas e da (ii) Desvinculação das Receitas da União, o Executivo pode editar medidas provisórias para abertura de créditos suplementares e extraordinários, sem observar o processo legislativo previsto na Constituição para elaboração do orçamento. ${ }^{1104}$

A análise do que constitui um crédito adicional extraordinário corrobora a tese de que seu uso tem sido desproporcional. Créditos adicionais são "as autorizações de despesa não computadas ou insuficientemente dotadas na Lei de Orçamento". ${ }^{1105}$ Estes podem ser

Legislativo, bem como pela condição de 'vereadores federais' que os sistemas de governo e eleitoral impõem à esmagadora maioria dos parlamentares.”

1102 DALLARI, Adilson Abreu. Lei orçamentária - processo legislativo - peculiaridades e decorrências. Caderno de Direito Constitucional, São Paulo, n. 17, 1997.

${ }^{1103}$ BENETON, Marco Antonio Hatem. Op. cit. p. 197.

1104 TORRES, Ricardo Lobo. Op. cit. p. 69-70.

${ }^{1105}$ BRASIL. Lei no 4.320, de 17 mar. 1964. Art. 40. 
suplementares ("destinados ao reforço da dotação orçamentária"), especiais ("destinados a despesas para as quais não haja dotação orçamentária específica”) e extraordinários (“destinados a despesas urgentes e imprevistas, em caso de guerra, comoção intestina ou calamidade pública"). ${ }^{1106}$

Com a estabilização monetária, uma das recomendações da CPMI do Orçamento foi atendida: foram feitos menos pedidos de créditos suplementares, que se prestavam à "manipulação de verbas públicas"; afinal, "não é esse mecanismo em si mesmo ilegítimo, mas suas características mostram-se propícias à utilização irregular”. De fato, aprovadas no processo legislativo sob pressão do Executivo, há relativamente pouco tempo para o Legislativo analisar as leis com pedidos de $\operatorname{créditos}^{1107}$ - é possível identificar nesse momento uma oportunidade para a troca de favores entre União e parlamentares. Após a diminuição da inflação, o uso dos créditos suplementares, antes utilizados para pedir autorizações adicionais em virtude do elevado processo inflacionário que superava as expectativas e estimativas do orçamento, foi restringido e substituído pelos créditos extraordinários, hipótese utilizada mais frequentemente pela União do que o necessário. ${ }^{1108}$ Assim, o relato da prática recente mostra como os créditos adicionais têm sido usados:

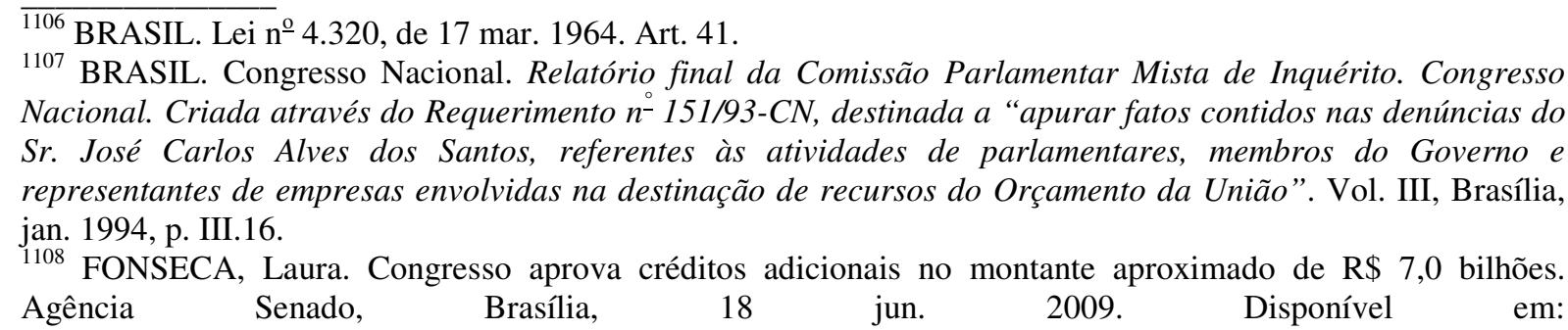
<http://www9.senado.gov.br/portal/page/portal/orcamento_senado/Noticias?codigo=212>. Acesso em: 2 jan. 2010 às 09h19. Embora afirmar que houve destinação política para créditos específicos exija um estudo pormenorizado do processo legislativo, a mera leitura das destinações de alguns desses créditos revela que, pelo menos, poderiam perfeitamente ter sido previstos na lei orçamentária. "O Congresso Nacional aprovou nesta quinta-feira (18) sete projetos para abertura de créditos especiais no valor global de, aproximadamente, $\mathrm{R} \$ 7$ bilhões, em favor da Presidência da República, dos ministérios das Cidades, da Defesa, das Relações Exteriores e da Ciência e Tecnologia, e da Empresa Brasileira de Infra-Estrutura Aeroportuária (Infraero). Os projetos seguem para sanção presidencial. O primeiro projeto aprovado beneficia a Presidência da República com crédito especial no valor de R \$ 492.078.530,00, que serão destinados à Secretaria Especial dos Portos para execução de obras de dragagem e adequação de navegabilidade em portos marítimos, que integram o Programa de Aceleração de Crescimento (PAC). Também foi aprovada emenda destinando mais R 9 milhões para obras no porto de Itajaí (SC). A líder do governo no Congresso, senadora Ideli Salvatti (PT-SC), considerou estratégica a preparação dos portos brasileiros para atender navios de grande calado, com o Brasil saindo da crise econômica e se preparando para acelerar o ritmo de crescimento. O segundo projeto aprovado destina R\$ 6 bilhões ao Ministério das Cidades, dos quais R $\$ 5,25$ bilhões serão direcionados para obras que diminuam o déficit habitacional, estimado em 6,2 milhões de unidades habitacionais. O crédito suplementar permitirá o financiamento à população de baixa renda para construção e compra de moradias urbanas e rurais. O terceiro projeto aprovado destina crédito especial no valor de $\mathrm{R} \$ 25$ milhões ao Ministério das Relações Exteriores para possibilitar apoio financeiro à Palestina, para reconstrução e desenvolvimento da Faixa de Gaza e prestação de assistência humanitária à sua população, notadamente nas áreas de segurança, alimentação saúde, habitação e infra-estrutura. Os parlamentares aprovaram ainda o quarto projeto em pauta, destinando crédito especial no 
E se também a LDO de 1990 não foi aprovada a tempo, nem antes mesmo do fim do exercício financeiro? Se o Estado não tiver um orçamento no início do exercício financeiro, nem a LDO, o Chefe do Poder Executivo terá que recorrer aos créditos extraordinários, encaminhando ao Poder Legislativo projeto de lei que solicite a abertura de crédito extraordinário em relação a órgãos específicos (princípio da unidade). O Governo Federal vem lançando mão do instrumento da medida provisória para poder obter a autorização necessária. Porém, trata-se de uma autoautorização, que prescinde, num primeiro momento, da figura do Poder Legislativo. ${ }^{1109}$

Outro mecanismo da União para controlar a execução orçamentária é o contingenciamento. Em teoria, consiste numa técnica que visa adequar as receitas efetivamente realizadas, antes somente previstas orçamento, às despesas autorizadas no orçamento: se as receitas se revelam menores do que as previstas no Anexo de Metas Fiscais da Lei de Diretrizes Orçamentárias, a União poderá limitar o empenho e a movimentação financeira. ${ }^{110}$

Está-se mais uma vez diante da escolha trágica de quais áreas sofrerão cortes - a própria LDO contém critérios a serem observados, o que poderia conceder maior objetividade ao processo. O problema reside justamente nos critérios estabelecidos, que são vagos e dotados de caráter quase que sugestivo: a própria Lei $\mathrm{n}^{\mathrm{o}}$ 12.017/09 confere ao Executivo ampla margem de discricionariedade, subvertendo a execução orçamentária com uma mera justificativa. ${ }^{1111}$

valor de R \$ 43.549.795,00 para a Infraero, para obras e renovação dos aeroportos de Fortaleza, Boa Vista, Salvador, Galeão (RJ), Guarulhos (SP) e Campinas (SP). Também foram acolhidos dois projetos concedendo créditos especiais ao Ministério da Ciência e Tecnologia (MCT). O primeiro, da ordem de R $\$ 42$ milhões, será repassado à empresa Centro Nacional de Tecnologia Eletrônica Avançada S.A. (Ceitec) para seu funcionamento e pagamento de pessoal e encargos sociais. A empresa tem como missão desenvolver soluções inovadoras em eletrônica e em tecnologia da informação com alto padrão de qualidade. O segundo crédito especial aprovado para o MCT, no valor de $\mathrm{R} \$ 149.299 .610,00$, também se destina ao desenvolvimento de novas tecnologias no Ceitec e no Centro Espacial de Alcântara, bem como para complementar os recursos referentes à parte brasileira na Alcântara Cyclone Space, empresa oriunda do Tratado de Cooperação Espacial assinado entre o Brasil e a Ucrânia. O sétimo e último projeto de concessão de crédito especial aprovado na sessão desta quinta-feira destina R $\$ 305$ milhões ao Ministério da Defesa, para reaparelhamento das Forças Armadas, em especial para fomentar o projeto de um avião cargueiro militar brasileiro, a ser desenvolvido pela Empresa Brasileira de Aeronáutica S.A. (Embraer). Na exposição de motivos, o Executivo argumenta que a Embraer reúne condições de potencializar a pesquisa militar que, numa etapa posterior, irá impulsionará a indústria civil. Os recursos também se destinam aos batalhões avançados do Exército que, nas fronteiras norte do Brasil, garantem a paz e cuidam de populações isoladas."

${ }^{1109}$ BENETON, Marco Antonio Hatem. Op. cit. p. 181.

${ }^{1110}$ BRASIL. Lei Complementar $\mathrm{n}^{\circ}$ 101, de 4 maio 2000. Art. $9^{\circ}$. "Se verificado, ao final de um bimestre, que a realização da receita poderá não comportar o cumprimento das metas de resultado primário ou nominal estabelecidas no Anexo de Metas Fiscais, os Poderes e o Ministério Público promoverão, por ato próprio e nos montantes necessários, nos trinta dias subseqüentes, limitação de empenho e movimentação financeira, segundo os critérios fixados pela lei de diretrizes orçamentárias."

${ }^{1111}$ BRASIL. Lei n⿳ 12.017, de 12 ago. 2009. Art. 4" "As prioridades e metas físicas da Administração Pública Federal para o exercício de 2010, atendidas as despesas que constituem obrigação constitucional ou legal da 
O relato de um ex-presidente da República é categórico sobre como se dá o personalismo no trato do orçamento público:

O ministro da Fazenda sabia, ou imaginava saber, o quanto seria arrecadado e dizia que não era nem 150 nem 100, mas 80. Então pedia ao presidente para baixar um decreto contingenciando o orçamento, ou seja, dizendo que, apesar de aprovado pelo Congresso, não seria executado. Ao contingenciar até a metade do ano, gasta-se $10 \%$ ou $12 \%$ do que foi aprovado. Isso distorce toda a administração e a subordina à área financeira. Quando o ministro da Fazendo tem uma visão política mais antiga, o que faz? Todos os outros ministros são subordinados a ele. Ele é quem decide se será feita essa ponte ou aquele hospital, porque é quem libera a verba. Isso arrebenta com qualquer administração que tenha metas, objetivos nacionais. Inverte tudo. ${ }^{112}$

Em consequência, uma vez mais se abre oportunidade para a União manobrar o empenho dos recursos conforme suas conveniências, utilizando um poder seu de modo não condizente com os deveres inerentes à administração pública. Sem a garantia de transferência dos recursos previstos no orçamento, este se torna mera peça de ficção, sujeitando à subserviência estados e municípios que necessitam desses recursos.

\subsubsection{A realização das despesas pelo Executivo e a não impositividade do orçamento}

Finda a elaboração da lei orçamentária anual, inicia-se a fase em que os recursos públicos são de fato despendidos. Apesar de a gestão orçamentária ser a fase em que as despesas são realizadas, a Constituição de 1988 e as demais regras de direito financeiro tendem a ser omissas a respeito. ${ }^{1113}$ Tal omissão causa surpresa, uma vez que a gestão requer maior atenção em virtude de sua complexidade. O paradoxo desta situação aumenta ao se constatar que há extensa regulamentação sobre os bens públicos, especialmente os imóveis, os

União e as de funcionamento dos órgãos e entidades que integram os Orçamentos Fiscal e da Seguridade Social, correspondem às ações relativas ao Programa de Aceleração do Crescimento - PAC e àquelas constantes do Anexo I desta Lei, especialmente as que promovam a redução do desemprego, igualdade de gênero e étnicoracial ou atendam a pessoas com deficiência e as despesas com a função irrigação, nos termos do art. 42 do Ato das Disposições Constitucionais Transitórias - ADCT, as quais terão precedência na alocação dos recursos no Projeto e na Lei Orçamentária de 2010, não se constituindo, todavia, em limite à programação da despesa. $\S 1^{\circ} \mathrm{O}$ Poder Executivo justificará, na mensagem que encaminhar o Projeto de Lei Orçamentária de 2009, o atendimento de outras despesas discricionárias em detrimento daquelas constantes do Anexo a que se refere o caput. [...] $\S 3^{\circ}$ Em caso de necessidade de limitação de empenho e movimentação financeira, os órgãos e as entidades da Administração Pública Federal deverão ressalvar, sempre que possível, as ações que constituam metas e prioridades estabelecidas nos termos deste artigo."

1112 TOLEDO, Roberto Pompeu. O presidente segundo o sociólogo: entrevista de Fernando Henrique Cardoso a Roberto Pompeu de Toledo. São Paulo: Companhia das Letras. 1998. p. 158. Apud TOLDO, Nino Oliveira. Op. cit. p. 168.

${ }^{1113}$ TORRES, Ricardo Lobo. Op. cit. p. 445. 
quais hoje possuem importância proporcionalmente muito inferior às despesas públicas. Três possíveis explicações para essa omissão se apresentam.

A primeira seria a complexidade da matéria, aparentemente sujeita às regras de contabilidade. Coincidentemente, em meados dos anos 1950, Almeida apontava a contabilidade como fator facilitador da frequência do crime de emprego irregular de verbas ou recursos públicos, tipificado no art. 315 do Código Penal. A contabilidade seria "tão propícia à regularidade da vida econômica da administração pública, quanto suscetível de, pelo artifício, pelo engenho e pelo sofisma, promover, com sensível nota, ensanchas para a prática do delito e para a impunidade dos delinqüentes". ${ }^{1114}$

A segunda explicação se relaciona com o patrimonialismo brasileiro. As autoridades enxergam o Estado como sua propriedade e utilizam-no personalizadamente: se a propriedade somente é limitada excepcionalmente, o mesmo deveria ocorrer com o modo de agir com a coisa pública. A autoridade não considerava que seu poder defluía da imposição de um dever para cumprir uma função, logo seria incoerente uma limitação oriunda do orçamento.

A terceira explicação remete a todas as exceções verificadas nas legislações orçamentárias, que as tornam meras peças de ficção, tais como os contingenciamentos, a desvinculação das receitas da União e as práticas cotidianas do jogo político. As autoridades percebem que a legislação orçamentária tem, de fato, capacidade de limitar o seu poder, na medida em que as vincula ao cumprimento de deveres e retira-lhes "direitos" que permitem dar as cartas no jogo político com estados e municípios. Para a sociedade civil, a faceta mais evidente da ação estatal é o fiscalismo, mas, para as autoridades, igualmente importante é poder utilizar o mais livre possível os vultosos recursos arrecadados.

Talvez por causa desse conjunto de traços implícitos na forma como as autoridades brasileiras enxergam o Estado e o posicionam na dicotomia público-privado, no passado ganhou força a ideia de que a gestão orçamentária estaria no âmbito da discricionariedade da administração. ${ }^{1115}$ A lei orçamentária seria lei em sentido formal, ou seja, apenas prevê receitas públicas e autoriza gastos, sem criar direitos subjetivos e sem modificar as leis tributárias e financeiras. As despesas fixas (v.g. funcionalismo e rolagem da dívida pública) vinculam de modo impositivo o Chefe do Executivo, sujeitando-o a crime de responsabilidade por sua não realização. Contudo, como as despesas variáveis não “criam direito subjetivo em favor das pessoas ou instituições, às quais viriam a beneficiar", acarretam apenas

\footnotetext{
$\overline{1114}$ ALMEIDA, Fernando H. M. Dos crimes contra a administração pública. São Paulo: Saraiva, 1955. p. 48-49. 1115 TORRES, Ricardo Lobo. Op. cit. p. 457.
} 
consequências políticas. ${ }^{1116}$ Embora tenha havido certa mitigação dessa visão, ${ }^{1117}$ as leis orçamentárias ainda assim seriam atos político-administrativos, protegidos pelo juízo de conveniência e oportunidade do mérito administrativo. ${ }^{1118}$ Essa era a posição reiterada do STF, que julgava escaparem ao controle abstrato de constitucionalidade as leis de efeito concreto como as orçamentárias. ${ }^{1119}$

A discussão remete àquela sobre a "obrigatoriedade da realização da despesa". ${ }^{1120}$ Como o orçamento é lei em sentido formal, não estaria o Executivo vinculado à realização das despesas ali contidas. A União decide o que executará do orçamento, especialmente na parte não vinculada e não sujeita às transferências obrigatórias. É impossível deixar de notar as condições propícias para a corrupção que tal interpretação enseja não só sobre o sistema federativo, mas também sobre todo o sistema político. Se, na moderna dicotomia públicoprivado, a autoridade que detém um poder só o detém para desempenhar uma função e cumprir um dever, então se está diante de uma exacerbação do personalismo na figura do Chefe do Executivo. Em desacordo com a teoria geral do direito, essa abordagem do orçamento torna sem efeito boa parte das regras de direito financeiro. Se o Parlamento outorga ao Executivo o poder de coletar tributos, não pode este ficar sem um correspondente

\footnotetext{
$\overline{1116}$ BALEEIRO, Aliomar. Op. cit. p. 441.

1117 TORRES, Ricardo Lobo. Op. cit. p. 458. “[...] outros atores e procedimentos ingressaram na prática orçamentária para moderar a discricionariedade administrativa: a) as titulações ou criação de direitos subjetivos pela legislação ou Judiciário; b) as vinculações constitucionais de receitas e despesas previamente indicadas; c) as despesas necessárias definidas pelo art. 17 da LRF; d) os tributos finalísticos e a pré-ponderação do constituinte ou do legislador."

1118 Idem, p. 96.

1119 BRASIL. Supremo Tribunal Federal. Ação Direta de Inconstitucionalidade n⿳o $1640-U F$. Pleno. Relator: Ministro Sydney Sanches. Julgado em 12 fev. 1998. "Direito constitucional e tributário. Contribuição Provisória sobre Movimentação Financeira - C.P.M.F. Ação Direta de Inconstitucionalidade da 'utilização de recursos da C.P.M.F." como prevista na Lei no 9.438/97. Lei orçamentária: ato político-administrativo - e não normativo. Impossibilidade jurídica do pedido: art. 102, I, 'a', da C.F. 1. Não há, na presente Ação Direta de Inconstitucionalidade, a impugnação de um ato normativo. Não se pretende a suspensão cautelar nem a declaração final de inconstitucionalidade de uma norma, e sim de uma destinação de recursos, prevista em lei formal, mas de natureza e efeitos político-administrativos concretos, hipótese em que, na conformidade dos precedentes da Corte, descabe o controle concentrado de constitucionalidade como previsto no art. 102, I, 'a', da Constituição Federal, pois ali se exige que se trate de ato normativo. Precedentes. 2. Isso não impede que eventuais prejudicados se valham das vias adequadas ao controle difuso de constitucionalidade, sustentando a inconstitucionalidade da destinação de recursos, como prevista na Lei em questão. 3. Ação Direta de Inconstitucionalidade não conhecida, prejudicado, pois, o requerimento de medida cautelar. Plenário. Decisão unânime”. BRASIL. Supremo Tribunal Federal. Ação Direta de Inconstitucionalidade no 2100-RS. Pleno. Relator: Ministro Néri da Silveira. Julgado em 17 dez. 1999. "Constitucional. Lei de diretrizes orçamentárias. Vinculação a programas. Previsão da inclusão obrigatória de investimentos não executados no orçamento anterior no novo. Efeitos concretos. Não se conhece da ação quanto a lei desta natureza, salvo quando estabelecer norma geral e abstrata. Ação não conhecida".
}

${ }^{1120}$ TORRES, Ricardo Lobo. Op. cit. p. 128. 
dever - o valor arrecadado deve ser executado de acordo com o que tiver sido autorizado pelo Parlamento, pois inexiste discricionariedade no trato das coisas afeitas ao espaço público. ${ }^{1121}$

Uma série de manobras do Executivo federal endossa essa tese.Independentemente da correição do argumento, o processo inflacionário dos anos 1980 foi associado ao déficit público. Como estratégia para conter o problema causador da inflação, os sucessivos governos ao longo dos anos 1990 adotaram medidas para limitar a execução do orçamento, o que é perfeitamente legal segundo a visão que considera a lei orçamentária uma lei em sentido formal e não obrigatória. O ímpeto desse processo de contenção da realização de despesas, denominado contingenciamento, tende a ser mais rígido no começo do ano e a relaxar à medida que o ano avança ou circunstâncias políticas o exigem. Toldo explica o curioso ciclo: "São inúmeras as notícias da liberação de verbas de emendas parlamentares em período próximo a votações de interesse do governo, em plenário ou, pior, em comissões parlamentares de inquérito. Ano após ano, a mesma coisa: em janeiro o contingenciamento; em dezembro, as liberações". ${ }^{1122}$

A alternativa para lidar com essa sujeição ao personalismo do orçamento pela União é torná-lo impositivo. Comparativamente aos regimes anteriores, a Constituição de 1988 reduziu bastante a discricionariedade do Executivo. ${ }^{1123}$ As dificuldades para implementar essa mudança são efetivamente grandes, inclusive do ponto de vista cultural da relação entre o Legislativo e o Executivo: mesmo naquela parte relativa às despesas que asseguram a independência institucional do Legislativo, Judiciário e Ministério Público, o Executivo de alguns estados por vezes relutam em transferir o que é devido de acordo com a lei orçamentária. ${ }^{1124}$ Entre as várias propostas, ao menos duas já deixaram suas casas de origem no Congresso Nacional. ${ }^{125}$

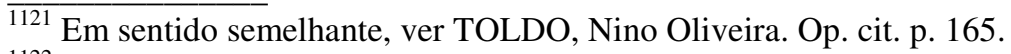

1122 TOLDO, Nino Oliveira. Op. cit. p. 168.

${ }^{1123}$ OLIVEIRA, Régis Fernandes de. Op. cit., 2003. p. 108. "Já se começa a ver que o legislador, ao estruturar a peça orçamentária, não tem mais a liberdade que possuía. Já está, parcialmente, vinculado. O que era uma atividade discricionária, que ensejava opções ao político na escolha e destinação das verbas, passa a ser vinculada. Não deixa de ser decisão política, uma vez que o constituinte optou por uma solução dentre as várias que possuía. Pode não ser a melhor, nem a menos ruim, mas é a solução que deu."

1124 BRASIL. Supremo Tribunal Federal. Ação Direta de Inconstitucionalidade no ${ }^{\circ}$ 732-RJ. Pleno. Relator: Ministro Celso de Mello. Julgado em 22 maio 1992. RTJ 143/57. "O comando emergente da norma inscrita no art. 168 da Constituição Federal tem por destinatário específico o Poder Executivo, o que está juridicamente obrigado a entregar, em conseqüência desse encargo constitucional, até o dia 20 de cada mês, ao Legislativo, ao Judiciário e ao Ministério Público, os recursos orçamentários, inclusive aqueles correspondentes aos créditos adicionais, que forma afetados, mediante lei, a esses órgãos estatais. A prerrogativa deferida ao Legislativo, ao Judiciário e ao Ministério Público pela regra consubstanciada no art. 168 da Lei Fundamental da República objetiva assegurar-lhe, em grau necessário, o essencial coeficiente de autonomia institucional. A ratio subjacente a essa norma de garantia radica-se no compromisso assumido pelo legislador constituinte de conferir às instituições destinatárias do favor constitutionis o efetivo exercício do poder de autogoverno que irrecusavelmente lhes compete. Assume inquestionável plausibilidade jurídica a tese, deduzida em sede de controle normativo abstrato, que sustenta a impossibilidade de o Estado-membro restringir a eficácia do preceito
} 
Por fim, deve ser lembrado que novo posicionamento do STF em sede de controle abstrato de constitucionalidade se inclina favoravelmente ao conhecimento de alegações de ilegitimidade na lei de caráter orçamentário, o que indica ser plausível uma atitude diferente em relação à não impositividade do orçamento. Apesar de se notar certa hesitação, o voto do ministro Gilmar Mendes considera equivocada a pretérita jurisprudência do STF, na medida em que "não se vislumbram razões de índole lógica ou jurídica contra a aferição de legitimidade das leis formais no controle abstrato, até porque abstrato - isto é, não vinculado ao caso concreto - há de ser o processo e não o ato legislativo submetido ao controle de constitucionalidade". ${ }^{1126} \mathrm{O}$ quanto essa jurisprudência avançará pode redefinir parte do caráter impositivo do orçamento.

consubstanciado no art. 168 da Constituição Federal. Essa norma constitucional impõe a observância compulsória das unidades políticas da federação e não parece admitir - para efeito de liberação mensal das quotas duodecimais - qualquer discriminação quanto à natureza dos recursos orçamentários, sejam estes referentes, ou não, às despesas correntes de custeio."

1125 As Propostas de Emenda à Constituição n⿳o 22 e 77 de autoria, respectivamente, dos senadores Antônio Carlos Magalhães e Íris Rezende, visam conferir impositividade à execução orçamentária e encontram-se em trâmite pelo menos desde 2000, mas avançam lentamente.

${ }^{1126}$ Supremo Tribunal Federal. Ação Direta de Inconstitucionalidade no ${ }^{\circ}$ 3949-MC/DF. Pleno. Relator: Ministro Gilmar Mendes. Julgado em 14 ago. 2008. "Medida cautelar em ação direta de inconstitucionalidade. 2. Art. 100 da Lei no 11.514 , de 14 de agosto de 2007. 3. Consideração dos efeitos de propostas de alterações na legislação tributária e das contribuições, inclusive quando se tratar de desvinculação de receitas, que sejam objeto de proposta de emenda constitucional, de projeto de lei ou de medida provisória que esteja em tramitação no Congresso Nacional, na estimativa das receitas do Projeto de Lei Orçamentária de 2008 e da respectiva lei. 4. Preliminar de não-cabimento rejeitada: o Supremo Tribunal Federal deve exercer sua função precípua de fiscalização da constitucionalidade das leis e dos atos normativos quando houver um tema ou uma controvérsia constitucional suscitada em abstrato, independente do caráter geral ou específico, concreto ou abstrato de seu objeto. Possibilidade de submissão das normas de diretrizes orçamentárias ao controle abstrato de constitucionalidade. Precedentes. 5. O art. 100 da Lei $\mathrm{n}^{-}$11.514/2007 possui conteúdo normativo comum a qualquer programa orçamentário, que deve conter, obrigatoriamente, a estimativa das receitas, a qual, por sua vez, deve levar em conta as alterações na legislação tributária. 6. A expressão 'legislação tributária', contida no § $2^{\circ}$ do art. 165, da Constituição Federal, tem sentido lato, abrangendo em seu conteúdo semântico não só a lei em sentido formal, mas qualquer ato normativo autorizado pelo princípio da legalidade a criar, majorar, alterar alíquota ou base de cálculo, extinguir tributo ou em relação a ele fixar isenções, anistia ou remissão. 7. A previsão das alterações na legislação tributária deve se basear nos projetos legislativos em tramitação no Congresso Nacional. 8. Apesar da existência de termo final de vigência da CPMF e da DRU (31 de dezembro de 2007), não seria exigível outro comportamento do Poder Executivo, na elaboração da proposta orçamentária, e do Poder Legislativo, na sua aprovação, que não o de levar em consideração, na estimativa de receitas, os recursos financeiros provenientes dessas receitas derivadas, as quais já eram objeto de proposta de Emenda Constitucional (PEC n⿳o 50, de 2007). O princípio da universalidade em matéria orçamentária exige que todas as receitas sejam previstas na lei orçamentária, sem possibilidade de qualquer exclusão. 9. Medida cautelar indeferida." Ver, também, precedente mais antigo no mesmo sentido: Supremo Tribunal Federal. Ação Direta de Inconstitucionalidade n⿳o 2925-DF. Pleno. Relatora: Ministra Ellen Gracie. Julgado em 19 dez. 2003. "Processo objetivo - Ação direta de inconstitucionalidade - Lei orçamentária. Mostra-se adequado o controle concentrado de constitucionalidade quando a lei orçamentária revela contornos abstratos e autônomos, em abandono ao campo da eficácia concreta. Lei orçamentária - contribuição de intervenção no domínio econômico - Importação e comercialização de petróleo e derivados, gás natural e derivados e álcool combustível - CIDE - Destinação Artigo 177, $\S 4^{\circ}$, da Constituição Federal. É inconstitucional interpretação da Lei Orçamentária no ${ }^{\circ}$ 10.640, de 14 de janeiro de 2003, que implique abertura de crédito suplementar em rubrica estranha à destinação do que arrecadado a partir do disposto no $\S 4^{\circ}$ do artigo 177 da Constituição Federal, ante a natureza exaustiva das alíneas 'a', 'b' e 'c' do inciso II do citado parágrafo." 


\section{CONCLUSÃO}

"Conhecidos os meios pelos quais se corrompem
e se dissolvem os Estados, podemos também
conjecturar qual o meio que os conserva. As
causas contrárias produzem efeitos contrários,
ora a conservação é o contrário da corrupção."

Aristóteles

Há mais de dois mil anos, os juristas têm pensado um sistema para dissuadir o descumprimento dos contratos, mas não se tem notícia de que alguém tenha propugnado um sistema que findaria por completo a inadimplência - a inadimplência é parte integrante dos contratos celebrados. Descumprir um contrato não é corrupção, mas, similarmente, revela uma ruptura na confiança que pressupõe a celebração do contrato. Como a base das relações contratuais é a confiança, também essencial para o funcionamento e o relacionamento do sistema político-administrativo, pode-se traçar um paralelo com o funcionário público que descumpre com o seu dever (e não obrigação, como se dá no direito privado) ou com o político que utiliza o seu poder (e não o seu direito, como se dá no direito privado) em desacordo com a finalidade inscrita no interesse público.

De igual modo, os direitos penal e administrativo tentam encontrar meios que fossem completamente o melhor sucedidos possíveis na dissuasão de comportamentos desviantes. É difícil acreditar que seja estabeleça uma situação totalmente à prova de falhas, o que permite concluir que a corrupção seria algo inerente à própria organização social e política. Acabar com a corrupção seria uma utopia. A experiência pretérita indica que aqueles que assim prometem normalmente precisam ser vistos com cautela pela sociedade.

Um sistema que tivesse por objetivo extirpar a corrupção por completo deveria criar um aparato fiscalizador que, por si só, seria custoso em demasia e poderia comprometer a eficiência da administração pública. Ademais, quem garantiria que tal mecanismo de controle seria à prova de falhas? Para ser eficaz, o sistema de controle utilizaria métodos que suscitariam questões sobre os direitos individuais, desnaturando a qualidade de Estado de Direito - por exemplo, até que ponto seria legítimo o Estado violar a privacidade de uma maioria de cidadãos honestos para punir um ou dois corruptos? 
Por esses motivos, mais racional seria a redução da corrupção a um nível mais aceitável. Logo, a pergunta correta seria: quanto se deve reduzir a corrupção?

Toda política pública, inclusive aquela voltada para o combate à corrupção, tem um custo para a sociedade, que deverá ser suportado por meio dos tributos arrecadados pelo Estado. Se a redução da corrupção é algo positivo para a sociedade e deve ser perseguida, qual o custo que se deve pagar? Qual o limite aceitável para o que deve ser gasto com o combate à corrupção?

A pergunta não possui resposta exata e precisa. Se moralistas relutam em admitir uma sociedade com algum grau de corrupção, os cínicos sustentam que alterar a tendência a um comportamento social estaria fora do alcance do direito. Há, porém, um referencial interessante que pode ser adotado: “[...] o grau dos gastos com prevenção à corrupção deve ser fixado onde os benefícios marginais [da diminuição da corrupção para a sociedade] são iguais aos custos". ${ }^{1127}$ Cada sociedade tem um referencial do que pode julgar tolerável da corrupção, bem como a avaliação do que sejam os benefícios resultantes da sua diminuição. Em outras palavras, o grau de intensidade do combate à corrupção varia de sociedade para a sociedade, de modo que a implementação de controles adicionais só fará sentido se o gasto adicional resultar em aumento do bem estar social suficientemente significativo para a sociedade. Tais medidas são úteis e podem reduzir grandemente as oportunidades para que a corrupção ocorra, na medida em que aumentam os custos para a prática e diminuem as recompensas.

Embora essas considerações, referentes à regulamentação microjurídica, estejam permeadas de uma visão mercantilizada da corrupção, tratando de problemas específicos e localizados, podem ter alguns de seus raciocínios aplicáveis ao plano macrojurídico. Não é factível promover mudanças estruturais permanentes na organização estatal, nem alterar com facilidade o comportamento de parcelas da população em seu comportamento com o Estado. Tampouco as mudanças radicais na estrutura do federalismo fiscal e do processo orçamentário são críveis no curto prazo em virtude do equilíbrio das forças políticas. Todavia, mudanças gradativas e pontuais mediante aperfeiçoamento institucional têm o condão de diminuir o grau de corrupção política na organização estatal e a confusão entre as esferas pública e privada, do mesmo modo que podem tornar a divisão de recursos e atribuições entre os entes federados menos desequilibrada. Não se deve subestimar o impacto de correntes modernizadoras, tais

$\overline{1127}$ ROSE-ACKERMAN, S. Corruption and government: causes, consequences and reform. Nova York: Cambridge University Press, 1999. p. 52. 
como a que defende uma reorganização de aspectos pontuais do federalismo fiscal brasileiro. Mesmo a importação da dicotomia público-privado desde o século XIX se fez sob o primado do império da lei e trouxe elementos modernizantes do positivismo jurídico, os quais foram aplicados sobre uma estrutura essencialmente patrimonialista, afastando-a em parte de alguns de seus caracteres originais.

Apesar do impacto da modernização ocorrida, tais considerações conduzem a uma hipótese de trabalho sobre a realidade brasileira cuja divulgação é bastante comum na imprensa: os mecanismos repressivos à corrupção funcionam de maneira insuficiente para dissuadir os potenciais infratores, uma vez que seria baixa a possibilidade de sanção efetiva. Por essa razão, foram analisadas as estratégias microjurídicas dos direitos civiladministrativo, penal e político-constitucional, a fim de compreender a sua estrutura, função e resultados. Do ponto de vista formal, embora haja a necessidade de uma melhor coordenação dos mecanismos de controle e repressão, cujos atores desempenham suas funções desarticuladamente, inexistem falhas substanciais no direito material, embora sempre haja a possibilidade de aperfeiçoamento - grosso modo, a importação formal da dicotomia públicoprivado foi completa pelo ordenamento jurídico brasileiro, o que significa que formalmente existe um Estado de Direito. Já do ponto de vista da efetividade da repressão, a sua insuficiência se traduz no alto índice de impunidade a esse crime do colarinho branco. Debateu-se, inclusive, como a teoria da regulação responsiva poderia contribuir para suprir essa deficiência, mas o uso das técnicas propostas também enfrentaria problemas similares aos da dicotomia público-privado.

Eventuais melhorias nas estratégias de regulamentação microjurídicas podem ter efeito limitado, pois no Brasil a corrupção tem causas mais profundas e estruturais do que a mera alocação de incentivos mercantis para os agentes envolvidos. Nesse ponto, a regulamentação microjurídica necessita compreender o direito pressuposto. As causas culturais que impregnaram a organização do Estado e, por meio do adesismo social, parte da sociedade brasileira tornam a eficácia da repressão microjurídica um desafio ainda maior. Deve-se perseguir sempre a melhoria no combate à corrupção na regulamentação microjurídica, quer seja no plano formal, quer seja no plano efetivo. Todavia, essa estratégia precisa ser reforçada.

O modo como a importação da dicotomia público-privado ocorreu no Brasil foi desacompanhado de mudanças estruturais na organização do Estado, o qual, em grande proporção, permaneceu patrimonialista em sua natureza. Não se trata da visão do soberano 
lusitano medieval que afirmava ser o Estado sua propriedade. Pelo contrário, o verniz modernizante aplicado pela positivação da dicotomia público-privado escamoteou as manifestações de apropriação do público pelo privado de tal modo que, em boa parte dos casos, a corrupção-solapamento é vista com naturalidade pelos envolvidos no jogo.

O neopatrimonialismo até pode estar associado à eficiência do Estado. A figura do coronel se modernizou e, atualmente, encarna o capaz de ter acesso aos recursos da União, adquiridos com o ímpeto arrecadatório fiscalista e despendidos de forma pessoalizada por seus detentores. O bem-sucedido coronel de hoje caminha com desenvoltura no espaço público em busca de recursos orçamentários para atender a seus interesses políticos pessoais, ignorando que o uso do seu poder, enquanto político eleito, somente pode ser feito para o cumprimento de um dever, voltado para uma finalidade pública.

Variados aspectos das manifestações do direito pressuposto foram descritas. A transparência, exigida por lei, enfrenta resistências até mesmo quando o texto normativo é explícito - com isso, esconde-se a apropriação do público pelo privado. Contudo, não é só esse viés da transparência que importa: em alguns momentos, a transparência é suprimida a pretexto da "segurança nacional", enquanto os interesses ocultos por trás da ação estatal distorcem o alcance e o significado do interesse público maior. Essa distorção revela que por diversas vezes o sistema político tende a camuflar as reais intenções de normas e atos administrativos sob o manto da discricionariedade. Parcela do funcionalismo público usa a estabilidade não para se defender das ingerências indevidas dos ocupantes de cargos políticos, mas sim para pleitear uma parcela maior das receitas dos tributos. Os 700 mil comissionados completam esse cenário, servindo de verdadeiro exército apenas aos interesses daqueles que os indicaram.

Ao examinar as peculiaridades do federalismo brasileiro, concluiu-se que a União centraliza os recursos da arrecadação fiscal e impõe a sua dominação aos demais entes federados de formas variadas em tamanha proporção que é inacurada a comparação com o funcionamento de outras federações, como os Estados Unidos e a Alemanha. Os políticos locais, movidos por suas ambições políticas, se submetem aos interesses da União e trocam apoio político incondicional por recursos financeiros para municípios e estados. Desarticulase o sistema partidário, pois o bom político é aquele que consegue verbas para seu município ou estado, não aquele que age fielmente ao que levou os eleitores a votar nele. O Legislativo se desvia de suas funções básicas de fazer leis e fiscalizar, tornando-se balcão de negócios, em que o apoio às bases e o acesso a cargos federais são a moeda de troca. 
Essas deformações institucionais no relacionamento entre as esferas pública e privada são parte do direito pressuposto e influenciam a corrupção no nível microjurídico, a qual, por sua vez, retroalimenta a corrupta organização estatal. Uma vez descartada a existência de um atavismo na formação nacional, pode-se, em quadro tão negativo, questionar a solução para romper esse círculo vicioso. "Receitas de bolo" trazidas de outros países e de instituições de pesquisa internacionais tendem a ignorar a específica realidade brasileira, considerando a corrupção como se fosse um fenômeno universal e atemporal. ${ }^{1128} \mathrm{O}$ mercantilismo das soluções desenhadas para o aperfeiçoamento da regulamentação microjurídica precisa ser analisado com muita cautela - as dificuldades já foram criticadas e expostas, ao se analisarem as limitações decorrentes da teoria da regulação responsiva, concebida em países anglo-saxões.

Quando se deixam de lado essas abordagens mercantis e redutoras da problemática da corrupção, outras "receitas de bolo" aparecem, similares às ideias ínsitas às leis de Duverger sobre o funcionamento dos sistemas político-representativos. À guisa de exemplo, tome-se como o modelo de Johnston analisa a corrupção no bojo do equilíbrio entre as elites e a sociedade, levando em consideração o tipo de oportunidades prevalentes para os indivíduos (onde estão as melhores chances de remuneração, na política ou no trabalho?) e o modo como se dá a concorrência entre as elites (apenas um grupo detém o poder ou há alternância?).

Seguindo o raciocínio proposto, a análise do Estado patrimonialista brasileiro revela que as melhores oportunidades estão na política, e o regime democrático tem formalmente garantido a alternância dos diversos grupos de interesse. Ao se observar o diagnóstico do cenário formulado por Johnston, existe certa aproximação com a realidade brasileira no tipo clientelismo fragmentado.

\footnotetext{
$\overline{1128}$ McDOUGAL, Myres S. The comparative study of law for policy purposes: value clarification as an instrument of democratic world order. Yale Law Journal, New Haven, v. 61, n. 6, p. 915-916, June/July 1952, Já nos anos 1950, o autor alertava para os riscos da importação pura e simples de modelos jurídicos. "We emphasize 'policy purposes' because we regard a jurisprudence which purports to be scientific only as inadequate. As important as it is for an observer not to permit his preferences to distort his vision of the events being observed, a creative jurisprudence requires not only the way of thinking and procedures of observation commonly called scientific but also a number of other integrated and interrelated methods of thought and observation. Such methods include the clarification of goal values, the description of historical and contemporary trends in the realization of values, the critical projection of trends into the future on the basis of historical and scientific knowledge, and the invention and evaluation of certain alternatives of policy by which fundamental goals can be most fully attained. The use of scientific procedure alone may, as many studies have demonstrated, be utterly haphazard and sterile. The other modes of thinking and observation are required to guide the use of scientific procedures to important problems, to determine the degree of mathematicization necessary in any particular investigation, and to process any kind of knowledge acquired for the use of decisionmakers. Effective inquiry into law requires emphasis upon both policy and science - in sum, a disciplined use of all relevant modes of thinking and observation."
} 
Tabela 31 - Estratégias para o controle da corrupção derivada do desequilíbrio político

\begin{tabular}{|c|c|c|}
\hline \multirow{2}{*}{$\begin{array}{l}\text { Equilíbrio de } \\
\text { oportunidade }\end{array}$} & \multicolumn{2}{|c|}{ Equilíbrio de elites entre Estado e sociedade } \\
\hline & Acessibilidade $>$ autonomia & Autonomia $>$ acessibilidade \\
\hline & \multicolumn{2}{|c|}{ Tipo de corrupção: } \\
\hline & Concorrência entre grupos de interesse & Hegemonia da elite \\
\hline & \multicolumn{2}{|c|}{ Estratégias de combate: } \\
\hline छี & $\begin{array}{l}\text { (i) Fortalecer e proteger a autonomia dos } \\
\text { agentes públicos, as fronteiras entre o Estado e } \\
\text { a sociedade, e prestar contas da burocracia } \\
\text { interna } \\
\text { (ii) Proteger a igualdade da concorrência } \\
\text { política }\end{array}$ & $\begin{array}{l}\text { (i) Ampliar a participação popular } \\
\text { (ii) Abrir os canais burocráticos e incorporá-los } \\
\text { à prática usual } \\
\text { (iii) Enfatizar a legalidade e a prestação de } \\
\text { de contas } \\
\text { (iv) Expandir a concorrência política }\end{array}$ \\
\hline
\end{tabular}

Exemplos:

(i) Leis de financiamento de campanha

(i) Independência burocrática judicial e de

(ii) Leis sobre formação de lobby

imprensa

(iii) Divulgação de bens e de interesses

(iv) Proteção e profissionalização do

funcionalismo público

(ii) Competitividade nas eleições

(iii) Fortalecimento da sociedade civil

(iv) Proteção dos direitos civis, políticos e de propriedade

Grupos estratégicos:

(i) Partidos políticos

(ii) Grupos lobistas

(iii) Grupos reformistas

(iv) Executivos burocráticos de nível médio

(v) Legisladores e suas equipes

(vi) Organização da sociedade civil (i) Parceiros de interesse econômico e de comércio exterior

(ii) Organizações comerciais

(iii) Juristas e burocratas do alto escalão

(iv) Profissionais liberais

(v) Legisladores e sua equipe

(vi) Elites de oposição em potencial

\section{Clientelismo fragmentado, Facciosismo}

Tipo de corrupção: ampliado e Mafiya

\section{Máquinas de clientelismo}

Estratégias de combate:
(i) Fortalecer e proteger a autonomia dos agentes públicos, as fronteiras entre Estado e
(i) Ampliar a participação popular e a sociedade

(ii) Fortalecer o Estado
(iii) Aumentar o crescimento econômico
(ii) Abrir o acesso à burocracia e incorporá-lo à prática usual

(iii) Aumentar o crescimento econômico

\section{Exemplos:}
(i) Leis eleitorais (verbas e partidos)
(i) Independência burocrática e judicial
(ii) Profissionalização burocrática e judicial
(ii) Liberdade de imprensa e direitos civis
(iii) Cumprimento da lei
(iii) Fortalecimento da sociedade civil
(iv) Amplo crescimento econômico
(iv) Leis de transparência eleitoral
(v) Amplo crescimento econômico

Grupos estratégicos:
(i) Partidos políticos, grupos de interesse e
(i) Elites e partidos de oposição burocratas
(ii) Grupos independente da sociedade civil
(ii) Grupos lobistas
(iii) Supervisores da lei e juristas
(iii) Juristas e burocratas do alto escalão
(iv) Parceiros de comércio exterior
(iv) Parceiros de comércio exterior
(v) Elites de oposição em potencial
(v) Tecnocratas e profissionais liberais com formação no exterior

Fonte: JOHNSTON, Michael. Agentes públicos, interesses particulares e democracia sustentável: quando política e corrupção se unem. In: ELLIOT, Kimberly Ann (Org.). A corrupção e a economia global. Tradução de Marsel Nascimento Gonçalves de Souza. Brasília: UnB, 2002. p. 124-126. 
Contudo, a generalidade das sugestões para o combate à corrupção as torna inócuas, ${ }^{1129}$ uma vez que reformas institucionais são mais complexas por mexerem com os mais diversos interesses do que meras "receitas de bolo" podem fazer crer - as soluções propostas indicam mais como num Estado moderno se deveria portar a dicotomia públicoprivado: “(i) Fortalecer e proteger a autonomia dos agentes públicos, as fronteiras entre Estado e sociedade, (ii) fortalecer o Estado, (iii) aumentar o crescimento econômico". Assim, análise de Johnston não enfrenta os complexos problemas brasileiro de troca de favores entre a União e os demais entes federativos consubstanciados no processo orçamentário, ensejadores de corrupção nos planos micro e macrojurídico.

Para evitar as generalidades, é necessário, antes de tudo, tomar as medidas adequadas para aumentar a eficácia do combate à corrupção no plano microjurídico, revertendo a percepção generalizada sobre a corrupção existente. Nesse aspecto, embora não se possa descartar por completo a experiência estrangeira, estudos voltados para a peculiar situação brasileira devem ser feitos e têm sido feitos. Como o plano microjurídico influencia o macrojurídico, é de esperar algum impacto positivo sobre os níveis de corrupção-suborno e corrupção-favorecimento, mas limitado pelos influxos decorrentes da corrupção política, relacionada à estrutura e funcionamento do federalismo.

A exaltação da burocracia em Weber e da lei em Kelsen, trazida para o Brasil, não gerou o mesmo processo de modernização que criou o Estado de Direito nos países da Europa e da América do Norte. O que aconteceu no Brasil foi distinto e resultou numa forma peculiar de positivismo. Em que pesem as críticas que possam ser dirigidas ao processo de importação formal da dicotomia público-privado, sua gradual positivação tornou inaceitável a corrupção na regulamentação microjurídica e tem pressionado por mudanças de práticas no plano macrojurídico.

\footnotetext{
$\overline{1129}$ JOHNSTON, Michael. Agentes públicos, interesses particulares e democracia sustentável: quando política e corrupção se unem. In: ELLIOT, Kimberly Ann (Org.). A corrupção e a economia global. Tradução de Marsel Nascimento Gonçalves de Souza. Brasília: UnB, 2002. p. 127. “[...] Os seguintes fatores contribuiriam para um urgente fortalecimento institucional do Estado: interações mais harmônicas entre agentes públicos e interesses privados (na verdade, uma distinção mais clara entre os dois), prestação de contas e disciplina mais vigorosa para a elite e aperfeiçoamento de padrões de profissionalismo e de proteção para juristas, burocratas e supervisores da lei. A consolidação de um número limitado de partidos políticos sólidos de amplas bases (talvez por meio de leis de representação e de financiamento político que estimulem um sistema partidário como esse), a proliferação de grupos de interesse na sociedade civil fora da dominação pessoal de figuras políticas, o efetivo cumprimento da lei e a proteção dos direitos civis serão elementos necessários para convencer as pessoas de que podem interagir com o Estado por meio dos canais oficiais em vez de desenvolver relações pessoais.”.
} 
Aos poucos, fica evidente que a forma como as "negociações políticas" são conduzidas pouco tem a ver com parte legítima do jogo democrático ou com algo que acontece até mesmo nas democracias mais maduras. O modus operandi dessas "negociações políticas" se espraia de cima para baixo e induz à aceitação de comportamentos limítrofes. Se no Congresso Nacional o parlamentar pode barganhar o seu voto por recursos para a sua base, por que, num certame, a nascente liderança política não poderia trocar o seu apoio a um licitante por apoio financeiro na campanha eleitoral? A ilegitimidade da conduta da nascente liderança municipal se desvanece diante de justificativas como "rouba mas faz", "favoreci o concorrente para ter recursos para minha campanha, que é apoiada pela população" ou "é necessário jogar de acordo com as regras".

Uma melhora num dos dois espectros pode iniciar um movimento depurador das práticas. Da perspectiva microjurídica, esse movimento provirá da melhora da repressão às práticas corruptas já ilegais no ordenamento jurídico. Apesar dos percalços no combate à corrupção, a inquietude dos vários órgãos envolvidos nessa função tem produzido efeitos, ainda que incipientes. Da perspectiva macrojurídica, as possibilidades parecem menos favoráveis, uma vez que os políticos, inseridos na cultura do Estado patrimonialista, têm dificuldade em distinguir o público do privado. Porém, a crescente educação da população e a redução da pobreza "tornam os eleitores mais atentos e menos dependentes da necessidade de favores de governos". ${ }^{1130}$

Implícita nessa transformação, existe a necessidade de trazer para a modernidade a atuação da autoridade pública. Não há, necessariamente, um fracasso da autoridade pública: ${ }^{1131}$ esta apenas desempenhou de forma limitada e enviesada as funções que seriam esperadas de uma autoridade pública no Estado moderno. O Estado de Direito funciona de acordo com o direito pressuposto do patrimonialismo. Tampouco se trata de mera contradição entre a função delimitadora do poder, típica do direito administrativo, e a sua tendência autoritária, expressa em princípios como o da supremacia do interesse público. ${ }^{1132}$ Essa

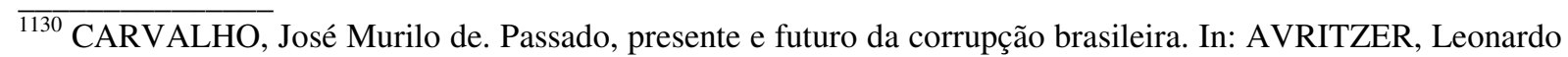
et al. (Org.). Corrupção: ensaio e críticas. Belo Horizonte UFMG, 2008. p. 242.

${ }^{1131}$ LOPES, José Reinaldo de Lima. Direitos humanos e tratamento igualitário: questões de impunidade, dignidade e liberdade. Revista Brasileira de Ciências Sociais. [online]. 2000, vol. 15, n. 42, p. 77-100. Disponível em: <http://www.scielo.br/scielo.php?script=sci_arttext\&pid=S010269092000000100006\&lng=en\&nrm=iso>. Acesso em: 28 dez. 2009. "A impunidade, a corrupção e outras formas de comportamento social predatório são estimuladas também pelo fracasso da autoridade pública. A autoridade, no Estado de direito, é naturalmente a autoridade da lei."

${ }^{1132}$ BUCCI, Maria Paula D. Direito administrativo e políticas públicas. São Paulo: Saraiva, 2002, p. 96. "A primeira contradição é aquela que existe entre a função do direito administrativo de organizar a estrutura administrativa, ao mesmo tempo em que é o instrumento jurídico de contenção do poder dentro dessa mesma 
contradição pode até existir, mas é, em relação ao problema ora investigado, subsidiária no contexto brasileiro.

O que existe é uma atitude em relação à autoridade que ignora a necessidade de que, no direito público do Estado moderno, o poder existe para cumprir um dever, e não para ser exercido personalizadamente. Da perspectiva da teoria geral do direito, esse movimento depurador implica um reposicionamento, no direito pressuposto, do conceito de autoridade e da forma como esta concebe sua atuação, especialmente quanto aos modo de operar atributos que lhe são inerentes. Deixar de lado o direito da autoridade de usar o poder em substituição ao poder da autoridade para desempenhar, exclusivamente, uma função prevista em lei é parte fulcral do processo de modernização efetiva do Estado no Brasil.

Tratar com otimismo simplório as reformas de inspiração sebastianista pode conduzir a decepções: o mecanismo do adesismo social, que reduz a sinceridade do ímpeto reformista, e a própria estrutura federal e fiscal, que dita práticas políticas legais, mas desprovidas de legitimidade, fomentam a corrupção no plano macrojurídico. A crescente tributação torna os eleitores, especialmente os da classe média, mais atentos à forma como os recursos são gastos: ${ }^{1133}$ o aumento da consciência fiscal pode redundar numa escolha eleitoral mais consciente.

Portanto, é possível ser otimista.

Não é à toa que a inspiração para a escolha do tema desta tese de doutorado surgiu da preocupação com a corrupção no Estado brasileiro na atualidade e com suas consequências sobre o funcionamento da economia e da sociedade. A subversão do interesse público pelo particular se faz presente nos noticiários quase que diariamente. Ao mesmo tempo, não raro o operador do direito se defronta com situações em que, apesar da forma legal, existe a impressão de que a finalidade condizente com o interesse público está sendo deixada de lado em favor de algum interesse privado.

Faz-se necessário encerrar a lógica corrupta que movimenta o sistema político, posto que esse verdadeiro vale-tudo, sob a égide do interesse público, não se coaduna com o verdadeiro significado deste - ainda que necessária, a regulamentação microjurídica abarca apenas parte do fenômeno. Muitas das decisões, aparentemente políticas ou técnicas,

estrutura. Os efeitos dessa contradição se revelam no fato de o direito administrativo estar na base do Estado de direito e de ter criado um quadro de legalidade que se fixou como padrão institucional mínimo para o exercício da autoridade em qualquer democracia liberal e, antagonicamente, ter construído o arcabouço de uma relação jurídica 'unilateral, autoritária e verticalizada' com os cidadãos."

${ }_{1133}$ CARVALHO, José Murilo de. Passado, presente e futuro da corrupção brasileira. In: AVRITZER, Leonardo et al. (Orgs.). Corrupção: ensaio e críticas. Belo Horizonte: UFMG, 2008. p. 242. 
justificadas pelo interesse público não se sustentariam num crivo mais exigente. Não se está propondo uma comissão de notáveis para avaliar o que é interesse público, tampouco se descarta o lobby legítimo de defesa de interesses, tentando demonstrar qual seria o interesse público. Uma transparência adicional, porém, seria bem-vinda, juntamente com reformas que se voltem para as áreas-chave do Estado brasileiro para diminuir a herança patrimonialista e torná-lo mais condizente com os parâmetros da dicotomia público-privado. Tão importante ainda, tais reformas precisam ser acompanhadas do necessário desenvolvimento político e cultural para evitar que as práticas corruptas se metamorfoseiem e permaneçam no Estado reformado. 


\section{BIBLIOGRAFIA}

ABBINK, K An experimental bribery game. Journal of Law, Economics and Organization, v. 18, n. 2, p. 428-454, 2002.

Staff rotation as an anti-corruption policy: an experimental study. European Journal of Political Economy, v. 4, n. 20, p. 887-906, 2004.

ABRAMO, Claudio Weber. Acham que somos idiotas? Folha de S. Paulo, São Paulo, 17 fev. 2006.

Brazil: a portrait of disparities. Brazilian Journalism Research, Brasília: UnB, v. 3, n. 1, p. 94-108, $1^{\text {o }}$ sem. 2007.

Percepções pantanosas: a dificuldade de medir a corrupção. Novos Estudos, São Paulo: Cebrap, n. 73, p. 34-37, nov. 2005.

ACOSTA, Fernando. La corruption politique dans le cadre du nouvel ordre mondial. Revista Brasileira de Ciências Criminais, São Paulo: Revista dos Tribunais, p. 251-316.

AFONSO, J. R. Rodrigues; SERRA, José. Federalismo fiscal à brasileira: algumas reflexões. Revista do BNDES, Rio de Janeiro: BNDES, v. 6, n. 12. p. 3-30, dez. 1999.

ALAM, M. S. Anatomy of corruption: an approach to the political economy of underdevelopment. American Journal of Economics and Sociology, Boston: Blackwell, v. 48, n. 4, p. 441-446, 1989.

ALATAS, S. H. The sociology of corruption: the nature, functions, causes and prevention of corruption. Kuala Lumpur: S. Abdul Majed, 1991.

ALMEIDA, Fernando H. M. Dos crimes contra a administração pública. São Paulo: Saraiva, 1955.

ALVES, Alaôr Caffé. Estado e ideologia: aparência e realidade. Apresentação de Dalmo de Abreu Dallari. São Paulo: Brasiliense, 1987.

Lógica, pensamento formal e argumentação: elementos para o discurso jurídico. Bauru: Edipro, 2000. 
AMUNDSEN, Inge. Political corruption: an introduction to the issues. Development Studies and Human Rights. Working paper n. 1999:7. Bergen: Chr. Michelsen Institute, 1999. Disponível em <http://www.cmi.no/publications/1999/wp/wp1999-7.pdf>. Acesso em: 24 nov. 2008 às $10 \mathrm{~h} 30$.

ANDERSON, James H.; GRAY, Cheryl W. Anticorruption in transition 3: Who is succeeding ... and why? Washington: World Bank, 2006.

ANDRADE, J. M. A.; MASSONETTO, L. F.; BERCOVICI, G. Reforma do Estado, prestações de serviços públicos, contribuições especiais e federalismo. Revista do Instituto de Pesquisas e Estudos, Bauru, v. 40, n. 45, p. 171-193, jan./jun. 2006.

ANDRADE, Mário. Macunaíma, o herói sem nenhum caráter. São Paulo: Livraria Martins, 1944.

ANDVIG, J. C. Experimental economics and corruption: a survey of budding research. In: Global Corruption Report. Berlim: Transparency International, 2005. p. 265-267.

ANDVIG, J. C.; MOENE, K. How corruption may corrupt. Journal of Economic Behavior and Organization, Montreal: Elsevier, v. 13, n. 1, p. 63-76, Jan. 1990.

ARCE, Javier; LE ROUX, Patrick (Org.) Cité et communauté civique en Hispania. Madri: Consejo Superior de Investigaciones Científicas, Casa de Velázquez, 1993.

ARENDT, Hannah. A condição humana. Tradução de Roberto Raposo. Posfácio de Celso Lafer. 9. ed. São Paulo: Forense Universitária, 1999.

The human condition. In: Philosophy and the problems of work: a reader. Maryland: Rowman \& Littlefield, 2001. p. 23-42.

ARISTÓTELES. A política. Tradução de Nestor Silveira Chaves. Introdução de Ivan Lins. Rio de Janeiro: Ediouro, [s.d.].

ATALIBA, Geraldo. Instituições de direito público e república. 1984. 215 f. Tese (Professor Titular)-Faculdade de Direito, Universidade de São Paulo, São Paulo. São Paulo.

ÁVILA, Humberto Bergmann. A distinção entre princípios e regras e a redefinição do dever de proporcionalidade. Revista de Direito Administrativo, Rio de Janeiro: Renovar, n. 215, p. 151-179, 1999.

AVRITZER, Leonardo et al. (Org.). Corrupção: ensaios e críticas. Belo Horizonte: UFMG, 2008. 
AZFAR, Omar: KNACK, Stephen. Are larger countries really more corrupt?. World Bank Policy Research. Working Paper n. 2470. Washington: World Bank, Nov. 2000, p. 20. Disponível em: <http://ssrn.com/abstract=632540>. Acesso em: 23 nov. 2008 às 22h34.

AYRES, I.; BRAITHWAITE, J. Responsive regulation: transcending the deregulation debate. Nova York: Oxford University Press, 1992.

AZEVEDO, Antonio Junqueira. O direito ontem e hoje. Crítica ao neopositivismo constitucional e à insuficiência dos direitos humanos. Revista do Advogado, São Paulo: AASP, ano 28, n. 99, p. 7-14, set. 2008.

BAIRD, Douglas G.; GERTNER, Robert H.; PICKER, Randal C. Game theory and the law. Harvard: Harvard University Press, 1998.

BALDWIN, R. Rules and regulation. Oxford: Oxford University Press, 1995.

BALDWIN, R.; CAVE, M. Understanding regulation: theory, strategy and practice. Oxford: Oxford University Press, 1999.

BALEEIRO, Aliomar. Uma introdução à ciência das finanças. 15. ed. rev. e atual. por Dejalma de Campos. Rio de Janeiro: Renovar, 1997.

BARBOSA, Rui. Comentários à Constituição Federal Brasileira. Coligidos e ordenados por Homero Pires. São Paulo: Saraiva, 1933. v. 4

BARDHAN, P.; MOOKHERJEE, D. Relative capture of local and central governments: an essay in the political economy of decentralization. Center for International and Development Economics Research (CIDER). Working Papers C99-109, University of California at 1998. Derkeley. <http://www.haas.berkeley.edu/groups/iber/wps/cider/c99-109.pdf>. Acesso em: 20 nov. 2009 às $22 \mathrm{~h} 30$.

BARDHAN, P.; MOOKHERJEE, D. Decentralization, corruption and government accountability: an overview. Boston University - Department of Economics - Working Papers Series WP2005-023, 2005. Disponível em: $<$ http://www.bu.edu/econ/workingpapers/papers/Dilip\%20Mookherjee/wp2005/decorr.p df>. Acesso em: 20 nov. 2009 às 23 h00.

BARKER, T.; ROEBUCK, J. B. Typology of police corruption. Social Problems, Berkeley, University of California Press, v. 21, n. 3, p. 423-437, 1974. 
BASTOS, Celso Ribeiro. Curso de direito constitucional. 20. ed. São Paulo: Saraiva, 2001.

BAYLEY, D. H. The effects of corruption in a developing nation. The Western Political Science Quarterly, Salt Lake City: University of Utah, v. 19, n. 4, p. 719-732, dez. 1966.

BECCARIA, Cesare. Dos delitos e das penas. Tradução de J. Cretella Jr. e Agnes Cretella. 3. ed. rev. São Paulo: Editora Revista dos Tribunais, 2006.

BELLUZZO, Luiz Gonzaga de Mello; GRAU, Eros Roberto. A corrupção no Brasil. Revista Brasileira de Estudos Políticos, Belo Horizonte, UFMG, n. 80, p. 7-20, jan. 1995.

BENETON, Marco Antonio Hatem. O processo legislativo financeiro. 2007. 256 f. Tese (Doutorado em Direito Econômico e Financeiro)-Faculdade de Direito, Universidade de São Paulo, São Paulo.

BERCOVICI, Gilberto. Desigualdades regionais, estado e Constituição. 1. ed. São Paulo: Max Limonad, 2003.

Federalismo e desenvolvimento regional no Brasil. In: SHOUERI, Luís Eduardo. Direito tributário. Homenagem a Paulo de Barros Carvalho. Quartier Latin: São Paulo, 2008. p. 879-905.

BERNARDI, Ovídio. Ação de enriquecimento ilícito e ação popular. Revista dos Tribunais, São Paulo, n. 314, p. 30-36, dez. 1961.

BERNSTEIN, M. H. Regulating business by independent commission. Westport, Connecticut: Greenwood Press, 1977.

BOBBIO, Norberto. Da estrutura à função: novos estudos de teoria do direito. Tradução de Daniela Beccaria Versiani. Revisão Técnica de Orlando Seixas Bechara e Renata Nagamine. Barueri: Manole, 2007.

Estado, governo, sociedade: por uma teoria geral da política. Tradução de Marco Aurélio Nogueira. Rio de Janeiro: Paz e Terra, 1987.

BOBBIO, Norberto; MATEUCCI, Nicola; PASQUINO, Gianfranco. Dicionário de política. Tradução de Carmen Varriale, Gaetano Lo Mônaco, João Ferreira, Luís Guerreiro Pinto Cacais e Renzo Dini. Coordenação da trad. João Ferreira. Revisão geral de João Ferreira e Luis Guerreiro Pinto Cacais. 11. ed. Brasília: UNB, 1998.

BODENHEIMER, Edgar. Teoría del derecho. 2. ed. Tradução de Vicente Herrero. México: Fondo de Cultura Económica, 1946. 
BOISSEVAIN, J. Patronage in Sicily. In: HEIDENHEIMER, Arnold J. Political corruption: readings in comparative analysis. 2. ed. New Brunswick: Transaction Books, 1978. p. 138-152.

BONAVIDES, Paulo. A constituição aberta: temas políticos e constitucionais da atualidade, com ênfase no federalismo das regiões. 2. ed. São Paulo: Editora Revista dos Tribunais, 1996.

Teoria do Estado. 6. ed. São Paulo: Malheiros, 2005.

BORSODI, Benjamin; FORKMAN, Anders. Is corruption still the second oldest business in the world?. Joint report of the Commercial Fraud, International Business, Banking, Finance \& Securities Law, Future of the Profession and Corporate Counsel Commissions (WS07 General Report) of the Association Internationale des Jeunes Avocat. Paris, 31 May 2008.

BRAITHWAITE, J.; GRABOSKY, P. Of manners gentle: enforcement strategies of australian business regulatory agencies. Melbourne: Oxford University Press, 1986.

BRASZ, H. A. The sociology of corruption. In: HEIDENHEIMER, Arnold J. Political corruption: readings in comparative analysis. 2. ed. New Brunswick: Transaction Books, 1978. p. 41-45.

BREMAEKER, François E. J. A situação fiscal dos municípios brasileiros em 2001. Rio de Janeiro: Instituto Brasileiro de Administração Municipal. Mar. 2003. (Série Estudos Especiais n. 47$)$. Disponível em: <http://info.worldbank.org/etools/docs/library/229953/Bremaeker\%20Situacao\%20Fisca 1.pdf>. Acesso em: 1 jan. 2009 às 15 h30.

A situação fiscal dos municípios brasileiros em 2002. Rio de Janeiro: Instituto Brasileiro de Administração Municipal. Set. 2003. (Série Estudos Especiais n. 55). Disponível em: $<$ http://info.worldbank.org/etools/docs/library/229953/Bremaeker\%20Situacao\%20Fisca 1.pdf>. Acesso em: 1 jan. 2009 às 16 h36.

BRESSER-PEREIRA, Luiz Carlos. Estado, sociedade civil e legitimidade democrática. Lua Nova - Revista de Cultura e Política, São Paulo: Cedec, n. 36, , p. 85-104, 1995. 
Prefácio. In: NUNES, Edson de Oliveira. Gramática política do Brasil: clientelismo e insulamento. Rio de Janeiro: Zahar, 1997.

BROSSARD, Paulo. O impeachment: aspectos da responsabilidade política do presidente da república. 3. ed. ampl. São Paulo: Saraiva, 1992.

BUCCI, Maria Paula D. Direito administrativo e políticas públicas. São Paulo: Saraiva, 2002.

BUGARIN, M. S.; FERREIRA, Ivan F. S. Transferências voluntárias e ciclo políticoorçamentário no federalismo fiscal brasileiro. Revista Brasileira de Economia, Rio de Janeiro, v. 61, n. 3, , p. 271-300, jul./set. 2007.

BURSZTYN, Marcel. O poder dos donos: planejamento e clientelismo no Nordeste. 3. ed. rev. e ampl. Rio de Janeiro: Garamond; Fortaleza: BNB, 2008.

CAGGIANO. Monica Herman S. Corrupção e financiamento das campanhas eleitorais. In: ZILVETI, Fernando Aurélio. LOPES, Silvia. O regime democrático e a corrupção política. São Paulo: Atlas, 2004. p. 116-143.

CAMERON, D. The expansion of the public economy: a comparative analysis. American Political Science Review, Washington, D.C., Cambridge University Press, v. 72, n. 4, p. 1243-1261, Dec. 1978.

CAMINHA, Pero Vaz de. Carta a El Rey Dom Manuel. Transcrita por Maria Angela Vilella. Fotografia por Antônio Caetano Santos. Ilustrações por Jorge Valente. 2. ed. com. e ilustr. São Paulo: Ediouro, 1999.

CARDONA, Alejandro Ramírez. Sistema de hacienda pública. Bogotá: Temis, 1970.

CARONE, Edgar. A República Nova (1930-1937). São Paulo: Difusão Europeia do Livro, 1970.

CARVALHO, José Murilo de. A construção da ordem. Rio de Janeiro: Civilização Brasileira, 2006.

Passado, presente e futuro da corrupção brasileira. In: AVRITZER, Leonardo et al (Org.). Corrupção: ensaios e críticas. Belo Horizonte: UFMG, 2008. p. 236-242.

CARVALHOSA, Modesto. A nova lei de sociedades anônimas. São Paulo: Paz e Terra, 1976. 
Poder econômico: a fenomenologia - seu disciplinamento jurídico. São Paulo: Editora Revista dos Tribunais, 1967. 145 f. Tese (Doutorado em Direito Comercial)Faculdade de Direito, Universidade de São Paulo, São Paulo.

CAVALCANTI, Márcio Novaes. Fundamentos da lei de responsabilidade fiscal. São Paulo: Dialética, 2001. p. 60-69.

CERVINI, Raúl. Os processos de descriminalização. Vários tradutores. Apresentação, notas e referências de Luiz Flávio Gomes. 2. ed. rev. da tradução. São Paulo: Editora Revista dos Tribunais, 2002.

CHARNESKI, Heron. Desvio orçamentário de finalidade das contribuições à luz do federalismo fiscal brasileiro: o caso Cide-combustíveis. Revista Dialética de Direito Tributário, São Paulo: Dialética, n. 128, p. 13- 23, maio 2006.

CHAUI, Marilena. Introdução à história da filosofia: dos pré-socráticos a Aristóteles. São Paulo: Companhia das Letras, 2002.

CLÈVE, C. M. Temas de direito constitucional e de teoria do direito. São Paulo: Acadêmica, 1993.

CLUNE, G. A. Implementation as autopoietic interaction of autopoietic organizations. In: TEUBNER, G.; FEBBRAJO, A. (Org.). State, law and economy as autopoietic systems: regulation and autonomy in new perspective. Milão: Giuffrè, 1992. p. 485-513.

COMPARATO, Fábio Konder. Ensaio sobre o juízo de constitucionalidade de políticas públicas. Revista dos Tribunais, São Paulo, ano 86, n. 737, p. 11-22, mar. 1997.

. O poder de controle na sociedade anônima. São Paulo: Editora Revista dos Tribunais, 1976.

COSTA, Susana Henriques da. O poder judiciário e a tutela do patrimônio público e da moralidade administrativa no Estado Democrático de Direito. 2006. 338 f. Tese (Doutorado em Direito Processual)-Faculdade de Direito, Universidade de São Paulo, São Paulo.

COULANGES, Foustel de. A cidade antiga. Tradução de Jean Melville. São Paulo: Martin Claret, 2001.

CRETELLA JÚNIOR, José. Direito administrativo brasileiro. Rio de Janeiro: Forense, 1999.

CURRAN, Mark J. História do Brasil em cordel. São Paulo: Edusp, 1998. 
DAHL, Robert A. Análise política moderna. Tradução de Sérgio Bath. Brasília: UnB, 1981. . Sobre a democracia. Tradução de Beatriz Sidou. Brasília: UnB, 2001.

DALLARI, Adilson Abreu. Lei orçamentária - Processo legislativo - Peculiaridades e decorrências. Revista de Informação Legislativa, Brasília, ano 33, n. 129, p. 157-162, jan./mar. 1996.

DALLARI, Dalmo de Abreu. Elementos de teoria geral do Estado. 19. ed. atual. São Paulo: Saraiva, 1995. O Estado federal. São Paulo: Ática, 1986.

DAVIS, K. C. Discretionary justice. Urbana: University of Illinois Press, 1969.

DAVOODI, H.; ZOU, H. F. Fiscal decentralization and economic growth: a cross-country study. Journal of Urban Economics, San Diego: Elsevier, v. 43, n. 2, p. 244-257, Mar. 1998.

DE CHIARA, José Tadeu. Instituições financeiras. In: FRANÇA, R. M. Enciclopédia Saraiva do direito. São Paulo: Saraiva, 1977. v. 47. p. 45-68.

DELGADO, Maurício Godinho. Curso de direito do trabalho. 8. ed. São Paulo: LTr, 2009.

DINAMARCO, C. R. Confiança. In: FRANÇA, R. M. Enciclopédia Saraiva do direito. São Paulo: Saraiva, 1977. v. 17. p. 512.

DININIO, Phyllis. Political science and anti-corruption assistance. Palestra apresentada no encontro anual da American Political Science Association, Boston Marriott Copley Place, Sheraton Boston \& Hynes Convention Center, Boston, Massachusetts, 28 ago. 2002, p. 14. Disponível em: http://www.allacademic.com/meta/p66389_index.html. Acesso em: 23 out. 2008 às 14h05.

DI PIETRO, Maria Sylvia Zanella. Direito administrativo. 20. ed. São Paulo: Atlas, 2007.

DOMINGUES, José Maurício. Patrimonialismo e neopatrimonialismo. In: AVRITZER, Leonardo et al. (Org.) Corrupção: ensaios e críticas. Belo Horizonte: UFMG, 2008. p. 188-201.

DROMI, Roberto. Sistema jurídico e valores administrativos. Porto Alegre: Sergio Fabris Editor, 2007. 
DURKHEIM, É. As regras do método sociológico. Tradução de Pietro Nassetti. São Paulo: Martin Claret, 2007.

DUVERGER, Maurice. Ciência política: teoria e método. Rio de Janeiro: Zahar, 1976.

ERNOUT, A.; MEILLET, A. Dictionnaire etymologique de la langue latine, histoire des mots. Paris: Klincksieck, 2001. v. 2.

FAORO, Raimundo. Os donos do poder: formação do patronato político brasileiro. 2. ed. rev. e aum. Porto Alegre: Globo; São Paulo: Edusp, 1975. 2v.

FARIA, José Eduardo. O direito na economia globalizada. São Paulo: Malheiros, 2000.

FAUPIN, Hervé. Le contrôle du financement de la vie politique, partis et campagnes. Prefácio de Claude Goyard. Paris: L.G.D.J/Montchrestien, 1998.

FAUSTO, Boris. O pensamento autoritário nacional. Rio de Janeiro: Jorge Zahar, 2001.

FAZZIO JÚNIOR, Waldo. Corrupção no poder público: peculato, concussão, corrupção passiva e prevaricação. São Paulo: Atlas, 2002.

FEOLI, Ludovico. Quarentena. In: AVRITZER, Leonardo et al. (Org.). Corrupção: ensaios e críticas. Belo Horizonte: UFMG, 2008. p. 583-590.

FERRAZ, Anna Cândida da Cunha. O poder constituinte do Estado-membro. São Paulo: Editora Revista dos Tribunais, 1979.

FERRAZ JÚNIOR. Tercio Sampaio. Introdução ao estudo do direito: técnica, decisão, dominação. 2. ed. São Paulo: Atlas, 1995.

Ética administrativa num país em desenvolvimento. Cadernos de Direito Constitucional e Ciência Política, São Paulo: Editora Revista dos Tribunais, jan./mar., p. 39-54, 1998.

FERREIRA, Waldemar Martins. O direito público colonial do estado do Brasil sob o signo pombalino. Rio de Janeiro: Editora Nacional de Direito, 1960.

FERREIRA FILHO, Manoel Gonçalves. A corrupção como fenômeno social e político. Revista de Direito Administrativo, Rio de Janeiro, n. 185, p. 1-18. jul./set., 1991.

. Corrupção e democracia. Revista de Direito Administrativo, Rio de Janeiro: Renovar, v. 226, p. 214-219, out./dez. 2001.

Do processo legislativo. 4. ed. São Paulo: Saraiva, 2001. 
FIGUEIREDO, Lúcia Valle. Corrupção administrativa. Revista Eletrônica de Direito do Estado, Salvador: Instituto de Direito Público da Bahia, n. 6, abr./maio/jun. 2006.

FILGUEIRAS, Fernando. Corrupção, democracia e legitimidade. Belo Horizonte: UFMG, 2008.

O problema da corrupção e a sociologia americana. Working paper. Juiz de Fora: Centro de Pesquisas Estratégicas Paulino Soares de Souza, 2006, p. 13. Disponível em: $<$ http://www.ecsbdefesa.com.br/fts/PCSA.pdf>. Acesso em: 8 dez. 2008 às 16h59.

FISMAN, R.; GATTI, R. Decentralization and corruption: evidence across countries. Journal of Public Economics, San Diego: Elsevier, v. 83, n. 3, ,p. 325-345, 2002.

FONSECA, Eduardo Giannetti da. Vícios privados, benefícios públicos?: a ética na riqueza das nações. São Paulo: Companhia das Letras, 2007.

FURTADO, Celso. Formação econômica do Brasil. 24. ed. São Paulo: Nacional, 1991.

GAETANI, Francisco. Funcionalismo público. In: AVRITZER, Leonardoet al. (Org.). Corrupção: ensaios e críticas. Belo Horizonte: UFMG, 2008. p. 485-493.

GATTO, Ruy Alberto. A atuação do Ministério Público em face da Lei nº 8429/92 (Lei Anticorrupção). Justitia, São Paulo, v. 55, n. 161, p. 54-60, jan./mar. 1993.

GERRING, J.; THACKER, S. Do neoliberal policies deter political corruption?. International Organization, Cambridge: University of Toronto, n. 59, p. 233-254, Winter 2005.

GOEL, Rajeev K.; RICH, Daniel P. On the economic incentives for taking bribes. Public Choice, Amsterdã, n. 61, p. 269-275, June 1989.

GOODNOW, Frank J. The principles of administrative law of the United States. Clark: The Lawbook Exchange, 2003.

GLYNN, Patrick; KOBRIN, Stephen J.; NAÍM, Moisés. Globalização da corrupção. In: ELLIOT, Kimberly Ann (Org.). A corrupção e a economia global. Tradução de Marsel Nascimento Gonçalves de Souza. Brasília: UnB, 2002. p. 27-58.

GRABOSKY, P.; BRAITHWAITE, J. Of manners gentle: enforcement strategies of Australian business regulatory agencies. Melbourne, Oxford University Press, 1986.

GRAU, Eros Roberto. A ordem econômica na Constituição de 1988. 3. ed. rev. e atual. São Paulo: Malheiros, 1997. 
O direito posto e o direito pressuposto. 3. ed. São Paulo: Malheiros, 2000.

. Elementos de direito econômico. São Paulo: Editora Revista dos Tribunais, 1981.

Ensaio e discurso sobre a interpretação/aplicação do direito. São Paulo: Malheiros,

2002.

Planejamento econômico e regra jurídica. São Paulo: Editora Revista dos Tribunais, 1997.

Tribunal de Contas - Decisão - Eficácia. Revista de Direito Administrativo, Rio de Janeiro, Renovar, n. 210, p. 351-356, 1997.

GRAY, M.; SANDHOLTZ, W. International integration and national corruption. International Organization, Cambridge: IO Foundation e Cambridge University Press, v. 57, p. 761-800, 2003.

GREENBERG, Theodore et al. Stolen asset recovery: a good practices guide for nonconviction based asset forfeiture. Washington: Banco Mundial \& UNODC, 2009. Disponível em: <http://siteresources.worldbank.org/EXTSARI/Resources/NCBGuideFinalEBook.pdf>. Acesso em: 27 nov. 2009 às 18 h20.

GUALAZZI, Eduardo Lobo Botelho; QUADROS NETO, Jânio. Jânio Quadros: memorial à história do Brasil. São Paulo: Rideel, 1996.

HANDLER, J. F. Dependent people, the state and the modern/postmodern search for the dialogic community. UCLA Law Review, Los Angeles, n. 35, p. 999-1113, 1988.

HAYEK, Friedrich A. von. Individualism and economic order. Chicago: University of Chicago Press, 1948.

HEIDENHEIMER, A. J.; JOHNSTON (Org.). Political corruption: concepts and contexts. 3.ed. New Brunswick: Transaction Publishers, 2002.

HOBBES, Thomas. Leviatã: ou matéria, forma e poder de um Estado eclesiástico e civil. Tradução João Paulo Monteiro e Maria Beatriz Nizza da Silva. Prefácio e revisão de João Paulo Monteiro. 2. ed. Lisboa: Imprensa Nacional, 1999.

HOLANDA, Sérgio Buarque de. A herança colonial - sua desagregação. In: HOLANDA, Sérgio Buarque de (Org.). História geral da civilização brasileira. 6. ed. São Paulo: Difel, 1985. t. II, v. 1. 
O Brasil monárquico. In: HOLANDA, Sérgio Buarque de (Org.). História Geral da civilização brasileira. 6. ed. São Paulo: Difel, 1985. t. II, v. 1.

HOOD, C. Explaining economic policy reversals. Buckingham: Open University Press, 1994.

HOUAISS, Antônio; VILLAR, Mauro de Salles. Dicionário Houaiss da língua portuguesa. Elaborado por Instituto Antônio Houaiss de Lexicografia e Banco de Dados da Língua Portuguesa S/C Ltda. Rio de Janeiro: Objetiva, 2001.

HORN, M. J. The political economy of public administration: institutional choice in the public sector. Cambridge: Cambridge University Press, 1985.

HORN, Norbert. Introdução à ciência do direito e à filosofia jurídica. Tradução da $2^{\mathrm{a}}$ ed. alemã de Elisete Anoniuk. Porto Alegre: Sergio Fabris Editor, 2005.

HORTA, Raul Machado. As novas tendências do federalismo e seus reflexos na Constituição brasileira de 1988. Revista do Legislativo, Belo Horizonte: Assembleia Legislativa de Minas Gerais, n. 25, p. 14-25, jan./mar. 1999. Disponível em: <http://www.almg.gov.br/revistalegis/Revista25/raul25.pdf>. Acesso em: 21 nov. 2009 às $13 \mathrm{~h} 22$.

HUNGRIA, Nélson. Comentários ao Código Penal (Dec.-Lei no 2.848, de 7 de dezembro de 1940). v. 9, Art. 250 a 361. 2. ed. Rio de Janeiro: Forense, 1959.

JAPIASSÚ, Carlos Eduardo Adriano. A corrupção em uma perspectiva internacional. Revista Brasileira de Ciências Criminais, São Paulo, Revista dos Tribunais, p. 29-53, jan./fev 2007.

JEHRING, Rudolf von. A evolução do direito. Tradução de O. de Meulenaere. Salvador: Livraria Progresso, 1953.

JELLINEK, Georg. Teoría general del Estado. Tradução da $2^{\mathrm{a}}$ ed. alemã. Prólogo de Fernando de Los Ríos. México: Nacional, 2000.

JOHSTON, Michael. Agentes públicos, interesses particulares e democracia sustentável: quando política e democracia se unem. In: ELLIOT, Kimberly Ann (Org.). A corrupção e a economia global. Tradução de Marsel Nascimento Gonçalves de Souza. Brasília: UnB, 2002. p. 103-134. 
KAGAN, R. A.; SCHOLZ, J. T. The criminology of the corporation and the regulatory enforcement strategies. In: HAWKINS, K.; THOMAS, J. M. Enforcing regulation. Boston : Kluwer-Nijhoff, 1984.

KANG, David C. Crony capitalism: corruption and development in South Korea and the Philippines. Cambridge: Cambridge University Press, 2002.

KANTI DEY, Harendra. The genesis and spread of economic corruption: a microtheoretic interpretation. World Development, v. 17, n. 4 , p. 503-511, 1989.

KAUFMAN, H. The forest ranger behaviour: a study of administrative behaviour. Baltimore: Johns Hopkins University Press, 1960.

KELSEN, Hans. Teoría general del Estado. México: Nacional, 1965.

Teoria pura do direito. Tradução de João Baptista Machado. 4. ed. São Paulo: Martins Fontes, 1994.

KLITGAARD, Robert. Controlling corruption. Berkeley/Los Angeles: University of California Press, 1988.

LAFER, Celso. O significado de república Estudos Históricos, Rio Janeiro, v. 2, n. 4, 1989, p. 214-224.

O sistema político brasileiro. São Paulo: Perspectiva, 1975.

LAMBSDORFF, Johann Graf. The institutional economics of corruption and reform: theory, evidence, and policy. Cambridge: Cambridge University Press, 2008.

LAMBSDORFF, Johann Graf; FRANK, Björn. Corrupt reciprocity: an experiment. Working Paper. Sept. 2007. Disponível em: $<$ http://www.wiwi.unipassau.de/fileadmin/dokumente/lehrstuehle/lambsdorff/downloads/Disc_Corrupt_Recipr ocity.pdf> Acesso em: 10 jan. 2010 às 13 h10.

LA PALOMBARA, Joseph G. A política no interior das nações. Tradução do $1^{\circ}$ ao $5^{\circ}$ capítulo de Marilu Seixas Correa e do $6^{\circ}$ em diante de Oswaldo Biato. Brasília: UnB, 1982.

LA PORTA, R. et al. Trust in large organizations. National Bureau of Economic Research. NBER Working Paper n. 5864, Cambridge, 1996. Disponível em: <http://www.nber.org/papers/w5864.pdf>. Acesso em: 1 dez. 2008 às $18 \mathrm{~h} 36$. 
LARENZ, Karl. Metodologia da ciência do direito. Tradução da $3^{\text {a }}$ edição portuguesa de José Lamego. Lisboa: Calouste Gulbenkian, 1997.

LEAL, Victor Nunes. Coronelismo, enxada e voto: o município e o regime representativo no Brasil. São Paulo: Alfa-Ômega, 1976.

LEITE, C.; WEIDMAN, J. Does mother nature corrupt? Natural resources, corruption, and economic growth. IMF Working Paper n. WP/99/85, Washington: FMI, July 1999. Disponível em: <http://www.imf.org/external/pubs/ft/wp/1999/wp9985.pdf>. Acesso em: 1 nov. 2008 às $20 \mathrm{~h} 48$.

LEITE, J. F. Marques; JORDÃO, A. J. Novaes. Dicionário latino vernáculo. Etimologia, literatura, história, mitologia e geografia. Rio de Janeiro: Lanston do Brasil e Henrique Velho, 1944.

LEVY, B.; SPILLER, P. T. A framework for resolving the regulatory problem. In: LEVY, B.; SPILLER, P. T. (Org.). Regulations, institutions, and commitment: comparative studies of telecommunications. Cambridge: Cambridge University Press, 1996. p. 1-35.

LIMA, M. Madeleine H. de P. Corrupção: obstáculos à implementação dos direitos econômicos, sociais e culturais. Revista de Direito Constitucional e Internacional, São Paulo: Editora Revista dos Tribunais, n. 33, p. 174-205, out./dez. 2000.

LIMA, Venício A. de. Mídia. In: AVRITZER et al. (Org.). Corrupção: ensaios e críticas. Belo Horizonte: UFMG, 2008. p. 527-533.

LIVIANU, Roberto. Corrupção e direito penal: um diagnóstico da corrupção no Brasil. Coimbra: Coimbra Editora, 2007.

LLANOS, Mariana; MUSTAPIC, Ana María. O controle parlamentar na Alemanha, na Argentina e no Brasil. In: LLANOS, Mariana; MUSTAPIC, Ana María (Org.). Controle parlamentar na Alemanha, na Argentina e no Brasil. Rio de Janeiro: Fundação Konrad Adenauer, 2005. p. 9-24.

LOEWENSTEIN, Karl. Teoría de la constitución. Traducción y studio sobre la obra por Alfredo Gallego Anabitarte. Barcelona: Ariel, 1970, 2t.

LOPES, J. R. L. Direitos humanos e tratamento igualitário: questões de impunidade, dignidade e liberdade. Revista Brasileira de Ciências Sociais, São Paulo: Anpocs, v. 42,
n.
15 ,
p.
77-100.
Disponível
em: 
$<$ http://www.scielo.br/scielo.php?script=sci_arttext\&pid=S010269092000000100006\&lng=en\&nrm=iso>. Acesso em: 28 dez. 2009.

LOWI, T. The end of liberalism: ideology, policy, and the crisis of public authority. Nova York: Norton, 1969.

MACDONELL, Arthur Anthony. A practical Sanskrit dictionary with transliteration, accentuation and etymological analysis throughout. Londres: Oxford University Press, Humphrev Milford, 1924.

MACRAE, J. Underdevelopment and the economics of corruption: a game theory approach. World Development, Montreal: Elsevier, v. 10, n. 8, p. 677-687, 1982.

MANCUSO, Wagner Pralon. O lobby da indústria no Congresso Nacional: empresariado e política no Brasil contemporâneo. Apresentação de Maria Hermínia Tavares de Almeida. São Paulo: Humanitas/Edusp, 2007.

MAJONE. G. From the positive to the regulatory state: causes and consequences of changes in the mode of governance. Journal of Public Policy, Cambridge: Cambridge University Press, n. 17, p. 139-167.

MARQUES NETO, Floriano Peixoto de Azevedo. Regulação estatal e interesses públicos. São Paulo: Malheiros, 2002.

MARSHALL, A. Principles of economics. 8. ed. Londres: Macmillan, 1920.

MARTINS, Fernando Rodrigues. Controle do patrimônio público: comentários à lei de improbidade administrativa. 3. ed. rev. atual e ampl. Prefácio à 3. ed. de José Tarcizo de Almeida Melo. São Paulo: Editora Revista dos Tribunais, 2009.

MAURO, Paolo. Os efeitos da corrupção sobre crescimento, investimentos e gastos do governo: uma análise de países representativos. In: ELLIOT, Kimberly Ann (Org.). A corrupção e a economia global. Tradução de Marsel Nascimento Gonçalves de Souza. Brasília: UnB, 2002. p. 135-167.

MBAKU, J. M. Bureaucratic corruption in Africa: the futility of cleanups. Cato Journal, Washington: Cato Institute, v. 16, n. 1, p. 99-118, 1996.

MCDOUGAL, Myres S. The Comparative study of law for policy purposes: value clarification as an instrument of democratic world order. Yale Law Journal, New Haven, v. 61, n. 6, p. 916-946. June/July, 1952. 
MEDAUAR, Odete. Direito administrativo moderno. 7. ed. São Paulo: Editora Revista dos Tribunais, 2003.

MEIRELLES, Hely Lopes. Direito administrativo brasileiro. 34. ed. São Paulo: Malheiros, 2008.

MELlo, Celso Antônio Bandeira de. Curso de direito administrativo. 19. ed. São Paulo: Malheiros, 2005.

MELLO, Marcos Bernardes de. Teoria do fato jurídico: plano da existência. 7. ed. atual. São Paulo: Saraiva, 1995.

MELLO, Oswaldo Aranha Bandeira de. Natureza jurídica do estado federal. São Paulo: Prefeitura do Município de São Paulo, 1948.

MEYNAUD, Jean. L'executif dans l'État moderne. Bulletin international des sciences sociales, Paris: Unesco, v. 10, n. 2, p. 185-211, 1958.

MILESKI, Hélio Saul. O controle da gestão pública. São Paulo: Editora Revista dos Tribunais, 2003.

MISHRA, A. Persistence of corruption: some theoretical perspectives. World Development, Montreal: Elsevier, v. 34, n. 2, p. 349-358, 2006.

MOMMSEN, Teodoro. Derecho penal romano. Reimpresión. Santa Fe de Bogotá: Temis, 1999.

MORAES, Alexandre de. Direito constitucional. 4. ed. São Paulo: Atlas, 1998.

MOTTA, Rodrigo Patto Sá. Corrupção no Brasil República - 1954-1964. In: AVRITZER, Leonardo et al. (Org.). Corrupção: ensaios e críticas. Belo Horizonte: UFMG, 2008. p. 243-249.

NASCIMENTO, Amauri M. Iniciação ao direito do trabalho. 17. ed. São Paulo: LTr, 1991.

NOHARA, Irene Patrícia. $O$ motivo no ato administrativo. 2002. 181 f. Dissertação (Mestrado em Direito do Estado)-Faculdade de Direito, Universidade de São Paulo, São Paulo.

NUSDEO, Fábio. Curso de economia: introdução ao direito econômico. 3. ed. rev. e atual. São Paulo: Editora Revista dos Tribunais, 2001. 
Fundamentos para uma codificação do direito econômico. 1993. 226 f. Tese (Titular)-Faculdade de Direito, Universidade de São Paulo, São Paulo.

OATES, W. An essay on fiscal federalism. Journal of Economic Literature, Nashville, American Economic Association, v. 37, n. 3, p. 1120-1149, Sept. 1999.

- Searching for Leviathan: an empirical study. American Economic Review, Nashville: American Economic Association, v. 75, n. 4, p. 748-757, Sept. 1985.

OLIVEIRA, Régis Fernandes de. Curso de direito financeiro. 2. ed. São Paulo: Editora Revista dos Tribunais, 2008.

Federalismo fiscal e pacto federativo. Revista Tributária e de Finanças Públicas, São Paulo: Editora Revista dos Tribunais, n. 61, p. 179-192, mar./abr. 2005.

OLIVEIRA, Régis Fernandes de; HORVATH, Estevão. Manual de direito financeiro. 6. ed. São Paulo: Editora Revista dos Tribunais. 2003.

PAGLIARO, Antonio; COSTA JÚNIOR, Paulo José. Dos crimes contra a administração pública. 4. ed. São Paulo: Atlas, 2009.

PAMPLONA, K. M. Federalismo fiscal, transferências intergovernamentais constitucionais e desenvolvimento regional: uma análise em prol da efetividade dos direitos humanos. Revista de Direito Tributário da APET, São Paulo, MP, v. 18, p. 103-123, 2008.

PARKER, C.; BRAITHWAITE, J.; STEPANENKO, N. ACCC enforcement and compliance project: report on ACCC compliance education and liaison strategies. Canberra: Centre for Competition and Consumer Policy, RegNet e Australian National University, 2004.

PIETH, Mark. Cooperação internacional no combate à corrupção. In: ELLIOT, Kimberly Ann (Org.). A corrupção e a economia global. Tradução de Marsel Nascimento Gonçalves de Souza. Brasília: UnB, 2002. p. 183-200.

PIRES, Adilson Rodrigues; TORRES, Heleno Tavares. Direitos fundamentais, federalismo fiscal e emendas constitucionais tributárias. In: Princípios de direito financeiro $e$ tributário. Estudos em homenagem ao Professor Ricardo Lobo Torres. Rio de Janeiro: Renovar, 2006. p. 63-74.

PRADO, Sérgio. Transferências fiscais e financiamento municipal no Brasil. São Paulo, jul. 2001. (Projeto Descentralização Fiscal e Cooperação Financeira Intergovernamental da Abep e Fundação Konrad Adenauer). Disponível em: < 
http://www.cepam.sp.gov.br/arquivos/artigos/TransferenciasFiscais\&FinancMunicipal.p df>. Acesso em: 1 jan. 2010 às 19h18.

QUEIROZ, Paulo de Souza. Do caráter subsidiário do direito penal: lineamentos para um direito penal mínimo. Belo Horizonte: Del Rey, 2002.

REALE, Miguel. $O$ direito como experiência: introdução à epistemologia jurídica. São Paulo: Saraiva, 1968.

REES, J. The development of communitarian regulation in the chemical industry. Law and policy, Hoboken: Blackwell, v. 19, n. 4, p. 477-528, Oct. 1997.

REZENDE, Flávio da Cunha. Por que falham as reformas administrativas?. São Paulo: FGV, 2004.

RODDEN, Johnathan. Federalismo e descentralização em perspectiva comparada: sobre significados e medidas. Revista de Sociologia e Política, Curitiba: UFPR, n. 24, p. 9-27, jun. 2005.

Reviving Leviathan: fiscal federalism and the growth of government. International Organization, Boston: Cambridge University Press, v. 57, n. 4, p. 695-729, 2003.

ROMANO, Roberto. Contra o abuso da ética e da mora. Educação \& Sociedade, Campinas: Cedes, ano 22, n. 76, p. 94-105, out. 2001.

ROSA, Christian Fernandes. Eficiência como axioma da teoria econômica do direito. 2008. 108 f. Dissertação (Mestrado em Filosofia do Direito)-Faculdade de Direito, Universidade de São Paulo, São Paulo.

ROSAS. Roberto A corrupção eleitoral. In: ZILVETI, Fernando Aurélio; LOPES, Silvia. $O$ regime democrático e a corrupção política. São Paulo: Atlas, 2004. p. 143-147.

ROSE-ACKERMAN, Susan. A economia política da corrupção. In: ELLIOT, Kimberly Ann (Org.). A corrupção e a economia global. Tradução de Marsel Nascimento Gonçalves de Souza. Brasília: UnB, 2002. p. 50-102.

Corruption and government: causes, consequences and reform. Nova York: Cambridge University Press, 1999.

Corruption: a study in political economy. Nova York/Londres: Academic Press, 1978. 
ROSS, Alf. Direito e justiça. Tradução de Edson Bini. Revisão técnica de Alysson Leandro Mascaro. Bauru: Edipro, 2000.

ROTH, André-Noël. O direito em crise: fim do Estado moderno?. In: FARIA, José Eduardo (Org.). Direito e globalização econômica: implicações e perspectivas. São Paulo: Malheiros, 1996. p. 15-28.

SABBAG, César de Moraes. Orçamento e desenvolvimento. 2005. 346 f. Tese (Doutorado em Direito do Estado)-Faculdade de Direito, Universidade de São Paulo, São Paulo.

SADEK, Maria Teresa. Ministério Público. In: AVRITZER, Leonardo et al (Org.). Corrupção: ensaios e críticas. Belo Horizonte: UFMG, 2008. p. 453-550.

SAINT-HILAIRE, Auguste. Voyage dans les provinces de Saint-Paul et de Sainte-Catherine. Paris: A. Bertrand, 1851.

SALDANHA JUNIOR, Cezar Saldanha. A supremacia do direito no Estado Democrático e seus modelos básicos. Porto Alegre: Novembro, 2002.

SALDANHA, Nelson. Ética e história. 2. ed. rev. e ampl. Rio de Janeiro: Renovar, 2007.

SANTA HELENA, Eber Zoehler. O processo de alocação de recursos federais pelo Congresso Nacional. Apresentação no Seminário Internacional de Assessoria e Consultoria Institucional do Poder Legislativo, realizado na Câmara dos Deputados de 30 de junho a 4 de julho de 2003. Disponível em: $<$ http://apache.camara.gov.br/portal/arquivos/Camara/internet/orcamentobrasil/orcament ouniao/estudos/artigos/Artigo170.pdf>. Acesso em: 10 dez. 2009.

SANTOS, Antônio Carlos dos. A política negada:poder e corrupção em Montesquieu. Prefácio de Marilena Chauí. São Cristóvão: Editora UFS/Fundação Oviêdo Teixeira, 2002.

SANTOS, Cláudia Cruz. O crime de colarinho branco, a (des)igualdade e o problema dos modelos de controlo. In: PODVAL, Roberto (Org.). Temas de direito penal econômico. São Paulo: Editora Revista dos Tribunais, 2001. p. 192-222.

O crime de colarinho branco: da origem do conceito e sua relevância criminológica à questão da desigualdade na administração da Justiça penal. Coimbra: Coimbra Editora, 2001. 
SANYAL, Rajib; SAMANTA, Subarna. Effect of perception of corruption on outward US foreign direct investment. Global Business and Economics Review, Worcester, v. 10, n. 1, p. 123-140, 2008.

SARTORI, Giovanni. Engenharia constitucional. Como mudam as constituições. Tradução de Sérgio Bath. Brasília: UnB, 1996.

SCANTIMBURGO, João de. Os paulistas. São Paulo: Imprensa Oficial, 2006. (Paulística, v. 21.)

SCHNEIDER, Aaron. Conflito político e instituições orçamentárias: aprofundando a democracia no Brasil. Revista de Sociologia Política, Curitiba, n. 24, p. 87-103, jun. 2005.

SCHUARTZ, Luís Fernando; POSSAS, Mario Luiz. Habilitação em licitações públicas e defesa da concorrência. Estudos Econômicos da Construção, São Paulo: SindusCon-SP, v. 3, n. 1, 1998.

SERRA, José. Orçamento no Brasil. 2. ed. rev. e ampl. São Paulo: Atual, 2004.

SHECAIRA, Sérgio Salomão. Criminologia e direito penal: um estudo das escolas sociológicas do crime. 2002. 406 f. Tese (Livre-Docência em Direito Penal)-Faculdade de Direito, Universidade de São Paulo, São Paulo.

SILVA, José Afonso da. Curso de direito constitucional positivo. 11. ed. São Paulo: Malheiros, 1996.

Processo constitucional de formação das leis. São Paulo: Malheiros, 2007.

SILVA, Luís Virgílio Afonso. Sistemas eleitorais: tipos, efeitos jurídico-políticos e aplicação ao caso brasileiro. São Paulo: Malheiros, 1999.

SILVA, Marcos Araujo. A utilização do SIAFI nas atividades de fiscalização do Tribunal de Contas da União. 2008. 52 f. Monografia (Especialização em Orçamento Público)Instituto Serzedello Corrêa do Tribunal de Contas da União, Centro de Formação, Treinamento e Aperfeiçoamento da Câmara dos Deputados e Universidade do Legislativo Brasileiro, do Senado Federal, Brasília.

SILVEIRA, Renato de Mello Jorge da. Direito penal econômico como direito penal de perigo. São Paulo: Revista dos Tribunais, 2006.

SIMONSEN, Mário Henrique. A nova economia brasileira. São Paulo: José Olympio, 1971. 
SIMPSON, A. E. The literature of police corruption. Nova York, John Hay Press, v. 1, 1977.

SMITH, Adam. A riqueza das nações: investigação sobre sua natureza e suas causas. Tradução de Luiz João Baraúna. Introdução de Edwin Cannan. Apresentação de Winston Fritsh. São Paulo: Abril Cultural, 1983. (Os Economistas.)

SOUZA, Amaury de; LAMOUNIER, Bolívar. O futuro da democracia: cenários políticoinstitucionais até 2022. Revisa Estudos Avançados, São Paulo: Instituto de Estudos Avançados da USP, v. 20, n. 56, p. 53-60, 2006.

SOUZA, Celina. Federalismo e descentralização na Constituição de 1988: processo decisório, conflitos e alianças. Dados - Revista de Ciências Sociais, Rio de Janeiro, v. 44, n. 3, p. 513-560, 2001.

SOUZA, Jessé. Weber. In: AVRITZER, Leonardo et al. (Org.) Corrupção: ensaios e críticas. Belo Horizonte: UFMG, 2008. p. 81-90.

SOUZA, Luciano Anderson. Expansão do direito penal e globalização. São Paulo: Quartier Latin, 2007.

SPECTOR, Bertram I. Fighting corruption. In: Fighting corruption in developing countries: strategies and analysis. Bloomsfield: Kumarian Press, 2005. p. 1-12.

STANTON, Angela A. Evolving economics: synthesis MPRA Paper n. 767, posted 7. Nov. 2007. Disponível em: <http://mpra.ub.uni-muenchen.de/767/> Acesso em: 10 jan. 2010 à 1 h20.

STIGLER, G. J. The economic theory of regulation. Bell Journal of Economics and Management Science, Rand Corporation, v. 2, n. 1, p. 3-21, Spring 1971.

SUHARA, Manabu. Corruption in Russia: a historical perspective. In: Hayashi, Tadayuki. Democracy and market economics in Central and Eastern Europe: are new institutions being consolidated?. Sapporo: Slavic Research Center, Hokkaido University, 2004. p. 383-403.

SUNG, Hung-En. Fairer sex or fairer system? Gender and corruption revisited. Social Forces - International Journal of Social Research, Chapel Hill, University of North Carolina Press, v. 82, n. 2, p. 703-723, dez. 2003.

SUTHERLAND, Edwin H. White collar crime: the uncut version. New Haven: Yale University Press, 1983. 
White collar criminality. American Sociological Review, v. 5, n. 1, p. 2-10, Feb. 1940.

TÁCITO, Caio. Improbidade administrativa como forma de corrupção. Revista Diálogo Jurídico, Salvador: CAJ - Centro de Atualização Jurídica, v. 1, n. 8, nov. 2001.

TEMER, Michel. Elementos de direito constitucional. 15. ed. São Paulo: Malheiros, 2000.

THATCHER, Mark. From industrial policy to a regulatory state: contrasting institutional change in Britain and France. In: HAYWARD, J. E. S.; MENON, A. Governing Europe. Oxford: Oxford University Press. p. 313-329.

TOCQUEVILLE, Alexis de. Democracy in America. Adelaide: The University of Adelaide Library, 2008. Disponível em: < http://ebooks.adelaide.edu.au/t/tocqueville/alexis/democracy/>. Acesso em: 27 set. 2009 às $15 \mathrm{~h} 11$.

TOJAL, Sebastião Botto de Barros. O controle judicial da atividade normativa das agências reguladoras. Revista da Academia Brasileira de Direito Constitucional, Curitiba, v. 2, p. 75-103, 2002.

TOLDO, Nino Oliveira. O orçamento como instrumento de efetivação das políticas públicas no Brasil. 2006. 205 f. Tese (Doutorado em Direito Econômico-Financeiro)-Faculdade de Direito, Universidade de São Paulo, São Paulo.

TOLEDO, Francisco de Assis. Princípios básicos de direito penal: de acordo com a Lei $\mathrm{n}^{\mathrm{o}}$ 7.209, de 11-7-1984 e com a Constituição de 1988. 5. ed. São Paulo: Saraiva. 1994.

TÔRRES, Heleno Taveira. Direito tributário e direito privado: autonomia privada, simulação, elisão tributária. São Paulo: Editora Revista dos Tribunais, 2003.

- Tipicidade e hermenêutica dos conceitos e formas na construção das normas jurídicas. In: LIMA, Martonio M. B.; ALBUQUERQUE, Paulo A. M. Democracia, direito e política: estudos internacionais em homenagem a Friedrich Müller. São José: Conceito, 2006. p. 361-374.

TORRES, Ricardo Lobo. Tratado de direito constitucional, financeiro e tributário. 3. ed. atual. Até 31.12.2007, incluindo a Emenda Constitucional n. 56, de 20.12.2007. Rio de Janeiro: Renovar, 2008. v. 5 (O orçamento na Constituição). 
TREBILCOCK, Michael J.; IACOBUCCI, Edward M. Designing competition law institutions. World Competition, Amsterdã: Kluwer, v. 25, n. 3, p. 361-394.

TREISMAN, D. Decentralization and inflation: commitment, collective action, or continuity? American Political Science Review, Washington, D.C., Cambridge University Press, n. 94, p. 837-857, Dec. 2000.

. The causes of corruption: a cross-national study. Journal of Public Economics, San Diego: Elsevier, v. 76, n. 3, p. 344-345, June, 2000.

TULCHIN, Joseph S.; ESPACH, Ralph H. (orgs.) Combating corruption in Latin America. Washington: Woodrow Wilson Center Press; Baltimore: The Johns Hopkins University Press, 2000.

VIANNA, Francisco José de Oliveira. Instituições políticas brasileiras. Brasília: Conselho Editorial do Senado Federal, 1999. v. 1. (Biblioteca Básica Brasileira.)

Problemas de política objetiva. Rio de Janeiro: Nacional, 1930.

VIEIRA, Pe. Antônio. Sermão de Santo António aos Peixes. Porto: Porto Editora. (Clássicos da Língua Portuguesa). Disponível em: <http://web.portoeditora.pt/bdigital/pdf/NTSITE99_SerStoAntPeix.pdf>. Acesso em: 26 nov. 2009 às $14 \mathrm{~h} 49$.

VINHOSA, Francisco Luiz Teixeira. História administrativa do Brasil: Brasil sede da monarquia, Brasil Reino. v. 8 Coordenação de Vicente Tapajós. Brasília: Fundação Centro de Formação do Servidor Público, 1984.

WEBER, Max. Economia e sociedade: fundamentos da sociologia compreensiva. Tradução de Regis Barbosa e Karen Elsabe Barbosa. Revisão técnica de Gabriel Cohn. Brasília: Editora UnB, 1999. 2 v.

The sociology of religion. Introdução de Talcott Parsons. Prefácio de Ann Swindler. Boston: Beacon Press, 1993.

WEFFORT, Francisco. Formação do pensamento político brasileiro: idéias e personagens. São Paulo: Ática, 2006.

WEHLING, Arno. História administrativa do Brasil. Administração portuguesa no Brasil de Pombal a D. João (1777-1808). Coordenação de Vicente Tapajós. Brasília: Fundação Centro de Formação do Servidor Público, 1986. 
WEI, S. Natural openness and good government. World Bank Policy Research. Working Paper n. 2411. Washington: World Bank, July 1999, p. 1. Disponível em: <http://wwwwds.worldbank.org/servlet/WDSContentServer/WDSP/IB/2000/09/01/0000 94946_00082205414670/Rendered/PDF/multi_page.pdf>. Acesso em: 1 nov. 2008 às $20 \mathrm{~h} 58$.

WERNER, Guilherme Cunha. O crime organizado transnacional e as redes criminosas: presença e influência nas relações internacionais contemporâneas. 2009. 241 f. São Paulo. Tese (Doutorado em Ciência Política)-Faculdade de Filosofia, Ciências Humanas e Letras, Universidade de São Paulo, São Paulo.

WIBBELS, E. 2000. Federalism and the politics of macroeconomic policy and performance. American Journal of Political Science, Washington, D.C., Cambridge University Press, n. 44 , p. $687-702$, Oct. 2000.

WILKS, S.; BARTLE, I. The unanticipated consequences of creating independent competition agencies. West European politics, Abingdon: Routledge, v. 25, n. 1, p. 148172.

WILLIAMSON, Oliver E. The economic institutions of capitalism. Nova York: Free Press, 1985.

WILSON, James Q. The politics of regulation. In: FERGUSON, Thomas; ROGERS, Joel. The political economy: readings in the politics and economics of American public policy. 4. ed. Nova York: Basic Books, 1984. p. 82-103.

ZIMMERMANN, Gustavo. Orçamentos municipais paulistas. São Paulo em perspectiva, São Paulo: Fundação Seade, v. 10, n. 3, p. 96-102, 1996. 


\section{BIBLIOGRAFIA PRIMÁRIA}

AGÊNCIA ESTADO. Senado fez "trem da alegria" secreto. 19 jul. 2009. Disponível em $<$ http://www.estadao.com.br/nacional/not_nac405069,0.htm>. Acesso em: 2 dez. 2009 às $19 \mathrm{~h} 23$.

BÍBLIA. Português. Bíblia sagrada. $168^{\mathrm{a}}$ ed. Tradução portuguesa da versão francesa dos originais grego, hebraico e aramaico pelos monges beneditinos de Maredsous. Revisada por Frei José Pedreira de Castro. São Paulo: Editora Ave Maria, 2005. Edição Claretiana.

BOMPAN, F. Meta para fiscais da Receita gera polêmica. Diário do Comércio e Indústria, São Paulo, 28 out. 2009 às 12h04. Disponível em $<$ http://www.sindifisconacional.org.br/index.php?option=com_content\&view=article\&id $=5111:$ POL $\%$ C3\%8DTICA\%20ECON\%C3\%94MICA\&catid=45:na-

midia\&Itemid=73>. Acesso em: 28 out. 2009 às $16 \mathrm{~h} 24$.

BRASIL. . Ato Institucional no 1, de 9 abr. 1964. Ato Institucional no 2, de 27 out. 1965. Ato Institucional nº 5, de 13 dez. 1968.

Carta de Lei de 16 de dez. 1830 (“Código Penal do Império”). Coleção das Leis do Império do Brasil de 1830, Parte I, p. 142.

. Código de Conduta da Alta Administração Federal, de 21 ago. 2000. Diário Oficial da União. Brasília, 22 ago. 2000.

. Constituição (1988).

. Constituição (1824).

. Constituição (1891).

. Constituição (1934).

. Constituição (1946).

. Constituição (1967).

. Constituiçãa (1969).

. Constituição (1988). 
. Decreto $\mathrm{n}^{\mathrm{o}}$ 27, de 7 de jan. 1892. Regula o processo e julgamento do Presidente da Republica e dos Ministros de Estados nos crimes communs.

. Decreto no 154, de 26 de jun. 1991. Promulga a Convenção Contra o Tráfico Ilícito de Entorpecentes e Substâncias Psicotrópicas. Diário Oficial da União. Brasília, 27 jun. 1991.

. Decreto $\mathrm{n}^{\mathrm{o}} 2.799$, de 8 de out. 1998. Aprova o Estatuto do Conselho de Controle de Atividades Financeiras - COAF. Diário Oficial da União. Brasília, 9 out. 1998.

. Decreto $\mathrm{n}^{\mathrm{o}}$ 4.177, de 28 de mar, 2002. Transfere para a Corregedoria-Geral da União as competências e as unidades administrativas da Casa Civil da Presidência da República e do Ministério da Justiça que especifica e dá outras providências. Diário Oficial da União. Brasília, 1 abr. 2002.

Decreto $\mathrm{n}^{\mathrm{o}}$ 4.991, de 18 de fev. 2004. Aprova a Estrutura Regimental e o Quadro Demonstrativo dos Cargos em Comissão e das Funções Gratificadas do Ministério da Justiça, e dá outras providências. Diário Oficial da União. Brasília, 18 fev. 2004.

Decreto no 5.683, de 24 de jan. 2006. Aprova a Estrutura Regimental e o Quadro Demonstrativo dos Cargos em Comissão e das Funções Gratificadas da ControladoriaGeral da União, e dá outras providências. Diário Oficial da União. Brasília, 25 jan. 2006.

. Decreto $n^{\mathrm{o}}$ 5.687, de 31 de jan. 2006. Promulga a Convenção das Nações Unidas contra a Corrupção, adotada pela Assembléia-Geral das Nações Unidas. Diário Oficial da União. Brasília, 1 jan. 2006.

Decreto $\mathrm{n}^{\mathrm{o}}$ 5.820, de 29 de jun. 2006. Diário Oficial da União. Brasília, 30 jun. 2006.

Decreto $n^{\mathrm{o}}$ 6.656, de 20 de nov. 2008. Dá nova redação aos arts. $3^{\circ}, 7^{\circ}, 11$ e 13 do Anexo I e ao Quadro "a" do Anexo II ao Decreto n⿳ 5.683, de 24 de jan. 2006, que aprova a Estrutura Regimental e o Quadro Demonstrativo dos Cargos em Comissão e das Funções Gratificadas da Controladoria-Geral da União, e dá outras providências. Diário Oficial da União. Brasília, 21 nov. 2008, retif. 24 nov. 2008.

Decreto $\mathrm{n}^{\mathrm{o}}$ 77.834, de 16 jun. 1976. Estende a financiamentos do BNDE a bancos de investimento privados o sistema de incentivo fiscal previsto nos artigos $1^{\circ}, 2^{\circ}$ e $3^{\circ}$ do 
Decreto-lei no 1542, de 30 de março de 1964. Diário Oficial da União. Brasília, 17 jun. 1976.

. Decreto-Lei no 200, de 25 de fev. 1967. Dispõe Dispõe sôbre a organização da Administração Federal, estabelece diretrizes para a Reforma Administrativa e dá outras providências. Brasília. 27 fev. 1967, retificado em 17 jul. 1967.

. Decreto-lei. no 259, de 17 de set. 1968. Cria a Comissão Geral de Investigações e dá outras providências. Brasília. 18 ago. 1968.

Decreto-lei no 579, de 30 de jul. 1938. Organiza o Departamento Administrativo do Serviço Público, reorganiza as Comissões de Eficiência dos Ministérios e dá outras providências. Diário Oficial da União. Secção 1, p. 15168. Rio de Janeiro, 30 jul. 1938.

. Decreto-lei n⿳ำ 1.004, de 21 de out. 1969 (“Código Penal de 1969”).

. Decreto-lei $\mathrm{n}^{\mathrm{o}} 1.713$, de 28 de out. 1939. Dispõe sobre o Estatuto dos Funcionários Públicos Civis da União. Coleção de Leis do Brasil. Rio de Janeiro, 31 dez. 1939.

Decreto-lei no 2.848, de 7 de dez. 1940 (“Código Penal”). Institui o Código Penal. Diário Oficial da União. Rio de Janeiro, 31 dez. 1940.

Decreto-lei n⿳ 5.452, de 1 de maio 1943 (“Consolidação das Leis do Trabalho”). Aprova a Consolidação das Leis do Trabalho. Diário Oficial da União. Rio de Janeiro, 9 ago. 1943.

BRASIL. Lei $\mathrm{n}^{\mathrm{o}}$ 1.079, de 10 de abr. 1950. Define os crimes de responsabilidade e regula o respectivo processo de julgamento. Diário Oficial da União. Brasília, 12 abr. 1950.

. Lei $\mathrm{n}^{\mathrm{o}} 3.164$, de 1 de jun.1957. Prevê quanto ao disposto no parágrafo $31,2^{\mathrm{a}}$ parte, do artigo 141, da Constituição Federal, e dá outras providências. Diário Oficial da União. Rio de Janeiro, 1 jun. 1957.

Lei $\mathrm{n}^{\mathrm{o}}$ 3.502, de 21 de dez. 1958. Regula o seqüestro e o perdimento de bens nos casos de enriquecimento ilícito, por influência ou abuso do cargo ou função. Diário Oficial da União. Rio de Janeiro, 22 dez. 1958.

Lei $\mathrm{n}^{\mathrm{o}}$ 3.692, de 15 de dez. 1959. Institui a Superintendência do Desenvolvimento do Nordeste e dá outras providências. Diário Oficial da União. Rio de Janeiro, 16 dez. 1959. 
Lei $\mathrm{n}^{\mathrm{o}}$ 4.320, de 17 de mar. 1964. Estatui Normas Gerais de Direito Financeiro para elaboração e contrôle dos orçamentos e balanços da União, dos Estados, dos Municípios e do Distrito Federal. Diário Oficial da União. Brasília, 23 mar. 1964, retificado em 9 abr. 1964 e 3 jun. 1964.

Lei $\mathrm{n}^{\mathrm{o}}$ 4.595, de 31 de dez. 1964. Dispõe sobre a política e as instituições monetárias, bancárias e creditícias, cria o Conselho Monetário Nacional e dá outras providências. Diário Oficial da União. Brasília, 31 jan. 1995.

Lei n⿳0 4.717, de 29 de jun. 1965. Regula a ação popular. Diário Oficial da União. Brasília, 5 jul. 1965, republ. 8 abr. 1974.

. Lei $\mathrm{n}^{\mathrm{o}}$ 4.737, de 15 de jul. 1965. Institui o Código Eleitoral. Diário Oficial da União. Brasília, 19 jul. 1965.

Lei $\mathrm{n}^{\mathrm{o}}$ 5.172, de 25 de out. 1966. Dispõe sobre o Sistema Tributário Nacional e institui normas gerais de direito tributário aplicáveis à União, Estados e Municípios. Diário Oficial da União. Brasília, 27 out. 1966, ret. 31 out. 1966.

. Lei $\mathrm{n}^{\mathrm{o}}$ 5.173, de 27 de out. 1966. Dispõe sôbre o Plano de Valorização Econômica da Amazônia; extingue a Superintendência do Plano de Valorização Econômica da Amazônia (SPVEA), cria a Superintendência do Desenvolvimento da Amazônia (SUDAM), e dá outras providências. Diário Oficial da União. Brasília, 29 out. 1966.

. Lei no 6.404, de 15 de dez. 1976. Dispõe sobre as Sociedades por Ações. Diário Oficial da União. Brasília, 17 dez. 1976 (suplemento).

. Lei $\mathrm{n}^{\mathrm{o}} 7.347$, de 24 de jul. 1985. Disciplina a ação civil pública de responsabilidade por danos causados ao meio-ambiente, ao consumidor, a bens e direitos de valor artístico, estético, histórico, turístico e paisagístico (VETADO) e dá outras providências. Brasília, 25 jul. 1985.

Lei n⿳0 8.078, de 11 de set. 1990. Dispõe sobre a proteção do consumidor e dá outras providências. Diário Oficial da União. Brasília, 12 set. 1990, retificado em 10 jan. 2007.

Lei $\mathrm{n}^{\mathrm{o}}$ 8.112, de 11 de dez. 1990. Dispõe sobre o regime jurídico dos servidores públicos civis da União, das autarquias e das fundações públicas federais. Diário Oficial da União. Brasília, 19 mai. 1991. 
Lei $\mathrm{n}^{\mathrm{o}}$ 8.429, de 2 de jun. 1992. Dispõe sobre as sanções aplicáveis aos agentes públicos nos casos de enriquecimento ilícito no exercício de mandato, cargo, emprego ou função na administração pública direta, indireta ou fundacional e dá outras providências. Diário Oficial da União. Brasília, 3 jun. 1992.

Lei n⿳0 8.443, de 16 de jul. 1992. Dispõe sobre a Lei Orgânica do Tribunal de Contas da União e dá outras providências. Diário Oficial da União. Brasília, 17 jul. 1992.

Lei $\mathrm{n}^{\mathrm{o}}$ 8.884, de 11 de jun. 1994. Transforma o Conselho Administrativo de Defesa Econômica (Cade) em Autarquia, dispõe sobre a prevenção e a repressão às infrações contra a ordem econômica e dá outras providências. Diário Oficial da União. Brasília, p. 8437. COL 1.13 jun. 1994.

Lei $n^{0}$ 9.034, de 3 de maio 1995. Dispõe sobre a utilização de meios operacionais para a prevenção e repressão de ações praticadas por organizações criminosas. Diário Oficial da União. Brasília, 4 maio 1995.

Lei $\mathrm{n}^{\mathrm{o}}$ 9.279/96, de 14 de maio 1996. Regula direitos e obrigações relativos à propriedade industrial. Diário Oficial da União. Brasília, 15 maio 1996.

Lei no 9.427, de dez. 1996. Institui a Agência Nacional de Energia Elétrica ANEEL, disciplina o regime das concessões de serviços públicos de energia elétrica e dá outras providências. Diário Oficial da União. Brasília, 12 dez. 1996.

. Lei $\mathrm{n}^{\mathrm{o}}$ 9.472, de 16 jul. de 1997. Dispõe sobre a organização dos serviços de telecomunicações, a criação e funcionamento de um órgão regulador e outros aspectos institucionais, nos termos da Emenda Constitucional $n^{\circ}$ 8, de 1995. Diário Oficial da União. Brasília, 17 jul. 1997.

Lei n⿳ํㅗ 9.504, de 30 de set. 1997. Diário Oficial da União. Brasília, 1 out. 1997. Lei $\mathrm{n}^{\mathrm{o}}$ 9.613, de 3 de março de 1998. Dispõe sobre os crimes de "lavagem" ou ocultação de bens, direitos e valores; a prevenção da utilização do sistema financeiro para os ilícitos previstos nesta Lei; cria o Conselho de Controle de Atividades Financeiras - COAF, e dá outras providências. Diário Oficial da União. Brasília, 4 mar. 1998.

Lei no 9.784, de 29 de jan. 1999. Regula o processo administrativo no âmbito da Administração Pública Federal. Diário Oficial da União. Brasília, 1 fev. 1999, retificado em 11 mar. 1999. 
Lei $\mathrm{n}^{\mathrm{o}} 10.028$, de 19 de out. 2000. Altera o Decreto-lei $\mathrm{n}^{\mathrm{o}} 2.848$, de 7 dez. 1940 Código Penal, a Lei $n^{\circ}$ 1.079, de 10 abr. 1950, e o Decreto-lei no 201, de 27 fev. 1967. Diário Oficial da União. Brasília, 20 out. 2000.

. Lei n⿳o 10.406, de 10 jan. 2002 (“Código Civil”). Institui o Código Civil. Diário Oficial da União. Brasília, 11 jan. 2002.

. Lei $\mathrm{n}^{\mathrm{o}} 10.683$, de 28 maio 2003. Dispõe sobre a organização da Presidência da República e dos Ministérios, e dá outras providências. Diário Oficial da União. Brasília, 29 maio 2003.

Lei $\mathrm{n}^{\mathrm{o}} 11.204$, de 5 dez. 2005. Altera a Lei $\mathrm{n}^{\mathrm{o}} 10.683$, de 28 maio de 2003, que dispõe sobre a organização da Presidência da República e dos Ministérios; autoriza a prorrogação de contratos temporários firmados com fundamento no art. 23 da Lei $\mathrm{n}^{\mathrm{o}}$ 10.667, de 14 maio 2003; altera o art. $4^{\text {o }}$ da Lei $\mathrm{n}^{\mathrm{o}} 8.745$, de 9 dez. 1993, e a Lei no 11.182, de 27 set. 2005; e dá outras providências. Diário Oficial da União. Brasília, 6 dez. 2005.

Lei $\mathrm{n}^{\mathrm{o}}$ 12.017, de 12 ago. 2009. Dispõe sobre as diretrizes para a elaboração e execução da Lei Orçamentária de 2010 e dá outras providências. Diário Oficial da União. Brasília, 13 ago. 2009.

. Lei Complementar $\mathrm{n}^{\mathrm{o}}$ 62, de 28 dez. 1989. Estabelece normas sobre o cálculo, a entrega e o controle das liberações dos recursos dos Fundos de Participação e dá outras providências. Diário Oficial da União. Brasília, 29 dez. 1989.

. Lei Complementar n⿳0 91, de 22 dez. 1997. Dispõe sobre a fixação dos coeficientes do Fundo de Participação dos Municípios. Diário Oficial da União. Brasília, 26 mar. 2001.

Lei Complementar $\mathrm{n}^{\mathrm{o}}$ 101, de 4 maio 2000. Estabelece normas de finanças públicas voltadas para a responsabilidade na gestão fiscal e dá outras providências. Diário Oficial da União. Brasília, 5 jun. 2000.

Lei Complementar $n^{\circ}$ 105, de 10 jan. de 2001. Dispõe sobre o sigilo das operações de instituições financeiras e dá outras providências. Diário Oficial da União. Brasília, 11 jan. 2001. 
Lei Complementar $\mathrm{n}^{\mathrm{o}}$ 124, de 3 jan. 2007. Institui, na forma do art. 43 da Constituição Federal, a Superintendência do Desenvolvimento da Amazônia - SUDAM; estabelece sua composição, natureza jurídica, objetivos, área de competência e instrumentos de ação; dispõe sobre o Fundo de Desenvolvimento da Amazônia - FDA; altera a Medida Provisória no 2.157-5, de 24 ago. 2001; revoga a Lei Complementar $\mathrm{n}^{\mathrm{o}}$ 67, de 13 jun. 1991; e dá outras providências. Diário Oficial da União. Brasília, 4. jan. 2007.

Lei Complementar $n^{-}$125, de 3 jan. 2007. Institui, na forma do art. 43 da Constituição Federal, a Superintendência do Desenvolvimento do Nordeste - SUDENE; estabelece sua composição, natureza jurídica, objetivos, áreas de atuação, instrumentos de ação; altera a Lei n⿳⺈ 7.827, de 27 set. 1989, e a Medida Provisória nº 2.156, de 24 ago. 2001; revoga a Lei Complementar n⿳o 66, de 12 jun. 1991; e dá outras providências. Diário Oficial da União. Brasília, 4 jan. 2007.

Medida Provisória nº 2.143-31/2001, de 2 abr. de 2001. Altera dispositivos da Lei n⿳0 9.649, de 27 de maio 1998, que dispõe sobre a organização da Presidência da República e dos Ministérios, e dá outras providências. Diário Oficial da União. Brasília, 3 abr. 2001.

. Medida Provisória no 2.146-1, de 4 maio 2001. Cria as Agências de Desenvolvimento da Amazônia e do Nordeste, extingue a Superintendência do Desenvolvimento da Amazônia - SUDAM e a Superintendência do Desenvolvimento do Nordeste - SUDENE, e dá outras providências. Diário Oficial da União. Brasília, 7 maio 2001.

BRASIL. Banco Central do Brasil. Carta-Circular nº 2.826, de 4 dez. de 1998. Divulga relação de operações e situações que podem configurar indicio de ocorrência dos crimes previstos na Lei $\mathrm{n}^{\mathrm{o}}$ 9.613, de 03.03.98, e estabelece procedimentos para sua comunicação ao Banco Central do Brasil.

Circular no 3.339, de 22 dez. 2006. Dispõe acerca dos procedimentos a serem observados pelos bancos múltiplos, bancos comerciais, caixas econômicas, cooperativas de crédito e associações de poupança e empréstimo para o acompanhamento das movimentações financeiras de pessoas politicamente expostas. 
BRASIL. Controladoria-Geral da União. Governo Federal já expulsou 2,3 mil servidores por práticas ilícitas. Disponível em: $<$ http://www.cgu.gov.br/Imprensa/Noticias/2009/noticia21009.asp>. Acesso em: $30 / 11 / 2009$ às 23 h31.

BRASIL. Controladoria-Geral da União. Transparência Brasil. Metodologia de Mapeamento de Riscos de Corrupção. Disponível em: $<$ http://www.cgu.gov.br/AreaPrevencaoCorrupcao/Arquivos/Metodologia.pdf $>$. Acesso em: 26 dez. 2009 às 13 h42.

BRASIL. Conselho de Controle de Atividades Financeiras. Resolução/COAF n ${ }^{\circ}$ 16, de 28 mar. de 2007. Dispõe sobre os procedimentos a serem observados pelas pessoas reguladas pelo COAF, na forma do $\S 1^{\circ}$ do artigo 14 da Lei $n^{0}$ 9.613, de 3 mar. 1998, relativamente a operações ou propostas de operações realizadas por pessoas politicamente expostas. Diário Oficial da União. Brasília, 30 mar. 2007.

. Relatórios de atividade do COAF 2003. Disponível em: $<$ https://www.coaf.fazenda.gov.br/conteudo/publicacoes/relatorios-coaf/RelatorioAtividades-2003.pdf>. Acesso em: 27 nov. 2009 às 17h00. . Relatórios de atividade do COAF 2004. Brasília. Fevereiro de 2005. Disponível em: <https://www.coaf.fazenda.gov.br/conteudo/publicacoes/relatorioscoaf/Relatorio-Atividades-2004.pdf>. Acesso em: 27 nov. 2009 às 17h02. . Relatórios de atividade do COAF 2005. Brasília. Março de 2006. Disponível em: <https://www.coaf.fazenda.gov.br/conteudo/publicacoes/relatorioscoaf/RelAtividades2005.pdf>. Acesso em: 27 nov. 2009 às 17h06. Relatórios de atividade do COAF 2006. Brasília. Março de 2007.

Disponível em: $<$ https://www.coaf.fazenda.gov.br/conteudo/publicacoes/relatorioscoaf/Relatorio\%20de \%20Atividades\%202006.pdf>. Acesso em: 27 nov. 2009 às 17h11. - Relatórios de atividade do COAF 2007. Brasília. Março de 2008. Disponível em: <https://www.coaf.fazenda.gov.br/destaques/downloads/relatorioscoaf/Relatorio\%20de \%20Atividades\%202008.pdf>. Acesso em: 27 nov. 2009 às 17h22. 
Relatórios de atividade do COAF 2008. 2 de março de 2009. Disponível

em:

$<$ https://www.coaf.fazenda.gov.br/destaques/downloads/relatorioscoaf/Relatorio\%20de \%20Atividades\%202008.pdf>. Acesso em: 27 nov. 2009 às 17h25.

BRASIL. Comissão de Valores Mobiliários. Instrução n⿳o 301, de 16 de abr. 1999. Dispõe sobre a identificação, o cadastro, o registro, as operações, a comunicação, os limites e a responsabilidade administrativa de que tratam os incisos I e II do art. 10, I e II do art. 11, e os arts. 12 e 13, da Lei n $^{\circ}$ 9.613, de 3 de mar. 1998, referente aos crimes de "lavagem" ou ocultação de bens, direitos e valores.

BRASIL. Secretaria de Previdência Complementar. Instrução Normativa $n^{0}$ 22. Estabelece orientações e procedimentos a serem adotados pelas Entidades Fechadas de Previdência Privada - EFPP, em decorrência da Lei no 9.613, de 19 julho de 1999. Diário Oficial da União. Brasília. Republicada por ter saído com incorreção do original nº 137-E, Seção I de 20 de jul. de 1999, página 15.

BRASIL. Superintendência de Seguros Privados. Circular n⿳ำ 88, de 26 de mar. 1999. Dispõe sobre Indenização no Seguro de Automóvel.

BRASIL. Congresso Nacional. Relatório final da Comissão Parlamentar Mistas de Inquérito, criada através do Requerimento $n^{o}$ 002/1993-CN, destinada a investigar fatos decorrentes da execução do Programa Nacional de Desestatização, do Relator Deputado Rubem Medina, bem como a declaração de voto vencido em separado do Senador Amir Lando. Brasília, 1994. . Resolução n⿳ำ 1 , de 2001. . Relatório parcial da Comissão Parlamentar Mista de Inquérito Criada para apurar as denúncias de recebimento de quaisquer vantagens patrimoniais elou pecuniárias indevidas por membros do Congresso Nacional, com a finalidade de aprovar as matérias de interesse do Poder Executivo e, as acusações do mesmo teor nas deliberações da Proposta de Emenda à Constituição $n^{\circ}$ 01/1995, que dispõe sobre a reeleição para mandatos executivos”. Brasília, nov. 2005.

Relatório dos trabalhos da CPMI das “ambulâncias”, criada por meio do Requerimento $n^{o}$ 77/2006-CN. Vol. I. Brasília, dez. 2006. 
Relatório final da Comissão Parlamentar Mista de Inquérito - Cartão de Pagamentos do Governo Federal. Relator Deputado Luiz Sérgio. Brasília, jun. 2008.

BRASIL. Senado Federal. Relatório final da Comissão Parlamentar de Inquérito, criada através do Requerimento $n^{\circ}$ 127, de 1999-SF, destinada a apurar fatos do conhecimento do Senado Federal, veiculados pela imprensa nacional, envolvendo instituições financeiras, sociedades de crédito, financiamento e investimento que constituem o Sistema Financeiro Nacional. Brasília, 1999.

. Relatório final da Comissão Parlamentar de Inquérito, destinada a apurar, no prazo de 180 (cento e oitenta) dias, as denúncias veiculadas a respeito da atuação irregular de Organizações Não-Governamentais -ONG's, nos termos do Requerimento $n^{\underline{o}}$ 22, de 2001-SF. Brasília, 2002.

Resolução n⿳0 16, de 14 de mar. 2006. Suspende a execução da expressão “manter ou não o sigilo quanto ao objeto e à autoria da denúncia”, constante do $\S 1^{\circ}$ do art. 55 da Lei Federal $n^{\circ}$ 8.443, de 16 jul. 1992, e do contido no disposto no Regimento Interno do Tribunal de Contas da União, que, quanto à autoria da denúncia, estabelece a manutenção do sigilo. Diário Oficial da União. Brasília, 15 mar. 2006.

Relatório final. Comissão de sindicância. Portaria n⿳ํㅡㄹ 01/2009, de autoria do Senhor Presidente do Senado Federal (BAP no 4.232, de 23 jun. 2009). Processo $n^{0}$ 010788/09.

BRASIL. Tribunal de Alçada Criminal do Estado de São Paulo. Acórdão unânime da $1^{\text {a }}$ Câmara Criminal na apelação criminal nº 50.499. Relator: Juiz Toledo de Assumpção. Decisão em 14 set. 1972. In: Revista dos Tribunais n. 448, p. 403.

BRASIL. Supremo Tribunal Federal. Ação Direta de Inconstitucionalidade n⿳ํㅜ 732-RJ. Pleno. Relator: Ministro Celso de Mello Julgado em 22 maio 1992. RTJ n. 143, p. 57. Ação Direta de Inconstitucionalidade no 1640-UF. Pleno. Relator: Ministro Sydney Sanches. Julgado em 12 fev. 1998. Ação Direta de Inconstitucionalidade n⿳0 2100-RS. Pleno. Relator: Ministro Néri da Silveira. Julgado em 17 dez. 1999. . Mandado de segurança n⿳o 23.550. Rel. Min. Sepúlveda Pertence. Decisão publicada em 31 out. 2001. 
Mandado de segurança $\mathrm{n}^{\mathrm{o}}$ 24.510. Rel. Min. Ellen Gracie. Decisão publicada em 31 nov. 2003.

. Medida cautelar inominada em procedimento preparatório. Petição $\mathrm{n}^{\mathrm{o}}$

1665. Requerente: Estado de Minas Gerais. Requerido: União Federal. Relator: Ministro Moreira Alves. Decisão em 15 fev. 1999.

. Recurso extraordinário no ${ }^{\circ}$ 197917/SP. Relator: Ministro Maurício Corrêa. Decisão em 5 jun. 2002. In: Diário de Justiça, 7 maio 2004. p. 8.

BRASIL. Tribunal de Justiça do Paraná. Acórdão unânime da $1^{a}$ Câmara na apelação criminal nº 597/69, originária da Comarca de Porecatu. Relator: Desembargador Carvalho Seixas. Decisão em 31 ago. 1972. In: Revista dos Tribunais n. 447, p. 435.

BRASIL. Tribunal de Justiça de São Paulo. Acórdão por maioria da 2a Câmara Criminal na apelação criminal $\mathrm{n}^{\mathrm{o}}$ 108.761, originária da Comarca de Itápolis. Relator: Desembargador Acácio Rebouças. Voto vencido do Desembargador Odyr Porto. Decisão em 21 fev. 1972. In: Revista dos Tribunais n. 442, p. 258.

BRASIL. Tribunal Regional do Trabalho da $2^{\mathrm{a}}$ Região. RO 02458200247102002. Relator: Sérgio Pinto Martins. DJU 16/11/2004.

BRASIL. Tribunal Regional do Trabalho da $10^{a}$ Região. Recurso Ordinário n⿳o 3469/2001. $3^{\text {a }}$ Turma. Relatora: Juíza Márcia Mazoni Cúrcio Ribeiro. DJU 18/01/2002.

. Recurso Ordinário n⿳o 3469/2001. 3 $3^{a}$ Turma. Relatora: Juíza Márcia Mazoni Cúrcio Ribeiro. DJU 18/01/2002.

BRASIL. Tribunal Regional do Trabalho da $23^{\mathrm{a}}$ Região. Recurso Ordinário 00935.2007.051.23.00-8. $1^{\text {a }}$ Turma. Relator: Desembargador Edson Bueno. DJU 29/05/08.

BRASIL. Tribunal Superior do Trabalho. AIRR 153/2002-029-15-40. $1^{\text {a }}$ Turma. DJ 02/09/2005.

BRASIL. Secretaria da Receita Federal. Coordenação Geral de Política Tributária. "Estudo Tributário nº 08. Sistema e Administração Tributária - Uma Visão Geral. Brasília, 2002. Disponível em: $<$ http://www.receita.gov.br/Publico/estudotributarios/estatisticas/20SistemaAdministraca oTributaria.pdf>. Acesso em: 23 dez. 2009 à 1 h30. 
BRASIL. Tribunal de Contas da União. Súmulas $\mathrm{n}^{\mathrm{o}}$ 78, de 25 nov. 1976. Presidente do TCU Ministro Wagner Estelita Campos. Relator: Ministro Luiz Octávio Gallotti. Diário Oficial da União. Brasília, 16 dez. 1976.

- Súmula no 88, de 25 nov. 1976. Presidente do TCU Ministro Wagner Estelita Campos. Relator: Ministro Luiz Octávio Gallotti. Diário Oficial da União. Brasília, 16 dez. 1976.

CARTA CAPITAL. As donzelas furadas. Entrevista concedida por Roberto Jefferson em 3 de fevereiro de 2006. São Paulo, no 279, 8 fev. 2006, p. 19.

CHILE. Foreign Investment Committee. Transparency is the Rule. Disponível em: $<$ http://www.foreigninvestment.cl/index/plantilla2.asp?id_seccion=3\&id_subsecciones= 78>. Acesso em: 18 nov. 2008 às 08 h30.

CONFEDERAÇÃO NACIONAL DOS MUNICÍPIOS. Estudos fiscais: estimativas da participação dos entes da federação no bolo tributário. Porto Alegre. 2008. Disponível em:

<http://portal.cnm.org.br/sites/9000/9070/Estudos/Financas/EstudoBoloTributario.pdf>. Acesso em: 31 out. 2009 às $17 \mathrm{~h} 45$.

CORPUS IURIS CIVILIS. 12 ${ }^{\mathrm{a}}$ ed. (Digesta por Theodorus Mommsen e Paulus Kruger). Berlim: Weidmannos, 1911.

DANTAS, P. Câmara do Rio aprova cotas raciais para cargos de confiança: Texto especifica que $10 \%$ das vagas sejam para negras e outros $10 \%$ para negros nas nomeações e contratações. O Estado de São Paulo, São Paulo, 12 dez. 2008. Disponível em: <http://www.estadao.com.br/nacional/not_nac281044,0.htm>. Acesso em: 28 out. 2009 às $11 \mathrm{~h} 39$.

ESTADOS UNIDOS DA AMÉRICA. Congresso Nacional. The Federal Regulation of Lobbying Act of 1946.

ESTADOS UNIDOS DA AMÉRICA. Corte Suprema. United States v. Harriss et al., 347 U.S. 612 (1954). Recurso da United States District Court para a District Court of Columbia n. 32. Proposto em 19 out. 1953. Julgado em 7 jun. 1954. Disponível em: http://caselaw.lp.findlaw.com/scripts/getcase.pl?navby=CASE\&court=US\&vol=347\&pa ge $=612>$. Acesso em: 19 dez 2009. 
FALCÃO, Márcio. Moraes diz que não se arrepende de ter dito que "se lixa" para a opinião pública. Folha de S. Paulo, São Paulo, 16 maio 2009. Disponível em: <http://www1.folha.uol.com.br/folha/brasil/ult96u564539.shtml>. Acesso em: 2 dez. 2009 às 19 h19.

FRANÇA, Reinaldo. Sem medo da verdade. Revista Veja, São Paulo, 2 dez. 2009. Disponível em: <http://veja.abril.com.br/021209/sem-medo-verdade-p-154.shtml>. Acesso em: 24 dez. 2009 às $18 \mathrm{~h} 01$.

FUNDAÇÃO GETULIO VARGAS. Revisão da Estrutura Organizacional Administrativa e Sistemática de Classificação e Remuneração de Cargos de Provimento em Comissão e Funções Comissionadas. Rio de Janeiro, 6 de maio de 2009. Disponível em: $<$ https://intranetsenado.senado.gov.br/ArqG/RelatorioFGV.pdf>. Acesso em: 21 nov. 2009 às $19 h 35$.

IBGE. Pesquisa de Informações Básicas Municipais - Perfil dos Municípios Brasileiros. Rio de Janeiro, 2008.

KROLL BRASIL; TRANSPARÊNCIA BRASIL. Fraude e corrupção no Brasil: a perspectiva do setor privado. 2. ed. São Paulo, 2002. Disponível em $<$ http://www.krollamericalatina.com/pesquisas/documents/fraudsurvey_2002_PT.pdf>. Acesso em: 12 dez. 2008 às 16h10.

MAAKAROUN, Bertha. Mais de $80 \%$ das cidades de Minas só sobrevivem com repasses da União. Estado de Minas, Belo Horizonte, 27 abr. 2009. Disponível em: http://wwo.uai.com.br/UAI/html/sessao_3/2009/04/27/em_noticia_interna,id_sessao=3\& id_noticia=107981/em_noticia_interna.shtml> Acesso em: 22 dez. 2009 às 23h14.

MOREIRA, Daniela. EUA, Europa e Japão: conheça os três padrões de TV Digital. IDG Now! São Paulo, 13 fev. 2006/ Disponível em: $<$ http://idgnow.uol.com.br/telecom/2006/02/13/idgnoticia.2006-02-

13.4003735509/paginador/pagina_1>. Acesso em: 18 dez. 2009 às 15 h32.

PNUD. A democracia na América Latina rumo a uma democracia de cidadãs e cidadãos. Trad. de Mônica Hirts. Santana de Parnaíba: LM\&X, 2004.

PORTUGAL. Ordenações manuelinas. Livro V. título LVI. "Dos Officiaes d'ElRey que recebem serviços, ou peitas, e das partes que lhas dam, ou prometem, e dos que deles 
defamam". Disponível em <http://www.ci.uc.pt/ihti/proj/manuelinas//ordemanu.htm>. Acesso em: 26 nov. 2009.

REINO UNIDO. Carta Magna. Disponível em:

$<$ http://www.bl.uk/treasures/magnacarta/translation/mc_trans.html>. Acesso em: 26 nov. 2009 às $15 \mathrm{~h} 22$.

RIO DE JANEIRO. Lei municipal n⿳ำ 4.978, de 9 dez. 2008. Estabelece estratégias de combate ao racismo e de incentivo às ações afirmativas para afrodescendentes, no Município do Rio de Janeiro e dá outras providências.

SINDICATO NACIONAL DOS AUDITORES-FISCAIS DA RECEITA FEDERAL. Subsídios para campanha salarial 2005/2006. 3. ed. Brasília, mar. 2006, p. 16. Disponível em: <http://www2.unafisco.org.br/campanhas/camp_salarial_2006/arquivos/caderno3.0.pdf>. Acesso em: 2 dez. 2009 às 19h35.

VOX POPULI. Voto, eleições e corrupção eleitoral. Pesquisa de opinião pública nacional. Encomendada pela Associação Brasileira de Magistrados (AMB) com 1502 entrevistados. jun. 2008, p. 28. Disponível em: $<w w w . a m b . c o m . b r / p o r t a l / d o c s / p e s q u i s a / p e s q u i s a \_p e r f i l \_e l e i t o r . p d f>$. Acesso em: 28 set. 2008 às $16 h 23$. 